\title{
Славянский АЛЬМАНАХ
}

\author{
Уч реди тель : \\ Институт славяноведения РАН
}

Журнал зарегистрирован

в Федеральной службе по надзору в сфере связи, информационных технологий и массовых коммуникаций (Роскомнадзор)

Свидетельство

о регистрации средства массовой информации ПИ № ФС77-61134 от 30 марта 2015 г. 


\section{РЕДКОЛЛЕГИя:}

Ю. А. Борисёнок, кандидат исторических наук, доцент T. И. Вендина, доктор филологических наук, профессор H. Н. Запольская, доктор филологических наук K. В. Никифоров, доктор исторических наук, директор Института славяноведения РАН (главный редактор) М. А. Робинсон, доктор исторических наук A. А. Плотникова, доктор филологических наук H. Н. Станков, доктор исторических наук H. Н. Старикова, доктор филологических наук E. C. Узенёва, кандидат филологических наук, доцент

\section{РЕДСОвет:}

А. Влашич-Анич, $\mathrm{PhD}$, Институт старославянского языка, Хорватия Д. Дзиффер, профессор, Университет Удине, Италия Л. Димич, академик САНИ, профессор, Белградский университет

П. Женюх, доктор филологических наук, профессор, директор Института славистики САН, Словакия A. Зупnан, академик Австрийской академии наук, Австрия M. Номати, $\mathrm{PhD}$, доцент, Славяно-евразийский исследовательский центр Университета Хоккайдо, Япония $B$. Радева, доктор филологических наук, профессор, Софийский университет, Болгария A. Розман, $\mathrm{PhD}$, профессор, Университет Любляны, Словения

РЕдАКция:

М. Ю. Дронов, кандидат исторических наук (отв. секретарь) Л. А. Кирилина, кандидат исторических наук K. A. Кочегаров, кандидат исторических наук M. М. Макариев, кандидат филологических наук О. В. Трефилова 
Институт славяноведения РАН

\section{Славянский AЛЬMAHAX $3-4 \cdot 2018$}

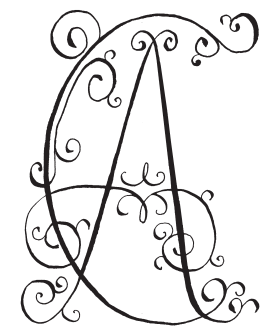

«ИНАРИК» Москва 2018 
Славянский альманах 2018. - Вып. 3-4 /

глав. ред. К. В. Никифоров. - М.: Индрик, 2018. - 512 с.

\section{ISSN 2073-5731}

\section{DOI 10.31168/2073-5731}

Очередной выпуск «Славянского альманаха» (№ 3-4 за 2018 г.) отражает основные направления комплексных научных исследований в области славяноведения. Издание включает статьи и материалы по актуальным проблемам истории славянских народов, этнолингвистики, ономастики и литературоведения. Хронологический охват материалов - от Средневековья до современности. Издание рассчитано как на специалистов, так и на широкий круг читателей.

Slavic Almanac 2018. Issues 3-4 /

ed. K. V. Nikiforov. - Moscow: Indrik, 2018. - 512 p.

This issue of "Slavic Almanach" $(3-4,2018)$ reflects the main directions of complex academic Slavic studies. The edition includes articles and materials on topical problematics from the history of Slavic people, ethnolinguistics, onomastics and literary studies. The chronological span of the publications is between the Middle Ages to date. The issue will interest both researchers and a wide range of readers.

(C) Институт славяноведения РАН, 2018

(C) Коллектив авторов, 2018

(C) Издательство «Индрик», 2018 


\section{Содержание}

\section{История}

Неменский О. Б. (Москва). Праистория славян в третьем издании «Хроники всего света» Мартина Бельского

Флоря Б. Н. (Москва). О переписке двух гетманов: М. Паца и

И. Самойловича

Фалькович С. М. (Москва). Исторические основы одного из

главных национальных праздников Республики Польша -

Дня Конституции 3 мая

Аржакова Л. М. (Санкт-Петербург). Группировка станьчиков как

проявление (само)организации краковских консерваторов,

ориентированных на Вену

Чуркина И. В. (Москва). Первое празднование юбилея Валентина

Водника

Новосельиева Л. К. (Москва). «Кто в молодости не был

либералом»: к политической биографии

Джордже Стратимировича

Дронов А. М. (Москва). Русские консульства в Далмации

в контексте политических процессов у южных славян

Австро-Венгрии и на габсбургско-османском пограничье

в 70-е гг. XIX в.

Фролова М. М. (Москва). К 140-летию русско-турецкой войны

1877-1878 гг. Еленский отряд Дунайской армии в контексте

исторических дискуссий

Вишняков Я. В. (Москва). Дунайский гамбит. Русско-сербское

военно-экономическое сотрудничество накануне и в годы

Первой мировой войны 103

Галимзянова E. А. (Москва). Из Царства Польского в Моршанский

уезд: А. А. Корнилов и Приютинское братство в борьбе с голодом 1891-1892 гг.

Гусев Н. С. (Москва). Русское общество и сербско-австрийский

конфликт 1912-1913 гг.: хотели ли русские войны

Станков Н. Н. (Москва). Образование Малой Антанты в документах миссии Красного Креста РСФСР в Чехословакии (1920-1921 гг.) 
Революция и Гражданская война на белорусских и украинских землях

Борисёнок Е. Ю. (Москва). «Украинский вопрос» в воспоминаниях

чиновников Украинской Державы гетмана П. Скоропадского ... 173 Короткова Д. А. (Москва). Белорусские организации

революционной России в воспоминаниях Е. С. Канчера 190

Ганин А. В. (Москва). Наградные документы чекиста Е. Г. Евдокимова как источник по истории Всеукраинской Чрезвычайной комиссии и красного террора в Крыму в 1920-1921 гг. 201

Робинсон М. А. (Москва). Судьба русского киевлянина: письма

С. Ю. Кулаковского А. И. Соболевскому (Революция,

Гражданская война, первые годы эмиграции)

Борисёнок Ю. А. (Москва). Путь к советской нации на фоне войн и революций: начальный этап белорусизации в интерпретации Алены Марковой

\section{Восточные славяне в Новом свете}

Мамедов И. М. (Москва). Украинская диаспора Канады: история и современность 254

Пилипенко Г. П. (Москва). Русские в Уругвае: полевые заметки 306

История культуры

Лабынцев Ю. А. (Москва). Судьбы Холмского православия в период революционных потрясений 1910-1920-х гг.:

Радочницкий Свято-Антониевский женский монастырь 318 Щавинская Л. Л. (Москва). Проблемы общественной и церковной жизни Холмщины в изданиях Холмской православной епархии в период эвакуации и революционных перемен: 1915-1917 гг.

\section{Этнолингвистика и ономастика}

Плотникова А. А. (Москва). «Водные хорваты» и специфика их традиции: обзор этнолингвистической экспедиции 343

Агапкина T. А. (Москва). Символика деревьев в традиционной культуре славян: липа

Гура А. В. (Москва). Об одном архаическом способе мотивировки

значения в снотолкованиях

Теуш О. А. (Екатеринбург). Исконная лексика с семантикой

‘залив’ в диалектах Европейского севера России 385 


\section{Литературоведение}

Красовеи А. Н. (Москва). Место визуального кода в поэзии

русского авангарда и его эволюция в 1910-1920-е годы 396

Кожина С. А. (Москва). Чешская литературная критика периода нормализации

Широкова Л. Ф. (Москва). Словацко-венгерское пограничье как

мультикультурное сообщество и объект художественной

рефлексии (романы Л. Баллека и Л. Грендела)

Адельгейм И. Е. (Москва). Память о польско-еврейском прошлом:

проблема пространства и вектора (молодая польская проза 2000-2010-х гг.)

\section{Публикации}

Кочегаров К. А. (Москва). Фрагмент статейного списка посольства А. С. Матвеева к Богдану Хмельницкому и другие документы русско-украинских отношений XVII в. в составе книги № 120 архива Малороссийского приказа

Колин А. И. (Кишинев), Стыккалин А. С. (Москва). «Историкуархивисту и археологу чужды мечты о лаврах, срываемых разными крикунами на митингах...» Письмо Ивана Халиппы архиепископу Арсению (Стадницкому), 1910 год

Никифоров К. В. (Москва). Балаклава под оккупацией 472

\section{Рецензии и обзоры}

Шевченко К. В. (Минск). «Жемчужина у моря» под микроскопом этнологов и историков: этнология Одессы в исторической и современной перспективах

\section{Хроника}

Дронов М. Ю., Слоистов С. М. (Москва). Международная научнопрактическая конференция «Церковь в исторических судьбах народов Центральной и Восточной Европы» 496

Лобачева Ю. В. (Москва). Круглый стол «Тенденции современных национальных историографий стран Центральной, ЮгоВосточной и Восточной Европы» 


\section{Content}

\section{History}

Nemensky O. B. (Moscow). Slavic prehistory in the third edition of Marcin Bielski's "Universal Chronicle" ................................................. 11 Florya B. N. (Moscow). On the correspondence of two Hetmans:

M. Pac and I. Samoylovych

Fal'kovich S. M. (Moscow). Historical grounds of one of the most

important holidays of the Republic of Poland: May, 3rd, the

Constitution Day

Arzhakova L. M. (Saint Petersburg). The faction of Stańczycy

as a demonstration of (self)organization

of the Krakow conservatives orienting themselves

toward Vienna

Churkina I. V. (Moscow). The first celebration of Valentine Vodnik's jubilee ..... 53

Novoseltseva L. K. (Moscow). "If you're not a liberal when you're

young": to the political biography of Đorđe Stratimirović

Dronov A. M. (Moscow). Russian consulates in Dalmatia

in the context of political processes by South Slavs

in Austria-Hungary and on the Habsburg-Ottoman border

in the 1870 s

Frolova M. M. (Moscow). To the 140th anniversary of the Russian-

Turkish war of 1877-1878. Elena detachment

of the Danube army in the context of historical discussions

Vishniakov Ya. V. (Moscow). The Danubian gambit. Russian-Serbian military

and economic cooperation before and during the First World War

Galimzyanova Ye. A. (Moscow). From the Kingdom of Poland to

Morshansky uyezd: A. A. Kornilov and the brotherhood of

Priyutino combating the famine of 1891-1892

Gusev N. S. (Moscow). Russian society and Serbian-Austrian conflict

of 1912-1913: Did the Russians really want war?

Stankov N. N. (Moscow). The Forming of the Little Entente in the documents

of the RSFSR Red Cross mission to Czechoslovakia (1920-1921)

Revolution and Civil War in Belarusian and Ukrainian Lands

Borisenok E. Iu. (Moscow). "Ukrainian question" in the memoirs of the officials of the Ukrainian State of Hetman P. Skoropadskyi

Korotkova D. A. (Moscow). Belarusian organizations of revolutionary

Russia: the memoir of Y. S. Kantcher 
Ganin A. V. (Moscow). Award documents of the CheKa officer

E. G. Evdokimov as a source on the history of All-Ukrainian

Extraordinary Commission and Red Terror in Crimea in 1920-

1921

Robinson M. A. (Moscow). The fate of a Russian dweller of Kiev:

Letters of S. Yu. Kulakovsky to A. I. Sobolevsky (Revolution,

Civil War, first emigration years)

Borisenok Y. A. (Moscow). The way to the Soviet nation against

the backdrop of wars and revolutions: the initial stage of

Belarusianization in the interpretation of Alena Marková 247

East Slavs in the New World

Mamedov I. M. (Moscow). Ukrainian Diaspora of Canada, its history

and modernity 254

Pilipenko G. P. (Moscow). The Russians in Uruguay: the field research notes .. 306

\section{History of Culture}

Labyntsev Yu. A. (Moscow). The fate of Orthodox Christianity of Cholm during the revolutionary turmoil of the 1910s-1920s: Radochnitsky

Svyato-Antonievsky nunnery 318

Shchavinskaia L. L. (Moscow). Problems of social and church life in

Cholm Land in the publications of Cholm Orthodox diocese during

the evacuation and revolutionary changes: 1915-1917

Ethnolinguistics and onomastics

Plotnikova A. A. (Moscow). "Water Croats" and the specifics of their tradition: A review of an ethnolinguistic expedition

Agapkina T. A. (Moscow). Symbolic functions of trees in Slavic

traditional culture: Linden

Gura A. V. (Moscow). On an archaic way of motivation of meaning in interpretation of dreams

Teush O. A. (Yekaterinburg). The native vocabulary with semantics

of 'bay' in the dialects of the European North of Russia

\section{Studies of literature}

Krasovec A. N. (Moscow). The place of visual code in the poetry of Russian avant-garde and its evolution in 1910s-1920s 
Kozhina S. A. (Moscow). The Czech literature criticism during

Normalization

Shirokova L. F. (Moscow). Slovak-Hungarian border area as a

multicultural community and an object of artistic reflection

(novels by L. Ballek and L. Grendel)

Adelgejm I. Ye. (Moscow). The memory of Polish and Jewish past: The problem of space and vector (young Polish prose of the 2000s-2010s) ... 432

\section{Publications}

Kochegarov K. A. (Moscow). A fragment of diplomatic mail (stateyny spisok) of A.S. Matveev embassy to Bohdan Khmelnytsky and other documents on Russian-Ukrainian relations in the 17th century in Book 120 of the archive of the Little Russia Office

Kolin A. I. (Chisinau), Stykalin A. S. (Moscow). "To a historian, archivist and archeologist, alien are the dreams of laurels of screamers at rallies..." A letter of Ivan Halippa to archbishop Arsenius (Stadnitsky), 1910 459

Nikiforov K. V. (Moscow). Balaklava under occupation 472

\section{Reviews}

Shevchenko K. V. (Minsk) "The Pearl at the Sea" under the microscope of ethnologists and historians. Ethnology of Odessa in historical and contemporary perspective 491

\section{Chronicle}

Dronov M. J., Sloistov S. M. (Moscow). International academic and practical conference "The Church on the Historical Paths of Central and East European Peoples" 496

Lobacheva Yu. V. (Moscow). The Roundtable "Tendencies of contemporary national historiographies of countries of Central, Southeastern and Eastern Europe"

About the authors 507 


\section{Праистория славян в третьем издании «Хроники всего света» Мартина Бельского}

В статье рассматриваются сведения по древнейшей истории славян, представленные в сочинении польского историка Мартина Бельского «Хроника всего света» (третье издание, 1564). Особое внимание уделено освещению Бельским вопросов о происхождении славян, их характерных свойств, географической локализации их прародины и последующих миграций, истории их разделения на отдельные народы.

Ключевые слова: Мартин Бельский, польские хроники, XVI век, Бернард Ваповский, славяне, сарматизм, роксоланы, готы, вандаль, библейская генеалогия.

DOI: $10.31168 / 2073-5731.2018 .3-4.1 .01$

Праистория славянских народов была важнейшим объектом внимания историографов раннего Нового времени. Свойственное эпохе Ренессанса стремление найти свои корни в античном мире побуждало искать упоминания о предках у древних авторов и связывать эти сведения с христианскими представлениями о происхождении и расселении народов. В попытках сформировать общую канву начальных страниц прошлого своих народов выражались и характерные особенности их самосознания и свойства сословных взглядов, близких авторам.

Исторические труды Мартина Бельского (1495-1575) ${ }^{1}$ обладали большим своеобразием на фоне всей прежней традиции польской историографии. Будучи светским человеком, шляхтичем, он критически относился к стремлению его предшественников, в основном духовных лиц, обращать внимание главным образом на отношения правителей и других крупных исторических деятелей с Церковью и оценивать их по масштабу их благодеяний и набожности. Его интересуют в первую очередь «рыцарские дела и поступки», «воинственность» и «боевая слава» - добродетели эпохи формирования особой сословной идеологии польской шляхты, получившей позже определение «сарматизма». И история, описанная Бельским, во многом легла в основы ее исторического самосознания. Огромное влияние Хроника Бельского оказала также на русское летописание благодаря ее современным переводам². 
Этому помогло и другое свойство его трудов - стремление автора сделать их общедоступными, а значит писать их не на латыни, а по-польски, причем довольно простым, доступным языком. «Хроника всего света» М. Бельского, первое издание которой вышло в 1551 г., стала первым историческим обзором на польском языке (и вообще первой «всемирной историей» на славянском языке). Надо отметить, что читательская аудитория для таких произведений тогда только начала складываться. Например, прежде на польский язык был почти сразу переведен знаменитый «Трактат о двух Сарматиях» Матвея Меховского, опубликованный в 1517 г. Однако его польскоязычный текст издателя не нашел и был опубликован уже только в XIX в. ${ }^{3}$ Большая часть его читателей в те годы были еще представителями церковной и университетской среды и предпочитали латинские тексты. Однако в середине XVI в. потребность в историческом труде на польском языке уже оказалась значительной - уровень образования и культурных запросов представителей шляхетского сословия, занятых в основном военным делом и сельским хозяйством, существенно возрос, а быстрое формирование особого сословного самосознания рождало запрос на описание мира на основе актуальных для него взглядов. В результате уже в 1554 г. вышло значительно дополненное второе издание «Хроники» Бельского, а в 1564 г. — серьезно переработанное и расширенное третье.

Первая редакция «Хроники» ${ }^{4}$ включала в себя Космографию, очерк всемирной истории и хроники Венгрии, Чехии и Польши, причем последней посвящена почти половина всего текста. Во второй редакции материал был иначе структурирован, сочинение было поделено на четыре книги, а в Космографию (III книга) добавлена глава «О славянских землях». Однако действительно новый текст содержался лишь в четвертой, в которой описывались Великие географические открытия. Третья редакция 6 была существенно дополнена новым материалом, а старые разделы были заметно переработаны и расширены. «Хроника» была разделена на десять книг, из них первые две остались неизменными со второй редакции, третья была посвящена истории Реформации, четвертая - Турции, пятая Космографии, далее расположились хроники Венгрии, Чехии и Польши. Девятая книга была «О народе Московском или Русском», и десятая - о Новом свете, к которой были добавлены главы «О евреях», «О рае», «Об аде» и «О воскрешении и Судном дне». В 1597 г. в шести книгах вышла «Польская хроника»7 сына Мартина Бельского Иоахима, представлявшая собой существенно расширенное за счет новых сведений (особенно из сочинений М. Кромера и М. Стрыйковского) описание истории Польши из Хроники Бельского. 
Источниками сочинения М. Бельского послужили «Всемирная хроника» Иоганна Науклера, сочинения польских историков Я. Длугоша, М. Меховского, Б. Ваповского, Л. Деция, М. Кромера, по чешской истории также «Чешская хроника» В. Гаека, по России - в первую очередь «Записки о Московии» С. Герберштейна. Особенно важно использование Бельским труда Бернарда Ваповского - королевского историографа и картографа, который с 1522 г. и до своей смерти в 1535 г. писал сочинение, не оконченное и в своей начальной части (с описанием истории до 1380 г.) до нас не дошедшее, но оказавшее большое влияние на последующую польскую историческую мысль.

Отрывки из этих книг приводились Бельским в сильно сокращенном виде и с некоторыми изменениями. При этом он не всегда пытался найти в противоречивых сведениях разных источников наиболее достоверную информацию, предлагая читателю разные версии прошлого. Как описал этот подход Б. Н. Флоря, сравнивая в этом плане Бельского с Кромером: «Бельский же, по-видимому, пришел к другому выводу: поскольку нет точных критериев для определения достоверного знания о прошлом, необходимо предлагать читателю разные точки зрения на этот счет, имеющиеся в существующих текстах» ${ }^{8}$. Впрочем, различные версии одних событий не собираются им в одном месте для предоставления читателю всей палитры взглядов и мнений, а содержатся в разных местах сочинения, соответствующих различным источникам информации.

В рамках проекта по изучению описаний праистории славян в историографии славянских стран в позднее Средневековье и раннее Новое время 9 , осуществляемого в отделе истории средних веков Института славяноведения РАН, уже была издана статья его руководителя Б. Н. Флори о ранней истории славян у М. Бельского ${ }^{10}$. Однако ее источником послужило только первое издание его «Хроники». В настоящем тексте предлагается рассмотреть, как вопросы о происхождении славян, географической локализации их прародины и последующих миграциях, разделении на отдельные народы, их характерных свойствах и судьбах в начальный период истории освещены в третьем, наиболее полном издании сочинения Бельского.

Бельский очень четко определяет важнейшее свойство праистории - ее дописьменный характер. А соответственно, и возможность судить о ней лишь по сведениям, переданным авторами из других народов. Он приводит рассуждения Бернарда Ваповского о том, что достоинства, приписываемые себе другими народами, объясняются их более ранним обучением письму: «Одни народы на свете раньше дру- 
гих писать научились, как греки и итальянцы, которые свою историю на письме явно показали значительно лучше, чем она была, а после них и немцы, хотя этот народ никогда воинственным не был» ${ }^{11}$. И определяет разные источники обучения письму: «Кто от кого писать научился: одни от греков, как русь, москва и армяне, другие от латинников, как мы, немцы, готы, лангобарды и многие другие язычники» ${ }^{12}$. Этим задается ощущение ущемленности в исторической памяти и потребность в восстановлении справедливого описания заслуг своих предков, что в данном случае соответствует защите их доброго рыцарского имени.

Возможно, потребность увидеть общность с другими народами, научившимися писать у «латинников», побудила Бельского отвергнуть концепцию М. Меховского, согласно которой славяне вели свой род от родоначальника греков Иавана. Он пишет, что «сарматы заложил» сын Ноя Гомер и его сын Аскеназ, что объединяет славян происхождением с немцами. Эта версия была обозначена уже в первой редакции «Хроники» ${ }^{13}$ и, очевидно, сложилась под влиянием Л. Деция ${ }^{14}$, описывавшего древнюю Сарматию от Волги до Рейна, в которой славяне жили вместе с немцами во главе с Туисконом ${ }^{15}$. Эта версия содержится в польской хронике во всех трех редакциях (главка «О początku a wywodzie narodu Polskiego»): «Несмотря на то, что старые наши хроникеры полагали, что мы вместе с греками от Иавана происходим, никаких свидетельств этому мы не имеем, притом что греки никогда с нами в Сарматии не были. А немцы, предками которых были Гомер и Туискон, $<\ldots>$ всегда при Сарматии были» ${ }^{16}$. При этом Бельский вступает в полемику и с утверждением Кромера, что сарматы произошли от Ассармота, потомка Сима. «Мы с немецким народом в прошлом соседями всегда были», - подчеркивает Бельский ${ }^{17}$. Надо отметить, что в этой части он, несомненно, вступает в сильное противоречие с Ваповским $^{18}$, имевшим очень определенные антигерманские взгляды, но нигде это не акцентирует.

Однако в сочинении Бельского содержится и совсем иная версия происхождения славян. Уже во второй редакции ${ }^{19}$, как и в третьей, появляется утверждение, что славянским прародителем был сын Иафета Mocox — «Mesech, od ktorego Moskwa y wszyscy Słowacy» ${ }^{20}$. Эта версия, которой позже придерживался также и М. Стрыйковский, восходит, возможно, именно к Ваповскому, так как у Стрыйковского мы находим прямую отсылку на него: «Поляки, чехи, болгары и другие все славяне и русские [“inszy wszyscy Sławacy i Rusacy”] происходят от Мосоха или Москвы, сына Иафетова [“Mosocha albo Moskwy syna Japhetowego"], и с московских земель вышли [“"z krain Moskiewskich 
wyszli”']. Так говорит Ваповский» ${ }^{21}$. Бельский не пытается разобрать противоречие между приводимыми теориями. Но вызывает удивление отсутствие сведений о прародителе Мосохе в первом издании его «Хроники», ведь сочинение Ваповского при его составлении уже активно использовалось.

По вопросу о древней прародине славян у Бельского были в распоряжении две основных версии. Согласно одной, традиционной для польской историографии и особенно ярко выраженной у Меховского, славяне при расселении из Месопотамии пришли на Балканы. Согласно другой, уходящей к Децию и сформулированной у Ваповского, прародиной славян была Восточная Европа. Первую версию Бельский описывает по Кромеру, пересказывая его словами «начала и исход нашего польского народа»: «Славяне в Далматии, в Иллирии, Истрии, Болгарии, в Венгрии издавна пребывали, от Потопа, являясь потомками Иафета, сына Ноя» ${ }^{22}$. Это то место у Кромера, в котором он описывает переселение Леха и Чеха «z Dalmaciey albo Karwacyey / ieszcze przed narodzeniem Pana Krystusa». Однако этим сведениям Бельский противопоставляет явно более убедительные для него слова Ваповского, согласно которому «Лех и Чех, предки наши, славянские князья, не из Далмации или Хорватии пришли сюда в края немецкие, и не из Чехии в Далмацию, как Кранц или другие писали, но из русских стран [“z Ruskich krain”], которые в то время широко обитали в Великом поле [“w wielkich polach”] между реками Волгой и Днепром и происходили от Москвы» ${ }^{23}$.

Эти «русские края», являющиеся славянской прародиной, Бельский отождествляет с Великой Булгарией, или Волгарией: «Булгария или великая Волгария [“Bulgarya albo Wolgarya wielka”], из которой мы, славяне, вышли, была между Азией и Европой на обоих берегах реки Танаис, которую мы называем Волгой, расположенной у Москвы» ${ }^{24}$. Даже само наименование славян он вслед за Ваповским возводит к названию озера в московских землях: «Ваповский пишет, что славяне, наши предки, названы были так по Словенскому озеру [“od ieziora Słowieńskiego"], которое находится в Москве» ${ }^{25}$. Славяне-волгары, «в поисках лучшей земли, < ..> пришли на море, которое мы называем Понт Эвксинский <.. > и на реку Днепр». Потом они пошли в Дакию, где сегодня валахи, потом переправились через Дунай и пришли во Фракию, повоевали с греческими государствами, овладели «Мизией Малой и Великой, и назвали ее отчим местом Булгарией, которую мы так называем по сей день». Бельский пишет, что славяне даже спалили Константинополь. Потом покорили Боснию, через Венгрию шли далеко до Далмации, Иллирика и до Истрии, «и в этих землях они и 
сегодня живут» ${ }^{26}$. «Славяне, разделившись на три части, всю Европу воевали», - при этом описывается три места нового поселения славян: первые осели в Истрии, вторые во Фракии, а третье «славянское войско» пошло на север. В этой области описания Бельского во всех трех редакциях его Хроники содержательно идентичны и, судя по приведенным отрывкам текста Ваповского, напрямую вторят его выводам.

Такое отождествление славянской прародины с «русскими краями» обусловило восприятие роксоланов также как предков всех славян, а не только русских. Бельскому свойственно полное отождествление славян с сарматами - традиция, идущая еще от Яна Длугоша. О роксоланах как о предках русских прежде писал М. Меховский, однако теперь они отождествляются в целом со славянами и болгарами, а значит и со всеми сарматами. В приведенном отрывке из начальной части текста Хроники Ваповского об этом говорится напрямую: «Roxolani albo Słowacy / drudzy piszą Bolgary / wszakże to wszytko iedno» ${ }^{27}$.

Описание Сарматии у Бельского полностью укладывается в уже устоявшуюся традицию: «Есть две Сарматии, одна Скифская, в которой заволжские татары или азиаты живут, другая Европейская, в которой мы сидим, москва, русь, литва, прусы, поморцы, валахи, готы, аланы и татары, которые на этой стороне реки Волги находятся» ${ }^{28}$. «Польский народ (с чем все согласны) происходит от славянского народа из страны Сарматии [“z krainy Sauromacyey”], которая лежит в третьей части света Европе. Эту Сарматию разделяет с востока река Танаис и озеро Меотис ${ }^{29}$, а с запада Висла, или, как другие настаивают, река Одер, с юга венгерские горы, которые мы называем Бещадами или Бескидами, а с севера Немецкое или Сарматское море, или Балтия [“morze Niemieckie albo Sarmatyckie, albo Balteum"], на котором Гданьск расположен» ${ }^{30}$. Однако в другом месте находится описание Скифии, полностью тождественное Сарматии: «Скифия, названная так, по мнению некоторых, по Скифу, сыну Геркулеса, двоякая - одна европейская, которую мы все, сарматы, наследуем, а также литва и валахи. Другая же - азиатская, где весь северный и восточный татарский народ. Разделяет нас от них река Танаис, то есть Волга ${ }^{31}$. Но случаев отождествления сарматов со скифами или татарами нет: написано, что они «пришли к нам, сарматам» ${ }^{32}$.

Примечательно описание готов. Бельский оспаривает мнение «некоторых, которые писали о них как о немецком народе». При этом оспаривается само их отождествление с каким-либо народом - готы видятся как сборище людей самого разного происхождения. Они «не одного народа были эти люди, между ними было достаточно русаков, 
уланов, москвы, гепидов, литвы, шведов, датчан, татар, прусов и других ${ }^{33}$, все это себе немцы присваивают. <..> Были эти люди также и разного языка, как и народа, поэтому из-за таких различий историки не могли согласиться друг с другом при их описании» ${ }^{34}$. «Эти края, из которых готы с соседями вышли, были и являются соседними с Роксоланией или Москвой [“są przyległe Roxolaniey albo Moskwi”]. Там было много наших предков роксоланов, то есть русаков или славян, как и между вандалов» [“wiele naszych przodkow Roxolanow / tho iest Rusakow / albo Słowanow / iako między Wandality"] $]^{35}$.

Бельский также опровергает представление о немецком происхождении вандалов, следуя во многом уже устоявшейся традиции польской историографии, рассматривающей их как славян: «Вандалы были того народа, которого и языка <..> потому как некоторые пишут, что они были немецкого народа и языка, другие пишут, что славянского, третьи - татарского» ${ }^{36}$. Бельский указывает на то, что вандалы вышли из той же Волгарии, и спрашивает: «Как они могли быть немцами, если они пришли от озера Меотис, а там никаких немцев по соседству не было?» ${ }^{37}$ «Вандалы были людьми нашего языка» ${ }^{38}$, — заключает в другом месте Бельский.

Однако вандалы и не отождествляются с поляками, а видятся иным славянским народом, который пришел на Вислу раньше поляков и потом пошел дальше: «сюда пришли на Вислу в немецкие края» ${ }^{39}$, а позже «двинулись всеми силами туда, где видели лучший корм, то есть в Венгрию, а потом в Италию, <..> в Африку» ${ }^{40}$. Когда был основан город Гнезно, на этих территориях «когда-то обитали вандалы, которые уже к тому времени погибли в боях в Африке» ${ }^{41}$.

И здесь мы сталкиваемся с довольно интересной концепцией, согласно которой народ может изменять свой язык и становиться иным, то есть, по сути, ассимилироваться. Бельский пишет об онемечивании вандалов: «По моему мнению, вандалы, народ сарматский <..> заселили немецкие края на Висле везде, проведя тут немалое время, и переняли обычаи и язык немецкий» ${ }^{42}$, «потом же, завязав с ними товарищество, они оставили эти места, и шли вместе с немцами в Венгрию как в землю с лучшей пищей» ${ }^{43}$. Таким образом, будучи изначально народом славянско-сарматским, вандалы выходили с Вислы на юг, уже будучи фактически немцами.

Сам ход расселения славян Бельский описывает довольно подробно: «Другие славянские орды [“hordy Słowańskie”] пошли к западу в немецкие края, как и наши славяне Чех с Лехом, осели в немецких землях — Чех в Чехии, Лех в Вандалии. Другие орды роксоланов 
[“drugie hordy Roxolanow”] пошли на север и там осели, где сегодня область Подляшья, другие на Волынь, которую от реки Волги назвали». При этом он указывает, что «поляки и чехи раньше сюда в эти края пришли, на Вислу, чем другие славяне в Мизию и Далмацию» ${ }^{44}$. Невозможность установления времени переселения польских предков на берега Вислы вновь обосновывается тем, что они тогда еще не имели письменности: «После них (вандалов. - $О$. Н.) наши роксоланы или славяне пришли на их места сюда на Вислу, но когда это произошло, трудно сказать, ведь в то время они писать не умели» ${ }^{45}$.

Бельский приводит текст «Грамоты Александра Великого», взятый им из «Чешской хроники» Вацлава Гаека (1541), которая свидетельствует, что «в Македонии роксоланы были во времена великого Александра, и потому немало греческих слов в нашем языке» ${ }^{46}$. Он описывает современное расселение славян в качестве подтверждения сказанному в этой грамоте о позволении славянам заселять земли от Ледовитого океана до Итальянского моря ${ }^{47}$. В настоящее время славянские народы живут везде, «начиная от Ледовитого моря, которое далеко за Москвой, и до Венецкого моря (“do morza Weneckiego”), которое мы называем Адриатикум. Между ними следующие народы нашего языка находятся: вначале с москвы начиная, потом русаки (“Rusacy”), поляки от полей названные», и далее идет перечисление других славянских народов: «Bolgary, Bosnowie albo Serbowie, albo Rusacy wszytko to iedno, Dalmate, Illirycy, gdzie była Liburnia, Charwaci, Styry, Burgundy, Istri» ${ }^{48}$. И здесь также содержится оговорка, что некоторые из славянских народов подверглись ассимиляции: «однако многие из них обратились в чужой обычай». Бельский перечисляет, какие народы обратились в турецкие обычаи, какие в немецкие, а какие в итальянские: «Bułgarow, Bosnow, Racow, Charwathow w Turecki; a Burgundow, Pomorczykow, Slęzakow w Niemecki; a Istrow, Dalmatow we Włoski». Однако это обращение не полное и не затронуло разговорного языка, «ведь все они, среди чужого народа находясь, используют свой природный язык» ${ }^{49}$.

Рассказ о Лехе и Чехе излагается Бельским в соответствии с Хроникой Гаека ${ }^{50}$, хотя в чешской части Лех обозначен старшим братом ${ }^{51}$, а в польской такого уточнения уже нет. Однако если в Чешской хронике их переселение отмечено 644 годом, то в Польской хронике время переселения славянских братьев Бельский оставляет под вопросом: «Когда же Лех в эти края на Висле привел из Роксолании свои орды, как и Чех в Чехию, в этом у хроникеров нет единого мнения» ${ }^{52}$. Он обращает внимание на то, что у Гаека говорится о прошествии шестисот 
лет после Рождества Христова, но отказывается в это верить, так как древние историки «нас тут обозначали задолго до этого» ${ }^{53}$.

Эпоха расселения славян является для Бельского материалом для воспевания идеала рыцарского образа жизни и нравственных ценностей. Сарматы не имели собственности и тяги к сребролюбию, вели кочевнический образ жизни и основным своим занятием почитали войны ради одной только славы. Описываются многочисленные войны «роксолан» с «понтийским королем» Митридатом, с римскими войсками и др. ${ }^{54}$ В этом отношении равными сарматам-славянам выступают разве что скифы-татары, воспеванию воинственности которых также уделено немало места. «Никогда их никто не побеждал, а они побеждали. < .. > Всю Азию подчинили. Турки, парфяне, персы, угры, франки и сикамбры из их народа происходят» («Turcy, Party, Persowie, Węgrowie, Francuzowie albo Sykambry z ich narodu poszli») ${ }^{55}$. «Татарский народ наиболее древний и наиболее воинственный из всех народов на свете, с этим все историки согласны» ${ }^{56}$. Такие же идеальные рыцарские порядки и нравы царили у славян и при князьях Чехе и Лехе: «законов не имели, но везде справедливость, страх и порядок был» ${ }^{57}$.

«Московскому» народу, который также называется русским, посвящена отдельная книга (IX), и уже в названии обозначен ее основной источник: «O narodzie Moskiewskim albo Ruskim według wypisania Zygmunta Herberstyna / ktory tam trzykroć iezdził w poselstwie od Cesarzow Krześcijańskich». Это сокращенный пересказ исторического очерка из «Записок» Сигизмунда Герберштейна. Везде проведено отождествление «московского или русского» народа со славянами и сарматами: «О московском или русском народе по-разному писали старые историки, но всегда считали их сарматами»; «Русаки или москва [“Ruszacy albo Moskwa"] все славянского языка и христиане, одни в греческом обряде, другие в римском» ${ }^{58}$. Примечательно такое полноценное отделение конфессиональной принадлежности от этнической, во многом являющееся результатом начавшегося века Реформации, которой Бельский сочувствовал, а также последовательно светского настроя его сочинения.

Здесь же содержится упоминание о третьем брате славянских князей - Русе, но в качестве одной из версий, которая, очевидно, не считается убедительной, так как в других местах, в которых упоминаются Чех и Лех, о Русе нет ни слова. Если учесть, что русский народ по сей день живет в славянской прародине, то фигура Руса, действительно, оказывается совершенно лишней. Здесь же упомянута и версия о происхождении названия Руси от городка Russo под Новгородом (Старая Русса), а также связка этого имени с Роксоланией. В целом 
описание названия Руси соответствует тексту Герберштейна. Указывается на то, что в самой Москве уверены в происхождении своего названия от рассеяния («od rozsiania / to iest rosseia»), с чем «согласны и греки» ${ }^{59}$. Так благодаря Герберштейну в польской историографии была проведена попытка осмысления названия «Россия» в привязке к Руси и к Москве. Здесь же приводятся наименования, используемые «латинниками»: «Roxolani», «Rossani» и «Ruteny».

B другом месте (в польской части) Бельский приводит иную версию происхождения имени Русь, увязывая его именно с роксоланами: «а те, которые на месте остались, и сегодня называются русью от русанов или роксоланов вместе с москвой [«zową Rusią od Rusanow albo Roxolanow z Moskwą społu»], которые тоже роксоланы, потому что одного народа и языка с роксоланами ${ }^{60}$. Такая трактовка, очевидно, входит в противоречие с идеей происхождения Руси от «рассеяния», ведь так называются как раз те, кто никуда со славянской прародины не уходил. Надо отметить, что источником сведений по русской истории в польской части «Хроники» для Бельского выступал в основном Меховский, из чего следуют неизбежные противоречия со сведениями Герберштейна ${ }^{61}$.

Приведена и легенда о призвании в Новгород трех варягов: «Эти три брата, как утверждает москва, происходят от римских господ, от них же родом и сегодняшний великий князь московский, который $<\ldots .>$ называет себя римлянином» ${ }^{62}$. Указан весь род московских князей от Рюрика до нынешнего Ивана. Примечательна эпиграмма на Ивана Грозного, опубликованная вместе с его портретом в самом начале книги: «Я государь великий князь народа русского, издавна наследник своей земли, государства московского». В ней Ивану приписывается особая гордость за свое автохтонное происхождение, которая служит ему обоснованием для нежелания жить в согласии с монархами соседних держав: «Не из чужого народа я в эту землю пришел. $<\ldots>$ Не так, как соседние князья и короли, которые пришли в свои державы из других стран». И поэтому он «не хочет иметь с ними согласия» ${ }^{63}$. Так конфликты с Россией послужили еще одним доказательством расположения в ней прародины славянских народов. Хотя, конечно, смысл этой эпиграммы прямо противоречит приведенным немного выше сведениям о римском происхождении московских монархов.

При этом Бельский отмечает, что под властью Москвы находится лишь часть Русской земли. Он описывает ее раскол на несколько частей: «Недавно турки завоевали немало их земель. $<\ldots>$ Другие части русских земель держат три великих государя. Первую наибольшую часть держит московский князь, другую литовский, третью король 
польский, особенно нижние земли (Подолию. - O. Н.) и Подляшье» ${ }^{64}$. Границы Русской земли («русских стран») он описывает максимально широко: «Русские страны с юга ограничены горами, которые мы называем Бещады, и рекой Днепр, и морем Понтийским, а с востока Волгой, на севере же Балтийским морем и Ледовитым» ${ }^{65}$.

Наименование народа «московским» разъяснено довольно определенно как частичное для Руси: «Город Москва является в наше время главой всей Московской земли, замок и река также называются Москвой, от них и весь русский народ [“lud wszytek Ruski”], который там живет, именуется тем же именем Москва» ${ }^{66}$. Однако наравне с отождествлением «русского» и «московского» народа у Бельского содержится и немало случаев рядоположенного употребления двух названий, при котором под Русью понимаются только земли в составе Польши и Литвы. При этом такое упоминание Руси рядом с Москвой имеется и в описаниях очень давних времен: князей «Батый татарин победил, и большую часть Москвы и Руси спалил, и с того времени татары приказывали московским и русским князьям, и дань с них брали - плоть до Василия, который был в 1520 г.». Но ни одного случая привязки названия «московского народа» и Москвы к Мосоху в этой части Хроники Бельского не находится.

Концепция восточноевропейской прародины славян в «русских краях» вокруг Москвы, имеющая корни в труде Б. Ваповского и так определенно прописанная у М. Бельского, радикально порывала с прежде господствующей линией польской историографии, идущей от Длугоша, согласно которой русские были некогда отколовшейся частью польского народа. Она же по своей логике препятствовала идеям противопоставления «русского» и «московского» народов как имеющих разное происхождение. Впоследствии эти идеи оказали большое влияние на работы Стрыйковского, Гваньини ${ }^{67}$ и других польских историков, а также западнорусских авторов XVII века. Однако господствующими в польской историографии раннего Нового времени они все же не стали.

\section{ПРИМЕЧАНИЯ}

1 О М. Бельском см.: Maciejowski W. A. Piśmiennictwo polskie, od czasów najdawniejszych aż do roku 1830. Warszawa, 1851. T. I. S. 393-413; Chrzanowski J. Marcin Bielski. Studium historyczno-literackie. Lwów; Warszawa, 1926; Ulewicz T. Sarmacja. Studium z problematyki słowiańskiej XV i XVI w. Kraków, 1950; Grygiel S. Próba rekonstrukcji zaginionej części Kroniki Bernarda Wapow- 
skiego // Studia źródłoznawcze. Warszawa; Poznań, 1964. T. LIX. S. 105-113; Рогов А. И. Известия по истории России в «Хронике всего света» Мартина Бельского // Новое о прошлом нашей страны. М., 1967. С. 123-133; Barycz H. Szlakami dziejopisarstwa staropolskiego: studia nad historiografią w. XVI-XVIII. Wrocław, 1981; Творогов О. В. Хроника Мартина Бельского [Исследовательские материалы для «Словаря книжников и книжности Древней Руси»] // Труды Отдела древнерусской литературы. Л., 1985. Т. 39. С. 169-171; Korolko M. Pionier sarmackiego dziejopisarstwa - Marcin Bielski // Pisarze staropolscy / Pod red. S. Grzeszczuka. Warszawa, 1991. T. 1. S. 439-473; Мыльников А. C. Картина славянского мира: взгляд из Восточной Европы. Этногенетические легенды, догадки, протогипотезы XVI - начала XVII в. СПб., 1996; Карнаухов Д. В. Концепции истории средневековой Руси в польской хронографии эпохи Возрождения. Новосибирск, 2010; Он же. История русских земель в польской хронографии конца XV - начала XVII в. Новосибирск, 2009; Спесивцева В. А. Первые два «века мира» в «Хронике всего света» Марчина Бельского // Вестник НГУ. Серия: История, филология. 2010. Т. 9. Вып. 1: История. С. 241-245; Флоря Б. Н. «Славяне» и «сарматы» в сочинениях польских историков конца XV - середины XVI века // Славянский альманах. 2017. № 1. С. 48-54; Флоря Б. Н. Мартин Бельский о древней истории славян и Польши // Славяноведение. 2017. № 2. С. 55-63.

2 О переводах сочинений М. Бельского и их значении для восточнославянских исторических текстов см.: Пташиикий С. Л. Западнорусские переводы хроник Бельского и Стрыйковского: (Библиографические занятия) // Новый сборник по славяноведению, изданный учениками В. И. Ламанского. СПб., 1905. С. 372-377; Ptaszycki S. Ruskie przekłady kronik Bielskiego i Stryjkowskiego. Karta z dziejów promieniowania kultury polskiej na wschód // Pamiętnik Literacki. 1933. № 3-4. S. 168-184; Лев В. Український переклад Хроники Мартина Бельского // Праці Українського наукового інституту. Варшава, 1935. T. 29. Кн. 4; Yarmolinsky A. Studies in Russian Americana: II. The Translation of Bielski's Chronicle (1584) // Bulletin of the New York Public Library. 1939. Vol. 43. № 12. P. 895-900; Procházková H. Po stopách dávného prátelství. Kapitoly z českoruských literárních styků do konce 17. století. Praha, 1959. S. 57-69; Sielicki F. Kronikarze polscy w latopisarstwie i dawnej historiografii ruskiej // Slavia Orientalis. 1965. № 2. S. 157-162; Казакова Н. А. Полные списки русского перевода «Хроники всего света» Марцина Бельского // Археографический ежегодник за 1980 год. М., 1981. С. 92-96; Бахтурина Р. В. «Космография» русской редакции XVI в. и «Хроника всего света» Мартина Бельского // Древняя Русь и Запад. Научная конференция: Книга резюме. М., 1996. С. 148-150.

3 Kronika Polska Stanisława Chwalczewskiego. Warszawa, 1829. (Станислав Хвальчевский был переводчиком «Трактата» Меховского.) 
4 Полное название: Bielski M. Kronika wszytkyego swyata, na ssesc, Monarchie czterzy rozdzielona, s Kozmographia nowa y z rozmaitemi Krolestwy tak pogańskimi Zydowskyemi yako y krzesćiańskyemi, s Sybillami y proroctwy ich po polsku pisana s figurami. W ktorey też żywoty Cesarskye, Papyeskye, y thych królów z ich Krolestwy, Asyryskich, Egipskich, Żydowskich, Greckich, Perskich, Tureckich, Węgyerskich, Czeskich, y inych rozmaitych thak Krolow, Kxyążat, yako inych przełożonych od początku swyata aż do thego roku ktory się pisze 1551 są napisane. Myędzy ktoremi też nasza Polska na ostatku zosobna yest wypisana. Kraków, 1551. (Далее - Bielski M. Kronika-1551.)

5 Полное название: Bielski M. Kronika Wssythyego swyata na ssesc wiekow a na czwory księgi takiez Monarchie rozdzielona, rozmaitych historij, tak w swyętym pismye yako w prostym, s Kosmografia nową y rozmaitemi krolestwy, tak pogańskimi żydowskimi, yako krzesciyanskimi: w ktorey też żywoty Papyeskye, Ceserskye, y królów inych takyeż Ksyażat, od początku aż do tego roku który sye pisse 1554 . Myedzy ktoremi też nassa Polska yest z osobna położona, y swyata nowego wypisanye. Dostatecznyey niż pirwssa s pisans y pilnyey figurami ochędożnemi Cum gratia et privilegio. Drukowano w Krakowie. 1554. (Далее - Bielski M. Kronika-1554.)

6 Полное название: Bielski M. Kronika tho iesth, Historya swiátá ná sześć wiekow, a cźterzy monárchie, rozdźielona z rozmáitych Historykow, tak w swiętym piśmie krześćijáńskim, żydowskim, iako y pogáńskim, wybierána y ná polski ięzyk wypisána dosthathecźniey niż pierwey, s przydánim wiele rzeczy nowych: od pocźątku swiátá, áż do tego roku, ktory się pisze 1564: s gurámi ochędożnymi y własnymi. Drukowano w Krakowie, 1564. (Далее — Bielski M. Kronika-1564.)

7 Kronika Polska Marcina Bielskiego. Nowo przez Joach. Bielskiego syna iego wydana. Cum gratia et priuilegio S.K.M. W Krakowie, 1597.

8 Флоря Б. Н. Мартин Бельский о древней истории славян и Польши. С. 57.

9 Программа ОИФН РАН «Исторические корни этноконфессиональных конфликтов в славянских странах. Средние века - начало Нового времени».

10 Флоря Б. Н. Мартин Бельский о древней истории славян и Польши. С. 55-63.

11 Bielski M. Kronika-1564. L. 338v.

12 Ibid. L. 335v.

13 Bielski M. Kronika-1551. L. 154v.

14 Флоря Б. Н. Мартин Бельский о древней истории славян и Польши. С. 59.

15 Людвик Деций в этой части своего сочинения «De vetustatibus Polonorum» (1521) следовал «Вандалии» немецкого историка Альберта 
Кранца (1519 г. изд.), в котором славяне объявлялись потомками второго сына прародителя немцев Туискона - Вандала.

16 Bielski M. Kronika-1564. L. 335.

17 Ibid.

18 См.: Флоря Б. Н. Бернард Ваповский о древней истории славян и Польши // Славянский альманах. 2016. № 3-4. С. 38-45.

19 Bielski M. Kronika-1554. L. 6v.

20 Bielski M. Kronika-1564. L. 7.

21 Stryjkowski M. Kronika Polska, Litewska, Żmudzka i wszystkiej Rusi (1582). Warszawa, 1846. S. 101.

22 Bielski M. Kronika-1564. L. 335v.

23 Ibid. L. 336.

24 Ibid. L. 170v.

25 Ibid. L. 336v. Под «Москвой» здесь скорее понимается страна, а не город.

26 Ibid. L. 170v.

27 Ibid. L. 338v.

28 Ibid. L. 335.

29 Азовское море.

30 Bielski M. Kronika-1564. L. 335.

31 Ibid. L. 286v.

32 Ibid.

33 «Było między nimi dość Rusakow, Ulanow, Moskwie, Gepidow, Lithwy, Swedow, Duńczykow, Tatharow, Prusow y drugich».

34 Ibid. L. 337.

35 Ibid.

36 Ibid. L. 336v.

37 Ibid.

38 Ibid. L. 159.

39 Ibid. L. 336v.

40 Ibid. L. 159.

41 Ibid. L. 318.

42 Ibid. L. 336v.

43 Ibid. L. 337.

44 Ibid. L. 336.

45 Ibid. L. 337.

46 Ibid. L. 337v.

47 Текст Грамоты приведен на 1. 337v-338. Она содержится и в первом издании, см.: Bielski M. Kronika-1564. L. 157v.

48 Ibid. L. 338. 
49 Ibid.

50 Ibid. L. 339-339v.

51 Ibid. L. 318.

52 Ibid. L. 336.

53 Ibid. L. 336v.

54 Ibid. L. 336-336v.

55 Ibid. L. 286v.

56 Ibid. L. $438 \mathrm{v}$.

57 Ibid. L. 318.

58 Ibid. L. 427.

59 Ibid.

60 Ibid. L. 336.

61 См. подробный разбор сведений по русской истории, представленных у Бельского, в главе «История русских земель в трудах Марчина и Иоахима Бельских» в кн.: Карнаухов Д. В. История русских земель в польской хронографии конца XV - начала XVII в. Новосибирск, 2009. С. 97-122.

62 Bielski M. Kronika-1564. L. 427v.

63 Ibid. L. 426v.

64 Ibid. L. 427.

65 Ibid.

66 Ibid. L. 430.

67 См.: Неменский О. Б. Праистория славян в «Хронике Европейской Сарматии» Александра Гваньини // Вертоград многоцветный. Сборник к 80-летию Б. Н. Флори. М., 2018. С. 397-408.

\section{O. B. Nemenskiy}

Slavic prehistory in the third edition of Marcin Bielski's "Universal Chronicle"

The article is dedicated to the information on the early history of Slavs from the Universal Chronicle by Marcin Bielski ( $3^{\text {rd }}$ edition, 1564). Special attention is given to Bielski's view of such issues as the origin of Slavs, their characteristic features, geographic localization of their ancestral lands and subsequent migrations, and the story of their partitioning into separate peoples.

Keywords: Marcin Bielski, Polish chronicles, 16th century, Bernard Wapowski, Slavs, Sarmatism, Roksolans, Goths, Vandals, biblical genealogy. 


\section{О переписке двух гетманов: М. Паца и И. Самойловича}

В статье рассматривается переписка великого гетмана литовского М. Паца и украинского гетмана И. Самойловича за 1677-1678 гг., когда стороны обменивались важной внешнеполитической информацией, способствуя поддержанию доверия в отношениях М. Паца и русского правительства в условиях острой конфронтации между Россией и Османской империей. Ключевые слова: Великое княжество Литовское, украинское гетманство, Россия, Польша, Османская империя.

DOI: $10.31168 / 2073-5731.2018 .3-4.1 .02$

В политической жизни Восточной Европы украинское гетманство было новообразованием, возникшим в результате восстания против Польско-Литовского государства его жителей, не принадлежавших ни к социальной, ни к политической элите. Разумеется, в разных ситуациях властям Речи Посполитой приходилось поддерживать контакты с властями гетманства. После его разделения в 1660-х гг. подобные связи поддерживались и с левобережным, и с правобережным казацкими политическими образованиями.

В практике левобережного гетманства 70-х гг. XVII в. такие контакты заметно оживились, когда актуальным стал вопрос о «случении» армий России и Речи Посполитой для совместной борьбы с османами. Кроме того, периодически возникала необходимость улаживать разного рода пограничные инциденты. Контакты эти, однако, четко ограничивались поставленными целями и не выходили за официальные рамки. Фоном для них служило напряжение, существовавшее в отношениях между казачеством и властями Речи Посполитой, которое не ослабевало с течением времени. Неслучайно в одном из очередных проектов русско-польского союза того времени, который был подготовлен в Москве, предусматривалось обязательство польско-литовской стороны, чтобы при соединении армий Войску Запорожскому «укоризны и бесчестия никакова не чинили» и наказывали виновных в таких поступках ${ }^{1}$. В этой общей картине существенно иное место занимают контакты украинского гетмана Ивана Самойловича с литовским великим гетманом и первым светским сенатором Великого княжества Литовского — виленским воеводой Михаилом Пацем. Об этом 
определенно говорит самое раннее известное в настоящее время свидетельство об этих контактах. В конце 1675 г. И. Самойловича посетил один из доверенных слуг М. Паца, Богдан Ратомский, и «в тайне наодине» передал просьбу литовского гетмана оказать ему военную помощь, «когда бы имел сопротивитись королевского величества хотению»². Такая просьба явно говорит о близком, доверительном характере контактов двух гетманов, а сами они, очевидно, были установлены значительно ранее указанной даты. Этот важный факт также позволяет предположить, что Пац и Самойлович поддерживали между собой регулярную связь.

Упоминания о такой переписке и доверительных контактах встречаются в ряде грамот И. Самойловича 1676 г. Так, в грамоте царю от 30 июня 1676 г. говорится о «листе», который прислал к нему М. Пац «с нарочным своим человеком с Керножитцким» ${ }^{3}$. А в декабре 1676 г. он сообщал царю о приезде к нему Б. Ратомского с «листом» от литовского гетмана 4 .

Свидетельствуя о существовании такой переписки, эти упоминания, однако, не раскрывают ее содержания. Лишь за следующие два года - 1677-1678 гг. - подобные тексты уже присутствуют в собрании корреспонденции И. Самойловича, когда он постоянно пересылал в Москву в Малороссийский приказ письма, которые получал и отправлял. Среди них находились и послания М. Паца И. Самойловичу и ответы на них со стороны левобережного гетмана.

В составе коллекции сохранилось письмо Б. Ратомского от 13 октября 1677 г. из Могилева И. Самойловичу. В нем говорилось, что, долго не получая писем от левобережного гетмана, М. Пац обратился к нему с посланием, которое он и пересылает И. Самойловичу. Письмо Ратомского заканчивалось обещанием, что, находясь в Могилеве, он готов способствовать регулярной корреспонденции обоих гетманов $^{5}$. Таким образом, переписка возобновилась по инициативе литовской стороны, желавшей ее регулярного продолжения.

В письме, отправленном из Вильно 14 сентября 1677 г. $^{6}$, М. Пац желал своему «брату» «сердцем християнским» победы над османами и просил сообщить о «повождении» русских и казацких войск. Такая просьба была вполне естественной в условиях, когда стало известно об отступлении османов от Чигирина. В послании также выражалось желание поддерживать постоянный обмен письмами. Литовский гетман писал, что «лутче бы было временным совокуплением сил обоих тех великих государств противитися, нежели розно ту тяготу понесть». Появление этого замечания в коротком письме М. Паца понятно, так как гетман, судя по материалам его сношений с Россией, был сторонником 
союза России и Речи Посполитой против османов и, вероятно, контакты с Самойловичем были одним из способов влияния на русскую внешнюю политику в этом вопросе. Характерно, что на краткое замечание М. Паца последовал пространный ответ И. Самойловича в письме от 21 октября 1677 г. Сообщая литовскому гетману о победе над османами, когда они отступили, бросив «мало не все свои тягости воинские», И. Самойлович писал, что, по его мнению, соединение сил «имело быти потребно и прибылно», и он не знает, «для чего не пришло столь надобное дело к совершению». Вместе с тем в его письме читаются слова и о том, что имеет место «в господах иных препона немалая нам». Учитывая, что литовский гетман находился в политической оппозиции королевскому двору, можно видеть в этой фразе замаскированный выпад по адресу польского монарха Яна III Собеского. Вместе с тем И. Самойлович подчеркивал, что теперь для союза сложились более благоприятные условия, чем прежде. Если раньше русские войска не могли пойти в поход «в польские дальние города», имея в тылу такого врага, как правобережный гетман П. Д. Дорошенко, то теперь это препятствие устранено. В заключительной части письма левобережный гетман выражал желание продолжать контакты и посылать литовскому коллеге интересующие его сведения. К письму было приложено «описание бою турского под Чигириным» ${ }^{8}$. И. Самойлович просил позволения царя продолжать переписку с М. Пацом, и 19 ноября Федор Алексеевич разрешил ему делать это «по своему разсмотрению» ${ }^{9}$ В письме из Вильно от 22 октября 1677 г. М. Пац поздравлял И. Самойловича с победой, одержанной «воинским милости твоим, моего милостиваго господина, промыслом ${ }^{10}$. Уже 7 ноября И. Самойлович получил это письмо и благодарил за поздравления ${ }^{11}$.

Затем в корреспонденции наступил перерыв, который заполнили контакты Самойловича с Б. Ратомским. 11 января н. ст. 1678 г. он писал левобережному гетману из Могилева ${ }^{12}$, передавая извинения М. Паца, что он «сам не пишет». Гетман, — писал Б. Ратомский, желает «крепкой братской надежности и хочет до конца совершать ее с твоею милостию». Он выражал надежду, что османы не возьмут верх над Россией и Речью Посполитой, «когда ваша милость оба с собою ссылатися и одно держати будете».

Б. Ратомский сообщал, что гетман напишет И. Самойловичу «по комиссии». «Комиссия», как известно, собиралась осенью 1677 - в начале 1678 г. для выплаты жалованья литовскому войску и его роспуска ${ }^{13}$. Представляет интерес, что сообщал о «комиссии» в своем письме именно Б. Ратомский. Он писал, что «королевское величество конечно того хочет», но гетман, «усматривая добро обоих тех наро- 
дов», этих военных «не отставит и продержит до весны, смотря куды дела наклонятца». Тем самым Б. Ратомский давал понять, что М. Пац вопреки желаниям короля не распускает литовскую армию, и это соответствует интересам России и Литвы.

В письме от 9 января 1678 г. И. Самойлович сообщал литовскому гетману важные сведения ${ }^{14}$. В Батурин пришли «ведомости», что «на весну» ожидается новый поход османов на Чигирин, и русская сторона готова «учинить отпор». Говорилось в письме и о том, что запорожские казаки в Сечи «о всякой помощи и о совете приклоняютца». Письмо И. Самойловича М. Пац получил в Жемайтии, куда он поехал собирать войска для возможных военных действий против шведов ${ }^{15}$. Свой ответ он отправил украинскому гетману из Байсогалы 15 февраля 1678 г. $^{16}$ М. Пац благодарил его за то, что «обыкло подерживаеш приятство», и желал победы над «бусурманами». «С нашей стороны, - писал литовский гетман, - любезный мир и христианская сохраняется дружба».

Это письмо И. Самойлович получил нескоро, и причины задержки остаются неясными: в сопроводительном письме Б. Ратомского от 22 мая 1678 г. ${ }^{17}$ отмечено лишь, что это произошло «не без подлинной причины». Позднее мешала весенняя распутица. В письме Ратомского краткие высказывания литовского гетмана получили ряд комментариев. Так, он передавал просьбу гетмана «в нынешних воинских делех ссылатися о всем, что належит к добру обоих государств». Наряду с этой просьбой письмо слуги литовского гетмана содержало и важные заверения. От имени Паца Ратомский убеждал Самойловича, «дабы никакой помешки и разврату в нынешней толикой войне от войск наших не опасались». Воевода виленский «с-ыными господами к тому радение приложить имать, как бы никакова нарушенья не было». В условиях, когда начиналась новая военная кампания и армия османов снова двигалась к Чигирину, а в Москву приходили сообщения о тайном союзе Яна Собеского с османами, эти заверения имели важное значение. Об этих обещаниях гетман И. Самойлович поспешил сообщить царю Федору в грамоте от 28 июня ${ }^{18}$. Еще ранее, 10 июня 1678 г., он отправил М. Пацу ответное письмо ${ }^{19}$, в котором сообщал о сборе войск для борьбы с османами, «которые давно в таковой бы бывали силе», и выражал радость по поводу того, что литовский гетман одобряет «отпорное намерение» царя и обещает сохранить мир «усердно сим благоприветствованием нас подкрепляеш».

Летом 1678 г. обрывается коллекция документов, содержащая сведения о переписке двух гетманов. В ней с большой полнотой отразилась корреспонденция И. Самойловича за конец 1677 — первую половину 1678 г. 
Знакомство с ней показывает, что за указанное время левобережный гетман обменивался посланиями и с коронными гетманами Дм. Вишневецким и Ст. Яблоновским, которым также было отправлено сообщение о неудаче османов под Чигириным. «За ту ведомость» они благодарили Самойловича в ноябре 1677 г. $^{20}$, но никаких посланий, которые носили бы признаки доверительных и дружественных контактов украинского гетмана с Вишневецким и Яблоновским, как и с другими коронными и литовскими политиками, в составе собрания не обнаруживается.

Чем объяснить появление и сохранение доверительных дружественных контактов между украинским и литовским гетманами? Наверное, окончательный ответ на этот вопрос можно будет дать после находки новых документов указанной переписки, но некоторые соображения можно высказать уже сейчас. Михаил Пац был не только единственным из крупных политиков Речи Посполитой, который поддерживал постоянные контакты с Самойловичем. Он был также единственным влиятельным вельможей Польско-Литовского государства, который рассчитывал укрепить свое положение и положение Великого княжества Литовского в Речи Посполитой благодаря соглашениям с Россией и старался поддерживать доверительные контакты с русским правительством. Связи с Самойловичем являлись в таком контексте и важным дополнительным каналом взаимоотношений, дававшим возможность через Самойловича влиять на русскую внешнюю политику.

Такие соображения имели, как представляется, важное значение и для Самойловича. М. Пац оказался важным источником информации для левобережного гетмана, давая ему возможности определенного влияния на внешнюю политику Польско-Литовского государства. Думается, что при этом имело значение то обстоятельство, что Великое княжество Литовское не воспринималось на Левобережной Украине как прямой опасный враг. В отличие от князей Вишневецких или Яна Собеского М. Пац не претендовал на какие-либо украинские земли.

Установление вышеописанных контактов было, как представляется, несомненным успехом украинского гетмана - сына священника, когда один из первых сенаторов Речи Посполитой именовал его «братом» и «приятелем» и выступал с инициативой возобновления корреспонденции и ее регулярного продолжения.

\section{ПРИМЕЧАНИЯ}

1 Российский государственный архив древних актов (далее РГАДА). Ф. 79 (Сношения России с Польшей). Кн. 195. Л. 125. 
2 См. об этом: Флоря Б. Н. Россия, Ян Собеский и гетман Михаил Пац в 1674-1675 гг. // Древняя Русь. Вопросы медиевистики. 2015. № 1 (59). C. $10-11$.

3 Акты, относящиеся к истории Юго-Западной России (далее АЮЗР). СПб., 1887. Т. 12. № 184. Стб. 662.

4 Там же. № 219. Стб. 831.

5 РГАДА. Ф. 229 (Малороссийский приказ). Оп. 2. Кн. 125. Л. 192об., 193.

6 Текст письма см.: Там же. Л. 191-192.

7 Текст письма см.: Там же. Л. 193об.-197.

8 Там же. Л. 197об. и сл. Опубл.: АЮЗР. СПб., 1885. Т. 13. № 88. Стб. 361-368.

9 РГАДА. Ф. 229. Оп. 2. Кн. 125. Л. 218.

10 Текст письма см.: Там же. Л. 366об.-367об.

11 Там же. Л. 367об.-368об.

12 Текст письма см.: Там же. Л. 434-435.

13 См. об этом: Bobiatyński K. Michał Kazimier Pac, wojewoda wileński, hetman wielki litewski. Warszawa, 2008. S. 362, 365-366.

14 РГАДА. Ф. 229. Оп. 2. Кн. 125. Л. 438-438об.

15 Bobiatyński K. Michał Kazimier Pac... S. 368-369.

16 Текст письма см.: РГАДА. Ф. 229. Оп. 2. Кн. 125. Л. 979-979об.

17 Текст письма см.: Там же. Л. 977-978об.

18 Там же. Л. 973об.-974.

19 Там же. Л. 989-992. Опубл.: АЮЗР. Т. 13. № 139. Стб. 607-610.

20 РГАДА. Ф. 229. Оп. 2. Кн. 125. Л. 503-504.

\section{B. N. Florya}

On the correspondence of two Hetmans: M. Pac and I. Samoylovych

The article is a study of correspondence of the Great Hetman of Lithuania M. Pac and Ukrainian Hetman I. Samoylovych, when they exchanged important information connected to foreign policy, supporting trustful relation between M. Pac and Russian government during the acute confrontation between Russia and Ottoman Empire.

Keywords: Great Duchy of Lithuania, Ukrainian hetmanship, Russia, Poland, Ottoman Empire. 
С. М. Фалькович

(Москва)

\title{
Исторические основы одного из главных национальных праздников Республики Польша - Дня Конституции 3 мая
}

\begin{abstract}
В статье рассматривается история официального праздника современной Польши - Дня Конституции 3 мая в контексте политических течений среди польской эмиграции XIX в. Автор характеризует различия, которые вкладывались в оценки этого события представителями демократического и консервативного лагерей польской эмиграции, показывает связь этих оценок с наиважнейшими вопросами ее общественной жизни в рамках дискуссий о путях и средствах возрождения Польского государства. Ключевые слова: Конституция 3 мая 1791 г., официальные праздники Республики Польша, Королевство Польское, Адам Чарторыский.
\end{abstract}

DOI: $10.31168 / 2073-5731.2018 .3-4.1 .03$

Каждое государство имеет свои официальные праздники, которые отмечаются ежегодно. Обычно это важные для страны и ее народа даты происходивших в прошлом событий. Каждый год отмечает такие даты и Польша, и вполне понятно, что среди праздников одно из первых мест занимает годовщина возрождения Польского государства из небытия в ноябре 1918 г. — дата рождения Республики Польша. Но есть ежегодный праздник, который, казалось бы, уносит нас в глубокое прошлое, ко дню 3 мая 1791 г. Это день принятия так называемым Четырехлетним сеймом, заседавшим в Польше в 1788-1792 гг., новой конституции. К этому времени польско-литовское государство под названием Речь Посполитая обоих народов значительно ослабло и подвергалось атакам соседних государств, результатом чего стал в 1772 г. первый раздел Польши между Россией, Австрией и Пруссией.

Главной целью работы Четырехлетнего сейма было принятие политических и социальных реформ, которые укрепили бы и сохранили Речь Посполитую. Реформы начались с увеличения численности армии, затем были нацелены на известное укрепление власти короля и ослабление магнатерии, на усиление позиций имущих слоев общества - поместной шляхты и мещанства: в частности, были расширены права городов. Провозглашалось также принятие крестьян под опеку государства и права, но рамки этой опеки были весьма ограничены и 
касались только договорных отношений с помещиками. В целом подтверждался шляхетский характер государства, сохранялись также преимущества католической веры, хотя и были сделаны определенные уступки православию, а евреи получили право личной неприкосновенности. Важнейшее внимание было уделено урегулированию будущих взаимоотношений «обоих народов», то есть Польши и Литвы. Шли споры вокруг проектов создания федеративного или унитарного государства: сторонники сплочения старались сохранить унитарное единство, тем не менее принятые вслед за Конституцией «Взаимные обязательства обоих народов» создавали возможность для подтверждения равноправности Великого княжества Литовского с Польской короной ${ }^{1}$.

Все эти важнейшие преобразования должны были получить развитие и продолжение в дальнейшем, но этот процесс оказался прерванным агрессивными соседями: в 1792 г. произошло вторжение в Польшу российской армии и состоялся второй раздел территории Речи Посполитой, а в 1795 г. она окончательно прекратила свое существование в результате нового, третьего раздела между Пруссией, Австрией и Россией. В течение 123 лет польского государства не было вообще, если не считать созданного под эгидой Наполеона I Княжества Варшавского (не имевшего определения «Польское») и Королевства Польского - части Российской империи, существовавшей на конституционной основе в 1815-1831 гг.

Все эти годы мысль о своем государстве не покидала поляков, и они вели борьбу за его восстановление. При этом воспоминания о нем, связанные с Конституцией 3 мая 1791 г., находили проявление в том, что день 3 мая стал его символом и ежегодно отмечался как важнейший праздник. Отмечать его открыто под чужеземной властью было невозможно, но за границей торжественное празднование этой даты входило в постоянный политический ритуал многотысячной польской политической эмиграции. А поскольку внутри нее существовали различные идейно-политические течения, каждое из них делало акцент на близкие ему стороны Конституции.

Так, консервативная партия, сформировавшаяся в Париже вокруг резиденции князей Чарторыских под именем Отеля Ламбер, в первую очередь ценила шляхетский характер государства, провозглашенного и утвержденного Конституцией 1791 г. Ее сторонники подчеркивали, что «народ породил шляхту из своего лона», а в речи 3 мая 1834 г. на праздновании годовщины Конституции Адам Чарторыский заявил, что «шляхта никогда не была врагом цивилизации и полезных реформ и не оказывала противодействия прогрессу в интересах касты», а напротив, «всегда подавала пример бескорыстной преданности родине», «использовала свой 
высокий ранг в стране, чтобы проявить инициативу во всех улучшениях, искренне предложить благо и последовательно его осуществить».

В документах, направленных правительствам западных держав после подавления царизмом польского восстания 1830-1831 гг., князь подчеркивал, что все права, провозглашенные Конституцией Королевства Польского в 1815 г., поляки уже имели в Конституции 1791 г. Он заявлял о признании принципов Конституции 3 мая как «последнего искреннего выражения политической воли всей давней Польши, способного принять всякие усовершенствования, необходимость которых показал опыт». На базе этих принципов Отель Ламбер сформулировал программу восстановления Польши как конституционной монархии, опирающейся на имущественную основу, т. е. создания единого сильного правительства, установления равенства граждан перед законом, обеспечения свободы личности, слова, вероисповедания, а также гарантии «святой и неприкосновенной собственности». В том числе предполагалось предоставить собственность крестьянам «при обеспечении приобретенных прав», то есть гарантировать собственность свободных сельских хозяев, а «тем, кто еще в неволе, дать свободу и собственность» ${ }^{2}$.

Эти идеи распространяли находившиеся в сфере влияния Чарторыских действовавшее в Париже Историческое общество и другие эмигрантские организации, в частности лондонское Литературное общество друзей Польши. В периодической печати консерваторов («Feniks», «Kronika emigracji polskiej», «Kraj i emigracja») подчеркивалась необходимость сохранить главные ценности, унаследованные из прошлого, - свободу, «безопасную для всех под сильным постоянным правительством», равенство, моральные устои, веру. Наилучшим строем для их сохранения называлась конституционная монархия. Сами князья Чарторыские не заявляли претензий на польский престол, но об их династических интересах можно было судить по обстановке «почти монаршей важности», которая ощущалась в их парижской резиденции. Пресса же Отеля Ламбер весьма активно пропагандировала эту идею. Поддержать ее должно было и название газеты «Trzeci Мај», напомнив о Конституции 1791 г.

В кругу сторонников Отеля Ламбер сложилась группа так называемых династиков, которые хотели заложить в эмиграции основу польской королевской династии во главе с А. Чарторыским в качестве короля «дефакто». Они утверждали, что «монархическая идея является польской», а «Польша пала потому, что не имела < .. > сильной власти», ее нужно восстановить, создав польскую католическую монархию. В связи с этим в 1837 г. на собрании Союза национального единства Я. Воронич выдвинул идею наследственной власти фамилии Чарторыских. «Династии являют- 
ся провидением нации. Польша имеет династию де-факто», - заявил он, провозгласив: «Да здравствует король Адам I!» Газета «Trzeci Мaj» в 1840 г. предупреждала, что без короля новое восстание грозит гибелью, a В. Замойский в брошюре «Вопрос о династии и монархии в Польше» (1839), утверждая о необходимости короля для Польши, подчеркивал, что А. Чарторыский «является живым представителем польской мысли» в глазах народа и Европы. Созданное тогда же Общество учредителей и друзей 3 мая пропагандировало мысль о том, что национальная династия Чарторыских — это обязательное требование для проведения восстания. Общество нашло поддержку европейского общественного мнения: в брошюре французского журналиста Ф. Кольсона (1841) говорилось о соответствии формы конституционной монархии специфике Польши, a eе персонификацией является князь Адам. Кольсон подчеркивал, что наличие национального короля создаст единство и обеспечит успех восстания, а Чарторыский — наилучшая кандидатура на роль «верховного и абсолютного правителя Польши» ${ }^{3}$.

Под давлением «династиков» князь Адам неофициально принял титул и в речи 29 ноября 1841 г., напоминавшей речь главы государства, вновь говорил, что отсутствие сильной власти стало причиной падения Польши. Эту позицию одобряли и некоторые представители демократической эмиграции, как например М. Мохнацкий, который, опираясь на Конституцию 1791 г., утверждал факт единства польского общества. «У нас массам, — заявлял он, — не требуется ничего ни у кого насильно отнимать, потому что все принадлежит им по праву, и по праву, не завоеванному силой, а добровольно, по-братски утвержденному меньшинством в пользу большинства». Что же касается кандидатуры князя Адама на польский престол, он поддержал эту идею4.

Однако консерваторам пришлось все же отказаться от своих планов, так как в их рядах не было единства по этому вопросу, а главное, против них выступил весь демократический лагерь. Самым ярким стало выступление Т. Кремповецкого, показавшего, что ни одна из польских конституций, в том числе и Конституция 1791 г., не предоставляла политических прав крестьянам, эти права и собственность имела лишь шляхта. В. Гельтман же, перечисляя грехи князя Адама за 60 лет, заявил, что его персона — это воплощение «ржавчины, которая в течение столетия точила сталь национального характера» 5 .

Тем не менее Чарторыские не отказались вовсе от претензий на руководство, и 3 мая 1854 г. князь Адам, сославшись на доверие европейских правительств и «услуги, оказанные в течение долгой жизни», заявил свое право на «пост, исполнение власти на котором может быть полезно 
и эмиграции, и будущей судьбе Польши». Он был готов, однако, в случае благоприятного разрешения судьбы Польши при помощи европейских союзников «обеспечить услуги и поддержку» какому-нибудь «принцу из царствующих династий», пожелавшему «встать на польскую основу» ${ }^{6}$.

В дальнейшем надежды Отеля Ламбер были связаны с ожиданием реформ в государствах, включавших польские земли, с расчетом на предоставление полякам национального самоуправления. Он пропагандировал путь легальной «органической» работы как путь, ведущий к свободе, и это отразилось в выступлениях консерваторов конца 1850 -х гг. Последним отзвуком претензий «фамилии» на руководство делами Польши явилась речь сына князя Адама - Владислава Чарторыского 3 мая 1861 г., а заключительным аккордом стали политическое завещание самого князя Адама, опубликованное летом того же года, и его похороны, проходившие с королевским размахом

Демократическая эмиграция отвергала восприятие таких ценностей Конституции 3 мая, как ее шляхетский характер, или, например, католическая монархия. Она ценила этот документ за иное - за провозглашение демократических принципов. Как писала газета «Demokrata Polski», «патриарх демократии Лелевель осмыслил прошлое польской истории на основе Конституции 3 мая». В. Гельтман не уставал напоминать: «Демократия - это наша родная идея, возникшая на родной земле много веков назад, и в течение веков ее кормили и пестовали, ее мощи мы были обязаны всем блеском нашего народа, а ее нарушению - ее упадком; в ней наше прошлое, а тем самым и наше будущее». В Конституции 3 мая демократы видели «принцип всемогущества люда» как основы «всякой политической реформы» и основного условия в борьбе за независимость. Что касается шляхты, разъяснялось, что не вся она плоха, «но зло лежит в ее основе, в самой шляхетской системе», и потому шляхетская Речь Посполитая была «отвратительной». Но само государство, существовавшее века, подчеркивали демократы, должно быть восстановлено, так как «народ истребить нельзя». «Не погибли наш язык, обычаи, религия, - говорилось в воззвании Польского национального комитета 25 июля 1831 г., — не погибла память о нашем величии, о польской власти над теми, кто ныне угнетает нашу родину». В обращении Комитета к английской Палате общин выдвигалось требование восстановления Польши в границах 1772 г. Такое же требование содержалось в протесте, направленном Польским демократическим обществом 8 мая 1832 г. по тому же адресу. Восстановление Польского государства в прежних границах стало целью национальной борьбы, вспыхивавшей на польских землях ${ }^{8}$. 
Характерно, что в вопросе о границах будущей Польши не было существенных различий в позиции аристократической и демократической эмиграции. Сторонники Чарторыских, выдвигая лозунг восстановления Польши в границах 1772 г., требовали включить в нее территорию Приднепровской Украины. Их орган «Wiadomości Polskie» писал, что она, «завоеванная и обороняемая польским оружием, населенная тем же самым народом, который породил шляхту из своего лона, есть и, Бог даст, не перестанет быть польской провинцией». Консерваторы не признавали права на самоопределение украинцев и литовцев и мысль об отдельной литовской национальности называли «болезнью, коснувшейся слабых голов» или родившейся в «преступных умах», призывая полностью ополячить литовское крестьянство

Не так агрессивно, но столь же безоговорочно на включении Украины, Белоруссии и Литвы в границы будущего Польского государства настаивали и демократы. А. Жабицкий подчеркивал, что «требование целостности Польши в дораздельных границах превратилось в фанатизм»; выдвигалась задача «восстановления Польши от Карпат до Днепра, от Балтики до Черного моря». Я. Н. Яновский указывал, в частности, что исторические границы Польши времен Ягеллонов включали также Курляндию и Малороссию с Киевом. Признание национальной самобытности украинцев и их права на национальную самостоятельность называлось «самоубийством» и «государственной изменой», так как подчеркивалось, что в прошлом Украина являлась неотъемлемой частью Польского государства, и этот факт был закреплен в Конституции 3 мая. «Польша, когда была живой и сильной, - утверждал 3. Милковский, — абсорбировала народы, объединялась с ними $<\ldots>$ во имя братства и свободы» ${ }^{10}$.

Вопрос о территориальном «единстве» Польши стал особенно острым в связи с выдвижением русской революционной эмиграцией тезиса о праве наций на самоопределение и включением этого тезиса в договор между варшавским Центральным национальным комитетом, готовившим восстание в Польше, и русской революционной организацией «Земля и воля». Демократическое польское коло отозвалось на это с возмущением: «Русь (т. е. Украина. - C. Ф.), Литва и Польша так срослись в неразрывное целое, что их ожидает или воскресение в виде нации, соединенной старыми узами, или вечное рабство в цепях угнетателей». «Пока либеральная Россия < .. > не пожелает воскресения всей Польши в дораздельных границах $<\ldots .>$, — заявлял печатный орган кола, — до тех пор мы, поляки, не можем идти с ней вместе рука об руку» ${ }^{11}$.

В кругу демократической эмиграции наиболее резко по этому вопросу выступал генерал Л. Мерославский. «Нашим идеалом, — заявил он, - 
является Польша нераздельная географически, единая в отношении социальных прав и политически всемогущая... Польша в границах 1772 г., ибо столько нужно этому государству пространства и воздуха, чтобы его существование, закрепленное и гарантированное, осталось нерушимым при всех опасностях и случайностях» ${ }^{12}$. Ведя переговоры с М. А. Бакуниным, генерал надеялся добиться от русских революционеров уступок в вопросе будущих границ Польши, требуя их гарантий. Он возмущался упомянутым договором Центрального национального комитета с «Землей и волей» и, выражая надежду, что «щедрость» ЦНК получит историческое возмездие, заявлял русским революционным эмигрантам: «Между нами или Польша 1772 г., Польша до разделов, или беспрестанная война». Так как переговоры с Бакуниным закончились безрезультатно, Мерославский, клеймя «позорную» позицию ЦНК, согласного на «расчленение» своего отечества, одновременно выдвинул против русских революционеров обвинения в «претензиях на дюжину воеводств польской республики», в том, что они приняли этот «дар из рук нескольких интриганов» ${ }^{13}$.

Правда, в кругу польских демократических эмигрантов были и левые элементы, принимавшие тезис русских революционеров о праве наций на самоопределение, но их было меньшинство. В результате в польской эмиграции в целом получила преимущество ориентация на постановку национального вопроса в духе Конституции 3 мая 1791 г. Эта Конституция стала объединяющим звеном для большинства эмигрантов, несмотря на внутреннюю неоднородность эмигрантского лагеря, и потому дата 3 мая отмечалась им на протяжении всего периода отсутствия Польского государства вплоть до его обретения, став праздником новой Польской Республики.

\section{ПРИМЕЧАНИЯ}

1 См.: Bardach J. Konstytucja 3 maja i zaręczenie wzajemne obojga narodów 1791 roku // Konstytucja 3 maja 1791. Warszawa, 2001. S. 5-52.

2 См.: Фалькович С. М. Польская политическая эмиграция в общественно-политической жизни Европы 30-60-х годов XIX в. М.; СПб., 2017. С. 17, 34, 48, 193.

3 Там же. C. 19, 48, 84-86; Trzeci Maj. Paris, 24.VIII 1840; Colson F. De la Pologné et des Cabinets du Nord. Paris, 1841. P. 163-164.

4 Mochnacki M. Powstanie narodu polskiego w roku 1830-1831. Warszawa, 1984. T. 2. S. 251. См. также: Фалькович С. М. Польская политическая эмиграция... С. 48-49. 
5 Фалькович С. М. Польская политическая эмиграция... С. 86-87; Łukaszewicz W. Tadeusz Krępowiecki: żołnierz rewolucjonista. 1798-1847. Warszawa, 1954. S. 66-68; Heltman W., Janowski J. N. Demokracja polska na emigracji. Warszawa, 1965. S. 101.

6 Kieniewicz S. Historia Polski. 1795-1918. Warszawa, 1969. S. 205; Heltman W., Janowski J. N. Demokracja polska... S. 418-419. См. также: Фалькович С. М. Польская политическая эмиграция... С. 121-126, 145-146.

7 Фалькович С. М. Польская политическая эмиграция... С. 201.

8 Demokrata Polski. Paryż. 21.I 1841. S. 233-237; Heltman W., Janowski J. N. Demokracja polska... S. 16-17, 53-56, 70, 138-139, 141-143, 259; Фалькович С. М. Польская политическая эмиграция... С. 20, 25, 66-67.

9 Wiadomości Polskie. Paryż. 7.V.1858, 22.XI.1859. S. 58; Фалькович С. М. Польская политическая эмиграция... С. 193.

10 Фалькович С. М. Польская политическая эмиграция... С. 172-174, 222; Przegląd Rzeczy Polskich. Paryż; Łondyn. 7.I.1863. S. 3-13; 3.I.1858. S. 27; 14.X.1858. S. 22; 15.II.1859. S. 7, 10, 12-13, 16-20; 19.III.1859. S. 20 22; 28.I.1860. S. 3, 10; 1.IX.1861; 24.III.1862. S. 20; 3.V.1862. S. $2-3$.

11 Фалькович С. М. Польская политическая эмиграция... С. 247-248; Przegląd Rzeczy Polskich. 30.IX.1862. S. 11; 15.X.1862. S. 4-6; 15.XI.1862. S. 1-5, 7-8; 7.I.1863. S. 51.

12 Demokrata Polski. 22.II.1845. S. 113-114; Postępowa publicystyka emigracyjna. 1831-1846. Wybór źródeł. Wrocław, 1961. S. 538-547.

13 Bakounin M. Le Comité Central de Varsovie et le Comité Militaire Russe. Réponse au général Mieroslawski. London, 1862. P. 5-8; Mierosławski L. Pamiętnik (1861-1863). Warszawa, 1924. S. 70-71; Гериен А. И. Полное собрание сочинений и писем. Петроград, 1920. Т. 15. С. 601.

\section{S. M. Fal'kovich}

Historical grounds of one of the most important holidays of the Republic of Poland: May, 3rd, the Constitution Day

The article describes the history of the official holiday in contemporary Poland - May $3^{\text {rd }}$, the Constitution Day, in the context of political movements of Polish emigration of the $19^{\text {th }}$ century. The author characterizes the differences that were put into evaluations of this event by the representatives of the democratic and the conservative camps of Polish emigration. The connection of these evaluations with the most important questions of Polish social life is shown within discussions about ways and means of recreation of Polish state.

Keywords: the Constitution of May, 3rd, 1791, official holidays of the Republic of Poland, Kingdom of Poland, Adam Czartoryski. 


\title{
Л. М. Аржакова \\ (Санкт-Петербург)
}

\section{Группировка станьчиков как проявление (само)организа- ции краковских консерваторов, ориентированных на Вену}

\begin{abstract}
Статья посвящена характеристике основных задач группировки станьчиков. Отмечена специфика положения «австрийских» поляков под властью Австро-Венгрии, его отличие от положения «русских» поляков под властью Российской империи. Подчеркнуто значение, какое станьчики придавали занятиям польской историей и организации разнородной историко-культурной деятельности, одновременно с выражением лояльности Венской администрации. Ключевые слова: краковские консерваторы, станьчики, Михал Бобжиньский, национальное польское прошлое, падение Польии, польский вопрос.
\end{abstract}

DOI: $10.31168 / 2073-5731.2018 .3-4.1 .04$

Когда речь заходит о рассмотрении разнородных обстоятельств бытования Австро-Венгерской композитарной монархии, хотя бы в двух словах нельзя не вспомнить о предшествовавших попытках осмысления процесса исторической эволюции этой части Европейского региона. Без малого чем полвека назад (1972) о необходимости перехода от изучения проблематики развития южных и западных славян к изучению проблематики развития народов Центральной и Юго-Восточной Европы заявил И. С. Миллер ${ }^{1}$. Спустя еще четверть века была поставлена задача «раскрыть и всесторонне изучить» опыт длительного «сосуществования разных народов в рамках политэтничного государственного образования, каким была Габсбургская монархия» ${ }^{2}$ на основе комплексного анализа процессов социального, национального, историко-культурного характера, свойственных внутреннему развитию страны. Два десятилетия, прошедшие со времени постановки этой задачи, показали, что она не только последовательно и успешно решалась, но постепенно выходила на новый уровень, свидетельством чему служит внушительный пласт современной литературы вопроса ${ }^{3}$.

Статья написана при финансовой поддержке Программы фундаментальных исследований Президиума РАН № 0178-2018-0008 «Австро-Венгрия: механизмы (само)организации культурно-сложных сообществ в композитарной монархии». 
Однако в том, что касается польской части Австрийской (с 1867 г. Австро-Венгерской) империи, которая волею судеб оказалась под властью Габсбургов на особом положении, обусловленном как разделами Польши (когда даже «многие выдающиеся поляки считали, что после третьего раздела перестала существовать не только Польша, но и польский народ» ${ }^{4}$, так и очередной перекройкой территории былой Речи Посполитой на Венском конгрессе, приходится признать, что вплоть до настоящего времени степень изученности истории польских земель в составе Австрийской (Австро-Венгерской) империи остается в отечественной историографии недостаточной. И это при том, что в последние годы появились посвященные характеристике общественно-политической деятельности краковских консерваторов работы ${ }^{5}$, которые есть основания рассматривать, в том числе, в контексте сколь актуального, столь и популярного в современной исторической и философской мысли исследовательского направления, сконцентрированного на изучении природы консерватизма как идейного течения и явления общественной жизни. В то время как отечественные историки пребывают на начальном этапе постижения польской консервативной идеологии и практики XIX в., дела в польской и украинской историографии, где никогда не ослабевало подчеркнутое внимание к различным аспектам истории польско-украинских (украинско-польских) отношений, обстоят вполне благополучно 6 .

Объяснением некоторой отстраненности российской историографии от изучения теоретических основ и практической деятельности краковских консерваторов, сыгравших заметную роль в упрочении позиций польского общества в Австро-Венгерской империи, отчасти может служить сосредоточенность на роковом, по ставшему хрестоматийным определению Н. Н. Страхова, польском вопросе ${ }^{7}$, поискам разрешения которого была подчинена русская общественно-политическая и историко-философская мысль «длинного» XIX века. Развиваясь под воздействием обстоятельств преимущественно вненаучного характера, отечественная историографическая традиция, в свою очередь, оказывала немалое воздействие на восприятие польского вопроса соотечественниками. При этом, что важно подчеркнуть, здесь вряд ли возможно строгое разграничение между собственно исторической традицией, выработавшей особое отношение к польскому вопросу, и его осмыслением русским обществом, что находило свое выражение в произведениях художественной литературы и злободневной публицистике на протяжении более чем столетия. Состояние современной отечественной литературы вопроса свидетельствует о том, что задача 
уяснения характера разнородных взаимоотношений между собственно Российской империей и Королевством Польским вместе с детальным изучением механизмов внутреннего развития этого автономного образования, во многом сопряженная с поисками ответа на злободневный для русского общества XIX в. польский вопрос, не теряет научной актуальности ${ }^{8}$.

Своеобразие взаимоотношений между Империей и Королевством в значительной мере было обусловлено положениями Конституционной хартии Королевства Польского (1815). Уже в первой, взрывоопасной по своему смыслу, статье Конституционной хартии было безапелляционно прописано, что «Царство Польское навсегда присоединено к Российской империи» ${ }^{9}$. Это на десятилетия определило специфику русско-польских отношений и тягостным образом повлияло на положение всего разделенного польского народа. Если одна часть польского общества последовательно стояла за полное восстановление независимости Польши посредством вооруженного восстания, то их оппоненты, после тяжелых поражений Ноябрьского и особенно Январского восстаний, предпочли отказаться - как, пожалуй, излишне категорично ${ }^{10}$ выразилась польская исследовательница - «от стремлений к независимости» ${ }^{11}$. Но факт остается фактом, горький опыт польских восстаний 1830-1831 и 1863-1864 гг. подводил к выводу, что они стали «вулканическими взрывами», на которые было «потрачено непроизводительно множество живых сил, которые пригодились бы на иное дело» ${ }^{12}$, как выразился один из наиболее известных петербургских «угодовцев» (приверженцев сотрудничества поляков с Российской империей ${ }^{13}$ ), юрист, публицист, историк В. Д. Спасович. Вместе с тем нельзя не принимать во внимание примирительных настроений, свойственных польским повстанцам, заявлявшим, в частности, что «Польша не желает явной диктатуры, но помышляет о скрытой конфедерации петербургских и киевских панславистов с литовскими князьями, краковскими графами и варшавскими господами Велепольским и Замойским» ${ }^{14}$.

В галицийских реалиях всё обстояло иначе. Однако было нечто общее, что объединяло поляков «австрийских» и поляков «русских»: этим общим было прошлое. Разделяя мнение, что «XIX столетие стало “веком истории”», когда «история < .. > активно профессионализируется, превращаясь из любительского занятия в признанную академическую дисциплину» ${ }^{15}$, следует особо подчеркнуть, что польская историческая наука, даже точнее - сама польская история, национальное прошлое, - стали для поляков своего рода спасением от не 
обязательно враждебного, но все-таки чуждого политического, этносоциального, этнокультурного контекстов. Национальное прошлое оказалось тем прибежищем, где сохранялась национальная идентичность и утверждалась национальная самодостаточность, в конечном счете гарантируя возможность национальной (культурной, социальной, политической) самореализации.

Славное прошлое было тем объединяющим фактором, которому предстояло обеспечить разделенному польскому народу решение насущных задач настоящего, важнейшая из которых заключалась в процессе восстановления (пусть и неодинаково понимаемом) национальной независимости. В этом смысле весьма символично, что наступившую после 1795 г. эпоху польской истории выдающийся историк Иоахим Лелевель (1786-1861) назвал эпохой возрождения Польши, что выдает глубокий оптимизм восприятия им польского прошлого и предвидения польского будущего ${ }^{16}$. По признанию Лелевеля, его занятия историей всегда были подчинены целям политическим, а суть его концепции польской истории основывалась на убежденности в том, что «народ, который лишился нормального существования, ищет свое возрождение в обращении к прошлому, стремясь его воскресить и тем самым черпая в прошлом силы» ${ }^{17}$.

Однако в скрепляемом исторической и культурной памятью польском обществе не было единства мнений по поводу того, каким должно стать национальное будущее. Одни считали возможным достижение общей для разделенного польского народа цели только путем «восстановления территории страны» в границах 1772 г. $^{18}$ Как твердо заявлял активный участник Ноябрьского восстания Мауриций Мохнацкий, Польша всегда была «республикой земель коронных, литовских и русских. В ином составе и сегодня мы ее не понимаем! Вековая Польша в извечных своих границах» ${ }^{19}$. Другие, напротив, постепенно (но главным образом после разгрома польского восстания 1863-1864 гг. ${ }^{20}$ ) приходили к мысли о необходимости значительной корректировки идеологических и общественно-политических ориентиров, что должно было способствовать выработке механизмов действий, позволяющих наладить диалог между польским обществом и властными структурами тех государств, в состав которых волею судеб были включены польские земли.

Когда в 1860-е гг. в польском обществе в противовес повстанческой идеологии, доминировавшей в первой половине XIX столетия, была выдвинута идеология лоялизма (тройного лоялизма), обе стороны - собственно Габсбургская монархия и польская ее часть - были 
вынуждены искать компромиссные варианты обще-жития в одной империи. Группировка так называемых станьчиков, объединившая в своих рядах краковских консерваторов, разделявших и, что важно, активно проповедовавших среди соотечественников идею лояльности Венской администрации, громко заявила о себе в 1869 г., вскоре после образования дуалистической Австро-Венгерской монархии. Формализации этой политической группировки немало поспособствовал изданный на страницах журнала «Przegląd Polski» (1866-1914 гг.) политический памфлет под названием «Teka stańczyka» («Папка станьчика»)21. Уже в словосочетании «Teka stańczyka» угадывался исторический подтекст, где само слово «teka» пробуждало в памяти поляков «Teki Naruszewicza» («Портфели Нарушевича»), выдающийся свод исторических памятников (точнее, копий), созданный в эпоху польского Просвещения под руководством видного историка Адама Нарушевича и сыгравший заметную роль в упрочении польской исторической памяти. Образ реального Станьчика (ок. 1480-1560), придворного шута польских королей Александра Ягеллончика, Сигизмунда I Старого и Сигизмунда II Августа, который с давних пор воспринимался поляками как символ патриотизма, также поддерживал идею служения народу.

Группировка станьчиков не была политической партией в привычном понимании, но зато являла собой в полном смысле слова сообщество единомышленников, разделявших представления друг друга о благе отечества. Это единство мнений проявилось и в том, что политический памфлет «Папка Станьчика» - своего рода фирменный знак краковских консерваторов - был результатом коллективного творчества. Можно сказать, что в ходе создания памфлета проходил апробацию тот замысел, идеи которого выработали и развивали соавторы. Среди соавторов были такие видные польские интеллектуалы, деятели культуры своего времени, как историк, основатель Краковской исторической школы, он же - поэт и прозаик Юзеф Шуйский (1835-1883); историк, литературовед, профессор и ректор Ягеллонского университета Станислав Тарновский (1837-1917); историк, критик, театральный деятель Станислав Козьмян (1836-1922); видный общественный и политический деятель Людвик Водзицкий (1834$1894)^{22}$. Основная идея ставшего знаменитым памфлета (впрочем, как и многих других публицистических сочинений станьчиков) сводилась к необходимости лояльности польского общества по отношению к австро-венгерским властям - лояльности, гарантировавшей соблюдение польских национальных интересов в языковой, культурной, политической и экономической сферах. Соавторы памфлета, будучи 
приверженцами консервативной идеологии и того же направления политической практики, не спешили, впрочем, стать активными участниками политических баталий. Идеологическое и политическое представительство станьчиков в общественно-политической жизни Галиции успешно обеспечивал такой опытный политический игрок, как граф Людвик Водзицкий, не раз выступавший депутатом Галицийского краевого сейма, а в 1877-1880 гг. занимавший пост председателя Галицийского краевого сейма 23.

Другие станьчики видели свое предназначение главным образом в служении отечеству посредством налаживания, так сказать, «диалога со временем». Можно согласиться с тем, что «представления о прошлом варьируются в зависимости от исторического времени, от происходящих в обществе перемен, смены поколений, появления новых потребностей, практик и смыслов» ${ }^{24}$, и это наблюдение в полной мере применимо к контексту, в котором пребывали станьчики. Проблема, однако, заключается в том, что представления о прошлом при общем прошлом и общем к нему тяготении - могут оказаться различными в одно и то же историческое время у различных хранителей этого прошлого.

Это, в частности, нашло свое подтверждение в разделении польского исторического сообщества на Краковскую и Варшавскую исторические школы, схлестнувшиеся в споре по поводу причин гибели Речи Посполитой. Для обеих сторон, противостоящих друг другу, история являлась тем полем, на котором разворачивалась их реальная деятельность, одновременно обращенная в прошлое и устремленная — через настоящее — в будущее.

Случай с одним из виднейших представителей Краковской исторической школы Михалом Бобжиньским (1849-1935), известным, помимо прочего, как депутат сеймов и наместник Галиции (1908-1913), также принадлежавшим к стану краковских консерваторов, подтверждает, что достаточно смелая, но, главное, выходившая за привычные рамки трактовка общего прошлого не могла гарантировать полного понимания со стороны соотечественников, оберегающих это прошлое и протестующих против новых его толкований. Непосредственным поводом к негодованию со стороны польского общества стал выход в свет книги М. Бобжиньского «Очерк истории Польши» $(1879)^{25}$. Бобжиньский, к тому времени снискавший признание коллег по цеху и получивший в профессиональной среде высокую оценку своих трудов, теперь оказался в центре внимания всего польского общества, и, как вскоре выяснится, внимания не совсем благожелательного. 
Как об этом позднее написал Н. И. Кареев: «Появление книги произвело сильную сенсацию и в обществе, и в прессе, что только способствовало оживлению полемики, которая возникла вследствие замечаний на книгу, сделанных компетентными критиками» ${ }^{26}$. Что же в книге Бобжиньского так взволновало, если не сказать возмутило, его соотечественников? Дело в том, что, сосредоточившись на поиске причин падения Речи Посполитой ${ }^{27}$, Бобжиньский пришел к выводу: «Не границы и не соседи, только наш внутренний разлад довел нас до потери государственного существования». Развивая и поясняя свою мысль, польский историк констатировал: «Везде < ..> существовало правительство, которое, усмотрев зло, раньше или позже поправляло или уменьшало его. У одних только нас недоставало этого оздоравливающего фактора, недоставало правительства, которое в решительную минуту совокупило бы около себя, хотя и разрозненные, общественные силы и придало им единое направление. Если поэтому, прожив победоносно столько веков, в конце XVIII столетия мы не могли противостоять опасности, то единственная причина этого заключалась в нашем внутреннем безнарядье ${ }^{28}$.

Казалось бы, особой новости здесь не было. По наблюдениям М. Серейского, «непосредственно после первого раздела в польской исторической мысли возобладало мнение о собственной вине, о губительной форме правления, необузданной свободе» ${ }^{29}$, но вот после гибели Польши в конце XVIII в. польское общество уверовало в то, что истинными виновниками польской драмы были Россия, Пруссия и Австрия. Так что ответ, предложенный Бобжиньским на один из фундаментальных для польской историографии XIX в. вопросов: в чем заключались главные причины крушения некогда могущественной Речи Посполитой, - многими поляками был воспринят крайне болезненно, тем более что он не мог не задеть национального самолюбия польского народа. Оберегая образ своего славного прошлого, читатели-соотечественники оказались попросту не готовы к восприятию выводов сугубо научного порядка, которые повергли многих польских патриотов в состояние шока. Последствия не заставили себя долго ждать: на серьезного ученого со всех сторон посыпался град не просто упреков, а едва ли не обвинений в прямом предательстве национальных интересов. Соотечественники смотрели на Бобжиньского как на «человека, “марающего родное гнездо” и чуть ли не подкупленного московскими рублями» ${ }^{30}$.

Поскольку активный пересмотр прежних, устоявшихся взглядов на прошлое своей родины в польской исторической мысли начинает 
происходить вскоре после поражения Январского восстания, вызывает некоторое недоумение столь бурная реакция польского общества на книгу Бобжиньского. Объяснение здесь самое простое. Пока профессор Ягеллонского университета М. Бобжиньский не представил миру свой труд, написанный в научно-популярном ключе и ориентированный, что называется, на широкий круг читателей, новые трактовки общего прошлого оставались известны лишь специалистам, тем самым ни в коей мере не задевая натянутые струны польского национального чувства. Бобжиньский же со своей живо написанной книгой, где не только давались четкие ответы на злободневные вопросы, но и явно был утрирован конечный вывод, вышел, так сказать, в народ, сделав результаты академических исследований достоянием широкой общественности.

Коллеги по перу с известным пониманием отнеслись к выступлению Бобжиньского. С точки зрения одного из его соратников по Краковской исторической школе Станислава Смольки, газетные нападки на автора «Очерка истории Польши» были вызваны лишь тем, что Бобжиньский «подвел общие итоги под результатами монографической разработки польской истории, произведшими коренной переворот во взглядах на прошлое Польши, но оставшимися неизвестными громадному большинству публики, которой Бобжиньский и должен был показаться опасным новатором, не уважающим национальных традиций» ${ }^{31}$.

Принимая во внимание свойственный польской научной среде плюрализм мнений, Бобжиньскому все-таки было трудно рассчитывать на всеобщую поддержку. Его книга не встретила одобрения не только в читательской аудитории, далекой от происходивших в польской историографии процессов по пересмотру взглядов на прошлое своего отечества, и среди газетных и журнальных критиков, ключевая идея Бобжиньского-новатора не вызвала особого сочувствия у большинства коллег по цеху. Сначала на Бобжиньского обрушились приверженцы лелевелевской традиции, не готовые отказаться от веры в величие Речи Посполитой и достоинства «шляхетской демократии». Свой протест выразили яркие представители Варшавской исторической школы Владислав Смоленьский и Тадеуш Кор$30 \mathrm{H}^{32}$, представившие доказательные аргументы в пользу того, что, не будь вмешательства извне, Речь Посполитая XVIII в. имела бы все шансы реформировать свое государственное устройство и оздоровить экономику. Больше того, крайне пессимистическую концепцию польской истории Михала Бобжиньского не принял даже Юзеф 
Шуйский ${ }^{33}$, основатель Краковской школы и один из виднейших станьчиков.

Весьма показательно, что всколыхнувшая профессиональную среду дискуссия не только не оставила равнодушным польское общество, но именно живая реакция общества в определенной мере способствовала более придирчивому взгляду на книгу со стороны коллег-историков. Со временем страсти, конечно, улеглись, и «польская научная критика $<\ldots>$ вступив в полемику с Бобжинским по некоторым частным вопросам, в общем признала за его трудом немалое значение» ${ }^{34}$. Но были и такие, кто не изменил своего мнения. Оставшийся строгим оппонентом Бобжиньского Владислав Смоленьский попрежнему считал, что «в своей основе фальшив и для науки вреден» такой подход к истории Польши, когда историк изначально исходит из самого факта польской катастрофы и всю предшествующую историю народа рассматривает исключительно под заданным углом зрения ${ }^{35}$.

В этом смысле некоторые возражения вызывает тезис А. Г. Васильева, который утверждает, что «польская национальная историческая память (в том числе и в историографической форме) развивалась в первую очередь как ответ на травму разделов страны» ${ }^{36}$. Здесь, скорее всего, надо бы иметь в виду не столько развитие исторической памяти как «ответ на травму разделов», сколько то, что для польских историков эпохи разделенной Польши занятие национальной историей воспринималось как единственно возможная «форма защиты национального существования» ${ }^{37}$, а историческая память, как и собственно историография, служили убедительным свидетельством реальности самого факта «национального существования».

Так или иначе, ситуацию вокруг книги Бобжиньского, посягнувшего, с точки зрения большинства польского общества, на фундаментальные основы признанного этим большинством национального прошлого, можно считать в известной степени знаковой. Пример Бобжиньского - одного из краковских консерваторов, разделявших основные идейные постулаты станьчиков, - показал, сколь рискованной может оказаться реализация замыслов историка, основанных на поиске причин настоящего в глубинах прошлого.

Взвешенная историко-культурная политика и последовательное построение образа национального прошлого посредством действий и механизмов настоящего - ради будущего — являлись ключевыми задачами станьчиков как выразителей лоялистских настроений, готовых ориентироваться на Вену, но - исключительно в польских национальных интересах. 


\section{ПРИМЕЧАНИЯ}

1 Миллер И. С. Развитие народов Центральной и Юго-Восточной Европы в эпоху перехода от феодализма к капитализму как проблема комплексного сравнительно-исторического изучения // Миллер И. С. Исследования по истории народов Центральной и Восточной Европы XIX в. М., 1980. С. 402.

2 От редакторов // Австро-Венгрия: интеграционные процессы и национальная специфика. М., 1997. С. 3.

3 См., напр.: Хаванова О. В. Нация, отечество, патриотизм в венгерской политической культуре: движение 1790 года. М., 2000; Хаванова О. В. Заслуги отцов и таланты сыновей: венгерские дворяне в учебных заведениях Габсбургов. 1746-1784. М., 2006; Хаванова О. В. Усердие, честолюбие и карьера. Чиновничество в монархии Габсбургов в эпоху просвещенного абсолютизма. М., 2018; Вынужденное соседство — добровольное приспособление в дипломатических и межнациональных отношениях в Центральной, Восточной и Юго-Восточной Европе XVIIIXXI вв. М.; СПб., 2017; Российско-Австрийский альманах: Исторические и культурные параллели. М., 2014. Вып. V; Российско-Австрийский альманах: Исторические и культурные параллели. К 150-летию образования Австро-Венгерской империи. М., 2018. Вып. VI.

4 Łepkowski T. Naród bez państwa // Polska. Losy państwa i narodu do 1939 roku. Warszawa, 2003. S. 270.

5 Булахтин M. A. Краковские консерваторы и польский епископат Галиции: кризис взаимоотношений в начале XX в. // Известия Уральского федерального университета. Сер. 2. Гуманитарные науки. 2008. № 59. Вып. 16. С. 92-103; Булахтин М. А. Принципы и компромиссы: эволюция взаимоотношений «краковских консерваторов» и польских социалистов в Австро-Венгрии в начале XX века // Вестник Челябинского государственного университета. 2008. № 34 (135). Вып. 27. С. 84-89; Булахтин М. A. Австрийский парламентаризм и «краковские консерваторы» накануне Первой мировой войны // Вестник Пермского университета. 2009. Вып. 1 (8). С. 80-85; Булахтин М. А. «Краковские консерваторы» и польские демократы в начале XX века: от конкуренции к партнерству // Вестник Пермского университета. 2007. Вып. 1 (8). С. 24-34.

6 См., например: Демкович-Добрянський М. Потоцький і Бобжинський: цісарські намісники Галичини. 1903-1913. Рим, 1987; Мудрий М. Галицькі намісники в системі українсько-польських взаємин (1849-1914) // Вісник Львівського університету. 1998. Вип. 33. Сер. Іст. С. 91-101; Аркуша O. Анджей Потоцький: біографія політика на тлі українсько-польських 
відносин. Ч. ІІ. Галицький намісник // Вісник Львівського університету. Сер. Іст. 2010. Вип. 45. С. 169-282; Аркуша О. Представники політичної еліти Галичини у Львові початку XX століття: між офіційним і приватним простором // Вісник Львівського університету. Сер. Іст. Спецвипуск. 2016. С. 272-309; Кучеренко А. А. Українське питання в політиці намісника Галичини А. Потоцького (1903-1908рp.) // Історичний архів. Наукові студії. Вип. 8. Миколаїв, 2012. С. 46-50; Wyka K. Teki Stańczyka na tle historii Galicji w latach 1849-1869. Wrocław, 1951; Szlachta B. Z dziejów polskiego konsewatyzmu. Kraków, 2000; Stoczewska B. Ukraina i ukraińcy w polskiej myśli politycznej. Od końca XIX wieku do wybuchu II wojny światowej. Kraków, 2013.

7 Русский [Страхов Н. Н.]. Роковой вопрос (Заметка по поводу польского вопроса) // Время. 1863. № 4. С. 152-163.

8 Польша и Россия в первой трети XIX века. М., 2010; Меж двух восстаний. Королевство Польское и Россия в 30-50-е годы ХIX в. М., 2016.

9 Конституционная Хартия Царства Польского // Польша и Россия в первой трети XIX века. С. 469.

10 Такая категоричность не вполне отвечает представлениям поляков, даже разочаровавшихся в повстанческой идеологии, подтверждение чему находим, например, у одного из соавторов «Teki stańczyka» Юзефа Шуйского. См: Szujski J. Dzieła Józefa Szujskiego. Kraków, 1894. T. 2. Pisma polityczne. S. 14-15, 37.

11 Wardzińska A. Dwa spojrzenia na historię Polski. Polemika demokratów lwowskich Henryka Schmitta i Ludwika Wolskiego z przedstawicielem krakowskiej «nowej szkoły historycznej» Józefem Szujskim w latach 70. XIX wieku // Klio Polska. Studia i materiały z Dziejów historiografii Polskiej. 2017. T. 9. S. 7.

12 Пыпин А. Н., Спасович В. Д. Обзор истории славянских литератур. СПб., 1865. С. 456.

13 Jaszczuk A. Spór pozytywistów z konserwatystami o przyszłość Polski. 1870-1903. Warszawa, 1986. S. 63-83, 269-282.

14 Mierosławski L. Pamiętnik (1861-1863). Warszawa, 1924. S. 193.

15 Васильев А. Г. «Падение Польши» и модели мемориализации травмы // Кризисы переломных эпох в исторической памяти. М., 2012. С. 215-248. Ср.: Васильев А. Г. «Падение Польши» в польской историографии XIX века // Образы времени и исторические представления. Россия - Восток - Запад. М., 2010. С. 813-843.

16 Chrzanowski I. Optymizm i pesymizn Polski. Warszawa, 1971. S. 205-226.

17 Цит. по: Grabski A. Zarys historii historiografii polskiej. Poznań, 2003. S. 118. 
18 Mochnacki M. Powstanie narodu Polskiego w roku 1830 i 1831. Warszawa, 1984. T. 1. S. 81.

19 Ibid. S. 61.

20 В современной польской историографии порой оспаривается тезис о зависимости между поражением Январского восстания и формализацией группировки краковских консерваторов. Подробнее см.: Stoczewska B. Ukraina i Ukraińcy. S. 39-40.

21 Kieniewicz S. Historia Polski. 1795-1918. Warszawa, 2002. S. 302; [Koźmian S.] Teka stańczyka // Koźmian S. Bezkarność. Wybór pism. Kraków, 2001; [Szujski J.] Teka stańczyka // Szujski J. Dzieła Józefa Szujskiego. Kraków, 1894. T. 2. Pisma polityczne.

22 Biernacki $W$. Jednostka, naród, niepodległość: myśl polityczna demoliberałów galicyjskich (1882-1905). Kraków, 1997; Szlachta B. Stanisław Koźmian — współtwórca «szkoły stańczykowskiej»// Koźmian S. Bezkarność. Kraków, 2001. S. VII-XXXV; Grabski A. F. Zarys historii historiografii polskiej. Poznań, 2003. S. 128-131; Rzegocki A. Wstęp // Tarnowski S. Z doświadczeń i rozmyślań. Kraków, 2002. S. VII-XXXI; Michalak H. Józef Szujski, 1835-1883. Światopogląd i działanie. Łódź, 1987; Łazuga W. Ostatni stańczyk. Michał Bobrzyński — portret konserwatysty. Toruń, 2005; Koźmian S. Ludwik Wodzicki. Życiorys. Kraków, 1894; Tarnowski S. Ludwik Wodzicki: wspomnienia pośmiertne. Kraków, 1894; Dutka W. Zapomniany stańczyk. Rzecz o Stanisławie Koźmianie (1836-1922). Toruń, 2015.

23 Tarnowski S. Ludwik Wodzicki... S. 27-32; Koźmian S. Ludwik Wodzicki... S. 44-52, 61-86.

24 Репина Л. П. События и образы прошлого в исторической и культурной памяти // Новое прошлое. 2016. № 1. С. 84.

25 Bobrzyński M. Dzieje Polski w zarysie. Kraków, 1879.

26 Кареев Н. И. «Падение Польши» в исторической литературе. СПб., 1888. С. 55; Szujski J. Kilka uwag o «Dziejach Polski w krótkim zarysie». Warszawa, 1879.

27 О польской историографии XIX — начала XX в. см.: Grabski A. F. Zarys historii... S. 122-153; Szujski J. Józefa Szujskiego z Ludwikiem Wolskim polemika w sprawach narodowych. Lwów, 1878.

28 Цит. по: Кареев Н. И. Новейшая польская историография и переворот в ней // Вестник Европы. 1886, декабрь. С. 556.

29 Serejski M. H. Europa a rozbiory Polski. Warszawa, 1970. S. 433.

30 Кареев Н. И. Прожитое и пережитое. Л., 1990. С. 170.

31 Цит. по: Кареев Н. И. От редактора перевода // Бобржинский М. Очерк истории Польши. СПб., 1888. Т. I. С. I. 
32 О полемике по поводу вопроса о причинах разделов Речи Посполитой на страницах варшавского журнала «Атенеум», среди авторов которого были Т. Корзон, Ю. Крашевский, А. Рембовский и др., см., например: Ромек А. Историческая проблематика на страницах «Атенеума» (1876-1901) // Славянские народы: общность истории и культуры. M., 2000. C. 270-271.

33 Szujski J. Kilka uwag...

34 Кареев Н. И. От редактора перевода... С. ІІ.

35 Smoleński $W$. Szkoły historyczne w Polsce. Główne kierunki poglądów na przeszłość // Historycy o historii. Od Adama Naruszewicza do Stanisława Kętrzyńskiego. 1775-1918. Warszawa, 1963. S. 355.

36 Васильев А. Г. «Падение Польши» в польской историографии XIX века. С. 819.

37 Grabski A. F. Zarys historii... S. 114.

\section{M. Arzhakova}

The faction of Stańczycy as a demonstration of (self)organization of the Krakow conservatives focused on Vienna

The article is devoted to the characteristics of the main tasks of the faction of Stańczycy. The author notes on the specific position of the «Austrian» Poles under the rule of Austria-Hungary and its difference from the position of the «Russian» Poles under the rule of the Russian Empire. Emphasized is the value of studying Polish history and organizing various activities focused on history and culture for Stańczycy, though at the same time they expressed their loyalty toward Vienna administration. Keywords: Krakow conservatives, Stanczyk, Michat Bobrzyński, national Polish past, the fall of Poland, the Polish question. 


\title{
Первое празднование юбилея Валентина Водника
}

\begin{abstract}
Известный словенский поэт, просветитель и издатель Валентин Водник сыграл большую роль в развитии словенского языка и культуры. На примере воскрешения из забвения имени Водника и первого празднования его столетнего юбилея в 1858 г. в статье затрагиваются вопросы становления исторической памяти словенцев, поисков ими своих национальных героев.

Ключевые слова: В. Водник, Я. Блейвейс, словенское возрождение, историческая память.
\end{abstract}

DOI: $10.31168 / 2073-5731.2018 .3-4.1 .05$

После окончания революции 1848-1849 гг. в Австрии установился так называемый неоабсолютизм, творцом которого был А. Бах, в период революции либеральный политик. В 1849-1859 гг. он являлся министром внутренних дел, практически определял внутреннюю политику страны. Бах установил режим, близкий к дореволюционному режиму К. Меттерниха: были закрыты политические газеты, запрещены национальные общества, возникшие в революционные годы. Желая приспособиться к новым условиям, лидеры словенцев, как и других славянских народов, стали осваивать новые формы деятельности. Матия Маяр, создатель политической программы «Объединенная Словения», писал в декабре 1851 г. своему другу Й. Муршецу: «С политикой теперь нечего и начинать, нужно только быть настороже, случись что, и заботливо поддерживать литературную деятельность. $<\ldots>$ Это сейчас наша политика» ${ }^{1}$.

По этому пути пошли и другие национальные деятели Крайны. В частности, признанный глава крайнских словенцев Янез Блейвейс (1808-1881), во время революции занимавший праволиберальную позицию, сумел сохранить свою газету «Кметийске ин рокодельске новице» («Kmetijske in rokodeljske novice», 1843-1941). Он и круг его сторонников организовали празднование столетнего юбилея со дня рождения известного словенского национального деятеля Водника.

Валентин Водник (1758-1819) родился в зажиточной крестьянской семье в селе Шишка около Любляны. В 1770-1775 гг. он учился в иезуитской гимназии Любляны, по окончании которой поступил в фран- 
цисканский монастырь, затем в 1784 г. покинул его и вплоть до 1793 г. служил капелланом в различных словенских селах. Еще будучи гимназистом, Водник примкнул к первому национальному обществу словенцев — кружку М. Похлина и Ф. Дева. Члены кружка изучали словенский язык, собирали народные песни, писали стихи на словенском языке.

В конце 1780-х гг. словенские национальные деятели стали группироваться вокруг богатейшего человека Крайны барона Сигизмунда (Жиги) Цойса. В кружок Цойса входили историк А. Линхарт, филолог и педагог Б. Кумердей, впоследствии знаменитый славист Е. Копитар и ряд других видных деятелей словенского возрождения. Цойс стремился привлечь к национальной деятельности как можно более образованных людей. В 1793 г. он уговорил Водника примкнуть к своему кружку. Тот перебрался с помощью Цойса в приход недалеко от Любляны, а с 1798 г. навсегда оставил священническую службу и стал по протекции Цойса профессором поэзии в Люблянской гимназии. На средства Цойса в 1795-1797 гг. Водник издавал календарь «Велика пратика», предназначавшийся прежде всего для крестьян и ремесленников, в 1798-1806 гг. — календарь «Мала пратика».

В 1797-1800 гг. в Любляне вышла первая газета на словенском языке «Лубланске новице» («Lublanske novice»). Ее редактором и основным автором был Водник. Газета предназначалась для широкого круга образованных людей. В ней с позиций австрийского патриотизма освещались политические новости, публиковались статьи об акушерстве, прививке оспы, виноградарстве, сообщались цены на продукты на рынке в Любляне. В статье «Рассказы о славянском языке» Водник давал сведения о славянах. «Крайнцы, - писал он, - лишь один отросток великого славянского народа, который в настоящее время обитает на территории от триестинского моря до холодного моря в Московии в ширину более 400 миль, и от Чехии до области Камчатки на окраине Московского царства более тысячи миль в длину. Почти все народы на этом пространстве - славяне. Это - крайнцы, словенцы, хорваты, далматинцы, босняки, славонцы, словаки под турецкой и венгерской властью на этой стороне Дуная. На другой стороне Дуная - чехи, мораване, поляки, поморяне, вандалы, литовцы, леты и единое неизмеримое пространство московитаров в Московии, Северии и на границе Татарии. Все эти народы называются общим именем - славяне, пользуются языком одной матери, а именно славянским языком».

Одновременно с издательской деятельностью Водник вернулся к поэтическому творчеству. К этому его активно побуждал Цойс, которого Водник обучал словенскому языку. 
Его стихи печатались в редактировавшихся им календарях. В 1806 г. вышел в свет единственный сборник стихотворений Водника «Поэтический опыт». Но наиболее известным стало его стихотворение «Иллирия возрожденная», посвященное Наполеону. Водник приветствовал создание Иллирийских провинций (1809-1813), писал о прошлом Иллирии, когда она владела многими землями вплоть до северных пределов и ее боялись галлы и Рим. Иллирией ее называли греки и римляне, а настоящим ее именем было Славеника. Водник мечтал, что в будущем Иллирия объединит все земли до Черного и Эгейского морей. Стихотворение было написано в знак одобрения языковой политики французских властей, которые разрешали вести обучение в школах на языке местного населения. Водник как педагог высоко оценивал это. Впоследствии, в 1817 г., восхваление Наполеона в этом стихотворении Водник объяснял своему ученику Смолникару тем, что он считал роль Наполеона в Европе преходящей, заключавшейся в разрушении государства, что дало бы возможность расцвета Иллирии. Ода воспевала славное будущее Иллирииㄹ․ Трудно сказать, насколько это объяснение соответствовало представлениям Водника в то время, когда французы заняли словенские земли.

Водник всеми силами стремился добиться введения обучения в школах на словенском языке. Для этого он написал и издал два учебника на словенском языке - «Катехизис» и «Письменность или грамматика для начальной школы». Они вышли в свет в 1811 г. Особый интерес представляет второй учебник. Это была первая грамматика, написанная на словенском языке, прежде все словенские грамматики писались на немецком или латинском языках. Водник первым из словенских лингвистов попытался создать грамматическую терминологию для словенского языка, опираясь при этом на церковнославянскую терминологию грамматики М. Г. Смотрицкого. Вообще Водник уделял большое внимание очищению словенского языка от многочисленных германизмов. Словенский ученый Ф. Якопин указывает, что до сих пор в словенском языке сохранилось 30 русских слов, введенных туда Водником ${ }^{3}$.

Именно желание сформировать словенский литературный язык, очистив его от иностранных, прежде всего немецких, заимствований, заставило Водника взяться за составление немецко-словенского словаря. В 1802 г. он начал работу над ним. В сборе словарного материала Воднику активно помогали его ученики из гимназии Я. Примиц, У. Ярник, а таже барон Цойс ${ }^{4}$. При работе над словарем, которую он вел вплоть до 27 сентября 1817 г., он использовал русские, чешские, лу- 
жицко-сербские слова. При этом Водник помечал, где, когда и у кого записывал то или иное слово. Из-за противодействия Е. Копитара, являвшегося цензором славянских, греческих и румынских книг, ему не удалось опубликовать словарь.

Рукописный словарь Водника побывал у М. Равникара, Ярника и др., а в конце концов попал в руки словенского лингвиста М. Цигале. В 1860 г. вышел в свет его немецко-словенский словарь. Словенский исследователь Й. Стабей подсчитал, что Цигале использовал в нем 95\% собранного Водником материала. Он полагал, что было бы справедливо указать его имя как соавтора ${ }^{5}$.

Историк словенской литературы И. Приятель считал, что Водник, несмотря на то, что был менее образован, чем С. Цойс и А. Линхарт, сумел дать словенцам гораздо больше, чем они ${ }^{6}$. Высоко оценивалась деятельность Водника и русскими учеными.

Несмотря на безусловные заслуги Водника в создании словенского литературного языка, словенской поэзии и журналистики, к 1850 -м гг. его имя было забыто. Оно не появлялось на страницах словенских изданий даже во времена революции 1848-1849 гг., поэтому празднование столетнего юбилея Водника имело особое значение для определения его истинной роли в словенском возрождении.

Празднование описал в статье «Торжество в честь столетнего юбилея со дня рождения Валентина Водника» Ф. Малавашич (1818$1861)$, писатель из круга Я. Блейвейса. Оно проходило два дня - 3 и 5 февраля 1858 г. В первый день толпы народа, кто в каретах, а кто пешком, отправились в село Шишка. Хотя народ почти забыл, кто был его будителем, отметил Малавашич, но благодаря юбилею он узнал об этом. В Шишку прибыли провинциальный судья Йош, председатель крестьянского общества Ф. Терпинц, председатель купеческой и ремесленной палаты Л. К. Лукманн, глава провинции граф К. З. фон Гогенварт, а также представители словенского национального движения Л. Томан и Я. Блейвейс. Остальную публику представляли гимназисты, ремесленники, торговцы, крестьяне, главным образом из Любляны и окрестных сел и деревень. Состав принявших участие в праздновании юбилея Водника указывает на то, что и местное начальство вполне сочувственно относилось к чествованию словенского национального деятеля, некогда испытывавшего враждебность со стороны властей.

Торжество началось в 3 часа дня. На стене дома, где родился Водник, была открыта мемориальная доска, на которой было написано: «Здесь 3 февраля 1758 г. родился Валентин Водник, первый словен- 
ский поэт». Перед тем как с мемориальной доски сорвали покрывало, выступили Л. Томан и граф Гогенварт. Томан приветствовал присутствие на торжестве Гогенварта. Затем он подчеркнул, что Водник является первым словенским поэтом, который внес большой вклад в развитие словенского языка. Словенский язык, продолжил Томан, за последние годы достиг большего прогресса, чем за несколько предыдущих столетий. И это произошло, подчеркнул оратор, благодаря мудрости словенских ученых и милости императора. Граф Гогенварт отметил, что участие в праздновании юбилея Водника большого количества народа указывает, что он был действительно народным поэтом. Это подтверждает и тот факт, что многие стихи Водника стали народными песнями. После выступлений военный оркестр стал играть популярные марши и песни, в том числе на слова Водника. После этого Томан повел гостей в комнату, где родился Водник. Над главным столом висел портрет Водника, обрамленный лавровыми ветками. Справа от главного стола был расположен стол, за которым сидели благородные господа, а слева - стол, за которым расположились дамы. Сын главы провинции А. Гогенварт выступил с речью, в которой выразил уверенность в том, что и через сто лет словенцы будут отмечать этот день. Гости пили вино и произносили тосты. Празднование господами юбилея Водника продолжалось до глубокой ночи. Между тем отдельно от господ в саду происходило празднование простого люда: крестьян из Шишки и окрестных деревень, ремесленников, мелких торговцев и др. Председатель крестьянского общества $Ф$. Терпинц поставил за счет общества вино, которое простая публика распивала до самого утра ${ }^{7}$.

Празднование продолжилось 5 февраля 1858 г. в театре Любляны. На нем сначала выступил Л. Томан. Он заявил, что словенцы празднуют столетний юбилей человека, «который первый нам показал сладость, крепость и богатство словенского языка в своих бессмертных песнях и литературных трудах, и мы его прославляем как общее достояние нашего народа» ${ }^{8}$. Затем выступали певцы, исполнявшие песни различных славянских народов 9 .

Чествование Водника на этом не закончилось. В 1859 г. вышла в свет посвященная ему книга «Памяти Водника. Альбом Водника». В ней были помещены статьи, стихи, посвященные не только поэту, но также и другим словенским национальным деятелям. Они были написаны как на словенском, так и на немецком языках. Среди них было две статьи Ф. Малавашича. Одна из них - о праздновании в селе Шишка, другая — «Водник и словенский язык» - о деятельно- 
сти поэта. Малавашич подчеркивал, что Водник выступал против тех, кто считал словенский язык бедным. «Крайнский язык богат, а люди бедны словами, так как мало помнят, чему их учила мать». Водник собирал слова для словаря у крестьян и деревенских ремесленников, а также искал их в старославянском книжном языке. Он обращался и к языкам других славянских народов, например «московитарскому», который считал наиболее близким крайнскому. «Московитары сохранили много слов, которые мы забыли» ${ }^{10}$.

Интересен очерк Я. Блейвейса «Новице Водника». Блейвейс, отметив, что в своей газете «Лубланске новице» Водник одновременно являлся редактором и автором, подчеркнул, что он «был не только первым словенским поэтом, но и родоначальником словенской журналистики». Блейвейс отметил, что Водник вел борьбу за очищение словенского языка от германизмов. Остановившись на некоторых статьях поэта, Блейвейс сделал вывод, что он всегда был патриотом и всегда был предан императору. При пересказе статей Водника Блейвейс особо остановился на очерке «Рассказы о славянском языке», отметив содержавшуюся в нем информацию об истории, обычаях и языке славян. Причину того, что «Лубланске новице» прекратили существование, Блейвейс видел в том, что они были предназначены только для Крайны, а в других словенских землях газету не знали. Все же Блейвейс считал, что «Лубланске новице» Водника «на века останутся золотой святыней нашей литературы» ${ }^{11}$.

Одновременно в сборнике «Памяти Водника» было опубликовано несколько сочинений, посвященных другим деятелям словенского национального движения. Так, известный немецкий поэт Анастасиус Грюн поместил стихи на немецком языке, посвященные знаменитому словенскому поэту Ф. Прешерну, а А. Янежич, один из первых историков словенской литературы, - очерк о У. Ярнике, словенском будителе и лингвисте.

Таким образом, празднование столетнего юбилея Водника имело большое значение не только для воскрешения из забвения имени замечательного деятеля словенского возрождения В. Водника, но и для дальнейшего развития словенского национального движения. Для этого важно было показать словенцам, что и у них, как и у немцев и других «исторических» народов, имеются свои герои, свои подвижники, которыми они могут гордиться и которые могут служить для них вдохновляющим примером. 


\section{ПРИМЕЧАНИЯ}

1 Ilešič F. Korespondenca dr. Muršeca. Ljubljana, 1905. S. 119.

2 Stanonik J. Smolnikar in Valentin Vodnik // Slavistična revija. 1977. № 2-3. S. 220-225.

3 Jakopin F. Ruske izposojenke v slovenščine // Jezik in slovstvo. 1975/1976. № 4. S. 134.

4 Петровский Н. М. Первые годы деятельности В. Копитаря. Казань, 1906. С. 25-29.

5 Там же. С. 43.

6 Prijatelj I. Duševni profili slovenskih preporoditeljev. Ljubljana, 1935. S. 52.

7 Malavašič F. Slovesnosti, obhajane v spomin stoletnega rojstnega dneva Valentina Vodnika, očeta slovenskega pesništva Vodnikov spomenik. Vodnik-Album. Ljubljana, 1859. S. 63-65.

8 Malavašič F. Slovesnosti... S. 66-67.

9 Ibidem.

10 Malavašič $F$. Vodnik in slovenščina // Vodnikov spomenik. Vodnik-Album. S. 19, 20.

11 Bleiweis J. Vodnikove Novice. Črtice k življenjopisju Vodnikovemu // Vodnikov spomenik. Vodnik-Album. S. 31-36.

\section{V. Churkina}

The first celebration of Valentine Vodnik's jubilee

The well-known Slovenian poet, educator and editor Valentin Vodnik played a major role in the development of Slovene language and culture. On the example of the resurrection from oblivion of the name of Vodnik and the first celebration of his centenary in 1858, the article touches upon the issues of the formation of the historical memory of the Slovenes, and the search for their national heroes. Keywords: V. Vodnik, J. Bleiweis, Slovene revival, historical memory. 


\title{
«Кто в молодости не был либералом»: к политической биографии Джордже Стратимировича
}

\begin{abstract}
Джордже Стратимирович (1822-1908) - романтическая фигура в истории сербского национального движения во второй половине XIX в. Прирожденный лидер и вдохновитель, он сыграл значимую роль в событиях революции 1848-1849 гг., оставшись в памяти поколений народным генералом. Однако его дальнейшая деятельность оказалась буквально вычеркнутой из истории политической мысли сербов Австрийской монархии, поскольку радикально отличалась от ранее проводимой им линии. Под влиянием жизненных и политических обстоятельств из молодого деятельного либерала он превратился в умудренного опытом и крайне осторожного лидера консервативного направления. Финальным аккордом политической карьеры Д. Стратимировича стала разработанная им в 1872 г. программа будущей партии умеренного толка, которая предполагала сотрудничество с властями Венгерского королевства. В условиях, когда сербский народ сплотился вокруг либералов, непримиримых борцов за национальные права, для Стратимировича такой шаг оказался роковым.

Ключевые слова: Стратимирович, сербское национальное движение в монархии Габсбургов, политические течения у сербов Воеводины.
\end{abstract}

DOI: $10.31168 / 2073-5731.2018 .3-4.1 .06$

Джордже Стратимирович родился 19 февраля 1822 г. в Нови-Саде (в то время - Венгерское королевство). Его отец Василие владел имением в Кулпине (Южная Бачка), при этом состоял на государственной службе и был фискалом по делам фрушкогорских монастырей ${ }^{1}$, мать, Юлиана Петрович, была дочерью новисадского сенатора Йована Петровича и крестницей епископа Бачки - Гедеона. Родители решили, что сын должен готовиться к карьере военного. Такой выбор считался наиболее благоприятным для молодого сербского дворянина и сулил довольно быстрое продвижение по службе в рядах австрийской армии.

Статья подготовлена в рамках работы над ПФИ Президиума РАН «Австро-Венгрия: механизмы (само)организации культурно-сложных сообществ в композитарной монархии» (№ 0178-2018-0008). 
Начальное образование Джордже Стратимирович получил дома: его учителями были лютеранский священник словак Рохони и известный сербский писатель Милован Видакович (1780-1841). Среднюю школу Стратимирович закончил в Кулпине, затем с 1832 по 1835 г. учился в лютеранской гимназии в Нови-Врбасе. В 1836 г. поступил в кадетский корпус в городе Тител, по специальности «математика», который закончил экстерном. По результатам экзаменов был зачислен в Военную инженерную академию в Вене, которую окончил в 1841 г. В том же году был произведен в чин подпоручика и до 1843 г. служил в гусарском полку в Ломбардии, когда по собственному желанию вышел в отставку и вернулся сначала в Нови-Сад, а затем в Кулпин. В доме родителей Стратимирович занимался самообразованием, посвятив себя изучению экономики и права ${ }^{2}$.

О его политических воззрениях в этот период практически ничего не известно, однако позиция, занятая им во время революции 1848-1849 гг., позволяет предположить, что его точка зрения на положение сербов во владениях дома Габсбургов отличалась от убеждений сверстников. Мы склонны связывать это с тем, что юность он провел в Вене, в отличие от большинства своих ровесников, которые жили и учились в Венгрии, а потому так или иначе подвергались влиянию венгерской политической мысли, идейными вдохновителями которой были граф Иштван Сечени (17911860) и Лайош Кошут (1802-1894). Впрочем, как отмечают исследователи, венгерский «либерализм с националистическим лицом» или был для молодых сербов заразительным примером, или воспринимался как угроза собственным национальным интересам ${ }^{3}$. Открытых симпатий курсу государственного канцлера князя К. фон Меттерниха (1773-1859) Стратимирович тоже не выражал, а его лояльность венскому двору была обусловлена военной присягой, данной при поступлении на военную службу.

В условиях революции в Венгрии, начавшейся 15 марта 1848 г., сербы оказались, образно говоря, между молотом и наковальней: не имея собственных сил для борьбы за национальные права, они были вынуждены выбирать меньшее из двух зол. Поддержав венгров во главе с Кошутом, они подписали бы смертный приговор своей национальной индивидуальности; оставшись на стороне Австрии, стали бы слепым орудием в борьбе между Веной и Пештом.

В сложившейся ситуации, когда никто не знал, какую из сторон выбрать, так как ни одна, ни другая не сулила ничего хорошего, духовный лидер, митрополит Карловицкий Иосиф Раячич (1785-1861), счел, что сербам лучше занять выжидательную позицию и соблюдать нейтралитет. Однако в своем обращении к «православному народу, консистории и епископам» он заявил, что «своим верным подданным император 
дарует новые милости, новые права, новые свободы», а старые привилегии сохранит и приумножит. Митрополит уверял паству, что развитие всех народов империи возможно только «под скипетром великой Австрийской империи» и необходимо переждать эти бурные дни в спокойствии и смирении и оградить себя от влияния «болтунов, смутьянов и бунтовщиков» ${ }^{4}$. Так митрополит охарактеризовал Стратимировича и его сторонников, которые 21 марта 1848 г. организовали в Нови-Саде революционный комитет и распространяли среди горожан манифест, основная мысль которого заключалась в том, что «свобода на своем пути заглянула к нам (сербам. - Л. Н.) домой, и здесь она воздвигнет свой алтарь». Кроме того, новисадский комитет сформировал и национальную милицию, чтобы избежать беспорядков и анархии. Стратимирович проявил себя как блестящий организатор и добился особого расположения среди сербов. 27 марта 1848 г. комитет объединил усилия с кружком сербских политиков из Пешта, и вместе они выдвинули состоящую из 17 пунктов программу «Требования сербского народа» венгерскому правительству. Главными из них были свободное использование сербского языка, автономия церкви и школы. Это обращение содержало дипломатичный призыв: «Верность королю, любые жертвы на благо отечества, братскую любовь - венграм» ${ }^{5}$. На основании этого мы можем сделать вывод, что, отстаивая национальные интересы сербов, молодой поручик Джордже Стратимирович был готов на выгодных условиях сотрудничать с венграми, пренебрегши посулами митрополита Раячича, вокруг которого начали объединяться будущие австрофилы.

В апреле 1848 г. Стратимирович вошел в состав делегации граждан Нови-Сада, которая представила свои требования Государственному собранию Венгрии. На очередном раунде переговоров, как потом оказалось, последнем, он перехватил инициативу у главы сербской делегации адвоката А. Костича и вступил в ожесточенный спор с Кошутом. От лица народа Стратимирович призывал вернуть сербам привилегии, данные им в 1690 г. императором Леопольдом I (1658-1705), действие которых венгры отменили 15 марта 1848 г., и признать сербов нацией. Кошут отвечал, что «в Венгрии может быть только одна нация - венгерская». Стратимирович предостерег его, что сербы вполне могут «обратиться к противоположной стороне», то есть к венскому двору. Ставшая знаменитой фраза Кошута «В таком случае нам придется скрестить мечи» поставила точку в данном споре, но последнее слово, по свидетельствам Йована Полита, непосредственного участника этих событий, было за Стратимировичем. Он парировал гневную реплику, заявив: «Серб никогда не был трусом». Таким образом, гото- 
вый к компромиссам и сотрудничеству молодой поручик превратился в противника венгерской революции и ее предводителей ${ }^{6}$.

Требования, выдвинутые им на переговорах с венграми, легли в основу первой политической программы сербов Воеводины, так называемой Карловицкой программы, которая была разработана в национально-конфессиональном, т. е. сербско-православном, ключе ${ }^{7}$ Кроме того, программа содержала недвусмысленный выбор союзника в борьбе за национальные интересы - в условиях открытого противостояния с венгерскими властями сербы обратились к «единокровным и единоплеменным братьям нашим хорватам» ${ }^{8}$. Гарантами этого союза выступили лично митрополит Раячич и бан Хорватии Йосип Елачич (1801-1859), в своих заявлениях уверявшие народ, что только совместными усилиями сербы и хорваты добьются исполнения национальных чаяний. Что касается взглядов Стратимировича на сербско-хорватское сотрудничество, то он в сложившейся ситуации в большей степени доверял бану Елачичу, чем карловицкому владыке. Об отношениях с хорватским лидером он с теплотой пишет в своих воспоминаниях, отмечая, что именно Елачич поспособствовал тому, что в ходе боевых действий против венгров в 1849 г. «народный генерал» Стратимирович был произведен в подполковники и вернулся в действующую армию, а также был лично представлен австрийскому министру-президенту князю Феликсу Шварценбергу (1800-1852), а затем и лично императору Францу Иосифу I (1830-1916). Несмотря на то, что пути хорватского и сербского вождей в дальнейшем разошлись, Стратимирович был благодарен Елачичу за предоставленную возможность в будущем проявить себя на службе у Его Величества

Своим главным политическим противником в 1848-1849 гг. Стратимирович считал митрополита, а с 13 мая 1848 г. — патриарха Иосифа Раячича, которого винил во всех своих неудачах. Младший их современник Михаил Полит-Десанчич (1833-1920), основываясь на воспоминаниях своего отца Йована Полита, писал, что это противостояние было неизбежно. «Очень молодой, но исключительно талантливый Стратимирович был вождем и душой сербского национального движения за свободу. Его популярность была безмерна. Граничары шли за ним, как слепые, под пули и штыки» ${ }^{10}$, в то время как умудренный опытом, признанный в Вене патриарх Раячич терял контроль над массами, заклиная сербов быть смиренными и верными короне и ждать милости от императора. Позднее в своей автобиографии, написанной перед смертью в 1861 г., владыка обвинил Стратимировича в том, что в сражениях с венграми тот погубил слишком много людей, забыв о ценности каждой человеческой души, пусть и принесенной в жертву ради народной свободы. Главным 
мотивом такого поведения своего оппонента Раячич считал его излишнее свободомыслие ${ }^{11}$. Но кто в молодости не был либералом?..

Стратимирович, в свою очередь, упрекал патриарха в доверчивости в отношениях с Веной. Вспоминая события 1860 г., когда решался вопрос о существовании Сербской Воеводины и Темешского Баната, он отметил, что Раячич как духовный лидер сербского народа не смог организовать должного отпора сторонникам упразднения провинции, т. е. немцам, венграм, населявшим города региона, а также сербам-мадьяронам. Кроме того, его удивило то равнодушие, которое в этом отношении продемонстрировали жители территорий, где сербы составляли большинство: по данным императорского уполномоченного графа А. Менсдорфа, их устроила бы некая административная единица, где будет преобладать сербское население, но на создании таковой опрошенные не настаивали ${ }^{12}$. После оглашения результатов своеобразного референдума, при встрече Франц Иосиф лично заверил Стратимировича в том, что если сербы готовы отстаивать свои интересы, император ни в коем случае не станет упразднять Воеводину в угоду венграм, и отправил собеседника донести эту мысль до народа. Сербы с восторгом встретили своего героя, который по долгу службы десять лет не был на родине, тем более что он принес им благую весть, что не могло не насторожить венгров. Как писал в воспоминаниях Стратимирович: «Почти все магнаты, состоявшие в консервативной партии, ринулись в Вену и заставили императора отозвать меня, угрожая тем, что, пока Воеводина существует, мира с венграми ему не видать» ${ }^{13}$. Вернувшись в столицу, он обнаружил, что упразднение провинции не за горами, а также фактически оказался под домашним арестом. Франц Иосиф запретил ему покидать Вену и возвращаться в Воеводину во избежание волны протестов, которые могли бы быть организованы от его имени, а в верности генерала Стратимировича государь не сомневался.

С особой язвительностью он вспоминал, как всполошился и засуетился патриарх Раячич после издания указа от 27 декабря 1860 г. об упразднении Сербской Воеводины и Темешского Баната и передаче этих земель Венгрии ${ }^{14}$. От сербских епископов императору была отправлена петиция о созыве народного сабора, на котором предполагалось обсуждение следующих вопросов: восстановление провинции или создание новой сербской административной единицы в составе Венгерского королевства. В случае если новые власти будут оказывать давление на сабор, патриарх просил Франца Иосифа лично выступить защитником сербских интересов ${ }^{15}$. Сам Стратимирович не без доли тщеславия считал, что Благовещенский сабор 1861 г. состоялся только благодаря тому, что он и госу- 
дарственный советник Д. Стоякович (1811-1863) уговорили австрийского министра внутренних дел А. Шмерлинга (1805-1893) дать разрешение на проведение этого политического форума, а значит, признать за сербами их национальные права в рамках Венгерского королевства ${ }^{16}$.

Участие в заседаниях сабора стало для Стратимировича испытанием: он был мало знаком с реальной расстановкой политических сил в сербских кругах и потому морально готовился бороться только с представителями клерикального течения во главе с патриархом Раячичем. Его позиция принципиально не изменилась - владыка и его сторонники все так же уповали на милость императора и ждали восстановления Сербской Воеводины. Уже в Сремских Карловцах Стратимирович столкнулся с новой политической группировкой, представлявшей интересы либерально настроенных граждан. Они видели разрешение сербского вопроса в сотрудничестве с венгерскими властями, а потому были согласны довольствоваться созданием нескольких жупаний (комитатов) с предоставлением необходимого минимума национально-политических свобод. Лидер этого течения Светозар Милетич (1826-1901) отличался повышенной агрессивностью по отношению к своим оппонентам, в чем в скором времени убедится и сам Стратимирович. В сложившейся ситуации генерал занял позицию «среднего пути», или, как сам он ее охарактеризовал, «умеренно-консервативную» ${ }^{17}$. По его мнению, в разрешении сербской проблемы весьма полезно было бы сотрудничество с другими славянскими народами империи, в первую очередь с хорватами. Наученный горьким опытом, Стратимирович руководствовался правилом «доверяй, но проверяй» и потому призывал сербов не доверяться сразу Вене или Пешту, а объединиться с хорватами и рассмотреть те предложения, которые центры силы представят сложившейся коалиции.

Судьба земель, населенных сербами, зависела от мнения большинства. В этой ситуации, несмотря на обоюдное недоверие, представителям правого клерикального и «среднего» путей удалось прийти к компромиссу и выступить единым фронтом за то, чтобы сербская административная единица, по возможности автономная, получила право на существование. Заключительные положения Благовещенского сабора ко двору императора доставили Стоякович и Стратимирович. Ожидая положительных результатов, они столкнулись с противодействием венгерских политиков, которые оспорили саму идею образования новой Воеводины. Для самого Стратимировича участие в Благовещенском саборе обернулось отставкой из австрийской армии. По его мнению, увлекшись сербским вопросом, он нажил себе врагов среди венгерских политиков, которые повлияли на императора 
и высших офицеров, и без того негативно к нему настроенных. В этой ситуации в 1863 г. Стратимирович был вынужден уйти на почетную пенсию с сохранением статуса генерального консула ${ }^{18}$.

К активной политической деятельности он вернулся в 1865 г., когда был избран делегатом венгерского Государственного собрания. В июле 1866 г. он, как и большинство сербских представителей, поддержал партию Ференца Деака (1803-1876), предлагавшего в случае переустройства монархии Габсбургов удовлетворить требования народов, населявших венгерские земли.

Однако в ходе работы над проектом австро-венгерского Соглашения стало понятно, что это были всего лишь обещания. Как заметил Стратимирович, «Ausgleich» (соглашение о превращении Австрийской империи в Австро-Венгерскую монархию) был последним шансом для сербов спасти национальную автономию. Опыт подсказывал ему, что это именно тот момент, когда он должен вспомнить о верности присяге и вновь обратиться к венскому двору. А потому в октябре 1866 г. согласился возглавить объединенное консервативно-клерикальное течение сербов, которое связывало свое дальнейшее будущее с Австрией и надеялось на переустройство государства на федеративных началах. Понимая, что у сербов нет исторического права на автономию, федералисты во главе со Стратимировичем обратились к праву естественному и потому просили Франца Иосифа лично гарантировать им удовлетворение национальных требований в обновленной империи ${ }^{19}$. Таким образом, генерал Стратимирович занял ту самую консервативную позицию смиренного и бесконечно верного подданного, на которой стоял его давний противник патриарх Раячич, а ядро его формирующейся партии составляла церковная иерархия. Кроме того, сербские федералисты рассчитывали на солидарность других славянских народов в попытках не доводить дело до дуализма и выдвинули лозунг «Славянам Австрия нужна так же, как Австрии нужны славяне!». Однако эта инициатива не увлекла ни чешских политиков Ф. Палацкого (1798-1876), Ф. Ригера (1818-1903), Я. Скрейшовского (1831-1883), с которыми Стратимирович дружил, ни хорватов, союз с которыми был более реальной перспективой. А потому встретить австро-венгерское Соглашение 1867 г. сербским консерваторам пришлось в одиночку, так как либерально настроенная часть общества, в основном молодежь, была против использования старинных методов борьбы за национальные права, предложенных Стратимировичем и его сторонниками. Так называемая «черная чета», в которую помимо генерала вошли церковные иерархи во главе с патриархом Самуилом Маширевичем (1804-1870) и предста- 
вители аристократии, по словам сербского историка В. Крестича, даже вступила в открытое противостояние с народом ${ }^{20}$.

Казалось, что это финальная точка в карьере Стратимировича. Но, переждав критический момент, он вернулся в большую политику в 1869 г., когда вновь стал депутатом Государственного собрания в Пеште. А в 1872 г. он готовился сформировать новую консервативную партию как основного конкурента Сербской либеральной партии С. Милетича, которая становилась все более радикальной под влиянием новых ее членов. По этой причине многие бывшие либералы стали открыто выражать симпатию Стратимировичу и даже переходить в его лагерь. Желая закрепить достигнутые успехи, он опубликовал в конце декабря 1872 г. «Призыв к добровольным пожертвованиям на издание газеты Сербская политика» («Српска политика»), на страницах которого появилась и программа будущей партии. Ее содержание в некотором смысле ошеломило публику. В первую очередь, Стратимирович призывал сербов «признать территориальное единство Земель венгерской короны и выполнять все обязательства, возложенные на них венгерским правительством» ${ }^{21}$. Кроме того, он считал, что добиться желаемой автономии церкви и школы сербы могут, требуя гражданских свобод, а не национальных, что в корне противоречило уже существующей стратегии борьбы за права сербов в Венгрии. И немаловажным пунктом программы являлось сотрудничество с хорватами, за которое ратовал Стратимирович. Он пытался убедить соотечественников в том, что собственными силами они неспособны добиться исполнения своих желаний, хотя прекрасно знал об отрицательном опыте сербско-хорватской коалиции в 1848-1849 гг. и понимал, насколько провокационно звучит из его уст такое предложение. Предлагая мирные способы осуществления сербских национальных чаяний (в тексте программы ни разу не встречается слово «борьба»), Стратимирович утратил поддержку даже своих сторонников, которые были шокированы его отказом от борьбы. «Странно было ощущать, что демонстративному порицанию меня подвергли не только противники, но и бывшие единомышленники. Так и закончилась моя политическая карьера в Венгрии» ${ }^{22}$, - подытожил в своих «Воспоминаниях» генерал Джордже Стратимирович.

По мнению историка В. Крестича, политическая программа Стратимировича - одна из наиболее интересных и ценных за всю историю политический мысли сербов Воеводины, поскольку изложенные в ней идеи так или иначе присутствовали в общественном мнении. Особенно актуальны они стали после расформирования Военной границы в 1873 г. и Берлинского конгресса 1878 г., когда стало очевид- 
но, что сербы малосильны в борьбе за свои национальные интересы ${ }^{23}$. Более того, в условиях, когда сербская общественность сплотилась вокруг фигуры С. Милетича, такая программа была проявлением исключительной политической храбрости, недооцененной современниками. Новое прочтение эти идеи получили в позиции, занимаемой сербскими «нобилитетами», оформившимися как течение в 1884 г., когда Стратимирович был далек от политики. В 1877 г. семья Стратимировичей переселилась из Нови-Сада в Вену, где отставной генерал провел долгие годы до самой кончины в 1908 г.

\section{ПРИМЕЧАНИЯ}

1 Монастыри Фрушской Горы - 16 монастырей Сербской православной церкви, расположенные на кряже Фрушка-Гора в Автономном крае Воеводина, в историко-географической области Срем.

2 Krestič V. Stratimirovič Đorđe // Enciklopedija Jugoslavije. Zagreb, 1971. T. 8. S. 191.

3 Бешлин Б. Српски и мађарски либерализам у XIX веку 一 идејне и политичке везе и поделе // Српско-мађарски односи кроз историју. Нови Сад, 2007. С. 155.

4 Крестич В. Срби у Угарской 1790-1918. Нови Сад, 2013. С. 81.

5 Проглас са одлукама донетим на заседању Срба окупленим у Пешти 6. марта 1848. године // Дигитална библиотека Матице Српске. URL: http://digital.bms.rs/ebiblioteka/publications/view/1780 (дата обращения - 15.05.2018).

6 Полит-Десанчић М. Како је то било у нас Срба у буни 1848-1849. Нови Сад, 1996. С. 64-65.

7 На русском языке см., например: Чуркина И. В. Хорваты и сербы в революции 1848 г. // Европейские революции 1848 года. «Принцип национальности» в политике и идеологии / Отв. ред. С. М. Фалькович. М., 2001. C. 369-392.

8 Гавриловић С. Срем у револуцији 1848-1849 године. Београд, 1963. C. 81.

9 Стратимировић Ђ. Успомене. Нови Сад, 2013. С. 43-44.

10 Микавииа Д. Михајло Полит Десанчић. Нови Сад, 2007. С. 32-33.

11 Описаније живота патријарха Јосифа Рајачића / Приређ. Ж. Димић, Љ. Јеремић. Нови Сад, 2011. С. 30.

12 Стратимировић Ђ. Успомене. С. 101

13 Ibid. C. 102. 
14 О периоде между революцией 1848-1849 гг. и подписанием Соглашения 1867 г. см., например: Deák $\dot{A}$. From Habsburg Neo-Absolutism to the Compromise, 1849-1867. New York, 2008.

15 Проглас патријарха Јосифа Рајачића о сазивању Благовештенског сабора // Дигитална библиотека Матице Српске. URL: http://digital. bms.rs/ebiblioteka/publications/view/1963 (дата обращения - 15.05.2018).

16 Стратимировић Ђ. Успомене. С. 104.

17 Ibidem.

18 Ibid. C. 107.

19 Анонимна промеморија групе конзервативних српских војвођанских политичара блиских Ђорђу Стратимировићу против Светозара Милетића и његове странке. Предлаже се стварање конзервативне аустрофилске странке на челу с Ђ. Стратимировићем. Беч, 1 октобра 1866 // Светозар Милетић и његова странка. Грађа 1860-1885. / Прирећ. Н. Петровић. Сремски Карловци, 1968. Књ. 1. 1860-1869. С. 330-335.

20 Крестич В. Срби у Угарской. С. 278.

21 Крестић В. О Ђорђу Стратимировићу и његовом политичком програму из 1872 године // Зборник Матице српске за историју. 1978. № 18. С. 31-49.

22 Стратимировић Ђ. Успомене. С. 115.

23 Крестић В. О Ђорђу Стратимировићу и његовом политичком програму. С. 45.

\section{K. Novoseltseva}

«If you're not a liberal when you're young»:

to the political biography of Đorđe Stratimirović

Đorđe Stratimirović (1822-1908) is a romantic figure in the history of the Serbian national movement in the second half of the nineteenth century. A born leader and inspirer, he played an important role in the Revolution of 1848-1849 and remained in the memory of generations as People's General. However, his further activities were thrown out of the history of political thought of the Serbs of the Austrian monarchy as altering from his earlier views. As a mature man, he - under the influence of political circumstances - turned from a young active liberal into a leader of the conservative direction. In 1872, he developed a program of the future moderate party, which included cooperation with the government of the Kingdom of Hungary. Given the Serbs were rather rallying around the liberals, uncompromising fighters for national rights, Stratimirović's choice was a wrong move. Keywords: Stratimirović, Serbian national movement in the Habsburg monarchy, the political parties of the Serbs in Vojvodina. 


\title{
Русские консульства в Далмации в контексте политических процессов у южных славян Австро-Венгрии и на габсбургско-османском пограничье в 70-е гг. XIX в.
}

\begin{abstract}
В статье рассматриваются функции русских консульств в Далмации в 70-е гг. XIX в. и их оценки политических процессов у южных славян в Австро-Венгрии и Османской империи. В центре внимания - деятельность русских консулов в Фиуме и Рагузе в их взаимоотношениях с австрийскими и венгерскими властями, а также место консульств в сети русских дипломатических представительств в Балканском регионе.

Ключевые слова: русские консульства, Далмация, хорватское национальное движение, сербское национальное движение, Военная граница, Хорватия, Австро-Венгрия, Черногория.
\end{abstract}

DOI: 10.31168/2073-5731.2018.3-4.1.07

В начале 70-х гг. XIX в. в Европе изменился баланс сил. В 1867 г. Австрийская империя превратилась в двуединую Австро-Венгрию. И хотя дипломатическое ведомство оставалось одним из немногих единых для Цис- и Транслейтании институтов, венгерская политическая элита, в том числе в лице министра иностранных дел венгерского графа Дюлы Андраши ${ }^{1}$, получила возможность влиять на международные отношения на континенте. В 1871 г. Пруссия в ходе скоротечной Франко-прусской войны положила конец Второй французской империи и сама стала ядром Германской империи, объединившей немецкие государства Центральной Европы. Между политической элитой Венгрии и Германией началось сближение на почве интереса к процессам на Балканах. Также на рубеже 1860-1870-х гг. активизировался и интерес России к региону, связанный с выходом страны в 1871 г. из обязательств по Парижскому мирному договору благодаря деятельности русского министра иностранных дел А. М. Горчакова ${ }^{2}$.

Интерес к Далмации в данной статье не случаен. Он обусловлен ее географическим положением и статусом в рамках Австро-

Статья написана при финансовой поддержке Российского фонда фундаментальных исследований, проект № 18-09-000346. 
Русские консульства в Далмации в контексте политических процессов.. 71

Венгрии. Если населенная преимущественно хорватами (но также и сербами) Хорватия-Славония входила в Венгерское королевство (относилась к Транслейтании), то присоединенная в конце XVIII в. к владениям Австрийского дома Далмация, где значительную часть населения составляли южные славяне, после 1867 г. осталась в Австрии (или Цислейтании). Для России в период после Крымской войны (1753-1755) Далмация представляла интерес сразу по нескольким причинам. Во-первых, не считая северной Адриатики, здесь был единственный в Габсбургской монархии выход к морю. Во-вторых, Далмация граничила с Османской империей. В-третьих, северная часть провинции входила в состав Военной границы - особой милитаризированной административной единицы, устройство которой привлекало внимание русских военных агентов, так как в то же время в России решался вопрос о дальнейшем существовании казачьих войск. В-четвертых, как Далмация, так и примыкающие к ней Военная граница и королевство Хорватии и Славонии были населены преимущественно славянами, одноязычными со своими соседями по ту сторону границы - славянами под властью Оттоманской Порты.

Одной из основных характеристик региона было его пограничное положение, что обуславливало пересечение здесь интересов политических сил как локального уровня, так и представляющих оба властных центра двуединой монархии. Кроме того, в регионе в середине XIX в. набрали силу хорватские политические движения, боровшиеся за воссоединение «исторических» хорватских земель, включенных в состав нескольких административных образований Габсбургской монархии. В рамках Венгерского королевства хорватам удалось получить ограниченную автономию по Хорвато-венгерскому соглашению 1868 г., закреплявшую право королевства Хорватии и Славонии на получение в будущем всей территории Хорватско-славонской военной границы. Однако хорватские политические деятели, придерживавшиеся «народняцких» (действовавших в интересах хорватского народа) и «правашских» (отстаивавших «историческое право» хорватского народа) взглядов, не останавливались на достигнутом и продолжали борьбу за обретение более широкой автономии. В качестве своих союзников они видели как других славян монархии (например, чехов, которые не смогли получить автономию в 1871 г. из-за противодействия венгерских политиков), так и внешние силы, не исключая Россию, оправлявшуюся после поражения в Крымской войне (1853-1856). В результате русские консульства, помимо обслуживания русских подданных в регионе, что им предпи- 
сывал Консульский устав ${ }^{3}$, еще и были «ушами и глазами» России, способными слышать и видеть чаяния местных политиков.

История русских консульств Далмации рассматривалась отечественными исследователями в контексте истории Хорватии и самого региона лишь в поздних работах В. И. Фрейдзона ${ }^{4}$. Сосредоточившись на истории славянских политических сил в Далмации, ученый уделил меньше внимания взаимоотношениям с соседним, вассальным от Османской империи Черногорским княжеством ${ }^{5}$. В данной статье мы предпримем попытку оценить влияние русских консульств в Далмации на южнославянское население в пограничье Австро-Венгрии и Османской империи, их воздействие на процессы, имевшие прямое отношение к становлению современной хорватской государственности, а также на славянские политические силы региона.

История русских консульств Далмации связана с именами братьев Константина Дмитриевича (1824-1894) и Андрея Дмитриевича (1837-1897) Петковичей, уроженцев Македонии (Османская империя), получивших образование в России. С 1858 по 1869 г. старший брат К. Д. Петкович служил консулом (затем генеральным консулом) в Рагузе (Дубровник). В 1869 г. на смену ему прибыл Александр Семенович Ионин (1837-1900), который до 1875 г. служил в ранге консула, а затем, в 1875-1878 гг., генерального консула в Рагузе. Младший Петкович, владевший несколькими европейскими языками, находился на должности русского консула в Фиуме (Риека) с 1873 по 1892 г., сменив там Леонида Васильевича Березина (1836-1889), который служил в Фиуме русским вице-консулом с ноября 1862 г. по 1869 г., а затем консулом - до 1873 г.

Вытянутость Далмации с севера на юг вдоль Адриатического побережья предопределила то, что каждое из консульств «специализировалось» на своей «области интересов». Так, русский консул в Рагузе следил за событиями в османских владениях - Черногории, а также Боснии и Герцеговине - даже больше, чем собственно в Далмации. Русский консул в Фиуме, в свою очередь, писал в значительной мере о королевстве Хорватии и Славонии, а также Военной границе. При этом степень вовлеченности консулов в локальные события была различной.

Современники, в первую очередь представители консульств других стран в регионе, например итальянский консул в Сараево Чезаре Дурандо, оценивали русское представительство в Рагузе как «чрезвычайно сильное» по составу сотрудников. Отмечалось хорошее знание русскими региона, а также наличие особой военной миссии, включая подполковника, капитана и их заместителей. Если рус- 
Русские консульства в Далмации в контексте политических процессов.. 73

ский консул в Рагузе имел тесные контакты с черногорским князем и повстанцами Герцеговины и Боснии, то консул в Фиуме больше был наблюдателем за происходящим в империи и имел гораздо меньше рычагов влияния на процессы на входящих в его круг ответственности территориях. Консульство в Фиуме не имело такого сильного состава. Тем не менее МИД России старался не разглашать (держать в секрете) имена сотрудников своих консульств и состав дипломатических миссий.

Русские консулы поддерживали между собой связь, хотя порядок был таков, что донесения с мест отправлялись в русское посольство в Вену, а переписка с главами департаментов МИД проходила через сотрудников венской миссии. В исключительных случаях телеграммы из Фиуме и Рагузы направлялись напрямую в СанктПетербург. Из Вены по консульствам рассылались и секретные телеграммы. Например, 31 мая 1878 г. Петкович в Фиуме получил секретную телеграмму из Рагузы от надворного советника И. С. Ястребова, в которой говорилось о приказании из Вены «мобилизовать войско, увеличив его численность и поставив его как можно скорее на военную ногу» в Далмации, что было связано с вводом австро-венгерских войск в Боснию и Герцеговину6 ${ }^{6}$ Кроме того, русский консул в одном городе мог получать сведения о происходившем в зоне ответственности другого консульства. Так, в феврале 1871 г. А. С. Ионин из Рагузы сообщал о приезде в город «православного серба» генерала Пешича из Военной границы, который передал важные сведения о ее ближайшем упразднении ${ }^{7}$

Как уже отмечалось выше, основным полем деятельности консульства в Рагузе стало Черногорское княжество, чье руководство опиралось на русскую помощь. Поэтому рагузинский консул выступал еще и главным советником черногорского князя, причем зачастую с возможностью влияния на принятие князем конечного решения по тому или иному вопросу, главным образом из области внешней политики. Более того, Р. Петрович писал, что даже английский представитель в Константинополе Генри Эллиот «несколько раз указывал, что штаб-квартира Герцеговинского восстания находится в Рагузе, подразумевая русское генеральное консульство» ${ }^{8}$. По мнению югославского историка, также под русским покровительством в Рагузе действовал «Дамский комитет», помогавший беженцам и раненым из Боснии и Герцеговины ${ }^{9}$. Здесь надо обратить внимание на то, что в 1876 и 1877 гг. русский консул в Фиуме А. Д. Петкович выдал градоначальнику этого города 50 форинтов на нужды нищих, в том числе и 
беженцев. То же самое он сделал в 1880 и 1881 гг. Таким образом, оба русских консула в Далмации были неравнодушны к нуждам славян, бежавших от кровавых событий в Османской империи.

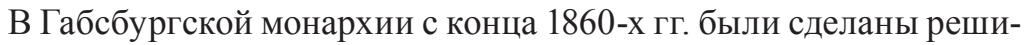
тельные шаги по упразднению системы Военной границы. Так, от уже упоминавшегося выше генерала Пешича А. С. Ионин узнал, что «присоединение границы хорватской к Венгрии в принципе окончательно решено, что Венгрия за это берет на себя $3 \%$ государственных расходов и что приобретение это она поставила непременным условием своего согласия одобрить бюджет военного министерства» ${ }^{10}$. Таким образом, уже более чем за четыре месяца до выхода санкционированных императором дополнений в закон о Военной границе (8 июня 1871 г.), продемонстрировавших стремление Вены к ее упразднению, наш МИД уже знал о готовившихся изменениях.

Сам процесс частичной демилитаризации Военной границы (в 1872 г. была упразднена восточная, сербско-банатская, ее часть) не остался незамеченным и для русских военных агентов в Вене (Ф. Ф. Торнау и В. В. Молоствова) $)^{11}$, тем более что в 1869 г. Боголюб Каталинич - граничар, перешедший на русскую службу, — представил для русского Генштаба записку, в которой подробно объяснял, как военный потенциал Границы можно использовать в интересах России ${ }^{12}$.

Ввиду непрерывных военных столкновений между черногорцами и турками венским Военным министерством рассматривалась возможность создания ландвера (ополчения) на границе австрийской Далмации с находящимся в вассальной зависимости от османов Черногорским княжеством. В марте 1871 г. наместник Далмации генерал Г. Родич собрал в Ризано предводителей приграничного племени кривошийцев и предложил им служить в ландвере, сохраняя свою народную одежду. Для переговоров со стороны Черногории был приглашен секретарь черногорского князя протоиерей Иован Сундечич, который являлся также одним из основных информаторов Ионина о политике Черногории, а также главным каналом связи последнего с самим князем Николой Петровичем-Негошем. Однако тогда переговоры не увенчались успехом. К идее ландвера вернулись снова уже в 1874 г. $^{13}$ Но и на этот раз генералу Г. Родичу не удалось достичь компромисса с черногорской стороной. К соглашению о ландвере прилагалась конвенция о выдаче Черногорией дезертиров из этого самого ландвера, которую русский консул Ионин не советовал князю Николе подписывать в таком виде, как она была предложена черногорцам ${ }^{14}$. 
Русские консульства в Далмации в контексте политических процессов... 75

Петкович тем временем в Фиуме следил за попытками хорватских политиков бороться за Военную границу и присоединить ее к королевству Хорватии и Славонии. 29 декабря 1876 г. вышел новый императорский закон, запрещавший создание новых задруг на Границе $(\S 1)^{15}$, что предполагало отход от основополагающего для граничар типа семейной организации. Таким образом, несмотря на попытки создания милитаризированных отрядов в гражданской части Далмации, всё шло к упразднению веками существовавшей Военной границы. Однако ландверная альтернатива Хорватско-славонской границе в Далмации не имела успеха, в том числе и из-за деятельности русского консула.

Протоиерей Сундечич (в дальнейшем агент черногорского князя в Задаре) - перед тем как поехать на переговоры о ландвере с генералом Родичем - заезжал к Ионину. Сундечич отправлялся в столицу Далмации - Зару (Задар) для переговоров с Родичем и в Вену — c министром-президентом графом Фридрихом Фердинандом Бойстом. Разрешение на аудиенцию ему должен был дать Г. Родич. На встрече с А. С. Иониным Сундечич не только сообщал ему содержание инструкций своего князя, но и советовался с русским консулом, как их лучше выполнить. Ионин мог даже при необходимости изменять содержание инструкций сам. При этом 8 марта (24 февраля по ст. ст.) 1871 г. Ионин написал русскому послу в Вене Евгению Петровичу Новикову (1826-1903) о том, что «исправлять или изменять их [инструкции] не нашел нужным, ибо в них не заключалось ничего особенно важного» ${ }^{16}$.

С одобрения А. С. Ионина черногорский князь выдвинул свои требования, среди которых было признание независимости Черногории со стороны Австро-Венгрии, а также пропуск соли в княжество из адриатических портов ${ }^{17}$. Всё это Ионин сообщил Новикову, добавив, что «он не представляет содержания сего донесения г. Директору Азиатского Департамента и потому просит Его Превосходительство распорядиться, если сочтет нужным, передачей вышеизложенного Императорскому Министерству» ${ }^{18}$. Таким образом, А. С. Ионин, так же как и консул в Фиуме А. Д. Петкович, поддерживал связь в первую очередь с послом в Вене, а не с Константинополем или Азиатским департаментом МИД, хотя порой специфика решаемых задач могла потребовать и такого сотрудничества.

Так, когда в июне 1873 г. проходили переговоры отдельно между Австро-Венгрией, Османской империей и вассальным от последней княжеством Черногория, Ионин писал в Вену Новикову, что считает 
нужным докладывать послу только о черногоро-австро-венгерских контактах, тогда как о черногоро-османских сообщает главе Азиатского департамента МИД П. Н. Стремоухову ${ }^{19}$. Тем не менее письма последнему Ионин прилагал к донесениям главе российского дипломатического представительства в Вене.

При этом на политику в регионе также оказывало влияние и другое вассальное княжество Османской империи - Сербия. Русскому консулу в Рагузе приходилось особенно учитывать сербский фактор во время многосторонних переговоров с участием всех вассалов Порты, а тем более и Австро-Венгрии. Для принятия правильных решений и проведения необходимых консультаций для князя Николы в таких случаях требовалась согласованность с русским консульством в Белграде, оказывавшим также пусть не столь определяющее, но значимое влияние на сербские власти. Однако, судя по неоднократным жалобам Ионина Новикову в неполучении вовремя сведений из Белграда от консула Н. П. Шишкина и многочисленным его просьбам присылать литографированные донесения последнего ${ }^{20}$, можно сделать вывод, что слаженная работа русских представительств в соседних империях давала сбой. Это негативно сказывалось и на возможности оперативных качественных советов князю Николе со стороны А. С. Ионина, который, по его словам, был вынужден полагаться лишь на сведения, получаемые черногорцами из Белграда ${ }^{21}$.

Об обратном влиянии Черногорского княжества на политические процессы в Далмации может свидетельствовать тот факт, что депутаты в далматинский ландтаг с самого юга региона ориентировались именно на Черногорию и поддерживали тесные контакты с ее главой. Такая ситуация вызывала необходимость для местных властей проводить гибкую политику в отношении соседнего княжества. В апрельском донесении 1873 г. Е. П. Новикову А. С. Ионин высказал предположение, почему губернатор Далмации генерал Г. Родич стал проявлять «особенную любезность» в отношении черногорского князя, несмотря на его строптивость и крайнюю осмотрительность при заключении ряда экономических сделок. Русский консул объяснял это актуальным положением дел в Далмации: «Родичу нужно поддержать пятерых депутатов, которые скомпрометировали себя в здешнем общественном мнении, а более всего главного из них, Любишу, на избрание которого князь может иметь сильное влияние. Кроме того, в Каттаро [Бока-Которска. - A. Д.] протестуют православные против присоединения их епархии к Буковинской Митрополии - здесь также не отстранить Черногорское влияние» ${ }^{22}$. 
Здесь следует заметить важность фигуры Стефана М. Любиши (1824-1878) для политических процессов в Далмации и распространения здесь идеи о том, что Далмация является частью единого Хорватского государства (королевства) в составе Габсбургской монархии. С. Любиша в 1860-х гг. являлся депутатом-народняком далматинского ландтага (сабора) от г. Бока-Которска. В 1867 г. он вошел в число пяти депутатов, делегированных сабором Далмации в австрийский рейхсрат. Среди этой группы он был единственным представителем Народной партии Далмации (глава М. Клаич), остальные четверо автономисты (противники союза с Хорватией и Славонией), которые были выразителями интересов патрициата далматинских городов. Такой состав делегации был вызван большинством мест в саборе у автономистов. Однако 1871 г. и здесь изменил ситуацию. На выборах победила Народная партия, что повлияло и на состав «пятерки» депутатов для рейхсрата: теперь они все были народняками. Свой мандат сохранил и С. Любиша. В 1873 г. в рейхсрате проходило голосование по реформе о прямых выборах депутатов этого представительного органа всей Цислейтании. Прямые выборы не устраивали Народную партию Далмации, однако все пять представителей далматинского сабора проголосовали за реформу, добавив нужные голоса для прохождения законопроекта.

В. И. Фрейдзон пишет, что правительство «просто подкупило депутатов» $2^{23}$. В дальнейшем, будучи исключенными из Народной партии, эти пять депутатов основали Национально-центристскую партию и группу «Земляк» в саборе. Несмотря на то что группа и партия состояли как из хорватов, так и из сербов, ее идею все больше начал формировать лидер «земляков» С. Любиша, считавший себя «сербом и православным христианином» ${ }^{24}$. Именно он впервые стал активно отстаивать интересы не всех славян, а именно сербского и вообще православного населения Далмации. В 1876 г. С. Любиша стал председателем далматинского сабора, а в январе 1877 г. открыто выступил против соединения Далмации с королевством Хорватии и Славонии, ссылаясь на «неудовлетворительный статус» сербского населения в этой части Габсбургской монархии ${ }^{25}$. Следует отметить, что это было еще до присоединения к Хорватии и Славонии территории Военной границы. Таким образом, Любиша на тот момент был крупнейшим далматинским политиком, выступившим против реализации идеи хорватской государственности в рамках Триединого королевства Хорватии, Славонии и Далмации, что сблизило позиции его партии с автономистами. Именно он за- 
ложил фундамент возникшей в 1880 г. в Далмации Сербской национальной партии, которая самим своим появлением окончательно «похоронила» идею политического словинства, т. е. формирования общей внеконфессиональной идеологии для славянского населения в регионе, которую пытались в 1860 -е гг. воплощать в жизнь некоторые лидеры местной Народной партии.

Фрейдзон писал, что С. Любиша получал указания от наместника Далмации Г. Родича, а также сотрудничал с руководством Сербского княжества, тем самым являясь «двойным агентом» ${ }^{26}$. Историк считал, что этого далматинского политика и его группу «Земляк» использовала в своих целях лишь австрийская администрация Далмации. Причем после того, как сама местная Народная партия отложила воссоединение с Хорватией и Славонией и тем самым перешла с 1877 г. на позиции «земляков», сделав такой маневр из-за невозможности быстрого достижения своей цели, группа С. Любиши перестала быть нужна австрийцам, быстро распалась, а сам ее лидер был обвинен в коррупции и выдворен из политической жизни.

Однако эта ситуация представляется куда сложнее, если рассмотреть донесения нашего консула Ионина. В частности, он сообщал следующее: «По поводу Любиши и будущих выборов князь уже спрашивал меня, как бы я думал. Я ему сказал, что на его месте я помог бы Любише, ибо это домашние далматинские дела» ${ }^{27}$. Таким образом, помимо австрийской и сербской сторон, в данном деле прослеживаются также активные черногорский и русский факторы, требующие дальнейшего изучения. Очевидны попытки русского консульства в Рагузе получить влияние на православное население региона, разыгрывая сербскую карту, что неизбежно могло привести к расколу в стане местной Народной партии, поддерживавшей тесные связи с народняками Хорватии и Славонии. Такую игру русских дипломатов против народняков можно попробовать объяснить сменой позиции партии с оппозиционной к Вене на примиренческую в 1871 г., что мешало формированию в Габсбургской монархии единой славянской силы из сторонников федерализации империи. Тем более Ионин относился прохладно к идее австрославизма и мог сам начать игру в пику таким настроениям хорватов ${ }^{28}$.

Следует также заметить, что честь князю Николе ПетровичуНегошу оказывал не только губернатор Далмации, но и премьерминистр Венгрии Дюла Андраши, например, выделяя ему лично военный пароход для перемещения из Каттаро в Рагузу на пути князя в Вену на встречу с императором Францем Иосифом ${ }^{29}$. Это, 
Русские консульства в Далмации в контексте политических процессов.. 79

видимо, показывает также заинтересованность руководства Венгрии в укреплении своего влияния в австро-османском пограничье. Тем более одной из главных тем переговоров в Вене между князем Николой, императором Францем Иосифом и графом Андраши должен был стать вопрос изменения границ вассального Черногорского княжества и особого статуса границы между последним и Австро-Венгрией.

Здесь следует заметить, что русское консульство в Фиуме не имело таких возможностей влияния на политические процессы в королевстве Хорватии и Славонии. Сами политики королевства не нуждались в каких-либо консультациях со стороны России, и даже им было очевидно, что таковые дадут их политическим противникам хорошие козыри для обвинений. При решении важных и неотлагательных вопросов, например, лидеры наиболее близкой по своей идеологии к панславистским взглядам из всех хорватских партий Народной партии, католический епископ Йосип Юрай Штросмайер (1815-1905) и Франьо Рачки (1828-1894), обращались непосредственно к русскому послу в Вене Новикову, ведь, как писал Рачки Штросмайеру, «пусть Новиков и не тот чиновник, который принимает решения, но он всё же выполняет приказания своих властей, а также их информирует» ${ }^{30}$. В своих обращениях к послу России епископ делал акцент на теме панславизма: «Хочет того Россия или нет, но подозрительность Европы всегда будет заставлять ее солидаризироваться со славянскими интересами во всем мире» ${ }^{31}$ или «страдания, причиняемые славянам, являются в то же время ранами, наносимыми России, которые когда-нибудь начнут кровоточить» ${ }^{32}$. При этом русского консула в Белграде Николая Павловича Шишкина (1830-1902) Штросмайер уверял по поводу Военной границы, что «наместники сильно ошибаются насчет расположения к Сербии граничар», также он говорил, что сербский князь Михаил Обренович обманул граничар и хорватов, на которых те ориентировались ${ }^{33}$. Что же хотели от России лидеры хорватской Народной партии? Финансовой подпитки. Епископ Штросмайер полагал, что помощь требуется: хорватским патриотам, пострадавшим от «мадьярских преследований»; Народной партии для успешной борьбы на выборах против их оппонентов, особенно из провенгерского лагеря (мадьяронов); партийной периодике (газеты Pozor и Zukunft, выходившие в Вене) ${ }^{34}$. Таким образом, наиболее пророссийским хорватским политикам от нашей страны была нужна лишь финансовая поддержка в обмен на расплывчатые идеи славянской взаимопомощи. Тогда как Новиков отмечал, что 
самому императору Й. Ю. Штросмайер клялся в лояльности и даже давал гарантии в ответ на его сомнения по поводу лояльности хорватов, что «потребовалась еще сотня лет для того, чтобы они созрели для независимости» ${ }^{35}$. Из чего следовало, что хорватские политики ведут многовекторную игру, пытаясь получить выгоду от всех заинтересованных сторон.

В ходе работы двух консулов у них сложились разные взаимоотношения с главами соответствующих регионов - наместником королевства Далмации и губернатором венгерского порта Фиуме. Рассмотрим эту сторону их деятельности на примере награждения за укрепление двусторонних связей. Так, А. С. Ионин в 1874 г. высказал Е. П. Новикову свое мнение «по поводу орденов, полученных Родичем и другими в Далмации, которые получили их <..> за то, что своим благоразумным политическим поведением способствовали нашей Австро-русской дружбе. Но если они способствовали этому, что, конечно, справедливо, то не было ли бы также прилично и со стороны Австрийского кабинета признать, что и консульство в Рагузе способствовало тому же, и ответить тем же? ибо без этого мы окажемся здесь слишком пассивными деятелями, не стоящими внимания» ${ }^{36}$. Таким образом, А. С. Ионин полагал, что работа консульства именно на ниве укрепления дружбы двух стран должна оцениваться выше, чем заслуги местных властей.

В 1886 г. А. Д. Петкович получил благодарственное письмо с положительной характеристикой и надеждой на дальнейшую дружбу от уходящего в отставку великого жупана (в официальной венгерской терминологии - фёишпана) Модрушско-Риекской жупании (административно-территориальной единицы, комитата) Л. Райзнера (1824-1902), который находился на своем посту с 1878 г. Но самые доверительные отношения сложились у него с венгерским губернатором Фиуме Г. Сапари (1828-1898), который занимал этот пост с 26 февраля 1873 по 1 ноября 1883 г. Наш консул дал ему такую характеристику:

«Состоя здесь консулом с 1873 года, я в течение этих десятилетий пего пребывания* поддерживал с графом Сапари самые лучшие отношения, и во всех случаях, когда я имел надобность обратиться к нему по службе, он оказывал мне полную готовность к удовлетворению моих требований. Кроме того, все подчиненные ему власти, политические и морские, оказывали мне всякое содействие при исполне-

* Зачеркнуто в источнике. 
Русские консульства в Далмации в контексте политических процессов.. 81

нии моих служебных обязанностей, сообщая по первому востребованию нужные мне сведения. К сему считаю своим особенным долгом засвидетельствовать, что при всех случаях, как радостных, так и нечаянных, касающихся нашего Августейшего Царствующего Дома, Граф Сапари являлся ко мне первым, чтоб выразить мне как от имени своего правительства, так и от имени себя самого выражения сочувствия. Гостеприимный его дом был также всегда открыт для приезжавших сюда русских вообще, в особенности же морских офицеров <..> и они всегда находили самый радушный прием» ${ }^{37}$.

На основе всего вышеизложенного А. Д. Петкович просил русского чрезвычайного полномочного посла в Вене А. Б. Лобанова-Ростовского (занимал пост с 1882 по 1895 г.) «в интересе наших торговых и политических дел в здешнем крае исходатайствовать для гр. Сапари какую-нибудь Монаршую награду, которая, сколько мне известно, не только ему доставит большое удовольствие, но также произведет весьма хорошее впечатление в высших правительствующих сферах в Будапеште» ${ }^{38}$. Однако помимо уже полученных графом Г. Сапари ордена св. Стефана первой степени (1875) и Большого креста ордена Леопольда (1881) губернатор, насколько удалось установить, других орденов не получил.

Возможно, на различие в характере взаимоотношений повлияло и местоположение консульств: если Фиуме являлся местом резиденции самого губернатора, то Рагуза не была столицей Далмации (напомним, что центром провинции был г. Зара).

В заключение можно сделать вывод, что русские консульства в таком традиционно пограничном регионе, как Далмация, не ограничивались сбором данных обо всем достойном упоминания, но были агентами русского влияния на местные политические процессы. Особое географическое положение Рагузы, близкой к Черногорскому княжеству и турецким владениям, сделало город одним из важнейших центров реализации интересов России в пограничье двух империй. Консульство в экстерриториальном венгерском порте Фиуме, напротив, скорее занималось информированием центра о политических процессах в соседних Хорватии и Славонии, а также на Военной границе, находившейся в процессе демилитаризации. То обстоятельство, что русский консул в Рагузе являлся фактически главным советником и даже порой куратором для черногорского князя Николы, а также координировал свою деятельность с нашими консулами в Белграде и Сараево, придерживавшимися просербской ориентации, предопределило и его симпатии. В регионе была оказана поддержка далматин- 
ским политикам - носителям сербского национального самосознания, работавшим на раскол местной Народной партии, в том числе и с подачи австрийских властей, тогда как лидеры народняков Хорватии и Славонии безуспешно обращались к русским дипломатам за финансовой помощью.

\section{ПРИМЕЧАНИЯ}

1 См.: Diószegi I. Bismarck und Andrássy. Ungarn in der deutschen Machtpolitik in der 2. Hälfte des 19. Jahrhunderts. Wien; München; Budapest, 1999; Медяков А. С. Между Востоком и Западом. Внешняя политика монархии Габсбургов в первые годы дуализма (1866-1871). М., 2009.

2 См., например: Виноградов В.Н. Балканская эпопея князя А. М. Горчакова. М., 2005.

3 Курбанов С. Г. Консульская служба в России от истоков до современности: развитие и становление // Управленческое консультирование. 2015. № 9. С. 177.

4 См.: Фрейдзон В. И. Далмация в хорватском национальном возрождении ХІХ в. К истории югославизма и его неудачи. М., 1997; Фрейдзон В. И. История Хорватии. Краткий очерк с древнейших времен до образования республики (1991 г.). М., 2001; Фрейдзон В. И. Русские консульские донесения из Дубровника о положении в Далмации в 60-х начале 70-х годов ХІХ века // Славяноведение. 2005. № 3. С. 38-46. См. также публикации архивных документов: Фрейдзон В. И. Две беседы Й. Ю. Штросмайера с российскими дипломатами // Славяноведение. 2004. № 1. С. 132-140; Фрейдзон В. И. Л. Березин. Путешествие по Хорватии и Военной границе (1863 год) // Славяноведение. 2004. № 5. С. 93-103.

5 Открытие русского консульства и его дальнейшую работу в Дубровнике изучал в контексте истории города советский историк М. М. Фрейденберг. Документы русских консульств в Далмации привлекали для изучения истории смежных регионов отечественные исследователи Е. К. Вяземская, В. М. Хевролина и др., а из зарубежных югославский (сербский) историк М. Экмечич. См.: Фрейденберг М. М. Дубровник и Османская империя. М., 1984; Вяземская Е. К. Босния и Герцеговина во внешнеполитических планах России в 50-70-х годах XIX в. // Россия и Балканы. Из истории общественно-политических и культурных связей (XVIII в. - 1878 г.). М., 1995; Хевролина В. М. Восточный кризис 70-х годов XIX в. // История внешней политики России. Вторая половина XIX века (от Парижского мира 1856 г. до русско-французского союза). М., 1999; Ekmeс̌ić M. Ustanak u Bosni: 1875-1878. Sarajevo, 1960. Крупнейшим историком русской дипломатической миссии в Далмации, 
в первую очередь в Дубровнике, остается югославский ученый Р. Петрович. См., например: Петрович Р. Роль русского консульства в Дубровнике в развитии югославянско-русских отношений // Босния, Герцеговина и Россия в 1850-1875 гг.: народы и дипломатия. Материалы «круглого стола» советских и югославских историков. М., 1990.

6 Архив внешней политики Российской империи (далее - АВПРИ). Ф. 172. Оп. 514/2. Д. 152. Л. 5.

7 Там же. Д. 88. Л. 13.

8 Miović V. Rec.: R. Petrović. Ruski konzulat u Dubrovniku od osnivanja do 1878. godine. Dubrovnik: Srpska pravoslavna crkvena opština u Dubrovniku, 2010 // Anali Zavoda za povijesne znanosti Hrvatske akademije znanosti i umjetnosti u Dubrovniku. Lipanj 2011. N 49. S. 361.

9 Петрович Р. Роль русского консульства в Дубровнике. С. 123.

10 АВПРИ. Ф. 172. Оп. 514/2. Д. 88. Л. 13.

11 См.: Перетятько А. Ю. Военная граница от битвы при Сольферино до начала демилитаризации: три взгляда из России (Ф. Ф. Торнау, Н. И. Краснов, Б. Каталинич). Ч. 1 // Военный сборник. 2016. Vol. 12. Is. 2. C. $79-99$.

12 Российский государственный военно-исторический архив. Ф. 428. Оп. 1. Д. 108. Л. 1-77.

13 АВПРИ. Ф. 172. Оп. 514/2. Д. 112. Л. 3.

14 Там же.

15 Zakon od 29.12.1876 // Sbornik zakonah i naredabah, valjanih za kraljevinu Hrvatsku i Slavoniju. 1877. Kom. IV. S. 159.

16 АВПРИ. Ф. 172. Оп. 514/2. Д. 88. Л. 18.

17 Там же. Л. 19.

18 Там же. Л. 23.

19 Там же. Д. 107. Л. 24; Д. 112. Л. 28-29.

20 Там же. Д. 107. Л. 30.

21 Там же.

22 АВПРИ. Ф. 172. Оп. 514/2. Д. 107. Л. 12.

23 Фрейдзон В. И. Далмация в хорватском национальном возрождении XIX в. С. 114.

24 Там же. С. 117.

25 Там же.

26 Там же. С. 116.

27 АВПРИ. Ф. 172. Оп. 514/2. Д. 107. Л. 12-13.

28 Фрейдзон В. И. Далмация в хорватском национальном возрождении XIX в. С. 113.

29 АВПРИ. Ф. 172. Оп. 514/2. Д. 107. Л. 11.

30 Rački - Strossmayeru. Zagreb, 06.02.1878 // Korespondencija Rački — Strossmayer / Ured. F. Šišić. Zagreb, 1929. Knj. 2. S. 143. 
31 Фрейдзон В. И. Две беседы Й. Ю. Штросмайера. С. 138.

32 Там же. С. 139.

33 Там же. С. 136.

34 Там же. С. 135.

35 Там же. С. 139.

36 АВПРИ. Ф. 172. Оп. 514/2. Д. 112. Л. 39.

37 Там же. Ф. 296. Оп. 608. Д. 1. Л. 274.

38 Там же. Л. 275.

\section{A. M. Dronov}

Russian consulates in Dalmatia in the context of political processes by South Slavs in Austria-Hungary and on the Habsburg-Ottoman border in the 1870 s

The article studies the functions of Russian consulates in Dalmatia in 1870s and how they evaluated political processes in South Slavic communities in Austria-Hungary and Ottoman empire. The focus is on the activities of Russian consuls in Fiume and Ragusa and on their relations with the Austrian and Hungarian authorities, as well as the place the consulates had in the network of Russian diplomatic missions in the Balkan region.

Keywords: Russian consulates, Dalmatia, Croatian national movement, Serbian national movement, Military Frontier, Croatia, Austria-Hungary, Montenegro. 
M. М. Фролова

(Москва)

\title{
К 140-летию русско-турецкой войны 1877-1878 гг. Еленский отряд Дунайской армии в контексте исторических дискуссий
}

\begin{abstract}
В фокусе настоящей статьи находится Еленский отряд Дунайской армии, действовавший в г. Елене и в его окрестностях. На основе опубликованных документов и воспоминаний через призму имагологии рассматриваются взаимоотношения русских и болгар, освещается деятельность болгарских вооруженных отрядов и чет. Ключевые слова: русско-туреикая война 1877-1878 г2., восприятие русскими болгар, Еленский отряд, болгарские вооруженные отряды, четы, Елена.
\end{abstract}

DOI: $10.31168 / 2073-5731.2018 .3-4.1 .08$

140-летний юбилей русско-турецкой войны 1877-1878 гг., переформатировавшей геополитическое пространство Балканского полуострова, в результате чего появились независимые государства - Сербия, Румыния и Черногория, а болгарскому народу была дарована государственность, не только привлекает внимание ученых и широких кругов общественности к этому знаменательному событию, но и вызывает научные дискуссии. К числу проблем, на наш взгляд, односторонне изученных в историографии, принадлежит проблема взаимоотношений русских и болгар во время войны. В советской исторической науке с 1950-х гг. исследовались (в качестве приоритетных) темы русско-болгарского боевого содружества, вооруженной борьбы болгарского народа за свою национальную независимость, имевшей, как тогда писалось, массовый характер и являвшейся непосредственным продолжением революционной национально-освободительной борьбы накануне войны (это героизм русских воинов и болгарских ополченцев, отряды болгарской милиции, народные четы), а также разнообразной помощи болгар русской армии (В. Д. Конобеев, П. К. Фортунатов, А. А. Улунян и др.). Болгарские ученые также стали работать энергично в этом направлении, особенно после IX съезда Болгарской коммунистической партии (1966), который поставил задачу патриотического воспитания народа. На встрече с болгарскими писателями первый секретарь ЦК БКП Т. Живков в декабре 1966 г., сообщая о своих впечатлениях от музея в Плевне, посвященного 
русско-турецкой войне 1877-1878 гг., подчеркивал, что болгарские историки, правильно рассказывая о роли и героизме русских войск - освободителей, недооценивали активную помощь и содействие, которые им оказал болгарский народ ${ }^{1}$. Благодаря этому импульсу болгарская историография значительно пополнилась трудами ученых - В. Хаджиниколова, Х. Христова, Ц. Генова, С. Дойнова и др. Концепция о двух основных факторах (или мощных силах), которые обеспечили освобождение Болгарии, т. е. русское военное вмешательство и широкое болгарское национально-освободительное или революционное движение, остается ключевой и в современной болгарской литературе ${ }^{2}$.

В фокусе настоящей статьи находится Еленский (Еленинский) отряд Дунайской армии, действовавший в городе Елена и в его окрестностях (Еленской казе). Нами делается попытка рассмотреть через призму имагологии взаимоотношения русских и болгар на основе опубликованных материалов из известного дореволюционного издания «Сборник материалов по русско-турецкой войне 1877-1878 гг. на Балканском полуострове» (97 выпусков в 111 томах), а также воспоминаний русских офицеров, принимавших участие в деятельности этого отряда [полковника А. М. Лермонтова (1838-1906), командира 13-го драгунского Военного ордена его императорского высочества великого князя Михаила Николаевича полка; майора 34-й пехотного Севского его императорского высочества наследного принца австрийского полка П. Пржецлавского; капитана 4-й батареи 9-й артиллерийской бригады Г. Я. Политковского (1844-?); офицера, который под своими воспоминаниями поставил только инициалы Л. Б. и который был прикомандирован к штабу XI армейского корпуса; прапорщика С. И. Кисова (1861-1915), командира 1-й роты III дружины Болгарского ополчения].

Небольшой, но богатый городок Елена находился в 35 верстах от Тырново на юго-востоке в узкой лощине у р. Еленки. В нем проживали преимущественно болгары («считается с пригородами 613 домов и 2940 жителей» ${ }^{3}$ ). «Турецкого здесь и прежде было только полиция и чиновники. Это был чуть ли не самый благообразный изо всех болгарских городов: улицы мощеные, чисто содержимые и настолько широкие, что две повозки могут свободно разъехаться... Улицы освещались керосиновыми фонарями. Домики по преимуществу двухэтажные, каменные, чисто выкрашенные в белую краску» ${ }^{4},-$ писал Л. Б. Но уже за с. Беброво (последнее болгарское селение) начиналась «страна», заселенная исключительно турками, так сказать, «колыбель башибузуков» ${ }^{5}$.

Формирование Еленского отряда началось 5 июля 1877 г., когда в город вошел 13-й драгунский Военного ордена полк с двумя орудиями 
20-й конной батареи капитана Фроста, чтобы охранять как город, так и горные проходы через Елену и Беброво. Между Еленой и Беброво, у с. Долна Марена (Долни Марян), полковником Лермонтовым была найдена достаточно удобная позиция (Маренская) для обороны от турок, которые, опомнившись от паники, произведенной быстрым движением генерал-лейтенанта И. В. Гурко на Тырново и за Балканы, стали стягивать свои силы против русских, «в то же время поголовно вооружая жителей-мусульман» ${ }^{6}$ «превосходными ружьями Генри-Мартини, Снайдера и Пибоди», а «наглость и зверства их в отношении к болгарам росли ежечасно» ${ }^{7}$. Этими вооруженными жителями и башибузуками, которые отправляли свои семейства и имущество к Шумле (Шумену) и Котлу (Котелу), командовали турецкие офицеры, им были приданы даже небольшие части регулярных войск, пеших и конных.

Драгунский полк, в силу особенностей этого рода войск и из-за своей небольшой численности, не имел возможности эффективно действовать в лесистой, сильно пересеченной, гористой и весьма обширной местности. Для его усиления 19 июля 1877 г. в Елену пришла VI дружина Болгарского ополчения под командованием поручика Сахарова. Лермонтов вспоминал, что «прибытие молодцов-дружинников», которых, правда, было всего 350 человек, «немедленно повлияло на действия башибузуков. Ежедневно составлялись летучие колонны из обоих родов оружия, которые скоро заставили турок умерить свой воинственный пыл» ${ }^{8} .30$ июля 34-й пехотный Севский полк с 5-й батареей 14-й артиллерийской бригады сменил болгарских дружинников. Драгуны с сожалением расставались с ополченцами: «знание местности, болгарская неутомимость, знакомство с характером и обычаями врага, наконец-то, кровавая, ничему не уступающая ненависть к мучителям родины делали из них неоценимых исполнителей самых смелых предприятий ${ }^{9}$, - перечислял их достоинства Лермонтов.

Против левого фланга Маренской позиции к северо-востоку поднималась высокая крутая гора, на которой находился драгунский пост и сторожевой пост из окрестных жителей, болгар, от 10 до 15 человек, отчего гору прозвали Болгарской ${ }^{10}$. Помимо русских войск, «вправо от Маренского плато к с. Игнатовцы и влево на гребне хребта Карабунар утвердились две болгарские четы", численностью от 150 до 200 человек под начальством известных партизан (гайдуков): Христо-Никола

* Чета - небольшой болгарский вооруженный отряд в Османской империи, который, как правило, дислоцировался в горах и действовал простив турок партизанскими методами. 


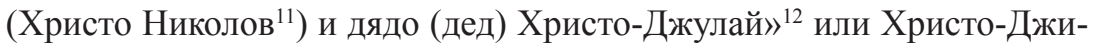
ляй ${ }^{13}$ (Христо Джулов ${ }^{14}$ ). Эти вооруженные караулы были сформированы начальником Еленского округа поручиком лейб-гвардии Павловского полка К. А. Рудановским (1850-1914) для охраны окрестных сел от появления и грабежа черкесов и башибузуков ${ }^{15}$.

В воспоминаниях полковника Лермонтова также говорится о двух болгарских четах, которые были организованы в помощь малочисленному отряду на Маренской позиции и для связи флангов с отдаленными драгунскими постами в селах Буйновцы и Златарицы. Предводителем одной четы, действовавшей на левом фланге, на гребне горы Карабунар, являлся известный партизан дед Жельо. Вторая чета, собранная из окрестных жителей, находилась под командой унтер-офицера 1-го эскадрона драгунского полка Павлюка, который «обучил свою команду, внушил ей строгую дисциплину, и чета его не раз оказывала услуги отряду» ${ }^{16},-$ писал Лермонтов.

Из опубликованных документов в сборнике «Освобождение Болгарии от турецкого ига» мы узнаем, что формированием чет в районе Елены также занимался и прославленный болгарский воевода Панайот Хитов ${ }^{17}$. Согласно рапорту полковника Генерального штаба Н. Д. Артамонова начальнику полевого штаба действующей армии генерал-адъютанту А. А. Непокойчицкому от 11 августа 1877 г., Хитов, получив необходимое разрешение от главнокомандующего великого князя, успел организовать к этому числу три четы: «1) чета из 55 человек под начальством Иордана Ненчова, расположенная от Черешовдяла до дер. Кринковцы, 2) под начальством Дойчо Койева (Колева) охраняет пространство от дер. Мерян (Марян) до дер. Мийковцы и состоит из 120 человек, 3) из 100 человек под начальством другого Койева (Христо Колева) - стережет тропинки от Мийковцы до Папратлива». По сведениям Артамонова, Хитов с 30 человеками продолжал заниматься формированием новых чет: «желающих много, но оружия нет». В этом рапорте также сообщалось, что 11 августа 150 башибузуков оттеснили чету Хитова и сожгли деревню Елаковрыт. «В казе Елены находилось мало русских войск, и четы прикрыли дороги из Котела, Сливны (Сливен) и Твардицы к сел. Беброво и Елена». Однако четы были «еще слишком слабы и числом, и вооружением»: не было ружей, а для охотничьих ружей, которыми обладали отдельные болгары, не хватало «ни свинцу, ни пороха», хотя в Тырнове имелось все в изобилии ${ }^{18}$. За несколько дней до этого рапорта от 11 августа 1877 г. начальник Еленского округа поручик Рудановский выделил «800 трофейных винтовок» жителям близлежащих сел для защиты от 
черкесов и башибузуков ${ }^{19}$. Современные болгарские историки К. Косев и С. Дойнов, сообщая о размахе вооруженной борьбы чет, отмечали, что настоящая власть в руководстве четами в районе Елены была сосредоточена в руках главного воеводы П. Хитова, а не полковника Артамонова ${ }^{20}$. Любопытно, что в своих мемуарах ни полковник Лермонтов, ни майор Пржецлавский ни разу не упомянули даже имени Хитова.

В воспоминаниях Л. Б. мы также находим подтверждение сведениям, что жителям Еленского округа были розданы ружья, с тем чтобы они сами охраняли свои селения от нападения турок. По сторонам аванпостов авангарда Еленского отряда болгары «держали свои посты, но весьма плохо». Тогда к ним начали командировать поочередно унтер-офицеров из стоявшего у Марена драгунского полка. Кадровые военнослужащие «взялись за дело очень искусно и, начальствуя постами вооруженных жителей, организовали службу их в некотором роде по-военному, а присутствием своим среди них придали им бодрости» ${ }^{21}$. Таким образом, было исполнено распоряжение Главной квартиры от 2 июля 1877 г. - стараться формировать вооруженную стражу преимущественно из болгар ${ }^{22}$.

Однако Л. Б. достаточно критично оценивал боеспособность болгарских сторожевых постов, которые, по его словам, разбегались «при сколько-нибудь серьезном на них нападении», а действовавшие в этом районе три-четыре четы по 50-100 чел. каждая, состоявшие преимущественно не из местных жителей, смотрели на войну главным образом «с точки зрения грабежа турок, а не сдерживания их нападений» ${ }^{23}$. Солдаты также подтверждали данное заключение, отзываясь о способности болгар к военному делу с большим пренебрежением. А к туркам они относились с уважением, подчеркивая, что они «дерутся молодцами, и если турок расходится, то, чтобы уложить его, надо порядком повозиться». «Живучи они больно, ваше благородие, рассказывал мне орденский драгун: подстрелили мы одного, а он стоит на коленке да ружьем помахивает: подойди, дескать. Народ-то ядреный, что говорить, не то, что братушки. Эти вон стоят, тоже посты занимают. А как пуля пролетит, ружья побросают да и давай Бог ноги. Как-то на деревню напали 10 турок, а в ней было со [так в тексте. - $M$. $\Phi$.] 100 болгар. Как увидели они турок - все тягу. Ну, теперь, как дали им наших унтеров, стали посмелее, а всё же народ ненадежный» ${ }^{24}$.

В нескольких рекогносцировках Еленского отряда (2, 3 и 6-7 августа) участвовали вооруженные конные болгары (50 человек) во главе с поручиком Рудановским ${ }^{25}$. Со 2 августа напор башибузуков 
стал заметно возрастать — «теперь из-за каждого почти камня, из-за каждого куста торчало дуло ружья мусульманина-волонтера» ${ }^{26}$. В продолжение четырехмесячной стоянки кроме служб разведки и охраны русскому отряду «пришлось выдержать и отбить с полным успехом» более 10 наступлений. Кроме того, «почти каждый день загорались перестрелки впереди с. Марена, большей частью между башибузуками и болгарами. У них шел спор за брошенные в селениях продукты и имущество». Как правило, столкновения оканчивались без потерь, но «когда огонь разгорался по всей линии, а конные орудия посылали гранату за гранатой, с Еленского отряда высылались роты на помощь, и дело принимало сравнительно большие размеры. Хотя турки каждый раз уступали нам поле, но требовалась большая бдительность драгунских постов, а также и быстрота пехотных рот, дабы предупредить появление неприятеля вблизи бивака» ${ }^{27}$, - свидетельствовал Пржецлавский.

Л. Б. отметил, что местные жители в селениях и деревушках, pacположенных в черте или позади русских передовых постов, продолжали свою обычную деятельность: «кругом бивака пахали, паслись стада ${ }^{28}$. В виду русских постов, свидетельствовал Пржецлавский, турки и болгары спокойно убирали с полей хлеб и увозили залежавшийся в копнах. «Но не всегда дележ полей проходил спокойно: болгары протестовали, если турки далеко распространяли свои претензии. С раннего утра уже гремели где-нибудь ружейные выстрелы». Граната капитана Фроста прекращала «этот спор, и здесь умолкали, но затем в другом месте спор возобновлялся снова и переходил в драку». Появлялись башибузуки, по временам начиналась перестрелка: «шлют роту, шлют гранату одну, другую, и к полудню вновь тихо» ${ }^{29}$.

В своей книге Пржецлавский привел несколько примеров обычных ситуаций, имевших место в период этого «стояния». В брошенную турецкую деревушку Чекал (Чакали), лежавшую между линиями русских и турецких аванпостов, за оставшимися продуктами направилась тяжелая болгарская можара*, колеса которой гулко стучат в предрассветной тишине. Турки также слышат, но не идут ловить болгарина, поскольку знают, что впереди деревни залегли уже «секреты» вооруженных болгар и можно легко попасть в засаду. Слышно, как в можару бросают початки кукурузы. Но вот восходит солнце, раздается первый выстрел по болгарам, они отвечают залпом, и «начинается с обеих сторон беспощадная трата патронов, пока болгары не окончат

* Можара - большая татарская или азиатская телега, арба. 
своих дел и не уедут». А вот привычная картина в дневное время: «Дети, выгнав свой скот на пастбище у подошвы Зеленой горки, беззаботно валяются на траве, распевая песни», «как бы сознавая безвредность перестрелки своих отцов с турками» ${ }^{30}$.

В самом городе Елена стояло по квартирам пять рот. Здесь же были расположены «околодки частей*, лошадиный лазарет, штабы, склады, мастерские и пр.» ${ }^{31}$. Рядом с городом был устроен бивак для резерва Еленского отряда, куда поочередно направлялись на отдых роты после пребывания на позициях. Здесь, на отдыхе, насколько позволяло время, офицеры знакомились с местными жителями, иногда устраивались, как, например, 26 и 30 августа, «импровизированные танцевальные вечера у кого-либо из более зажиточных болгар». Пржецлавский отмечал, что «барышни-болгарки любили потанцевать», а «радушие и простосердечие хозяев много оживляли гостей, и молодежь охотно тянулась туда» ${ }^{32}$.

В Елене и ее округе с приходом русских было введено гражданское управление. Жители «быстро свыклись с новым порядком вещей и, спокойные за свое существование и имущество благодаря присутствию среди них наших войск, ловко обделывали свои делишки, считая, что они совершенно обеспечены от турок и уже никогда не увидят последних у себя в гостях» ${ }^{33}$, - замечал Л. Б. Болгары, приходившие с занятых турками мест, перебежчики и пленные сообщали, что «турки решились во что бы то ни стало взять и разграбить богатую Елену». Но все их попытки приблизиться к городу до 22 ноября 1877 г. разбивались о мужество русских, крепко удерживавших Маренскую позицию ${ }^{34}$.

Не только роты и эскадроны привыкли к постоянной тревожной обстановке, но и жители Елены перестали обращать внимание на долетавшие до них от Марены звуки пушечной пальбы. «Свыклись они с пребыванием у них отряда до того, что, казалось, начали смотреть на его офицеров и солдат как на лиц, находившихся между ними только для того, чтобы дать им случай прирастить их капиталы. Торговля Елены заметно увеличилась, явились лавки с товарами, предназначавшимися исключительно для войска. Цены тут брались втридорога, так что офицеры находились вынужденными посылать за покупками в другие места. “Как вступили мы, ваше благородие, в Елену, - рассказывали мне драгуны, - так первые два дня угощали они нас и хлебом, и мя-

* Околодок - устаревшее обозначение для врачебного пункта при воинской части. 
сом, и вином; потом стали уже давать за деньги, сперва, что говорить, дешево, а теперь и подступу ни до чего нет. Прежде брали за булочку один-два галагана*, а теперь дерут три и четыре, а об угощении и думать не моги"» ${ }^{35}$, — сообщал Л. Б., посетивший Елену в сентябре.

Поручик Рудановский привлекал болгар для строительных работ на позициях, для постройки шоссе от Елены до Марены. К сожалению, это шоссе не было окончено ко времени сражения у Елены ${ }^{36}$, т. е. к 22 ноября 1877 г. Из-за перебоев в доставке сухарей и плохой работы интендантства по распоряжению городского совета некоторые жители Елены выпекали хлеб для полков (с 15 сентября по 12 октября), за который им хорошо платили. Скот сначала приобретался у жителей Елены, а затем в окрестных деревнях ${ }^{37}$.

К 15 ноября 1877 г., в связи с поступавшими известиями о концентрации турецких войск у Елены, сюда были направлены дополнительно 36-й Орловский пехотный полк, а также 5-я батарея 14-й артиллерийской бригады (8 орудий). «Все эти слухи, постоянные тревоги и другие приметы, вместе взятые, как, например, исчезновение четников со своих мест, служили верным признаком приближения серьезных событий. Чтобы быть всегда готовыми к бою, на передовых позициях люди обедали с рассветом и ходили на обед в полном снаряжении с ружьями» ${ }^{38}$, - вспоминал Пржецлавский.

Следует сказать, что в Еленском отряде информацию о противнике собирали буквально по крупицам. Дело в том, что особенности местности за Маренской позицией при активизации фанатичного мусульманского населения не позволяли Еленскому отряду уже с августа вести результативную разведывательную деятельность, поскольку «добыть сведения о неприятеле можно было только посылкой подвижных колонн». «Единственным источником сведений о том, что происходило у неприятеля», были болгары, бежавшие группами или поодиночке из турецких лагерей, где они занимались возведением укреплений и другими работами. «Проверить же их сведения почти не было возможности. С другой стороны, под прикрытием вооруженных жителей и черкесов неприятель всегда имел возможность сосредоточить регулярный отряд в любом пункте» ${ }^{39}$, - отмечалось в «Дневнике 13-й Кавказской дивизии». В то же время «неприятель имеет самые подробные сведения о наших распоряжениях» ${ }^{40}$, - констатировал офицер, не поставивший подпись под своей резолюцией на донесении поручика Павловского.

* Галаган (гологан) - мелкая медная монета. 
В мемуарах и официальных бумагах, исходивших из Еленского отряда, нет информации о болгарских разведчиках, как принято считать в историографии, якобы успешно действовавших в этом районе. Имеются сведения только о двух девушках из села Игнатовцы, которых допрашивал Сулейман-бей о числе и расположении русских под Еленой. Но они притворились, что не понимают турецкого языка. Затем болгарки явились к генерал-майору А. В. Домбровскому, начальнику Еленского отряда с 15 августа 1877 г., и сообщили, что турки при них обсуждали план нападения на Елену, обойдя Маренскую позицию с правого фланга на Трашли, Игнатовцы и Миковцы ${ }^{41}$.

Впрочем, не все болгары сочувствовали русским. Капитан Г. Я. Политковский рассказал о болгарине Саранди, который был послан в качестве лазутчика к туркам в те тревожные и полные напряженного ожидания нападений со стороны неприятеля ноябрьские дни. Его информация «сбила всех с толку». Саранди уверял, что побывал в Беброво, Ахмедли (ныне Константин) и Стара-Реке. В Беброво и Ахмедли, по его словам, находилось не более 1800 башибузуков и арнаутов при четырех горных орудиях, а в Стара-Реке вообще никого не было. Саранди предлагал убедиться в точности его сведений, послав вместе с ним в Стара-Реку офицера и двух-трех нижних чинов. Болгарину отчасти поверили и заплатили 50 золотых. Только один доктор, В. И. Порай-Кошиц (1843-1891), впоследствии приват-доцент Харьковского университета, был убежден, что Саранди подкуплен турками и ему нельзя доверять. Генерал-майор Домбровский запретил планировавшуюся экспедицию. И вскоре мнение доктора полностью подтвердилось, поскольку 22 ноября Саранди пропал ${ }^{42}$ В болгарской литературе фигурирует чета Христо Сарандито, которая много раз совершала разведывательные рейды в тыл туркам ${ }^{43}$.

22 ноября 1877 г. Еленский отряд (6 батальонов, 18 орудий, 4 эскадрона) был атакован противником в пять раз сильнее - дивизией Фуада-паши, шедшей в авангарде войск Сулеймана-паши. Русские оставили Елену только после того, как все ее жители с их имуществом ушли из города. В восьмичасовом ожесточенном сражении погибли треть нижних чинов (1807 чел.) и половина офицеров (52 чел. $)^{44}$. Героическим сопротивлением Еленский отряд не допустил, чтобы неприятель проник за ущелье Св. Николая, откуда открывался свободный и незащищенный путь на Тырново. Вскоре к отступившему на позиции у села Иовковцы (Йовковцы) Еленскому отряду стали подходить значительные подкрепления, чтобы отбить Елену, в которой турки заметно укреплялись. 
23 ноября Л. Б., выполняя поручение генерал-лейтенанта барона Э. К. Деллинсгаузена, познакомился с начальником нахии“ Дряново Жеговым, «одним из представителей болгарской интеллигенции, но довольно редким по трезвому и беспристрастному отношению к своим соотечественникам». Во взятии турками Елены он, по словам Л. Б., винил жителей, которые «сами должны были бы взяться за оружие и деятельно помогать нам в их охранении, а они вместо того занимались только торговлей и обиранием с нас денег». Очень любопытны и важны следующие заявления Жегова: «Вы же [русские. - M. Ф.] сами виноваты, - говорил, горячась, Жегов, если мы не делаем того, чего бы требовалось от нас любовью к родине, виноваты тем, что обходитесь с нами не так, как следовало бы. Вы пришли к нам со своими порядками, строгой законностью, гуманными началами, забывая, что всё это пока к нам еще не применимо. Мы воспитаны на других началах, на началах 400-летнего ига и рабства. Поучениями, советами, просьбами, мягкими мерами с нами ничего не поделаете. Требуйте, как требовали от нас турки. Не сделано - не давайте спуску, наказывайте со всей строгостью и требуйте, тогда вы от нас добьетесь. Вводимые же вами порядки невозможно привить к нам сразу, для этого требуется много времени» ${ }^{45}$. Жегов указал на красивого, рослого, курчавого болгарина лет 20-ти, который, лениво переваливаясь, шел за ослом, навьюченным мешками с товарами. «Ведь ружье бы ему носить, а он, когда турки в каких-нибудь 30 верстах, и знать ничего не хочет, кроме зашибания денег. А я ручаюсь собрать вам десятки тысяч таких молодцов, из которых в короткое время вышли бы прекрасные солдаты. Прикажите только. А не прикажете, будете как теперь созывать охотников - и 5000 не соберете». «Какие мы борцы за свободу, — с отчаянием в голосе заключил Жегов, - варвары мы. Бить нас следует, вот что! ${ }^{46}$

Суждения Жегова сопоставимы с высказываниями воеводы Панайота Хитова, который, как указывал Л. Б., пользовался «заслуженной репутацией отчаянного болгарского патриота». Л. Б., будучи командирован из штаба армии для рекогносцировки Балкан восточнее Шипки в конце сентября 1877 г., ехал с ним из Елены на Маренскую позицию. На вопрос офицера, почему болгары не проявляли особенной охоты помогать русским в борьбе, предпринятой в их же интересах, Хитов отвечал, что болгарское юношество не было подготовлено к ратному делу, к

* Нахия - самая маленькая административно-территориальная единица в Османской империи, часть казы (уезда). В нее входили примерно 10 селений, объединенных вокруг самого большого села. 
тому же множество «молодых и сильных болгарских рук» находилось в Румынии, где они занимались огородничеством. Хитов выразил желание, «чтобы русские войска оставались в Болгарии, так как иначе для нее будет слишком дорого стоить содержать свое войско, - умозаключение в болгарском духе», прокомментировал офицер. Впрочем, затем прибавил Хитов, «с болгарами без принуждения ничего не сделаешь, а если их хорошенько принудить, то у них и свое войско будет» ${ }^{47}$.

24 ноября, прогнав черкесов из Минде (Миндя), подошедшие на выручку Еленского отряда войска 1-й бригады 26-й пехотной дивизии [командир генерал-майор Н. Н. Малахов (1827-1908)] и 42-й пехотный Якутский полк в результате шестичасового боя захватили Златарицу, которую защищали от 10 до 12 турецких таборов* при 12 орудиях и 400 черкесов. Следует подчеркнуть, что 101-й Пермский пехотный полк вступил в бой с турками после 30-часового форсированного марша в 70 км без сна и горячей пищи, имея лишь небольшой привал в селе Шереметлере ${ }^{48}$.

Л. Б., посланный с поручением бароном Деллинсгаузеном к Минде, на одной из горок повстречал воеводу Хитова с четой, которые «глазели», как русские солдаты бьют турок. «“Ваши теперь идут напред” [вперед. - M. Ф.], — с довольным видом и крутя усы, пояснил Хитов». Русский офицер предложил Хитову «вместо того, чтобы со всей своей четой предаваться этому занятию, лучше выставить сторожевые посты по ближайшим вправо высотам» ${ }^{49}$. Л. Б. завершил описание сражения у Златарицы следующим замеченным им фактом: вначале болгары совершенно отсутствовали как в Минде, так и на поле боя. «Но как только дело начало видимо клониться в нашу пользу, откуда ни возьмись, высыпали братушки, все с ружьями, и пошли бродить по турецкой позиции, раздевая убитых, доканчивая раненых. Само собой разумеется, что начальники и солдаты наши всячески препятствовали этим занятиям братушек». Командир Пермского полка полковник В. Б. Прокопе (1839-1906), «увидав, что к лежавшему на земле раненому турку подошли несколько болгар, из которых один уже замахнулся на него штыком, бросился к раненому, уже закрывшему глаза в ожидании смерти, и, отпарировав саблей занесенный на него удар, разогнал болгар. Заметив двух раненых наших солдат, шедших, поддерживая один другого, на перевязочный пункт, полковник приказал им остаться около раненого турка и сторожить его до тех пор, пока их всех тро-

* Табор - батальон пехоты в турецкой армии, состоял из 8 рот (бейлюк) и по штату имел 774 человека. 
их подберут санитары. Но понятно, что физически невозможно было везде усмотреть за братушками. Нам пришлось видеть несколько еще теплых тел раздетыми догола, и навстречу нам попадались болгары, тащившие домой снятую ими с турок одежду. А один даже обратился ко мне с предложением купить турецкий мундир. Конечно, мне не оставалось ничего более, как с отвращением отворачиваться от этих гиен поля брани, и предложившего мне покупку я, грешный человек, не выдержав, вытянул плетью» ${ }^{50}$.

Не следует подозревать Л. Б. в пристрастности к болгарским четникам, имея в виду приведенный выше сюжет. Не менее ярко описывал их «подвиги» прапорщик Болгарского ополчения С. И. Кисов. Так, по настоятельной просьбе жителей Котела, опасавшихся нападения башибузуков, которые во множестве собрались в окрестных турецких селах, 15 января 1878 г. в Котел были направлены болгарские дружины во главе с генерал-майором Н. Г. Столетовым. 20 января I и III дружины под командованием майора Чиляева были посланы в район с. Садово, Кадыр-Факлии и др. План действий был следующий: I и III дружины должны были наступать с фронта, а четы воевод деда Жельо и Панайота Хитова в количестве около 1000 человек, которые до этого располагались в селах Градце и Жеравне, должны были наступать с возвышенности на левый фланг и в тыл неприятеля. Сражение закончилось, «башибузуки были прогнаны из Садова, а воеводы, к нашему удивлению, совсем не показывались!» - восклицал Кисов. Однако преследование турок было приостановлено, так как на возвышенности, на которой должны были быть воеводы, появилась масса народа. «Если бы это были четы, то они должны были давно уже спуститься вниз и ударить по противнику». Затем разведчики донесли, что люди, стоявшие на возвышенности, и «были храбрые воеводы со своими юнаками». Майор Чиляев негодовал: из-за них турки успели уйти. У села Кадыр-Факлии башибузуки встретили дружинников залпами, но затем отступили. И только тогда, когда Кадыр-Факлия была занята ополченцами, «храбрые воеводы сошли с возвышенности». Их отряд разделился на две части: «одна последовала за дружинниками, а вторая храбро атаковала многочисленное стадо турецкого домашнего скота» в 6-8 тыс. голов (коров, волов, буйволов, овец, коз и лошадей). В Кадыр-Факлии воеводы явились к начальнику отряда. Вид у них был очень воинственный: «Они, как и подчиненные им добровольцы, были вооружены с ног до головы: ружье за плечом, шашки, надетые накрест, ятаганы и пистолеты за поясом и патронташи через плечо». Майор Чиляев был возмущен, увидав, что четники уводят скот. Но приказание 
майора - отобрать скот и отправить его в с. Медвен - было сложно выполнить, так как четники уже давно успели отвести большую часть скота (4-5 тыс. голов), а кавалерия была впереди и наблюдала за неприятелем. Отобранный у чет скот был отдан болгарскому населению. «Но в данном случае было то возмутительно, что воеводы вместо исполнения долга и предначертанного плана ударить во фланг неприятеля, ударили в тыл <..> и то в тыл домашнего скота» ${ }^{51}$, - не скрывал своего негодования Кисов. В «Журнале военных действий XI армейского корпуса» также имеются сообщения подобного рода ${ }^{52}$.

28 ноября 1877 г. пришла радостная весть о падении Плевны. 2 декабря турки, уходя из Елены, подожгли ее. Русские войска потушили пожар, сгорело только 40 домов. Но Беброво, которое турки покинули в ночь с 3 на 4 декабря, нашли совершенно разоренным: они буквально «не оставили камня на камне в этом несчастном местечке» ${ }^{53}$. Хотя в Елене сгорело немного, но зато «разнесено было всё, что только было найдено внутри домов, а что нельзя было увезти или унести, то было побито, попорчено, разметано. Исключение было сделано только относительно немногих домов чорбаджиев*, державших руку турок» ${ }^{54}$. Однако как ни старались турки уничтожить всё захваченное ими в Елене, это им всё-таки не удалось. Были найдены большие склады вещей, галет, фуража и прочего, около которых поставили часовых.

4 декабря Жегов привез в Елену для русских войск 15 подвод с вином, хлебом, табаком, теплой одеждой и прочим как выражение признательности от жителей Дрянова ${ }^{55}$. Следует сказать, что 26 ноября болгары с. Горного Ряховца (Горна-Оряховица), узнав о победе русских при Златарице, на радостях прислали на подводах всему отряду много хлеба, водки, табака и соли в сопровождении депутации с поздравлениями ${ }^{56}$, что было очень кстати.

Вслед за первыми войсками в Елену прибыл начальник Еленского округа поручик Рудановский и немедленно приступил к приведению города в порядок, для чего в его распоряжение была назначена рота. Следует подчеркнуть, что из Тырново он привез 1000 франков, выданных ему П. В. Алабиным (1824-1896) от имени Московского и Петербургского славянских комитетов для оказания «первоначальной помощи» и «на удовлетворение вопиющих потребностей бежавшего населения». Кроме того, участь еленских беженцев была обеспечена

* Чорбаджий - (здесь) староста в селении, старшина, из зажиточных крестьян. В XIX в. болгары называли чорбаджи богатых крестьян и торговцев, которых османские власти привлекали к работе в судебных и административных органах. 
«существованием значительной суммы, отпущенной тырновскому губернатору по распоряжению главнокомандующего в помощь беженцам всей губернии» (20 тыс. руб. в месяц), для чего был образован особый комитет под председательством губернатора ${ }^{57}$.

«Город становился всё люднее... Появились и лавочки то с кусками сыра, несколькими коробками сардин, бутылками рома и медом, тут с печеным хлебом, пачками табаку и проч.». Л. Б. в своих мемуарах описал такую сцену: «На полу лавки, поджав под себя ноги, сидел болгарин, усердно работая иглой над какой-то принадлежностью своего костюма, и невозмутимо слушал солдатика, который, перегнувшись в широкое отверстие, какими здесь лавки сообщаются с улицей, внушительно говорил: "Нет, ты, булгар, слушай, что я тебе скажу. Сердца в вас мало. Был я и в Тырнове, на Шипке, в Казанлыке, в Заграх — всё едино. Вы, болгаре, за галаган душу продадите". Удалось ли солдату убедить болгарина, чтобы тот уступил ему галаган, - не знаю, но сомневаюсь» ${ }^{58}$.

Состав Еленского отряда начал меняться. 7 декабря 1877 г. Севский и Орловский полки выступили в поход к Травно (Трявна) и приняли участие в знаменитом сражении под Шипкой-Шейново 26-28 декабря 1877 г. 2 января 1878 г. орденские драгуны направились в Твардицу, Сливно, а 24 января заняли Бургас. В начале января 1878 г. в Елену прибыли дружины Болгарского ополчения и заняли Маренскую позицию.

22 ноября 1879 г. начальник 9-й пехотной дивизии генерал-адъютант князь Н. И. Святополк-Мирский получил от командира ХІІІ болгарской дружины капитана Рудановского телеграмму из Елены, которую препроводил в Севский полк. В ней сообщалось: «Жители Еленского округа, празднуя сего числа годовщину славного боя, в коем полки, Вами предводимые, проявили беззаветную храбрость, мужество и стойкость, благодаря которым было спасено от верной гибели всё население, поручили мне выразить Вашему сиятельству их глубокую признательность, которую просят передать также и полкам, стяжавшим бессмертную Славу. Командуемая мной XIII Еленская дружина, принимавшая участие в открытии памятника, воздвигнутого на бывшей Маренской позиции павшим Героям, в настоящую минуту неумолкаемо кричит громкое “ура" в честь Вас и славных полков, защищавших Елену»

Изученный нами материал (воспоминания участников русско-турецкой войны и официальные документы: реляции, отчеты, донесе- 
ния, телеграммы и т. п.) раскрывают сложную палитру взаимоотношений русских офицеров и солдат с болгарами, жителями г. Елены и ее окрестностей. Как мы видели, чувства радости у болгар от встречи своих спасителей вскоре перешли в прямой коммерческий интерес, что не могло не вызывать негативных эмоций у русских. Однако в воспоминаниях не содержится ни одного упрека в адрес болгар, только горькая констатация негативных моментов, прежде всего страшной дороговизны. Не всегда добросовестно выходили болгары и на строительные работы, отчего шоссе длиной в несколько верст от Елены до Маренской позиции так и не было закончено.

Минимальным было участие жителей Елены в самообороне. Четы наполнялись отнюдь не местным контингентом, может быть, поэтому, несмотря на имена прославленных болгарских воевод, они больше напоминали шайки разбойников, грабивших легко достающуюся добычу. Деятельность чет и их боевые успехи, таким образом, были весьма сомнительного свойства. В отличие от мусульманского населения, выставившего сотни воинов для охранения своей религии и селений, защитники болгарских очагов исчислялись лишь десятками.

Бесспорно, Елена являла собой один из значимых центров Болгарского возрождения, ее жители ратовали об образовании своих детей, о просвещении, о чем убедительно свидетельствовали строительство нового здания для училища, наличие в городе библиотеки и богатство (в формате Болгарии) ее фондов. Но в Еленском округе не было заметно так называемого подъема национально-освободительной борьбы, о котором столь восторженно пишется в болгарской литературе, и четы, как оказалось, не стали его прямым выражением. Действительно боеспособными являлись лишь те болгарские отряды, которые формировались русскими и которыми руководили русские офицеры.

Только будучи освобожденными от многовекового смертельного страха перед турками и башибузуками благодаря победе России в войне 1877-1878 гг. и не без ее действенной помощи, болгары смогли создать сильную армию из настоящих бойцов, что наглядно показала история Болгарского княжества после 1878 г.

\section{ПРИМЕЧАНИЯ}

1 Хаджиниколов $B$. Някои проблеми относно участието на българския народ в Освободителната война // Освобождението на България. 1878-1968. София, 1970. С. 62. 
2 Косев К., Дойнов С. От Шипка и Плевен до Сан Стефано и Берлин. София, 2007. С. 176-177; Цветков Ж. България - Русия. Заедно или разделени. София, 2015. С. 132-133.

3 Генерал-майор Домбровский. Командир 1-й бригады 9-й пехотной дивизии командиру XI армейского корпуса. 3 октября 1877 г. Елена // Сборник материалов по русско-турецкой войне 1877-1878 гг. на Балканском полуострове (далее - Сборник материалов...). СПб., 1905. Вып. 47. С. 16.

4 Л. Б. Дела у Елены и Златарицы (Из воспоминаний о походе 1877 г.) // Военный сборник (далее - ВС). 1878. № 5-6. С. 142.

5 Лермонтов А. Драгунский Военного ордена полк под Мареной и Еленой // ВС. 1880. Т. 136. С. 17.

6 Дневник 13-й Кавказской дивизии // Сборник материалов... СПб., 1910. Вып. 92. С. 33.

7 Лермонтов А. Драгунский Военного ордена полк... С. 182.

8 Там же.

9 Там же.

10 Пржеилавский П. 34-й пехотный Севский Его Императорского Высочества наследного принца австрийского полк в войну с турками в 1877-1878 гг. Харьков, 1888. С. 66.

11 Косев К., Дойнов С. От Шипка и Плевен до Сан Стефано и Берлин. София, 2007. С. 216.

12 Пржеилавский П. 34-й пехотный Севский... С. 67.

13 Пржеилавский П. Дневник 34-го пехотного Севского полка // Сборник материалов... СПб., 1911. Вып. 93. С. 162.

14 Чолов П. Българските въоръжени чети и отряди през XIX век. София, 2003. С. 205.

15 Пржеилавский П. 34-й пехотный Севский полк в деле под Еленой 22 ноября 1878 г. // ВС. 1900. Т. 253. С. 239.

16 Лермонтов А. Драгунский Военного ордена полк... С. 186.

17 Освобождение Болгарии от турецкого ига: Документы: В 3 т. М., 1964. Т. 2: Борьба за национальное освобождение Болгарии в период Русско-турецкой войны. 1877-1878. С. 185-186.

18 Там же. С. 232-233.

19 Улунян А. А. О формировании болгарских чет в период русскотурецкой войны 1877-1878 гг. // Славяне и Россия. К 70-летию со дня рождения С. А. Никитина. М., 1972. С. 243-244.

20 Косев К., Дойнов Ст. Указ. соч. С. 211-212.

21 Л. Б. Дела у Елены и Златарицы... С. 143.

22 Главная квартира. Распоряжения и донесения за время с 30 июня по 2 июля 1877 г. // Сборник материалов... Вып. 2. С. 213. 
23 Л. Б. Дела у Елены и Златарицы... С. 140.

24 Там же. С. 142-143.

25 Генерал-майор Борейша. Командир 1-й бригады 9-й пехотной дивизии командиру VIII армейского корпуса, 3 августа 1877 г., Елена // Сборник материалов... СПб., 1902. Вып. 36. С. 46-47; Пржеилавский П. 34-й пехотный Севский... С. 70, 71.

26 Лермонтов А. Драгунский Военного ордена полк... С. 184.

27 Пржеилавский П. 34-й пехотный Севский... С. 69.

28 Л. Б. Дела у Елены и Златарицы... С. 145.

29 Пржеилавский П. 34-й пехотный Севский... С. 84.

30 Там же. С. 82-83.

31 Генерал-майор Домбровский. Командир 1-й бригады... Вып. 47. C. 16 .

32 Пржеилавский П. 34-й пехотный Севский... С. 82.

33 Л. Б. Дела у Елены и Златарицы... С. 137.

34 Лермонтов А. Драгунский Военного ордена полк... С. 183.

35 Л. Б. Дела у Елены и Златарицы... С. 140.

36 Там же. С. 142.

37 Пржеилавский П. 34-й пехотный Севский... С. 225-226.

38 Там же. С. 240.

39 Дневник 13-й Кавказской дивизии. С. 34.

40 Описание местности г. Елены с окрестностями // Сборник материалов... СПб., 1902. Вып. 36. С. 33.

41 Лермонтов А. Драгунский Военного ордена полк... С. 189; Пржеилавский П. 34-й пехотный Севский... С. 104.

42 Политковский Г. Я. Около Шипки. Воспоминания // Сборник военных рассказов [составленных офицерами - участниками войны 18771878 гг.]. СПб., 1879. Т. 3. С. 148.

43 Чолов П. Българските въоръжени чети... С. 207.

44 Рапорт начальника 9-й пехотной дивизии командующему XI apмейского корпуса // Сборник материалов... СПб., 1906. Вып. 54. С. 349.

45 Л. Б. Дела у Елены и Златарицы... С. 163.

46 Там же.

47 Там же. С. 142.

48 Журнал военных действий XI армейского корпуса // Сборник материалов... СПб., 1911. Вып. 91. Ч. 1. С. 65-66; Рапорт командующего 26-й пехотной дивизии командующему XI армейским корпусом. 25 ноября 1877 г. Златарица // Сборник материалов... Вып. 54. С. 365.

49 Л. Б. Дела у Елены и Златарицы... С. 287.

50 Там же. С. 296. 
51 Кисов С. И. Из боевой походной жизни. 1877-1878 гг. София, 1903. С. 416, 419, 420, 424.

52 Журнал военных действий XI армейского корпуса. С. 81, 85.

53 Рапорт главнокомандующего действующей армии государю императору. 12 января 1878 г. Казанлык // Сборник материалов... Вып. 14. СПб., 1898. С. 112.

54 Л. Б. Дела у Елены и Златарицы.... С. 312.

55 Там же. С. 313.

56 Дневник военных действий 101-го пехотного Пермского полка // Сборник материалов... СПб., 1911. Вып. 91. Ч. 2. С. 20; Л. Б. Указ. соч. С. 313.

57 Освобождение Болгарии. С. 373-374.

58 Л. Б. Дела у Елены и Златарицы... С. 314.

59 Пржеилавский П. 34-й пехотный Севский... С. 163-164.

\section{M. Frolova}

To the 140th anniversary of the Russian-Turkish war of 1877-1878. Elena detachment of the Danube army in the context of historical discussions

This article focuses on Elena detachment of the Danube army, which operated in the town of Elena and its surroundings. We examine the relations between Russians and Bulgarians, the activities of the Bulgarian armed groups on the basis of published documents and memoirs through the prism of imagology.

Keywords: the Russian-Turkish war 1877-1878, Russian perception of the Bulgarians, Elena detachment, Bulgarian armed groups, town of Elena. 


\title{
Дунайский гамбит. \\ Русско-сербское военно-экономическое сотрудничество накануне и в годы Первой мировой войны
}

\begin{abstract}
Статья раскрывает недостаточно изученный в отечественной историографии вопрос о русско-сербских военно-экономических связях, ставших особенно тесными в канун Первой мировой войны. Значительное место, в контексте общих стратегических интересов России на Дунае, автор уделяет деятельности Особой экспедиции под командованием М. М. Веселкина, специально образованной в 1914 г. для снабжения сербской армии оружием и боеприпасами.

Ключевые слова: Сербия, Дунайская экспедиция, М. М. Веселкин, Н. Пашич, Николай II, Первая мировая война, Болгария, Австро-Венгрия.
\end{abstract}

DOI: $10.31168 / 2073-5731.2018 .3-4.1 .09$

Тема характера и особенностей русско-сербских связей в Новое время, являющаяся ключевой для понимания глобальных целей балканской политики России в XIX-XX вв., получила глубокое освещение в российской и зарубежной историографии, в научный оборот введен громадный пласт источникового материала, посвященный анализу самых разнообразных аспектов этих отношений, тем более что к началу XX в. Сербское королевство стало важной составной частью широкого российскоавстрийского соперничества за политическое влияние на Балканах. При изучении этого стратегического пласта российской внешней политики исследователи, по вполне понятным причинам, к тому же актуализированным недавней столетней годовщиной начала Первой мировой войны, делают главный акцент на политический аспект этих отношений, увязывая проводимую Россией политику в регионе с ее общими глобальными внешнеполитическими планами и интересами.

Данный вектор российской политики, в связи с анализом ее военно-политических целей в регионе, международной проблемы черноморских проливов, общих причин превращения Балкан в «пороховой погреб Европы», неоднократно поднимался как на страницах монографий, так и научной периодики, в том числе и автором данной ста- 
тьи ${ }^{1}$. Однако через анализ российской политики в Сербии уместно будет поставить вопрос об общей стратегии российской дипломатии в прибрежном дунайском регионе как важном элементе российскоавстрийского противостояния. Этот аспект, в свою очередь, открывает нам новый пласт российско-сербских отношений. Речь идет о ставших особенно тесными к началу XX в. военно-экономических связях двух стран, исследование которых еще не получило должного освещения в отечественной историографии ${ }^{2}$. Данная статья призвана частично восполнить этот пробел.

Прежде всего отметим, что первые робкие российские попытки экономического проникновения в страну начались в 80-е гг. XIX в., что было связано с задачей противодействия «новому курсу» сербского князя (с 1882 г. - короля) Милана Обреновича, связавшего после Берлинского конгресса 1878 г. свой внешне- и внутриполитический курс с Двуединой монархией - заключением с ней в 1881 г. торгового договора и тайной политической конвенции. Действительно, потребности как экономического, так и общественно-политического развития молодого сербского государства требовали от белградских правящих кругов выбора стратегического союзника, каковым, в силу географической близости, могла стать только Австро-Венгрия. Именно Вена виделась белградским политикам «окном в Старый Свет» ${ }^{3}$, тем ключом, с помощью которого можно было добиться процветания собственной страны, тем более что именно на нее приходилось около $66 \%$ импорта и до $93 \%$ экспорта страны.

Однако конец XIX в. стал временем обращения серьезного внимания Российской империи к судоходству по Дунаю, что стало особенно заметно после окончания войны с Турцией 1877-1878 гг., когда Россия вернула утерянные по итогам Крымской войны порты в его устье - Рени и Измаил, что дало ей возможность конкурировать с австрийскими пароходными компаниями ${ }^{4}$. Укрепление экономических позиций России в среднем и нижнем течении Дуная могло стать одним из серьезных противовесов австро-венгерской экспансии в балканском регионе. В 1881 г. вступило в силу «Положение о срочном товаро-пассажирском пароходном сообщении между городами Одессой и Измаилом с заходом в Килию и Рени», а государственный советник князь Ю. Е. Гагарин-Стурдза принял на себя обязательство «содержания посредством принадлежащего ему парохода "Ольга" правильного товаро-пассажирского сообщения...». Так в 1883 г. появилось первое российское пароходное общество «Князь Гагарин и $\mathrm{K}^{\circ} \gg$, осуществлявшее регулярные рейсы между крупнейшим черно- 
морским портом России Одессой и придунайскими городами Сербии, Болгарии и Румынии. Однако для поддержания регулярных перевозок личных средств князя было недостаточно. Требовались вложения государственного капитала. В 1886 г. его компания трансформировалась в довольно успешное акционерное общество «Черноморско-дунайское пароходство», к 1902 г. располагавшее 12 пароходами водоизмещением в 2087 т. Следует заметить, что Австро-Венгрия, организовав пароходство на Дунае в 1830 г., в 1880-х гг., т. е. в годы появления на Дунае первого русского парохода «Ольга», - уже имела в своем распоряжении более 200 пароходов и около 1000 грузовых барж5. Российское правительство выкупило акции «Черноморско-дунайского пароходства», основав в марте 1903 г. коммерческое предприятие «Российское дунайское пароходство», правление которого находилось в Санкт-Петербурге, а представительства в крупнейших городах России и Европы - Москве, Лодзи, Марселе, Гамбурге. Компания осуществляла перевозки между Одессой, Систовом и Кладово, а также обеспечивала судоходство вплоть до Батума ${ }^{6}$.

Организация российского судоходства на Дунае способствовала появлению в Сербии русских товаров и инвестиций. В ноябре 1881 г. российский предприниматель, сербофил А. Л. Мураневич, отмечая важность для России организации пароходного движения по Дунаю, поскольку «пролитая ею кровь за славян Балканского полуострова была орошающею влагою не только для внутренних, но и для их внешних экономических и преимущественно торговых сношений», составил заявление в Московский биржевой комитет, в котором, пытаясь привлечь внимание российских деловых кругов к выгодам торговли с этой страной, обращал внимание в том числе и на политическую важность этих экономических связей как противодействие проавстрийскому курсу Милана. Он подчеркивал, что между «сербами распространяется все больше и больше убеждение, что лишь торговая связь с Россией спасет их страну от полного порабощения Австрии. В Сербии предполагают даже составить целое общество, члены которого намерены покупать исключительно русские произведения, как только они явятся на сербском рынке, и в последнее время собирались подписи между влиятельными лицами - сербами для этой цели. Сербы, взявшие на себя обязанность вытеснить из своего отечества всё то, что носит на себе австрийскую печать, известны у нас в России под именем русско-сербских патриотов, или "русской партии", как называют их сами сербы» ${ }^{7}$. При этом объем как импорта, так и экспорта не мог быть значительным и составить настоящую конкуренцию с товарооборотом 
Сербии с Двуединой монархией. Тот же Мураневич подчеркивал, что «главное место при ввозе в Россию займут сербские виноградные вина разных сортов, между которыми по своему качеству славятся неготинские (красные) и смедеревские (белые). Чернослив сербский тоже весьма важное место занимает в заграничной торговле Сербии. Сербский чернослив и вина приходят из-за границы в Россию под именем французских и продаются дороже, чем настоящие французские» ${ }^{8}$. Несколько позже, в 1891 г., отношение в Московский биржевой комитет составил и князь Ю. Е. Гагарин-Стурдза. Он предложил организовать под его патронатом в Белграде выставки-ярмарки русских товаров, что, по его мнению, позволило бы «с одной стороны, русским товарам открыть новые рынки и, с другой, - сербскому народу со временем освободиться от экономического ига Австро-Венгрии»9.

В начале XX в. ситуация стала меняться кардинально. Политические события в Сербии, убийство 29 мая 1903 г. короля Александра Обреновича, коренным образом изменили и русско-сербские отношения, принявшие с этого времени характер стратегического партнерства, а экономическое сотрудничество стало определяться прежде всего военными целями и интересами, тем более что традиционное австрийское влияние существенно снизилось в результате таможенной войны 1906-1911 гг. ${ }^{10}$ В страну стал проникать крупный русский капитал, что было связано с заинтересованностью Белграда в военных поставках из Российской империи. Так, например, в июле 1904 г. российский император дал разрешение на отложенную, ввиду осложнения внутриполитической ситуации в мае 1903 г., поставку в Сербию 10 миллионов патронов к ружьям Бердана. Правда, сама поставка, вследствие халатности сербского военного министерства, смогла осуществиться силами Дунайского пароходства только в апреле 1905 г., поскольку, как указывал российский военный агент Сысоев, сербское правительство в течение полутора месяцев не могло решить, кого отправить в Россию для ее получения. Лишь в середине октября 1904 г. в Россию был командирован поручик Иоксимович - выпускник российской артиллерийской академии, который, по словам российского военного агента в Белграде И. Н. Сысоева, «вполне соответствует данному ему поручению». Однако к тому времени навигация по Дунаю уже была прекращена, и ему пришлось ждать в Петербурге до следующей весны ${ }^{11}$. Заметим при этом, что после переворота 1903 г. Россия стала принимать деятельное участие в модернизации сербской армии, встав, в частности, у истоков создания военно-воздушных сил королевства ${ }^{12}$. 
В то же время русские миноритарные акционеры появились в Сербском судоходном обществе, которое с начала XX в. стало координировать свою деятельность с Черноморско-дунайским пароходством. Это иллюстрируется примером масштабной российской инвестиции в Сербии, которую можно считать единственным до 1917 г. крупным вложением в сербскую недвижимость русских капиталов, - строительством делового центра «Страховое общество Россия», которое смогло реализоваться благодаря конкурировавшему с Австрийским пароходством бывшему директору Сербского пароходного общества С. Вукадиновичу ${ }^{13}$. Это самое высокое тогда здание в Белграде - нынешний отель «Москва», который и сегодня является одной из главных достопримечательностей и самым узнаваемым зданием сербской столицы, - стало возводиться, с использованием новейших технологий, в 1906 г. А тремя годами ранее Правление страхового общества «Россия» обратилось в Министерство внутренних дел с прошением о разрешении приобрести недвижимость в сербской столице, обещая при этом сделать в бюджет страны значительные финансовые вливания ${ }^{14}$. В свою очередь, российский МИД, на основании сообщения дипломатической миссии в Сербии, известил 10 ноября 1903 г. Министерство внутренних дел о том, что согласно сербскому законодательству всякое страховое общество, действующее в Сербии, должно приобрести в Белграде незаложенное недвижимое имущество ценностью от 150000 до 200000 франков. Страховое общество «Россия», в свою очередь, вместо приобретения готовой недвижимости решило выстроить в сербской столице здание своего представительства ${ }^{15}$. В 1905 г. был объявлен конкурс на лучший проект, который выиграл архитектор из Земуна Йован Илкич. Затем его проект дорабатывался в Петербурге российским архитектором немецкого происхождения Павлом Бергштрессером. В 1906 г. строительство на улице Теразие началось. Уже в январе 1908 г. величественное семиэтажное здание было торжественно открыто. Его сооружение обошлось в 2 млн руб.

Красноречивые воспоминания не только об урбанистическом, но и о политико-символическом значении здания, связанном с демонстрацией влияния Российской империи в Сербии, оставил секретарь российской дипломатической миссии В. Н. Штрандтман: «На панораме Белграда, на месте впадения Савы в Дунай, выделялись колокольня Соборной церкви - символ веры, королевский дворец с тремя куполами - символ королевской власти и отель “Москва” - символ веры в Россию!» ${ }^{16}$ Впечатлило это здание, учитывая общий облик сербской столицы и ее улиц, и еще одного современника — известного публи- 
циста и журналиста газеты «Новое время» Д. Н. Вергуна ${ }^{17}$, прибывшего в сербскую столицу в 1910 г. Он не без гордости говорил о нем как о символе смены на Балканах австрийского влияния на российское: «Странная участь славянских столиц на Балканах. Белград - это точно жених, ожидающий наследия американского дядюшки. <..> Какая-то лень, сонливость и беспечность на неумолимом солнцепеке. Говорят, город этот сделал теперь заем в 60 миллионов для приведения себя в культурный вид. Но работа что-то не спорится. <.. > Впрочем, есть одно новое здание в Белграде, останавливающее внимание каждого путешественника. Уже издали высится его громоздкий пятиэтажный корпус. Это гостиница "Москва", принадлежащая страховому обществу "Россия”, успевшему за какие-нибудь пять-шесть лет почти совершенно вытеснить из Сербии австро-венгерские страховые общества» ${ }^{18}$. А русский философ А. И. Введенский, увидев только что построенный «небоскреб», воскликнул: «Тут просто какая-то символика: над Белградом господствует “Москва”!»19

Новым крупным сербско-российским стратегическим проектом, вызвавшим серьезную озабоченность Австро-Венгрии, стало начало строительства в канун балканских войн 1912-1913 гг. железной дороги в юго-восточной Сербии, связавшей г. Ниш с дунайской пристанью Прахово ${ }^{20}$. Ее инициатором и проектировщиком стал инженер и журналист И. П. Табурно ${ }^{21}$. Предвидение не обмануло талантливого русского инженера. Начавшаяся вскоре Первая мировая война показала важность русского экономического присутствия в дунайском регионе и использования сербских речных портов в военных интересах России и ее союзников. Река стала ареной острого военного и дипломатического противостояния, что связано с организацией Особой дунайской экспедиции во главе с капитаном первого ранга М. M. Весёлкиным, созданной для снабжения союзной сербской армии столь необходимыми ей оружием, боеприпасами и продовольствием ${ }^{22}$.

Именно на начальный период Первой мировой войны пришелся пик российско-австрийского соперничества на Дунае. Кораблями Дунайского пароходства в течение 1914-1915 гг. происходила переброска военных материалов в воюющую Сербию, а доставку и оплату сербских военных заказов осуществляло его представительство в Одессе ${ }^{23}$. При этом российские правящие круги приняли в октябре 1914 г. решение об освобождении Сербии от оплаты за поставляемые грузы, а все расходы за доставку и конвоирование были возложены на российское государственное казначейство и причислены к смете особого военного фонда. Кроме того, чиновники пароходства негласно 
выполняли функции осведомителей. Как говорилось в секретной телеграмме российского посланника в Софии И. О. Савинского, отправленной консулу в Рущук, - «для безопасного плавания весьма важно иметь возможно больше сведений о передвижении австрийских пароходов. Благоволите предложить агентам Дунайского пароходства во всех болгарских и насколько возможно в румынских портах доносить вам все, что они узнают, а сами срочно сообщайте по телеграфу сведения консулу в Галаце, посланнику в Бухаресте, мне, в министерство и, по возможности, Веселкину» ${ }^{24}$. Большую помощь в организации сербской части маршрута экспедиции оказывали посланник в Сербии Г. Н. Трубецкой и военный агент полковник В. А. Артамонов.

Первый караван, подготовленный для отправки в Сербию к середине сентября 1914 г., состоял из четырех барж мостового материала и военного груза - 2 барж патронов, 9000 пудов бензина, 100 вагонов спирта, 1100 лошадей. «Военные грузы пойдут в несколько рейсов на буксире двух пароходов. Для боя остаются пароходы "Румыния", “Игнатьев" и “Сербия"; чтобы экспедиция не потерпела неудачи, нужно испросить в Севастополе пушки: для пароходов: $8-75$ мм и 500 патронов и $10-47$ мм и 1000 патронов, 6 пулеметов, 10 ящиков патронов на каждый и 2 решетки с двумя минами. На все соответственное количество команды и офицеров», - отмечалось в телеграмме Веселкина от 13 сентября 1914 г. ${ }^{25}$ При том, что в собственно русской армии в то время остро ощущался «снарядный голод», в начале декабря 1914 г. в Рени было доставлено 10.00075 мм снарядов, а до конца января 1915 г. караванами экспедиции предполагалось перевезти еще 20000 штук $^{26}$. Два первых конвоя экспедиции прибыли в Сербию 21 октября и 24 ноября 1914 г. Из самого необходимого было доставлено 32814 винтовочных боекомплектов и большое количество боеприпасов для артиллерии: 24000 снарядов калибра 75 мм, $4000-80$ мм, $6000-120$ мм, $1000-152$ мм и т. д. ${ }^{27}$

В ведение Дунайской экспедиции, «в пользование русскому Дунайскому пароходству», с формальным их выводом задним числом из состава военного флота, в феврале 1915 г. были приданы посыльные суда «Кинжал» и. «Сабля» под командованием лейтенантов Иванова и Шахова, входившие в состав созданного для постановки «минных заграждений, бонов с сетями у границы австрийского побережья у Железных Ворот на Дунае» отряда старшего лейтенанта Семенова ${ }^{28}$. Суммарная грузоподъемность судового состава экспедиции позволяла перевезти одновременно 20 тыс. человек с полным вооружением и снабжением ${ }^{29}$. 
Однако при организации доставки грузов российским военным и дипломатическим структурам пришлось одновременно решать несколько задач, а сама экспедиция стала заложником сложных политических комбинаций, которые вел российский МИД, пытаясь обеспечить благожелательный нейтралитет болгарского правительства в вопросе об организации дунайского транзита, одновременно пытаясь договориться об организации через ее территорию альтернативного провоза военных грузов. Эти вопросы российский МИД напрямую увязывал с возможностью вовлечения Болгарии в войну на стороне Антанты, что, в свою очередь, делало необходимым решение в ее пользу вопроса о македонской территории, которую Сербия получила по итогам Балканских войн 1912-1913 гг. «Уступки Болгарии признаются нами необходимыми не в силу симпатий или антипатий, а зрелого расчета, который должен и сербам показать то же решение» ${ }^{30}$, именно так указывал глава МИД С. Д. Сазонов в телеграмме, отправленной В. Н. Штрандтману в конце октября 1914 г. Сербский премьер Н. Пашич решительно отвергал саму возможность подобного обмена, твердо стоя на убеждении, что Македония, будучи стратегически важной территорией («У кого в руках Македония, тот контролирует все Балканы»), остается неотъемлемой частью Сербии. Его позиция была непоколебима даже несмотря на заверения главы российского МИД о том, что «Россия, близкая к окончательному разгрому главных австрийских сил, сумеет вместе с союзниками вознаградить Сербию, подобно Бельгии, за временные тяжелые испытания» ${ }^{31}$. В разговоре с российским посланником Трубецким Пашич прямо заявил, что «лучше с честью погибнуть, чем идти на самоубийство» ${ }^{32}$.

В свою очередь, российский посланник в Софии А. А. Савинский, передавая предложения главы МИД представителям болгарских правящих кругов, доказывал, что «даже в случае сопротивления сербов» у России будет «достаточно средств и нравственного и материального воздействия». Как видно из его обширного рапорта от 8 октября 1914 г., он убеждал представителей болгарской политической элиты в том, что «у болгар нет никакого права не верить России и ее обещаниям». Савинский писал, что как «в прошлом - 1877 году и 1912 году — так и в будущем весь интерес Болгарии - быть в тесном единении с Россией, ибо задачи обеих стран общи, и их взаимные интересы тесно связаны: сильна Россия - сильна и Болгария и наоборот; напротив, все выдумки наших врагов о желании России образовать из Болгарии “придунайскую губернию”, воскресить режим Каульбарса, воспользоваться Болгарией лишь как ступенью к овладению Константинопо- 
лем и т. д. - это лишь одни бредни, которым никто не может и не должен верить. Соотношение между силами России и Болгарии слишком неизмеримо: та выгода, которую Россия может извлечь из своих хороших отношений с Болгарией, слишком ничтожна в сравнении с выгодами, извлекаемыми Болгарией из дружбы с Россией; если ход мировой политики и необходимость разрешения задач нашей высшей политики приведет нас к решению о занятии Царьграда и проливов, то болгары могут быть уверены, что они нам в этом не помешают и им только будет лучше, если они свяжут судьбу теснее с нами» ${ }^{33}$.

Аналогичные переговоры, но более успешные, велись с румынским правительством, за которым союзники хотели признать право на Банат. Румынский премьер И. Братиано заверил русское правительство, что Румыния «просто закроет глаза» и негласно окажет «всякое содействие» провозу российских грузов ${ }^{34}$. Кроме того, как доносил российский посланник в Бухаресте С. А. Поклевский-Козелл, румынские власти отдали «секретное распоряжение снабжать нашу флотилию нужными ей продуктами, и даже овсом, вывоз коего из Румынии воспрещен» ${ }^{35}$.

Болгарское же правительство, официально нейтральное, в свою очередь, стараясь извлечь как можно больше политических выгод из создавшегося положения, уже осенью 1914 г. открыто склонялось в пользу союза с австро-германским блоком, чему немало способствовало критическое положение, сложившееся к тому времени на сербо-австрийском фронте. В сентябре 1914 г., в момент критического положения на сербо-австрийском фронте, возникла опасность того, что австрийцы захватят сербское побережье Дуная ниже румынского города Оршовы, т. е. у самого узкого места реки - Железных ворот, что не только поставило бы экспедицию Веселкина в весьма сложное положение, но и позволило бы австрийцам установить прямое сообщение с Болгарией, столь важное для «обеспечения доставки по реке судов с зерном для Австрии» ${ }^{36}$. В этом смысле ключевое значение для обеспечения безопасности русского транзита имело произведенное русскими моряками минирование Железных ворот.

Для Австрии стратегическая важность контроля над средним и нижним течением Дуная была очевидна, однако, несмотря на все усилия, вплоть до разгрома сербской армии осенью 1915 г. австрийской военной флотилии так и не удалось прорваться в нижнее его течение, что позволило беспрепятственно осуществлять сообщение между сербским портом Прахово и Рени ${ }^{37}$. Ситуация усугублялась еще и тем, что в конце осени 1914 г. болгарское правительство настоятельно тре- 
бовало обеспечить свои интересы как формально нейтральной страны, а именно разрешить пропуск из Оршовы груза из 2 барж, которые, как выяснил российский посланник в Софии А. А. Савинский, «включают кабель, телеграфные аппараты, 200000 артиллерийских снарядов, заказанных еще в прошлом году на заводе Эргарда». Он доносил также, что кроме этого в Оршову было доставлено «для переправки в Болгарию» 12000 ружей, 75000 шанцевых лопат и кирок, и «ожидается прибытие еще 25000 ружей, 120000 пар сапог, 500 лошадей и медицинских материалов». В обратном направлении, в Видине, как доносили российские военный и дипломатический агенты, было заготовлено 500000 бараньих шкур для «зимних потребностей германской армии. Шкуры должны быть доставлены в Оршову болгарским пароходом, предназначенным для буксирования барж с военными припасами из Оршовы в Болгарию». Не случайно болгарский премьер В. Радославов в беседе с сербским посланником Античем в декабре 1914 г. заявил, что «болгарские суда могли бы идти по Дунаю при непрекращающемся бое сербов. Лишь бы они были гарантированы от их оружейного огня» ${ }^{38}$. Кроме того, «по агентурным сведениям, высланным из Бухареста, по распоряжению румынского правительства обратно в Германию груз радиотелеграфных приборов, предназначенных Турции, всего 52 вагона - отправлен в Оршову, откуда германцы решили спустить его по Дунаю в болгарский порт, для чего покупают в Румынии буксирный пароход, который будет ходить под болгарским флагом». Учитывая все эти факты, а также «в виду все более выясняющегося потворства болгарских властей враждебной нам военной контрабанде», российский дипломатический и военный агенты считали, что «ни в коем случае не нужно содействовать ввозу груза в Болгарию, затягивая этот вопрос вплоть до получения инструкций» ${ }^{39}$. При этом мнение российского МИД было выражено вполне определенно - «мы можем допустить военные грузы в Болгарию только после того, как она вполне ясно определит свое отношение к нам» ${ }^{40}$.

Однако, несмотря на все усилия российских дипломатов по блокированию этих конвоев, выход все же был найден. С целью беспрепятственного провоза военной контрабанды из Австро-Венгрии в Болгарию и Турцию австрийская и венгерская пароходные кампании совершили фиктивные сделки, продав свои пароходы Болгарии, которая, в свою очередь, как в начале ноября 1914 г. с тревогой сообщал Веселкин, открыла рейсы до Оршовы, «обещая уничтожить нас, если сербы не пропустят пароходы Болгарии». В качестве ответной меры он предлагал передать сербам «два наших вооруженных парохода», 
а также затопить в Железных воротах две баржи с камнями. Его пессимизм был столь высок, что он предлагал «самим же нам оставить груженые баржи в Радуевце, возвратиться в Рени и ликвидировать экспедицию, тем более что Румыния дала согласие пропускать боевые грузы по железным дорогам» ${ }^{41}$. В ноябре 1914 г. Сербская королевская миссия сообщала в российский МИД, что «по Дунаю транспорт встречался с австро-венгерскими пароходами, которые плавали под болгарским флагом. Очевидно, благодаря этому, что они плавают под болгарским флагом, они не посмели и не посмеют в будущем атаковать русские пароходы. Нужно использовать это благоприятное обстоятельство, как и время навигации по Дунаю, в особенности для перевозки орудий, которых иначе нельзя перевезти» ${ }^{42}$.

Все это не могло не сказаться на проходе российских конвоев. Заметим, что безопасный проход первого российского каравана барж был обеспечен активным дипломатическим давлением российского посланника в Софии на правительство Радославова: «В последние дни мы с напряженным вниманием следим здесь за движением по Дунаю нашего транспорта, предназначенного для Сербии. Здесь шла по-видимому сильная работа для его уничтожения. Австрийский и германский посланники с помощью своих военных агентов успешно совещались с какими-то австро-германскими агентами - евреями из Бухареста, предлагая им до 100000 франков за потопление транспорта. Как только предстоящий проход транспорта был мне возвещен Вашим высокопревосходительством, я сейчас же принял все бывшие в моей власти меры; я категорически заявил как Радославову, так и Фичеву, что возлагаю всецело на них ответственность за все могущее произойти, и держал их в курсе всех поступавших ко мне сведений о готовящихся покушениях. Надо сказать, что особенного содействия с их стороны, кроме слов, я не встретил, но, слава богу, вчера под вечер Радославов, при мне телефонировавший в Видин, получил известие, что наши суда прошли это опасное место, где в рукавах Дуная скрывались вооруженные венгерские пароходы, а сегодня получено известие, что транспорт благополучно достиг сербской гавани в Кладово» ${ }^{43}$. Однако без инцидентов все же не обошлось. При проходе этого конвоя «на 547 километре около острова Вардина болгарский пикет произвел несколько выстрелов по пароходу “Прут” без попадания. Стрельба прекратилась, когда подошедший пароход “Румыния”, сняв чехлы, навел орудия» ${ }^{44}$.

Проход последующих российских конвоев также сопровождался регулярными провокациями со стороны болгар. Так, например, 
12 (25) ноября 1914 г. В. Н. Штрандтман сообщал, что «10 ноября у места Ечкагуровой, близ Аде-Кале, румынами захвачена лодка, на которой находились австрийский морской офицер, один турок и серб с бомбами и минами для нападения на русский транспорт». Также до русского командования доходили сведения об отправке через Румынию из Австрии в Болгарию мин «для действий против транспорта Веселкина». В декабре 1914 г. Савинский доносил, что «в Рущук из Аде-Кале прибыл турок Мехмед Читак-Аслан с рекомендательными письмами к австрийскому и турецкому консулам, с четырьмя плавучими минами для покушения на наши транспорты. Аслан будто бы уехал на днях в Видин за дополнительными частями мин, находящихся в местном австрийском консульстве». Случались и трагические события, в которых гибли гражданские лица. 2 февраля 1915 г. в районе Олтула, буквально через полчаса после прохода российского транспорта, миной, пущенной с болгарского берега, были подорваны две пассажирские лодки, следовавшие по маршруту Никополь - Самовит, при чем погибло не менее 5 человек. Болгарское правительство постаралось замять этот случай, а Радославов в беседе с российским посланником заявил, что «принесенные сверху Дуная и направляемые течением к болгарскому берегу мины составляют для самих болгар постоянную опасность» ${ }^{45}$. В марте 1915 г. во время прохода русских пароходов «Патриот», «Румыния», «Сербия» и «Шевченко» произошла стрельба на болгарском пограничном посту Лабец. Крупный инцидент произошел 29 августа 1915 г., незадолго до объявления Болгарией всеобщей мобилизации. Начальник 42 транспорта кавторанг Дедюхин сообщал, что около часу ночи у баржи «Светлана» «вытащены из воды два голых немца с подрывными приспособлениями» ${ }^{46}$. Этот эпизод даже был доведен до сведения Николая II, а российская миссия в Софии сделала соответствующее представление болгарскому премьеру.

Для успешного провоза грузов немаловажное значение имела борьба с австрийскими аэропланами, для базирования которых «нейтральное» правительство Болгарии любезно предоставило собственную территорию, что нашло отражение в многочисленных рапортах. Так, например, по сообщениям Веселкина, «австрийские аэропланы, вылетающие из Оршовы для метания бомб в наши транспорты, постоянно залетают на болгарскую территорию вблизи Лом-Паланки, где спускаются на землю для ночлега» ${ }^{47}$. Озабоченность российских военных властей вызывали сообщения российского военного агента в Румынии о том, что «в Топлице находится 15 аэропланов “Таубе”, которые, имея целью атаковать наши транспорты с военными при- 
пасами в Сербии на Дунае, совершают полеты над городом ТурнуСеверин и Ада-Кале и опускаются на болгарскую территорию близ Видина». В ответ на соответствующий запрос болгарский премьер ответил, что эти самолеты предназначены для Болгарии и находятся не в Топлице, а около г. Предеала. «Румынское правительство не хочет их пропускать в разобранном виде, и будто бы министр финансов предложил болгарам, чтобы они пролетели над Румынией», — отмечалось в донесении российского посланника в Софии. Радославов, в свою очередь, лицемерно заметил, «что в случае спуска немецких аэропланов на болгарской территории они и летчики будут задержаны». Между тем Савинский сделал вполне обоснованный вывод: «Заявления Радославова не соответствуют сведениям российского военного агента, по которым три аэроплана не взяты у немцев, а доставлены последними, взамен разрешения болгарского правительства провести тройное количество в Турцию. Кроме того, полковнику Татаринову кажется, что 15 аэропланов, находящихся будто бы в Предеале, слишком большое количество для Болгарии» ${ }^{48}$. Впрочем, воздушные атаки австрийцев, в том числе с болгарской территории, не нанесли судам экспедиции никакого вреда. «Ежедневные отражения атак неприятельского воздушного флота выработали в личном составе отряда поразительное хладнокровие, и после приспособления пулемета к стрельбе под большим углом возвышения два неприятельских аэроплана, подбитые пулеметным огнем, сделав несколько неуверенных ныряний, вернулись обратно в Австрию, где, по непроверенным агентурным сведениям, не долетев до парка, спустились в горах, поломав себе крылья. Во всяком случае, после этого полеты значительно сократились, и последнее время их совершенно не наблюдается» ${ }^{49}$, отмечал М. М. Веселкин в рапорте по обзору деятельности экспедиции с 1 октября 1914 г. по 20 апреля 1915 г.

Усилия России не пропали даром. Во многом благодаря вовремя полученной русской помощи, в том числе снарядами, в октябре - ноябре 1914 г. сербским войскам удалось не только сдержать австрийское наступление, но и подготовить мощный ответный удар. В ходе 12-дневных боев на р. Колубаре и р. Дрине они разгромили австровенгерские войска Потиорека, а 15 декабря был освобожден Белград. На сербской территории не осталось ни одного австро-венгерского солдата; было захвачено более 50 тыс. пленных, 126 орудий, 70 пулеметов и немало прочих трофеев.

Вытеснение австрийцев с сербской территории придало развитию дунайского транзита новый, не менее важный импульс. Речь идет 
о перевозке, под видом сербских грузов, «военной контрабанды» из Англии и Франции, а именно военных товаров и оборудования, которые либо не производились в России вовсе, либо выпускались в недостаточном количестве. К ним относились важнейшие комплектующие для военной промышленности империи, а именно - автомобильные и авиационные двигатели, аэропланы, автозапчасти и сами автомобили, прожекторы, бинокли, оптика, радиотелеграфное оборудование и пр. ${ }^{50}$

В декабре 1914 г. военный агент во Франции А. А. Игнатьев через посла А. П. Извольского доносил в МИД и Генеральный штаб, что «имеется необходимость организовать “на широких началах" безопасную перевозку грузов из Англии и Франции в Россию». В качестве маршрута была предложена доставка грузов на французских пароходах в официально нейтральный порт Салоники, оттуда по железной дороге до сербской станции Парачин, затем по узкоколейке до Заечаpa, а оттуда уже по нормальной железной дороге до дунайского порта Прахово, откуда грузы должны были доставляться в Рени ${ }^{51}$ Выгоды организации этого транзита были очевидны, и именно поэтому данная идея нашла благоприятный отклик в Ставке. Греческий премьер Венизелос, в свою очередь, обещал от имени своего правительства оказывать этим перевозкам всяческое содействие. Отметим при этом, что важным успехом российской дипломатии можно считать изданный в начале февраля 1915 г. королевский декрет, согласно статьям которого запрещался вывоз и транзит всех предметов военной контрабанды, а «греческим таможенным властям предписано сообразовываться по сему поводу со списками военной контрабанды, опубликованными воюющими сторонами». Немедленным следствием этого указа стало то, что «4000 ящиков с керосином для Дедеагача ${ }^{52}$ уже задержано в Салониках». Российский посланник в Афинах Е. П. Демидов имел полное право резюмировать итоги этих переговоров следующим образом: «Лучшего исхода едва ли можно ожидать. Вывоз наших грузов остается, разумеется, обеспеченным греко-сербским соглашением ${ }^{53}$.

Во главе этого предприятия был поставлен бывший генеральный консул в Константинополе А. Ф. Шебунин. Он курировал разгрузку вагонов в Салониках до погрузки в Прахово, где они переходили в ведение Экспедиции особого назначения. Помощниками Шебунина стали бывший секретарь того же консульства Н. И. Дубягский и подполковник Л. М. Новиков, бывший до этого комендантом железнодорожного участка станции Воронеж. Приемку этих грузов в Рени и организацию дальнейшей их доставки осуществляла специальная комиссия под руководством полковника Э. Б. Кригер-Войновского. При- 
чем поставки касались не только непосредственно казенных военных материалов. В начале февраля 1915 г. в Салоники прибыл комиссионер Малиновский. Он поставил вопрос о возможности переправки грузов, адресованных «поставщикам наших военного и морского ведомств, например, Промету, русско-балтийскому заводу в Риге, Дуксу ${ }^{54}$, Ильину в Москве, Щетинину и Лебедеву в Петрограде, и другим». В этом смысле Шебунин предлагал: «1) Ввиду недостатка вагонов эти грузы всегда идут после казенных. 2) Поставщиками казны я признаю лишь тех, список коих мне пришлет генеральный штаб. 3) Исключение из второго пункта будут допускаться лишь по особым удостоверениям военных агентов» ${ }^{55}$. Согласно справке генконсульства в Салониках, с первых чисел февраля и до начала апреля 1915 г. «провозились через Салоники для отправления в Россию путем Салоники, Гевгели, Ниш, Парачин, Заечар, Кладово - далее по Дунаю до Рени караваном флигель-адъютанта Веселкина следующие правительственные грузы:

1. Части аэропланов, моторы для них и вообще авиационный материал.

2. Моторы для автомобилей, отдельные части для их замены.

3. Военные грузы, содержание коих императорскому генеральному консульству в Солуни неизвестно.

4. Груз серного цвета для департамента земледелия, отправленный в начале марта тем же путем, что и военный груз. О пропуске через Грецию и облегчении следования этого груза, объявленного греческим правительством абсолютной военной контрабандой, хлопотал директор департамента земледелия д. с. с. Слободчиков» ${ }^{56}$.

Однако за 1914-1915 гг. этот маршрут так и не удалось вывести на достаточный уровень грузоперевозок, сравнимый с поставками, осуществляемыми через Архангельск и Мурманск. Сказались как типичная для России межведомственная несогласованность, так и тот факт, что приемная способность сербского порта в Прахове, а также пропускная способность железнодорожной ветки из Прахова внутрь Сербии оказались на весьма низком уровне. За 1914-1915 гг. изменить ситуацию к лучшему так и не получилось. Также остро ощущалась нехватка вагонов. Обеспечить их бесперебойную работу, несмотря на все усилия, сербам также так до конца и не удалось. Начавшееся осенью 1915 г. австро-германское наступление на сербском фронте поставило на российском дунайском транзите окончательный крест, не дав возможности превратить линию Салоники - Прахово — Рени в крупный транспортный и логистический узел по снабжению русской армии. Однако даже среди такого небольшого количества грузов в Россию были 
доставлены важные и дефицитные материалы, что отражено в сводной таблице, составленной исследователем А. Ю. Тимофеевым.

Список грузов, перевезенных по маршруту

Салоники - Прахово — Рени с февраля по октябрь 1915 г.57

\begin{tabular}{|l|c|c|c|}
\hline Род груза & $\begin{array}{c}\text { Число } \\
\text { партий }\end{array}$ & $\begin{array}{c}\text { Число } \\
\text { мест }\end{array}$ & $\begin{array}{c}\text { Число } \\
\text { тонн }\end{array}$ \\
\hline Орудия & 2 & 30 & 74,30 \\
\hline Порох и другие взрывчатые вещества & 12 & 10269 & 812,06 \\
\hline Снаряды, взрыватели и т. п. & 10 & 25394 & 2272,55 \\
\hline Аэропланы и гидроаэропланы & 10 & 223 & 412,76 \\
\hline Моторы и принадлежности авиации & 27 & 1223 & 228,02 \\
\hline Машинные части & 11 & 591 & 266,19 \\
\hline $\begin{array}{l}\text { Автомобили, шасси, принадлежности и } \\
\text { запасные части к ним }\end{array}$ & 15 & 277 & 425,15 \\
\hline Велосипеды и запасные части & 2 & 535 & 91,74 \\
\hline Радиотелеграф и радиотелефон & 6 & 74 & 12,44 \\
\hline Прожекторы & 8 & 140 & 85,61 \\
\hline Бинокли, оптика, перископы & 11 & 59 & 11,69 \\
\hline Шелк для артиллерии & 3 & 4 & 0,16 \\
\hline Каски для пехоты & 6 & 8 & 1,27 \\
\hline Термометры, медикаменты, целлулоид & 11 & 4466 & 743,50 \\
\hline Сера, мешки, ореховое дерево, шелковые & 1 & 162 \\
\hline
\end{tabular}




\begin{tabular}{|l|c|c|c|}
\hline $\begin{array}{l}\text { Электрический кабель, ртуть, алюминий } \\
\text { и проволока }\end{array}$ & 4 & 5361 & 366,97 \\
\hline Барографы & 1 & 1 & 0,05 \\
\hline Трансформаторы & 1 & 33 & 15,92 \\
\hline Итого & 141 & 48689 & 5820,30 \\
\hline
\end{tabular}

9 (22) сентября 1915 г. Болгария объявила мобилизацию, а 1 (14) октября начала военные действия против Сербии. 5 (18) октября 1915 г. Россия вынуждена была объявить войну стране, за свободу и независимость которой еще не так давно пролили кровь десятки тысяч русских солдат. Эти события, вкупе с австро-германским наступлением, стали катастрофой для сербской армии. Но еще за полторы недели до этого события произошел инцидент, ясно обозначивший позицию Болгарии. 24 сентября 1915 г. в районе Лом-Паланки болгары попытались заблокировать русские транспорты, при этом ими был захвачен пароход «Белград» с 5 баржами, груженными кукурузой, мукой и ячменем. «Таким образом, из всего каравана, состоящего из 7 пароходов и 19 барж, пришли в Сербию 2 парохода с 6 баржами. 3 парохода с 8 баржами находятся в Карабии, в Румынии, и 1 пароход - «Белград», с комендантом лейтенантом Гаврилюком, вооруженный 47-мм орудием и 5 винтовками, задержан болгарами» ${ }^{58},-$ сообщал Веселкин. Сам же пароход «Белград», быстро переименованный в «Варну», стал совершать рейсы уже под болгарским флагом. Его команда из 44 человек, отпущенная болгарами, в начале января 1916 г. прибыла через Бухарест в Рени. В ноябре 1916 г. моряки команды Веселкина под командованием капитанов 2-го ранга Ильина и Леванды перешли греческую границу и прибыли в Салоники, причем «под видом рабочих Путиловского завода, запрятав оружие ${ }^{59}$. Оттуда на французских пароходах они отбыли в Марсель.

Тем не менее за 1915 г. в Сербию было отправлено 45 транспортов с военными грузами, включавшими в себя артиллерийские орудия, понтонные мосты, телефонное оборудование, патроны, ружья, бензин, спирт и другие материалы ${ }^{60}$. Так, например, после Колубарской битвы до 15 марта 1915 г. из России в Сербию было поставлено военного снаряжения на 15 млн руб., а из Франции было послано 206 тыс. ружей разного калибра и 231544 снарядов для полевой артиллерии ${ }^{61}$. 
Последним же пароходом с грузом военной контрабанды оказался «Вашингтон», который, выйдя из Генуи, 25 августа 1915 г. сел на мель около греческого острова Эвбея. Груз удалось спасти и доставить в Салоники, но большая его часть до России так и не дошла. 27 октября (9 ноября) 1915 г. Шебунин писал: «Спасенные в "Вашингтоне" прожекторы в двух ящиках вышли из Салоник с последними партиями военного груза 16 сентября, прошли в Ниш, но были задержаны спешным движением войск и, по имеющимся здесь сведениям, попали к последнему транспорту Веселкина, ушедшему из Прахово. Четыре ящика доставили на баржу, отведенную к румынскому берегу. Оставшиеся же были возвращены в Заечар на узкую колею, где, по-видимому, и остались» ${ }^{62}$. В Рени, таким образом, было доставлено всего 4 прожектора.

После окончания Первой мировой войны фактический контроль над нижним течением Дуная, несмотря на международный статус этой речной артерии, в конце концов достался третьей стороне. При поддержке Великобритании Румыния оккупировала российскую провинцию Бессарабия, что на долгие годы положило конец российскому дунайскому судоходству. Однако тема участия Российской империи в судоходстве на Дунае в начале XX в., связь между ее стратегическими интересами в регионе и деятельностью ее пароходных компаний, общие экономические интересы России как в Сербии, так и в других странах региона могут стать предметом новых исследований как российских, так и зарубежных историков.

\section{ПРИМЕЧАНИЯ}

1 См., например: Готлиб В. В. Тайная дипломатия во время Первой мировой войны. М., 1960; Виноградов К. Б. Боснийский кризис 19081909 гг. Пролог Первой мировой войны. Л., 1964; Поповић Н. Србија и царска Русија. Београд, 1994; Первая мировая война. Пролог XX века. М., 1998; За балканскими фронтами Первой мировой войны. М., 2002; В «пороховом погребе Европы» 1878-1914. М., 2003; Яси О. распад Габсбургской монархии. М., 2011; Seton-Watson R. Europe in the melting-pot. London, 1919; Fisher F. Germany's War Aims in the First World War. New York, 1967; Jelavich B. A Century of Russian Foreign Policy 1814-1914. Philadelphia, 1964; Jelavich B. The Habsburg Empire in European Affairs, 1814-1918. Chicago, 1969; Jelavich B. History of the Balkans. Cambridge, 1983; Вишняков Я. В. Сербия в начале мировой войны: 1914-1915 годы // Новая и новейшая история. 2013. № 2. С. 53-65; Вишняков Я. В. Сербский 
фронт: от войн балканских к мировой // Первая мировая война: историография и уроки истории. Материалы VIII Конвента РАМИ, апрель 2014 г. М., 2015. С. 7-45; Вишняков Я. В. Военный фактор и государственное развитие Сербии начала ХХ века. 2-е изд. М., 2016; Тимофеев А. Ю., Вишняков Я. В., Милорадович Г. Битва двуглавых орлов. Очерки по истории русско-сербских отношений в годы Первой мировой войны. М., 2016.

2 Частично этот вопрос позволяют восполнить материалы, опубликованные в сборнике: «Москва-Сербия, Белград-Россия». Сборник документов и материалов. Москва; Белград, 2012. Т. 3. Общественнополитические и культурные связи 1878-1917. Этой же проблеме были посвящены статьи тематического «дунайского» номера журнала «Родина» за ноябрь 2010 г. В академическом ключе этот вопрос поднимался историком А. Ю. Тимофеевым. См.: Россия на Сербском фронте Первой мировой войны. Помощь армии и флота России Королевству Сербия в 1914-1918 гг. / Сост. А. Ю. Тимофеев, Д. Кремич. М., 2014.

3 Шемякин А. Л. Сербия на переломе. Обретение независимости и проблема модернизации // Токови историје. 2000. № 1-2. С. 21-22.

4 Об этом см. подробнее материалы тематического «дунайского» номера исторического журнала «Родина» за ноябрь 2010 г.

5 Россия на Сербском фронте Первой мировой войны. С. 12.

6 Там же. С. 12-13; Черников И. И. Флот на реках. СПб., 2003. C. 492-495.

7 Москва-Сербия, Белград-Россия. С. 128-129.

8 Там же. С. 129.

9 Там же. С. 133.

10 В 1902 г. истек срок межгосударственного торгового договора, заключенного в 1892 г. В 1904 г. в Сербии был введен новый таможенный тариф, а в 1905 г. заключен невыгодный для Австро-Венгрии торговый договор с Болгарией и Черногорией, что, в свою очередь, усиливало перспективы их политической интеграции, весьма опасной для интересов двуединой монархии. В ответ на эти действия сербского правительства австро-венгерское правительство запретило ввоз на свою территорию продукции животноводства, составлявшего главную статью экспорта Сербии. В ответ сербское правительство запретило ввоз австрийских промышленных товаров. Таможенная или «свиная» война продолжалась с 1906 по 1911 г. и закончилась фактическим поражением Австро-Венгрии, поскольку Франция и Россия оказали экономическую поддержку сербскому правительству. С 1905 по 1907 г. экспорт сербских товаров в Австро-Венгрию с первоначальных 64,7 млн упал на 12 млн динар. Экономические отношения между Сербией и Австро-Венгрией были воз- 
обновлены в 1911 г. подписанием нового торгового соглашения. См.: Dedijer V. Sarajevo 1914. Beograd, 1978. Knj. II. S. 74.

11 Российский государственный военно-исторический архив (далее РГВИА). Ф. 400. Оп. 4. Д. 312. Л. 45-46, 50-51, 52-54. При этом, как следует из донесения русского военного агента, «доставка совершена без шума, без огласки в местных газетах и без неприятных справок со стороны австрийских властей». Не случайно «за перевозку патронов, исполненную в порядке и по весьма дешевой цене, директор пароходства и капитан парохода, буксировавшего баржи с патронами, представлены к наградам, а начальник отделения артиллерийского управления, полковник Юрлов, в ведении которого было это дело, уже награжден за него». См.: Там же. Л. 53-54.

12 Степанов Д. Н. К истории российско-сербского военного сотрудничества. Русские летчики в составе сербской авиации на Салоникском фронте в период Первой мировой войны // Первая мировая война и судьбы народов Центральной и Юго-Восточной Европы: Очерки истории. М., 2015. С. $157-168$.

13 Россия на Сербском фронте Первой мировой войны. С. 10-11.

14 Москва-Сербия, Белград-Россия. С. 141.

15 Там же. С. 163.

16 Штрандтман В. Н. Балканские воспоминания. М., 2014. С. 71.

17 В следующем, 1911, году поведение Вергуна на проходившем в Белграде съезде славянских журналистов вылилось в настоящий скандал, а ему самому спешно пришлось покинуть сербскую столицу. См. подробнее: Вишняков Я. В. «Подальше от нашего порога»: съезд славянских журналистов в Белграде 1911 года // Родина. 2011. № 8. С. 137-138.

18 Москва-Сербия, Белград-Россия. С. 120.

19 Там же. С. 215.

20 См.: Докладная записка инженера И. П. Табурно председателю Совета министров и министру финансов о мерах для поднятия торговопромышленных оборотов России на Балканском полуострове. Режим доступа: https://www.prlib.ru/item/357639

21 Табурно Иероним Павлович (1862-1913) — русский инженер и военный журналист. Один из проектировщиков Транссибирской железной дороги. Как инженер внес большой вклад в развитие угольной отрасли на Донбассе. В качестве корреспондента «Нового времени» освещал события Русско-японской войны, затем, в 1912 г., - Первой балканской войны, и о той, и о другой войне он написал книги. Был редактором газеты «Вечер».

22 Тюриков С. В. Экспедиция особого назначения на Дунае по оказанию помощи Сербии в 1914-1915 гг. СПб., 2015. Отметим, что в обороне Сербии участвовали также российские артиллеристы, военные ин- 
женеры и минеры. Однако в данной статье, исходя из ее проблематики, главное внимание уделено именно транзиту военных грузов по Дунаю.

23 Российское правительство приняло решение оказать военную помощь Сербии в разгар июльского кризиса. 28 июля 1914 г. поверенный в делах России в Белграде В. Н. Штрандтман поспешил передать Н. Пашичу «сообщение, что от Сазонова поступило указание оповестить его о благоприятном решении вопроса о выделении винтовок и боеприпасов Сербии. Он в ответ попросил меня смиреннейшим образом выразить глубочайшую признательность сербского правительства императору Николаю II за оказанную милость. В телеграмме министру я мог добавить, что за прием поставки назначен ответственным сербский военный атташе в Петрограде полковник Лонткиевич». См.: Штрандман В. Н. Балканские воспоминания. С. 257.

24 АВПРИ. Ф. Политархив. Оп. 1. Д. 4014. Л. 18.

25 Там же. Л. 2. Значение этих грузов для воюющей Сербии было велико. К осени 1914 г. положение армии страны было на грани поражения. В ней ощущалась острая нехватка снарядов. Российский военный агент в Сербии В. А. Артамонов отмечал, что в «полевой артиллерии осталось приблизительно сто двадцать снарядов на орудие», а «сербы отвечают теперь на артиллерийский огонь противника в пропорции один выстрел на двадцать австрийских. Некоторые батареи были сняты с позиций за отсутствием снарядов». См.: Каширин В. Б. Неотвращенная катастрофа союзника: Борьба на балканском фронте в 1914-1915 гг. в суждениях русского военного агента при сербской Верховной команде // Русский сборник. Исследования по истории России. М., 2006. Т. III. С. 197.

26 АВПРИ. Ф. Политархив. Оп. 1. Д. 4014. Л. 80.

27 Краткий обзор деятельности Экспедиции особого назначения, начиная с первого похода 1 октября 1914 года по 20 апреля 1915 года // Россия на Сербском фронте Первой мировой войны. С. 48.

28 Там же. С. 199-200.

29 АВПРИ. Ф. Политархив. Оп. 1. Д. 4014. Л. 16-21. См.: Черников И. И. Флот на реках. С. 500.

30 Там же. Л. 50.

31 Там же. Л. 50-50об.

32 Трубецкой Г. Н. Русская дипломатия 1914-1917 гг. и война на Балканах. Монреаль, 1983. С. 141. Подробнее об этих переговорах см.: Вишняков Я. В. Сербия в начале мировой войны: 1914-1915 годы // Новая и Новейшая история. 2013. № 2. С. 53-65.

33 АВПРИ. Ф. Политархив. Оп. 482. Д. 4014. Л. 24-31.

34 Донесение С. А. Поклевского-Козелла от 29.12.1914 г. (11.01. 1915 г.) // Там же. Д. 4007. Л. 10. 
35 Там же. Д. 4014. Л. 34.

36 Там же. Д. 4014. Л. 15.

37 Большую роль в этом сыграли минные заграждения, установленные под руководством лейтенанта Григоренко и старшего лейтенанта Волковицкого. Уже 25 августа 1914 г. русским минерам удалось взорвать дамбу у впадения реки Босута в Саву, в результате чего заблокированными оказались два австрийских монитора. В ночь с 9 на 10 октября 1914 г. недалеко от острова Оршадска Ада на русской мине подорвался австрийский флагманский монитор «Темеш». См.: Россия на Сербском фронте Первой мировой войны. С. 42.

38 АВПРИ. Д. 4014. Л. 82.

39 Савинский в МИД 6 (19) ноября 1914 г;; Штрандтман в МИД 8 (21) ноября 1914 г. // Там же. Л. 57, 62.

40 Там же. Л. 82.

41 Там же. Л. 65.

42 Там же. Л. 70.

43 Там же. Л. 31.

44 Донесение С. А. Поклевского-Козелла в МИД 6 (19) октября 1914 г. // Там же. Л. 20.

45 Там же. Л 83, 94-98.

46 Там же. Л. 113, 157.

47 Там же. Л. 118.

48 Там же. Л. 99.

49 Россия на Сербском фронте Первой мировой войны. С. 201.

50 Важность этих поставок была проиллюстрирована историком В. В. Поликарповым: «К концу первого года войны французская армия была оснащена “лучше любой другой союзной армии”; она уже не испытывала недостатка в винтовках, патронах, полевых орудиях и снарядах к ним, хотя не имела излишка в орудиях и винтовках. Франция производила больше артиллерии и боеприпасов, чем Англия, снабжала ее Экспедиционный корпус орудиями и танками, большей частью самолетов, 4/5 снарядов. <..> К середине 1915 г. французская артиллерия располагала почти таким же количеством легких орудий, как русская, но сверх того имела 3538 тяжелых орудий (в 1916 г. 3376), промышленность выпускала в начале 1916 г. 148 тысяч 75-мм снарядов в день». Поликарпов В. В. Русская военно-промышленная политика. 1914-1917. Государственные задачи и частные интересы. М., 2015. С. 366-367.

51 АВПРИ. Ф. Политархив. Д. 4007 Л. 2-3.

52 Дедеагач - город на северо-востоке Греции, недалеко от границ Болгарии и Турции. В то время, по итогам Балканских войн, принадлежал Болгарии. 
53 АВПРИ. Ф. Политархив. Д. 4007. Л. 53.

54 ДУКС - московская фирма, один из крупных в дореволюционной России производителей автомобилей и самолетов.

55 АВПРИ. Ф. Политархив. Д. 4007. Л. 75.

56 Там же. Л. 96. Имеется в виду действительный статский советник Дмитрий Яковлевич Слободчиков. См.: https://www.prlib.ru/item/677719

57 Тимофеев А. Ю. Россия на Балканах в годы Первой мировой войны // Тимофеев А. Ю., Вишняков Я. В., Милорадович Г. Битва двуглавых орлов. С. 42. См. также: Тюриков С. В. Экспедиция особого назначения... С. 162.

58 АВПРИ. Ф. Политархив. Оп. 482. Д. 4012. Л. 3.

59 Там же. Д. 4009. Л. 9.

60 Писарев Ю. А. Сербия и Черногория в Первой мировой войне. M., 1968. C. 125.

61 Писарев Ю. А. Тайны первой мировой войны. Россия и Сербия в 1914-1915 гг. М., 1990. С. 168. Список перевезенных экспедицией грузов в период с 1 октября 1914 г. по 1 октября 1915 г. приводит С. В. Тюриков. См.: Тюриков С.В. Экспедиция особого назначения... С. 154-163.

62 АВПРИ. Ф. Политархив. Д. 4007. Л. 146.

\section{Y. V. Vishnyakov}

The Danubian gambit. Russian-Serbian military and economic cooperation before and during the First World War

The article discloses the issue of Russian-Serbian military and economic contacts, that has not been studied sufficiently in Russian historiography. The contacts between Russia and Serbia became especially close on the eve of the First World War. In the context of general strategic interests of Russia on Danube, the author gives attention to the activities of the Special Expedition under the command of M. Veselkin. The Special Expedition was formed in 1914 in order to supply Serbian army with weapon and armament.

Keywords: Serbia, expedition on the Danube, M. Veselkin, N. Pashich, Nickolas II, First World War, Bulgaria, Austria-Hungary. 


\title{
Из Царства Польского в Моршанский уезд: А. А. Корнилов и Приютинское братство в борьбе с голодом 1891-1892 гг.
}

\begin{abstract}
Участие Приютинского братства, и в частности А. А. Корнилова, в борьбе с голодом не получило должного отражения в историографии. Однако оно сыграло большую роль в становлении политических взглядов братства. Голод 1891-1892 гг. не только продемонстрировал русской интеллигенции бедственную ситуацию народной жизни, но и стал первым большим опытом конкретной частной помощи крестьянству. Со времени голода аграрный вопрос стал одним из ключевых в программах всех общественно-политических движений, кружков и партий. Ключевые слова: русский либерализм, Приютино, кружок Ф. Ф. Ольденбурга, голод 1891-1892 годов, А. А. Корнилов, Польша.
\end{abstract}

DOI: $10.31168 / 2073-5731.2018 .3-4.1 .10$

Приютинское братство - сообщество известных ученых, общественных и политических деятелей, среди которых выделялись ставшие в молодые годы близкими друзьями В. И. Вернадский, князь Д. И. Шаховской, братья Ф. Ф. и С. Ф. Ольденбурги, А. А. Корнилов и И. М. Гревс. Одним из основных стремлений приютинцев было усовершенствование своей жизни и личности путем улучшения жизни других, служения людям. Борьба с голодом 1891-1892 гг. стала для них одним из вариантов такого служения. Она же заставила их внести определенные изменения в свои идеи, а именно обратиться к политической деятельности как важному рычагу помощи народу. Братство привлекало внимание исследователей по различным поводам ${ }^{1}$, но эта сторона деятельности приютинцев пока не получила достаточного освещения. В рамках настоящей статьи мы попытаемся осветить наиболее существенные моменты проблемы, делая основной акцент на деятельности А. А. Корнилова, оставившего ради помощи голодающим крестьянам должность комиссара по крестьянским делам в Привислинском крае.

Происходивший из дворян Тверской губернии, из того же рода, что и герой Крымской войны В. А. Корнилов, Александр Александрович Корнилов (1862-1925) получил в начале XX в. известность как политик, дважды исполнявший должность секретаря ЦК партии кадетов, и историк, создавший прежде всего свой яркий курс по истории России XIX века $^{2}$. Он был членом Приютинского братства с самого его зарождения 
в стенах Санкт-Петербургского университета в начале 1880 -х гг. Но, в отличие от других приютинцев, Корнилов не сразу выбрал научную стезю. Более десяти лет он отдал государственной службе, сначала в качестве комиссара по крестьянским делам в Конском уезде Радомской губернии Привислинского края (1886-1892), а затем - чиновника для особых поручений при иркутском генерал-губернаторе (1893-1900).

Корнилов выбрал службу не из карьеристских соображений, он считал ее средством, способным изменить жизнь людей к лучшему. С этими устремлениями, вполне соответствовавшими идеям братства, он и отправился в Польшу служить «по совести» ${ }^{3}$. Впрочем, решение выпускника юридического факультета столичного университета уехать в Радомскую губернию было связано и с местом службы отца, Александра Александровича-старшего, служившего в Польше с 1871 г., а с 1883 г. бывшего управляющим канцелярией Варшавского генерал-губернатора И. В. Гурко. Корнилов-младший за годы, проведенные в Польше, достаточно глубоко изучил местную ситуацию, что в 1915 г. получило выражение в виде монографии об имперской политике в польском вопросе 4

Институт комиссаров по крестьянским делам появился в Польше в период проведения там «милютинской» крестьянской реформы 1864 г., которой Корнилов в 1893 г. посвятил отдельную работу ${ }^{5}$. Обязанности комиссаров включали в себя разрешение земельных споров между помещиками и крестьянами и наблюдение за правильным ходом крестьянского самоуправления. Работая на пользу польских крестьян (например, борясь с нарушениями их земельных прав), Корнилов заслужил их уважение и, в то же время, неприязнь со стороны местных помещиков. Служебное рвение комиссара зачастую вызывало и противодействие со стороны вышестоящих властей ${ }^{6}$. Возникшее неверие в возможность улучшить жизнь народа бюрократическим путем побудило приютинца оставить «русскую Польшу», в которой после смерти отца 10 февраля 1891 г. его ничто не удерживало и в личном плане. Непосредственным поводом, чтобы уехать, стал разразившийся в империи голод. Из Радомской губернии 29-летний Корнилов по просьбе товарищей по Приютинскому братству уехал в Тамбовскую губернию и провел там семь месяцев, помогая крестьянам Моршанского и Кирсановского уездов. Его впечатления были изданы в 1893 г. ${ }^{7}$, но в обширной историографии о борьбе с голодом эта публикация пока не нашла адекватного отражения.

Как известно, голод 1891-1892 гг. стал страшным бедствием, поразившим с октября 1891 г. около 20 губерний центральной, юго-восточной и приволжской России вследствие полного неурожая 8 .

Как же отнеслись к этой страшной беде власти? Известно, что сам Александр III первое время относился к голоду несерьезно9. Хо- 
дили слухи, что государь на докладе одного из министров, в котором упоминалось о голоде, написал: «У меня нет голодающих, есть только пострадавшие от неурожая» ${ }^{10}$. Циркуляром от 12 ноября 1891 г. запрещалось публиковать в газетах призывы частных лиц вносить пожертвования голодающим, если эти лица не будут иметь особых разрешений от «подлежащих властей». Когда же факт голода стал неоспоримым, правительство было вынуждено ассигновать средства для борьбы с ним, но и они сильно урезались. Не удалась и правительственная идея общественных работ для голодающих крестьян: сами условия их были невыносимыми, а выделяемые деньги разворовывались ${ }^{11}$.

Учреждение в 1892 г. «Особого комитета для помощи нуждающимся в местностях, пострадавших от неурожая» под председательством наследника цесаревича удалось лишь частично - комитет смог объединить только консервативную часть общества. Борьба с голодом на местном уровне затруднялась бюрократическими препонами.

В таких условиях общество становилось единственной силой, потенциально способной оказать действенную помощь в борьбе с голодом. Л. Н. Толстой предлагал помогать пострадавшим путем покупки на пожертвованные деньги муки и ее раздачи, также путем организации работ, помощи безлошадным хозяйствам, а самое главное, устройством даровых столовых на селе ${ }^{12}$. Начинания великого писателя нашли отклик в обществе. Общими усилиями к 1893 г. голод удалось побороть. Свой вклад внесли многие представители «третьего элемента» земства — земские врачи и учителя, студенты.

Активно и оперативно поддержали реакцию общества и члены Приютинского братства. А. И. Попов, управляющий имением В. И. Вернадского в Вернадовке Моршанского уезда, писал в октябре 1891 г.: «Часть населения питается как следует, четвертая часть в ржаной хлеб подсыпает гороховую муку <.. > а половина питается просяными блинами, размалывая просо прямо с шелухою, и из такой муки пекут блины, а есть даже такие жители, которые начали уже побираться. Помощи от казны пока нет, обещают давать по 30 ф. на месяц. Частная помощь слабая... Недостаток теперь у всех, но с половины ноября будет совсем горе» ${ }^{13}$.

Приютинцы понимали, что при таких тяжелых условиях нельзя ограничиться только высылкой денег и раздачей муки. Члены братства решили по опыту Толстого открывать свои столовые. Сам Вернадский поехать в Вернадовку не мог, так как преподавал в Московском университете. Д. И. Шаховской был занят работой в Ярославском уездном земстве, его не отпускала управа ${ }^{14}$. Старший из братьев Ольденбургов Федор не мог оставить работу в Тверской женской учительской гимназии им. П. П. Максимовича, младший же Сергей преподавал санскрит в Петербургском университете. В итоге работу 
по борьбе с голодом в Моршанском уезде с февраля 1892 г. возглавил Корнилов, переезд которого из Польши потребовал времени.

Первыми в Моршанский уезд отправились приютинцы Л. А. Обольянинов и В. В. Келлер. Оба они ранее побывали у Толстого и осмотрели организованные писателем столовые ${ }^{15}$. По словам Келлера, местная жизнь превратилась в ад: «Здесь голод начался и голод сплошной... Это так коротко и так страшно! То, что я видел в Данковском уезде [Рязанской губернии. - E. $\Gamma$ ], ничто в сравнении с этим: там виден голод грядущий <..> здесь он пришел, здесь он хозяин, здесь он отпечатан на каждом лице. Там есть еще надежда отстоять, предупредить, здесь надо спасать от голодной смерти, там есть помощь и земства, и Толстых, в общем не допускающих голода там, где они действуют, здесь же земская помощь почти нуль...» ${ }^{16}$

Келлер и Обольянинов начали активно действовать. Вслед за ними приютинцы отправляли новых энтузиастов: «на голод» отправлялись молодые люди: «студент-юрист четвертого курса Дубенский», «студент Алексеевский», «студент Б. А. Юрковский» и др. ${ }^{17}$ К марту 1892 г. на голоде в Моршанском и Кирсановском уездах под руководством энергичного Корнилова работало уже десять человек, «и теперь легче доставать людей», как писал Вернадский жене ${ }^{18}$. Периодически в Вернадовку приезжал и сам Владимир Иванович.

Несмотря на активность жертвователей, к декабрю 1891 г. приютинцы располагали, по подсчетам Вернадского, всего 3300 руб. ${ }^{19}$ На эти деньги они рассчитывали открыть и содержать в течение семи месяцев (т. е. до первого урожая хлебов) столовые на 250 взрослых крестьян и 155 школьников. Но члены кружка получили неожиданную поддержку. 3 декабря 1891 г. на заседании Московского комитета грамотности было принято решение оказать помощь школам в голодающих местностях. Комитетом был организован сбор пожертвований и комиссия для распределения собранных средств. Тогда же В. И. Вернадский обратился в эту комиссию, которая ассигновала на устройство школьных столовых в селах Подъем, Каменка, Липовка, Поминаевка Моршанского уезда 1775 руб. ${ }^{20}$

В декабре 1891 г. Келлером и Обольяниновым в Моршанском уезде были организованы первые столовые для голодающих. К концу января 1892 г. было открыто уже 14 столовых для взрослых и 4 столовых при школах. Кормились в них примерно 1000 человек, что уже существенно превзошло первоначальные расчеты приютинцев ${ }^{21}$.

По словам Корнилова, для столовой в первую очередь выбиралась изба, а точнее крестьянская семья, которая бы содержала у себя столовую, готовила бы обеды, пекла хлеб, ездила бы за провизией и дровами, распределяла поровну хлеб между едоками, наблюдала бы, чтобы еда доставалась тем, кто состоял в списках. Для этого выбиралась семья 
здоровая и порядочная, а также бедная, так как за всю свою работу по столовой она сама вся должна была поголовно в ней кормиться, а также получать на 1,5 фунта хлеба больше, чем остальные едоки.

В первый день после открытия столовой кто-то из приютинцев присутствовал там для организации процесса, после этого организаторы появлялись в столовой не чаще раза в неделю. Школьные же столовые открывались либо так же у семьи, либо в самой школе, если там была печь для приготовления еды. В последнем случае нанимали кухарку. В этих столовых питались все дети, кроме самых зажиточных. Надзор за столовыми осуществляли учителя ${ }^{22}$.

Большую часть продуктов удавалось достать на месте. Так, у каменского землевладельца Рымарева по приемлемым ценам приютинцы покупали пшено (1,5 руб. за пуд), горох (1,5 руб. за пуд), капусту (30-40 коп. за ведро), картофель (1,20 руб. за пуд). В январе 1892 г. благодаря усилиям Ф. Ф. Ольденбурга, Д. И. Шаховского, И. И. Петрункевича и др. удалось устроить покупку ржи по дешевым ценам в Тверской и Ярославской губерниях. В ее перевозке приютинцам помог председатель Моршанской уездной управы Н. М. Котельников, доставший для этих целей даровые провозные свидетельства Красного Креста. С помолкой ржи помог тот же Рымарев, предложивший делать это бесплатно на его мельнице ${ }^{23}$. Об уездных моршанских властях А. А. Корнилов писал, что они нередко содействовали им ${ }^{24}$. Случай не столь частый на фоне всевозможных злоупотреблений различного начальства по всей стране.

Как отмечал Корнилов, в первых столовых, устроенных в Каменке, обед состоял из двух блюд, также каждому к обеду полагался один фунт хлеба. Затем выработалось стандартное меню:

— понедельник - похлебка и каша;

— вторник - щи и картофель;

- среда - кулеш и горох;

— четверг — похлебка и каша;

— пятница - щи и каша;

— суббота — кулеш и каша;

- воскресенье - щи и горох.

Расходы составляли не более 1 руб. в месяц на человека. Самый дорогой обед (похлебка и горох) обходился в 46,5 руб. на 30 человек. Самый дешевый (кулеш и картофель) - в 23,5 руб. на 30 человек ${ }^{25}$. Такое питание, впрочем, не позволяло голодающим есть досыта, его хватало лишь для того, чтобы выжить в сложнейших условиях.

К началу февраля 1892 г. положение приютинцев изменилось к лучшему. 20 января С. Ф. Ольденбург писал Вернадскому в Москву: «Одно лицо, которое назвать не могу, хочет дать 30-50,000 руб. на то, чтобы поддержать и не допустить до разорения <..> деревню. Тебе надо к нему 
явиться, переговорить с ним» ${ }^{26}$. Владимир Иванович отправился в Петербург, как он писал, «для сбора средств по голоду» ${ }^{27}$. Видимо, как раз тогда состоялась его встреча с состоятельным жертвователем. Им оказался великий князь Николай Михайлович, внук Николая I, получивший известность как историк. Он не доверял официальным организациям помощи голодающим, подозревая их в хищениях. Узнав о хорошо организованной помощи в Моршанском уезде, великий князь познакомился с Вернадским и пожертвовал 35 тыс. руб. при условии сохранения своего инкогнито ${ }^{28}$.

Эта инвестиция позволила расширить и качественно улучшить помощь голодающим Моршанского уезда. Новые планы предполагали: открыть столовые на 5 тыс. человек; прокормить до 560 лошадей с 15 февраля до 21 апреля и еще 2000 лошадей в две недели самой горячей весенней пахоты - с 29 марта до 14 апреля; купить лошадей для 220 безлошадных дворов ${ }^{29}$. К концу февраля 1892 г. были открыты уже 34 столовые, а к концу марта их число увеличилось сразу до $80^{30}$.

К началу марта в Моршанском уезде появились новые благотворители. В Тарасовку приехал Л. Ф. Пантелеев с пожертвованиями на общую сумму в 6000 руб. В Богоявленское, имение графа Воронцова-Дашкова, приехали его дочери. Они решили помочь крестьянам Богоявленской и Мало-Моршевской волостей, открыть столовые на 350-380 человек и прокормить 500-600 лошадей до начала весенних работ. Теперь вместо 5000 человек приютинцам нужно было прокормить 4 тысячи ${ }^{31}$.

И. М. Гревсу, бывшему в то время в Париже по научным делам, удалось наладить контакты с французскими благотворителями ${ }^{32}$. Всего, по данным А. А. Корнилова, из Парижа в разное время было получено свыше 6000 руб. ${ }^{33}$ В апреле 1892 г. на эти средства было открыто 25 новых столовых (на 1400 человек), которые вошли в так наз. район французской помощи (села Рудовка и Вышенка Кирсановского уезда) ${ }^{34}$.

К началу мая 1892 г. организация новых столовых закончилась. В Моршанском уезде была открыта 121 столовая. Общее число обедающих составило 6256 человек ${ }^{35}$.

Другой важной задачей, которую поставило перед собой Приютинское братство в феврале 1892 г., было прокормление лошадей и покупка их для безлошадных крестьян, чтобы те смогли справиться с весенними пахотными работами. Всего на это предполагалось потратить 15 тыс. руб. И с этими проблемами удалось справиться успешно ${ }^{36}$.

В апреле 1892 г. приютинцам пришлось решать новую трудность. Крестьяне страдали от нехватки озимых и яровых семян для посева. Земство брало на себя удовлетворение этой нужды, но, по свидетельству А. А. Корнилова, делало оно это неважно. Как правило, земские озимые семена были плохи, яровые же были выданы слишком поздно - только к 10 апреля. Тогда было решено самим раздавать кре- 
стьянам семена. Приютинцы закупили 111 пудов проса и раздали его жителям Громовской, Питимской, Осино-Гаевской и Тараксинской волостей. Была раздана также часть имевшегося в запасе картофеля - около 800 пудов. В Комаревском участке раздали 45 пудов овса ${ }^{37}$.

К июню 1892 г. «семь месяцев среди голодающих крестьян» подошли для А. А. Корнилова и его соратников к концу. Удалось сделать очень многое, даже больше, чем они рассчитывали изначально. Это и столовые, и приобретение, и прокорм лошадей, и закупка семян, и борьба с пожарами и помощь погорельцам, а также борьба с болезнями, особенно распространившимися весной ${ }^{38}$. Помимо приведенных выше цифр, на дом было роздано для больных 869 пудов и 9,5 фунтов муки, 584 пуда и 25,5 фунтов пшена, 120 пудов и 19,5 фунтов гороха, 70 пудов картофеля. Осуществлялась постоянная помощь одеждой, обувью и деньгами погорельцам, а также медицинская помощь больным.

Готовность Приютинского братства помочь крестьянам проявила себя и в 1893 г., во время так наз. вторичного голода. В частности, А. А. Корнилов организовывал тогда помощь голодающим в Воронежской и Тульской губерниях, а другие приютинцы старались найти дополнительные материальные средства для его работы ${ }^{39}$.

Труд энтузиастов в помощь голодающим сделал главное - спас большое количество крестьян Моршанского уезда от голодной смерти. Братство справедливо полагало, что именно даровая, безвозмездная помощь была нужна, «когда население уже на грани голодной смерти» ${ }^{40}$. В деревне такая работа вызывала огромную благодарность.

При этом никакая помощь не влияла на причины голода. Она смогла спасти от смерти многих, но не изменила их жизнь. Жизнь же эта ужасала при близком с ней знакомстве. В 1905 г. в своей книге «Крестьянская реформа» А. А. Корнилов писал: «С голода 1891-1893 гг. начинается пробуждение нашего общества из апатии и застоя, в котором оно находилось с начала восьмидесятых годов. Повязка спала с многих глаз, и многие, до тех пор спокойно дремавшие, увидели вдруг, что положение народа, который считался возрожденным для новой свободной и привольной жизни после падения крепостного права, - остается попрежнему бедственным, беспомощным и серым» ${ }^{41}$.

\section{ПРИМЕЧАНИЯ}

1 См., например: Еремеева С. А. Приютинское братство как феномен интеллектуальной культуры России последней трети XIX первой половины XX в.: Автореф. дис. ... канд. культурологии. М., 2007; Левандовский А. А. Кружок Ф. Ф. Ольденбурга (из истории либерального 
движения 80-х годов ХІХ века) // Проблемы истории СССР. М., 1977. Вып. 6. С. 166-183; Лубков А. В. К истории «Братства Приютино» // Идейное наследие русской философии. СПб., 2000. С. 146-174.

2 Корнилов А. А. Курс истории России ХІХ века. М., 1912-1914. Ч. ІIII; о наследии Корнилова как историка см.: Левандовский А. А. Из истории кризиса русской буржуазно-либеральной историографии. А. А. Корнилов. M., 1982.

3 Корнилов А. А. Воспоминания // Вопросы истории. 1994. № 2. С. 148.

4 Русская политика в Польше со времени раздела до начала XX века. Пг., 1915.

5 Крестьянская реформа 1864 года в Царстве Польском. Б. м., 1893.

6 Корнилов А. А. Воспоминания // Вопросы истории. 1994. № 2. C. $150-152$.

7 Корнилов А. А. Семь месяцев среди голодающих крестьян. Отчет о помощи голодающим некоторых местностей Моршанского и Кирсановского уездов, Тамбовской губернии, в 1891-1892 г. М., 1893.

8 См. напр.: Круглов В. Н. Царь голод. Факты против мифов // Сборник Русского исторического общества. М., 2011. Т. 11 (159): Правда истории. С. 87-106; Пьянков С. А., Михалев Н. П. Голод 1891-1892 гг. в России в советской и современной отечественной историографии // Вестник Вятского государственного университета. 2015. № 1. С. 44-55; Фоломеев С. Н. Власть и общество в условиях кризиса: социальные последствия голода 1891-1892 годов в Самарской губернии // Историческая психология и социология истории. 2015. Т. 8. № 2. С. 64-79.

9 Ламсдорф В. Н. Дневник 1891-1892. М., 1934. С. 293.

10 Цит. по: Кузьмина И. В., Лубков А. В. Князь Шаховской. Путь русского либерала. М., 2008. С. 147.

11 Соколов Н. П. Голод в 1891-1892 годах и общественно-политическая борьба в России: Автореферат дис. ... канд. ист. наук. М., 1987. С. 12.

12 Толстой Л. Н. О голоде; Страшный вопрос; Голод или не голод // Полн. собр. соч.: В 90 т. М., 1954. Т. 29. С. 47, 49.

13 Архив Российской академии наук (далее - АРАН). Ф. 518. Оп. 2. Д. 158. Л. 13-13об.

14 АРАН. Ф. 518. Оп. 3. Д. 1835. Л. 17.

15 Тамбовские страницы жизни В. И. Вернадского. Документы и материалы. Тамбов, 2013. С. 33-34.

16 АРАН. Ф. 518. Оп. 3. Д. 749. Л. 2-2об.

17 Вернадский В. И. Указ. соч. С. 190, 191.

18 Там же. С. 198.

19 Там же. С. 188. 
20 Корнилов А. А. Семь месяцев... С. 39.

21 Там же. С. 40.

22 Там же. С. 57-63.

23 Там же. С. 64-66.

24 Там же. С. 4.

25 Там же. С. 46, 49, 48.

26 АРАН. Ф. 518. Оп. 3. Д. 1194. Л. 19.

27 Вернадский В. И. Указ. соч. С. 189.

28 Там же. С. 202, 206, 230, 236.

29 Корнилов А. А. Семь месяцев... С. 94.

30 Там же. С. 98, 114-118.

31 Там же. С. 102, 104.

32 Там же. С. 147; АРАН. Ф. 518. Оп. 3. Д. 458. Л. 27; Вернадский В. И. Указ. соч. С. 223.

33 Корнилов А. А. Семь месяцев... С. 157.

34 Вернадский В. И. Указ. соч. С. 232.

35 Корнилов А. А. Семь месяцев... С. 192.

36 Там же. С. 104, 125-129.

37 Там же. С. $166-169$.

38 Там же. С. 171.

39 Вернадский В. И. Письма Н. Е. Вернадской. М., 1994. Кн. 3. 1893-1900. C. 11, 16.

40 Корнилов А. А. Семь месяцев... С. 204-213.

41 Корнилов А. А. Крестьянская реформа. СПб., 1905. С. 248-249.

\section{E. A. Galimzyanova}

From the Kingdom of Poland to Morshansky uyezd: A. A. Kornilov and the brotherhood of Priyutino combating the famine of 1891-1892

There is not much studies dedicated to the participation of Priyutino brotherhood and Alexander Kornilov in the struggle with famine. However, it played an important role in the construction of the political views of the brotherhood. The famine of 1891-1892 showed the Russian intellectuals the terrifying life of people. The fight against the famine was the first big experience of concrete private enterprises aiming at helping Russian peasantry. Since the famine, the agrarian question erased and became one the main questions in all politico-social programs, from liberal to Marxist.

Keywords: Russian liberalism, Priyutino, F. F. Oldenburg's circle, famine of 1891-1892, Alexander Kornilov, Poland. 


\title{
Русское общество и сербско-австрийский конфликт 1912-1913 гг.: хотели ли русские войны
}

\begin{abstract}
В статье проанализированы неопубликованные воспоминания генерала П. С. Махрова о событиях революции и Гражданской войны на Украине в 1917-1919 гг. Мемуары Махрова являются важным источником по различным событиям конца XIX — первой половины XX в., прежде всего по истории Первой мировой и Гражданской войн. Мемуарист подробно освещает процесс украинизации Юго-Западного фронта в конце 1917 - начале 1918 г. и поведение офицерства в этой связи, деятельность офицеров в период существования Украинской державы гетмана П. П. Скоропадского и последующий выбор.

Ключевые слова: Гражданская война, революция, Украина, офииерство.
\end{abstract}

DOI: $10.31168 / 2073-5731.2018 .3-4.1 .11$

Осенью 1912 г. началась Первая балканская война - Болгария, Сербия, Греция и Черногория совместно выступили против Османской империи. Сделали они это вопреки мнению великих держав, стремившихся предотвратить конфликт и угрожавших, что никакого изменения status quo на Балканах допущено не будет. Однако наперекор большинству прогнозов за короткий период времени войска православных государств полуострова разбили турецкую армию и установили линию фронта на Чаталджинских укреплениях близ Константинополя, оставив осажденными три крепости - Адрианополь, Скутари и Янину. Под давлением общественного мнения и в силу сложившейся ситуации европейские правительства «позабыли» о своих угрозах, и казалось, что мечты балканских союзников по разделу европейских владений султана близки к реализации. Но подобное самовольство было встречено в штыки Австро-Венгрией, имевшей свои планы проникновения на Балканы. Сербия рассчитывала разделить побережье Адриатического моря с Грецией, тем самым получить самостоятельный выход к морю и избавиться от зависимости от северной соседки. Имперское и королевское правительство прекрасно по-

Статья написана при финансовой поддержке Российского фонда фундаментальных исследований, проект № 18-59-18002 «Россия, Болгария, Балканы. Проблемы войны и мира. XVIII-XXI вв. (Мифы и реальность)». 
нимало, что тогда возможности «ползучей» колонизации полуострова исчезнут, и выступило за создание независимого албанского государства в границах, ставящих крест на проектах Сербии.

Взоры Белграда обратились на Петербург и русское общественное мнение, отдельные представители которого давали поводы для оптимизма, заверяя сербское руководство, что русский народ вопреки официальной политике сочувствует Сербии и сербам необходимо двигаться по намеченному пути, без оглядки на российский МИД. Современники отмечали особое усердие в этом вопросе лидера октябристов А. И. Гучкова и посланника в Сербии Н. Г. Гартвига ${ }^{1}$, но и в самой России нередко этот тезис постулировался публично. По мнению Л. Д. Троцкого, тогда являвшегося корреспондентом нескольких русских газет на Балканах, «бесшабашная агитация некоторых русских газет и “салонов”» и привела к тому, что сербы впустую выбивались из сил, стремясь как можно скорее завладеть опорными пунктами на Адриатическом побережье ${ }^{2}$.

Но пока итог был неясен, надежды на общественное мнение возлагались большие. В Петербурге работу по поддержке нужных настроений вели выходцы из югославянских земель Д. И. Семиз, И. П. Табурно ${ }^{3}$ В октябре в российскую столицу прибыл профессор Белградского университета Р. Кошутич. Согласно документам охранки, он обратился к либеральному общественному деятелю М. М. Ковалевскому с вопросом: «Правда ли, что русская прогрессивная демократия, проповедующая на словах свободу, равенство и братство, <..> отказывается признавать их в отношении югославян, находящихся под турецким ярмом». М. М. Ковалевский ответил, что единолично ответа он дать не может, и для обсуждения этой проблемы организовал 11 октября 1912 г. у себя дома собрание, куда пришли многие известные представители общественности. Присутствовавший там глава партии кадетов П. Н. Милюков выступал против усиления патриотических настроений, могущих вызвать укрепление самодержавия. Но пламенная речь Р. Кошутича убедила участников собрания проголосовать за текст воззвания, в котором говорилось об обеспечении «русским национальным самосознанием» за балканскими славянами плодов их побед ${ }^{4}$.

Тем временем дипломатическое противостояние Белграда и Вены вошло в стадию эскалации. 15 октября 1912 г. премьер-министр Сербии Н. Пашич через печать выразил просьбу к великим державам передать его стране «хотя бы небольшой порт» на Адриатике, в тот же день министр иностранных дел Австро-Венгерской монархии 
Л. Бертхольд на объединенном заседании австрийской и венгерской делегаций заявил, что монархия имеет «на Балканах жизненно важные интересы и будет отстаивать их при всяких обстоятельствах» ${ }^{5}$. Как вспоминал С. Д. Сазонов, вопрос сербского выхода к морю на продолжительное время сделался центральным во всей европейской политике, хотя сам по себе имел «чисто местное значение». Отношение к нему сербского общества перекинулось и на российское, близкие ко двору круги и националистическая столичная печать начали активную, «шумную кампанию», выражавшуюся в уличных демонстрациях, собраниях, потоке газетных статей, обвинявших руководство страны едва ли не в государственной измене ${ }^{6}$.

28 октября военный министр В. А. Сухомлинов прислал не ожидавшему этого председателю правительства В. Н. Коковцову экстренное требование об отпуске в его распоряжение «в связи с событиями на Балканах» 63 млн руб. на усиление обороны на австрийском фронте. При этом он отметил, что Николай II запрос уже одобрил ${ }^{7}$ тем самым демонстрируя пренебрежение мнением премьера и обособленное положение собственного ведомства ${ }^{8} .31$ октября на заседании Совета министров вопреки позиции главы кабинета запрос об отпуске средств в военное министерство был удовлетворен ${ }^{9}$. Департамент полиции стал спешно выяснять моральную готовность населения к войне.

22 ноября В. А. Сухомлинов обратился к В. Н. Коковцову с письмами о необходимости готовиться к войне. На последовавшем совещании у императора С. Д. Сазонов указывал, что проведение мобилизации лишь обострит отношения с Австро-Венгрией и подтолкнет Сербию к неуступчивости. В результате было принято решение начать закупку лошадей, усилить охрану мостов и передислоцировать кавалерийские части ближе к границе с Дунайской империей. Мобилизационные мероприятия отложили, поставив их реализацию «в зависимость от дальнейшего хода событий» ${ }^{10}$. В конечном итоге в Петербурге ограничились задержкой на службе нижних чинов, подлежащих увольнению в запас, что довело численность войск западных округов до штата военного времени. Согласно докладу по военному министерству за 1912 г., это было обусловлено «тревожной политической обстановкой и возможностью вооруженного столкновения с державами Тройственного союза» ${ }^{11}$.

Мысль о войне витала в воздухе, что вызывало у современников понятные опасения. Ставший вскоре петербургским городским головой И. И. Толстой записал об увеличении армии 31 октября в дневнике: «Несомненно имеет связь с балканскими делами» ${ }^{12}$. Исто- 
рик С. С. Ольденбург позднее вспоминал, что «в ноябре был момент, когда война казалась возможной» ${ }^{13} .12$ ноября поэт А. А. Блок среди прочего зафиксировал в дневнике: «Чай пьем у мамы, Франц, усталый и печальный, говорит - война: австрийцы мобилизовали 8 пограничных корпусов» ${ }^{14}$. В декабре он узнал от служившего вольноопределяющимся К. К. Кузьмина-Караваева, что полк последнего готовится к войне ${ }^{15}$. Проникали эти сведения и в крестьянскую среду. В декабре житель деревни Тотьмы Вологодской губернии А. А. Замараев отметил в дневнике: «Австрия готова к войне, у [н]ее 800 тысяч солдат готовы к бою» ${ }^{16}$; а один из агентов охранки докладывал о настроениях общества: «С самого начала вмешательство России считается неизбежным» ${ }^{17}$.

Писатель М. Горький в это время находился на о. Капри, но слухи и тревожные настроения доходили и до него. Он в письмах спрашивал своих знакомых о реальности войны с Дунайской империей. Кто-то ему сообщал, мол, «собираемся воевать», он их называл «болванами». Писатель А. В. Амфитеатров, много раз бывавший на Балканах, писал, что в это «покуда плохо верю». Для М. Горького муссирование слухов о столкновении стало даже поводом для шуток. В декабре 1912 г. он задал вопрос критику и историку литературы Е. А. Ляцкому: «Ваш приезд столь же, кажется, гадателен, как австро-русская война?» ${ }^{18}$

Однако ожидание и предчувствие войны далеко не означало ее желания. В этом вопросе подданные российского императора отнюдь не были единодушны, что заметно даже по донесениям чинов полиции, в которых часто проглядывают позиции самих авторов. Отсутствие согласия даже среди сотрудников центрального аппарата ведомства демонстрирует подготовка текста доклада императору об отношении населения к вероятной войне - на различных этапах выработки документа постоянно менялись акценты, делавшие войну то желанной, то нет ${ }^{19}$.

В войсках, где, очевидно, пестовались требуемые настроения, царило единодушие. Агенты полиции сообщали, что в Москве солдаты «охотно пойдут бить австрияков, защищать братьев-славян» ${ }^{20}$, в провинции офицерство выступало за вооруженное выступление, ожидая повышений и наград ${ }^{21}$, а отбывшие лагерные сборы запасные и задержанные к увольнению нижние чины проявляли «пожелание идти на войну» ${ }^{22}$. Последнее подтверждал депутат-националист В. М. Пуришкевич, заявляя, что когда в Киеве солдатам объявили об отсрочке увольнения в запас, то «такое громкое, такое грозное "ура" раздалось среди запасных, какого давно не слышали». А в Петербурге, по его словам, 
«отпускаемые солдаты уходят с горечью, с печалью» ${ }^{23}$. Эта информация соответствовала данным полиции, по которым столичные гвардейские офицеры проявляли к вопросу о войне безразличие, а нижние чины не возмущались задержкой на службе. «Вообще, настроение войск вполне благоприятное», - у утверждал сотрудник охранного отделения ${ }^{24}$. Хотя в то же время из Смоленска сообщали о противоположных настроениях: «Среди запасных ходят слухи, что они не явятся [в] случае мобилизации в войска» ${ }^{25}$. Следует учесть, что запасные уже успевали вкусить мирной жизни, вышли из-под воздействия армейской дисциплины и пропаганды, чем, вероятно, и объясняется отличие их позиции.

В случае полномасштабной мобилизации и серьезных боевых действий именно запасные должны были составить основную массу войск, среди них бы превалировали выходцы из наиболее многочисленных категорий населения - крестьян и рабочих, потому властям приходилось учитывать их мнение. Сейчас обрисовать его во всей полноте крайне сложно, поскольку не проводились социологические опросы, периодическая печать адекватно не отражала позицию крестьян и рабочих. На основании скупых донесений полиции можно утверждать следующее.

Рабочим Петербурга события на Балканах в целом были безразличны, проявляя некоторое сочувствие славянам, беспартийные пролетарии «будучи поглощены своею личною жизнью и заботами, считают войну для России нежелательной» ${ }^{26}$. Казалось бы, это доказывает, что пролетариат услышал слова В. И. Ленина, дескать «травля Австрии, науськивание на войну с ней, крики о “славянских задачах" России - все это есть шитое белыми нитками стремление отвлечь внимание от внутренних дел России и “урвать кусок” Турции» ${ }^{27}$. Однако донесения из Москвы показывают, что газета «Правда» имела меньшее влияние, нежели «Новое время». Работавший в типографии агент охранки под псевдонимом «Андреев» сообщал, что относительно Австро-Венгрии «зачастую приходится слышать восклицание <...> “Россия тебе покажет”», при этом особую воинственность проявлял «правый элемент, а в частности пожилые люди». Другие московские агенты докладывали, что «рабочие из запасных не прочь сами повоевать. Верят в возможность вовлечения России в войну с Австрией и одобряют ее». В общем, как подытоживал начальник Московского губернского жандармского управления, рабочие придерживаются позиции: «если Австрия вмешается, мы все пойдем».

Донесения полиции из провинции также не дают однозначный ответ об отношении населения к войне. Если в Туле настроения со- 
впадали со столичными, в Нижнем Новгороде бытовало мнение, «что Россия окажет славянам полную поддержку», то в Рязани были осторожнее, рассматривая вмешательство «лишь как крайнее средство для поддержания нашего престижа на Балканах», а в Твери «большинство высказывает необходимость со стороны России поддерживать все славянские требования до вмешательства включительно», однако крестьяне относились к нему «отрицательно [в] смысле больших жертв».

В Смоленске на вооруженный конфликт смотрели «как на народное бедствие», в Орле слухи о возможности вооруженного столкновения наводили «некоторый страх» ${ }^{28}$, в Царицыне рабочие и крестьяне в большинстве негативно воспринимали такой вариант развития событий ${ }^{29}$.

В Сибири население было настроено сдержанно. В Иркутске лишь военные и правые выступали за войну, остальные же считали, что война на Балканах «ведется буржуазией за свои интересы, а народ от нее ничего не выиграет» ${ }^{30}$. Из Томска же сообщалось, что «вообще население Западной Сибири мало интересуется славянским вопросом», признает необходимость поддержки балканских народов, «но избегая вооруженного вмешательства, могущего нарушить внутреннюю жизнь государства» ${ }^{31}$. При этом в ряде регионов отмечалось опасение, что Россия еще не готова к полномасштабным боевым действиям, упоминался горький опыт русско-японской войны ${ }^{32}$. Обособленность позиции жителей региона, видимо, объясняется удаленностью от столиц и тем, что косвенно Сибирь была вовлечена в войну 1904-1905 гг.: через нее шли поставки, эшелоны с войсками в одну сторону и ранеными - в другую.

Иные настроения царили в столицах, прежде всего в среде интеллигенции и политиков, поскольку читающая публика так или иначе была вовлечена в перипетии внешней политики. Настроения этих кругов оказывались наиболее важными, поскольку именно они транслировались на всю страну, и власть слышала прежде всего их, а не крестьян, рабочих или жителей провинции.

Резкую позицию занимали правые. В Киеве правые организации считали «священной обязанностью России заботу о славянах, необходимость оказывать им поддержку в самых широких размерах», а в случае войны ожидали энтузиазма в обществе ${ }^{33}$. В кулуарах Госдумы националист В. В. Шульгин говорил: «Хочешь мира, готовься к войне. Слишком уже дерзко-вызывающе ведут себя господа австрийцы». Другие представители этого политического направления считали повод недостаточным. Князь А. П. Урусов считал, что общеевропейская война из-за порта на Адриатике «совершенно немыслима», национа- 
листу П. Н. Балашову казалось, что «воевать из-за какого-то Дураццо нелепо», но при этом «всякой уступчивости есть предел, и в случае, если общеславянские интересы будут затронуты, Россия не может не выступить в защиту их» ${ }^{34}$.

Известный публицист М. О. Меньшиков 1 ноября на страницах «Нового времени» советовал сербам не превращать свое требование выхода к Адриатике в casus belli, а подождать, поскольку «крайней необходимости» в порту нет, а спустя некоторое время им отойдет все восточное побережье Адриатического моря ${ }^{35}$. Однако в конце ноября вышла книга другого сотрудника «Нового времени», уроженца Боки Которской И. П. Табурно. В ней он доказывал, что выход к морю для Сербии - вопрос жизни и смерти, и Австро-Венгрия не имеет права выступать с позиции силы, поскольку серьезных войн никогда не выигрывала. И каким бы несущественным не казался для России повод, она должна предъявить своим верным балканским союзникам «более веские доказательства дружбы и поддержки. Недостаточно лишь восторгаться их победами, их успехами». Для этого, указывал он, можно и вспомнить про оружие, столь непростительно забытое дипломатами ${ }^{36}$.

Примыкали в вопросе желательности войны к основной массе правых и октябристы. М. М. Алексеенко высказывал в Думе следующую мысль: «Само собой разумеется, что воевать из-за маленького порта нелепо, но нельзя же отрицать того, что выход Сербии к морю является для нее насущнейшим и жизненным вопросом». По его словам, если у этого государства по-прежнему останется заслон на пути развития в виде Австро-Венгрии, то такой порядок не сможет долго существовать, «искра будет тлеть, и в самом ближайшем будущем пожар неминуем» ${ }^{37}$. Лидер этой партии А. И. Гучков, согласно данным полиции, также настаивал на необходимости раздела адриатического побережья между Грецией и Сербией, так как создание Албании «вновь послужит яблоком раздора между всеми державами» ${ }^{38}$. В целом, как считал начальник охранного отделения Петербурга, «среди названных общественных кругов (умеренно правых, умеренных и прогрессистов) мысль о войне России за славянское дело при указанных условиях является ныне популярной, между тем как к русскояпонской войне те же круги относились вполне отрицательно» ${ }^{39}$.

Не имели четкой позиции либералы. П. Н. Милюков в Думе выступал против войны: «Говорят о необходимости удовлетворить самолюбия, но положение дел таково, что есть нечто более важное, чем самолюбия. Быть может, ни та, ни другая сторона вполне удовлетворены не будут, но зато будут предотвращены осложнения весьма серьез- 
ные». Но если он «указывать не брался», в каком направлении должен разрешиться конфликт, то его однопартиец В. А. Маклаков предлагал выход из ситуации: по примеру КВЖД Сербия могла бы взять в аренду территорию Албании на 100 лет, дабы там провести железную дорогу к морю. Однако он признавал изъян своего плана: «Было легко ладить с мирными китайцами, а албанцы народ дикий». Но и это препятствие казалось преодолимым, поскольку «важно то, что конфликт необходимо решить мирным путем». Прогрессист А. А. Бубликов и вовсе считал, что «никаких реальных интересов на Балканском полуострове у нас нет», поэтому и речи не может идти ни о каком другом разрешении конфликта, кроме как мирном ${ }^{40}$. Таким образом, в Думе либералы сохраняли бо́льшую трезвость рассуждений. Надо отметить, это касалось и их изданий. С. Д. Сазонов вспоминал, что газеты данного направления в вопросах внешней политики «не утрачивали способности беспристрастной и здравой оценки политического положения ${ }^{41}$. Надо признать, что этому немало поспособствовал сам глава МИД, который в октябре провел закрытую встречу с представителями этого лагеря. После нее газета кадетов «Речь», ранее упрекавшая министра в чрезмерной уступчивости Австро-Венгрии, стала хвалить осторожность российской внешней политики ${ }^{42}$.

Однако внутрипартийного согласия по поводу войны у кадетов не было. Довольно топорно и явно с некоторым пристрастием это описывал столичный чин охранного отделения: «Среди же собственно кадет, по агентурным сведениям, образовалось два течения: одно - еврейское, в главе с Милюковым и Винавером, и другое - славянское. Группа еврействующих становится на сторону австрийских притязаний и защищает политику Сазонова. Славянское же направление, во главе с М. Ковалевским, солидарно с прогрессистами, октябристами и националистами» ${ }^{43}$.

В действительности же, конечно, ситуация была сложнее. В октябре 1912 г. вопрос вмешательства в войну активно обсуждался на заседании Петербургского отделения ЦК кадетов. Один из его членов, А. Р. Ледницкий, опасался, что сдержанная позиция приведет к тому, что «общественное движение пройдет мимо нас». П. Б. Струве указывал, что русские «определенные задачи при ликвидации Турции в Европе» - проливы, а данный момент для борьбы за них более благоприятен, чем в 1853 г. С ним соглашался Н. А. Гредескул, считая, что текущая ситуация выгодна России, а не Австро-Венгрии. «Война в высшей степени нежелательна, но и для самого предотвращения войны нельзя от нее зарекаться», — заявлял он на заседании ЦК. 
П. Н. Милюков выдвинул в защиту своей позиции ряд обдуманных аргументов. Он не считал необходимым для России сейчас вступать в войну из-за интересов южного славянства, стране необходимо реализовывать свои цели - приобретение проливов. В данной же ситуации «вопрос о ликвидации Турции еще не наступил». Поэтому, по мнению лидера кадетов, партия должна вести себя тонко и дипломатично, открыто не заявлять свое видение вопроса, чтобы в глазах населения не быть связанной с захватнической политикой ${ }^{4}$.

Тем не менее жесткая партийная дисциплина у кадетов отсутствовала, и профессор М. П. Чубинский публично заявлял в обществе Славянского научного единения, что на Балканах идет борьба за начала свободы и культуры, «и если России во имя этих лозунгов придется пережить кровавые минуты, то мы верим, что из этого исторического испытания она выйдет с громадным выигрышем для себя и для своего будущего внутреннего развития» ${ }^{45}$.

Затем этот вопрос подняли на заседании Московского отделения ЦК кадетов, оказавшегося еще более воинственным, нежели Петербургское ${ }^{46}$. Но и в первопрестольной кадеты не были едины. Правая часть членов партии считала, что уступка России нанесет удар по престижу страны не только за рубежом, но и среди широких масс. Левое течение придерживалось мнения, что война приведет к революционным потрясениям. В частной беседе бывший профессор Московского университета А. А. Кизеветтер утверждал, что правительство «хорошо помнит внутренние последствия японской войны» ${ }^{47}$.

Этого же опасалась часть московских правых ${ }^{48}$, а газета «Земщина», известная своими германофильскими взглядами, и вовсе строила конспирологические теории, предполагая, что в прославянской агитации части прессы кроется «масонская интрига», суть которой - стравить Россию и Германию в войне, на почве которой вызвать новую революционную смуту ${ }^{49}$. На это, согласно донесениям охранки, рассчитывали левые партии в большинстве регионов, а также финны, поляки и прибалты. По непроверенным агентурным сведениям, черноморские моряки даже планировали заявить протест против участия в боевых действиях ${ }^{50}$. Гораздо реже революционные партии опасались «усиления национализма и реакции в случае победоносного заступничества России за славян $\rangle^{51}$.

Совершенно обособленную позицию занимали представители буржуазии. Они уже второй год, с начала итало-турецкой войны в 1911 г., терпели убытки в связи с нарушенным режимом работы черноморских проливов, через которые шла значительная часть русского в 
первую очередь хлебного экспорта: несмотря на то, что в 1912 г. сбор хлеба вырос на 26\% по сравнению с 1911 г., доход от его экспорта уменьшился на $37 \%{ }^{52}$. По этой причине посетивший Одессу накануне Первой балканской войны глава болгарского парламента С. Данев встретил негативное отношение местного торгового мира к возможному столкновению, которое, в принципе, могло бы решить проблему черноморских проливов ${ }^{53}$. Полномасштабная же война грозила буржуазии еще бо́льшими потерями. И, как сообщал агент московской охранки, среди торгово-промышленных кругов «проскальзывает нотка, что сочувствие сочувствием, а не надо забывать своих экономических интересов» ${ }^{54}$. Сходно донесение его коллеги из Ярославля, утверждавшего, что указанная категория населения губернии «погруженная в личные заботы, весьма слабо реагирует на балканские события, <...> остается в стороне от активных проявлений» ${ }^{55}$. Аналогично мнение современника событий К. Арсеньева, высказанное им в подводящем итоги 1912 г. номере газеты «Русские ведомости»: «Как ни велико сочувствие к грекам и славянам, льющим кровь за независимость и свободу, как ни заманчиво звучат голоса, призывающие к новому вооруженному вмешательству в вековую распрю, воинственное настроение не находит почвы в умах, занятых великой домашней работой» ${ }^{56}$.

Чем же руководствовались сторонники войны? В первую очередь соображениями престижа. Столичные умеренные круги считали войну допустимой лишь в случае вооруженного выступления Австро-Венгрии или «оскорбления достоинства России» ${ }^{57}$. Кадет В. А. Маклаков заявлял, что «России нельзя умывать руки» перед балканскими событиями, поскольку это стало бы показателем слабости страны и нанесло «страшно тяжелый удар престижу России не только за границей, но в широкой массе русского же общества» ${ }^{58}$. Харьковские жандармы доносили, что «если Россия помимо воли, в целях охранения своего достоинства» будет вынуждена начать боевые действия, то война будет популярной ${ }^{59}$. Их коллеги из Центральной России считали, что «терпимость России в случае агрессивной политики Австрии вызовет горькое чувство народных масс и нападки оппозиции на бессилие России, на политику правительства, создавшего это бессилие» ${ }^{60}$. Подобное восприятие целей войны не единожды отмечалось. Петербургская профессура считала, что в случае разгрома Австрией Сербии «будет взрыв негодования и порицания бездеятельности правительства» ${ }^{61}$. Начальник Киевского охранного отделения и вовсе утверждал, что «вооруженное вмешательство как идейная поддержка славян не имеет почвы, <...> но твердая политика 
к недопущению Австрии до посягательств на интересы России будет встречена сочувственно» ${ }^{62}$.

Весь ноябрь 1912 г. общественные настроения все более и более склонялись к войне. 5 декабря 1912 г. в Таврическом дворце выступал председатель правительства В. Н. Коковцов, приветствуя новый состав Государственной Думы, и изложил взгляды и планы правительства на ближайшее время. Не мог он не затронуть и «вопроса, на котором с тревогою и напряженно сосредоточено ваше внимание, так же как и внимание всей России». Его слова были дипломатично бессодержательны. Правительство, как он подчеркнул, при принятии решения должно руководствоваться прошлым наравне и с «условиями современной политической обстановки», стремиться к «фактически достижимому, не поддаваясь увлечениям чувства». В конце своей речи премьер заявил, что выступает за сохранение европейского мира, выразил надежду, что «грядущие события не затронут жизненных интересов России, которые мы призваны ограждать всеми нашими силами во имя чести и достоинства нашей родины» ${ }^{63}$.

Не всех депутатов удовлетворило выступление В. Н. Коковцова. Монархист В. В. Шульгин заявлял, что речь должна была быть жестче, следовало бы указать, «что хотя мы войны и не желаем, но ее не боимся» ${ }^{64}$. Буквально дословно вторил ему с трибуны Думы кадет В. А. Маклаков. 13 декабря в Думе публично защищал позицию правительства П. Н. Милюков, утверждая, что русского крестьянина «нельзя вести на убой» из-за второстепенных интересов ${ }^{65}$. Но он, очевидно, оставался в меньшинстве.

Подтверждает описанную картину донесение болгарского посланника С. Бобчева своему руководству. В декабре 1912 г. он сообщал, что часть русского общества желает непременно удовлетворить желания сербов. Во главе идеологов этого течения, по его мнению, стояла редакция газеты «Новое время». Прогрессивная печать и оба полюса политического спектра выступали за примат интересов самой России, основную же часть населения пугала война, поэтому они ограничивались выражением симпатий славянам. Ощущение грядущей войны при этом не было перманентным - по словам С. Бобчева, все постоянно менялось: сегодня все чувствуют, что накануне столкновения с Австро-Венгрией, а на следующий день в обществе царит спокойствие 6 .

В конечном итоге, поняв опасность ситуации, не получив от союзников твердых заверений в полной поддержке, российская дипломатия согласилась на создание Албании. «Новое время» незамедли- 
тельно назвала это «дипломатическим Мукденом» ${ }^{67}$. Однако угроза войны была отодвинута. Как справедливо отметил болгарский историк И. Илчев, «уступки ускорили распад Балканского союза, но отсрочили четко вырисовывавшийся в некоторые моменты серьезный международный кризис, могущий перерасти и в европейскую войну» ${ }^{68} .$.

Осенью 1912 г. русское общество раскололось. Большинство политиков и публичных изданий яро выступали за твердую поддержку сербских притязаний вплоть до объявления войны Австро-Венгрии. Доходило до того, что, как отмечала охранка, несогласные с такой позицией московские газеты боялись печатать статьи иного настроения, чтобы не потерять популярность ${ }^{69}$. В итоге, как отмечает российский исследователь Е. Г. Кострикова, частью общества была пройдена черта, за которой общеевропейская война перестала восприниматься со всей опасностью, «слово “война" легко произносилось на "патриотических" манифестациях, мелькало на страницах газет» ${ }^{70}$.

Однако хотя монархисты и октябристы за редкими исключениями к этому относились положительно, в качестве мотивов у них редко выступала защита интересов Белграда. Как ни старались сербские эмиссары донести до русского общества важность порта на Адриатике, абсурдность создания албанского государства, для этих кругов основным мотивом оставались интересы и престиж России. Понимание интересов России раскалывало либералов: часть из них видела их в защите Сербии, часть - в обладании проливами, а война с Австро-Венгрией не могла решить эту проблему. Но, поддаваясь общим настроениям, и либералы постепенно переходили на воинственные позиции.

Больше всего войны боялась буржуазия, которая мечтала о пресловутых двадцати годах покоя внутреннего и внешнего. И эта часть общества главу МИД С. Д. Сазонова, уступившего Австро-Венгрии в вопросе Адриатического побережья, не кляла, а благодарила. Как он затем рассказывал своему подчиненному, на выставке в Ярославле перед ним на колени бросился «один известный русский купец», чтобы выразить свою благодарность за то, что «во время Балканской войны он спас Россию от войны» ${ }^{71}$.

Предчувствие войны проникало и в крестьянскую среду. Упомянутый А. А. Замараев в дневнике подвел итог 1912 г.: «Этот год был для России тихой. Войны и мятежей не было. Только к концу года Австрия пугала нас войной, и Россия была настороже» ${ }^{72}$. В то же время понимание причин и поводов отсутствовало, поскольку, как показало проведенное в 1914 г. исследование, в деревнях не было принято выписывать и читать газеты ${ }^{73}$. Поэтому, когда во время Первой мировой 
войны генерал А. А. Брусилов спрашивал в окопах у солдат о причинах войны, получал следующий ответ: «Какой-то там эрц-герц-перц с женой были кем-то убиты, а потому австрияки хотели обидеть сербов. Но кто такие сербы, не знал почти никто» ${ }^{74}$.

Принятое осенью руководством России решение не начинать войну с Австро-Венгрией с целью защиты сербских интересов не могло предотвратить Первую мировую войну, оно ее лишь отсрочило. Но начавшаяся осенью 1912 г. антиавстрийская истерия, которая получила продолжение в славянских манифестациях и обедах весны 1913 г. $^{75}$, воздействовала на настроения русского общества, стремительно эволюционировавшие в сторону воинственности. И это в совокупности с тем фактом, что требования Австро-Венгрии в 1914 г. угрожали уже не экономическому развитию Сербии, а самому ее существованию, послужило причиной патриотического подъема и одобрения населением вступления в Первую мировую войну.

\section{ПРИМЕЧАНИЯ}

1 Штрандтман В. Н. Балканские воспоминания. М., 2014. С. 193; Nekludoff A. Diplomatic reminiscences before and during the World War, 1911-1917. London, 1920. Р. 98-100. Накануне объявления войны об этом же в частной беседе с сербским посланником Д. Поповичем говорил бывший председатель III Государственной Думы Н. А. Хомяков (Сръбските интриги и коварства срещу България (1804-1914). София, 2009. С. 356).

2 Троикий Л. Перед историческим рубежом. Балканы и Балканская война. СПб., 2011. С. 100-101.

3 Гусев Н. С. Болгария и Сербия в 1912-1913 гг.: соперничество за статус «любимца» России на Балканах // Вынужденное соседство добровольное приспособление в дипломатических и межнациональных отношениях в Центральной, Восточной и Юго-Восточной Европе XVIIIХХІ вв. М.; СПб., 2017. С. 77-85.

4 Государственный архив Российской Федерации (далее - ГАРФ). Ф. 102. Оп. 121. 4-е делопроизводство. 1912 г. Ед. хр. 278. Л. 28-29об.

5 Писарев Ю. А. Великие державы и Балканы накануне Первой Мировой войны. М., 1985. С. 116.

6 Сазонов С. Д. Воспоминания. Мн., 2002. URL: militera.lib.ru/memo/ russian/sazonov_sd/04.html (дата обращения: 22.04.2018).

7 Коковцов В. Н. Из моего прошлого. Воспоминания 1911-1919. M., 1991. C. 178. 
8 Последовавшее противоборство В. А. Сухомлинова и В. Н. Коковцова осенью 1912 г. освещается на основании мемуаров главы правительства и «Особых журналов Совета министров» в статье М. Ф. Флоринского (Совет министров России и Военное министерство накануне Первой мировой войны // Труды Исторического факультета СПбГУ. СПб., 2011. Т. 5: История России: экономика, политика, человек).

9 Коковцов В. Н. Из моего прошлого. С. 178-179.

10 Особые журналы Совета министров Российской империи. 19091917 гг. / 1912 год / Сост. Б. Д. Гальперина. М., 2004. С. 386-391. Согласно мемуарам В. Н. Коковцова, ситуация выглядела несколько иначе. 19 ноября император созвал совещание, куда пригласил председателя правительства и министра иностранных дел, и поставил их перед фактом: днем ранее на встрече с командующими войсками варшавского и киевского военных округов он принял решение о проведении полной мобилизации киевского, частичной - варшавского, подготовке к аналогичным действиям в одесском военном округе. При этом российский монарх рассчитывал на поддержку германского императора (Коковиов В. Н. Из моего прошлого. C. 182).

11 Военная промышленность России в начале XX века. 1900-1917. М., 2004. С. 423. В то же время С. Д. Сазонов в воспоминаниях относит эти события к первой половине 1913 г., в его памяти они явно смешались с конфликтом в связи со Скутарийским вопросом (Сазонов С. Д. Воспоминания).

12 Толстой И. И. Дневник. 1906-1916. СПб., 1997. С. 414.

13 Ольденбург С. С. Царствование Императора Николая II. Мюнхен, 1949. T. 2. C. 96.

14 Блок А. Дневник. М., 1989. С. 151.

15 Там же. С. 394.

16 Дневник тотемского крестьянина А. А. Замараева. 1906-1922 год. М., 1995. С. 56.

17 ГАРФ. Ф. 63. Оп. 32. Ед. хр. 1346. Л. 19.

18 Литературное наследство. Т. 95: Горький и русская журналистика начала XX века. Неизданная переписка. M., 1998. URL: http://az.lib. ru/g/gorxkij_m/text_0460.shtml (дата обращения: 22.04.2018).

19 Гусев Н. С. «...Какие вообще высказываются соображения по вопросу желательности вмешательства России в славянский вопрос»: доклад Департамента полиции об отношении населения России к возможности общеевропейской войны в 1912 г. // Славянский альманах. 2017. Вып. 1-2. С. 428.

20 ГАРФ. Ф. 63. ОП. 32. Ед. хр. 1346. Л. 19. 
21 Там же. Л. 11, 12.

22 Там же. Ф. 102. Оп. 121. 4-е делопроизводство. 1912 г. Ед. хр. 278. Л. 15.

23 Стенографические отчеты / Гос. дума, четвертый созыв, сессия первая. Заседания 1-30: (с 15 ноября 1912 г. по 20 марта 1913 г.). СПб., 1913. Стб. 2418.

24 ГАРФ. Ф. 102. Оп. 121. 4-е делопроизводство. 1912 г. Ед. хр. 278. Л. 33 об.

25 Там же. Л. 7.

26 Там же. Л. 33об.

27 Ленин В. И. О лисе и курятнике // Полное собрание сочинений. М., 1968. T. 22. С. 149.

28 ГАРФ. Ф. 63. Оп. 32. Ед. хр. 1346. Л. 3-16.

29 Государственный архив Волгоградской области (далее - ГАВО). Ф. 6. ОП. 1. Ед. хр. 297. Л. 120.

30 ГАРФ. Ф. 102. Оп. 121. 4-е делопроизводство. 1912 г. Ед. хр. 278. Л. 17.

31 Там же. Л. 18.

32 Там же. Л. 16, 20.

33 Там же. Л. 24.

34 Гальперина Б. Д., Перегудова 3. И., Стариев В. И. Донесения Л. К. Куманина из Министерского павильона Государственной думы, декабрь 1911 - февраль 1917 года // Вопросы истории. 1999. № 2. С. 6-7.

35 Кострикова Е. Г. Геополитические интересы России и славянский вопрос: Идейная борьба в российском обществе в начале XX века. М., 2017. С. 268-267.

36 Табурно И. П. О сербских битвах (впечатления очевидца войны сербов с турками 1912 г.). СПб., 1913. С. 140-144.

37 Гальперина Б. Д., Перегудова 3. И., Стариев В. И. Донесения Л. К. Куманина... С. 6-7.

38 ГАРФ. Ф. 102. Оп. 121. 4-е делопроизводство. 1912 г. Ед. хр. 278. Л. 31 об.

39 Там же. Л. 31.

40 Гальперина Б. Д., Перегудова 3. И., Стариев В. И. Донесения Л. К. Куманина... С. 6-7.

41 Сазонов С. Д. Воспоминания.

42 Шелохаев В. В. Либеральная модель переустройства России. М., 1996. C. 179.

43 ГАРФ. Ф. 102. Оп. 121. 4-е делопроизводство. 1912 г. Ед. хр. 278. Л. 29 об. 
44 Шелохаев В. В. Либеральная модель... С. 200-205.

45 Чубинский М. П. Балканская война и вопросы культуры // Славянский вопрос в его современном значении. СПб., 1913. С. 119.

46 Шелохаев В. В. Либеральная модель... С. 200-205.

47 ГАРФ. Ф. 102. Оп. 121. 4-е делопроизводство. 1912 г. Ед. хр. 278. Л. 3.

48 Там же. Л. 2.

49 Котов Б. С. Образы Германии и Австро-Венгрии в российской прессе накануне Первой мировой войны. 1912-1914 гг. (по материалам либеральной и консервативной печати): Дисс. ... канд. ист. наук. М., 2014. C. 183.

50 ГАРФ. Ф. 102. Оп. 121. 4-е делопроизводство. 1912 г. Ед. хр. 278. Л. 15 об.

51 Там же. Л. 17.

52 Шепелев Л. Е. Царизм и буржуазия в 1904-1914 гг. Проблемы торгово-промышленной политики. Л., 1987. С. 21.

53 Данев С. Мемоари. София, 1992. С. 140.

54 ГАРФ. Ф. 102. Оп. 121. 4-е делопроизводство. 1912 г. Ед. хр. 278. Л. 21 об.

55 Там же. Л. 12.

56 Русские ведомости. 1913. 1 янв.

57 ГАРФ. Ф. 102. Оп. 121. 4-е делопроизводство. 1912 г. Ед. хр. 278. Л. 30об.

58 Там же. Л. 2об.

59 Там же. Л. 21.

60 Там же. Л. 20.

61 Там же. Л. 33об.

62 Там же. Л. 24об.

63 Стенографические отчеты... Стб. 279-280.

64 Гальперина Б. Д., Перегудова 3. И., Стариев В. И. Донесения Л. К. Куманина... С. 14-15.

65 Шелохаев В. В. Либеральная модель... С. 207-208.

66 ГАРФ. Ф. Р8091. Оп. 36. КМФ-5. Болгария, поступление 3А-36. Ед. хр. 84. Л. 15-18.

67 Кострикова Е. Г. Геополитические интересы... С. 271.

68 Илчев И. България и Антантата през Пьрвата световна война. София, 1990. С. 20.

69 ГАРФ. Ф. 102. Оп. 121. 4-е делопроизводство. 1912 г. Ед. хр. 278. Л. 2 об.

70 Кострикова Е. Г. Российское общество и внешняя политика накануне Первой мировой войны. 1908-1914. М., 2007. С. 398-399. 
71 Соловьев Ю. А. Воспоминания дипломата. 1893-1922. М., 1959. URL: http://dugward.ru/library/solovyev_diplomat/solovyev_vosp_diplomata. html\#madrid (Дата обращения: 21.05.2018).

72 Дневник тотемского крестьянина... С. 56-57.

73 Александров H. «Мы сначала возьмем Краков, а потом уже Берлин». Костромская деревня в начале войны // Родина. 2014. № 6. С. 112.

74 Брусилов А. А. Воспоминания. М., 1963. С. 82.

75 О них см.: Гусев Н. С. Разгон манифестаций в поддержку славян в России весной 1913 года // Славяноведение. 2018. № 3.

\section{N. S. Gusev}

Russian society and the Serbian-Austrian conflict of 1912-1913:

Did the Russians want war

In the autumn of 1912, the first Balkan war began, in which Serbia sought access to the Adriatic sea. However, Belgrade's claims came across the tough position of Vienna, which advocated the creation of Albania, putting an end to Serbian plans. None of the parties was unwilling to concede, the Austro-Hungarian government passed to demonstratively threats. This article deals with the attitude of different strata of Russian society to the possibility of war in the defense of Serbia and analyzes the reasons for their positions. It is stated that the society became more and more ready for war, however not because of the protection of Serbia, but because of the preservation of a sense of dignity before the aggressive actions of Austria-Hungary. Keywords: Balkan wars, Russian society, Serbia, Austria-Hungary, Serbian-Austrian conflict of 1912. 


\title{
Образование Малой Антанты в документах миссии Красного Креста РСФСР в Чехословакии (1920-1921 гг.)
}

\begin{abstract}
В статье рассматриваются документы миссии Красного Креста РСФСР в Праге в 1920-1921 гг., в которых отражены проблемы формирования Малой Антанты - союза Чехословакии, Югославии и Румынии. Значительное внимание уделено анализу политики ЧСР в отношении Советской России и влиянию на нее внутри- и внешнеполитических факторов. Ключевые слова: Малая Антанта, миссия Красного Креста РСФСР в Чехословакии, С. И. Гиллерсон, Г. В. Чичерин, Э. Бенеш.
\end{abstract}

DOI: $10.31168 / 2073-5731.2018 .3-4.1 .12$

В фондах Архива внешней политики Российской Федерации хранятся документы советской миссии Красного Креста в Чехословакии, которая прибыла в Прагу 10 июля 1920 г. и продолжала свою деятельность до июня 1921 г. Несмотря на то, что официальной целью миссии была репатриация военнопленных, ее руководитель С. И. Гиллерсон был наделен наркоматом иностранных дел РСФСР более широкими полномочиями, о чем он сообщил министру иностранных дел ЧСР Э. Бенешу во время первой же встречи 16 июля 1920 г. ${ }^{1}$ Постоянное пребывание миссии в Праге позволяло поддерживать контакты с президентом и правительством ЧСР, с представителями различных политических партий и общественных организаций. В донесениях Гиллерсона в Москву содержатся сведения о переговорах с руководством ЧСР, о внутриполитической и экономической ситуации в стране, о ее внешней политике. В настоящей статье предпринята попытка показать, как в документах миссии отражены проблемы образования Малой Антанты, на какие аспекты ее деятельности обращалось особое внимание советской стороной.

22 августа Гиллерсон в шифровке наркому иностранных дел РСФСР В. Г. Чичерину сообщил о заключении между Югославией и ЧСР оборонительного союза против Венгрий‥ Предполагая, что Югославия последует примеру Праги, заявившей 9 августа о нейтралитете в польско-советской войне, Гиллерсон писал: «Ожидается официальное объявление нейтралитета Белградом, отмечается охлаж- 
дение сербов к Франции». Он считал, что следовало бы воспользоваться ситуацией и предложить Югославии «возобновление нормальных отношений». Гиллерсон спрашивал Чичерина, не предложить ли Бенешу выступить в роли посредника в советско-югославских переговорах и «устроить мне неофициальный проезд в Белград» для встречи с председателем королевского правительства М. Весничем. В этой же шифровке сообщалось, что в целях привлечения Румынии к чехословацко-югославскому союзу и «проектируя образования Малой Антанты» Бенеш отправился в Бухарест³.

Из-за плохой связи эта телеграмма была получена в Москве лишь 13 сентября и расшифрована на следующий день. К тому времени Чичерин располагал информацией о создании Малой Антанты из других источников. 31 августа он направил Гиллерсону депешу, которая в основном состояла из вопросов: Как обстоит дело с Малой Антантой? Какова роль Бенеша? Будет ли результатом нейтралитет или наоборот объединение против нас? Залечиваются ли раны, разделяющие Венгрию и Румынию? Для чего в Румынию ездил Бенеш? Какова теперь политика Румынии? Можно ли ожидать переговоров с нами? Продолжается ли благоприятное для нас направление в Праге? ${ }^{4}$

2 сентября из Москвы на Гиллерсона обрушился новый поток вопросов: «Нам необходимо выяснить позицию Румынии. Вообще мы слишком мало осведомлены о роли Малой Антанты. В чем заключается противоположность между ней и французской системой Дунайской конфедерации? В чем тут роль Бенеша? Каковы взаимоотношения Румынии и остальных этих правительств? Какая связь между румынско-чешскими отношениями и возможностью выступления Румынии против нас?» ${ }^{5}$

Получив шифровку Гиллерсона от 22 августа, Чичерин согласился на его поездку в Белград «для подготовительных и информационных целей с тем, чтобы будущие переговоры с Югославией вело специально посланное туда лицо» ${ }^{6}$. Москва была крайне заинтересована в диалоге с Белградом. 18 августа советские представители в Лондоне вступили в переговоры с министром иностранных дел А. Трумбичем, но уже 26 августа председатель правительства М. Веснич распорядился их прекратить ${ }^{7}$ В этих условиях предложение Гиллерсона о посреднической роли Бенеша и поездке в Белград было как нельзя более кстати, если не считать того, что правительство Югославии в то время не намерено было вступать в переговоры с большевиками. К тому же осенью возникла натянутость в отношениях Гиллерсона с чехословацким руководством, в частности с Бенешем, получившим 
доказательства о подрывной деятельности советской миссии в ЧСР. Поэтому, несмотря на настойчивые требования Чичерина, поездка Гиллерсона в Белград не состоялась.

20 сентября 1920 г. Гиллерсон направил Чичерину многостраничный обзор «Малая Антанта», в котором попытался ответить на интересующие наркома вопросы. Не будучи осведомленным о подготовке чехословацко-югославского договора и основываясь преимущественно на материалах прессы, Гиллерсон сообщал, что переговоры были начаты Бенешем в дни VII Всесокольского слета в Праге в июне 1920 г., куда прибыли представители Югославии. 13 августа в газетах появилось официальное сообщение о поездке Бенеша в Белград. «Далее последовал ряд официальных и полуофициальных сообщений о пребывании Бенеша в Белграде, о его переговорах с премьером Весничем и заместителем министра иностранных дел Нинчичем, о приеме его принцем-регентом Александром и интервью с сербскими журналистами», - отмечалось в обзоре. 19 августа было официально сообщено, что «о заключении союза между Чехословакией и Югославией поставлена в известность Лига Наций». Из Белграда Бенеш направился в Бухарест, где имел беседу с министром иностранных дел Румынии Д. Таке Ионеску, был приглашен к королю Карлу Фердинанду на обед, данный в честь него и гостившего в то время в Бухаресте французского маршала Ж.-Ж.-С. Жоффра ${ }^{8}$.

По возвращении в Прагу Бенеш сделал доклад о результатах переговоров в Белграде и Бухаресте на заседании совета министров, а 1 сентября произнес «обширную программную речь» в комиссии по иностранным делам Национального собрания ЧСР. В обзоре прежде всего обращалось внимание на причины, которые, по словам Бенеша, побудили его к заключению союзного договора с Югославией и переговорам с Румынией. Первоочередной причиной было устранение «мадьярской опасности». Кроме того, «побуждающим мотивом к сближению трех государств» было стремление обезопасить себя от реставрации монархии Габсбургов и от создания Дунайской конфедерации или других «каких бы то ни было федераций». «Создание новых объединений в духе таковых конфедераций, - говорил чехословацкий министр, - было бы для нас опасно в политическом и экономическом отношении» ${ }^{9}$. В наркоминделе особое внимание обратили на слова Бенеша: «Наше соглашение, первый шаг к созданию новой политической и хозяйственной системы в Центральной Европе, значительно более жизнеспособно, чем другие союзы. Отдельные государства этого экономического и политического объединения 
должны заключить между собой ряд краткосрочных, отвечающих моменту договоров». Эта фраза выделена карандашом. Принимая во внимание, что данный документ хранится в фонде Г. В. Чичерина, можно с определенной долей уверенности предположить, что пометку сделал сам нарком. Наконец, еще одной причиной, приведшей, по словам Бенеша, к созданию Малой Антанты, являлось очень сложное «общее политическое положение в Европе», которое определялось тремя большими политическими блоками, а именно «блоком Антанты на западе, германским блоком на севере и русским на востоке». «Положение Европы будет обусловлено, с одной стороны, взаимоотношением этих блоков, с другой - взаимоотношениями государств, лежащих между этими блоками, и, наконец, отношением последних государств к большим блокам» ${ }^{10}$. Бенеш рассчитывал, что, несмотря на все политические затруднения, единство западных союзников сохранится. Но вместе с тем он считал, что со временем неизбежно восстановление Германии и России и усиление их влияния на ход европейских событий. Бенеш не исключал возможности заключения соглашения между Германией и Россией. По его мнению, ко всем этим блокам необходимо занять определенную позицию и быть готовыми к любым случайностям, которые могли бы возникнуть в результате взаимоотношений трех европейских блоков ${ }^{11}$. «Мы должны стремиться обеспечить внутреннюю консолидацию союзом с ближайшими государствами и стать в более определенные отношения к каждому из решающих европейских блоков, чтобы содействовать упорядочению политических отношений в современной Европе. Чтобы спасти Центральную Европу от того краха, который переживают в настоящее время Польша и Россия, мы должны найти общую линию поведения с Румынией и Югославией» ${ }^{12},-$ заявил чехословацкий министр. В обзоре миссии особое внимание обращалось на слова Бенеша, что Чехословакия заинтересована «в наикратчайший срок установить экономические сношения с Россией» ${ }^{13}$. За установление отношений с Москвой выступили социал-демократы. Лидер Чехословацкой социал-демократической рабочей партии (правицы) ${ }^{14}$ А. Немец в своем выступлении заявил о необходимости «по возможности скорее установить дружественные отношения с Россией» ${ }^{15}$. А немецкие социал-демократы, как отмечается в обзоре, потребовали «немедленного признания русского правительства, как проявления независимости республики от Антанты» ${ }^{16}$.

Что же касается оценки «программной речи» Бенеша в целом, то голоса депутатов разделились по национальному признаку. «Все 
чехословацкие партии отнеслись к сообщению министра с полным сочувствием», - отмечалось в обзоре. Представители же всех немецких политических партий в парламентской комиссии выступили с резкой критикой Бенеша, называя Малую Антанту «продуктом тайной дипломатии, империалистической организацией, направленным против Германии союзом» ${ }^{17}$.

Рассматривая отношение соседних стран к Малой Антанте, в обзоре отмечалось, что Венгрия «немедленно забила тревогу по поводу кольца, которым ее собираются окружить». Венгерская печать стремилась доказать, будто Малая Антанта «несет опасность ужасной катастрофы для всей Европы и доставит немало бед западным державам», якобы политика Бенеша отвечает интересам Германии и направлена против союзников ${ }^{18}$.

Указывалось, что польские реакционные круги вели энергичную пропаганду в пользу тесного союза Польши с Венгрией, подчеркивая желательность установления польско-венгерской границы, а следовательно, возвращения Словакии и Подкарпатской Руси Венгрии. Польская пресса прямо заявляла, что необходимой предпосылкой вступления Польши в Малую Антанту является пересмотр решения по тешинскому вопросу и что Польшу мало удовлетворяет союз государств, возглавляемый Чехословакией и враждебный Венгрии. Для Варшавы предпочтительнее тесная дружба с Венгрией и Румынией, направленная против России ${ }^{19}$. Впрочем, отношение к Польше и перспективе ее участия в Малой Антанте в чехословацкой печати было не менее недружелюбным. Выражавшая позицию Бенеша газета С̆as отмечала: «Только миролюбивая, а не теперешняя империалистическая Польша могла бы стать членом Малой Антанты». Вместе с тем газета полагала, что факт возникновения Малой Антанты сделает Польшу уступчивее в конфликте с Россией ${ }^{20}$.

Союз Чехословакии с Югославией вызвал тревогу в Италии, где высказывались опасения, что возник антиитальянский славянский блок и будто Прага поддержит Белград в конфликте с Римом. Чехословацкая официозная печать усиленно стремилась рассеять эти опасения ${ }^{21}$.

В обзоре отмечалось, что чехословацкая пресса выражала надежду на включение в состав Малой Антанты Греции и Болгарии. Имели место предположения, что вступлению Болгарии в Малую Антанту будет способствовать ожидавшийся визит в Прагу председателя болгарского правительства А. Стамболийского ${ }^{22}$.

Одной из главных предпосылок новой политики Бенеша, выразившейся в создании Малой Антанты, советская миссия считала все 
усиливавшееся отчуждение Чехословакии от Франции, которое началось после решения конференцией послов в июле 1920 г. тешинского вопроса, вызвавшего немалое разочарование в чешском обществе, рассчитывавшем получить всю Тешинскую Силезию. Кроме того, появились слухи о переговорах французских дипломатов в Вене с австрийскими и венгерскими реакционными кругами на предмет создания Дунайской конфедерации. Эта идея встречала во Франции особое сочувствие, так как в ней видели единственную возможность воспрепятствовать присоединению Австрии к Германии. Бенеш же постоянно выступал против самой идеи Дунайской конфедерации ${ }^{23}$. Еще одной причиной, приведшей к отчуждению ЧСР от Франции, по мнению составителей обзора, были расхождения в «русском вопросе» во время польско-советской войны. Несмотря на давление Франции, Чехословакия, а вслед за ней и Югославия сохранили полный нейтралитет. Со ссылкой на австрийскую и польскую печать в обзоре утверждалось, что «за лояльной по отношению к союзникам фразеологией Бенеша и Веснича скрыто направленное против французской политики острие» ${ }^{24}$.

Очевидно, советская миссия значительно преувеличивала степень антифранцузской направленности чехословацкой и югославской политики, выдавая желаемое за действительное. На самом деле и Прага, и Белград считали Францию гарантом Версальской системы и, следовательно, своей государственности. Что же касается Франции, то она вначале отрицательно отнеслась к деятельности Э. Бенеша по созданию Малой Антанты. Генеральный секретарь французского министерства иностранных дел М. Палеолог, строивший планы создания Дунайской конфедерации и экономической консолидации всей Центральной Европы, воспринял создание Малой Антанты как шаг, противоречащий интересам Франции и враждебный выпад против себя. Он считал, что политика ЧСР создала большие проблемы: она привела к изоляции Венгрии, которая в поисках поддержки неизбежно присоединится к Германии. В тех условиях он пытался удержать Румынию от подписания союзного договора с ЧСР и Югославией ${ }^{25}$.

Однако в конце сентября 1920 г. отношение Франции к Малой Антанте переменилось. Это было связано с приходом к власти нового правительства во главе с Ж. Лейгом, который занял и пост министра иностранных дел. Генеральным секретарем французского МИД стал Ф. Бертело. Во время первой же встречи с чехословацким посланником в Париже Ш. Осуским он дал ясно понять, что не разделяет взгля- 
дов своего предшественника - Палеолога. Бертело одобрил подписание чехословацко-югославского союзного договора и подчеркнул, что создание Малой Антанты поддерживает и А. Мильеран, избранный 23 сентября президентом Франции. Но он считал, что к Малой Антанте должны присоединиться Польша и Греция. Бертело сообщил Осускому, что об этом уже шла речь в ходе переговоров Мильерана с Таке Ионеску и И. Падеревским ${ }^{26}$.

Французская позиция совпадала с румынским проектом Малой Антанты. В рассматриваемом выше обзоре советской миссии от 20 сентября подчеркивалось, что «Таке Ионеску, путешествующий в настоящее время по государствам Антанты, признавая в своих интервью важность Малой Антанты, дает характеристику задач ее, ничуть не похожую на заявления Бенеша». Румынский министр указывал на необходимость включения в Малую Антанту Греции и Польши. «Предвидя заключение в будущем союза между Германией и Россией, - отмечалось в обзоре миссии, - он полагает, что в этом случае Малая Антанта принесет большую пользу Франции» ${ }^{27}$. Другими словами, по замыслам Бухареста Малая Антанта должна была служить барьером между Берлином и Москвой, чтобы изолировать их друг от друга.

23 октября Гиллерсон сообщал шифровкой Чичерину: «Сейчас можно предположить, что главная роль от Бенеша перешла к Ионеску, который в угоду Франции стремится создать союз при участии Польши, Венгрии, если не для антисоветской интервенции, то для образования антисоветского барьера от Балтийского моря до Средиземного» ${ }^{28}$.

После переговоров в Париже, Лондоне и Риме Таке Ионеску намерен был посетить Прагу и Белград с тем, чтобы приступить к реализации своего плана Малой Антанты. Визиту Таке Ионеску в Прагу посвящена значительная часть следующего обзора «Малая Антанта», направленного советской миссией Красного Креста в наркоминдел 1 декабря. В обзоре сообщалось, что румынский министр 29 октября прибыл из Лондона в Прагу «для ведения переговоров с Бенешем о расширении Малой Антанты на Польшу и Грецию». На основании официальных заявлений и выступлений Бенеша и Таке Ионеску, опубликованных в прессе, в обзоре отмечалось: «Двухдневные переговоры с румынским министром иностранных дел окончились полным достижением согласия относительно актуальных политических вопросов, и в первую голову о Малой Антанте и о взаимных отношениях обоих государств». Чрезвычайно скупо сообщалось, что «министр Бенеш высказал наше [ЧСР. - H. C.] отношение к Польше в вопросе Восточной Европы». Далее коротко излагалось содержание речей ми- 
нистров во время обеда, данного в честь румынского гостя. Чехословацкий министр поблагодарил Таке Ионеску «за стремление и работу по устранению недоразумений между Чехословакией и Польшей», над чем, подчеркнул Бенеш, усиленно работало и само чехословацкое министерство иностранных дел. Бенеш «горячо говорил об обязанности продолжать работу по восстановлению мира и консолидации, что является общим интересом Средней Европы и б у д у щ е й Р о с с и и» [разрядка в тексте документа. - H. C. . $^{29}$. Таке Ионеску ответил, что «стремления обоих государств одинаковы и направлены к тому, чтобы распространить Малую Антанту на образовавшиеся после мировой войны государства от Балтийского моря до Средиземного, охранять все пять договоров, которыми окончилась мировая война и которые являются самыми справедливыми, какие когда-либо победители давали побежденным» ${ }^{30}$. Несмотря на уверения в тождестве стремлений, даже из этих фрагментов выступлений видны различия в подходах Бенеша и Таке Ионеску в определении характера и направленности Малой Антанты. Если первый акцентировал внимание на общности интересов стран Центральной Европы и будущей России, то второй - на объединении государств между Балтийским и Средиземным морями.

Из Праги Таке Ионеску поехал в Варшаву, где ему не удалось достичь желанных результатов: Польша отказалась вступить в Малую Антанту вследствие «позорного поведения Чехословакии во время польско-большевистской войны». Польша же «своею кровью спасла Чехословакию от нашествия большевиков и, во всяком случае, от большевистского переворота внутри Чехословакии, который уже готовился». Варшава также считала несправедливым решение спорных пограничных вопросов, в особенности тешинского.

Чехословакия со своей стороны выдвигала обвинения против Польши. Еще перед приездом Таке Ионеску в Прагу в печатном органе Бенеша С̆as появилась с точки зрения советской миссии «сенсационная статья», в которой высказывалось мнение, что союз с Польшей невозможен: «Польская политика есть политика авантюр и азарта, было бы безумием отождествлять связь с нею». Цели и методы политики Польши и Чехословакии в Восточной Европе совершенно различны. «Рижский мир носит в себе зародыш новой войны, ибо никакая Россия, какой бы окраски она ни была, не примет его; поэтому ни одно славянское государство не согласится взять на себя бремя Риги: с Польшей можно жить в мирных соседских отношениях, но союз с нею означает гибель» ${ }^{31}$. После неудачи Таке Ионеску в Вар- 
шаве чехословацкая официозная печать, объясняя отказ Польши от вступления в Малую Антанту, подчеркивала, что Чехословакия имеет интерес лишь в удержании Трианонского мира, в котором Польша совершенно не заинтересована, а заинтересована она в защите Рижского мира, к которому Чехословакия, по меньшей мере, может быть лишь равнодушна ${ }^{32}$. После неудачного визита в Варшаву Таке Ионеску вынужден был отказаться от первоначального плана поездки в Белград.

В обзоре сообщалось, что 2 ноября чехословацкое правительство опубликовало договор с Югославией от 14 августа, положения которого сводились к следующему: оборона в случае нападения Венгрии; безоговорочное соблюдение Трианонского мира; срок действия договора - два года; ни одно из подписавших договор государств не имеет права заключать союз с третьей державой, не уведомив заранее своего союзника; этот договор доводится до сведения Лиги Наций ${ }^{33}$. Как отмечалось в обзоре: «Союз с Югославией вся печать горячо приветствовала, усматривая в нем дело мира и успокоения Средней Европы». Этой же цели, по мнению чехословацкой печати, служило и соглашение с Румынией. Из всех чешских печатных изданий только газета левицы Rudé právo утверждала, что Малая Антанта главным образом направлена против Советской России. Правые социал-демократы выражали недовольство такими заявлениями левицы и видели в Малой Антанте лишь инструмент обороны в случае нападения Венгрии или реставрации Габсбургов. Схожая точка зрения нашла отражение и в обзоре миссии: «Подводя итоги, надо сказать о Малой Антанте следующее: Чехословакия стремится удержать за собой территорию нынешней республики и государственную независимость. К завоеваниям она не стремится. Правда, нац[иональные] демократы во главе с Крамаржем хотели бы захватить и остальную часть Тешинской области, отошедшей к Польше, но и они на войну не пойдут. Чехословакия заключила поэтому действительно лишь оборонительный союз с Югославией и Румынией против нынешней Венгрии и против восстановления старой Австро-Венгрии и тем самым против Германии» ${ }^{34}$. И Венгрия, и Габсбурги представляли в то время реальную угрозу для Чехословакии. «Интриги в Будапеште и в Швейцарии не прекращаются», - отмечалось в обзоре. Несмотря на ратификацию Трианонского договора, Венгрия вопреки ему, по утверждению чехословацкой печати, держала у границы «большой контингент войск, ожидающих удобного момента для нападения на Чехословакию», всеми средствами вела пропаганду в Словакии и Карпатской Руси ${ }^{35}$. 
Составители обзора считали, что большую опасность для Чехословакии представляет и Германия. Чехи - это лишь небольшой островок в немецком море. В самой Чехословакии при шести миллионах чехов проживает три с половиной миллиона немцев на окраинах республики, причем немцы с самого момента образования Чехословакии открыто рвались к присоединению к Германии. Допустить отделение немцев Прага не могла, поскольку в пограничье среди немцев живут значительные меньшинства чехов. В случае монархического переворота в Германии, который Бенеш предрекал в ближайшее время, возникла бы с ее стороны прямая угроза Чехословакии. По мнению составителей обзора, «Чехословакия должна искать союзников не только против Венгрии, но еще больше против Германии. Помимо Югославии и Румынии естественным союзником могла быть Польша, которой Германия угрожает не менее, чем Чехословакии» ${ }^{36}$. Поэтому Прага была заинтересована привлечь Польшу в качестве союзника против нападения Германии. Но Польша, вновь повторялось в обзоре, за свое вступление в Малую Антанту требовала поддержки ее восточной политики, возвращения Тешинской области и некоторых исправлений границ в Словакии. Чехословацкие газеты перепечатывали материалы из польской прессы, в которых содержались нападки на чехов и заявления, что посредством дипломатии или силой оружия «польский народ в Тешинской области должен быть освобожден от ига чехов». Министр национальной обороны ЧСР О. Гусак, отвечая на запрос депутатов, 22 ноября заявил, что поляки стягивают в польской части Тешинской области новые войска и вновь активизировали свою деятельность польские банды. Кроме того, поляки агитировали в Словакии за федерацию Словакии и Польши, используя в этих целях словацких ксендзов, ненавидящих еретиков-гуситов чехов. За счет Чехословакии Польша и Венгрия хотели установить общую границу и быть естественными союзниками. Из обзора следовало, что разногласия между ЧСР и Польшей на руку Москве, и делался вывод: «Итак, Малая Антанта без Польши означает союз против Венгрии и Габсбургов. С Польшей это был бы оборонительно-наступательный союз против Сов[етской] России» ${ }^{37}$.

В заключительной части обзора рассматривается отношение к Советской России различных политических сил ЧСР, которые разделялись на три течения. К первому относилась левица, требовавшая «полного единения» с Советской Россией. Второе направление было представлено правительством, правыми социал-демократами, национальными социалистами, аграриями. Это направление высту- 
пало за нейтралитет, «за мир с Россией, но против большевистского правительства, которое должно скоро пасть не от интервенции, а от внутренних противосоветских народных сил», и «на место большевиков должно прийти демократическое правительство, которое будет представлело в первую очередь эсерами, меньшевиками и кадетами». Указывалось на влияние эсеров на чехословацкое правительство и поддерживавшие его партии. Издания аграрной партии и национальных социалистов «весьма охотно» цитировали статьи из эсеровской газеты «Воля России». Третье течение представлял К. Крамарж и его национально-демократическая партия, остававшиеся непримиримыми противниками советской власти ${ }^{38}$.

В обзоре советской миссии от 1 декабря 1920 г. была вскользь затронута еще одна тема, которая спустя месяц стала одной из основных в донесениях Гиллерсона в Москву. Речь шла о Рапалльском договоре, который 12 ноября 1920 г. был подписан между Югославией и Италией. В обзоре от 1 декабря отмечалось, что с его заключением «Малая Антанта не только избавилась от одного интриговавшего против нее государства, но, может быть, приобрела могучего союзника против Венгрии и против Габсбургов» ${ }^{39}$. В шифровке 3 января 1921 г. Гиллерсон сообщал Чичерину о слухах об ориентации Малой Антанты на Рим, о предстоящих переговорах Бенеша с итальянским министром иностранных дел К. Сфорцей ${ }^{40}$. Спустя пять дней Гиллерсон писал наркому: «Тенденция к сближению чехов с Италией заметно усиливается» ${ }^{41}$. Наконец, в обзоре внешней политики ЧСР, направленном миссией в Москву 8 февраля 1921 г. (в документе ошибочно указана дата 8 января), тема чехословацко-итальянских отношений вышла на первое место в связи с визитом Бенеша в Рим 4-9 февраля. В обзоре отмечалось, что Италия и Югославия наряду с ЧСР - единственные государства, «непосредственно заинтересованные в невозвращении Габсбургов», и «Бенеш энергично стремится достичь итало-чешское согласие». Его поездка в Рим, «широко рекламируемая чешской правительственной печатью», имела официальной целью достижение соглашения об экономическом сотрудничестве, по венгерскому и австрийскому вопросам, по вопросу о Габсбургской династии. В обзоре подчеркивалось, что предполагался приезд в Италию также председателя правительства и министра иностранных дел Югославии Н. Пашича, т. е. «возможность тройственного согласия» ${ }^{42}$.

Серьезную обеспокоенность советской дипломатии вызвали появившиеся с начала 1921 г. сообщения о румыно-польских переговорах о военном союзе и возможном сближении Чехословакии с Польшей. 
7 февраля 1921 г. Гиллерсон писал Чичерину: «Убежденный в нашей агрессивности, пугаясь предстоящей красной опасности для Чехословакии в случае разгрома Польши, считая необходимым этот разгром предупредить, принимая во внимание польско-румынский союз, являющийся, по-видимому, свершившимся фактом, Бенеш со своей вертлявой политикой, приноровленной к сегодняшнему дню, подготовляет, как мне кажется, общественное мнение к возможному присоединению Чехословакии к польско-румынскому союзу» ${ }^{43}$. По сравнению с летом 1920 г., по мнению Гиллерсона, ситуация в чехословацко-польских отношениях изменилась. Тогда было сильным взаимное раздражение изза Тешина, Красная армия приближалась к границам Чехословакии, разгром Польши казался неминуем. «Если бы мы действительно разгромили поляков, Бенеш бы, как волчок, вертелся между нами и Парижем». Теперь же условия другие. Польша не только уцелела, но и расширилась. Степень ее сопротивляемости оценивается теперь выше, и, как, вероятно, кажется Бенешу, совместно с Румынией и Чехословакией она «сумеет приостановить наше наступление».

Несмотря на сложности ЧСР в отношениях с Польшей и возникшие недоразумения с Румынией из-за территориальных разграничений, Гиллерсон считал «польско-румынско-чешское соглашение оборонительного характера» весьма вероятным. Он не сомневался в том, что такой союз «благословит» Франция, которая на одну Польшу не очень надеется ${ }^{44}$.

Новая международная ситуация в регионе вызвала, по мнению Гиллерсона, существенные изменения в политике Бенеша в отношении Советской России. В обзоре миссии от 8 февраля отмечалось, что в последнее время Бенеш неоднократно заявлял как о невмешательстве во внутренние дела России, так и о недопустимости антигосударственной пропаганды, которую до сих пор Советская Россия вела в Чехословакии. Он уверял, что идея интервенции всеми похоронена, но, если большевики перейдут в наступление, Чехословакия всеми силами будет обороняться - армия наготове. «Здесь у Бенеша постоянная умышленная неясность: какое наступление большевиков имеется в виду — непосредственно ли угрожающее чехам или же также война с Польшей, Румынией, Латвией, Эстонией. Давление, оказываемое Францией на Бенеша, и недвусмысленные реверансы последнего в сторону Польши заставляют считаться с возможностью второй интерпретации», - подчеркивалось в обзоре миссии. Далее отмечалось, что по сравнению с августом 1920 г. в заявлениях министра это — «новая нотка»: «Бенеш не без влияния увивающихся вокруг него эсеров больше решительно не 
верит в жизнеспособность советского режима и уверен во внутреннем перевороте, за которым после более или менее длительного периода тяжкой анархии последует предположительно установление демократического режима». Если в дни советского наступления на Варшаву печать, близкая Бенешу, серьезно считалась с перспективой Советской Польши и, несмотря на французское давление, не могло быть и речи о какой бы то ни было поддержке Польше со стороны Чехословакии, то теперь Прага утратила веру в военную мощь Советской России, а после неудачного выступления в декабре левицы - и в силу коммунистического движения в собственной стране. Но главную причину «того холодно-враждебного тона в отношении России», который отмечала пресса в парламентской речи Бенеша 27 января, в советской миссии видели в том, что чехословацкий министр «пришел к убеждению неминуемого союза будущей России (безразлично, советской ли, монархической ли или «третьей» кадетско-эсеровской) с Германией, союза, прежде всего направленного к сокрушению версальского мира» ${ }^{45}$. Бенеш тесно связывает свою политику в отношении Советской России с политикой Антанты, поэтому он «приветствует признание Антантой окраинных государств, возмущается советской политикой на Кавказе, умело используя при этом фразеологию русских эсеров, наконец, назойливо заигрывает с Польшей, несомненно рассчитывая на важность среднеевропейского противорусского кордона (Польша, Чехословакия, Румыния) и лишь вычеркивая из такового кордона звено, опасное для Чехословакии, - Венгрию» ${ }^{46}$.

В обзоре отмечалось, что политику Бенеша в отношении Советской России поддерживает большинство чехословацких партий. Крамарж уже не в состоянии противопоставить ей иной реальной программы. Против политики Бенеша выступает левица. Кроме того, в обзоре указывалось на особую позицию одного из лидеров правых социал-демократов А. Немеца, который хотя и одобрил основные постулаты внешней политики Бенеша, но в то же время подчеркнул, что в некоторых пунктах чехословацкая социал-демократия с ними расходится. По его мнению, западной ориентации для внешней политики Чехословакии недостаточно, нельзя сбрасывать со счетов Россию, которая может восстановиться и отплатить. Немец считал, что возможность советско-германского союза не должна вызывать опасений, поскольку Чехословакия могла бы к нему присоединиться ${ }^{47}$. Сообщая о выступлении Немеца в донесении Чичерину 7 февраля, Гиллерсон отмечал: «В устах представителя правицы подобное заявление крайне неожиданно. Но странно, оно прошло как-то незаметно и в парламен- 
те, и в печати» ${ }^{48}$. Гиллерсон был убежден, что со временем и Бенешу придется считаться с большевистской Россией ${ }^{49}$.

Гиллерсон вынужден был объяснять наркому причину своей несостоявшейся миссии в Белград. Отвечая на косвенное обвинение Чичерина, что ничего не вышло из плана возобновления отношений с Белградом и поэтому Югославия стала убежищем для армии Врангеля, чего будто можно было не допустить, «если бы мы были там представлены», «если бы мы там на месте против этого боролись» ${ }^{50}$, Гиллерсон писал, что благоприятный момент, «каковым являлось время наших удачных операций на польском фронте», был упущен. Тем не менее он предлагал наркому «обратиться с требованием, именно с требованием, допустить нашего представителя в целях реэвакуации бывших деникинцев и врангелевцев в Россию», ссылаясь на то, что в советскую миссию Красного Креста в Праге поступают из Югославии соответствующие просьбы от российских граждан ${ }^{51}$. В то же время он отмечал, что югославское правительство настроено против большевистской России и сурово расправляется с местными коммунистами $^{52}$. Наркоминдел, дважды обращавшийся в конце 1920 г. в Белград с предложением установления отношений, не достигнув желаемого результата, на этот раз избрал другой путь. К королевскому правительству последовало обращение Югославянского Совета рабочих и крестьянских депутатов в России, который требовал немедленно начать переговоры с РСФСР «с целью обмена исстрадавшихся измученных людей, переживших кровавую войну и тоскующих теперь по родине» ${ }^{53}$. Однако это обращение, как и предшествовавшие ему предложения наркоминдела, осталось без ответа.

По поводу замечания о перемене политики ЧСР в отношении Москвы Чичерин 23 февраля писал Гиллерсону, что его оценки политики Бенеша не совсем сходятся с «до сих повторяющимися публичными выступлениями, в которых он [Бенеш. - H. C.] подчеркивает, что не питает никаких планов против Советской России и что Чехословакия будет держаться в стороне от всяких направленных против нас планов и комбинаций». Чичерин упрекал Гиллерсона в том, что он недооценивает значение выступления Немеца, которое свидетельствует, что «имеется довольно-таки сильное давление на чешское правительство в благоприятном для нас смысле». Нарком также настаивал на необходимости «использовать Прагу для хотя бы первоначального контакта с различными правительствами юго-восточной Европы» ${ }^{54}$.

Значительное внимание в обзорах и сообщениях советской миссии из Праги уделялось чехословацко-венгерским отношениям. Ука- 
зывалось на венгерскую античешскую пропаганду в Словакии и Подкарпатской Руси, на контакты словацких сепаратистов с венгерским посольством в Вене, с австрийскими христианскими социалистами, с окружением экс-императора Карла Габсбурга в Швейцарии ${ }^{55}$.

Час испытания для Чехословакии и всех стран Малой Антанты наступил, когда 26 марта из Швейцарии в Венгрию прибыл Карл Габсбург, чтобы утвердиться на венгерском троне, воспользовавшись тем, что Венгрия оставалась королевством, а он после распада империи в 1918 г. формально не отрекся от престола, а лишь отказался «от всякого участия в государственных делах». Обретение венгерской короны рассматривалось как первый шаг реставрации империи Габсбургов. 5 апреля Гиллерсон сообщал Чичерину: «Вся печать занята внезапным появлением Карла на территории Венгрии. Этот эпизод начинает вызывать сильную тревогу. Тон по отношению к Венгрии угрожающий». Особую позицию заняла клерикальная печать, считавшая происходившее внутренним делом Венгрии и, по-видимому, сочувствовавшая реставрации. Гиллерсон указывал, что правительство ЧСР сделало энергичное представление Венгрии, рассматривая реставрацию Габсбургов как casus belli ${ }^{56}$.

В тот самый день, когда Гиллерсон составлял эту шифровку, Карл Габсбург, уступая давлению союзников, вынужден был вернуться в Швейцарию.

28 апреля Гиллерсон писал Чичерину о заявлении Таке Ионеску, что «энергичное вмешательство Малой Антанты, т. е. Югославии, Чехословакии и Румынии, содействовало быстрой ликвидации Карлистской авантюры», в то время как югославская печать указывала на двойственную политику Румынии, которой будто далеко не враждебна идея восстановления Габсбургов ${ }^{57}$.

Гиллерсон отмечал, что за прошедшие месяцы состав Малой Антанты не изменился. Заигрывание Бенеша с Польшей, посещение Варшавы некоторыми чехословацкими парламентскими группами результатов пока не дали. Польша вела себя даже несколько заносчиво. К тому же в польской печати время от времени все же поднимается тешинский вопрос. Не оправдались надежды и на вступление в Малую Антанту Италии. Гиллерсон ссылался на свидетельства, что здесь сказалось влияние Франции. Между Чехословакией и Италией лишь усилились «кордиальные отношения», пока проявившиеся лишь в заключении торгового договора ${ }^{58}$.

«С представлением о Малой Антанте принято связывать и Румынию, хотя она договора и не подписывала, - отмечал в донесении от 
28 апреля Гиллерсон. - Она, так сказать, пока еще "не партийная, а лишь сочувствующая" $\gg{ }^{59}$. Данное утверждение свидетельствует о недостаточной осведомленности руководителя советской миссии. 23 апреля 1921 г. в Бухаресте министр иностранных дел Румынии Таке Ионеску и чехословацкий посланник Ф. Веверка подписали союзный договор между Чехословакией и Румынией ${ }^{60}$. Но Гиллерсон сообщил об этом в Москву только спустя десять дней ${ }^{61}$. Вместе с тем в донесении от 7 мая он утверждал, что подписание румыно-чехословацкого договора «еще не означает официального включения Румынии в Малую Антанту». На очереди было заключение румыно-югославского договора, и Гиллерсон отмечал, ссылаясь на Česke slovo, что Прага в этом случае выступит в качестве посредника ${ }^{62}$.

Из опубликованного текста чехословацко-румынского договора следовало, что он направлен исключительно против Венгрии. Но, не доверяя официальной версии, Гиллерсон по различным каналам пытался выяснить, не было ли в договоре пунктов, направленных против Советской России. Ему удалось установить, что в договоре имелось обязательство Чехословакии пропускать для Румынии военные грузы в случае столкновения с какой-либо державой. Об этом он сообщил в Москву 20 мая $^{63}$.

28 мая 1921 г. Гиллерсон писал, что, предполагая наличие в румыно-чехословацком договоре пунктов, предусматривавших совместные действия договаривающихся сторон в случае столкновения Румынии с Советской Украиной, он «кой-кого» направил в военное министерство и в МИД. Военный министр Гусак уверял, что конвенция имеет в виду лишь Венгрию и Германию. В министерстве иностранных дел заявили, что в случае конфликта между Румынией и Украиной Чехословакия будет соблюдать нейтралитет. Но Гиллерсон считал, что «едва ли возможно будет ей сохранить подобный нейтралитет, ввиду союзных отношений с Румынией» ${ }^{64}$.

До конца пребывания в Праге Гиллерсон не прекращал поиски ответа на этот вопрос. В одной из последних шифровок он писал Чичерину: «К сожалению, ничего определенного узнать пока не удается. Но чую, что там имеется пункт против нас. Нет сомнения, что Чехия обязана не препятствовать провозу оружия, амуниции и прочего для Румынии, Польши и других участников Версальского договора ${ }^{65}$.

7 июня 1921 г. в Белграде был подписан румыно-югославский договор, отличавшийся от договоров ЧСР с Румынией и Югославией тем, что он был направлен против «неспровоцированного нападения» не только со стороны Венгрии, но и со стороны Болгарии. 
13 июня Гиллерсон сообщал в Москву, что подписание югославорумынского договора в ЧСР рассматривается как «увенчание дела Малой Антанты» ${ }^{66}$.

Неожиданным следствием подписания югославо-румынского договора явилось посещение Гиллерсона накануне его отъезда в Москву в связи с завершением миссии и прибытием в Прагу советской торговой делегации болгарским посланником. Посланник заявил, что поторопился нанести визит, который не прочь был сделать год назад, но тогда этому мешало формальное запрещение Антанты каких-либо контактов с советскими представителями. Теперь, по его словам, это стеснение свободного волеизъявления Болгарии аннулировано, и он нанес визит с ведома болгарского правительства, чтобы «успеть исправить неучтивость». Глава советской торговой делегации П. Н. Мостовенко, присутствовавший при этом разговоре, писал Чичерину, что из слов посланника следовала «возможность завязать сношения с Болгарией и послать туда нашего представителя под флагом разрешения репатриационного вопроса». Мостовенко предполагал, что визит связан с заключением румыно-югославского договора и опасностью международной изоляции Болгарии ${ }^{67}$. В ответном письме Чичерин указал на желательность установления официальных отношений с Болгарией ${ }^{68}$. Но в 1921 г. дело до этого не дошло.

Советское представительство в Праге для наркомата иностранных дел было не единственным источником информации о Малой Антанте. Но о том, насколько значительное внимание ему придавалось, свидетельствует письмо Чичерина Мостовенко в связи с его назначением главой торговой делегации в ЧСР. «Прага есть очень важный узел дипломатических комбинаций, там противостоят друг другу несколько проектов так называемой Малой Антанты», — писал Чичерин. Нарком указывал на «французский проект широкой коалиции, направленной против нас в пользу восстановления в России реакционного режима и генеральской власти с острым острием против Германии». Наряду с ним Чичерин отмечал польский проект, «обнимающий Румынию и Венгрию, старающийся эти две страны мирить и в то же время этой комбинацией оказывать давление на враждебную Польше Чехословакию». Третий, чехословацкий, план Малой Антанты охватывал страны, объединенные враждой против Венгрии, и преследовал цель установить гегемонию Чехословакии. «Все эти страны никак не могут между собой столковаться, а это очень выгодно для нас, потому что мешает враждебным коалициям и интригам против нас, - подчеркивал нарком. - Именно эта постоянная борьба против замыслов и заговоров, 
имеющих целью борьбу против нас, есть то, что придает очень большое значение нашему представительству в Праге» ${ }^{69}$.

Таким образом, советская миссия в Праге рассматривалась наркоминделом как важный источник информации не только о ситуации в Чехословакии, но и в соседних государствах, прежде всего ее союзниках - Югославии и Румынии, в которых не было каких-либо официальных представительств РСФСР, о международных отношениях в регионе. Этим объясняются частые обращения и запросы Чичерина к Гиллерсону, попытки использовать предоставляемую информацию, чтобы повлиять на ситуацию в интересах Советской России. Зачастую требования наркома были завышены. Гиллерсон и его сотрудники имели весьма ограниченный круг источников и не всегда могли раздобыть необходимую информацию. Не обладали они и таким влиянием, чтобы, используя Малую Антанту, развернуть активную дипломатическую деятельность в странах Юго-Восточной Европы. Тем не менее советская миссия Красного Креста, будучи первым официальным представительством РСФСР в Праге, регулярно информировала Москву о внутриполитической борьбе в ЧСР по вопросам внешней политики, об отношении различных политических сил к Советской России, о становлении Малой Антанты, о деятельности чехословацкой дипломатии на международной арене.

\section{ПРИМЕЧАНИЯ}

1 Архив внешней политики Российской Федерации (далее - АВП РФ). Ф. 04. Оп. 43. П. 273. Д. 53926. Л. 2.

2 Договор был подписан 14 августа 1920 г. во время визита Бенеша в Белград. См.: Diplomatické dokumenty o spojeneckých smlouvách Republiky Československé s Královstvím srbů, chorvatů a slovinců a s Královstvím Rumunským. Prosinec 1919 - srpen 1921. Praha, 1923. S. 59-61. Dok. 25; Dokumenty československé zahraniční politiky. Československá zahraniční politika a vznik Malé dohody 1920-1921. Praha, 2004 (далее - DČZP). Sv. I. S. 161-162. Dok. 82.

3 АВП РФ. Ф. 04. Оп. 43. П. 273. Д. 53927. Л. 13. В документе указано «в Будапешт». Очевидно, ошибка допущена при дешифровке.

4 АВП РФ. Ф. 04. Оп. 43. П. 273. Д. 53926. Л. 5.

5 Там же. Л. 6.

6 Там же. Д. 53924. Л. 3.

7 Москва - Сербия, Белград - Россия: сб. документов и материалов. Београд; М., 2017. С. 731. Док. 123. 
8 АВП РФ. Ф. 04. Оп. 43. П. 273. Д. 53928. Л. 5.

9 Там же. Л. 6.

10 Там же.

11 Там же.

12 Там же. Л. 7.

13 Там же. Л. 8.

14 Размежевание в Чехословацкой социал-демократической рабочей партии (ЧСДРП) произошло под влиянием РКП(б) и Коминтерна. 7 декабря 1919 г. в Праге была созвана конференция сторонников леворадикального крыла ЧСДРП, которая приняла свою программу. Революционная фракция в ЧСДРП стала называться марксистской левицей (подробнее см.: Politické programy českoslovanské a československé sociálně demokratické strany dělnické. 1878-1948. Praha, 1999. S. 142-144. Dok. 64). Остальных членов ЧСДРП, и прежде всего руководство партии, рассматривали как правых. Окончательный раскол партии на правицу и левицу произошел в сентябре 1920 г. на ХІІІ съезде ЧСДРП. В 1921 г. левица стала организационной базой Коммунистической партии Чехословакии (КПЧ). Учредительный съезд КПЧ состоялся 14-16 мая 1921 г. в Праге.

15 АВП РФ. Ф. 04. Оп. 43. П. 273. Д. 53928. Л. 9.

16 Там же.

17 Там же.

18 Там же. Л. 10.

19 Там же. Л. 14.

20 Там же.

21 Там же. Л. 15.

22 Там же.

23 Там же. Л. 10.

24 Там же. Л. 11.

25 Подробнее см.: DČZP. Sv. I. S. 195-196. Dok. 113; S. 204-205. Dok. 117; S. 209-211. Dok. 122.

26 Ibid. S. 226. Dok. 135.

27 АВП РФ. Ф. 04. Оп. 43. П. 273. Д. 53928. Л. 13.

28 Там же. Д. 53927. Л. 40.

29 Там же. Д. 53928. Л. 22.

30 Там же.

31 Там же. Л. 23.

32 Там же.

33 Там же. Л. 22.

34 Там же. Л. 23. 
35 Там же.

36 Там же. Л. 24.

37 Там же. Л. 23.

38 Там же. Л. 24.

39 Там же. Л. 22.

40 Там же. П. 274. Д. 53932. Л. 3.

41 Там же. Л. 8.

42 Там же. Д. 53937. Л. 1.

43 Там же. Д. 53929. Л. 2.

44 Там же.

45 Там же. Д. 53937. Л. 2-3.

46 Там же. Л. 3.

47 Там же.

48 Там же. Д. 53929. Л. 4.

49 Там же. Л. 3.

50 Там же. П. 273. Д. 53924. Л. 8.

51 Там же. П. 274. Д. 53929. Л. 3-4.

52 Там же. Л. 4.

53 Советско-югославские отношения. 1917-1941 гг. Документы и материалы. М., 1992. С. 116. Док. 87.

54 АВП РФ. Ф. 04. Оп. 43. П. 274. Д. 53931. Л. 2.

55 Там же. Д. 53932. Л. 3.

56 Там же. Л. 23.

57 Там же. Д. 53929. Л. 23.

58 Там же.

59 Там же.

60 Diplomatické dokumenty o spojeneckých smlouvách Republiky Československé s Královstvím srbů, chorvatů a slovinců a s Královstvím Rumunským. Prosinec 1919 - srpen 1921. S. 141-143. Dok. 65; DČZP. Sv. I. S. 644-645. Dok. 445.

61 АВП РФ. Ф. 04. Оп. 43. П. 274. Д. 53929. Л. 25.

62 Там же. Д. 53932. Л. 122.

63 Там же. Л. 136.

64 Там же. Л. 146.

65 Там же. Д. 53929. Л. 30.

66 Там же. Д. 53932. Л. 164.

67 Там же. Л. 175.

68 Там же. Д. 53931. Л. 22.

69 Там же. Л. 12. 


\section{N. N. Stankov}

The Forming of the Little Entente in the documents of the RSFSR Red Cross mission to Czechoslovakia (1920-1921)

The article concentrates on the documents of the RSFSR Red Cross mission to Prague in (1920-1921) that reflects the problems of forming of the Little Entente - the union of Czechoslovakia, Yugoslavia and Romania. A special attention is paid to the analysis of the policy of Czechoslovakia toward Soviet Russia and the influence of home and foreign political factors on it.

Keywords: Little Entente, RSFSR Red Cross mission to Czechoslovakia, S. I. Gillerson, G. V. Chicherin, E. Beneš. 


\title{
«Украинский вопрос» в воспоминаниях чиновников Украинской Державы гетмана П. Скоропадского
}

\begin{abstract}
Статья посвящена анализу воспоминаний политических и военных деятелей, служивших гетману П. Скоропадскому. Рассматриваются их отношение к «украинскому вопросу», режиму гетмана, воззрения на будущее российского государства и др. Ключевые слова: гетман Скоропадский, мемуары, революиия, «украинский вопрос».
\end{abstract}

DOI: $10.31168 / 2073-5731.2018 .3-4.2 .01$

Мемуарная литература о революционных событиях на Украине начала XX в. довольно обширна. Представители различных идейнополитических направлений - и видные деятели украинского движения, и представители белого лагеря, и большевики - стремились выразить личное мнение о происходивших переменах. Особый интерес представляют воспоминания о таком неоднозначном периоде украинской истории, как гетманат Павла Скоропадского. Среди современников было немало и противников, и сторонников П. П. Скоропадского. Они пытались найти ответы на вопрос, почему Центральная Рада оказалась свергнутой, почему произошла смена власти, что этому способствовало, в чем особенности внутренней и внешней политики гетманата, как следует трактовать отношение гетмана к России, в конце концов, как следует квалифицировать сам гетманский режим и т. п. Деятели Украинской Народной Республики (УНР) и Центральной Рады выдвигали в его адрес немало обвинений, большевики трактовали деятельность гетмана как белогвардейский контрреволюционный переворот, марионеточный режим, поддерживаемый германскими штыками, а сторонники гетманской власти стремились доказать право на существование конституционной монархии во главе с гетманом.

Скоропадский вспоминал, что спустя несколько дней после переворота к нему явились представители украинских партий и заявили о своей готовности поддерживать гетмана, если он согласится на роль президента республики. Скоропадский же считал это гибельным, полагая, что спасти страну можно только диктаторской властью ${ }^{1}$ В результате после переворота партии социалистической и национальной ориентации стали в оппозицию к режиму гетмана, и Скоропадский столкнул- 
ся с острой кадровой проблемой: «Украинцы все говорят о том, что я пользовался русскими силами для создания Украины, - писал гетман. - Да потому, что одними украинскими силами нельзя было создать ничего серьезного. Культурный действительно класс украинцев очень малочислен. Это и является бедой украинского народа»². Действительно, гетманская Украина была «островком спокойствия» в революционном потоке, захватившем распадавшуюся Российскую империю. Сюда устремились представители русской политической, промышленно-финансовой элиты, военные, интеллигенция. В то же время гетманат был украинским государством. В декларации Совета министров от 10 мая 1918 г. говорилось: «Грамота гетмана, положившая начало новой эпохи в истории государственной жизни Украины, свидетельствует о том, что не может быть речи о стремлении нового правительства к подавлению украинской национальности, ее языка, культуры и государственности. Напротив, правительство, избегая насилий и крутой ломки, будет в то же время твердо проводить в жизнь идею дальнейшего и всестороннего развития украинской национальной культуры, обеспечения прав украинского языка в школе, в государственных и общественных учреждениях и укрепления всех форм украинской государственности» ${ }^{3}$.

Формировавшаяся гетманом правящая элита Украинской Державы имела несомненные отличия от элиты УНР. П. П. Скоропадский сразу же распустил Центральную Раду и освободил от должностей всех министров УНР. Состав первого кабинета министров во главе с полтавским земским деятелем Ф. А. Лизогубом был утвержден 3 мая. Поскольку украинские социалистические партии отказались принимать участие в формировании правительства, в него вошли члены партии кадетов и сочувствующие им. «Идейным украинцем» в правительстве был Д. И. Дорошенко - «потомок гетманского рода, известный украинский деятель, комиссар Галиции и Буковины времен Временного правительства» ${ }^{4}$.

24 октября гетман утвердил новый состав Совета министров: теперь в него вошли социалисты-федералисты. Но это правительство просуществовало недолго, уже 14 ноября Скоропадский отправил его в отставку. В новый кабинет вошли деятели правой, проантантовской и прорусской ориентации во главе с царским чиновником С. Н. Гербелем. Однако гетманское правительство не сумело удержать власть, и 14 декабря полномочия были переданы Директории. «Первое министерство (с начала мая по 19 октября) было попыткой синтеза украинского и русского начала; второе министерство (существовавшее около месяца) было резко выраженной реакцией украинского национализма, а третье было противоположной крайностью. Гербель (премьер- 
министр третьего министерства) начал с манифеста гетмана, торжественно объявлявшего федерацию с Россией... Уже эти колебания хорошо показывают в своей диалектике всю нерасторжимость русско-украинского единства и подтверждают правильность того курса в национальном вопросе, который был принят в первом министерстве Лизогуба...» ${ }^{5}$, - вспоминал министр вероисповеданий гетманского правительства В. В. Зеньковский.

Отбирая новых чиновников, гетман учитывал и деловую репутацию, и управленческий опыт кандидатов. В то же время, как отмечает украинский исследователь Р. Пыриг, Скоропадский «должен был учитывать и степень “украинскости” лиц высшего кадрового эшелона, то есть украинское (малорусское) этническое происхождение и их предыдущую деятельность, территориально связанную с Украиной. Делал он это не только по собственному осознанию, но и под давлением немцев, которые побаивались дрейфа гетманата в сторону России, а также требований оппозиционных партий, которые настаивали на формировании украинского по составу и политике правительства» ${ }^{6}$.

В данной связи представляют несомненный интерес воззрения на происходившие на Украине события политических и военных деятелей, служивших гетману. Обычно исследователи опираются преимущественно на воспоминания самого П. П. Скоропадского и некоторых украинских политических деятелей, прежде всего Д. И. Дорошенко. Однако свои воспоминания оставили государственный деятель, правовед Виктор Евгеньевич Рейнбот ${ }^{7}$, этнограф, антрополог, государственный деятель и дипломат Николай Михайлович Могилянский ${ }^{8}$, горный инженер, ученый и общественный деятель Владимир Александрович Ауэрбах ${ }^{9}$, философ, священнослужитель и политический деятель Василий Васильевич Зеньковский ${ }^{10}$, валуйский общественный деятель Роман Юльевич Будберг ${ }^{11}$. О гетманском периоде вспоминали также военные деятели - Владимир Андреевич Мустафин ${ }^{12}$, Петр Иванович Залесский ${ }^{13}$, Сергей Яковлевич Гребенщиков ${ }^{14}$, Борис Семенович Стеллецкий ${ }^{15}$ и др. ${ }^{16}$ Они не придерживались «левых» взглядов. Так, Могилянский был членом партии кадетов, Зеньковский — «вступив в правительство беспартийным, вскоре стал убежденным кадетом» ${ }^{17}$, Рейнбот принадлежал к «правой пророссийской группе правительства» ${ }^{18}$.

Стоит признать, что между позицией самого Скоропадского и его правительством существовали значительные расхождения. Существенно различались и взгляды самих правительственных чиновников. Как справедливо отметили А. Н. Артизов и О. К. Иванцова, «правительство П. П. Скоропадского не только менялось по составу, но и не име- 
ло единства по ключевым вопросам внешней и внутренней политики: представители украинских националистических кругов педалировали национальную тематику и делали акцент на национальной идее, кадеты - на идее прав и свобод граждан, а представители правых кругов на идее сильной власти» ${ }^{19}$. Без сомнения, подобное многообразие стало отражением общей картины распадающейся Российской империи и, казалось бы, неожиданной картины: генерал русской армии стал во главе Украинской Державы. Современники пытались осмыслить, как попытка вернуться к «здоровым основам дореволюционной жизни» сочетается с украинской окраской режима гетмана ${ }^{20}$. Российские специалисты отметили парадоксальность ситуации: «лидеры Белого движения обвиняли гетмана П. П. Скоропадского и его правительство в самостийности и предательстве интересов России, а украинские националисты - в попытке “отменить украинскую государственность и присоединить Украину к Московскому (Российскому) Государству вооруженной силой”» ${ }^{21}$.

Действительно, среди чиновников Скоропадского было немало тех, кто с подозрением относился к украинскому национальному движению, придерживаясь весьма распространенного в русском обществе мнения о нем как об интриге внешнеполитических противников России. Ауэрбах прямо отмечал, что «на украинстве, как известно, лежала печать "made in Germani"»"2 . По его мнению, многих смущал «украинский с сильной дозой самостийничества шовинизм и полубуржуазный, полубольшевистский [э]с[э]-ровский социализм, та противоестественная смесь национального шовинизма с социализмом, что так отличала специфическую "украинскую" интеллигенцию» ${ }^{23}$. Впрочем, он признавал, что причину «украинско-социалистических настроений» нужно было искать «в реакции против дореволюционного режима», а сам собой «украинский национализм и тем более украинский шовинизм так же не свойственны малороссам, как социализм чужд всему русскому народу, и это подтверждается событиями революционной эпохи на Украине и теми фактами, что мне пришлось наблюдать» ${ }^{24}$. Генерал В. Н. Посторонкин также указывал на «искусственность» украинского движения: «Австрия и Германия стремились использовать славянский элемент, организуя из подвластных им славян “польские”, украинские “сечевые" и др. легионы. И не только по этому именно обстоятельству следует искать “корень” украинизации вне России. Корни вопроса “украинизации" следует искать вне России именно потому, что враги России - Австрия и Германия - употребили следующее губительное средство, считавшееся ими радикальным для полного обессиления России, как часть процесса общего распадения нашей монархии» ${ }^{25}$. 
Тем не менее, сделать вид, что «украинского вопроса» не существует, уже было невозможно. Прав был Н. М. Могилянский, утверждавший: «Можно, конечно, без конца спорить о том, существует или нет Украйна, термин, известный уже в летописи, можно отрицать существование украинцев и признавать лишь малороссов, можно еще больше потратить слов, доказывая, что никакого особого украинского языка не существует, а есть малорусское или южно-русское наречие русского языка, но если мы оставим вовсе в стороне все спорное, то бесспорным все же останется факт существования в южной России особой этнической группы, как бы мы ее не называли - украинской или малорусской, с ей свойственной суммой признаков антропологических, этнографических и лингвистических, группы весьма значительной по числу индивидуумов к ней принадлежавших и имеющей уже значительно изученное территориальное распространение» ${ }^{26}$.

Двойственность в настроениях и действиях тех, кто служил Скоропадскому, ярко проявилась в отношении к языковому вопросу. Зеньковский признавал существование украинского языка, более того, он считал, что «украинцы должны были стать достаточно сильными, чтобы не бояться влияния русской культуры, должны были приучиться к свободному сосуществованию двух культур $2^{27}$. Другие же, как Ауэрбах, подчеркивали, что «родной язык большей части сельского населения - малороссийский, городского же и фабричного (украинской и неукраинской крови) - русский. Императорское российское правительство, естественно, отдавало предпочтение более культурному русскому языку и притом языку, на котором говорила хотя меньшая, но более культурная часть местного населения, признавая его государственным и ведя на нем обучение в школах и армии». Может быть, такая позиция и была «слишком категоричной», но она не вызывала «никакого раздражения среди местного населения, за исключением кучки шовинистов». «Но когда немцам понадобилась "независимая Украина", и эта кучка шовинистов оказалась у власти, то она распорядилась как раз обратно: в полном пренебрежении высшей культурой русского языка и интересами более культурных слоев населения государственным - и притом единственным государственным языком - был признан украинский (“мова”). Как я слышал от самих “щирых” украинцев, этот язык, приведенный из Галиции, довольно близок к малороссийскому, но отличается следами влияния более культурного польского языка ${ }^{28}$, - негодовал Ауэрбах. В. А. Мустафин писал: «Эта "мова" самостийно создавалась в каждом учреждении из смеси малороссийских и польских слов» ${ }^{29}$. А В. А. Ауэрбах заявлял: «Я много слышал от людей — как русских, так и украинцев по рождению, — вла- 
девших малороссийским языком и познакомившихся с “мовою”, о неудобствах применения этого языка в качестве государственного равно как в науке и в технике, но всегда я подозревал в этих суждениях некоторое и вполне понятное пристрастие» ${ }^{30}$. «Ваши стремления к украинскому языку - молодому и совершенному - мне кажутся не только не практичными, но и сложными. Вспомните, что английский язык не помешал американцам создать самостоятельное государство; и это ведь не единственный пример подобного вида?! Неужели с помощью украинского языка вы хотите утвердить самостоятельность Украины?» ${ }^{31}$ — восклицал генерал П. И. Залесский.

Язык стал определенным маркером отношения к русско-украинской проблеме. Рейнбот очень ярко описал первое заседание кабинета Лизогуба. Как он считал, «сразу было ясно, что единства в среде министров нет и не может быть. Во-первых, заговорили на трех языках: большинство - по-русски, в меньшинстве - одни прекрасно по-украински в галицийской обработке, другие - по-малороссийски, по-полтавски языком Шевченки, Котляревского со многими и многими руссицизмами, изменяя в русских словах только их произношение...» ${ }^{32}$

Ауэрбах замечал, что «если применение "мовы” в качестве государственного языка вышучивалось веселым обывателем (в особенности в качестве командного языка в армии, где будто бы русское "ружье на караул” было заменено украинским “железяки до пузаки хоп”), то деловыми кругами оно решительно осуждалось» ${ }^{33}$. После переворота «декларацией гетмана, сделанной им тотчас же по его “избрании”, он подтверждал сохранение “украинского” языка в качестве государственного, а эта декларация рассматривалась как бы конституцией. Некоторые из министров полагали, что признание и русского языка государственным формально не противоречило бы декларации, но другие считали натяжку слишком явной» ${ }^{34}$, — писал Ауэрбах. Он отмечал, что «со стороны “щирых” украинцев такое разрешение вопроса, разумеется, вызвало бы метание грома и молний: по признанию Шелухина, с которым мне пришлось об этом говорить, равноправие обоих языков привело бы к полному исключению украинского (!), а у министров были основания опасаться, что “щирые” будут поддержаны немцами». В результате «в ожидании разрешения вопроса об языках фактически в большей части министерств пользовались обоими» ${ }^{35}$.

К тому же служившие Скоропадскому деятели подчеркивали непопулярность «украинской идеи» в массах. Так, Могилянский, которого никак нельзя упрекнуть в антиукраинстве, признавал, что «народная масса, демократические слои ее городского и сельского населения в 
своей массе были по меньшей мере равнодушны к украинизации вообще. И это можно было проверить на каждом шагу. Из ста крестьян, украинских земледельцев, на вопрос об их отношении к украинизации большинство отвечало стереотипной фразой: “Зачем нам это?” У них были свои, другие материальные и духовные запросы и потребности, но они лежали вне орбиты украинского национализма и сепаратизма. Сами немцы всем своим поведением в самой столице Украины и в центре ее национальной активности, обращаясь с воззванием к населению, всегда прибегали к русскому, а не к украинскому языку» ${ }^{36}$.

Рейнбот заявлял: «Донецкий бассейн, большая часть Херсонской губ., крупные города и промышленные центры с многочисленным фабрично-заводским населением определенно не сочувствовали украинской самостоятельности. Масса населения остальной земледельческой Украины мало усваивала значение отделения ее от России. При искусном ведении пропаганды можно было собрать тысячи голосов и в одну, и в другую стороны» ${ }^{37}$.

Ауэрбах привел в своих воспоминаниях один пикантный пример: «На одной из небольших станций под Киевом, где наш поезд простоял почему-то довольно долго, я подошел к группе крестьянок, из-за станционной изгороди продававших разную снедь.

- Zwei, - настойчиво повторял германский унтер-офицер.

— Nein, drei, — упорствовала хохлушка.

- Давно ли, тетка, по-немецки научилась? Или ты немка? вмешался я.

- Шо ты, дядько, мы руські, — обиделась “украинка”» ${ }^{38}$.

Что же привело всех этих людей на службу Украинской Державе? Как они оценивали причины гетманского переворота? Генерал В. А. Мустафин утверждал, что, несмотря на то, что «победа далась украинцам легко», было очевидно, что их власть недолговечна. Она была непопулярна, «опираясь на тощий слой украинской полуинтеллигенции, сельских учителей и учащейся молодежи, чуждых краю галицийцев, да на младшее офицерство, преимущественно прапорщиков из украинцев, занявших высшие командные должности; значительная часть населения городов, состоявшего из великорусов, служащие железных дорог, солдатская масса, оставшаяся на Украине после демобилизации армии, да рабочие относились к этому правительству с явной враждебностью, особенно после объявления Малой Радой 14 января 1918 г. 4-го универсала о полной самостоятельности Украинской республики, а также и целого ряда притеснений, придирок, направленных против великорусов услужливыми агентами украинского правительства» ${ }^{39}$. «Последние часы социалисти- 
ческой власти на Украине» Н. М. Могилянский назвал «топтанием на месте» ${ }^{40}$ : правительство, «чувствуя свою непрочность», «с лихорадочной поспешностью и настойчивостью силилось придать хотя бы по видимости своей резиденции в Киеве вид украинского города» ${ }^{41}$. Многих, как В. А. Мустафина, раздражали внешние проявления «украинскости»: приказ о замене русских названий «на магазинах, банках, торговых и учебных заведениях украинскими», желто-голубые флаги, «объявления о запрещении говорить на иной “мове", кроме державной» ${ }^{42}$. Генерал прямо называет правление Центральной Рады шовинистическим, отталкивающим «от него и тех из русских людей, которые готовы были служить ему как антибольшевистскому $\rangle^{43}$, а программа украинского правительства, «объявлявшая об отмене института частной земельной собственности и во многих подробностях совпадавшая с программой большевиков, также не вызывала к себе симпатий в населении, проникнутом в наиболее влиятельных своих отношениях до мозга костей самым примитивным, ярким инстинктом собственничества» ${ }^{44}$.

Немцы же «быстро убедились, что социалистическое правительство не в силах дать стране порядок, что последний поддерживается страхом перед немцами» ${ }^{45}$. Как считал С. Я. Гребенщиков, «те социалистические приемы российской власти, которые так приветствовались немцами, когда им надо было развалить русскую страну, теперь, по занятии ими Украины, перестали уже им нравится, т. к. здесь немцам нужен был порядок для выполнения своей задачи по выкачиванию из Малороссии продовольствия и отправления его в Германию». Поэтому «социалистическая Рада, так любезно пригласившая немцев на Украину для поддержки и укрепления, как она надеялась, ее власти», удержать власть не смогла, и «немцы без всякого стеснения решили заменить Раду гетманской властью, что и было сделано в Киеве перед Пасхой 1918 г.» ${ }^{46}$.

«Период между занятием Киева немцами 2 марта нового стиля и концом апреля, когда Украина из народной Республики превращается de jure в самостоятельное гетманство, de facto - в скрытую зону немецкой оккупации, был, по существу, периодом колебания немецкой власти в вопросе о том - необходимо ли просто оккупировать Украину manu militari и создать там свое управление по закону военного времени или оставить на Украине видимость местной, самостоятельной власти» ${ }^{47}$, писал Могилянский. Он подчеркивал, что «немцам нужен был хлеб, а не социализация земли»: «Что если украинский крестьянин вместо того, чтобы пахать землю, займется дележкой земли в земельных комитетах и в беспорядках, неизбежных в этом случае, утратит драгоценное время ра- 
бот, обеспечивающих урожай текущего года. Весьма понятно, что немцы не могли в такой момент рисковать самым для них дорогим, важным и наиболее существенным: урожаем года, от которого зависело все». Учитывая то, что «захваченная $<\ldots>$ территория была огромна в сравнении с оккупационными силами» ${ }^{48}$, немцы сделали ставку на замену власти Центральной Рады властью гетмана, в качестве которого был избран П. П. Скоропадский — «аристократ, монархист, генерал, богат, гетманского происхождения, слабовольный, но достаточно честолюбивый» ${ }^{49}$. В воспоминаниях и гетманский переворот, и само правление Скоропадского нередко обозначаются как «оперетка». Для Р. Ю. Будберга «рождение в киевском цирке гетмана и гетманщины» было полной неожиданностью: «На нас, харьковских обитателей, вся эта история произвела впечатление какой-то оперетки, но всем нам было ясно, что сделано это было не хлеборобами и не украинцами, а было инсценировано: рука немцев была слишком видна» ${ }^{50}$. По его словам, «с самого рождения гетманщины вся эта авантюра производила на меня впечатление оперетки....»

Для многих была очевидна «двоякость» конструкции власти: «официально - гетман и совет министров, а за кулисами - немецкое командование; первая власть являлась видимой всеми, хотя до некоторой степени ответственной пред общественным мнением, наружно облеченной всею полнотою власти и в то же время фактически совершенно бессильной и вполне зависимой от власти второй, немецкой, действовавшей за кулисами, никому не видной, но единственной, обладавшей реальной силой» ${ }^{52}$. При этом «идея восстановления гетманства» привлекала внимание общества по разным причинам. Как считал Мустафин, только «немногочисленные романтики-фантазеры» «воспринимали эту идею как восстановление старого идеализированного института гетманства со всеми его историческим атрибутами, как символ украинской самостийности, национальной государственности». А «более реально мыслящие националисты» рассчитывали, что власть гетмана будет «призрачной», а фактически будет принадлежать национальному правительству. «Более же широкие круги населения воспринимали гетманство просто как идею сильной государственной власти, не носящей узкого националистического характера, опирающейся на буржуазные классы, главным образом на земельных собственников» ${ }^{53}$, - утверждал Мустафин.

В результате «вокруг гетманства сгруппировались все элементы и группы антисоциалистические», утверждал Могилянский ${ }^{54}$. Зеньковский, в свою очередь, подчеркивал антибольшевистскую направленность гетманства. По его мнению, «гетманщина была прежде всего и 
больше всего опытом социально-политической реставрации [здесь и далее выделено Зеньковским. - E. Б.], опытом внешнего и внутреннего преодоления большевизма и возврата к нормальным условиям политической, экономической, гражданской жизни» ${ }^{55}$.

При этом роль внешнего фактора в становлении гетманского правления была очевидна всем. Как подчеркивал Могилянский, «вместо quasi-парламента, Центральной Рады, источник власти переходил к украинцу по происхождению и семейной традиции, генералу царской службы П. П. Скоропадскому. Поддерживалась фикция “свободной Украины”, действительными хозяевами которой оставались, конечно, немцы. Необходимый технический аппарат управления поручался правительству Скоропадского. Но немцы имели самое строгое наблюдение за каждым шагом власти, контролировали каждую мелочь, оставаясь распорядителями судеб Украины. Это была, по существу, та же оккупация, но скрытая, не названная своим именем ${ }^{56}$.

Почему же в таком случае был поддержан гетман, хотя в перевороте была очевидна «немецкая рука»? Общее мнение выразил Могилянский. Он писал, что «гетманство являлось компромиссом и, как всякий компромисс, носило в себе яркие следы фальши». Но в то же время «те, кто хотели вовсе отречься от немцев и до конца идти против них, должны были отдать Украину большевикам», что для многих было недопустимо. «Кто испытал режим большевиков, тот имеет право предпочесть ему любой другой, самый тяжкий, даже морально угнетающий режим иноземной оккупации. Ибо этот режим допускает все же хотя бы ростки, зародыши национальной жизни, школы, культуры; режим большевиков - смерть и запустение. Этот тезис не совсем, не до конца понятен особенно иностранцам, ибо они не отдают себе отчета в том, что жизнь оставшихся, прозябающих в России идет лишь в обход принципов коммунизма и существует лишь в меру отступления власти от своих же положений. Десятки и сотни беженцев из России на Украину подтвердят то, что гетманский режим, хотя бы и скрытой за ним германской оккупации Украины, был раем по сравнению с ужасом и режимом, которые создала в России советская власть» ${ }^{57}$.

Однако важны были не только допускавшиеся при гетманате «зародыши национальной жизни». Для многих гетманское правление было передышкой, временем собирания сил для борьбы с большевизмом во имя освобождения России. «Служение Украине и служение России не было для нас двумя задачами, а были по существу, а не только на словах одной задачей, - вспоминал Зеньковский. - Мы искренно служили свободной Украине, но мы слили ее в такой нерушимой связи с Россией, что, служа Украине, служили и России. Важнее еще было то, что мы сво- 
им честным и добросовестным служением Украине стремились спасти Украину для России» ${ }^{58}$. Рейнбот прямо указывал: «Стремление во что бы то ни стало спасти и укрепить Украину какою угодно ценою до окончания мировой борьбы, чтобы в ней иметь базу для освободительного похода на Москву, — только это стремление, эта цель руководили гетманом в его политике с германцами, в его политике внутренней в отношении различных течений в украинских партиях. Крайняя необходимость диктовала линию тяжелого угодливого поведения перед Берлином» ${ }^{59}$. Иными словами, «абсолютная “самостийность” Украины должна быть всецело поддерживаема, доколе не возродится правовая Россия. Тогда взаимоотношения Украины и Великороссии сами собою возвратятся к единству с известным автономизмом Малороссии в связи с ее особым бытовым и хозяйственным укладом. Необходимо полностью использовать нынешний украинский национализм, чтобы его противопоставить течениям большевизма, врывающимся из-за советской границы; недопустимо, однако, на Украине русофобское направление, которое прививают политики из Галиции ${ }^{60}$. Ауэрбах признавал, что германская оккупация была фактом, против которого бороться было невозможно, но эту ситуацию можно было использовать «для восстановления народного хозяйства, для установления прочных социальных отношений, для приобретения государственной властью опоры в устойчивых слоях населения, для сформирования надежной армии, которая могла бы освободить Россию от советского правления, совместно с другими противобольшевистскими силами» ${ }^{61}$.

Поэтому задачей гетманского правительства было создание и укрепление украинской государственности при использовании поддерживаемого оккупационной армией внешнего порядка. «В этом пункте могли сходиться украинцы разных течений - автономисты, федералисты и самостийники - с русскими, думавшими о возрождении России при участии Украины» ${ }^{62}$, - замечал Ауэрбах.

Зеньковский выразил мнение тех, кто, признавая необходимость развития украинской культуры, отнюдь не считал ее враждебной культуре русской. Он отстаивал необходимость претворения в жизнь принципа «культурного параллелизма», поддержки «украинской школы, украинских научных учреждений», дабы наметить «правильную линию взаимоотношения двух культур на Украине» ${ }^{63}$. По его мнению, «история требовала разрешения двух первейших задач былой России - вопросов социального и национального» ${ }^{64}$. Большевики «психически овладели народом потому, что они кончили войну, отдали крестьянам всю землю, - а национальностям предоставили действительно полную (по крайней мере, первое время) свободу “самоопределения” ${ }^{65}$. Именно 
в этом, по мнению Зеньковского, и была причина победы большевиков: они сумели воспользоваться остротой национального вопроса для решения своих задач, тогда как «для ряда лиц» вопрос об украинской культуре и национальной задаче был «временным и чисто декоративным» моментом, который сам собой устранится, когда освободится вся Россия. «В этом беззаботном и циническом даже отношении к “украинской” проблеме (которую и проблемой-то не считали) пребывало довольно значительное число не только в партии к[онституционных] д[емократов], но и в правых и левых группировках, - и это настроение влиятельных русских групп было известно в украинской интеллигенции, не только ее раздражая, но и создавая справедливое недоверие к “украинским симпатиям" этих русских групп» ${ }^{66},-$ писал Зеньковский.

При этом «антиукраинская группа (В. М. Левитского, Ефимовского и др.), впоследствии до конца слившаяся с течением “малороссов", возглавляемых В. В. Шульгиным», была «менее многочисленна, но очень шумлива и криклива». Этой группе Зеньковский противопоставляет кадетов, обнаруживших «большую гибкость и трезвость». Они, учитывая «реальную политическую обстановку, ни на минуту не забывая об общерусской задаче», сочли возможным создать особую «Всеукраинскую партию к[онституционных] д[емократов]» и пошли на сотрудничество с гетманом. В то же время «левые - и украинские, и русские группы - оказались в оппозиции» ${ }^{67}$. Для Зеньковского был неприемлем как «сепаратизм» «украинских национальных деятелей», так и нежелание их противников удовлетворить «национальные стремления». «Из этого исторического “противоречия" выход мог бы быть найден лишь в том, чтобы разрешить проблему украинской национальной культуры в пределах России, но на этот путь не стала украинская интеллигенция» ${ }^{68},-$ настаивал Зеньковский.

Проанализировав политику гетмана, Р. Пыриг делает вывод, что украиноцентричность и революционность лидеров УНР сменились «лозунгами и практикой возрождения украинской исторической традиции, единого украинского гражданства, толерантной украинизации и т. п.». Политика гетманата была обусловлена несколькими факторами: консервативно-либеральной идеологией государственного строительства; двойственной лояльностью, национально-территориальным патриотизмом правящей элиты; прагматическими интересами немецкой стороны; имперским наследством ${ }^{69}$.

Действительно, как подчеркивал Н. М. Могилянский, «в области национального вопроса гетманский период выгодно отличается от последующего за гетманским периода Директории и атаманской анархии. Полная терпимость ко всем национальностям, полная религиозная тер- 
пимость отличает гетманский период и от Центральной Рады, когда преследовалось все русское. < . . > По отношению к украинцам старались, по крайней мере, сделать все, чтобы удовлетворить национальное чувство и достоинство. < . .> Русские, попавшие на украинскую службу, старательно изучали украинский язык, делали усилия к его освоению, и лишь в редких случаях замечалось нескрываемое неприязненное отношение к языку Украины» ${ }^{70}$.

Без сомнения, чиновники гетманата в своих воспоминаниях старались оправдать свои действия, критиковали противников, пытались снять с себя обвинения в пособничестве немцам и объяснить причины избранного ими пути. В сложных внешнеполитических условиях каждый из них решал для себя сложную задачу: каким будет будущее российской государственности, какое положение займет Украина, как должен быть решен национальный вопрос. Подобного рода мемуарная литература не только показывает, как воспринимались революционные перемены на Украине на индивидуальном уровне, но и со всей очевидностью демонстрирует, что гетманат был особым периодом в истории русско-украинских отношений, изучение опыта которого поможет избежать ошибок в будущем.

\section{ПРИМЕЧАНИЯ}

1 Павло Скоропадський. Спогади. Кінець 1917 - грудень 1918. Київ; Філадельфія,1995. С. 173-174.

2 Там же. С. 233.

3 Цит. по: Гетман П. П. Скоропадский. Украина на переломе. 1918 год: Сб. док. М., 2014. С. 967. В документах сохранены орфография и пунктуация автора.

4 Пиріг Р. Я. Українська гетьманська держава 1918 року. Історичні нариси. Київ, 2011. С. 91.

5 Воспоминания В. В. Зеньковского о его пребывании в должности министра вероисповеданий в составе правительства гетмана П. П. Скоропадского [1931 г.] // Гетман П. П. Скоропадский. Украина на переломе. 1918 год. С. 313.

6 Пиріг Р. Діяльність урядів гетьманату Павла Скоропадського: персональний вимір. Київ, 2016. С. 9-10.

7 Виктор Евгеньевич Рейнбот (1869-1956) - действительный статский советник, до революции занимал прокурорские и судебные должности, был обер-прокурором Уголовного кассационного департамента Правительствующего сената в период Временного правительства. При гетмане был товарищем министра внутренних дел, а потом министром юстиции Украинской Державы. 
8 Николай Михайлович Могилянский (1871-1933) - профессор этнографии и антропологии, служил в Музее антропологии Российской академии наук, был заведующим этнографическим отделением Русского музея Александра III, преподавал в Педагогическом институте в Петербурге, на педагогических курсах при Военно-педагогическом музее в Петербурге и на Высших женских естественно-исторических курсах. После Октябрьского переворота переехал в Киев, был заместителем государственного секретаря Украинской Державы, участвовал в мирных переговорах с австро-венгерским командованием в Одессе и представителями РСФСР, затем был назначен послом во Франции, но прибыл в Париж уже после падения гетманата.

9 Владимир Александрович Ауэрбах преподавал в Алексеевском Донском политехническом институте в Новочеркасске, накануне революции был членом правления многочисленных обществ по добыче угля на Юге России, управляющим делами Сометалла, заместителем председателя и управляющим делами съезда горнопромышленнов Юга России, а затем товарищем министра торговли и промышленности Украинской Державы.

10 Василий Васильевич Зеньковский (1881-1962) - философ, священнослужитель и политический деятель, профессор Киевского университета, министр исповеданий в правительстве П. П. Скоропадского.

11 Роман Юльевич Будберг (1863-1930) - барон, общественный деятель, окончил Воронежский Михайловский кадетский корпус, 1-е Павловское военное училище, Петровскую сельскохозяйственную академию. Председатель Валуйской земской управы Воронежской губернии, деятель местного комитета партии кадетов, член Главного комитета Всероссийского Земского союза. Принимал участие в аграрной комиссии при гетмане, являлся управляющим Державным земельным банком.

12 Владимир Андреевич Мустафин (1867-1933) - окончил Александровский кадетский корпус, Константиновское военное училище, Военно-юридическую академию, офицер лейб-гвардии 1-го стрелкового полка, участник Русско-японской войны. Затем был военным следователем, помощником военного прокурора, управляющим канцелярией Туркестанского генерал-губернатора, атаманом Забайкальского казачьего войска, читинским генерал-губернатором. Мустафин - генерал-майор Военно-судебного ведомства, генерал для поручений при главнокомандующем армиями Юго-Западного фронта, служил в гетманской армии, был градоначальником Одессы и одесским генерал-губернатором.

13 Петр Иванович Залесский (1867 - после 1925) - окончил Михайловское артиллерийское училище, Академию Генерального штаба, генерал-майор, был начальником 6-й кавалерийской дивизии, командую- 
щим 7-м кавалерийским корпусом, позже - в Донской армии. При гетмане был харьковским генерал-губернатором.

14 Сергей Яковлевич Гребенщиков (1874-1933) окончил Николаевскую академию Генерального штаба и Офицерскую военную школу, служил в кавалерийских полках, командовал лейб-гвардии драгунским полком. Во время Первой мировой войны служил вместе с П. П. Скоропадским. В период гетманства служил уездным старостой сумского уезда.

15 Борис Семенович Стеллецкий (1872-1939) окончил Одесское пехотное юнкерское училище, Академию Генерального штаба, во время Первой мировой войны служил офицером для поручений при главнокомандующем армиями Юго-Западного фронта, затем - начальником войсковых соединений Дунайской армии. При гетмане был назначен начальником Главной квартиры и Собственного штаба гетмана.

16 Воспоминания этих деятелей вошли в сборник документов «Гетман П. П. Скоропадский. Украина на переломе. 1918 год», опубликованный в 2014 г. Большинство документов ранее не публиковались или же были опубликованы без археографической обработки, многие - не полностью. Стоит упомянуть публикацию воспоминаний В. В. Зеньковского, дневниковых записей Н. М. Могилянского, воспоминаний В. А. Мустафина. См.: Зеньковский В. В., протопресвитер. Пять месяцев у власти (15.V-19.X.1918 г.): воспоминания / Публ. текста и ред. М. А. Колерова. М., 1995; Зеньковский В. В. Пять месяцев у власти [Воспоминания] / Под ред. М. А. Колерова. М., 2011; Россия и Украина. Из дневников Н. М. Могилянского и писем к нему П. П. Скоропадского. 1919-1926 / Публ. А. Сергеева // Минувшее. Исторический альманах М.; СПб., 1993. Т. 14. С. 257-259; 1917 год в судьбах России и мира. Октябрьская революция. От новых источников к новому осмыслению / Под ред. С. В. Тютюкина, В. П. Булдакова. М., 1998. С. 388-401.

17 Пиріг Р. Діяльність урядів гетьманату... С. 81.

18 Там же. С. 137.

19 Артизов А. Н., Иванцуова О. К. Гетманат П. П. Скоропадского как историческая, историографическая и источниковедческая проблема // Гетман П. П. Скоропадский. Украина на переломе. С. 31.

20 Там же.

21 Там же. С. 46.

22 Воспоминания В. А. Ауэрбаха о его пребывании в должности товарища министра торговли и промышленности в составе правительства гетмана П. П. Скоропадского [1923 г.] // Гетман П. П. Скоропадский. Украина на переломе. С. 160. Сохранена орфография документа.

23 Там же. С. 135.

24 Там же. 
25 Воспоминания ген. В. Н. Посторонкина о создании гетманом П. П. Скоропадским вооруженных сил Украинской державы [12, 19 мая 1928 г.] // Гетман П. П. Скоропадский. Украина на переломе. С. 533.

26 Очерк Н. М. Могилянского «Трагедия Украины». 23 мая 1919 г. // Гетман П. П. Скоропадский. Украина на переломе. С. 583-584.

27 Воспоминания В. В. Зеньковского... С. 338.

28 Воспоминания В. А. Ауэрбаха... С. 175.

29 Воспоминания ген. В. А. Мустафина о назначении его одесским губернским старостой в период правления гетмана П. П. Скоропадского [не позднее 31 декабря 1921 г.] // Гетман П. П. Скоропадский. Украина на переломе. С. 431.

30 Воспоминания В. А. Ауэрбаха... С. 175.

31 Воспоминания ген. П. И. Залесского о его пребывании в должности харьковского губернского старосты в период правления гетмана П. П. Скоропадского [1926 г.] // Гетман П. П. Скоропадский. Украина на переломе. С. 508.

32 Воспоминания В. Е. Рейнбота о его пребывании в должности товарища министра внутренних дел, министра внутренних дел, а позже министра юстиции в составе правительства гетмана П. П. Скоропадского [не ранее 31 декабря 1918 г.] // Гетман П. П. Скоропадский. Украина на переломе. С. 93.

33 Воспоминания В. А. Ауэрбаха... С. 176.

34 Там же.

35 Там же.

36 Из очерка Н. М. Могилянского «Украина во время мировой войны» [не ранее 1922 г.] // Гетман П. П. Скоропадский. Украина на переломе. С. 607.

37 Воспоминания В. Е. Рейнбота... С. 79.

38 Воспоминания В. А. Ауэрбаха... С. 136.

39 Воспоминания ген. В. А. Мустафина... С. 430.

40 Из очерка Н. М. Могилянского... С. 608.

41 Воспоминания ген. В. А. Мустафина... С. 431.

42 Там же.

43 Там же.

44 Там же. С. 432.

45 Там же. С. 457.

46 Из воспоминаний ген. С. Я. Гребенщикова о его пребывании в должности сумского уездного старосты в период правления гетмана П. П. Скоропадского [не позднее мая 1919 г.] // Гетман П. П. Скоропадский. Украина на переломе. С. 516.

47 Из очерка Н. М. Могилянского... С. 605.

48 Там же. С. 605-606. 
49 Воспоминания генерала Б. С. Стеллецкого о его пребывании в должности начальника штаба гетмана П. П. Скоропадского и событиях на Украине в 1918 г. [1923 г.] // Гетман П. П. Скоропадский. Украина на переломе. С. 667.

50 Воспоминания Р. Ю. Будберга о его пребывании в должности управляющего державным земельным банком в период правления гетмана П. П. Скоропадского [1924 г.] // Гетман П. П. Скоропадский. Украина на переломе. С. 406.

51 Там же. С. 416.

52 Там же. С. 409.

53 Воспоминания ген. В. А. Мустафина... С. 460-461.

54 Очерк Н. М. Могилянского... С. 596.

55 Воспоминания В. В. Зеньковского... С. 308.

56 Из очерка Н. М. Могилянского... С. 608.

57 Там же. С. 618.

58 Воспоминания В. В. Зеньковского... С. 337.

59 Воспоминания В. Е. Рейнбота... С. 116.

60 Там же. С. 65.

61 Воспоминания В. А. Ауэрбаха... С. 142.

62 Там же. С. 183.

63 Воспоминания В. В. Зеньковского... С. 336.

64 Там же. С. 213.

65 Там же. С. 214.

66 Там же. С. 220.

67 Там же.

68 Там же. С. 312.

69 Пиріг Р. Національна політика Української гетьманської держави (квітень - грудень 1918 р.) // Національне питання в Україні XX початку XXI ст.: історичні нариси. Київ, 2012. С. 135.

70 Из очерка Н. М. Могилянского... С. 629.

\section{E. Iu. Borisenok}

"Ukrainian question" in the memoirs of the officials of the Ukrainian State of Hetman P. Skoropadskyi

The article focuses on the analysis of the memoirs of the political and military officials that served Hetman P. Skoropadskyi. Their positions toward "Ukrainian question", Hetman regime, views on the future of the Russian state etc. are studied.

Keywords: Hetman Skoropadskyi, memoirs, revolution, "Ukrainian question". 


\title{
Белорусские организации революционной России в воспоминаниях Е. С. Канчера
}

\begin{abstract}
Статья посвящена воспоминаниям деятеля белорусского движения Е. С. Канчера. Будучи активным участником событий 1917 г. в Белоруссии, он достаточно подробно описал картину политической жизни края в этот период. Отдельное внимание уделено характеристике белорусских организаций левого спектра в России.

Ключевые слова: Белорусский областной комитет, БСДРП(б), организаиии моряков Балтийского флота.
\end{abstract}

DOI: $10.31168 / 2073-5731.2018 .3-4.2 .02$

Евсевий Степанович Канчер (1882-1979) являлся одним из ключевых деятелей белорусского автономистского течения, признавших в 1917 г. советскую власть и сотрудничавших с ней.

Е. С. Канчер родился в Минской губернии. Трудовую деятельность начал в качестве рабочего в Главных мастерских Закавказской железной дороги. С 1906 по 1908 г. находился в заключении за участие в революционном движении. В 1908-1910 гг. обучался на Высших курсах по кавказоведению в Тифлисе. В 1910 г. переехал в СанктПетербург. С тех пор и до конца жизни жил и работал в Северной столице, занимаясь в основном преподавательской деятельностью. Кроме того, Канчер известен как автор многих работ по экономике и деятель кооперативного движения.

После победы Февральской революции Е. С. Канчер принимал активное участие в работе белорусских национальных организаций. Был председателем Белорусского областного комитета при Всероссийском Совете крестьянских депутатов, являлся одним из организаторов Всебелорусского съезда в Минске в 1917 г. В 1918 г. он стал заведующим статистическим отделом Белорусского национального комиссариата при Народном комиссариате по делам национальностей РСФСР в Петрограде. Встречался с руководителями Советской России: Лениным, Сталиным, Свердловым, Луначарским и другими. Являлся автором целого ряда книг и статей, посвященных положению Белоруссии и аграрному вопросу. Так, сборник статей «Белорусский 
вопрос», изданный в Петрограде в 1919 г., является одним из важнейших источников по истории Всебелорусского съезда и обстоятельств его роспуска. В 1938 г. он был арестован как «участник белорусской антисоветской националистической организации» ${ }^{1}$, но в 1939 г. отпущен «за отсутствием состава преступления».

В 1967 г. молодой белорусский историк Виталий Владимирович Скалабан, в то время студент Ленинградского университета, узнал, что в 1937 г. Канчер передал в Секретариат истории гражданской войны Центрального партийного архива (ныне Российский государственный архив социально-политической истории - РГАСПИ) рукопись своих воспоминаний о событиях 1917-1919 гг. После многолетних поисков В. В. Скалабану удалось обнаружить этот документ. Он представляет собой рукописный текст объемом 280 листов. Часть его, порядка 40 листов, дублирована на печатной машинке (видимо, это та часть, которую редакторы «Истории гражданской войны» сочли возможным использовать в работе). В 2010 г. Скалабан опубликовал часть V главы воспоминаний, посвященную Всебелорусскому съезду в декабре 1917 г. и переговорам Канчера с Лениным и Сталиным². В белорусских СМИ отмечалась важность находки для одной из самых запутанных страниц белорусской истории и даже ее сенсационность ${ }^{3}$.

Мемуары посвящены перипетиям становления левого крыла белорусского национального движения в бурный революционный период, взаимоотношениям внутри этих организаций, оценке их влияния на общество, характеристикам лидеров. Также значительное внимание уделено его контактам с правым крылом движения.

Зарождение левого течения и организаций описано в мемуарах Е. С. Канчера как создание группы «белорусов-интернационалистов» на первом съезде белорусских партий 7-9 апреля (25-27 марта) 1917 г. Они, «не отделяя себя от белорусского движения, стали на позицию углубления революции». Канчер подчеркивал, что левое крыло образовалось именно в противовес сепаратистским тенденциям. Его сторонники считали, что излишний упор на национальный вопрос приведет к свертыванию революционных преобразований, лишив белорусов необходимой для проведения социальных реформ связи с трудящимися всей империи.

Левые национальные организации Канчер классифицирует следующим образом: из созданных до Октябрьской революции наиболее многочисленным являлся Белорусский областной комитет при Всероссийском съезде крестьянских депутатов (далее БОК ВСКД или БОК). До 7 ноября (25 октября) 1917 г. он имел 25-30 активных работ- 
ников, а после переворота - 60-80 (всего же в нем состояло свыше 10 тыс. чел., главным образом, по оценке Е. С. Канчера, крестьян и солдат). На втором месте стояла возрожденная в 1917 г. старейшая белорусская партия Белорусская социалистическая громада (БСГ) с 50-60 активистами, объединявшая до 1,5 тыс. чел. - рабочих, солдат, интеллигенции и мелкой буржуазии. Из организаций, возникших после октябрьских событий, могут быть отмечены Белорусская социал-демократическая партия (большевиков) (БСДРП(б)), влившаяся в феврале 1918 г. в РКП(б) в качестве ее белорусской секции, и Белорусская партия левых эсеров (интернационалистов) (БПЛСР(и)). В них состояло по 300-350 чел., а актив достигал 30-40 чел. Остальные партии и организации не имели и такого количества ${ }^{4}$.

БОК был организован при Всероссийском совете крестьянских депутатов сначала в виде секции Западной области $(\mathrm{C} 3 \mathrm{O})^{5}$ по инициативе М. В. Фрунзе (Михайлова) и М. М. Харитонова на I Всероссийском съезде крестьянских депутатов, проходившем с 18 (5) по 23 (10) мая 1917 г. в Петрограде. Секция объединяла крестьянских депутатов от белорусских губерний, а также депутатов крестьянских секций фронта и тыла - уроженцев белорусских губерний. В партийном отношении Канчер характеризует секцию Западной области как «коллектив партийных и непартийных социалистов (большевиков, левых социалистов-революционеров интернационалистов, анархистов-коммунистов)» ${ }^{6}$. После Октябрьской революции начался второй период деятельности организации — с 13 (1) ноября 1917 г. по 2 июня (20 мая) 1918 г. «в качестве Белорусского областного комитета при ВСКД, с учетом национального движения» ${ }^{7}$ В первый период наиболее деятельными были: М. В. Фрунзе (Михайлов), М. М. Харитонов, Тризна, Ф. М. Короткевич, Жуков, Разживин, Е. С. Канчер. Всего от области числилось 25 чел., из коих в «группе Михайлова» состояло 14. Эту группу так и называли: «группа Михайлова», «белорусская группа», «большевическая группа». Во второй период, т. е. после образования БОК, наиболее деятельными были Е. С. Канчер, Ф. М. Короткевич, Д. М. Соболевский, М. Б. Гольман, В. С. Селиванов, И. М. Пашковский, Л. С. Колядко, В. Л. Карпов, А. Т. Вазилло, Г. И. Певзнер и др. Всего в БОК в период Чрезвычайного и 2-го съездов вошло 98 депутатов, из которых было 21 большевик, 23 левых эсера-интернационалиста, 5 анархистов-коммунистов и 49 беспартийных ${ }^{8}$. Они представляли Минскую, Могилевскую, Витебскую, Смоленскую, Виленскую и Гродненскую губернии. Кроме того, среди этих делегатов были и представители от 25 крестьянских секций комитетов солдат и моряков 
армии, флота и тыла, «в общем охватывающих до 10540 организованных крестьян Западной (Белорусской) области». В первый период СЗО ставила перед собой задачи: а) политическая организация крестьянства вокруг лозунгов большевиков; б) конфискацию всех земель бесплатно и передача их крестьянам через земельные комитеты; в) рабочий контроль над производством и распределением; г) ликвидацию империалистической войны, д) расширение и укрепление роли советов; е) подготовка к учредительному собранию9.

После Октябрьского переворота БОК по договоренности с Лениным и Сталиным организовал при СНК Белорусское представительство в лице Ф. М. Короткевича, В. С. Селиванова и Е. С. Канчера, по договоренности с ними же и на средства СНК созвал 28 (15) декабря 1917 г. Всебелорусский демократический съезд в Минске, участвовал совместно с БСДРП(б) в создании и работе центрального белорусского национального комиссариата (Белнацком) при Народном комиссариате по делам национальностей РСФСР (А. Х. Устилович, Е. С. Канчер, И. В. Лагун, А. Г. Червяков и др.), вел переговоры с И. В. Сталиным, председателем Областного исполнительного комитета Западной области (Облискомзапа) А. Ф. Мясниковым, членами коллегии Наркомнаца С. С. Пестковским и И. П. Товстухой об организации Белорусской советской территориально-государственной автономии, принимал участие в комиссии по подготовке к мирным переговорам в Брест-Литовске (другие члены комиссии - акад. Е. Ф. Карский, Д. М. Соболевский, Е. С. Канчер, А. Т. Вазилло). Можно видеть, что задачи Секции западной области и Белорусского областного комитета существенно различаются. Точнее было бы сказать, что ряд членов БОК ранее сотрудничали с большевиками с $\mathrm{C}^{3} \mathrm{O}^{10}$. Однако, так как Канчеру было важно подчеркнуть, насколько тесным было это сотрудничество, он сознательно затушевывал эти различия.

Для БОК ВСКД опорными организациями были губернские и уездные советы крестьянских депутатов Белорусской области, а также Исполнительный комитет моряков Балтийского флота, Представительство при СНК РСФСР, Белорусское научно-экономическое общество ${ }^{11}$. В воспоминаниях Е. С. Канчер описывает деятельность Исполкома моряков Балтфлота и Представительства БОК при СНК.

Исполнительный комитет моряков-белорусов Балтийского фло$m a$. Накануне Октябрьского переворота в Петрограде по инициативе СЗО состоялась конференция моряков-белорусов Балтийского флота. В конференции приняли участие 152 делегата, представлявшие при- 
мерно 4-5 тыс. матросов, машинистов, мастеровых и рабочих судов и крепостей Балтийского моря. Было решено создать Исполнительный комитет моряков-белорусов Балтийского флота в составе 25 чел. «Весь ноябрь-декабрь 1917 г., т. е. в самый острый момент взятия власти буржуазии большевиками, моряки-белорусы стояли на страже октябрьской революции» ${ }^{12}$. После Октябрьского переворота началось массовое дезертирство. Вот как описывает Е. С. Канчер развал флота: «Уходившие нередко брали с собою вооружение и оборудование кораблей. Порой казалось, что опустевшие корабли будут разграблены дотла. Уносили винтовки, пулеметы, ленты, бомбы, брезент, хозяйственную утварь. <..> в первой половине февраля Белоруссия была вдруг занята немцами, и пути к бегству на родину [были] отрезаны. Среди моряков-белорусов наступило угрожающее брожение, готовое вылиться в массовый поход против немцев. Ко мне на квартиру явилась депутация моряков в количестве 25 чел. Они приехали в полном боевом вооружении и в квартиру вкатили два пулемета. Первым вопросом их было: "Или мы идем в Белоруссию, чтобы бить врага, или мы перестреляем всех, кто нас обманывает”. Тогда комитет моряковбелорусов совместно с БОК устроил чрезвычайную конференцию, на которой были обсуждены два вопроса: об отношении к занятию немцами (и поляками) Белоруссии и об охране имущества Балтийского флота. Оказалось, что флот на $70 \%$ находится в руках моряков-белорусов. Пришлось употребить много силы и настойчивости, чтобы не дать морякам выкинуть дезорганизующий поступок» ${ }^{13}$. Моряки Балтфлота участвовали непосредственно в осуществлении Октябрьского переворота. Из важных для белорусского движения событий можно отметить еще их участие во Всебелорусском съезде в декабре 1917 г. Исполнительный комитет существовал до марта 1919 г., а затем распался, так как многие моряки-белорусы после образования БССР устремились на родину ${ }^{14}$.

Представительство Белорусского областного комитета при СНК РСФСР. 8 ноября (26 октября) 1917 г. в Минске было получено известие о большевистском перевороте в Петрограде. Это был сигнал для аналогичных действий минских большевиков, в особенности организаций Западного фронта ${ }^{15}$. С 15 (2) ноября 1917 г. в Белоруссии установилась общекраевая Советская власть, в состав которой вошли большевики Минска и Западного фронта во главе с А. Ф. Мясниковым и небольшая группа левых эсеров-интернационалистов во главе с Н. М. Дайнеко ${ }^{16}$. При СНК РСФСР «с одобрения и согласия 
гениального политика и вождя народов т. Сталина» в начале ноября 1917 г. было создано представительство Белорусского областного комитета при Всероссийском совете крестьянских депутатов (Е. С. Канчер, Ф. М. Короткевич, В. С. Селиванов). Представительство БОК являлось специальной комиссией по делам Белоруссии и белорусского национального движения при комиссаре по делам национальностей И. В. Сталине. В обязанности Представительства БОК входили «информация и содействие советскому правительству по вопросам: а) аграрного движения в Белоруссии, б) перевыборов Советов и их перестройки на основе Советской власти в Белоруссии, в) объединения и руководства белорусским национальным движением на основе признания Советской власти в Белоруссии и организации общекраевой власти» ${ }^{17}$. Е. С. Канчер подчеркивал, что «Представительство БОК возникло несколькими днями позже Военно-революционного комитета Западной области и фронта и за 10 дней раньше до образования Облисполкома и СНК Западной области», т. е., видимо, должно было быть не менее значимым, чем эти органы власти.

Белорусская соииалистическая громада (БСГ) и ее местные организации: старейшая белорусская партия возродилась в марте 1917 г., но была уже скорее неоднородным конгломератом различных политических сил. От нее очень скоро начинают «отпочковываться» новые организации. Е. С. Канчер описывает деятельность ряда «опорных организаций» БСГ в Москве и Петрограде, а также возникшей в недрах БСГ Белорусской социал-демократической партии (большевиков) (БСДРП(б)), позднее влившейся в РКП(б) в качестве ее белорусских секций.

Московская белорусская народная громада (МБНГ) возникла 22 (9) апреля 1917 г. в Москве по инициативе Московской организации БСГ, «с приданием ей нарочито несоциалистического характера. Объединяла элементы от правых национал-демократов до правых национал-социалистов. Опиралась на беженские массы, в большом количестве разместившиеся в губерниях великорусских, украинских, юго-восточных и сибирских. Через это ее проникновение в другие города. Имела свои отделения в Туле, Калуге, Саратове, Орше, Жиздре, Торжке, Белеве и других городах с беженским населением». В центре наиболее активное ядро организации составляли: И. И. Василевич, Перевой, Рудзяк, Вакусевич, священники Корчинский, Виноградов и Митропольский, А. Цвикевич, Сычев, А. Бурбис, И. Дыло, 
А. О. Бонч-Осмоловский, П. А. Бодунова, А. В. Прушинский (Алесь Гарун), В. Пичета. В центре насчитывалось до 120 чел., в отделах до 390 чел. ${ }^{18}$ Московская БНГ пользовалась значительным влиянием среди белорусских беженцев, из нее вышли ряд известных общественных и политических деятелей, а также деятелей культуры.

Гельсингфорсская белорусская народная громада была организована в июле 1917 г. по инициативе моряков Балтфлота и порта Гельсингфорса. Ее руководителями стали П. Вербицкий, Осипович, Семенов и Григорьев. Всего в ней состояло около 150-180 чел. С момента возникновения эта организация дрейфовала влево, вследствие чего изменялись ее программа и требования. «Отметим и подчеркнем, пишет Канчер, - что эта Гельсингфорсская Громада, объединявшая членов БСГ, белорусских меньшевиков и эсеров, мало общего имела с революционным движением моряков-белорусов Балтийского флота. В общественном отношении - чиновники, учителя, преподаватели высшей школы, писатели, артисты, священники, офицеры, собственники. В отделах были крестьяне и рабочие. Задачи ставила следующие: объединение белорусов на основе национально-демократического возрождения, защита белорусских краевых интересов перед правительством и соседними народностями, создание территориально-государственной автономии Белоруссии, развитие экономики и культуры края, оказание различных видов помощи гражданам-белорусам. После октябрьского переворота заняла “незалежную” ориентацию, что выразилось в ее декларации по поводу мирных переговоров Советов в Брест-Литовске» ${ }^{19}$. После роспуска Всебелорусского съезда 18 (31) декабря 1917 г. она была переименована в Белорусскую громаду социал-демократов (большевиков) и социалистов-революционеров (левых) в Гельсингфорсе. В начале 1918 г. организация приняла советскую национальную платформу для Белоруссии, сочетая революционные лозунги с национальными. Очень характерно, как менялась ориентация Громады в течение примерно года: автономистская до Октябрьского переворота, в ноябре-декабре 1917 «незалежническая», с начала 1918 г. - советская федеративная. Однако неизменно во главу угла ставился национальный вопрос. После отделения Финляндии Громада перекочевала в Кронштадт и перестала существовать в начале 1919 г. $^{20}$

Белорусская сочиал-демократическая рабочая партия (большевиков) (БСДРП(б)), впоследствии Петроградская белорусская секция 
РКП(б), возникла в конце ноября 1917 г. путем выделения «рабочей группы» из БСГ и присоединения к ней нарвского отделения Громады. Инициаторами были рабочие: И. В. Лагун, Полецко, А. Х. Устилович, И. В. Скоринко, Афиногенов, Сосно. Наиболее деятельными, кроме перечисленных, были Гуринович, Г. Г. Ковшилло, Рытинский. Впоследствии к ним присоединились Д. Ф. Жилунович, Козырев, Мазур, А. Г. Червяков, Харламов и др. Партия насчитывала не более 120 членов. Она пользовалась сравнительно ограниченным влиянием среди рабочих. БСДРП(б) ставила перед собой следующие задачи: а) укрепление Советской власти в России, б) создание Белорусской автономной республики Советов в составе РСФСР, в) белорусизацию края и коренизацию государственных и общественных учреждений Белоруссии, г) создание белорусских советов рабочих, солдатских и крестьянских депутатов в Белоруссии < .. > Ориентация общероссийская федеративная, но в отличие от БОК партия стояла на позиции отделения от России с последующей федерацией с Россией» ${ }^{21}$. Канчер обвиняет лидеров партии в скрытом сепаратизме и подчеркивает, что, в отличие от них, Белорусский областной комитет стоял на гораздо более умеренных позициях в национальном вопросе. «Правый уклон» БСДРП(б) он объясняет влиянием на нее Белорусской социалистической громады ${ }^{22}$.

Основываясь на личных воспоминаниях, записях, находившихся в его распоряжении, и материалах своих соратников, Е. С. Канчер составил широкую картину политической жизни белорусов в самом крае и белорусских беженцев в России. О необходимости издания полного текста воспоминаний Канчера писал В. В. Скалабан ${ }^{23}$. Однако неожиданная смерть историка не дала ему исполнить задуманное. Эти записки остаются неизданными по сей день. Конечно, время их написания наложило свой отпечаток, в частности, во всех событиях ключевой показывается роль Сталина, значительно сглажены оценки - особенно если сравнить с его же сборником 1919 г. «Белорусский вопрос», где Канчер позволяет себе весьма резкую критику большевиков. В 1937 г. он, как и многие, подстраивался под современную конъюнктуру ${ }^{24}$.

Е. С. Канчер был сторонником белорусской автономии в составе Советской России с довольно широкими полномочиями самоуправления краем. Определять внутреннее устройство края и прочие вопросы, не касающиеся внешней политики и армии, по мнению Канчера, должно было избранное трудящимися края местное правительство. Автономию он видел территориальной, т. е. постулировал равенство всех наций, населяющих край ${ }^{25}$. Отношение к белорусскому языку у автора было не вполне последовательным. Он считал попытку его ко- 
дификации, предпринятую «незалежниками», неудачной, и созданный ими язык - искусственным и непонятным самим белорусам, но в то же время он был и противником русификации. Решение языкового вопроса в условиях войны и революции он не считал первостепенным, предлагая поэтапное внедрение белорусского языка в школы и официальные учреждения, а также корректировку языковой политики по мере необходимости ${ }^{26}$. В революционные годы, будучи социалистом и надеясь на победу левых в России, он рассчитывал, что они смогут решить белорусский вопрос наиболее прогрессивным образом. Разгон Всебелорусского съезда и особенно Брестский мир вызвали в нем недоумение и досаду, но, несмотря на это, он был уверен в том, что Белорусскому краю следует остаться в составе революционной России, что это наиболее отвечает интересам ее трудящихся всех наций.

\section{ПРИМЕЧАНИЯ}

1 Скалабан В. Яўсей Канчар - палітык, гісторык, мемуарыст // Беларуская думка. 2010. № 1. С. 88.

2 Канчер E. С. Из истории гражданской войны в Белоруссии в 1917-1920 гг. (по личным воспоминаниям, записям и документам). Фрагменты 5-й главы // Беларуская думка. 2010. № 1. С. 92-97; № 2. С. 72-79.

3 Так, например, главный редактор журнала «Беларуская думка» В. Ф. Гигин отметил: «Это своего рода историческое открытие, которое позволяет пролить свет на довольно запутанную, мало задокументированную страницу развития Беларуси непосредственно сразу после Октябрьской революции 1917 года. То есть на проект создания Белорусской советской республики, который был разработан в ноябре-декабре 1917 года». По словам Гигина, в мемуарах впервые приводятся достаточно полные сведения о составе Всебелорусского съезда декабря 1917 г. и о партийном составе его делегатов (http://belapan.by/archive/2010/02/03/ media_archive/. Дата доступа: 29.10.2017).

4 Российский государственный архив социально-политической истории (РГАСПИ). Ф. 71. Оп. 15а. Д. 1656. Л. 129об.

5 Там же. Л. 24.

6 «Первый всероссийский съезд КД, состоявшийся 18 (5)-23 (10) мая 1917 г. в Петрограде в количестве 1353 чел., в целом прошел под влиянием российской партии с-р/правых и центр. Избранный ими же ИК [исполнительный комитет. - Д. К.] в основном оказался в их руках. Этим объясняется долгая и упорная борьба ВСКД и его ИК первого созыва с 
советской властью и с большевиками. На этом фоне СЗО и БОК целиком шли в разрыве со всем ВСКД, избрав линию по личному указанию В. И. Ленина, как члена ВСКД первого созыва» (Там же. Л. 26).

7 Там же. Л. 28.

8 Там же. Л. 27.

9 Там же. Л. 28.

10 Лазько $P$. Ленінскі саўнарком, Яўсей Канчар и падрыхтоўка Ўсебеларускага з'езда (лістапад - снежань 1917 г.) // Беларусь праз прызму рэгіянальнай гісторыі: Рэчыцкі край. Да 150-годдзя $з$ дня нараджэння Мітрафана Доўнара-Запольскага. Зб. навуковых артыкулаў. Мінск, 2018. C. 224.

11 РГАСПИ. Ф. 71. ОП. 15а. Д. 1656. Л. 69.

12 Там же. Л. 196.

13 Там же. Л. 196об.

14 Там же. Л. 198.

15 Там же. Л. 222.

16 Там же. Л. 223.

17 Там же. Л. 226.

18 Там же. Л. 183.

19 Там же. Л. 183, 183об.

20 Там же. Л. 184, 184об.

21 Там же. Л. 31.

22 Там же. Л. 59-61.

23 Как отметил В. В. Скалабан, благодаря публикации есть возможность сравнить то, что писал Канчер в 1918 г., и его воспоминания 1937 г., написанные в Ленинграде. Историк признал, что в этих материалах «есть определенные противоречия, есть явные неточности, но в целом это уникальный источник, который требует, прежде всего, издания» (http://belapan. by/archive/2010/02/03/media_archive/. Дата доступа 29.10.2017).

24 А. Т. Вазилло, соратник Е. С. Канчера по работе в Петроградском отделении Белнацкома, арестованный в 1932 г. по обвинению в антисоветской деятельности, на допросе дал следующую характеристику Канчеру: «... он человек без определенного политического лица. В свои “важные" рассуждения он любил вставлять высокие слова из “идеалистической философии”. По крайней мере, в Минске Канчера я узнал не как марксиста, а скорее, как “народника” - правый эсер... В комиссариате держался, как я уже немного показал выше, гордо, вызывающе, как уверенный генерал в свои "стратегические" соображения насчет действий на "белорусском фронте”. А уверен он был, я понимал, в то, что Белоруссия должна быть “независимой республикой”» // Скалабан В. Яўсей Канчар... С. 90. 
25 РГАСПИ. Ф. 71. ОП. 15а. Д. 1656. Л. 177.

26 Канчер Е. С. Из истории гражданской войны... № 1. С. 94.

\author{
D. A. Korotkova
}

Belarusian organizations of revolutionary Russia:

the memoir of Y. S. Kantcher

The article is dedicated to the memoir of the Belarusian movement activist Kantcher. He participated in political life of Belarus in 1917 and described it thoroughly in his work. We'll dwell upon his testimonial of the left Belarusian organizations in Russia.

Keywords: Belarusian regional committee, BSDLP(b), organizations of sailors of the Baltic fleet. 


\title{
Наградные документы чекиста Е. Г. Евдокимова как источник по истории Всеукраинской Чрезвычайной комиссии и красного террора в Крыму в 1920-1921 гг.
}

\begin{abstract}
В статье проанализированы наградные документы начальника Особого отдела Всеукраинской Чрезвычайной комиссии Е. Г. Евдокимова как источник по истории красного террора в Крыму в 1920-1921 гг. и в отношении деятельности украинских чекистов. На сегодняшний день эти материалы являются единственным известным ведомственным свидетельством о масштабах крымских расстрелов. Кроме того, представляет интерес восприятие этих событий главнокомандующим всеми вооруженными силами Украины и Крыма М. В. Фрунзе, оставившим на документах две своих резолюции.

Ключевые слова: Гражданская война в России, Крыл, Украина, красный террор, Всеукраинская Чрезвычайная комиссия.
\end{abstract}

DOI: $10.31168 / 2073-5731.2018 .3-4.2 .03$

Трагическая история крымских расстрелов 1920-1921 гг. после оставления полуострова войсками Русской армии генерала П. Н. Врангеля в ноябре 1920 г. уже почти столетие вызывает ожесточенные споры, прежде всего об инициаторах террора, о составе и численности жертв.

18 октября 1920 г. датирована телеграмма председателя РВС республики Л. Д. Троцкого № 961, адресованная РВС Южного фронта, с предложением в ответ на приказ Врангеля о безжалостном расстреле всех комиссаров и активных коммунистов, захваченных в бою, издать приказ о поголовном истреблении «всех лиц врангелевского командного состава, захваченного с оружием в руках» ${ }^{1}$. Троцкий отмечал, что советское правительство уже дважды предлагало врангелевским офицерам сдаваться, обещая полную амнистию. Предложение Троцкого РВС Южного фронта отклонил по целому ряду причин, прежде всего из-за наличия «значительного количества у Врангеля комсостава из Красной армии, в том числе красных командиров, что установлено их перебежкой во время последних боев, во-вторых, пониженного настроения среди врангелевского офицерства, которое в последних боях легко сдавалось в плен, в-третьих, возможного при дальнейших не- 
удачах Врангеля восстания демократической части офицерства...»² Однако после советизации Крыма возобладал иной подход.

Общая численность лиц, сдавшихся в плен частям РККА в Крыму в ноябре 1920 г. и оставшихся на полуострове после ухода белых гражданских беженцев, неизвестна, однако есть основания полагать, что эта цифра значительна. 16 ноября 1920 г. председатель ВЧК Ф. Э. Дзержинский приказал начальнику Особого отдела Юго-Западного и Южного фронтов В. Н. Манцеву принять все меры, «чтобы из Крыма не прошел на материк ни один белогвардеец»³. Манцеву предписывалось действовать согласно полученным в Москве инструкциям. Возможно, эти инструкции послужили основой для последовавших массовых репрессивных акций. Впрочем, документы свидетельствуют и о распоряжениях в отношении эвакуации пленных врангелевцев ${ }^{4}$.

Крымский большевик, врач и ученый С. В. Констансов с ужасом писал в секретариат ЦК РКП(б) 26 декабря 1920 г. о начавшемся в Крыму в 20-х числах ноября красном терроре: «Через два или три дня после окончания первой регистрации военных была назначена новая регистрация, которая производилась Особой комиссией по регистрации 6-й армии и Крыма; этой регистрации подлежали наряду с военными также юристы, священники, капиталисты. Все военные, только что зарегистрированные и амнистированные, были обязаны вновь явиться на регистрацию. Регистрация продолжалась несколько дней. Все явившиеся на регистрацию были арестованы, и затем, когда регистрация окончилась, тотчас же начались массовые расстрелы: арестованные расстреливались гуртом, сплошь, подряд; ночью выводились партии по несколько сот человек на окраины города и здесь подвергались расстрелу.

В числе расстрелянных оказались и офицеры, и рабочие, и врачи, и мелкие военные чиновники, и советские служащие, и больные, и здоровые - без разбора» ${ }^{5}$.

В годовом отчете КрымЧК за 1921 г. отмечалось, что в декабре 1920 - январе 1921 г. был произведен «общий учет оставшегося белогвардейского офицерства, чиновничества и др. прислужников старого режима. "Весь этот элемент беспощадно расстреливался” (по решениям троек).

Эти меры имели свои и хорошие стороны (заставили вздрогнуть все антисоветские элементы - и очистили от таковых Крым) и в известной степени плохие - погибло много специалистов, которые могли бы быть использованы во время хозяйственной работы республики» ${ }^{6}$. В отчете отмечалось, что в 1921 г. Крымская ЧК расстреляла 
461 человека7 ${ }^{7}$ Очевидно, эти цифры не отражают масштабов репрессий конца 1920 г.

Разброс публиковавшихся данных о численности жертв крымских расстрелов колоссален ${ }^{8}$. Противник большевиков, историк-эмигрант С. П. Мельгунов в своей книге о красном терроре, к примеру, называл от 50 до 150000 расстрелянных ${ }^{9}$. При этом сам автор признавал, что не обладал точными данными по этому вопросу. В эмиграции со ссылкой на якобы официальные советские данные также фигурировала цифра в 52-53 000 расстрелянных ${ }^{10}$. Эти цифры представляются существенно завышенными, хотя порой встречаются даже в работах серьезных исследователей. К примеру, В. П. Булдаков утверждал, что в течение зимы 1920-1921 гг. в Крыму были казнены «едва ли не 100 тыс. человек» ${ }^{11}$.

Обращение к документам дает намного меньшие данные. В частности, член коллегии наркомата по делам национальностей М. Х. Султан-Галиев в докладе о положении в Крыму наркому И. В. Сталину отметил, что, «по отзывам самих крымских работников», число расстрелянных достигает 20 000-25000 человек, причем до 12000 человек только в Симферополе ${ }^{12}$. С этими данными солидаризировался известный исследователь истории органов госбезопасности А. Г. Тепляков $^{13}$. Исследователи истории Крыма А. Г. и В. Г. Зарубины отметили, что минимально доказуемой является цифра в 20000 жертв ${ }^{14}$. Однако эти данные пока документально не подтверждены.

В письме заместителя председателя Крымского ревкома Ю. П. Гавена от 14 декабря 1920 г. в ЦК РКП(б) на имя Н. И. Бухарина отмечалось, что председатель Крымского ревкома Б. Кун организовал массовый террор, в результате которого расстреляны около 7000 человек, а подверглись арестам 20000 человек ${ }^{15}$.

Опубликованы отрывочные отчетные данные сотрудников ЧК, характеризующие масштаб репрессий в отдельных местах за определенные дни. В частности, начальник Особого отдела 13-й армии и уполномоченный Крымской ударной группы И. М. Данишевский телеграфировал Е. Г. Евдокимову 27 ноября 1920 г.: «Задержано, приговорено за сутки 273 белогвардейца, из них: 5 генералов, 51 полковник, 10 подполковников, 17 капитанов, 23 штабс-капитана, 43 поручика, 84 подпоручика, 24 чиновника, 12 чинов полиции, 4 пристава» ${ }^{16}$. Аналогичная шифротелеграмма от 29 ноября сообщала о работе Данишевского в Феодосии: «За истекшие сутки задержано, приговорено [к] расстрелу 136 контрреволюционеров, из них: 27 полковников, 4 подполковника, 8 капитанов, 14 поручиков, 37 подпоручиков, 6 чин[овников] 
воен[ного] времени, 2 госстражи, 1 пристав, 1 вахмистр, 31 бежавших $[c]$ севера» ${ }^{17}$. Эти донесения свидетельствуют как о масштабе повседневной репрессивной практики, так и о составе репрессированных.

Начальник Особого отделения 9-й стрелковой дивизии П. Зотов докладывал В. Н. Манцеву 8 декабря 1920 г. о том, что:

«1. Из зарегистрированных и задержанных в Феодосии белогвардейцев в количестве приблизительного подсчета - 1100, расстреляно 1006 человек. Отпущено 15 и отправлено на север 79 чел[овек].

2. Задержанных в Керчи офицеров и чиновников приблизительно 800 человек, из которых расстреляно около 700 человек, а остальные отправлены на север или отпущены. Причем отпущенных не более $2 \%$ - случайно задержанных, никогда не служивших, но явившихся или по ходатайствам парткомов или по принадлежности к подпольщикам, хотя и офицеров $<\ldots>$

В настоящее время регистрация и расправа офицеров и чиновников закончена и приступлено к регистрации бежавшей с севера буржуазии $<\ldots>$ думаю, что нужно будет расстрелять в обоих городах ${ }^{18}$ до 100 человек» ${ }^{19}$. Из этого доклада следует, что уничтожению, по данным из Феодосии и Керчи, подлежали не менее $87,5 \%$ зарегистрированных.

Единственным известным на сегодня ведомственным документом ВЧК, содержащим данные о реальных масштабах красного террора в Крыму после завершения там боевых действий против белых, является хранящееся в Российском государственном военном архиве (РГВА) и, насколько можно судить, в архиве управления ФСБ России по Омской области наградное представление чекиста Е. Г. Евдокимова $^{20}$ к ордену Красного знамени, датированное 1921 г. Документы Евдокимова не только свидетельствуют о крымских расстрелах, но также проливают свет на работу ВЧК и Всеукраинской Чрезвычайной комиссии (ВУЧК), а кроме того, показывают отношение такого видного советского военно-политического деятеля, как М. В. Фрунзе, к массовому террору - вопрос, который длительное время оставался дискуссионным. Наконец, по этим бумагам можно проследить идейную эволюцию самого героя документов, видного чекиста Е. Г. Евдокимова, прошедшего непростой путь от сторонника эсеров и анархистов до большевика и активного участника ликвидации анархического подполья в Москве и руководителя борьбы с махновцами на Украине. В силу этого их публикация представляет интерес.

В моей книге «Семь “почему” российской Гражданской войны» содержалось краткое упоминание о крымских расстрелах с указанием 
на то, что, по заслуживающим доверия данным, было расстреляно не менее 12000 человек ${ }^{21}$. При этом я ссылался как на наградные документы Е. Г. Евдокимова, хранящиеся в РГВА, так и на монографии А. Л. Литвина о терроре Гражданской войны, а также М. А. Тумшиса и А. А. Папчинского о работниках госбезопасности, кроме того, приводилась ссылка на книгу Л. М. Абраменко, содержащую публикацию списков части расстрелянных.

При обсуждении моей книги один из читателей поднял вопрос о том, что формулировка наградного документа Евдокимова содержит фразу не о расстреле перечисленных лиц, а об их изъятии. Соответственно, был поставлен под сомнение факт расстрела такого количества людей.

К сожалению, наградные документы Евдокимова исследователями публиковались фрагментарно, причем те или иные авторы не всегда обращались к первоисточнику, что дало повод для подобных вопросов. Так, А. Л. Литвин в обобщающей работе о терроре Гражданской войны привел фрагмент наградного листа Евдокимова со смягченной формулировкой об изъятии до 12000 человек, а не об их расстреле 22. При этом Литвин не привел ссылки на архивный документ, а ссылался на то, что получил такие сведения от историка спецслужб А. А. Здановича. Другие авторы, в том числе наиболее известный на сегодня специалист по этому вопросу Л. М. Абраменко, в свою очередь, ссылались на работу Литвина ${ }^{23}$. Наконец, иную формулировку документа с указанием на расстрел привели в своем интересном исследовании М. А. Тумшис и А. А. Папчинский, ссылавшиеся на личное дело Евдокимова, хранящееся в Омске ${ }^{24}$. Однако остался не проясненным вопрос, почему в одном случае указывалось «изъяты» и что это означает. Чтобы ответить на этот вопрос, пришлось вновь обратиться к наградным документам Евдокимова и подготовить их публикацию, которая устраняет вопросы и сомнения.

При каких обстоятельствах появились эти документы? В 1921 г. был поднят вопрос о награждении начальника Особого отдела ВУЧК Е. Г. Евдокимова орденом Красного знамени. Заслуги Евдокимова носили специфический характер - чекист активно участвовал в ликвидации антисоветского подполья, различных банд и принимал деятельное участие в проведении массового террора в Крыму после ухода белых. Все это потребовало особого порядка рассмотрения наградного представления и породило публикуемые документы.

Первоначальные аттестационные документы Евдокимова не удовлетворили главнокомандующего всеми вооруженными силами 
Украины и Крыма М. В. Фрунзе, который поручил составить дополнительную аттестацию на Евдокимова, что и было сделано к 12 мая 1921 г. $^{25}$ Затем 10 июня 1921 г. М. В. Фрунзе через своего старшего адъютанта С. А. Сиротинского отправил представление на Евдокимова заместителю председателя Реввоенсовета республики Л. Д. Троцкого Э. М. Склянскому ${ }^{26}$. Благодаря этому обращению наградные документы Евдокимова сохранились в архиве Склянского и доступны для изучения.

Документы представляют собой машинопись с рукописной правкой. В весьма секретном отношении Особого отдела Всеукраинской ЧК командующему всеми вооруженными силами Украины за № 6838/ общ., датированном 21 апреля 1921 г., вр. и. д. начальника Особого отдела ВУЧК С. С. Дукельский отмечал: «Особый отдел Всеукраинской Чрезвычайной комиссии считает необходимым ходатайствовать перед командованием всеми Вооруженными силами Украины о награждении орденом "Красного знамени” начальника Особ[ого] отдела ВУЧК тов. Евдокимова Ефима Георгиевича.

Тов. Евдокимов происходит из пролетарской семьи. Принимая непосредственное участие в революционном движении с 1905 года в сформированной читинским исполкомом дружине, при разгроме Читинской республики в январе 1906 года тов. Евдокимов был ранен в обе ноги. В 1908 году он был арестован и предан суду по 102 ст. Уг[оловного] Ул[ожения] и осужден на 4 года каторги, но как не достигшему 17 лет каторга заменяется ему 3 годами тюремного заключения, которые т. Евдокимов отбыл в Верхнеудинском централе. Выйдя из тюрьмы, т. Евдокимов продолжает начатое дело, и спустя 5 месяцев после выхода из тюрьмы в 1911 году он снова арестовывается по обвинению в возбуждении против “царского правительства" гарнизона на Березовке (близ Верхнеудинска) и высылается из пределов Иркутского генерал-губернаторства на Урал. Оттуда т. Евдокимов бежал на Дальний Восток, где с прежней энергией продолжал революционное дело на заводах, копях и среди моряков Владивостока, Хабаровска и Благовещенска, пока он был снова арестован и выдворен на Урал. За это время т. Евдокимов состоял в группе c.-p. ${ }^{27}$, затем, ввиду расхождения, примкнул к анархо-синдикалистическому течению, принимал участие в ряде террористических актов против руководителей Нерчинской каторги, как член Сибирского летучего отряда ставил типографии и пр. Империалистическая война застает тов. Евдокимова на Урале, откуда он в 1915 году перебирается нелегально в Москву и входит в анархо-синдикалистскую группу Лефортовского района (эта 
группа тесно соприкасалась в своей работе с большевистской группой Замоскворечья). 9-го января организуется т. Евдокимовым демонстрация, после которой ему как дезертиру и преследуемому пришлось скрыться на Кавказ, где его застает Февральская революция, в которой он принимает самое энергичное участие. После этого т. Евдокимов отправляется на Родину, вступает в 12-й Сибирский запасный полк, избирается председателем полкового комитета и ведет работу под флагом “беспартийного", так как он стоит на рубеже вступления в коммунистическую партию. Октябрьские события застают его в Москве, где, состоя председателем Революционного комитета Центросоюза, он принимает в них живейшее участие и непосредственно ведет работу на баррикадах в рядах Красной гвардии Лефортовского района.

После переворота т. Евдокимов работает в[о] ВЦИК в должности заведывающего распорядительным отделом (впоследствии справочным отделом), оттуда председатель ВЦИК тов. Свердлов командирует т. Евдокимова в академию Генштаба ${ }^{28}$.

В 1918 году т. Евдокимов вступает в Коммунистическую партию, проявив себя преданным делу революционной работы.

Из академии Генштаба он был отозван ЦК РКП для работ в тылу у Колчака, но туда он не поехал в связи с изменившейся военной обстановкой, после чего т. Евдокимов командируется ЦК РКП в распоряжение председателя ВЧК т. Дзержинского и назначается начальником Особого отдела МЧК, где, работая в период 1919 года, участвовал в ликвидации Национального Центра (аресты школ: Высшей артиллерийской, маскировки, стрелковой и др. ${ }^{29}$ и ликвидации анархистов подполья, произведших покушение в Леонтьевском переулке (дача в Краскове $)^{30}$.

В конце 1919 года т. Евдокимов командируется с председателем Всеукраинской Чрезвычайной комиссии т. Манцевым ${ }^{31}$ на Украину, где $4^{\text {го }}$ января 1920 года вступил в исполнение обязанностей его заместителя по Особ[ым] органам на Украине вначале Юго-Западного фронта, Южного - Юг[о-]Зап[адного] фронтов ${ }^{32}$ и ныне - Особ[ого] отдела Цупчрезкома Украины ${ }^{33}$ с 12 января 1921 г. (приказ № 1 § 1).

Создав могучий военно-контрразведывательный и охранный аппарат Красной армии по розыску и расправе над контрреволюцией, т. Евдокимов своим личным и непосредственным участием в руководстве административной и оперативной сторонами работ и, порой, личным участием в ликвидации вынес на своих плечах титанический этап борьбы с организованной контрреволюцией, пытавшей[ся] орга- 
низовать восстания, подпольные боевые дружины, шпионские организации и успешно почти все в свое время ликвидированные.

Безустанно днем и ночью т. Евдокимов со своим аппаратом, внедряясь вовремя в контрреволюционные кружки и группировки, ликвидировал на Украине непосредственно своим аппаратом (кроме особ[ых] органов на местах) до 6 организаций врангелевского оттенка, до 15 организаций петлюровского типа, до 5 организаций “польских военных организаций”, до 10 махновского типа организаций, до 15 банд разложены и ликвидированы, больше 100 отдельных шпионов румынских, польских, врангелевских, махновских, петлюровских выловлены.

За 1920 год аппарат Особ[ого] отдела под руководством т. Евдокимова разобрал дел: по шпионству 108, по контрреволюции - 289 , по польской контрреволюции - 66, по петлюровщине - 25, по махновщине - 17, за службу у белых - 800, за службу в контрразведке - 21, по бандитизму — 112, за восстания - 28, по уголовщине и разным делам - больше 2000.

В этих делах фигурируют ликвидированные громкие дела польских шпионских организаций "ПОВ”34, врангелевских организаций в Харькове, Одессе, 13-й армии. Петлюровских организаций: “Центральный повстанческий комитет”, где арестован был почти весь кабинет $\mathrm{YHP}^{35}$, Повстанком на Полтавщине, комитет вызволения Украины и пр.

Предпринятой экспедицией под руководством т. Евдокимова в Крыму был очищен Крымский полуостров от оставшихся врангелевцев и в результате были расстреляны до 12000 человек, из коих до 30 губернаторов, больше 150 генералов, больше 300 полковников, несколько сот контрразведчиков, шпионов, в результате предотвращена была возможность появления в Крыму белых банд.

Предпринятой непосредственно под руководством т. Евдокимова экспедицией в 13[-ю] армию во время отступления нашей армии и успешного продвижения ${ }^{36}$ Врангеля в Донбасс был основательно очищен состав армии в верхушках и низах и в районе территории армии, что в значительной мере способствовало победоносному движению армии вперед.

Участием в экспедиции в Полтавщине против Махно т. Евдокимов заложил веское начало борьбы организованной с Махно, результатом чего успешнее стало внедрение в тылу к Махно $^{37}$ для разложения его частей.

Подводя итог проделанной работе Особ[ого] отдела во главе с т. Евдокимовым, можно сказать с удовлетворением, что долг перед ре- 
волюцией выполнен этим аппаратом блестяще и первый этап борьбы с контрреволюцией на Украине вынесен на плечах Особ[ого] отдела под руководством т. Евдокимова с успехом. Контрреволюция не сумела соорудить ни одного серьезного выступления, и все ее начинания в зародыше и в корне разбивались стоящим на страже испытанным борцом рабочей революции.

Т. Евдокимов родился 20 января 1891 г. в гор. Копале» ${ }^{38}$.

На документе имеется трудночитаемая карандашная резолюция М. В. Фрунзе, которую удалось расшифровать после изучения скана документа в высоком разрешении: «Сек[ретариа]т. Знаю, что своей работой т. Евдокимов вполне заслужил право на признательность Республики. Но награждение "Кр[асным] зн[аменем]" требует одного момента - личного участия в какой-нибудь [?] операции сопряженно с опасностью для жизни. Предлагаю дать аттестацию именно с этой стороны. Что же касается общей деятельности как руководителя Особ[ого] отдела, то этот момент решающего значения согласно установившейся практике не представляет. М. Фрунзе ${ }^{39}$.

Помимо ходатайства Дукельским был составлен наградной лист, в котором было учтено замечание М. В. Фрунзе и содержалась иная формулировка (ранее составленное отношение прилагалось к наградному листу): «Особый отдел Всеукраинской Чрезвычайной комиссии ходатайствует перед главным командованием всех Вооруженных сил на Украине о награждении начальника Особого отдела Всеукраинской Чрезвычайной комиссии тов. Евдокимова Ефима Георгиевича орденом “Красного знамени”.

В 1919 году, в чрезвычайно опасный момент для Советской республики, т. Евдокимов, будучи начальником Особого отдела Московской Чрезвычайной комиссии, принимает непосредственное участие в ликвидации крупнейшей организации, возглавлявшей все белогвардейское контрреволюционное движение в России (аресты высшей школы артиллерийской, высшей стрелковой школы и школы маскировки с опасностью для жизни), — “Национальный центр”.

В том же году т. Евдокимов принимает участие в ликвидации анархистов подполья, произведших покушение в Леонтьевском переулке, и, невзирая на опасность от взрывавшихся бомб и сильной перестрелки, смело ликвидирует штаб анархистов на даче Краскова ${ }^{40}$.

В 1920 году, находясь с экспедицией в Полтавщине в разгар махновского повстанческого движения, руководил постановкой агентурно-разведывательных аппаратов и помимо специального задания принимал участие со своим отрядом в операциях против бандитов. 
Тов. Евдокимов создал дисциплинированный боевой отряд особого назначения, который в течение всего 1920 года принимал участие в целом ряде операций против бандитизма и, главным образом, против Махно.

Тов. Евдокимов создал образцовый аппарат Особ[ого] отдела, который в течение всего 1920 года без отдыха громил контрреволюцию в тылу: ликвидировал до 50 организаций белогвардейских шпионских, подпольно-боевых и подрывных, разложил 6 банд и систематически производил чистку Красной армии.

Тов. Евдокимов организовал и руководил экспедицией по очистке 13-й армии от белогвардейского элемента в период катастрофического отступления 13-й армии и стремительного наступления Врангеля, что в значительной степени повлияло на состояние армии и ее дальнейшее движение вперед.

Во время разгрома армии ген. Врангеля в Крыму тов. Евдокимов с экспедицией очистил Крымский полуостров от оставшихся там для подполья белых офицеров и контрразведчиков, изъяв до 30 губернаторов, 50 генералов, более 300 полковников, столько же контрразведчиков и в общем до 12000 белого элемента, чем предупредил возможность появления в Крыму белых банд» ${ }^{41}$.

На наградном листе имелась резолюция М. В. Фрунзе: «Т. Склянскому. Считаю деятельность т. Евдокимова заслуживающей поощрения. Ввиду особого характера этой деятельности проводить награждение в обычном порядке не совсем удобно. Поддерживая ходатайство, направляю его непосредственно Вам. Команд[ующий] войск[ами] Укр[аины и Крыма] М. Фрунзе» ${ }^{42}$. В том же году Евдокимова наградили на основании приказа РВС республики № 264.

Итак, как удалось установить, документы с формулировкой о расстреле и смягченный вариант с формулировкой об «изъятии» были составлены почти одновременно одними и теми же людьми. Следовательно, разночтение не носит принципиального характера.

Одобрение заслуг Евдокимова со стороны М. В. Фрунзе показательно. Дело в том, что еще 11 ноября 1920 г. Фрунзе обратился к врангелевцам с радиограммой и предложением сдаться с возможностью «искупить свою вину перед народом честным трудом» ${ }^{43}$. Вместо ответа генерал Врангель распорядился прервать радиосвязь ${ }^{44}$. 12 ноября глава советского правительства В. И. Ленин телеграфировал в РВС Южного фронта, что «крайне удивлен непомерной уступчивостью условий» Фрунзе ${ }^{45}$. В случае непринятия белыми этих предложений Ленин предлагал больше не повторять их и «расправиться беспощадно» ${ }^{46}$. 
Радиограмма закрепила за Фрунзе определенный ореол гуманиста, однако публикуемые резолюции свидетельствуют о том, что он, как и другие видные большевистские деятели, считал акцию массового террора заслуживающей поощрения и лишь беспокоился о том, что осуществлять такое награждение обычным порядком «не совсем удобно».

Легкость превращения в двух редакциях наградного представления 50 генералов в 150 генералов не позволяет считать наградные документы абсолютно точным отчетом о численности расстрелянных. Однако они показывают, что массовый террор расценивался руководством ВУЧК как заслуживающий награждения подвиг. Кроме того, общее представление о документированном размахе крымского террора публикуемые материалы все же дают. В документах представлена минимальная из известных цифр репрессированных, которая представляется заслуживающей доверия. При этом следует учитывать, что это наградное представление только на одного руководящего чекистского работника, которое вполне может касаться только жертв Крымской ударной группы при Особом отделе ВЧК Юго-Западного фронта, которой руководил Евдокимов. Следовательно, масштаб жертв репрессий может быть выше. Окончательный ответ на этот вопрос в будущем даст только серьезная работа с архивами органов ЧК и поименный учет жертв.

\section{ПРИМЕЧАНИЯ}

1 Неизвестная телеграмма Л. Д. Троцкого Реввоенсовету Южного фронта // Военно-исторический журнал. 1990. № 7. С. 73. При публикации не был указан шифр хранения этой переписки.

2 Там же. С. 74.

3 Ф. Э. Дзержинский - председатель ВЧК-ОГПУ. 1917-1926. Сб. док. М., 2007. С. 215.

4 Там же. С. 220.

5 Сорокин А., Григорьев Е. «Красный террор омрачил великую победу Советской власти...» Два взгляда большевистских руководителей на репрессии в Крыму // Родина. 2016. № 8. С. 119.

6 Реабілітовані історією. Автономная республика Крым. Симферополь, 2004. Кн. 1. С. 58.

7 Там же. С. 59.

8 Обзор литературы см.: Соколов Д. В. «Железная метла метет чисто...» Советские чрезвычайные органы в процессе осуществления политики красного террора в Крыму в 1920-1921 гг. М., 2017. С. 240-244. 
9 Мельгунов С. П. Красный террор в России 1918-1923. М., 1990. C. 66 .

10 Красный террор в годы Гражданской войны. По материалам Особой следственной комиссии по расследованию злодеяний большевиков / Сост. Ю. Г. Фельштинский, Г. И. Чернявский. М., 2013. С. 298-299.

11 Булдаков В. П. Красная Смута. Природа и последствия революционного насилия. М., 2010. С. 506.

12 «Россия опять может очутиться перед фактом потери Крыма...» (докладная записка М. Султан-Галиева) / Публ. С. А. Усова // Крымский архив (Симферополь). 1996. № 2. С. 86.

13 Тепляков А. Г. Чекисты Крыма в начале 1920-х гг. // Вопросы истории. 2015. № 11. С. 140.

14 Зарубин А. Г., Зарубин В. Г. Без победителей. Из истории Гражданской войны в Крыму. Симферополь, 2008. С. 692.

15 Скоркин К. В. На страже завоеваний революции. История НКВДВЧК - ГПУ РСФСР. 1917-1923. М., 2011. С. 906.

16 Русская военная эмиграция 20-40-х годов. Документы и материалы. М., 1998. Т. 1. Так начиналось изгнанье. 1920-1922 гг. Кн. 1. Исход. C. 406.

17 Там же. С. 407-408.

18 Керчи и Феодосии.

19 Русская военная эмиграция 20-40-х годов. Документы и материалы. М., 1998. Т. 1. Так начиналось изгнанье. 1920-1922 гг. Кн. 1. Исход. C. $235-236$.

20 Подробнее о Е. Г. Евдокимове см.: Шаповал Ю., Пристайко В., Золотарьов В. ЧК-ГПУ-НКВД в Україні: особи, факти, документи. Київ, 1997. С. 79-116; Тумшис М. А., Папчинский А. А. 1937. Большая чистка. НКВД против ЧК. М., 2009. С. 140-273; Тумшис М. А. Щит и меч Советского Союза. Краткие биографии руководителей органов государственной безопасности СССР и союзных республик (декабрь 1922 - декабрь 1991 гг.). М., 2016. С. 147-153.

21 Ганин А. В. Семь «почему» российской Гражданской войны. М., 2018. C. 77.

22 Литвин А. Л. Красный и белый террор в России. 1918-1922 гг. M., 2004. C. 105.

23 Абраменко Л. М. Последняя обитель. Крым, 1920-1921 годы. Киев, 2005. С. 8-9.

24 Тумшис М. А., Папчинский А. А. 1937. Большая чистка. НКВД против ЧК. М., 2009. С. 152-153.

25 РГВА. Ф. 33988. Оп. За. Д. 41. Л. 302. 
26 Там же. Л. 301.

27 Эсеров.

28 Е. Г. Евдокимов обучался до мая 1919 г. на так называемом параллельном курсе академии Генерального штаба РККА.

29 Подробнее о деле антибольшевистской подпольной организации «Национальный центр» см.: Красная книга ВЧК. М., 1989. Т. 2; Всероссийский Национальный центр. М., 2001; Тактический центр. Документы и материалы. М., 2012. О военной составляющей см.: Ганин $A$. B. «Мозг армии» в период «Русской Смуты»: Статьи и документы. М., 2013. C. 644-694.

30 Речь идет о взрыве в помещении московского комитета РКП(б) в Леонтьевском переулке 25 сентября 1919 г., в результате которого погибли 12 (в том числе секретарь комитета В. М. Загорский) и были ранены 55 человек. Организаторами взрыва оказались анархисты-подпольщики. В ночь на 5 ноября 1919 г. чекисты окружили дачу в поселке Красково под Москвой, где находилась штаб-квартира анархистов, типография и лаборатория для изготовления бомб. После двухчасового боя анархисты подожгли и взорвали дачу. При взрыве погибли шесть человек. Восемь организаторов взрыва были расстреляны по постановлению Московской ЧК. Подробнее см.: Красная книга ВЧК. М., 1989. Т. 1. С. 311-400; Голинков Д. Л. Крушение антисоветского подполья в СССР. Изд. 3-е. М., 1980. Кн. 1. С. 298-302.

31 Манцев Василий Николаевич (05.03.1889-19.08.1938) - начальник управления ЧК и Особых отделов ВЧК на Украине (с 12.1919), начальник Особого отдела Юго-Западного фронта (12.1919-05.1920), член коллегии НКВД УССР (03.1920-03.1922), начальник Центрального управления чрезвычайных комиссий Украины по борьбе с контрреволюцией и саботажем (03.1920-04.1921), заместитель начальника Особого отдела и тыла Юго-Западного фронта (05-07.1920), начальник Особого отдела и тыла Юго-Западного и Южного фронтов (с 07.1920). Председатель ВУЧК (с 04.1921).

32 Е. Г. Евдокимов занимал пост заместителя начальника Особого отдела Юго-Западного фронта (с 01.1920), начальника Особого отдела Юго-Западного фронта (с 08.1920), начальника Особого отдела Юго-Западного и Южного фронтов (11.1920-01.1921), начальника Крымской ударной группы.

33 Центральное управление чрезвычайных комиссий Украины по борьбе с контрреволюцией и саботажем.

34 ПОВ (Polska Organizacja Wojskowa) - польская военная организация. 
35 Украинской народной республики.

36 В документе - успешному продвижению.

37 В документе - в Махно.

38 РГВА. Ф. 33988. Оп. За. Д. 41. Л. 303-304.

39 Там же. Л. 303.

40 Правильно - Красково.

41 РГВА. Ф. 33988. Оп. За. Д. 41. Л. 305.

42 Там же.

43 М. В. Фрунзе на фронтах Гражданской войны. М., 1941. С. 440.

44 Врангель П. Н. Воспоминания. Южный фронт (ноябрь 1916 г. ноябрь 1920 г.). М., 1992. Ч. 2. С. 422.

45 The Trotsky papers 1917-1922 / Edited and annotated by J. M. Meijer. Hague; P., 1971. Vol. 2. P. 356.

46 Ibidem.

\section{A. V. Ganin}

Award documents of the CheKa functionary E. G. Evdokimov as a source on the history of All-Ukrainian Extraordinary Commission and Red Terror in Crimea in 1920-1921

The article analyzes the award documents of the head of the Special Department of all-Ukrainian CheKa E. G. Evdokimov as a source on the history of Red Terror in Crimea in 1920-1921 and in relation to the activities of Ukrainian CheKa officers. To date, these materials are the only known departmental evidence of the scale of the Crimean executions. In addition, of interest is the perception of these events by the commander-in-chief of all armed forces of Ukraine and Crimea M.V. Frunze, who left two resolutions on the documents.

Keywords: Civil war in Russia, Crimea, Ukraine, Red Terror, allUkrainian CheKa. 


\title{
Судьба русского киевлянина: \\ письма С. Ю. Кулаковского А. И. Соболевскому \\ (Революция, Гражданская война, первые годы эмиграции)
}

\begin{abstract}
В статье на основании архивных источников описываются события Революции и Гражданской войны в Киеве, восприятие их молодым ученым С. Ю. Кулаковским. Анализ его писем А. И. Соболевскому позволяет также представить научные интересы Кулаковского, выяснить причины, побудившие его эмигрировать в Польшу.

Ключевые слова: Сергей Кулаковский, А. И. Соболевский, B. Н. Перети, Киев, Револючия и Гражданская война, украинизачия, Сказания о Римской иконе Богоматери.
\end{abstract}

DOI: $10.31168 / 2073-5731.2018 .3-4.2 .04$

Сергей Юлианович Кулаковский (1892-1949) происходил из профессорской семьи. Его отец Юлиан Андреевич Кулаковский (18551919) - известный филолог-классик, специалист по истории Римской и Византийской империй, заслуженный профессор Императорского университета св. Владимира, многолетний председатель Исторического общества Нестора Летописца при университете (1908-1919), член-корреспондент Академии наук - был убежденным монархистом, в 1909 г. избран в Совет Киевского клуба русских националистов. Известный славист Платон Андреевич Кулаковский (1848-1913) приходился Сергею дядей.

Возможно, последнее обстоятельство подвигло Сергея Кулаковского выбрать для получения высшего образования славяно-русское отделение Киевского университета, и здесь он стал членом семинария, которым руководил В. Н. Перетц. Не исключено, что такому решению поспособствовали и дружеские отношения А. И. Соболевского с Ю. А. Кулаковским, поэтому академик живо интересовался университетскими делами С. Кулаковского. Когда Сергей решил изменить выбранное направление в образовании, ученый его не одобрил. «Официально я перехожу на романскую специальность, - сообщал С. Кулаковский Соболевскому 8 января 1914 г., — к этой перемене привело меня много обстоятельств и отчасти желание воспользоваться своей 
привилегией - знанием языков; В. Н. Перетц не имел ничего против этого перехода. Папа передал Ваши слова о том, чтобы я не менял своей специальности; меня это очень озадачило и заставило сомневаться в правильности выбора пути. На славяно-русском отделении мною сдано три реферата, все 19 экзаменов; осталось только прослушать славянские языки и литературы, кроме сербохорватской, что я и сделаю» ${ }^{2}$ Таким образом, Кулаковский прислушался к совету Соболевского, но решил совместить учебу на историко-филологическом факультете Петербургского университета и закончить славяно-русское отделение в Киеве. При этом Кулаковский не просто продолжал обучаться в Киеве, но начал и исследовательскую работу, постоянно консультируясь с Соболевским. Так, в письме от 28 июня 1914 г. он сообщал академику, что «обдумывал» его «указания» при своих занятиях над текстом Сказания о Римской иконе Богоматери (л. 4, 6).

Своими впечатлениями о работе молодого ученого Соболевский делился с коллегами и друзьями семьи Кулаковских. Это мнение доходило и до Сергея. Он писал Соболевскому 12 января 1915 г.: «От В. С. Иконникова* узнал Ваше мнение о моем педантизме. Следуя, конечно, Вашему совету, оставил мысль просмотреть все списки, но почти две трети уже просмотрены и дают полную картину истории текста» (л. 7). В том же письме Кулаковский сообщал и о продолжении обучения в Киеве: «Надеялся во время праздников окончить реферат и прочесть Перетцу, но это все расстроилось» (л. 7). А в ноябре 1916 г. Кулаковский был оставлен на кафедре романо-германской филологии Петроградского университета для приготовления к профессорскому званию².

Февральскую революцию Кулаковский встретил в Киеве. По прошествии месяца, 23 марта 1917 г., он делился впечатлениями с Соболевским. Случившееся стало шоком для семейства Кулаковских и их ближайших коллег и друзей, также принадлежавших по своим убеждениям к русским консервативным кругам киевского общества. Так, об отце Кулаковский писал: «Дней десять он хворал, даже лежал в постели, что для него редкость. Сильно потрясли его события. Да кого не потрясли они!» (л. 14об.-15). А Т. Д. Флоринский"** имел все основания ожидать репрессий от новых властей. «Тимофей Дмитриевич, - сообщал он, - опасался за свою свободу, но это не оправдалось» (л. 15). Возможно, отсутствие репрессий Кулаковский объяснял тем, что, по его мнению, «украинский сепаратизм торжествует пока

* Иконников Владимир Степанович (1841-1923) - историк, академик (1914).

** Флоринский Тимофей Дмитриевич (1854-1919) — историк-славист, филолог. 
в теории» (л. 13об.). Очень скептически отзывался молодой ученый о ситуации в Киевском университете. «Конечно, не иметь права участвовать здесь в университетской жизни очень обидно, - отмечал он, - однако это такой хаос, в котором тяжело находиться. 1905-й и следующие года не научили студенчество самостоятельно и разумно мыслить, все то же стадо, которое умные рабочие даже вразумляли» (л. 14-14об.). В общем, ничего хорошего от революционных перемен Кулаковские не ожидали. «Законы в России ныне меняют депутаты Петрограда, — подытоживал Сергей, — они вершат судьбами всех граждан без их согласия. Захватное право процветает всюду» (л. 14). Однако все бурные общественные перемены не мешали Кулаковскому думать и о своих учебно-научных делах. Он благодарил Соболевского за помощь в организации публикации его заметки в «Русском филологическом вестнике». Его беспокоило положение на фронте, от которого также зависели его планы. «Если не будет прорыва, — писал он, то все же не теряю надежды быть в Петрограде к началу мая, чтобы продолжить собирание литературы о Феофиле", представить отчет и объяснение Д. К. Петрову ${ }^{* *}$; все же он мой патрон» (л. 15).

Но киевское сообщество молодых гуманитариев не забыло, кто был первым учителем Кулаковского. Так, он отмечал: «Ученики В. Н. Перетца предложили мне принять участие в сборнике, издаваемом к 25-летию научной деятельности» (л. 15об.).

Если Кулаковский просто констатировал «хаос», царивший в действиях студенчества, то коллега Перетца А. М. Лобода, будущий академик ВУАН (1922), в апреле ${ }^{* * *}$ так описывал внутреннее нестроение в университете: «Боюсь, немало путаницы внесет и украинский вопрос, студенты-украинцы начали с очень радикальной постановки его, до полной украинизации Ун[версите]та включительно, и притом чуть не с будущего же учебного года. На этой почве на нашем факультете между студентами начался даже острый раскол, но потом как будто: острота стала исчезать, - надолго ли?» ${ }^{3}$ Надо, однако, заметить, что сам

* Скорее всего речь идет о Феофиле (Теофиле) Аданском, монахе, поддавшемся искушению и отрекшемся от Христа и Девы Марии, но раскаявшемся и прощенном благодаря заступничеству Богородицы. Уже в эмиграции Кулаковский опубликовал в 1926 г. в варшавском еженедельнике «Воскресное чтение» статью «Чудо о Богоматери и Феофиле».

** Петров Дмитрий Константинович (1872-1925) - филолог-медиевист, профессор Петроградского университета по романским языкам, истории испанской и французской литератур.

*** Письмо датируется по отметке Перетца: «Получ. 13.IV.1917». 
ученый был сторонником постепенной украинизации, но видел в этом деле серьезные препятствия со стороны большинства университетских коллег. Он подчеркивал: «В ближайшем заседании ф[акульте]та думаю поднять вопрос об украинских кафедрах, согласно распоряжению Мануйлова; осуществить бы их [нрзб] надо было, но Вы знаете и наш факультет, и наш совет. Если же и кафедры провалятся, тогда в будущем уч[ебном] году совсем плохо будет. Поживем - увидим» ${ }^{4}$.

В следующем письме Соболевскому от 29 мая Кулаковский вначале обратился к своим научным делам, благодаря за «покровительство» и прося «указаний» по источникам и литературе (л. 16-16об.). Его продолжало волновать душевное состояние отца, в котором можно предположить начало тяжелой депрессии. «С большим интересом читаем Ваши письма, - писал Кулаковский, - чувствуем, что Вы бодры, несмотря на события. Папе прямо необходимо возможно чаще получать от Вас вести. Он их ждет всегда. Нервы его расшатаны до крайности, стонет и часто желает смерти. Помочь ничем нельзя - везде один развал, но никто так страшно не отчаивается, как он» (л. 17об.-18). Сын, по-видимому, надеялся на то, что летний отдых улучшит состояние отца. «...собираемся к Муретовым* в Черниговскую губ[ернию], но и туда трудно добраться» (л. 18), — писал Кулаковский.

Кулаковский вновь вкратце останавливался на описании общей обстановки: «В Киеве пока сравнительно тихо. Приезжие облегченно вздыхают. Украина действует. Полки и прочее шумят знаменами, устраивают сборы на улицах» (л. 18). Далее он вновь обращался к более волновавшей его теме, юбилею своего учителя. «Кстати о В. Н. Перетце, писал Кулаковский. - Готовился сборник ко дню 25-летия от киевлянсеминаров, значит, и от меня; сам Перетц через промежуточное лицо поставил странное условие: принять в киевский сборник его каких-то питерских учеников. Это вызвало бурю негодования». По-видимому, чтобы скрыть свою ревность к новым ученикам Перетца, киевляне представили следующее объяснение своей позиции, они «ответили, что чествуемый не может распоряжаться чествующими». Была предприня-

* В Черниговской губернии находилось имение семьи Муретовых, хутор Вернигоровщина. Имением управляли Д. Д. Муретов и его жена Наталья Платоновна, старшая дочь П. А. Кулаковского, приходившаяся племянницей Ю. А. Кулаковскому и двоюродной сестрой С. Ю. Кулаковскому. См. подробнее: Гузь Б. Судьбы дворян Муретовых // URL:http://www.proza.ru/2017/04/16/898 (дата обращения: 1.09.2017). 
та попытка обеспечить финансовую основу предприятия. Кулаковский отмечал: «...собирали деньги. Но 50 р. за 12 стр. ныне недостаточно, а просят 120-140 за набор один, отчего публика жмется, и ничего не выйдет из всего предприятия» (л. 18-18об.). В своем предположении Кулаковский оказался прав, сборник так и не состоялся.

Что касается своих киевских учеников, то Перетц с некоторым сарказмом писал А. А. Шахматову 24 февраля 1914 г. после своего избрания академиком: «Если мое дело пройдет в высшей инстанции и я переселюсь в СПб., то я не смогу перетащить сюда моих киевлян! Они - ужасные буржуи и любят хорошо питаться, и иметь верный заработок, а что я его достану им?! Здесь же в Киеве они имеют не менее 11/2-2-х тысяч каждый в среднеуч[ебных] завед[ениях], а также некот[орые] и на курсах. Поехать могут в Киев" ${ }^{*} 1-2$ челов[ека], значит, надо создавать новые кадры ${ }^{5}$. Однако Перетц внимательно следил за научными и карьерными успехами своих учеников. Информировал его об этом все тот же А. М. Лобода. К 1917 г. большинство из них не только закончило магистерские экзамены, но и в качестве приват-доцентов приступило к чтению лекций в университете. Сообщая о положении дел у одного из них, Лобода писал: «...у Сушицкого почти готова диссертация и как раз из области укр[аинской] литературы». Кроме того, он констатировал появление новых политических обстоятельств, которые могут поспособствовать получению искомого места в университете. «Наконец, — отмечал Лобода, — в пользу Сушицкого и то, что его кандидатура наиболее желанна и с точки зрения местных укр[аинских] кругов» ${ }^{6}$.

Однако для Кулаковского эти новые обстоятельства могли создать только проблемы, о чем он и писал Соболевскому 24 июля 1917 г. из поместья Муретовых, куда семья Кулаковских все-таки смогла выехать на отдых: «Устраиваться в Киеве при наличности украинизма (моя фамилия не может быть приятна высшей нынешней “администрации"), а также при связи с Петроградом, я не считал возможным» (л. 20). Кулаковский явно полагал, что активное участие отца в деятельности Киевского клуба русских националистов не могло в новых условиях поспособствовать его карьере. Но скорое возвращение в Петроград также уже не входило в его планы по нескольким причинам. «Уезжая из Киева на лето, - писал Кулаковский, — я думал, что осенью поеду с отчетом в Петроград, чтобы там или всю осень прожить, или, побывавши в библиотеках и у Д. К. Петрова, отправиться

* Это явная описка, следует читать «Петербург». 
с книгами и наставлениями в Киев. За это время положение России настолько ухудшилось и продовольственное дело так запуталось, что без явно-крайней необходимости и двигаться в столицу не имеет нужды: все равно в беспокойной петроградской атмосфере наука и занятия процветать не могут» (л. 19-19об.). Невозможность найти какой-либо заработок беспокоила Кулаковского («стипендии я не получаю»). В этой ситуации он надеялся на советы Соболевского. «Понимаю, - писал он, - что теперь многие живут сегодняшним днем, ничего не предпринимая. Но я как раз очутился на перепутье и ничего не могу придумать на близкое будущее» (л. 20-20об.). Беспокоило его и душевное состояние отца. «Папа по-прежнему нервничает, - писал Кулаковский, - в природе он скучает, чего раньше не было. Опасается за судьбу Киева в ближайшем будущем, но, кажется, пока локализована катастрофа, хотя отступление продолжается, и анархия уже успела проявить себя довольно властно» (л. 20об.).

Вскоре, в конце июля или начале августа*, Кулаковский сообщал Соболевскому о подготовке семьи к возвращению в Киев. Он описывал общую ситуацию в губернии: «Здесь украинизация еще не чувствуется. Только много солдат гуляет». Писал и о неутешительных продовольственных перспективах: «У крестьян хлеба в этот год так мало, что они в испуге увеличивают запашки, говоря, что в этот период девяти месяцев будет трудно прокормиться. А что повезут в города?» Описывал и настроение членов семьи: «Ваши письма всегда бодрят папу, он их ждет с большим нетерпением, особенно в те дни, когда чувствует себя подавленнее. Кузина Наташа по-прежнему бодрится, одна хозяйничает везде; просила передать Вам свои поклоны» (л. 78об.).

В сентябре, узнав о возможной поездке Соболевского в Петроград, Кулаковский хотел выехать туда в то же самое время, чтобы встретиться с ним. Но здоровье отца повлияло на его планы. «Папу волнует теперь всякое обстоятельство, - писал Кулаковский 16 сентября, - в том числе он задумывается над моей, так давно проектируемой, поездкой. Не знаю, как быть» (л. 21-23). В итоге Кулаковский решил не отрываться от семьи и остаться в Киеве.

Несмотря на условия Гражданской войны, переписка между Киевом и Москвой продолжилась. Но не всякое письмо можно было доверить почте, она не могла гарантировать быструю доставку письма адресату; кроме того, в переписку вмешивалась цензура. Но и от-

* Письмо не датировано. 
правленные с оказией письма также могли не дойти до адресата. Свое письмо Соболевскому от 14 апреля 1918 г. Кулаковский начал с фразы: «Снова пишу Вам с оказией"; вместо папы обращаюсь к Вам, так как он не может писать теперь писем, а Вам, наверное, много сообщу я нового». Свое письмо он посвятил описанию самых разных сторон жизни Киева в новых условиях, связанных с вступлением в Киев 1 марта 1918 г. по приглашению Центральной Рады немецких войск. Случившееся в целом было воспринято Кулаковским с удовлетворением. «Наш край умиротворен, да не совсем - слишком мало здесь немецких сил, - с сожалением отмечал Кулаковский. - Большевики отброшены за Харьков, куда через 3 дня идет поезд (классный). Повидимому, верховья Днепра не предполагается переступать - как не украинские земли. В городе строгий порядок, вооруженная полиция и сторожа (часто офицеры), чистота по мере сил. Немцы ведут себя очень корректно, их патрули имеют вид очень добродушный. Жизнь течет нормально». При этом продолжал Кулаковский: «...все огромные интендантские запасы увозятся в Германию. Там нет ровно ничего; голод; тканей, железа, угля - нет; сами немцы на украинский рынок ничего не дадут; они говорят, что Германия была накануне сдачи» (л. 24).

Останавливался Кулаковский и на примерах немецкой пропаганды и ее неожиданных результатах. «Чуть было не забыл передать, писал он, - как подвели немцев русские пленные, окультуренные в украинском духе. Торжественно прибыли они сюда, одетые в синие жупаны, и должны были агитировать в пангерманском духе; однако многие обольшевичились, после чего свыше 50 чел[овек] было расстреляно, а остальные почти все увезены на западный фронт. Вести оттуда тревожные; видимо, немцы после неудачной попытки прорваться на Париж отрезали там англичан» (л. 24об.-25). Упоминал Кулаковский и издания немецкой пропагандистской литературы, распространявшиеся в Киеве, и их основную направленность. ““Иллюстрированный мир", - отмечал он, - издаваемый в Гамбурге на 12 языках, и "Русский вестник” (газета для русских пленных) проповедывают Deutschland über alles, “Одумайтесь” Толстого (по поводу войны 1904 г. еще) и ненависть к Англии, а также натравливают на царя Николая II как виновника войны». Своей качественной периодической прессы для него явно не хватало, а та, что была, вызывала только раздражение. «Русских газет “настоящих” нет, — писал Кула-

* Упомянутого письма в архиве не обнаружено. 
ковский, - (за московские платят до 500 р[у]б[лей] №). Здесь выходят дрянные газетки наряду с подлой “Киевской мыслью”; вышел 1-й вып[уск] "Малой Руси” - журнала Шульгина; “Киевлянин” закрылся уже давно. Как будто, просвета нет еще» (л. 25). Само перечисление и характеристика изданий говорит о политических пристрастиях молодого ученого. Ему, безусловно, близки правоконсервативные идеи, поэтому его огорчает закрытие «Киевлянина», газеты национально-монархического направления, редактором которой был тот же В. В. Шульгин, теперь издавший журнал, направленный против идей украинского сепаратизма. Леволиберальная же «Киевская мысль» проходит у Кулаковского по разряду «подлых» газет. О потребности в своих газетах свидетельствовало и сообщение Кулаковского: «Образовалось тут великорусское м[инистерст]во, русский союз» (л. 24об.), и та непомерная цена, которую могли заплатить за номер «московской» газеты, которая могла соответствовать на продовольственных рынках Киева более чем 130 килограммам белого хлеба («1 р[убль] 50 к[опеек] ф[унт]») (л. 24). Здесь речь могла идти только о московских газетах начала 1918 г., когда, например, в Москве еще издавалась газета «Великая Россия», позиционировавшая себя органом русской государственной и национальной мысли, или либеральная «Свобода России» (бывшие «Русские ведомости»). Относительная свобода прессы в Москве была ликвидирована 18 марта, Совет народных комиссаров принял «Постановление о закрытии московских буржуазных газет».

Сообщал Кулаковский и о важном для университетской жизни событии, кратко и верно охарактеризовав его основное содержание: «...начался съезд профессоров и преподавателей высших учебных заведений Киева, Одессы, Екатеринослава (из Харькова пока никто не прибыл) с тем, чтобы выяснить насущные вопросы (украинизация, против которой все профессора одесские, а киевские - частью, отчего университет идет на компромисс)» (л. 24об.). В специальной статье, посвященной истории Киевского университета, отмечается: «Совещание представителей высших школ Украины было громко названо участниками “съездом”. Между тем проходило оно в кабинете ректора Университета св. Владимира и объединяло менее двадцати делегатов от вузов Киева и Одессы», при этом «главным вопросом съезда был вопрос об украинизации высшей школы». И как указывают исследователи, Е. В. Спекторский*, избранный 5 апреля 1918 г. ректором

* Спекторский Евгений Васильевич (1875-1951) - правовед, декан юридического факультета и ректор Киевского университета. 
университета, «не высказывал резкого неприятия украинского языка, что было свойственно, например, декану историко-филологического факультета Киевского университета Н. М. Бубнову и профессору Новороссийского университета И. А. Линниченко» ${ }^{7}$.

Несмотря на то, что киевские газеты Кулаковский называл «дрянными», самая разнообразная информация о событиях в центральной России доходила до Киева. И сообщения эти не могли не вызывать беспокойство не только за судьбу своих коллег, но и за сохранность культурных ценностей. Так, Кулаковский отмечал: «О России слухи самые разнообразные; говорят о разгроме Патриаршей ризницы и прочих хранилищ Москвы, о петроградской голодухе и зверствах в обеих столицах» (л. 24об.). О тех же событиях Соболевскому из Киева 12 февраля писала жена академика В. С. Иконникова: «По газетам у Вас очень плохо с разными заболеваниями и голодовкой. Оправилась ли Москва после разорения? Как же это Вы не уберегли Патриаршей ризницы при существовании и наличности патриарха? Были ли Вы у него? Как московские архивы и библиотеки?» ${ }^{*}$ Исключительно уголовная история с ограблением Патриаршей ризницы явно связывалась с действиями новых властей, точно так же, как это понимали в академической среде Москвы и Петрограда. Так, Н. П. Лихачев** 24 ноября 1917 г., вскоре после случившегося ограбления, писал В. И. Срезневскому ${ }^{* * *}$ : «Думали увозить сокровища культуры и древности от немцев, а теперь вся Россия в руках таких стенько-разинцев и пугачевцев, истребляющих накопленные поколениями блага. < ..> В Москве в самом Кремле разбили Патриаршую ризницу и уничтожили часть древнего Дворцового архива — куда идти дальше» ${ }^{8}$.

Типичным для переписки этого времени стало и сообщение о положении с продовольствием. «Городская продовольственная управа, сообщал Кулаковский, — не дает хлеба, который все достают на базаре по 1 р[ублю] ф[унт] черного и 1 р[убль 50 к[опеек] ф[унт] белого (мука черная ок[оло] 30 р[ублей] п[уд], белая 45-75 р[ублей] п[уд] смотря по качеству; сахару везде много — свыше 1 р[убля] ф[унт], но по карточ-

* РГАЛИ. Ф. 449. Оп. 1. Д. 176. Л. Зоб. В архиве этот документ ошибочно отнесен к письмам В. М. Истрина, что привело к воспроизведению этой ошибки в нескольких публикациях О. В. Никитина, посвященных А. И. Соболевскому. См., например, последнюю: Никитин О. В. Наследие академика А. И. Соболевского в научной культуре России (к 160-летию со дня рождения) // Вестник РУДН. Серия: Русский и иностранные языки и методика их преподавания. 2017. Т. 15. № 4. С. 382.

** Лихачев Николай Петрович (1862-1936) - историк и искусствовед. *** Срезневский Всеволод Измайлович (1867-1938) — археограф, литературовед. 
кам)» (л. 24). При этом он отмечал: «Живем замкнуто — каждый город своей жизнью. Одесса даже выпустила особые деньги, а Киев все печатает украинские кредитки в 50 и 100 р[у]б[лей]» (л. 24об.).

«Умиротворение», воцарившееся в Киеве с немецким присутствием, все-таки воспринималось как явление временное. И, как с некоторой иронией отмечал Кулаковский: «Здешние оптимисты могут лишь доходить до мысли, что новые римляне, покорив славян, не смогут их поработить и что положение провинции продлится недолго» (л. 25). Что же касалось текущей политической обстановки в Киеве, то он характеризовал ее следующим образом: «Все поговаривают о том, что 15-го объявят оккупацию Волыни, Подолии и Киевщины, т[ак] к[ак] новоиспеченные министры и Рада власти не имеют, а Грушевского сами украинцы клянут» (л. 24). Эти предположения довольно скоро оправдались, и фактическая оккупация продлилась в несколько иной форме. Через две недели, 29 апреля, произошел государственный переворот, и Украину возглавил гетман Скоропадский.

Физическое состояние старшего Кулаковского продолжало ухудшаться. «От этих всех больших и малых переворотов, - писал Сергей, - папа совсем занемог; привязалось расширение вен в ноге, отчего последние дни пришлось лежать, а до того сердце не позволяло ходить так, как привычно, от чего папа еще более угнетен и мрачен. Думаю, что он делает приписку* в моем письме» (л. 24об.).

Подписал письмо Кулаковский только инициалами «С. К.» со следующим объяснением: «Титула писать не смею страха ради большевикска» (sic!) (л. 25). Он сделал таким образом отсылку к евангельскому рассказу об Иосифе Аримафейском, который «страха ради иудейска» скрывал, что он ученик Иисуса (Ин 19: 38).

Прошло два месяца, и неожиданные события в жизни Соболевского вызвали новое письмо к нему Кулаковского. Обеспокоенный, он писал 30 июня 1918 г.: «В одной из киевских газет промелькнул слух об аресте Вашем. Приехавший сюда некто Перфецкий** (которого я у Вас встречал) подтвердил этот слух. Вчера к нам зашел Н. М. Семенов, окончивший московский университет по классическому отделению этой весной, и передал Ваш привет. Не решаюсь писать, какие мысли вызвало во мне это известие» (л. 26).

Кулаковский был весьма скептически настроен относительно современного состояния Киевского университета и сообщал Соболевско-

* Приписка есть, но нечитаемая (л. 25).

** Перфецкий Евгений Юлианович (1888-1947) — историк-славист. 
му предположения о его дальнейшей судьбе. Так, он писал: «Университет прозябает кое-как. В будущем году обратится в частное предприятие» (л. 26об.). Но, с другой стороны, научная жизнь отнюдь не затихала, а приобретала новые формы. И судя по письму, Кулаковский принимал в ней активное участие. «В Киеве недавно открылось историко-литературное общество, — сообщал он, — состав, гл[авным] обр[азом], семинарий Перетца. В апреле чествовали день столетия рождения Буслаева, на котором поднят был вопрос об избрании трех почетных членов, среди которых нам было бы дорого видеть Вас, как нашего духовного деда (если считать Перетца духовным отцом)» (л. 26). Но о своих личных делах и общем положении в Киеве Кулаковский был немногословен. «К сожалению, - писал он, - диплом, да и тот “военного времени”, еще не готов пока» (л. 26). Кулаковский по-прежнему оставался «без официального положения, без надежды скорее устроить свои дела» (л. 26об.). И далее: «О политике не смею писать. Что касается другого больного вопроса - "питательного", то здесь пока голода нет, но тоже грозит быть». Психологическое и физическое состояние отца все больше беспокоило Сергея: «Папа все хворает: нервы, одышка, легкие; он очень плох, потому что сам все дни — вот уже год — говорит о смерти, а ведь человек сам себя губит» (л. 26об.).

Начатые в мае 1918 г., сразу после ареста Соболевского, хлопоты Академии наук еще не увенчались успехом. «В Киев дошли слухи, что Вы все еще томитесь в тюрьме. Душевно, горячо сочувствует Вам папа, который, несмотря на заметное улучшение (после летнего отдыха у кузины Наталии Платоновны), все так же очень нервен. Я присоединяю к своему письму его приветы, т[ак] к[ак] сам он никак не может взяться за письмо» (л. 27), — писал Кулаковский Соболевскому 19 сентября 1918 г. Это письмо он также пересылал с оказией. «Письмо это направляю к Сергею Ивановичу", с тем же добрым Н. М. Семеновым». Состояние отца все-таки оставалось прежним: «Папа так же мрачен, ничто его не подбодрит - и в противоположность ему Т. Д. Флоринский и В. С. Иконников все бодрятся, умеют бодриться. Грустит папа и о Вас» (л. 29об.). Да и сам Сергей пребывал в мрачном расположении духа: «Киев все по-старому - у немцев. Тяжело писать о том, что делается у Вас и у нас, чудится, будто связали меня, бьют, издеваются. Бессильная, страстная злоба закипает против всего, против еврейского царства. И когда же перемена?» (л. 27-27об.).

* Соболевский Сергей Иванович (1864-1963) - филолог-классик, переводчик. 
Но все же Кулаковский думал, что при немцах в Киеве лучше, чем при большевиках в Москве. «У меня явилась тайная мысль, - размышлял он, — не приехали бы Вы к нам после освобождения от плена? Но так опасно загадывать сейчас». И далее: «Было бы радостно получить вести от Вас, а еще более радостно знать о Вашем освобождении» (л. 29об.).

Не способствовали улучшению настроения самого Кулаковского отсутствие заработка, так как «материальный вопрос остро поставлен», а также его учебно-научные дела. «Свои предметы к магистерскому далеко не закончил. Виной этому я сам, конечно, - сетовал Сергей, - а также обстоятельства, не позволяющие ехать за границу и в Москву. Здесь сидя, ни одного вопроса не могу закончить из специальных; только русскую литературу да историю средних веков мог бы завершить и отшлифовать наскоро, что уже сделано. А ведь в минуты, когда думаешь о поездке куда-нибудь, о моем начатом при Вашем добром покровительстве Феофиле, то размечтаешься о диссертации по истории французского театра в средние века. Но приедешь в университетскую библиотеку и разочаруешься» (л. 27об.-29).

Быструю украинизированность некоторых коллег, ранее в этом не замеченных, Кулаковский явно не одобрял. Так, он напоминал Соболевскому об их общем знакомом - Е. Ю. Перфецком: «Встречал я здесь Перфецкого, который бывал у Вас. Он украинизировался, ему покровительствует Вернадский. Странный какой-то этот Перфецкий» (л. 27об.). «Один из любимых учеников ${ }^{9}$ академика А. А. Шахматова, как характеризовал его В. Ягич в письме С. Ф. Ольденбургу, Перфецкий специализировался на вопросах русского летописания, занимался он также и проблематикой Угорской Руси, которая очень интересовала В. И. Вернадского ${ }^{10}$. Судя по дневниковым записям Вернадского, Перфецкий его действительно очаровал. Так, он отмечал 6 июня 1919 г.: «Евген. Юлиан. Перфецкий, который был у меня вчера и произвел самое приятное впечатление, заходил. С ним разговор об Угорск[ой] Руси» ${ }^{11} .8$ июня Перфецкий вновь заходил к Вернадскому ${ }^{12}$. Запись от 10 июня: «С Перфецким отдыхал и гулял в Ботаническом саду. Замечательно хорошее делает впечатление: служитель науки. < ..> Перфецкий много рассказывал об Угорской Руси. <...> П[ерфецкий] влюблен в Княжескую Русь, и масса интересных идей у него» ${ }^{13}$.

Можно представить, каким ударом стало для Вернадского поведение Перфецкого всего лишь через полгода, когда Киев находился уже во власти Директории. Над Вернадским «реально нависла угроза физической расправы. Прямым доказательством может служить развязанная кампания Е. Ю. Перфецким против Вернадского в этот пе- 
риод. В начале января 1919 г. Перфецкий подал в правительство Директории записку об "антиукраинской" деятельности "россиянина" Вернадского, “малоросса” Василенко и близких к ним ученых. Власть среагировала мгновенно, и уже 10 января на заседании правительства был поднят вопрос об удалении из состава Комиссии Национальной библиотеки Украины В. И. Вернадского и ближайших его подвижников, ставя в обвинение ученному, что он ведет "русификаторскую политику”»14. В защиту Вернадского против обвинений его в антиукраинстве выступил ряд ученых. Так, его поддержал литературовед и украинский общественно-культурный деятель П. И. Зайцев*. Прочитав статью последнего в газете «Нова рада» (№ 27 от 6 февраля 1919 г.) $)^{15}$, Вернадский отметил в дневнике 10 февраля 1919 г.: «Всетаки как-то мне не верится в подлость природы П[ерфецкого]. Думаю, что много здесь психоза и отсутствия ясного ума» ${ }^{16}$. Дальнейшие события привели Вернадского к следующему умозаключению относительно украинского национального движения, к которому он относил и Перфецкого. Он записал в дневнике 30 сентября 1919 г.: «Удивительно мало среди людей, охваченных этим движением, людей, которые сохраняют нетронутыми моральные принципы, когда вопрос переходит в область национальной политики $<\ldots>$ многие из которых лично порядочные люди - теряют эту порядочность, когда переходят в область национальных вожделений и национальной политики. Такие люди - слабые, но с искрой божьей, как А. Грушевский, Перфецкий, Данилевич, в конце концов совершают бесчестные поступки» ${ }^{17}$.

Вернадский, вспоминая грозившую ему в 1919 г. опасность физической расправы, когда был расстрелян его украинский коллега, известный ученый и общественно-политический деятель В. П. Науменко, не забывал поступок Перфецкого, превратив его фигуру в символ. Он писал в дневнике в конце января 1920 г.: «Я думаю, что те укр[аинские] группы, которые сознательно устранили Науменко как лицо, мешавшее их самостийничеству, легко могли - и еще легче - найти ненужным и меня. Такие фигуры, как Перфецкий и Кㅇ, потерявшие всякую нравственную почву» ${ }^{18}$.

Стоит отметить, что Перфецкий, оказавшийся в 1921 г. в эмиграции в Чехословакии, к 1927 г. засобирался обратно. И теперь его мысли были только о России. Так, он писал П. А. Лаврову 24 сентября 1928 г: «Я очень счастлив, что моя научная работа возвращается

* Зайцев Павел Иванович (1886-1965) - украинский литературовед и общественно-культурный деятель. 
на родную почву, в Россию. Я и моя жена (жена моя словачка $<\ldots>$ ) грезим о России, ибо только в ней я вижу свою цель. Но каким путем вернуться в Россию, не знаю» ${ }^{19}$.

Следующее письмо Кулаковского было написано почти через полгода - 11 марта 1919 г. За это время произошли серьезные политические события. В Киеве Скоропадского сменила Директория, ее, в свою очередь, сменили пятого февраля 1919 г. большевики, владевшие городом до 31 августа. К этому периоду относится только одно письмо Кулаковского. Для его семьи и близкого окружения время оказалось трагическим. Итак, 11 марта Кулаковский сообщал Соболевскому: «Ваше письмо в обычно бодром духе было для меня большим утешением в первые дни после кончины папы, которого оно не застало в живых. Скончался папа 21-II [февраля. - M. P.] н[ового] с[тиля], уснул без всякого страдания от своей давней гостьи - чахотки, которая развилась в нем благодаря всему, что нас окружает. Кончина мамы, а раньше - дяди Платона, крушение идеалов государственности, мрак и неведение - не болезнь - свели его в могилу. Много было горячего к нему чувства, много речей. Чрез месяц Несторовское общество вместе с новым Историко-литературным устраивают памяти папы заседание» (л. 30). Нам представляется, что главной причиной кончины отца С. Кулаковский все же считал «крушение идеалов государственности». Жена Ю. А. Кулаковского, Любовь Николаевна, скончалась в 1914 г., а П. А. Кулаковский — в конце 1913 г. Отметим, что к 1914 г. относятся воспоминания тогдашнего студента Киевского университета В. М. Асмуса*, который так описывал профессора: «Кулаковский был уже старик**, но чрезвычайно бодрый, живой и энергичный» ${ }^{20}$.

Радикально изменилось и настроение близкого друга и политического единомышленника Ю. А. Кулаковского Т. Д. Флоринского. «Тимофей Дмитриевич сильно постарел, - писал Сергей, - живет в одиночестве с Верой Ив[ановной] (сыновья его за границей ${ }^{* * *}$ ); он завидует папе; как и другие» (л. 30). Действительно, такие мрачные

* Асмус Валентин Фердинандович (1894-1975) - специалист по истории античной и западноевропейской философии, искусствовед.

** Оставим за скобками определение Асмуса «старик», Ю. А. Кулаковскому в 1914 г. было 59 лет, а скончался он на 63-м году.

*** Братья Михаил (1895-1981) и Дмитрий (1899-1939) выбрали разные жизненные дороги. Старший, Михаил, офицер, эмигрировал и в итоге стал профессором Колумбийского университета в США. Младший, Дмитрий, стал советским дипломатом, заведовал протокольным отделом НКИД, расстрелян в ГУЛАГе. 
настроения встречались, в частности, и у других корреспондентов Соболевского. Так, В. М. Истрин писал ему 30 августа 1918 г.: «Отовсюду только [нрзб] унижение: умершим теперь лучше». ${ }^{21}$ «А Вы так бодры, несмотря на ужасы жизни» (л. 30), — восхищался Кулаковский стойкостью Соболевского.

Кулаковский вряд ли мог предположить, какая страшная участь ждала Флоринского, который менее чем через два месяца, 2 мая 1919 г., был расстрелян по приговору ЧК. Несложно предположить, что и Ю. А. Кулаковского ожидала бы такая же судьба. Нам неизвестно, состоялось ли намеченное заседание Общества Нестора Летописца памяти Ю. А. Кулаковского, но хотя бы прощание с ним прошло торжественно. А для расстрелянного Флоринского после занятия Киева Белой армией потребовалось перезахоронение. О судьбе Флоринского Соболевский узнал уже в начале июня 1919 г. из письма Д. К. Зеленина*. «Из киевских газет мы узнали, — писал тот 3 июня, — что там расстреляны, среди 53-х заложников, проф[ессора] Флоринский и Армашевский**»».

Братья вынуждены были сдать часть квартиры, а Сергею «удалось получить охранный лист на $1 \frac{1}{2} 2$ тысячи изданий» семейной библиотеки, но пришлось задуматься о реализации оставшейся части. Но с этим сразу же возникли проблемы. Из киевских учреждений, готовых покупать книги, отмечал Кулаковский, «приятнее всего новая державная библиотека, но она дает 7 р[ублей] за т[ом] огулом, как и Вл. Ст. Иконникову, что по нынешним временам насмешка» (л. 30об.).

Отмечал он зыбкость положения и нервозность в деятельности новой власти. «Жизнь требует теперь полной ясности в этих делах и спешных решений, - писал Кулаковский, — т[ак] к[ак] иначе реквизуют, поселят, выгонят и т[ак] д[алее]. Здесь выселяют из крупных домов поголовно, реквизуют многое. Цены выросли. Почему-то нет прочной связи с “русским” правительством, нет законных планомерных действий, а какие-то случайности» (л. 30об.). Кулаковский не случайно заключил определение правительства большевиков в кавычки, так как, с его точки зрения, это правительство не отвечало русским национальным интересам.

Сообщая о ценах на продовольствие, он констатировал: «Московские цены во много раз выше, но ведь мы живем в хлебных местах.

\footnotetext{
* Зеленин Дмитрий Константинович (1878-1954) - этнограф, фольклорист. ** Армашевский Петр Яковлевич (1851-1919) — минералог и геолог, товарищ председателя Киевского клуба русских националистов.
} 
Слухами полнится земля. При Петлюре много было апельсин, мандарин и лимонов (съедобных; их я папе покупал); теперь даже яблоки дороги. Но лимонов ждут, хотя пессимисты уверяют, что придется пить чай скоро без сахара, а про лимоны забыть. Да и чая нет вовсе. Может быть, вместо всего начнем пить польские меды и немецкое пиво. Говорят, что появятся запасы, хоть и прежние. Сказ про Улиту». В заключение письма Кулаковский сообщал о семействе кузины и выражал надежду хоть на какую-нибудь стабилизацию общего положения. «Из деревни вести есть, - писал он, — все живы, но, вероятно, обобраны. Все ждем весны. Восток или Запад, а Киев не может сидеть долго в мешке» (л. 31).

Но в 1919 г. для Кулаковского суждено было случиться еще одной трагедии. При отступлении большевиков Н. П. Муретова (Кулаковская) была смертельно ранена в своем имении. Она скончалась 11 августа (по старому стилю), когда местность уже была занята войсками белых ${ }^{23}$.

Пережил Кулаковский и период владения Киевом поляками, и следующее письмо он написал Соболевскому 23 июня 1920 г., после окончательного установления в Киеве советской власти. После занятия Киева Красной армией 12 июня восстановилась работа почты. Кулаковский отмечал: «Ваше письмо от 13.IV н. с. на днях получили; шло, как видите, очень долго». Это не удивительно, ведь отправлено письмо было, когда Киев был еще занят большевиками. Поляки завладели городом 6 мая. Кулаковский довольно подробно описывал ситуацию в городе вскоре после оставления его польскими войсками. Судя по ответу, Соболевский интересовался возможностью киевских коллег отреагировать на смерть профессора Московского университета Р. Ф. Брандта*. Итак, Кулаковский писал: «"Нестор” не существует, отчего бесполезно обращаться к кому-либо по поводу смерти проф. Брандта». И продолжал далее: «У нас за последнее время не было смертей, но сам университет перестал фактически существовать с февраля, как и многие гимназии. Культуры и науки нет. Город мертв» (л. 32). Сообщал Кулаковский и о том, что начал готовиться к магистерским экзаменам, поэтому и в городе будет «сидеть до последней крайности», и о том, что перестал бывать в университете «и книг домой натаскал много». А в это время «многие учителя и университетские люди бегут или собираются бежать на продолжительный срок в село», и «про летний семестр пока одни разговоры» (л. 32об.).

* Брандт Роман Федорович (1853-1920) - славист, член-корреспондент АН. Брандт скончался 2 марта 1920 г. 
Общую ситуацию в городе Кулаковский также вкратце описал Соболевскому. Он отметил, что «поляки взорвали все мосты киевские через Днепр», что «поляки сожгли несколько зданий со своими запасами, но на станции не все успели сжечь, и многие растаскали добро мешками. Великороссы удивляются здешнему хаосу; шутка ли: шестнадцатая власть и ждут 17-ю; сейчас власти нет» (л. 32). И «дороговизна - не хуже московской», и это «все необыкновенно для Киева». Что же касается материального положения, то Кулаковский уже пытался обобщать и писал: «Денег ни при каких режимах не полагается; пайков и карточной системы с реальным содержанием нет и никогда не было. Только сплетни - хоть пруд пруди». Выручить же какие-нибудь деньги от продажи имущества возможности нет, «вещи не идут» (л. 32).

На фоне развала академической жизни молодой ученый откровенно отмечал: «Начинаю убеждаться, что Москва - счастливый город; говорят о печати, о гонораре, надеются на выпуск книг» (л. 32).

Коснулся в своем письме Кулаковский и ситуации на фронтах. «Советская армия на западе крупно успевает, но я опасаюсь сильно за южный фронт, да и за московское настроение*. Но, надеюсь, все кончится благополучно. Дай Бог» (л. 32). Что же подвигло Кулаковского, явно не сочувствовавшего и даже враждебно относившегося к власти большевиков, желать им успеха? Что касается советско-польской войны, то позиция русского патриота выглядит вполне логично. Хорошо известно, что многие офицеры откликнулись на воззвание генерала А. А. Брусилова от 30 мая, призвавшего русских патриотов помочь советской власти в борьбе с Польшей. Возможно, что к 1920 г. Кулаковский уже понял, что окончательная победа в Гражданской войне будет за большевиками, свои научные и жизненные планы он связывал с Москвой или Петроградом, где власти советов уже ничто не угрожало.

Общее настроение Кулаковского явно улучшалось, он уже не так трагически воспринимал действительность и размышлял о переживаемых событиях как внимательный наблюдатель. «Я периодами вел записи, - писал он, - но не систематически. И вот, оглядываясь на прошлое, с 1917 г., видишь пред собой новую фазу революции. Где и каков конец? Увлекательно жить, хоть голодно и холодно» (л. 32об.). Отметим, что примерно в то же время Соболевский с высоты своего возраста и жизненного опыта дал более академичную оценку действи-

* О каком «настроении» идет речь, неясно, возможно, это описка и следует читать «направлении». 
тельности. Он писал Б. М. Ляпунову“ в Одессу 18 сентября 1920 г.: «Мы присутствуем при интересных событиях для будущего историка, которые, однако, страшны для настоящего свидетеля» ${ }^{24}$.

Переписка Кулаковского и Соболевского приобрела регулярный характер. Сергей постоянно сообщал академику о своих учебно-научных планах. Его все больше по самым разным причинам тяготила жизнь в Киеве. Так, 7 августа, упоминая о том, что его вторая кузина устраивается учительницей в Гатчину, он писал: «Ведь на севере приюты, пайки - хоть какой-то порядок». «А в Киеве, - продолжал Кулаковский, - ожидают 17-ю власть и толкуют, что с объявлением войны англофранцией и с занятием Одессы что-то изменится» (л. 34). Эти ожидания были, безусловно, связаны с известной нотой министра иностранных дел Великобритании Д. Н. Керзона от 11 июля 1920 г. с угрозами оказать помощь Польше в случае непрекращения наступления Красной армии.

Письмо свидетельствует и о том, что Кулаковский решил принять участие и в общественно-политической жизни, организованной новой властью, и даже обеспечил себе некоторое положение. Так, он писал: «Киевский совет раб[очих] и красн[оармейских] деп[утатов] не созывается, и трудно уловить темп политики. Мобилизация военная и трудовая, изъятия из квартир разного рода имущества. Накануне отъезда из Киева** были и у меня, но мое депутатское звание ${ }^{* * *}$ освобождает меня от обыска. Однако сейчас я не уверен, что в квартире все цело и что по приезде не придется бегать по разным учреждениям и лицам» (л. 34).

После долгого отсутствия в переписке вновь возникла национальная тема. «А картина жизни киевской ужасна, - писал Кулаковский. - Университетские профессора бегут, куда можно. Целая группа молодежи и несколько стариков собираются устроить украинский университет на одном из сахарных заводов, но хотят от казны 2 миллиона, что не устроится, так как даже старых долгов работникам учреждений не выплатили. О пайке - говорить нечего. Мертвый Киев, духовно убогий надолго, раздираемый в клочья украино-русской борьбой, противен» (л. 34-34об.).

Возможность перебраться в Москву все больше привлекала Кулаковского. Он писал: «Мечтаю о различных выходах, между прочим о

* Ляпунов Борис Михайлович (1862-1943) - лингвист-славист.

** Точно установить, куда уезжал Кулаковский, не представляется возможным, но скорее всего это был Петроград.

*** Какого уровня было «депутатское знание», определить не удалось. 
поездке в Москву». Он просил Соболевского сообщить, «какие требования существуют при университетских испытаниях магистрантов», потому что в Киеве «остается облегченная форма экзаменов, по устаревшей программе». Отмечал Кулаковский и убыль тех специалистов, которые могли бы принимать экзамены: «Историков Средних веков (Бубнов) и Нового времени (Ардашев) нет, то эти два предмета приходится взять на себя историку Древнего Востока (Покровскому); читать он их не собирается, но может экзаменовать». Славист на кафедре остался только один приват-доцент, так как профессор «Лукьяненко давно уехал».

Еще сложнее обстояло дело с формальным научным руководителем молодого ученого. «Моего патрона Шаровольского ${ }^{*},-$ сообщал Кулаковский, — и калачом в город не заманить — он обучает на своем хуторе грамоте ребят» (л. 34об.).

Соболевский никогда не прекращал своей научной работы, в круг его интересов входили и вопросы диалектологии, ономастики и топонимики. Он не преминул воспользоваться помощью Кулаковского для получения нужной информации. «После получения Вашего письма, писал Кулаковский 28 декабря 1920 г., - я виделся с В. З. Завитневичем и др. лицами, но с главным - Леон[идом] Павл[овичем] Добровольским ${ }^{* *}$, учителем истории и автором историко-топографических исследований, поговорить не мог, т[ак] к[ак] он вот две уже недели умирает от истощения в больнице и находится в забытьи. Узнал только, что Жуляны (бывшее княжеское урочище Желань) не представляет никакого сейчас интереса в диалектологическом отношении» (л. 36).

Сообщал Кулаковский и о подготовке к экзаменам, не расставался он и с идеей уехать из Киева. «И вот я надумал Вас спросить, писал он, - нельзя ли устроиться в Московском университете, воз-

* Бубнов Николай Михайлович (1858-1943) - историк-медиевист и филолог. В ноябре 1919 г. эмигрировал. Ардашев Павел Николаевич (1865-1922 или 1924) историк, политический публицист. В 1917 г. переехал из Киева в Симферополь, затем в Белоруссию. Покровский Алексей Иванович (1868-1928) — историк-классик. Лукьяненко Александр Митрофанович (1880-1974) - филолог, лингвист, профессор кафедры славянской филологии Киевского университета, в 1920 переехал в Симферополь. Шаровольский Иван Васильевич (1876-1954) - языковед и историк литературы, специалист по германской и романской филологии.

** Завитневич Владимир Зенонович (1853-1927) - гражданский и церковный историк, богослов, философ, археолог, литератор, публицист, профессор Киевской духовной академии; Добровольский Леонид Павлович (1867-1928) - историк, краевед, член Постоянной комиссии для составления историко-географического словаря украинской земли ВУАН. 
можно ли это принципиально; насколько мне было известно, кроме М. Н. Розанова и Н. С. Арсеньева по романогерманистике за смертью московского Брауна и Отенева. Да, еще Фриче, но тот вместе с петроградским Коганом* способен только наводить жуть глупыми книгами. Если не в Университете (хоть четвертой спицей в колесе), то вообще в высшей школе?» (л. 36об.).

Сообщал Кулаковский также об очередных потерях в научной среде. «В Синодик русской профессуры, - писал он, - следует внести и С. Т. Голубева**, скончавшегося около месяца тому назад». Кончина Голубева была, по мнению Кулаковского, ускорена трагическими событиями в семье ученого. «Общее состояние его было отчаянное, а за некоторое время до смерти, - подчеркивал Кулаковский, — это состояние ухудшил еще расстрел его дочери. Сознавая, что умирает, Ст[епан] Т[имофеевич] просил передать приветы всем друзьям, значит и Вам, дорогой Алексей Иванович» (л. 36об.). Голубев скончался 22 ноября, а еще летом Соболевский имел в виду его кандидатуру для избрания в академики. Об этом он писал В. М. Истрину 21 июля: «Кандидатов на места в Ак[адеми] н[аук] у меня сколько угодно: < ..> киев[ский] Голубев» ${ }^{25}$. Тому же Истрину академик писал 21 января следующего 1921 г. о неясной ситуации с работой типографии и интересовался перспективой получить печатный отчет Академии за 1920 г. Этот интерес носил не праздный характер. «Не получив отчета, писал Соболевский, - не удивился, но любопытство мое осталось неудовлетворенным, любопытство, касающееся старого моего приятеля С. Т. Голубева: что в память его сказано в отчете и сколько сказано? Я не прочь бы написать кое-что о нем вроде воспоминаний... Для "Изв[естий]", если...»"

Удивлялся Кулаковский и той стойкости, с которой Соболевский переносил все трудности жизни. «Завитневич в разговоре со мной ска-

* Розанов Матвей Никанорович (1858-1936) - литературовед, профессор Московского университета, читал основные и специальные курсы по истории западноевропейских литератур; Арсеньев Николай Сергеевич (1888-1977) - литературовед, философ, историк религии, приват-доцент кафедры западноевропейских литератур Московского университета до 1917 г., с 1920 г. — в эмиграции; Браун Евгений Густавович (1866-1917) — филолог, литературовед, профессор романогерманского отделения Московского университета; Фриче Владимир Максимович (1870-1929) - литературовед, с 1917 г. — член РКП(б), с 1920 г. — профессор Московского университета; Коган Петр Семенович (1872-1932) - литературовед, литературный критик, переводчик, профессор Московского университета.

** Голубев Степан Тимофеевич (1848-1920) — церковный историк, член-корреспондент РАН. 
зал, - с восхищением отмечал Кулаковский, — что Вы героический человек. Да, папа, если бы здоров был, не выдержал бы всей тяжести такой жизни, без воды, без света, без дров и в голодовке» (л. 36об.). И действительно, Соболевский старался никогда не унывать. Сам академик с долей иронии так писал об этом Ляпунову 19 апреля 1920 г.: «Я порядком одряхлел (64-й год идет!); ноги работают лениво, уши слабеют, но чувствую себя бодрым и работаю в множестве (верно!) направлений: пилю, рублю, копаю, покупаю, продаю, делаю доклады, пишу, читаю и т. д.» ${ }^{27}$.

Летом, возможно, и с конца мая, 1921 г. Кулаковскому удалось побывать в Москве и погостить у семейства Соболевских. Возвращение в Киев не порадовало молодого ученого. «Киев показался мне еще более пустым» (л. 38), - писал Кулаковский Соболевскому 25 июня. «Если быть стесненным здесь, т. е. ничего не получать, - далее размышлял он, - лучше в Москву явиться, где не так пустынно, не так уныло: здесь пропадешь. Нельзя ли напомнить в нужный момент обо мне Матвею Никаноровичу?» (л. 40об.).

С нескрываемым сарказмом Кулаковский отмечал: «Здесь опять реформы. Во главе бывшего университета — одноклассник брата моего, Арсения, милый мальчик 27 л[ет]» (л. 38об.). Более подробно о состоянии дел в университете весной 1921 г. Перетцу писал Лобода: «...учебные заведения переживают кризис: нас все реорганизуют и трансформируют; от университета не осталось и тени - его превратили постепенно в простой учительский институт, хоть и носит он громкое название Высш[его] инст[ута] нар[одного] обр[азования] им. Драгоманова; его ректор (по назначению) - недавно окончивший наш филолог, мой однофамилец*; декан 1-го общеобразов[ательного] курса — б[ывший] наш студент историк 2 курса Оглоблин ${ }^{* *} \gg .{ }^{28}$ Заметим, что у А. М. Лободы с появлением в бывшем Киевском университете этого «однофамильца» возникли определенные проблемы. В конце 1922 г. Пететц и Е. Ф. Карский выдвинули Лободу, к тому времени уже академика ВУАН, в члены-корреспонденты РАН. Выдвижение оказалось неудачным, о чем Перетц писал Соболевскому 23 ноября 1922 г. Уже в следующем письме от 17 декабря 1922 г. Перетцу пришлось

* Лобода Николай Иванович (1894-1941) — в 1917 г. закончил историко-филологический факультет Киевского университета, в 1919-1920 гг. заведовал Киевским губернским отделом народного просвещения. В 1921-1924 гг. - ректор Высшего института народного образования.

** Оглоблин Александр Петрович (1899-1992) - советский и американский историк, видный деятель украинской научной эмиграции. 
разъяснять Соболевскому: «Насчет Лободы - скажу, что “дрянь”, т. е. ректор Киевского ИНО - не сын Лободы, а лишь однофамилец, чем доставляет моему протеже немало неприятных минут» ${ }^{29}$. На следующий год Перетц в выдвижении Лободы решил опереться на авторитет Соболевского. Он писал 18 октября 1923 г.: «...предложите в чл[ены]-корр[еспонденты] Андр[ея] Митр[офановича] Лободу <...> но, боюсь, опять подведет Никольский (он и Вас[илий] Мих[айлович] [Истрин. - M. Р.] воображают, что Лоб[ода] — “большевик”).

N.B. в Киеве есть Лобода Н. И. такой марки, но он даже не родственник проф[ессора] А. Мит[рофановича]!» ${ }^{30}$.

Летом 1921 г. Кулаковский продолжил интенсивную переписку с Соболевским и отправил еще шесть писем. Все они свидетельствуют, что молодой ученый разрывался между желанием перебраться в Москву и опасениями по разным причинам оставить Киев. Так, 1 июля он вновь сравнивал Киев и Москву и писал: «...здешние трудные условия жизни и общий пессимизм (глубокая безотрадность настроения) несколько сбили мою восторженность от Москвы. Делал доклад в одном обществе - сделаю в Академии наук, по ее личной просьбе. Провинция сейчас живет скверно, так что не верится: ведь был в Москве - там идет жизнь, а кругом - смерть, мерзость запустения. Разве при таких условиях можно жить?» (л. 41об.). Немногим более чем через неделю, 10 июля, Кулаковский со смешанными чувствами вновь пишет Соболевскому: «Ведь опасно, как Вы справедливо говорите, расставаться сейчас с насиженным гнездом. Впрочем, тут такое болото, и так отсутствует возможность заработка, что не знаешь, куда уйти бы» (л. 69). И вообще, продолжал Кулаковский: «О здешнем нечего писать. Все общие знакомые так живут, будто только век дотягивают. Вот бы им Вашей бодрости!» (л. 73).

В постскриптуме к письму Кулаковский поделился информацией, которая в перспективе определила его судьбу. Он писал: «Когда я вернулся сюда, то застал письма арендатора имения матери (оно в общем владении с ее родными, кот[орые] не откликаются 5 лет). Он просит папу или кого из нас приехать - все в полн[ом] порядке. Это в польск[ой] части Гродн[енской] губ[ернии] (папа управлял по доверенности), такой же запрос прислали в прошл[ом] году из виленск[ого] дома матери. Дайте совет: 1) не поехать ли туда за деньгами; 2) не уехать ли вообще в таком случае за кордон (правда, увы, это можно сделать только нелегально)».

* Гродненская губерния отошла к Польше по условиям Рижского мирного договора, подписанного 18 марта 1921 г. между РСФСР, УССР и БССР с Польшей. 
Письмо со столь важной информацией Кулаковский отправлял с оказией. «Буду на эту часть письма ждать ответа с его подателем, - писал он и подчеркивал, - на которого можно положиться совсем» (л. 69-72). На обороте конверта Кулаковский нарисовал подробный план пути от вокзала к дому Соболевского в Москве (л. 71об.).

Прошло две недели, и Кулаковский одно за другим написал два письма (26 и 29 июля) Соболевскому, обращался к нему за советом и делился своими сомнениями. С одной стороны, Кулаковский вновь задавал сам себе вопрос: «На что же в Москву переселяться, где не сразу что-н[ибудь] получится?» (л. 45). И продолжал: «Лучше бы в Москву, но денег много надо». С другой стороны, «есть насиженное отцовское гнездо». И, размышлял Кулаковский: «Значит, уже легче. Затем тут я больше известен. Но если пока сидеть в К[иеве], значит, надо тут торопиться с экзаменом» (л. 46). Молодой ученый прямо спрашивал совета Соболевского, где же ему лучше сдавать магистерские экзамены.

Из письма очевидно, что во время своего посещения Москвы Кулаковский вел переговоры с М. Н. Розановым о возможности сдачи экзаменов в Московском университете. Но это желание не осталось тайной для университетских коллег в Киеве. И теперь, как писал Кулаковский, «...все факультетские в обиде за “измену”, особенно как сына папы» (л. 45). Решаясь все-таки на сдачу экзаменов в Киеве, он в следующем письме повторил этот же аргумент как основной: «Всетаки здесь мой экзамен не такой уж балаган, а если не выдержу тут, то обижу факультет (это мне говорят профессора). С Туницким ${ }^{*}$ сговорился о славистике. Сослался на то, что Вы одобрили юнацкие сербские песни. Благословите!» (л. 51-51об.) А в качестве отрицательного момента в сдаче экзамена в Москве Кулаковский обращал внимание на следующее обстоятельство: «Розанов (ему ничего пока не говорите) может после экзамена дать мне только Кострому или нечто подобное, а здесь все-таки бывший культурный центр» (л. 50).

Исполнено сомнений и следующее письмо Кулаковского от 8 августа. Он сообщал, что книги продать не удается, поэтому «денег на переезд нет». Все больше он задумывался о возможности эмиграции. «И я, писал Кулаковский, - если перееду, то скорее в Гродненскую деревню матери. Ведь и тут есть нечего. А с другой стороны, рус[скому] человеку только и жить, что в России теперь» (л. 74). Через неделю, 14 августа,

* Туницкий Николай Леонидович (1878-1934) - филолог-славист, в 1918-1922 гг. профессор кафедры славистики Киевского университета. Жертва сфабрикованного ОГПУ «Дела славистов». 
Кулаковский решил отправить письмо с оказией: «К. В. Базилевич* отвезет Вам это письмо» (л. 74об.). В нем наряду с упоминанием проблем, уже ставших типичными - «денег и пайка вот уже 5 мес[яцев] нет», Кулаковский неожиданно обратился к рассуждениям о будущем страны: «Когда я смотрю на разорение и нищету, - писал он, - когда (О, Вы пророк!) провижу голод и холод на зиму — мне становится страшно и отрадно вместе с тем; м[ожет] б[ыть], чрез анархию и голод мы скоро — да, скоро, - придем к более здоровым формам государственности. Правда, высшей школе суждено так долго быть уничтоженной, но ведь это угол госуд[арственного] устройства - она наладится» (л. 75). Кулаковский с огорчением информировал Соболевского о том, что не получил из Москвы ожидаемых важных сообщений: «Само собою, из Наркоминдела никакой телеграммы нет и от Гливенки - ни звука» (л. 75). Таким образом, становится ясно, что в Москве Кулаковский вел переговоры не только с Розановым, но и с И. И. Гливенко** о возможном устройстве на работу. Не совсем понятно, какой информации ожидал он от НКИД, возможно, это касалось разрешения выехать в Польшу. И вновь сравнение Москвы и Киева не в пользу последнего. «Впрочем, - констатировал Кулаковский, - как ни крути - а только в М[оскве] чувствуешь, что живешь в России и проживаешь заодно со всеми всё на родине. Тут глухой угол. Но, если будут деньги, поеду в командировку» (л. 75об.).

Прошло чуть более месяца, и Кулаковский написал Соболевскому 20 сентября 1921 г. свое последнее письмо из Киева. За это время он успешно сдал магистерские экзамены и вернулся «из деревни, куда ездил отдыхать после экзаменов» (л. 53). «Бывший культурный центр» еще более разочаровал его. «В Киеве тоже реформы, - писал Кулаковский, - но глупые и бестолковые. Появились четыре профессора из [нрзб] губпрофобра (3 учителя и 1 студент 2 курса**). Полная апатия» (л. 55). Но и перспектива обосноваться окончательно в обеих столицах уже не привлекала молодого ученого. Открывшаяся реальная возможность обеспечить себя нормальными условиями жизни и научной работы оказалась привлекательней. «Узнал, - сообщал Кулаковский, - что бумаги мои неоспоримо доказывают принадлежность мне части заграничного имущества. Не рискнуть ли поездкой

* Базилевич Константин Васильевич (1892-1950) — историк, киевлянин, во время описываемых событий студент Московского университета.

** Гливенко Иван Иванович (1868-1931) - литературовед, профессор Московского университета, действительный член НИИ языковедения и истории литературы при факультете общественных наук.

*** Имеется в виду А. П. Оглоблин. 
туда? Здесь только измельчать, в М[оскве] или П[етрограде] гоняться за пайками и не иметь свободного для занятий времени». Поэтому неожиданную возможность получить работу в Москве Кулаковский уже рассчитывал использовать только с одной целью. В сложившейся ситуации он настоятельно просил Соболевского о совете: «Приехал сюда один проф[ессор], — писал он, — гов[орит], что Глив[енко] удивл[яется], отчего я не еду: я-де устроен науч[ным] сотр[удником]. Я подожду офиц[иальных] бумаг: м[ожет] б[ыть], оттуда дадут команд[ировку] за границу? Посоветуйте, ради Бога!» (л. 55).

Мы не знаем, что посоветовал Кулаковскому Соболевский, но следующее письмо тот написал академику только через два с половиной года. Отсутствие писем Кулаковского из Киева говорит о том, что после сдачи магистерских экзаменов он перебрался в Москву. Это обстоятельство подтверждается и в «Польском биографическом словаре». В наиболее полно представленной биография Кулаковского отмечено, что после «хабилитации» в Киеве он «получил доцентуру в Московском университете» ${ }^{31}$. Авторы статей о Кулаковском относят его появление в Польше к 1925 г., а начало его преподавательской деятельности в высших учебных заведениях Варшавы - к 1926 г.32 В специальном материале в рижской газете от 7 июля 1936 г., подготовленном известным русским журналистом Н. М. Волковыским* и посвященном десятилетию этой работы, отмечалось: «С. Ю. - питомец Киевского и Петербургского университетов, ученик целой плеяды русских ученых: академиков А. И. Соболевского и поныне здравствующего В. Н. Перетца, профессоров: Д. К. Петрова (выдающегося испановеда) и проживающего сейчас в Лейпциге Ф. А. Брауна. В именах этих больших авторитетов в разнородных областях и славяноведения, и романо-германизма читатель найдет ключ и к разносторонней литературно-научной работе их ученика С. Ю. Кулаковскаго. После доцентуры в Киеве и Москве С. Ю. приехал в Польшу» ${ }^{33}$. В информацию Волковыского вкрались две неточности, до заграницы еще не дошло известие о кончине В. Н. Перетца 25 сентября 1935 г. в ссылке в Саратове. «Доцентуры» у Кулаковского в Киеве не было.

Итак, Кулаковский сообщал Соболевскому о своих делах: «За это время - т. е. за эти $1 \frac{1}{2}$ года - я кое-что приобрел в своей специальности, а гл[авным] обр[азом], знакомился с Европой и с тем, что сделано в наших областях» (л. 58). Следовательно, ученый отправился за

\footnotetext{
* Волковыский Николай Моисеевич (1881 - после 1940) - журналист, состоял членом правления петроградского Союза писателей. Выслан в 1922 г., с 1934 г. жил в Варшаве.
} 
границу примерно в сентябре 1922 г., именно в этот период «он был доцентом в Москве» ${ }^{34}$, и эта поездка оказалась долгожданной командировкой, из которой он решил на родину не возвращаться. Письмо уже полно ностальгии. «Вы не поймете, - писал Кулаковский, — как тоскуется при воспоминаниях о М[оск]ве, о том, когда я сидел на месте, на родной земле. Здесь везде мне оч[ень] трудно и часто думается о всех на том берегу. Перед глазами часто Ваш домик, горячая вода с сухой черной смородиной, Зинаида Ивановна, Николай Иванович, Вы. Как-то у Вас? Здоровы ли? Что Сергей Иванович?» (л. 58об.).

Из письма становится известно, что, пребывая в Москве, ученый не только преподавал, но и занимался переводами научной литературы. Он с удовлетворением отмечал: «Узнал, что мой перев[од] “Испан[ской] лит[ературы] "35 вышел в М[оскве] в той же серии, что и перевод Сергея Ивановича (Соболевского. - M. Р.) "Итал[ьянской] лит[ературы]"з6. Горжусь таким соседством» (л. 58). Английское издание книги Д. Фицмориса-Келли ${ }^{*}$ увидело свет в 1921 г. ${ }^{37}$ Выражал Кулаковский и надежду на реализацию и других своих трудов: «Кое-что обещают напечатать во $Ф \mathrm{p}\left[\right.$ анции], в Голландии, напечатали в Германии ${ }^{* *}$. Все это подбодряет» (л. 58). Зарубежная командировка позволила Кулаковскому вернуться к активным научным занятиям по темам, определенным еще в студенческие годы, и предпринять попытки к их публикации. Он сообщал Соболевскому: «“Римлянку” < . .> хотят в Париже по-франц[узски] издать в "Patrologie Orientaly"*** (клише приложений уже готовы). Там я кириллицу и паерки рисовал, ч[то]б[ы] шрифт по моим рисункам отлили» (л. 58об.). Этому проекту во Франции не суждено было сбыться.

Сообщал Кулаковский и об успехах М. Р. Фасмера ${ }^{* * * *}$, петербургского знакомого и младшего коллеги Соболевского: «Послал

* Фицморис-Келли Джеймс (1857-1923) - английский испанист.

** Очевидно, имеется в виду перевод со старофранцузского: Три повести Марии Французской / Пер. С. Кулаковского. СПб.: Астрея. [1923?]. Аукционный дом «Литфонд» выставил лот с этим редким изданием весной 2017 г. URL:http://www. litfund.ru/auction/48/180/ (дата обращения: 1.09.2017). Нам удалось полностью расшифровать дарственную надпись на книге: «Екатерине Николаевне на память о quattrocento, Блоке и Мадонне. С. К. Лейпциг в июне 1923 г.».

*** Patrologie Orientalis (Восточная патрология) - собрание сочинений христианских авторов. Многотомная серия, продолжающаяся с 1904 г.

**** Уезжая за границу, Фасмер писал Соболевскому 15 декабря 1920 г.: «Очень и очень сожалею, что во время непродолжительного своего пребывания в Москве не смог с Вами повидаться» (РГАЛИ. Ф. 1. 387. Л. 2об.). Фасмер помогал Соболевскому в поисках в Юрьеве (Тарту) неопубликованных работ коллеги и друга Соболевского Б. В. Никольского (1870-1919), расстрелянного ЧК. 
я как-то Вам новейшую работу Фасмера, он в Лейпц[иге] славист после Лескина* - первый в Германии; очень деятелен. Основал славяно-балтийский институт при университете с библиотекой, есть ученики, печатается серия работ» (л. 58-58об.). Однако подобную ситуацию Кулаковский относил к нетипичным: «На западе профессора-филологи еле сводят концы с концами, а уж о русских говорить нечего» (л. 58).

Следующий пассаж из письма Кулаковского, касающийся украино-польских культурных связей, уже дает основания предполагать, что в Польше Кулаковский обосновался не в 1925 г., а в 1924 г. Ученый писал: «Здесь, м[ежду] пр[очим], прочел кое-что для меня новое об украин[ских] писат[елях] XVII в., оказывается, "Небо новое" И. Голятовского* ${ }^{* *}$ было сперва издано по-польски, Лазарь Баранович $^{* * *}$ и др[угие] писали по-польски и печатали. Занятно. Вообще все культ[урно]-нац[иональное] движение на Украине в XVI-XVII вв. обязано искл[ючительно] польской культуре. Об этом Перетц ничего нам не рассказывал, когда читал курс (оч[ень] интересн[ый]) укр[аинской] лит[ературы]ры XV-XVIII вв.» (л. 58об.).

Следующее письмо Кулаковского от 27 мая не датировано годом, но из его текста дата выясняется без труда. Кулаковский вспоминал: «Ведь уже три года минуло с тех пор, как я к Вам впервые попал, пил воду с сушеной смородиной, познакомился с Николаем Ив[ановичем] и Зин[аидой] Ив[ановной]». Известно, что впервые ученый посетил московский дом Соболевских в мае-июне 1921 г. Рядом с датой Кулаковский сделал пометку «в деревне». Следовательно, ученый находился в том самом имении, о котором шла речь в его письмах Соболевскому летом 1921 г. Таким образом, можно с уверенностью установить время обоснования Кулаковского в Польше - это 1924 г.

Кулаковского интересовали самые разные стороны жизни Соболевского. Он писал: «Совершенно не могу представить себе Вашу жизнь, условия материальные прежде всего. Читал в газетах, что Вы с Серг[еем] Ив[ановичем] читаете лекции молодым поэтам, там, где Ив[ан] Ал[ександрович] Аксенов ${ }^{* * * *}$, этот чудак, но талантливый чело-

* Лескин Август (1840-1916) - известный немецкий лингвист-славист.

** Иоанникий (Голятовский) (ок. 1620 - 1688) — архимандрит, православный церковный деятель.

*** Лазарь (Баранович) (1616-1693) - архиепископ, православный церковный деятель.

****Аксёнов Иван Александрович(1884-1935)— —оэт, критик, литературовед, переводчик. 
век. Поставили забор от переулка? < ..> Что Ваши п[етер]б[ургские]

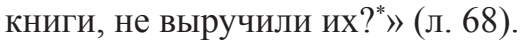

Кажется, что переписка вновь затухает на три года, так как следующее письмо от Кулаковского датировано ноябрем 1927 г. Возможно, что какие-то письма от этого периода могли не сохраниться, но совершенно очевидно, что контакты между учеными продолжались, о чем и свидетельствует письмо Кулаковского от 14 ноября. Итак, он писал: «Сегодня получил, наконец, Вашу открытку и, несмотря на ее лаконичность, очень ей обрадовался. Вместе с тем до глубины души возмущен тем, что Вам до сих пор не передали “Римлянку"» (л. 60). Наконец, Кулаковскому удалось опубликовать свое исследование о Римской иконе Богоматери ${ }^{38}$, которое он пересылал Соболевскому. Ученый рассчитывал опубликовать свои наблюдения и на русском языке. Письмо свидетельствует, что Кулаковский был не только в курсе подготовки сборника в честь юбилея Соболевского, но надеялся принять в нем участие, хотя и выражал некоторые опасения: «Радует меня то, что сборник уже готов и что он так-таки обложки дождется $^{* *}$. Но не удалил ли меня оттуда редактор по соображениям личного характера? Было бы очень обидно» (л. 60-60об.). Кулаковский волновался напрасно, Перетц, организатор и редактор сборника, не покусился на права своего бывшего ученика. Статья Кулаковского была опубликована в сборнике ${ }^{39}$.

Обе работы Кулаковского прочно вошли в круг современных исследований, связанных не только с изучением самого Сказания о Римской иконе Богоматери ${ }^{40}$. Как отмечает венгерская исследовательница средневековой русской культуры А. Криза: «Благодаря множеству легенд, описанных в Сказании, благодаря слиянию этих повестей, Сказание перестает быть повествованием об одном конкретном образе, но представляет тему иконы в более обобщающей форме». Она

* Петербургская квартира Соболевского была реквизирована. О судьбе библиотеки сообщает ответ и. о. председательствующего в ОРЯС В. М. Истрина в июле 1923 г. на запрос С. Ф. Ольденбурга: «По вопросу о библиотеке акад. А. И. Соболевского имею честь сообщить, что библиотека акад. Соболевского в 1920 г. акад. А. А. Шахматовым перевезена в Академию наук (см. прот. VI засед. Отд. р. яз. и слов. от 23 июля 1920 г.) и в настоящее время находится на сохранении в Библиотеке Академии. Что же касается ее состава, то он еще не приведен в надлежащую известность ввиду неустройства еще самого помещения» (СПбФ АРАН. Ф. 9. Оп. 1. Д. 1137. Л. 21).

** О сложностях, сопровождавших подготовку сборника, см. подробнее: Робинсон М. А. Судьбы академической элиты: отечественное славяноведение (1917 начало 1930-х годов). М., 2004. С. 270-273. 
же признает несомненный приоритет Кулаковского в обращении к данной проблематике: «Хотя Сказание о чудесах иконы Римляныни оказало огромное влияние на древнерусскую литературу (прежде всего, оно послужило образцом для весьма многочисленных сказаний о чудотворных иконах) и на иконопись, сам текст долгое время не привлекал внимания исследователей. Из исследований С. Кулаковского, появившихся в 20-х годах XX века, мы знаем, что самые ранние русские рукописи текста восходят к концу XIV века. С. Кулаковский также изучил влияние Сказания на древнерусские произведения» ${ }^{41}$.

Из письма видно, что Кулаковский продолжал внимательно следить за европейской славистической периодикой (он упоминает рецензии Н. С. Трубецкого в «Archiv für slavische Philologie»). Касался ученый и сложных взаимоотношений среди славистов. Судя по тексту, Соболевский в своей открытке негативно отозвался о личных качествах Фасмера. Эту позицию поддержал и Кулаковский в довольно резкой форме: «То, что Вы пишете о Фасмере, возбуждает и здесь недовольство. <..> Уж такой отвратительный у него характер; кроме того, при всех его лингвистических дарованиях есть в нем - полное отсутствие солидарности, если можно так выразиться, откуда его поразительная любовь к мелкой сплетне, его известные всем нападки на Ф. А. Брауна»* (л. 60об.). Возможно, Кулаковского особенно задевали «нападки» на Брауна, у которого он стажировался в Лейпциге.

Волновали Кулаковского и проблемы, не потерявшие своей не только научной актуальности и в настоящее время. «Ждал от Вас разъяснения занимающего меня сейчас вопроса о границах русской, древнерусской и украинской литератур, - писал он. - Вопрос очень важный, особенно ввиду того, что некоторые придают ему остро политическую окраску» (л. 60об.).

В последней открытке от 15 октября 1928 г. Кулаковский сообщал Соболевскому варшавский «адрес проф[ессора] Шобера**, участника “Сборника”» (л. 66).

Кулаковский был первым, кто откликнулся на кончину Соболевского в мае 1929 г. В опубликованном в парижском еженедельнике некрологе он вновь сердечно, с большой теплотой вспоминал посещения московского дома Соболевских. Свидетельства Кулаковского добавляют новые краски к портрету выдающегося ученого, которому «приходилось самому ходить на базар с корзинкой в поисках припасов, носить книги

* Браун Федор Александрович (1862-1942) - филолог-германист, славист. ** Шобер Станислав (1879-1938) — известный польский филолог-славист. 
из дому на далекую Моховую в университетскую библиотеку, подметать улицу и воевать с беспризорными, которые наводняли его садик, после того как заборы были расхватаны “на дрова”. Рядом был “детдом”, и дети часто приходили к “дедушке”, влезали к нему на колени и мешали заниматься, зная, что “дедушка” их обласкает и пожалеет» ${ }^{42}$.

Кулаковский продолжил активную научную и преподавательскую деятельность в Польше. В конце жизни он заведовал кафедрой русского языка и литературы в Лодзинском университете.

\section{ПРИМЕЧАНИЯ}

1 Российский государственный архив литературы и искусства (далее - РГАЛИ). Ф. 449. ОП. 1. Д. 220. Л. 1об.-Зоб. Далее ссылки на листы писем С. Ю. Кулаковского даются в тексте в круглых скобках.

2 Центральный государственный исторический архив Санкт-Петербурга (далее - ЦГИА СПб). Ф. 14. Оп. 1. Д. 11262.

3 РГАЛИ. Ф. 1277. ОП. 1. Д. 46. Л. 21.

4 Там же. Л. 21-21об.

5 Санкт-Петербургский филиал Архива РАН (далее - СПбФ АРАН). Ф. 134. ОП. 3. Д. 1141. Л. 14.

6 РГАЛИ. Ф. 1277. ОП. 1. Д. 46. Л. 25-25об.

7 Михальченко С. И., Ткаченко Е. В. Академическая жизнь Киевского университета св. Владимира в 1917-1918 гг. // Научные ведомости БелГУ. 2008. № 1 (41). Вып. 5. С. 184.

8 РГАЛИ. Ф. 436. ОП. 1. Д. 2787. Л. 3.

9 СПбФ АРАН. Ф. 208. ОП. 3. Д. 693. Л. 12.

10 Вернадский В. И. Угорская Русь с 1848 г. // Вибрані наукові праці академіка В. І. Вернадського. Київ, 2011. Т. 1. Володимир Іванович Вернадський і Україна. Кн. 2. Вибрані праці. С. 187-204.

11 Вернадский В. И. Дневники 1917-1921. Октябрь 1917 - январь 1920. Киев, 1994. С. 93.

12 Там же. С. 95.

13 Там же. С. 97.

14 Лавров В. В. «Найти ненужным и меня...» (об одном конспиративном письме академика В. И. Вернадского) // Екологічна безпека. Кременчуг, 2013. № 1. С. 11.

15 Вернадский В. И. Дневники 1917-1921. Октябрь 1917 — январь 1920. C. 251.

16 Там же. С. 127. 
17 Там же. С. 158.

18 Вернадский В. И. Дневники 1917-1921. Январь 1920 - март 1921. Киев, 1997. С. 24.

19 СПбФ АРАН. Ф. 284. Оп. 3. Д. 147. Л. 2.

20 Вспоминая В. Ф. Асмуса / Сост. М. А. Абрамов, В. А. Жучков, Л. Н. Любинская. М., 2001. С. 212.

41 РГАЛИ. Ф. 449. ОП. 1. Д. 176. Л. 37об.

44 РГАЛИ. Ф. 449. ОП. 1. Д. 161. Л. 23.

45 Гузь Б. Судьбы дворян Муретовых // URL:http://www.proza. ru/2017/04/16/898 (дата обращения: 1.09.2017).

24 СПбФ АРАН. Ф. 752. Оп. 2. Д. 293. Л. 15.

25 Там же. Ф. 332. Оп. 2. Д. 151. Л. 11об.

26 Там же. Л. 19.

27 СПбФ АРАН. Ф. 752. Оп. 2. Д. 293. Л. 11.

28 РГАЛИ. Ф. 1277. ОП. 1. Д. 46. Л. 29.

29 Там же. Ф. 449. Оп. 1. Д. 290. Л. 26об.

30 Там же. Л. 44-44об.

31 Chróścielewski T. Kułakowski Sergiusz // Polski słownik biograficzny. Wrocław; Warszawa; Kraków, 1971. T. XVI. S. 173.

32 Ibid.; Zienkiewicz T. Sergiusz Kułakowski — popularyzator literatury polskiej w środowisku emigracji rosyjskiej. Acta Polono-Ruthenica. 2000. № 5. S. 152.

33 Волковыский H. «Малый юбилей» С. Ю. Кулаковскаго (От варшавского корреспондента «Сегодня») // Сегодня. 1936, 7 июля.

34 Zienkiewicz T. Sergiusz Kułakowski... S. 152.

35 Келли Д. Испанская литература / Пер. и предисл. С. Кулаковского. М.; Пг., 1923.

36 Оветт А. Итальянская литература / Пер. проф. С. И. Соболевского. М.; Пг., 1923.

37 Fitzmaurice-Kelly J. A history of Spanish literature. New York; London, 1921.

38 Kułakowski S. Legenda o obrazie Matki Boskiej Rzymskiej w literaturze staroruskiej. La legende de Maria Romaia dans la litterature russe. Warszawa, 1926. S. VIII, 99 (Prace Towarzystwa Naukowego Warszawskiego, Wydział I).

39 Кулаковский С. Ю. Состав сказаний о чудесах иконы «Богоматери Римляныни» // Сб. ст. в честь академика Алексея Ивановича Соболевского. Статьи по славянской филологии и русской словесности: Сб. ОРЯС. Л., 1928. Т. 51. № 3. С. 470-475.

40 См., например: Квливидзе Н. В. Сказание о Лидской-Римской иконе Богоматери в московском искусстве второй половины XVI в. // 
Вестник РГГУ. Серия: история, филология, культурология, востоковедение. 2007. № 10. С. 230-237; Плюханова М. Б. Культ Божьей Матери Лоретской, его русские параллели и связи // ТОДРЛ. СПб., 2008. Т. 58. C. 669-696.

41 Круза А. Летающие иконы Богородицы - покровители русского государства. URL: http://www.academia.edu/3061002/Flying_icons_of_the Mother_of_God_as_Defenders_of_the_Russian_State_in_Russian (дата обращения: 20.01.2018).

42 Кулаковский С. Памяти Алексея Ивановича Соболевского // Россия и славянство. 1929. 15.VI. С. 4.

\section{A. Robinson}

The fate of a Russian dweller of Kiev:

Letters of S. Yu. Kulakovsky to A. I. Sobolevsky

(Revolution, Civil War, first emigration years)

The article dwells upon the events in Kiev during the Revolution of 1917 and the Civil War and their perception by a young researcher, S. Yu. Kulakovsky, on archival data. The analysis of S. Yu. Kulakovsky's letters to A. I. Sobolevsky represents the academic interests of the former and the reasons that made him migrate to Poland. Keywords: Sergey Kulakovsky, A. I. Sobolevsky, V. N. Peretz, Kiev, Revolution of 1917 and Civil War, ukrainization, Legends about the Roman Icon of Saint Virgin Mary. 
Ю. А. Борисёнок

(Москва)

\title{
Путь к советской нации на фоне войн и революций: начальный этап белорусизации в интерпретации Алены Марковой
}

\begin{abstract}
В рецензии анализируется монография исследовательницы из Чехии А. Марковой, посвященная процессу белорусизации как одному из самых актуальных вопросов белорусской истории $\mathrm{XX}$ века. Книга вносит важный вклад в современное прочтение сложных национальных и этнических перемен, происходивших на белорусской территории в период между двумя мировыми войнами.

Ключевые слова: белорусизация, военные конфликты ХХ века, ассимиляџия, национальная политика, историография 2010-х годов.
\end{abstract}

DOI: $10.31168 / 2073-5731.2018 .3-4.2 .05$

В последнем, 12-м, номере журнала «Русская старина» за 1896 г. муж двоюродной сестры В. И. Ленина, выпускник Витебской духовной семинарии Матвей Леонтьевич Песковский (1843-1903) в заключительной части своих воспоминаний так оценил этнонациональную политику времен М. Н. Муравьева на белорусских землях, продвижению которой в молодые годы способствовал и сам автор: «Просветительная деятельность Виленского учебного округа около половины 60-х годов представляет собою в высшей степени назидательный пример, каким образом следует при нашей разноплеменности бороться со столь сложной пестротой народностей, населяющих нашу империю, при помощи народного образования, этого мощного ассимилятора всевозможных племен и наций, этого благодетельного зиждителя неразрывного, органического соединения всех племен, населяющих государство, как бы ни был разнообразен их состав. Бесспорно, достигнутые уже результаты обрусения в Северо-Западном крае есть одно из лучших и почетнейших перед судом истории приобретений России в последнее 30-тилетие. Не трудно представить себе, во сколько раз возросли бы сила и почет России при условии гражданской и нацио-

Статья подготовлена при финансовой поддержке РФФИ, проект № 1721-01011. 
нальной ассимиляции с русским народом всех племен, населяющих нашу колоссальнейшую империю!...» ${ }^{1}$

События постреволюционной эпохи уже к началу 1920-х гг. показали, что в отношении белорусского вопроса столь радикальная постановка вопроса пережила свое время. Но изложенный родственником Ильича вариант, внешне парадоксально соединяющий в себе идеологию крайне правых и начала интернационализма, а одновременно весьма близкий пониманию ассимиляции в тогдашнем польском национализме в версии Романа Дмовского, был, как представляется, реализуем и в реалиях ранней советской эпохи по окончании длительного периода войн и революций (1914-1921). Взгляды многих из тех, кто принимал участие в решении белорусских проблем в тот период, в частности А. А. Иоффе и его покровителя Л. Д. Троцкого, возглавлявших белорусскую компартию В. Г. Кнорина (25 ноября 1920 - май 1922 г.) и В. А. Богуцкого (с мая 1922 по 4 февраля 1924 г.), были, при всех различиях лексики, похожи на планы Песковского: за звонкими марксистскими фразами у них скрывался все тот же интернационализм через ассимиляцию.

Песковский выдавал политику Муравьева и попечителя Виленского учебного округа И. П. Корнилова ${ }^{2}$ за системный и состоявшийся курс, но калейдоскопичность подходов к решению национального вопроса в последние годы существования Российской империи, несмотря на рост влияния крайне правых, этот радикальный вариант модернизации этнонациональных отношений отсрочила, прежде чем военное и политическое лихолетье, начавшееся в августе 1914 г., эту концепцию похоронило. Напротив, в первое десятилетие советской власти, после решений Х и ХІІ съездов РКП(б) по национальному вопросу, народное образование в категорической форме перестало быть «ассимилятором племен», а большевики сделали ставку на проект из сферы консервативной модернизации, в условиях БССР получивший название белорусизации. Именно об этом своевременная и основанная на солидной источниковой базе книга историка из Праги Алены Марковой, выдержавшая в 2010-е гг. уже два издания - на чешском (под названием «Советская белорусизация как путь к нации. Иллюзия или реальность?» ${ }^{3}$ ) и белорусском языках. Второе из них, увидевшее свет в самом конце 2016 г. в минском издательстве «Галіяфы», существенно дополнено и содержит ряд интересных новых выводов ${ }^{4}$ (далее в тексте ссылки на страницы этого издания).

Стоит прежде всего отметить, что вплоть до недавнего времени политике белорусизации в историографии были посвящены исключи- 
тельно статьи и главы в коллективных трудах, поэтому книги А. Марковой стали первыми монографическими исследованиями проблемы. Проделанная исследовательницей, получившей историческое образование и на родине в Минске, и в Праге, работа заслуживает самой высокой оценки как достойный подражания пример камерного исторического исследования, не претендующего на всеохватность и жестко нацеленного на конкретные исследовательские задачи.

Документальная база книги опирается на материалы белорусских архивов и опубликованные источники, проработанные автором основательно и добросовестно: это заметно и в тексте книги, в частности в интересном выводе автора о «многоуровневости» источников при описании одних и тех же событий и в принципиально важном замечании о сознательной корректировке статистических данных в 1920-е гг. (c. 35), и еще более ярко в обширной рецензии Марковой на вышедшую в 2015 г. в Питтсбурге книгу шведского историка П. А. Рудлинга о белорусском национализме 1906-1931 гг. 5 Если в монографии исследовательница подошла к работе коллеги академично, не выражая своего к ней отношения (с. 25-27), то рецензия, выдержанная в наступательном стиле, обоснованно и на конкретных архивных источниках фактически нокаутировала уязвимые стороны концепции Рудлинга, подробно рассмотрев «неоднократные проявления <...> сознательных, смысловых искажений в интерпретации сведений из источников (как первоисточников, так и из литературы)» ${ }^{6}$.

Принципиально важно, что, в отличие от многих предшественников, Маркова четко представляет себе формат и масштаб этнонациональных процессов в БССР в 1920-е гг. По мнению автора, «белорусизацию можно рассматривать как процесс культурной и языковой консолидации белорусской нации в условиях незавершенного процесса ее формирования в межвоенный период. < ..> Белорусизация представляла собой специфический культурный феномен, который являлся неотъемлемой частью белорусского нациотворческого процесса. $<$.. > Белорусизацию нельзя сужать лишь к ее языковому аспекту, ибо часто и на многих направлениях эти языковые рамки были превзойдены. <..> Из политического решения о приоритетном продвижении национальных языков смог развиться более широкий и комплексный общественный процесс, который затрагивал и преобразовывал культурную и общественную сферы БССР» (с. 44).

Круг описываемых в монографии сюжетов, благодаря строгости подходов автора, замыкается преимущественно на отражении процессов белорусизации в области просвещения и образования (с. 86-146), 
показе роли национальной белорусской интеллигенции и особенно учителей в реализации этой политики (с. 74-85, 147-158), отображении географии и исторического прошлого белорусских земель в учебниках 1920-х гг. (с. 159-191), а также проникновении белорусизации в государственные структуры (с. 192-248), включая политику «коренизации кадров», которая у автора почему-то именуется просто «коренизацией» (с. 242), создавая путаницу с курсом, провозглашенным весной 1923 г. на XII съезде РКП(б).

Предпосылки белорусизации изложены, на наш взгляд, излишне кратко (с. 45-73), последствия же процесса вообще остались вне поля зрения историка, что обидно. При этом отрадно, что исследовательский ракурс автора оказался шире традиционных узких представлений времен «холодной войны» о «советском тоталитаризме», априори тупо и безжалостно угнетающем все нации и народности от белорусов до нганасанов. Маркова абсолютно верно связывает постановку вопроса о белорусизации с речью И. В. Сталина на Х съезде РКП(б) в 1921 г. (с. 61), но приводит лишь первую часть высказывания будущего «вождя народов», где говорится о безусловном признании существования белорусов, опуская важнейшее продолжение, в котором на примере Риги и Будапешта обосновывается тезис о быстрой смене этнической окраски городов и регионов Восточной Европы ${ }^{7}$ Оба сталинских высказывания взаимосвязаны и в дальнейшем именно в связке друг с другом отражались в исторической реальности. Без учета этой теоретической модели сложно оценить реальные причины свертывания активной фазы процесса белорусизации в конце 1920-х гг.

Заметим, что автор отводит этой политике в БССР всего пять лет (1924-1929), тогда как даже настроенный с начала 1990-х гг. априори антисоветски белорусский историк старшего поколения Л. М. Лыч пишет о процессах белорусизации и в 1930-е гг. ${ }^{8}$, а в статье 2016 г. верно указывает и на постановление ЦК КП(б)Б от 10 января 1941 г. «Об изучении белорусского языка в вузах, техникумах и школах БССР» ${ }^{9}$. Стоит подчеркнуть, что начало реального внедрения преподавания на белорусском языке даже в фактически еще остававшихся в составе РСФСР белорусских уездах Витебской, Гомельской и Смоленской губерний, подлежавших передаче в состав БССР в 1924 г., по решению центральных союзных властей было реализовано уже с 1 сентября 1923 г. ${ }^{10}$ При этом осуществление мероприятий в духе большевистской национальной политики не было однородным: укрупнение БССР за счет нескольких уездов Гомельской губ. завершилось в декабре 1926 г., уже в сентябре 1927 г. руководству БССР пришлось 
отчитываться в Москве по линии ЦИК СССР не о чем-нибудь, а об итогах белорусизации, что было исполнено со всеми характерными для эпохи ритуалами показухи и отражено в специальном объемистом двухтомнике, в котором собственно белорусизации посвящался первый том ${ }^{11}$.

Итак, современная историография национальных процессов в БССР в 1920-е гг. обогатилась весьма полезным монографическим исследованием с акцентом на образовательно-культурные процессы. В то же время обращает на себя внимание, что Маркова в своей монографии почти не затронула конфессиональный аспект проблемы и совершенно не придала значения внешнеполитическому измерению объективно многоуровневого процесса (в работе нет ни слова даже о реально антипольском содержании как всей политики белорусизации, так и ее старта в 1923 г., что делает весьма актуальным специальное обращение к этой проблеме ${ }^{12}$ ).

При всех бесспорных достоинствах книги ее очевидная уязвимость - в упорном настаивании на предельно узких рамках осуществления белорусизации, за которыми, по мнению автора, следуют не только широко употребимое в историографии выражение о «свертывании» процесса, но и «конец политики белорусизации», чему в книге посвящена специальная глава (с. 249-271). В этом плане уместно припомнить одну из любимых сталинских поговорок «за деревьями не видят леса». 1924-1929 гг. были важнейшим периодом в развитии белорусизации, ее своего рода апогеем, но при этом всего лишь самым первым и достаточно кратким этапом большого и протяженного процесса распространения в широких массах населения белорусского языка и культуры. При этом стоит помнить и о том, что отдельные новации в жизни белорусского общества, связанные именно с белорусизацией (школьное обучение, массовый охват печатью и радио на белорусском языке, создание Академии наук БССР в 1928 г., музеев и других культурно-просветительных учреждений) при всех изменениях курса советских властей непрерывно и реально существовали вплоть до распада СССР в 1991 г.

Реальным «концом» белорусизации могла стать лишь никогда не осуществившаяся на практике реализация радикальных ассимиляционных идей ленинского родственника родом из Витебской губернии М. Л. Песковского и его советских почти что единомышленников; именно об этом проекте по модернизации сферы народного образования стоит помнить при оценке национальной политики межвоенного СССР, и не только на белорусском примере. Драматичные повороты отношения центральной и местной советской власти к стоявшей у ис- 
токов этого процесса национальной интеллигенции, обернувшиеся масштабными преследованиями и жесткими репрессиями, совершенно не означали прекращения основной для инициировавшей этот курс большевистской бюрократии линии на внедрение белорусского начала в школьную систему и средства массовой информации. В 1930-е гг. белорусизация на низовом, «простонародном» уровне не только не была свернута, она обогатилась массовым внедрением в БССР доступного широким слоям радиовещания на белорусском языке. При всех особенностях образовательного курса времен Н. С. Хрущева и Л. И. Брежнева эта линия в целом сохранила свое массовое звучание до времен перестройки, когда развитию белорусской самобытности был придан новый импульс.

\section{ПРИМЕЧАНИЯ}

1 Песковский М. Л. На службе. (Из личных воспоминаний) // Русская старина. 1896. Т. 88. № 12. С. 563.

2 См. новейшие подходы белорусской историографии к этой проблеме в коллективной монографии, изданной Институтом истории НАН Беларуси: Грамадска-палітычнае жыццё ў Беларусі 1772-1917 гг. Мінск, 2018.

3 Marková A. Sovětská bělorusizace jako cesta k národu: iluze nebo realita? Praha, 2012.

4 Маркава А. Шлях да савецкай нацыі. Палітыка беларусізацыі (1924-1929). Мінск, 2016.

5 Rudling P. A. The Rise and Fall of Belarusian Nationalism, 19061931. Pittsburgh, 2015.

6 Маркава А. Пакараць смерцю нельга злітавацца: беларускі нацыяналізм у даследаванні Пэра Андэрса Рудлінга // Беларускі гістарычны агляд. 2016. Т. 23. Сш. 1-2. С. 251.

7 Сталин И. В. Марксизм и национально-колониальный вопрос. M., 1937. C. 81.

8 Лыч Л. Беларусізацыя: 30-я гады // Маладосць. 1995. № 12. C. 197-207.

9 Лыч Л. Міжваенная беларусізацыя і яе ўрокі. Дзяржаўная моўная палітыка ў БССР у 1920-1930-я гады // Беларуская думка. 2016. № 3. С. 85.

10 Борисёнок Ю. А. На крутых поворотах белорусской истории: общество и государство между Польшей и Россией в первой половине ХХ века. М., 2013. С. 131. 
11 Практическое разрешение национального вопроса в Белорусской Социалистической Советской Республике: по материалам Национальной комиссии ЦИК БССР. Минск, 1927. Ч. 1: Белорусизация.

12 Подробнее см.: Борисёнок Ю. А. На крутых поворотах... С. 126-145.

\section{Y. A. Borisenok}

The way to the Soviet nation against the backdrop of wars and revolutions: the initial stage of Belarusianization in the interpretation of Alena Marková

The review focuses on the monograph of the researcher from the Czech Republic A. Marková, devoted to the process of Belarusianization as one of the most topical issues of the Belarusian history of the twentieth century. The book makes an important contribution to the modern interpretation of complex national and ethnic changes that took place on the Belarusian territory in the period between the two world wars.

Keywords: Belarusianization, military conflicts of the 20th century, assimilation, national policy, historiography of the 2010s. 


\section{Украинская диаспора Канады: история и современность}

Миграция украинцев в Канаду прошла в четыре этапа: до Первой мировой войны, вслед за ней, после Второй мировой войны и в конце $\mathrm{XX}$ в. Она была вызвана, соответственно, экономическими, политическими, военно-политическими и социально-экономическими причинами. Официальное отношение к украинцам в Канаде основывалось на расовых представлениях об их ущербности и неполноценности по сравнению с доминирующими англосаксами. Хотя эта политика позже была трансформирована в мультикультурализм, она молчаливо продолжала применяться в повседневной практике.

Ключевые слова: ассимилящуия, диаспора, иммиграция, интеграцุия, Канада, миграциия, община, украинцьь, эмиграция.

DOI: $10.31168 / 2073-5731.2018 .3-4.3 .01$

Международная организация по миграции (MOM) утверждает, что вне Украины проживает от 8,2 млн (в соответствии с переписью стран проживания) до 20 млн (на основе различных расчетов) людей украинского происхождения ${ }^{1}$. По данным Всемирного конгресса украинцев (ВКУ), украинская диаспора насчитывает около 20 млн человек². Согласно канадским источникам, в стране проживает 1251170 украинцев, что составляет 3,8\% общего числа населения. Канада является третьей, после Украины и России, страной, где проживают украинцы. Они проживают во всех провинциях и территориях страны. Большая их часть (345 410) проживает в провинции Альберта. Онтарио является второй провинцией по количеству украинцев (342 005). За ней следуют провинции Манитоба (174 995), Саскачеван (136 415) и Квебек (32 265). В остальных в провинциях их численность составляет от 160, как в Нунавите, до 8520 как в Новой Шотландии. До 1971 г. иммигрировали 17\% канадских украинцев, в 1971-1980 гг. — 3\%, в 1981-1990 гг. - 4\%, в 1991-2000 гг. — 33\% и в 2001-2011 гг. — 43\%. В 2011 г. в Канаду им-

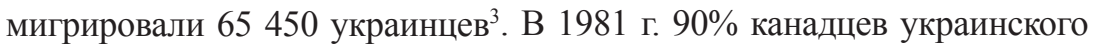
происхождения родилось в Канаде, что было самой высокой цифрой среди нефранцузской и небританской иммигрантских групп ${ }^{4}$.

Тема украинской диаспоры в российской историографии не изучена. В то же время политика Канады в отношении Украины, равно 
как и России, в значительной мере определяется украинским кризисом 2014 г. В нем Канада обвиняет Россию, против которой ввела санкции. Канада увеличила свою финансовую помощь Украине. Канада также участвует в мерах НАТО по повышению присутствия альянса в Восточной Европе. Эта политика Канады как части западного сообщества, в общем, и члена НАТО, в частности, дополняется фактором влияния украинской диаспоры. Все это предопределяет политическое значение темы. Мы попытаемся рассмотреть термин диаспора и сопутствующие термины, их применимость к канадским украинцам, проследить историю возникновения украинской диаспоры в Канаде, основные этапы ее развития, современное состояние и влияние на политику этой страны.

Работа написана в значительной мере на основе исследований, проведенных канадскими учеными, часть из которых украинского происхождения. Поэтому определенная тенденциозность, характерная для западных исследований, сочетается с украинской пристрастностью. Вместе с тем, они содержат информацию и заключения, представляющие интерес для нашей темы. Мы также опирались на собственные наблюдения и опыт общения с представителями различных диаспор во время проживания за рубежом, в том числе в Канаде.

После Второй мировой войны украинцами, проживавшими за пределами Украины, термин диаспора не употреблялся. Лишь с конца 1980-х гг. этот термин вошел в повседневную лексику украинцев. Они обычно использовали его для описания своей организационной жизни и идентичности. Украинский всемирный координационный совет (УВКС) и ВКУ, каждый из которых претендует на представительство интересов украинцев в диаспоре, разделяют их на две диаспоры: «восточную», которая живет в различных странах Восточной Европы и бывшего Советского Союза, и «западную», которая живет в Северной и Южной Америке, Западной Европе и Австралии ${ }^{5}$.

По мнению Томаса Примака, профессора истории университета Торонто, есть три причины, по которым неправильно называть украинцев диаспорой. Во-первых, подавляющее большинство украинцев всегда жили и оставались на своей европейской родине. Во-вторых, только небольшая часть украинцев покинула Украину по политическим причинам. В-третьих, в Канаде люди украинского происхождения настолько прочно ассимилированы, что подавляющее большинство считает себя сначала канадцами, а затем украинцами 6 . Первая причина касается количества проживающих за рубежом, вторая - их политической активности, третья - идентичности. Мы не уверены, 
что количество живущих на родине и за рубежом, их политическая вовлеченность и самосознание являются однозначными критериями диаспоры. Все гораздо сложнее.

\section{1. История}

До 1917 г. большая часть территории нынешней Украины была в составе России и Австро-Венгрии. Украинцы, жившие в Российской империи, мигрировали на восток, украинцы, проживавшие в Габсбургской монархии, - на запад .

\section{1. Первая волна миграции}

Первая волна миграции датируется концом XIX — началом XX в. Большинство украинцев уезжали из Галиции, Буковины, Волыни и Угорской Руси. По данным МОМ, в 1896-1914 гг. в Канаду приехало 2,5 млн иммигрантов, среди них более 170000 украинцев. До 10\% населения Западной Украины, тогда части Австро-Венгрии, уехали в Новый свет ${ }^{8}$. По данным Сатцевича, между 1870 и 1914 гг. около 2,5 млн украинцев покинуло свои дома по экономическим причинам. С 1891 по 1914 г. около 250000 украинцев, в основном из Галиции и Буковины, эмигрировали в Канаду. Почти 80000 человек вернулось до Первой мировой войны, либо потому, что они планировали уехать только временно, либо потому, что они разочаровались в жизни в Канаде. Большинство первых украинских семей в Канаде стало фермерами или сельскохозяйственными рабочими и поселилось в провинциях Альберта, Саскачеван и Манитоба9 .

Многие украинцы были расселены в крупных поселениях от юго-восточной Манитобы до восточно-центральной Альберты. Во всех основных местах украинского расселения были построены украинские грекокатолические, православные и протестантские церкви. Хорошо организованная украинская общинная структура развивала сеть региональных, национальных и международных связей. К началу послевоенного периода развитие канадского Запада шло полным ходом ${ }^{10}$.

\section{2. Операции по «интернированию»}

В годы Первой мировой войны украинских иммигрантов - выходцев из Австро-Венгерской империи правительство Канады включило в категорию «подданный враждебного государства» и насильственно переселило в лагеря для интернированных лиц в провинциях 
Британская Колумбия и Квебек. Это были концентрационные лагеря, созданные задолго до аналогичных лагерей нацистов в Европе.

После вступления Великобритании в Первую мировую войну 4 августа 1914 г., правительство Канады издало законодательный акт о военных мерах 1914 г., который создал правовые рамки для регистрации и интернирования иностранцев «вражеской национальности». Внезапно, в результате правительственного постановления, многие украинцы и другие европейцы стали «вражескими чужестранцами». В следующие шесть лет против них были предприняты различные репрессивные меры. Большинство из 171000 украинцев, проживавших в Канаде, к 1914 г. были заселены в прериях. После 1905 г. значительные общины начали формироваться в Онтарио и Квебеке, где украинцы работали в лесной и горнодобывающей промышленности, строительстве, а также на различных заводах. Поскольку эти иммигранты приехали в Канаду из австрийских владений Галиции и Буковины, их можно было назвать «австрийцами» или «австро-венграми» по гражданству, но не по национальности. Те, которые были определены в эти категории, в соответствии с положениями акта о военных мерах, который в дальнейшем будет использован против японских канадцев (1941) и квебекцев (1970), подлежали заключению в одном из 24 приемных пунктов и «концентрационных лагерях», созданных по всей Канаде, или, по крайней мере, регистрации в качестве «вражеских чужестранцев».

По сообщению генерал-майора Уильяма Оттера, командующего операциями по интернированию в департаменте юстиции, в период с 1914 по 1920 г. в заключении находилось 8579 «вражеских чужестранцев», в том числе женщины и дети. Из них только 3138, согласно расчетам генерала Оттера, можно было классифицировать в качестве «военнопленных», все остальные были гражданскими лицами. Из оставшихся 5441 большинство (возможно, даже 5000) были украинского происхождения. Более 80000 человек, в основном также украинцев, были классифицированы как «вражеские чужестранцы» и обязаны были регулярно отчитываться перед местными полицейскими властями. Им были выданы документы, удостоверяющие личность, которые они должны были постоянно носить при себе. Несоблюдение каралось арестом и возможным лишением свободы ${ }^{11}$.

Определение гражданства интернированных лиц или тех, кто был зарегистрирован как «вражеские чужестранцы», было проблематичным, поскольку после Второй мировой войны материалы в Национальном архиве Канады были уничтожены. Из сохранившихся записей показаний выживших очевидцев вытекает, что очень многие из 
так называемых «австро-венгров» были украинского происхождения. Большинство военнопленных немецкой национальности и немецкоязычных австрийцев были отделены от других интернированных и помещены в категорию «первого класса». Это означало, что они, как правило, содержались в относительно более удобных лагерях, таких как созданный в Форте-Генри, около Кингстона, Онтарио, и не были обязаны заниматься тяжелым трудом. В то же время большинство из тех, кого описывали как «австрийцев» (в списках заключенных эти люди часто классифицировались как «галичане, греческой [украинской] католической» религии или как «русины», хотя в некоторых официальных отчетах слово «украинец» также использовалось), были отправлены на рабочие пункты в приграничных районах Канады, в такие места, как Спирит Лейк, Квебек; Касл Маунтин, Альберта; Оттер Крик, Британская Колумбия. Там они должны были не только строить лагеря для интернированных, но и работать в строительстве дорог, расчистке земель, железнодорожном строительстве и деревообрабатывающей отрасли, часто к выгоде своих тюремщиков ${ }^{12}$.

Поскольку потребность в солдатах за рубежом привела к нехватке рабочих рук в Канаде, многие из этих «австрийских» интернированных были освобождены условно-досрочно для работы в частных компаниях, федеральном и провинциальных правительствах и железнодорожных компаниях. Их зарплата была установлена на уровне, эквивалентном довольствию солдата, однако была меньше, чем они могли бы получать, если бы были в состоянии предложить свой труд на рынке. Как сухо отметил генерал Оттер, эта «система оказалась большим преимуществом для организаций, которым не хватало рабочих рук». Таким образом, заключает Луцюк, операции по интернированию не только привели к разрушению семей, но и позволили эксплуатировать труд многих из этих интернированных гражданских лиц ${ }^{13}$.

После ареста каждого все их ценности изымались. Часть конфискованных денег была украдена. В 1915 г. генерал Оттер писал: «Трудности $<\ldots>$ возникли при учете полученных денежных средств». В своем заключительном докладе он заметил, что многие из интернированных были жителями Канады и обладали недвижимостью, ценными бумагами и т. п. Таковые были обращены в категорию «хранитель собственности вражеского чужестранца» в ожидании будущего решения правительства. В конце операций интернирования более 32000 долл. наличными были оставлены в общих приемных отделениях. Сколько имущество, ценные бумаги и другие ценности, которые так- 
же были конфискованы, могли стоить, еще предстояло подсчитать. В докладе Прайс Вотерхаус «Экономические потери украинских канадцев в результате интернирования во время Первой мировой войны» (1992) отмечается, что сумма, безусловно, исчисляется многими миллионами. Человеческие издержки этих операций по интернированию, разумеется, не поддаются подсчетам ${ }^{14}$.

Ежедневное существование в лагерях для интернированных было, по общему мнению, напряженным. Заключенные часто были лишены доступа к газетам, их переписка подвергалась цензуре и ограничивалась. Они были вынуждены не только содержать лагеря, но и работать на государственные и частные интересы. Иногда заключенные подвергались жестокому обращению со стороны охранников. Так писал об этом генерал Оттер: «Различные жалобы, поданные заключенными на грубое поведение охранников, я боюсь, были не совсем беспричинными, факт, заслуживающий большого огорчения, и, признаюсь с сожалением, это ни коей мере не было редкостью на других станциях». Трудные условия работы и жизни и принудительное лишение свободы приводили к физическим и психическим расстройствам. Всего погибло 107 интернированных, из них 69 «австрийцев». Но были и другие последствия. Уотсон Киркконнел, служивший в лагерях для интернированных в Форт-Генри и Капускасинге, заметил, что «среди населения лагеря» были «немногие, на ком долгие годы плена не оставили своего следа $<\ldots>$ Лишение свободы на чужой земле, бездеятельность и безнадежность ожидания были сами по себе достаточны, чтобы подорвать нервы и надломить здоровье». Оттер также признался, что «безусловно, безумие не было среди заключенных необычным явлением». Один родственник рассказал, как брат его жены пострадал в интернированном лагере Петавава: «Они там сломили его дух <... Он никогда не смог бы забыть, как несправедливо с ним обращались и как оказались его надежды ложными в этом новом мире» ${ }^{15}$.

Хотя пассивное сопротивление было обычным явлением, некоторые интернированные были более решительными в протестах против условий, в которых они оказались. В 1916 г. был полномасштабный бунт в лагере для интернированных в Капускасинге, в котором участвовало около 1200 заключенных против 300 охранников. В Сиднее, Нова Скотия, группа интернированных, направленных из Онтарио для работы на местные шахты и сталелитейные заводы, пошла на голодовку, требуя возвращения в Онтарио или отправления обратно в Австрию. Были также многочисленные попытки побега. Во время нескольких из них были убиты украинские канадцы. Другие конча- 
ли жизнь самоубийством. Группа расследования гибели в Альберте в 1916 г. Уильяма Перчалюка определила, что он покончил собой в полицейском участке, находясь под стражей в ожидании расследования его гражданства. Был сделан циничный вывод, что его «скоропалительное действие, как представляется, было совершено в порыве уныния» ${ }^{16}$.

Власти получали информацию о том, что они интернировали украинцев, которые были противниками военных целей Австро-Венгерской монархии. В 1916 г., например, группа украинских канадцев обратилась к канадскому народу с заявлением, которое, в частности, гласило: «Украинцы < . .> Западной Канады < .. > с начала войны оказались в глубоко неполноценном положении из-за их австрийского рождения, что привело $<\ldots>$ к их несправедливой классификации как австрийцев и, следовательно, вражеских чужестранцев со стороны правительства доминиона, а также канадских работодателей. Многие из них были интернированы, хотя они не более симпатизировали врагу, чем поляки, поскольку последние являются отдельной национальностью $<\ldots>$, которые надеются выйти из войны с широкой национальной автономией $<\ldots>$ C украинцами в Канаде обращаются как с врагами-австрийцами. Они подвергаются преследованиям, их тысячами интернируют, их увольняют с работы, и их обращения на работу не рассматриваются. И почему? Только по одной причине, что они были так несчастны, что родились в австрийском рабстве» ${ }^{17}$.

На протяжении военных лет многочисленные другие письма, петиции и меморандумы были адресованы федеральным и провинциальным органам власти украинскими канадскими организациями, где подтверждалась верность украинских канадцев доминиону Канады и британской империи. Аналогичные послания были направлены отдельными лицами. Например, в 1914 г. Павел Вачик из Комарно, Манитоба, написал Р. Флетчеру, заместителю министра образования Виннипега: «Я не слышал о каком-либо движении здесь со стороны людей, которое каким бы то ни было способом могло бы указать на их нелояльность Британской империи» ${ }^{18}$.

Слово «украинский» использовалось в официальных описаниях лагерей и в газетных отчетах. Выжившие интернированные сообщали, что они объясняли следователям различие между «австро-венгерским» подданством и украинской национальностью. Юристы направляли письма комендантам лагерей, где указывали, что некоторые из заключенных из-за плохого знания английского языка «не смогли объяснить [свою] национальность», что, вероятно, было единствен- 
ной причиной их интернирования. Даже генерал Оттер признал, что вовсе не нелояльность, а «тенденция муниципалитетов отделаться от нищих была истинной причиной заточения в немалых количествах» ${ }^{19}$.

В лояльности украинских канадцев к Канаде и Британской империи не было сомнения. Они вступали в канадскую армию в рекордных количествах, искажая место своего рождения или даже меняя свои фамилии на «Смит». Х. А. Маки, член парламента от Эдмонтона, писал премьер-министру Бордену в октябре 1918 г.: «Оценить количество украинцев, которые завербовались в канадские экспедиционные силы, было очень трудно, поскольку они вербовались в различные батальоны от Атлантики до Тихоокеанского побережья. Но можно с уверенностью сказать, что примерно полмиллиона солдат в Канаде, если бы цифры военного ведомства были доступны, можно было показать, что эти люди, в расчете на душу населения, дали большую долю мужчин войне, чем определенные расы в Канаде, которые в течение столетий или более пользовались привилегиями британского гражданства» ${ }^{20}$.

В то время как некоторые украинские канадцы служили с отличием, и один из них, капрал Филип Коновал, был награжден крестом Виктории, высшим военным отличием, присуждаемым британской империей, другие, которые были зачислены в армию, но затем уличены как «австрийцы», были изгнаны из армии и интернированы. Такова была судьба Ника Чонормода. Из лагеря близ Галифакса он написал капитану Адамсу 6-й военной дивизии, что не только присоединился к батальону, сформированному в Эдмонтоне в августе 1914 г., но и жил в Канаде в течение семи лет, женился на женщине, родившейся в Канаде, натурализовался и жил в Альберте. Подтвердив свою преданность, он добавил, что не может понять, «по какому обвинению меня держат здесь» ${ }^{21}$.

За интернированием нескольких тысяч украинцев в 1917 г. последовало принятие закона о выборах военного времени, который лишил гражданских прав большинство украинских канадцев. Протест против этого был малоэффективным, хотя газета «Дейли Бритиш Виг» сделала наблюдение: «Вполне вероятно, что если это предложение становится законом предполагаемых “иностранцев" и до тех пор, пока “натурализованные” канадцы будут кротко терпеть их поношение, то они посеют в себе семена горечи, которую никогда не смогут устранить. Человек, чья честь была подвергнута недоверию, и кто был обособлен для национального унижения, будет помнить это и рано или поздно это придется искупить» ${ }^{22}$.

Антииммигрантские настроения были частью культурной среды большинства ветеранов. Следствием этого в 1918 г. была значитель- 
ная поддержка требований Ассоциации ветеранов Великой войны закрытия газет «вражеских чужестранцев», обязательного клише для «иностранцев» и принудительных работ для «австрийских» и немецких мужчин в Канаде. В 1918 г. канадское правительство объявило незаконными несколько украинских газет и организаций. После окончания войны несколько сотен украинцев также были депортированы в результате так называемого «красного страха». Еще сотни остались в лагерях для интернированных, некоторые из которых действовали до 1920 г. Бывшие «вражеские чужестранцы» были определены как «опасные иностранцы» или «большевики» после революций 1917 г. в России. Последний из канадских лагерей для интернированных был закрыт только 24 февраля 1920 г. Само отделение операций по интернированию в Оттаве было закрыто 20 июня того же года ${ }^{23}$.

Учитывая подобный политический климат, многие украинские канадцы долго оставались, как констебль доложил начальству в Оттаве, «в страхе перед забором из колючей проволоки». Американские разведчики подтвердили этот вывод, отмечая, что «украинские канадцы все еще находятся под грузом неполноценности в результате их опыта в Первой мировой войне». Спустя 10 лет украинский канадец вспомнит, что эти годы были «плохим временем, чтобы быть украинцем» в Канаде. Вспоминая собственный опыт, другой интернированный написал: «Воспоминания о лагере постепенно начинают исчезать <...> [но] никто никогда не может забыть это». Напоминая о том, как они пострадали как народ в этой стране, украинские канадцы обратились к правительству Канады с призывом публично признать, что в период между 1914-1920 гг. применительно к их общине было совершено зло, и попросили вернуть современную стоимость той части богатства интернированных, которое не было возвращено. Эти средства будут использоваться для различных образовательных, исследовательских и культурных программ, чтобы помочь напомнить всем канадцам о том, что произошло, и необходимости сохранения бдительности в защите гражданских свобод и прав человека в периоды внутреннего и международного кризиса. Никакие другие канадские этнические, религиозные или расовые меньшинства не должны когда-либо пострадать, как украинские канадцы во время Первой мировой войны. Хотя то, что произошло, никогда не может быть отменено, безусловно настало время для искупления ${ }^{24}$.

\section{3. Вторая волна миграциии}

Как формулирует МОМ, «в результате неудачи национальноосвободительной революции 1917-1920 гг. экономическая эмиграция 
сопровождалась политической эмиграцией» ${ }^{25}$. В 1919-1939 гг. 1,6 млн иммигрантов были приняты в Канаде, включая 68000 украинцев, главным образом из Польши, Румынии, частично из Чехословакии ${ }^{26}$. Сатцевич утверждает, что между мировыми войнами в Канаду переехали около 67000 украинцев из Польши (Галиция, в т. ч. Лемковщина), Румынии (Буковина) и Чехословакии (Подкарпатье $)^{27}$. Марунчак называет близкую цифру, согласно которой в 1918-1939 гг. из $68000-$ 70000 украинцев примерно 56000 прибыли в 1926-1930 гг. ${ }^{28}$

Вторая волна украинской эмиграции по-прежнему состояла из элементов трудовой диаспоры. Но были и городские, с национальным самосознанием, образованные и политически подготовленные. Эти люди стали эмигрантами, потому что они принимали участие в борьбе за достижение украинской независимости между 1917 и 1920 гг. Этот новый сегмент диаспоры состоял из солдат, офицеров, правительственных функционеров и представителей интеллигенции, обладавших национальным самосознанием, и их семей ${ }^{29}$.

Иммиграционный опыт тех, кто прибыл в Канаду в период между двумя мировыми войнами, во многом отличался от предыдущего поколения. Изменилось положение дел как в Европе, так и в Канаде. Украинцы, которые въехали в Канаду до Первой мировой войны, были в основном из контролируемых Габсбургами районов Восточной Галиции и Северной Буковины. Но после Первой мировой войны политическая карта Европы была перекроена. Восточная Украина была в составе СССР, а Западная Украина была разделена между Польшей, Румынией и Чехословакией. Украинцы составляли крупное меньшинство во всех этих новых государствах ${ }^{30}$.

В Канаде в период после Первой мировой войны существовал спрос на новых поселенцев. Предназначенные для заселения в сельских местностях по всей западной прерии, многие переехали на фермы в уже обустроенных районах украинских поселений. Но другие особенно рабочие - тяготели к городам, промышленности и несельскохозяйственным занятиям.

Реакция Канады на эти обстоятельства и иммиграцию в целом была значительной. Она нашла свое отражение в новых приоритетах и новых процессах в иммиграционной политике. Новые предложения представляли собой формализацию давних взглядов на этнические различия и их значение для канадского национального строительства. В 1919-1939 гг. эти предложения были реализованы в качестве четких критериев для установления приоритетов в иммиграционной политике. Эти предложения и приоритеты регулировались новыми про- 
цедурами проверки, допуска и наблюдения последующего прогресса иммигрантов. Отныне новые проблемы были связаны с «отбором» и «квотами». Иммиграция регулировалась положениями Закона об иммиграции 1910 г., и только отдельные категории иммигрантов поощрялись к въезду ${ }^{31}$.

Одним из первых послевоенных приоритетов, которых придерживались в 1918-1925 гг, стал прием и расселение тысяч бывших канадских и британских военнослужащих и членов их семей. Толкование закона об иммиграции 1910 г., однако, выкристаллизовало два важных императива, касающихся канадской экономики и общества. Во-первых, Канада отдавала предпочтение тем иммигрантам, которые будут развивать расселение в сельскохозяйственных районах и способствовать развитию природных ресурсов. В 1911 г. в закон об иммиграции были внесены изменения. Иммигрантам из Великобритании и США позволили практически ничем не ограниченный въезд. Другие граждане допускались только в том случае, если они располагали достаточными средствами для создания ферм или же являлись сельскохозяйственными рабочими или домашней прислугой. Таким образом, была создана экономическая основа для допустимой иммиграции с континента фермеров, сельскохозяйственных рабочих и домашней прислуги ${ }^{32}$.

Однако дела обстояли гораздо сложнее. Так называемый «красный страх» в сочетании с враждебностью к гражданам центральных держав породил антагонизм к европейским иммигрантам, которые поселились на западе Канады. Поэтому неудивительно, что Канада ужесточила свои и без того жесткие иммиграционные ограничения. Закон 1910 г. запрещал въезд «иммигрантам, принадлежащим к любой расе, которая считается не соответствующей климатическим требованиям Канады, или иммигрантам любого определенного класса, рода занятий или характера». В 1919 г. это положение стало еще более ограничительным и исключило иммигрантов, принадлежавших к какой-либо национальности или расе, или иммигрантов какого-либо определенного класса или рода занятий, по причине какого-либо экономического, промышленного или иного положения, временно существующего в Канаде, или по причине того, что такие иммигранты считаются непригодными с учетом климатических, промышленных, социальных, образовательных, трудовых или других условий или требований Канады, или потому, что такие иммигранты считаются нежелательными из-за их специфических обычаев, привычек, образа жизни и методов владения собственностью, а также из-за их вероятной неспособности 
легко ассимилироваться или взять на себя обязанности и ответственность канадского гражданства в течение разумного срока после их въезда в страну ${ }^{33}$.

В 1919 г. специальным приказом был воспрещен прием подданных Австро-Венгрии, Германии, Болгарии и Турции, а также духоборов, гуттеритов и меннонитов. Эти группы были исключены по причине их «специфических обычаев, привычек, образа жизни и методов владения имуществом», а также из-за их неблагоприятного положения в государствах, которые были враждебными во время мировой войны. Один иммиграционный чиновник был достаточно откровенен: «В настоящее время мы готовим более эффективный метод, чем тот, который мы применяем, чтобы предотвратить прибытие сюда многих невзрачных европейцев, чье прибытие рассматривается больше как катастрофа, чем что-либо еще». Эти действия и установки были отражением настроений тех дней. Фактически в эти годы иммигранты неофициально классифицировались как «привилегированные», «непривилегированные» и имеющие «специальное разрешение». Хотя эта терминология никогда не использовалась в иммиграционном законодательстве, нормативных актах или ежегодных докладах, она была распространена в переписке между должностными лицами и имела центральное значение для иммиграции вплоть до Второй мировой войны и даже после нее ${ }^{34}$.

К числу лиц, считавшихся «удовлетворяющими» требованиям Канады, относились жители Британских островов, США, Норвегии, Швеции, Дании, Исландии, Франции, Бельгии, Голландии, Швейцарии и, в последующем, Германии. «Неподходящими» или «нежелательными» были граждане из остальной Европы: Австрии, Венгрии, Польши, Румынии, Прибалтики, Югославии, Чехословакии и Германии (после Первой мировой войны). Иммигранты со «специальным разрешением» включали албанцев, арабов, армян, болгар, восточных индийцев, греков, евреев, итальянцев, японцев, мальтийцев, чернокожих, персов, португальцев, испанцев, испано-американцев, сирийцев, турок и многих других. Им требовалось специальное разрешение на въезд в Канаду ${ }^{35}$.

Но растущий спрос на сельскохозяйственную рабочую силу и неспособность «предпочтительных» стран обеспечить ее потребовали, чтобы по крайней мере некоторым представителям «непривилегированных» народов было разрешено въехать. В 1923 г. министр иммиграции и колонизации признал необходимость «поощрять миграцию этих людей < ..> способных и желающих поселиться на земле и ока- 
зать помощь в развитии сельского хозяйства». Политика по-прежнему основывалась на «имперском и британском предпочтении» для тех, кто жил «в колыбели Британской империи, чтобы приехать и успешно поселиться в доминионе». Но отныне по крайней мере некоторых из «непредпочтительных» надо было терпеть. Они селились на Западе и использовали железную дорогу. Железнодорожные кампании приветствовали это ${ }^{36}$. Государственные и корпоративные взгляды на иммиграцию и размещение совпадали.

В 1919-1924 гг. в Канаду прибыло 700000 иммигрантов, украинцев среди них было всего 3700. В 1920-е гг. сельскохозяйственному сектору экономики требовались рабочие руки. Даже «непредпочтительные» народы определенно были нужны ${ }^{37}$.

В 1925-1930 гг. более 800000 иммигрантов приезжает в Канаду. Немалое количество прибывших из стран Центральной и Восточной Европы состояло из крестьянских семей, однако большинство составляли одинокие рабочие и домашние работники. Среди них насчитывалось около 55 тыс. украинцев, которые составили самую большую национальную группу, допущенную в эти годы ${ }^{38}$.

Первоначально общественная реакция была незначительной. Была даже расчетливая поддержка, о чем свидетельствует отчет о колонизационной деятельности за 1927 г.: «Несмотря на некоторую неблагоприятную критику о слишком большом проценте не англосаксонского населения в итогах об иммиграции за год, можно с уверенностью сказать, что однозначно значительное большинство на Западе благоприятно относится к выросшей иммиграции и центральноевропейцам, занятым в сельском хозяйстве для проведения первичной работы, необходимой для развития сельского хозяйства Запада с целью закладки прочной основы значительно возросшей британской иммиграции для промышленных целей». Но в 1927 г. началось общественное беспокойство, которому предстояло усилиться в течение остальной части десятилетия. Извечный «красный страх», утверждения о размывании англосаксонской популяции иностранцами, а также засухи и экономическая разруха конца 20-х гг. - все это послужило толчком к общественному протесту против иммиграции. Кроме того, переизбыток сельскохозяйственных рабочих привел к очень заметному росту европейцев, ищущих работу в городах, лесозаготовительных лагерях и на промышленных объектах. Но если правительство было обеспокоено тем, что иммигранты переезжают из сел в города, фермеры были обеспокоены тем, что еще слишком многие остаются на фермах ${ }^{39}$. Украинцы как наиболее многочисленная группа были главным объектом недовольства. 
В 1930-1939 гг. правительство продолжало регулировать поток иммигрантов. В 1931 г. с учетом безработицы в Канаде в иммиграционный закон вновь была внесена поправка. Прибытие в Канаду представителей всех социальных слоев и профессий было запрещено, за исключением британских и американских подданных, жен и детей постоянных жителей Канады, а также земледельцев, имевших достаточно средств для работы в Канаде ${ }^{40}$.

В 1930 г. в Канаду въехало всего 130000 иммигрантов, из них менее 7000 украинцев. Значительное число иммигрантов, недавно прибывших в Канаду, находилось в рядах безработных, или, наоборот, они вытеснили канадцев, которые стали безработными. Учитывая это, новой заботой стала задача ассимиляции и поглощения этих людей ${ }^{41}$. По данным переписи 1941 г., население Канады, состоявшее из 11,5 млн человек, включало 305929 украинцев «по расовому происхождению», 313273 украинцев «по родному языку» и 324894 украинцев «по происхождению». Эту общину обслуживали пятнадцать украинских газет, более десятка организаций и около 1429 культурных центров ${ }^{42}$.

Период 1919-1939 гг. был непростым как для поколений, прибывших до Первой мировой войны, так и для приехавших в послевоенные годы. Сочетание экономических, социальных, политических и расистских опасений привело к новой политике. Отныне все иммигранты подвергались тщательной проверке на предмет их пригодности для ассимиляции и совместимости с канадским общественным строем. Канада вступила в эпоху планового общества и социальной инженерии ${ }^{43}$.

Дебаты о том, является ли Канада плюралистической и космополитической или номинально бикультурной, но по существу ксенофобной, все еще продолжаются. Один аналитик, комментируя сочетание страха перед чужими людьми и страха перед экономическим стрессом, придумал термин «ксэконофобия». Это точно определяет настроения тех, кто выступал против миграции «непривилегированных» украинцев в течение 1920-х и 1930-х гг. По иронии судьбы, потомки этих украинцев теперь являются частью канадского истеблишмента, который охраняет ворота страны от новых пришельцев из Центральной и Восточной Европы и Азии ${ }^{44}$.

Среди мигрантов второй волны были люди, придерживавшиеся националистических и социалистических взглядов. Для многих из них украинцы первой волны, в особенности их дети, казались уже слишком канадцами, точнее, сильно ассимилированными. Идеологические и организационные основы украинцев, придерживавшихся 
социалистических взглядов, были заложены до Первой мировой войны. Период 1920-х и депрессивных 1930-х гг. был отмечен острым соперничеством проукраинских и антиукраинских фракций. Отношение к Советской Украине было определяющим фактором культурной и общественной жизни, разделявшим не только общину, но и семьи ${ }^{45}$. Первая волна больше придерживалась социалистических, вторая волна - националистических взглядов ${ }^{46}$.

К началу Второй мировой войны украинская диаспора находилась в раздробленном состоянии. Социалисты и националисты попрежнему имели совершенно разные взгляды на Советскую Украину и свою роль как диаспоры. Националисты в Организации украинских националистов (ОУН) не смогли преодолеть свои внутренние разногласия. Прибытие третьей волны иммиграции еще больше осложнило и без того запутанную ситуацию ${ }^{47}$.

\section{4. Третья волна миграџии}

Вторая мировая война и ее последствия вызвали третью волну украинской эмиграции на Запад. Она была почти полностью, как принято это называть в канадской историографии, политической ${ }^{48}$. В период с 1947 по 1955 г. около 38000 украинцев переехало в Канаду ${ }^{49}$.

Многие из мигрантов воевали против СССР и Германии. Некоторые служили в дивизии СС «Галичина». В отличие от предыдущих волн иммиграции, преимущественно из Галиции и Буковины, третья волна была со всех концов Украины ${ }^{50}$. Эти иммигранты привезли с собой еще больший идеологический пафос и националистическую патетику. Идеологически ими двигали воинственный антикоммунизм и украинский национализм, а также озабоченность выживанием украинской культуры. Некоторые мечтали о свободной и независимой Украине. Но многие были ориентированы на расширение прав украинцев, живших под советской властью, поддержку диссидентов и религиозных лидеров, выступая за жесткую антикоммунистическую внешнюю политику Канады ${ }^{51}$.

Послевоенных мигрантов из Украины в канадской историографии называют «перемещенными лицами». Этим термином обозначают советских граждан, оказавшихся вследствие войны за пределами СССР и не пожелавших вернуться. Внутри диаспоры существовал конфликт из-за отношения к этим мигрантам. Социалисты и коммунисты их презирали. Они критически относились к этим лицам, равно как и к националистам, которые доставляли их в Северную Америку. Для левых нежелание мигрантов вернуться в Советский Союз было 
свидетельством их вины в зверствах, которые они совершили против евреев на Украине ${ }^{52}$.

Ассоциация объединенных украинских канадцев неоднократно обвиняла украинских переселенцев в предательстве ${ }^{53}$. В конце 1940-х гг. ассоциация усердно работала над тем, чтобы убедить правительство Канады и широкие слои населения в том, что украинские переселенцы являются нацистами и что националисты в диаспоре сознательно пытаются привезти в страну военных преступников. На слушаниях постоянного комитета по вопросам иммиграции и труда социалисты диаспоры охарактеризовали переселенцев как состоящих из: «(1) военных преступников; (2) бывших коллаборационистов с немецкими оккупационными властями на Украине; и (3) небольшой группы людей, которых уговорили поверить, что, эмигрировав в Канаду, они могут избежать трудностей послевоенного восстановления на их разрушенной войной родной земле» ${ }^{54}$.

Первоначальный энтузиазм националистов по отношению к новым иммигрантам быстро превратился во враждебность. Один из членов украинской общины, прибывший в Канаду до Второй мировой войны, с сожалением отметил: «Они приехали из Украины, которую я никогда не знал и в которой большинство из нас не проживало. С другой стороны, у них не было никакого представления о том, каково было положение дел здесь для нас, кто эмигрировал задолго до Второй мировой войны. Просто разные представления, два разных мира, сходящиеся вместе» ${ }^{55}$.

Националисты в диаспоре отвергали обвинения социалистов в том, что переселенцы были нацистами, коллаборационистами и военными преступниками. Националисты, тем не менее, начали чувствовать, что новоприбывшие могут принести больше вреда, чем пользы ${ }^{56}$.

\section{5. Четвертая волна миграџии}

Четвертая волна иммиграции началась в конце XX в. и была вызвана в первую очередь социально-экономическими факторами ${ }^{57}$. Между сложившейся диаспорой и новой, четвертой, волной легальной иммиграции установились достаточно непростые взаимоотношения $^{58}$. Данный факт закономерен, поскольку считается, что украинцы диаспоры и украинцы Украины являются двумя различными этническими группами ${ }^{59}$. Современная украинская диаспора, в частности в Северной Америке, имеет сравнительно немного иммигрантов первого поколения. Например, в 1986 г. 93\% канадских украинцев родились в Канаде ${ }^{60}$. Причем 74\% составляют иммигранты третьего и последу- 
ющих поколений. На сегодняшний день подавляющее большинство украинцев - 76\% - иммигрировало в Канаду после распада $\mathrm{CCCP}^{61}$.

В 1970-1980-е гг. важным событием в украинско-канадской общине стало прибытие новых иммигрантов из Польши и, в меньшей степени, из Чехословакии, Румынии и самой Украины ${ }^{62}$. Они расселялись в городах со значительным присутствием украинцев, в частности в Торонто. В основном это были молодые люди, которым было за 20 или 30 лет. Большей частью они были несемейными. Большинство из них были детьми людей из Лемковщины на польско-украинском пограничье, которых польское правительство сразу после Второй мировой войны выслало из насиженных столетиями мест на север Польши. В украинской общине они выполняли две роли: во-первых, экономическую, а во-вторых, культурную, развивая национальное образование и возрождая использование украинского языка.

Политика перестройки и гласности в Советском Союзе изменила отношения между украинскими канадцами и их родиной и повлияла на саму общину. Правительство и народ Советской Украины проявляли повышенный интерес к украинским канадцам. Это, однако, выявило несколько различий внутри диаспоры. Например, довоенные и послевоенные эмигранты демонстрировали разное отношение к Украине и визитам туда, а также разное отношение к приезжим из Украины. Изменения на Украине в целом удовлетворили интеллектуальные ожидания послевоенной иммиграции. Многие научные учреждения и периодические издания диаспоры публиковали книги и статьи об украинской истории, которые еще не могли появиться на Украине. Интерес довоенных эмигрантов к Украине, похоже, был продиктован больше желанием восстановить семейные связи, чем идеологией. Третье поколение, однако, интересуется своими корнями, желает узнать о своей культуре и заново открыть свою идентичность. Есть также примеры людей третьего поколения, которые привержены украинскому делу, но они составляют лишь небольшой сегмент ${ }^{63}$.

Сложность четвертой волны и положения диаспоры потребовала от ученых более глубокого исследования проблемы. Так, Исайив рассматривал украинскую общину периода 1971-1991 гг. в контексте следующих вопросов: 1) отношение этнической группы меньшинства к группе большинства общества и к обществу в целом, включая другие этнические меньшинства; 2) связь этнической группы меньшинства с соотечественниками, живущими на родине; 3) связь между различными секторами или подгруппами внутри самой этнической группы меньшинства; и 4) соотношение между группами меньшинств такого 
же этнического происхождения в других крупных обществах, как, например, в Канаде и США ${ }^{64}$.

Вопрос отношения украинской общины к канадскому обществу имеет как минимум четыре аспекта: отношение украинцев, особенно молодого поколения, к обществу в целом и к собственному этносу; отношение большинства канадцев к украинцам; социально-экономическое встраивание, или инкорпорация, украинцев в канадское общество; потеря украинской идентичности или, наоборот, ее сохранение. Преобладающая социологическая теория заключается в том, что второе поколение восстает против своей этнической группы и имеет сильное желание стать частью общества в целом. Тем не менее оно также проводит большую часть своего досуга и свободного времени с представителями своей этнической группы. Другими словами, как правило, второе поколение проходит через процесс так называемой двойной социализации как внутри своей общины, так и внутри общества в целом. Оно часто чувствует себя естественной частью обоих.

Это, конечно, производит диссонанс между чувствами, желаниями и лояльностью. Данная теория в отношении третьего поколения указывает на необходимость заново открыть свою этническую самобытность. Таким образом, заключает Исайив, родившиеся в Канаде поколения украинцев демонстрируют решительную попытку соединить свою украинскую и канадскую идентичности как взаимодополняющие друг друга. Быть канадцем не исключает быть хотя бы в какой-то степени украинцем. Однако большинство канадцев, особенно британского происхождения, вовсе не разделяют подобный подход ${ }^{65}$.

Для выяснения отношения большинства общества к меньшинству необходимо изучить как политику по отношению к нему правительства, так и отношение населения в целом. Канадское правительство традиционно рассматривает иммигрантов как способ развития рабочей силы. До недавнего времени единственным обещанием, которое правительство давало иммигрантским меньшинствам, была возможность выйти на рынок труда. Никаких политических или культурных обязательств перед этническими группами не предполагалось. Лишь в 1970-1980-е гг. правительство Канады признало требования некоторых этнических групп о компенсации за несправедливость, допущенную по отношению к ним, как, например, в случае коренных народов и японских канадцев. В эти же годы политика мультикультурализма официально признала культурные притязания менышинств. Однако следует также помнить, что правительство в значительной степени 
дало такое признание из-за политического давления, оказываемого французами в Канаде в защиту своих культурных прав. Вместе с тем в указанные десятилетия отношение правительства к целям политики мультикультурализма колебалось. С одной стороны, правительство рассматривало эту политику как средство предоставления этническим группам постоянного статуса, с другой стороны - в качестве временного средства содействия «адаптации» и интеграции нынешних иммигрантов в принимающее общество ${ }^{66}$.

Что касается отношения к группам меньшинств у населения в целом, то общеизвестно, что в канадском обществе зачастую широко распространены предрассудки в отношении некоторых этнических групп, особенно расово отличающихся. С целью измерения распространенности и степени этнических предрассудков социологи изобрели такие методики, как шкала социальной дистанции Богардуса и шкала этнического социального положения. В Северной Америке группы, наиболее отличающиеся по расовому признаку от доминирующих англоязычных групп, обычно оказываются в нижней части шкалы, даже если их социально-экономический уровень высок. Наиболее важным исследованием является исследование Питера Пиньо из университета Макмастера, который пытался определить престижный статус около тридцати этнических групп в Канаде, среди которых были украинцы. На основе своих исследований он разделил континуум престижа на три категории: верхняя, средняя и нижняя. Украинцы были в средней категории, но среди одиннадцати этносов этой категории они были в самой нижней ${ }^{67}$.

Отношение большинства общества к украинцам в Канаде не совсем ясно, заключают ученые. Правительство, по-видимому, в основном позитивно относится к ним, но это во многом связано с политикой мультикультурализма. Однако сама политика преследовала различные цели и никогда не получала полной поддержки со стороны населения в целом, особенно со стороны общественных элит. Поэтому трудно сказать, существенно ли улучшилось отношение населения Канады к украинцам в 1971-1991 гг. ${ }^{68}$

Для изучения вопроса о социально-экономическом встраивании, или инкорпорации, в канадское общество была предложена концепция социального встраивания, которая отличается от концепции интеграции тем, что она не предполагает гармоничное целое или полное равенство. Она также не предполагает культурную ассимиляцию. Иными словами, она оставляет открытыми вопросы о том, каков уровень культурной ассимиляции и сохранения этнической самобытности и 
в какой степени члены той или иной этнической группы рассредоточены по всей социально-экономической структуре. Она сохраняет только понятие встраивания в структуру общества и, следовательно, предлагает, по мнению канадских ученых, лучший способ измерения степени вовлеченности в общество ${ }^{69}$.

В 1980 г. был проведен анализ украинской структуры занятости в Канаде, при котором сравнивались также данные переписей 1961 и 1971 гг. В результате анализа был сделан вывод о том, что украинская восходящая мобильность в канадском обществе была значительной, за исключением мобильности в управленческие, финансовые и высшие бизнес-профессии. В исследовании также сделан вывод, что украинцы, как и несколько других этнических групп (особенно французы), в значительной степени зависят от государственного сектора в плане своей социальной мобильности. Украинцы продолжают переходить от сельскохозяйственных занятий к рабочим профессиям. В 1941 г. более 55\% украинской мужской рабочей силы было занято в сельском хозяйстве; к 1971 г. этот показатель снизился до 13\%, а к 1986 г. он упал до 8\%. Аналогичным образом, в 1941 г. 18\% украинской рабочей силы числились «белыми воротничками»; к 1971 г. этот показатель увеличился до 33, а к 1986 г. - до 57\%. Как свидетельствуют статистические данные об участии в управленческой деятельности, социальная мобильность по-прежнему зависит от государственного сектора. Переход на управленческие должности в целом продолжается, и, в отличие от 1971 г. или предыдущих лет, в 1986 г. украинцы были лучше представлены в управленческой категории, чем канадская рабочая сила в целом. Это существенное изменение. Однако, как упоминалось выше, украинцы по-прежнему недостаточно представлены на высших управленческих постах ${ }^{70}$. Ученые увидели в этом некоторые структурные блокировки ${ }^{71}$.

В 1970 г. Исайив предложил теорию этапов этнической мобильности в канадском обществе. Согласно этой теории, этнические группы, прибывающие с низким статусом в страну (то есть чрезмерно представленные в профессиях с низким статусом на момент их въезда в страну), проходят три модели профессиональной мобильности. Первая - уход с работы с низким статусом, в нашем случае из сельского хозяйства. Вторая закономерность представляет собой стремительный рост участия в обслуживании, конторских и производственных профессиях, с наибольшим приростом в последнем. Третий этап начинается, когда участие в рабочих профессиях снижается ниже точки равного представительства со всей рабочей силой в целом, уча- 
стие в промышленных должностях либо остается постоянным, либо уменьшается ниже точки равного представительства, но и значительное увеличение в торговых, управленческих и профессиональных категориях достигает чрезмерной представленности и продолжает расти. Эти модели этнической мобильности являются социально значимыми, поскольку они отражают различные отношения этнической группы к обществу. Первая модель отражает процесс образовательно-культурной ассимиляции группы, то есть члены группы изучают профессиональные навыки, доступные через образовательные или иные институты общества, перенимая ценности и поведение общества. Вторая модель отражает процесс структурной ассимиляции. Она представляет собой шаг в направлении равенства, с тем чтобы обеспечить себя и свои интересы. В 1960-е гг. украинцы, как и многие другие группы, находились на втором этапе поиска своего равного места в обществе. В 1980-е гг. украинцы завершили этот процесс и вошли в третью модель. Для украинцев это новый и вместе с тем ограниченный опыт, поскольку он не распространяется на более высокий — или «стратегический» - уровень высоких статусных профессий. Тем не менее они достигли той стадии, когда существуют структурные условия для «достижения» некоторых прав истеблишмента ${ }^{72}$.

В этой связи ученые задаются вопросом: сохраняют ли украинцы, которые мобильны, значительную степень своей идентичности, или мобильность на более высокие уровни статуса обусловлена отказом от этнической идентичности и полной ассимиляцией основной культурой? В 1979 г. было завершено социологическое обследование девяти основных этнических групп в Торонто. Оно включало сравнительное исследование относительного сохранения этнической идентичности и ее утраты тремя поколениями в пяти этнических группах, включая украинцев. Цель исследования заключалась в том, чтобы установить факт утраты или сохранения этнической самобытности на основе как можно большего числа различных показателей ${ }^{73}$. Исследования в целом показали, что от поколения к поколению связь со своим народом, его обычаями, традициями, привычками и языком ослабевает. Вопрос о том, является ли сохранение этнической самобытности недостатком социальной мобильности, также меняется в зависимости от этнической группы и поколения. Анализ данных исследования показал, что для немцев этническая идентичность является «недостатком» в первом поколении, а не во втором или третьем. Для еврейской группы это не является «недостатком» ни в каком поколении. На самом деле это можно рассматривать как ресурс, и люди, 
которые идентифицируют себя со своей группой, также социально высоко мобильны. Для итальянцев - это ресурс, особенно для второго поколения. Для украинцев этническая принадлежность является «недостатком» для первого поколения, но не оказывает влияния на социальную мобильность второго или третьего поколения. То есть те украинцы в первом поколении, которые высоко ценят свою идентичность, менее социально мобильны, чем те, чья идентичность средней интенсивности. Однако во втором и третьем поколении это не имеет значения: те, чья идентичность высока, столь же мобильны, как и те, чья идентичность средней или низкой интенсивности ${ }^{74}$.

Подводя итог периоду 1970-1980-х гг., Исайив утверждает, что в структуре украинской общины Канады произошли значительные изменения. Эти изменения привели к решительному переходу в средний класс и в какой-то степени к достижению равенства с большинством этнических групп в Канаде. В общине сложилось дифференцированное отношение к обществу и самой себе. Но субъективный статус общины в Канаде и ее престиж в глазах всего канадского населения, похоже, не сильно изменились.

\section{2. Восприятие украинцеев в Канаде}

Чрезвычайно важным вопросом является то, как в Канаде относились к иммигрировавшим украинцам. К началу украинской иммиграции в Канаду коренные жители Канады, индейцы, были уже прочно отделены, отгорожены, обособлены и во всех смыслах изолированы от белого населения. Политическая история Канады начинается с Акта о Британской Северной Америке, вступившего в силу 1 июля 1867 г. и создавшего страну под названием «доминион Канада». Закон о канадском гражданстве был принят только в 1946 г. и вступил в силу в следующем году. После этого появился термин «канадец» в юридическом смысле. До этого жители назывались британцами или британскими канадцами, осознавая себя больше британцами.

Согласно исследованию Сатцевича, во многих отношениях одним из главных определяющих факторов оценки экономических и социальных способностей мигрантов было то, вписывались ли они в западные расовые представления ${ }^{75}$. Как в Канаде, так и в США существовавшие расистские суждения применялись к украинским иммигрантам, чтобы понять, кто они такие. Существовало почти всеобщее согласие, что они отличаются в расовом отношении от канадцев. Влиятельный канадский обозреватель объяснил достаточно откровен- 
но, как люди из Южной и Восточной Европы вписывались в науку о расах: линия, проведенная через весь континент Европы с северовостока на юго-запад, отделяющая Скандинавский полуостров, Британские острова, Германию и Францию от России, Австро-Венгрии, Италии и Турции, разделяет страны не только с различными расами, но также отдельными цивилизациями. Она отделяет тевтонскую расу от латинской, славянской, семитской и монгольской рас. Политически влиятельные части англо-канадской и американской элит хотели сохранить свои страны белыми, и поэтому сомневались являются ли украинцы белыми людьми как они. Сторонники украинцев думали, что их можно ассимилировать, но недоброжелатели подчеркивали, что «орды» галицийцев, буковинцев и русинов принадлежат явно к низшему расовому фонду ${ }^{76}$.

Именно подходы и воззрения англо-канадцев обеспечивали контекст для восприятия украинцев. Когда украинцы впервые в значительном количестве прибыли в страну, «мифические просторы британского империализма и широко искаженная логика теории происхождения видов Дарвина» привели к тому, что «британские канадцы поставили себя на вершину расовой лестницы». Следующими в этой иерархии шли северно- и центральноевропейцы, такие как скандинавы, голландцы и немцы, а также французские канадцы. Украинцы и другие славяне как более чуждые и недавно прибывшие оказались в низу этнической иерархии, но выше южных европейцев, чернокожих, арабов и китайцев, которых допустили в Канаду для строительства железных дорог. Негодование украинцев было повсеместным. На провинциальных выборах в Манитобе в 1899 г. консерваторы охарактеризовали украинцев как расу, непригодную для участия в канадской политике. Фрэнк Оливер из Альберты, будущий министр внутренних дел, который, по иронии судьбы, будет руководить заселением еще большего числа украинцев, заявил в палате общин в 1901 г., что он возмущен «идеей о том, чтобы жернов этого славянского населения висел на наших шеях в наших усилиях по строительству, обустройству и улучшению нашей страны». Англосаксонские протестанты смотрели на украинские свадьбы как на пошлые оргии. Даже благонамеренные социальные реформаторы изображали славян невежественными, неквалифицированными, грязными и склонными к преступлениям и пьянству. История интернирования и лишения гражданских прав украинцев во время Первой мировой войны очень показательна: украинцы превратились из чужестранцев, поддерживающих Австрию и Германию, в 1914-1915 гг., в большевиков и советских попутчиков 
после 1917 г. Канадская иммиграционная политика была обусловлена желанием сохранить Канаду британской. Однако на это повлияли экономические и политические нужды, а именно необходимость заселения запада Канады и сохранения его вне американской экспансии ${ }^{77}$.

Некоторые политики, которые получали прямую поддержку от украинского голосования, - такие как Чарльз Даннинг, либеральный премьер Саскачевана в 20-х гг. и министр финансов правительства Маккензи Кинга в 30-х гг. - пренебрежительно относились к украинцам. «В целом он [Даннинг] не очень дружелюбен к иммиграции из Центральной Европы», - писал Джон У. Дафо, влиятельный редактор газеты «Свободная пресса», издававшейся в Манитобе, Клиффорду Сифтону, бывшему министру иммиграции. «Он говорит, что страна вообще не хочет никаких поляков. Русины намного лучше, но он, кажется, думает, что они портятся в этой стране, особенно если они образованны. Он говорит, что они могут быть хорошо образованны, но они не могут быть цивилизованными, по крайней мере не в одном поколении; и что образованный русин является угрозой для его собственных соотечественников и для общества». Сам Дафо, после всеобщей забастовки в Виннипеге в 1919 г., которую возглавляли иммигранты британского происхождения, призвал ограничить новую иммиграцию британцами и северными европейцами. Как и многие другие, он потребовал, чтобы правительство «очистило это сообщество от иностранцев и отправило их обратно». Его газета «Свободная пресса» пропагандировала идею о том, что большинство украинцев являются коммунистами, отмечая, что украинские канадцы посещали Советский Союз и что «очень значительная часть проживающих украинцев теперь являются открытыми или тайными приверженцами большевизма и прилагают все усилия, чтобы превратить Канаду в коммунистическую страну, по образцу Советской России». Судья Хью Джон Макдональд, бывший премьер-министр и сын первого премьер-министра, рекомендовал депортировать русинов, русских, поляков и евреев. Когда при переписи 1921 г. статистическое бюро доминиона впервые признало «украинцев» отдельной группой, Министерство иностранных дел предпочло, чтобы украинцев из Галиции называли галичанами ${ }^{78}$.

В результате подобного отношения украинцы сталкивались с проблемами в трудоустройстве. Исследования канадских ученых показали, что ни один из крупных банков, трастовых или страховых компаний Виннипега не нанимал украинцев, поляков или евреев, а прием славянских и еврейских абитуриентов в медицинскую школу 
университета Манитобы был ограничен произвольными квотами еще в $1940-е$ гг. ${ }^{79}$

По мнению канадских ученых отношение населения Канады к пришельцам важно по двум причинам. Во-первых, канадское общество исторически характеризуется высокой степенью социальной, экономической и политической иерархии. Согласно классической формулировке, Канада была вертикальной мозаикой, в которой доминировала англосаксонская элита, но лишь посредством сложных союзов с другими этническими, классовыми и территориальными группами. Таким образом, взгляды англосаксов как отдельной культурной группы, а не только англоязычных канадцев любого происхождения, были взглядами доминирующей группы в канадском обществе в период после Первой мировой войны. Во-вторых, канадское общество никогда не отличалось высокой степенью согласия в отношении своих национальных целей или даже своей национальной самобытности. В отличие от таких «предопределенных» наций, как Франция или США, уверенных в своей миссии и самобытности, Канада является «самоопределившейся» страной, которая с 1867 г. участвует в сложных дебатах о своих целях и самобытности. Поэтому мнения принимающих народов в отношении новых народов являются частью продолжающейся дискуссии по поводу содержания национализма в Канаде. Таким образом, подытоживают ученые, отношение британских канадцев к украинским канадцам не только иллюстрирует неясную канадскую национальную идентичность, но приводит к усилиям по поиску определения собственного национального самосознания, которое так долго характеризовало Канаду и ее интеллигенцию ${ }^{80}$.

В Канаде достаточно долго возражали против иммигрантов. Это основывалось на культурных или классовых подходах. Иммиграция увеличивала число социально и культурно нежелательных народов. Даже простые скептики иммиграции заняли позицию жесткого экономического детерминизма, аргументируя, что дешевая иммигрантская рабочая сила вытеснила местную рабочую силу. Такая критика и различие между «предпочтительными» и «непривилегированными» иммигрантами были центральными для канадского иммиграционного мышления и политики до $1970-\mathrm{x}$ гг. ${ }^{81}$ Действовали также расовые факторы. Очень немногие обозреватели по вопросам иммиграции в Канаде до Второй мировой войны выступали против расовых барьеров, основанных на тройном разделении людей на более или менее предпочтительных белых и полностью непредпочтительных черных 
и желтых, что было зафиксировано в обзоре 1913 г. о влиянии иммиграции на канадское население ${ }^{82}$.

В исследовании о канадском национализме 1965 г. утверждалось, что «украинцы» были «самыми активными», «самыми энергичными» и «организованными» и поэтому самым главным, кроме британцев и французов, народом, способствующим изменению мнений канадцев о своей государственности. Спустя 20 лет после этого исследования украинским канадцам присваивались почти все заслуги в появлении с 60-х гг. в качестве канадской политики мультикультурализма. Что привело к выделению украинцев среди европейских иммигрантов после 1900 г.? Этот вопрос приводит к трем основным проблемам, на которых обозреватели украинской и другой европейской иммиграции сосредоточились в первой половине XX в. Во-первых, каковы были свойства общества, которое принимало новые народы? Во-вторых, чем отличались украинцы как народ? В-третьих, как новые люди и обустроившееся население будут взаимодействовать друг с другом? Эти вопросы занимают центральное место в отношении британских канадцев к украинским канадцам ${ }^{83}$.

По первому вопросу, предполагая, что разработка какой-либо формы общего канадского общества была целью французов и британцев в Канаде, комментаторы обозначили две предпосылки. Их основное предположение состояло в том, что иммигранты должны быть ассимилированы канадским обществом. Однако ассимиляция с самого начала сводилась на нет второй предпосылкой: Канада, признавались комментаторы, осталась страной с несформированной или плохо сформированной нацией ${ }^{84}$.

Относительно второго вопроса, попытка идентификации украинцев и их главных черт привела ученых к двум выводам. Во-первых, они должны были попытаться определить критерии отличия украинцев от других центральноевропейских народов. Во-вторых, выделить ключевые культурные черты украинцев. К концу 1950-х гг., по признанию исследователей, среди украинских канадцев было заметное религиозное, географическое и даже этническое разнообразие. Они отмечали, что украинцы настолько разнообразны, что лишь их родной язык является той особенностью, о которой можно говорить уверенно. Действительно, согласие относительно термина «украинский» отсутствовало вплоть до окончания Первой мировой войны, и даже тогда слово было неправильно написано в отчете о переписи 1921 г. До войны большинство британских канадцев писали о «галичанах», «буковинцах», «русинах» или, реже, «малороссах». Они, таким об- 
разом, использовали смесь географических и языковых категорий для идентификации людей со своими характерными особенностями. Средства, с помощью которых было введено общее название, не были полностью объяснены послевоенными писателями, но почти все они стали использовать «украинцы» в качестве общего термина ${ }^{85}$.

Канадские ученые отмечают две особенности народов Центральной Европы. Первая заключалась в переходе от лингвистической классификации к физической и культурной. Именно по физическим и культурным критериям они отличали этнос в течение всей первой половины XX в. Вторая исходила из желания вывести черты характера из физических и социальных критериев. Такое уверенное приписывание индивидуального и группового поведения было достаточно оскорбительным. Это было больше, чем просто форма этноцентризма, расизма, канадской вариации социального дарвинизма или этнического национализма. Причем с подобным соглашалось большинство работ ${ }^{86}$.

Два аспекта украинско-канадского общества привлекли особое внимание британо-канадских авторов. Во-первых, считалось, что украинцы имеют склонность к тяжелому труду, которой у других народов не было. Во-вторых, что украинцы имеют приверженность к школьному обучению ${ }^{87}$. Некоторые ученые были озабочены тем, что приверженность к образованию на украинском фактически подорвала бы главную цель образования, которая заключалась в его роли как органе культурной трансформации. Для них образование на английском языке в государственных школах было решающей силой, ведшей к ассимиляции украинцев и всех неанглоговорящих людей ${ }^{88}$.

Что касается третьего вопроса, то среди средств взаимодействия помимо языковой продвигалась политическая, экономическая, социальная и культурная ассимиляция. Последствия переосмысления ассимиляции в период между двумя мировыми войнами привели к задаче поиска концепции «канадского гражданства» для объединения различных народов Канады. Именно этой цели авторы стремились достичь между 1920-ми и 1940-ми гг. Требования культурных изменений были признаны как требующие времени и предполагающие взаимное приспособление. В этом ученые следовали линии аргументации, что нет канадской культуры, которая могла бы ассимилировать новых канадцев, и это заставило всех жителей Канады, обустроенных или новых, работать над созданием общей культуры ${ }^{89}$.

В 1930-е гг. была выдвинута идея о мозаичной культуре. Учитывая историю непростых отношений между Канадой и Соединенными Штатами, канадцы не использовали американскую модель «плавиль- 
ного котла», хотя иногда они употребляли этот термин. Часто использовалась национальная модель Соединенного Королевства. В этой связи канадских украинцев сравнивали с ирландцами и шотландцами. Все параллели показывали, что культурная идентичность, которой обладали украинцы, будет не более опасной и не менее ценной, чем та, которая была у ирландцев и шотландцев в Канаде. Однако сохранение традиции рассматривали как средство для успешной адаптации и психологического благополучия ${ }^{90}$.

Британские канадцы определили к 1940-м гг. форму ассимиляции, находившуюся за пределами культурных и социальных сфер, которые были в центре многочисленных дискуссий вплоть до 1930-х гг. В 30-е географы, экономисты и социологи завершили часть научной работы по теме сельскохозяйственного заселения прерий и поэтому внимательно изучили экономический и социальный опыт поселенцев. Вывод этих исследований заключался в том, что адаптация к особым физическим и экономическим условиям сформировала политическое и экономическое поведение всех социальных групп, поселившихся в прериях ${ }^{91}$.

Использовались также демографические показатели. Взяв за основу данные по бракам и рождаемости, ученые отметили переход одного поколения от первоначального европейского поведения к канадскому.

Поскольку труд украинцев был источником культурной самобытности, свойственная им склонность к тяжелой работе втянула их в коммерческую экономику и интегрировала в экономический и политический порядок прерий. Эта интеграция как признак ассимиляции была гораздо важнее для экономистов и социологов, чем принятие некоторых социальных нравов и культурных форм, о которых постоянно говорили другие авторы, особенно историки. Экологические факторы в итоге составляли мощное ядро «естественных сил» ${ }^{92}$.

Как представлялось ученым, историки беспокоились по поводу расплывчатых культурных целей и ценностей, второстепенных для экономистов и социологов, которые в качестве единственно приемлемых мер интеграции настаивали на первичном экономическом и политическом участии в жизни прерий украинцев и других групп иммигрантов. Наконец, почти все британо-канадские обозреватели определили вклад украинцев в будущую канадскую культурную самобытность и участие в канадской экономике к 1940-м гг. С этими двумя важнейшими выводами британские канадцы были готовы, наконец, провозгласить, что участие как старых, так и новых канадцев заключалось в создании нового «общего канадства», на которое надеялись авторы предыдущих десятилетий. 
Но некоторым этого было недостаточно, и для них ассимиляция стала звучать как усвоение англосаксонских культурных целей, что закончилось поиском гораздо более широкого «нового канадского гражданства». Хотя британские канадцы также признали, что украинцы приняли политические и экономические цели Канады, они заявили единственную претензию - чтобы «наши новые канадцы исправили свои жизненные привычки, и при необходимости свой язык, чтобы сделать возможным сотрудничество между нами» ${ }^{93}$.

Канадские комментаторы все чаще признавали, что существенная приверженность стране - участие в экономике и верность политическому порядку - была важной характеристикой украинских канадцев к 1930-м и 1940-м гг. Они рассматривали принятие украинскими канадцами обязанностей и лояльности в контексте привилегий канадских граждан. Пока ученые спорили, послевоенное правительство Маккензи Кинга перешло к политическому решению этой проблемы. Государственный секретарь Пол Мартин отметил, что законопроект о канадском гражданстве наконец предоставит определение гражданства, которое будет признано на международном уровне и объединит канадцев внутри страны. Как выразился Мартин, цель заключалась в том, чтобы четко установить основу и определить канадское гражданство, которое будет основным законом, от которого будут зависеть права и привилегии канадцев. Когда Мартин пришел к определению основы этого нового общего гражданства, устраняя различия между рожденными в Канаде, подданными Великобритании и натурализованными канадцами, он утверждал, что единственным критерием является то, что человек «доказал, что он является верным гражданином» своим проживанием и работой в Канаде. Он заявил, что знание французского или английского не является критерием. Главное в заявлении Мартина было то, что он полностью отказался от культурных критериев, которые так много лет беспокоили британских канадцев. Закон о канадском гражданстве 1947 г. означал отказ от цели культурной ассимиляции и культурного соответствия ${ }^{94}$.

Отношение британо-канадской интеллигенции к украинским канадцам привело к отходу от интерпретаций отношений между принимающими народами и новыми поселенцами, бытовавших в первой половине $\mathrm{XX}$ в. Британские канадцы, не отказываясь от самой возможности канадской идентичности в аморфной концепции мозаичной или ненациональной идентичности, были убеждены, что смесь исторических, местных и новых народов (куда они относили украинцев) ведет к уникальной и сильной идентичности для Канады. Как бы они ни были обеспокоены 
отношениями между принимающим обществом и новыми народами, а также сильными сторонами собственной культуры, к 1920-м гг. британские канадцы были уверены в положительных результатах этнических отношений между ветвями европейских народов. Канадские авторы считали, что ассимиляция означает смешение как принимающих, так и новых народов. Они также были убеждены в том, что культурная ассимиляция имеет гораздо меньшее значение, чем экономическая и политическая ассимиляция. Здесь сказывались последствия отношений между французскими и британскими канадцами. Канадские идеи национализма в середине XX в. изменились в результате обсуждения места украинских канадцев. Пренебрежительное британо-канадское мнение о двукультурной Канаде значительно изменилось в 1920-1940-е гг. Противостояние и взаимодействие британских канадцев с европейскими иммигрантами показывает возможность достижения договоренностей, которые также проложили дорогу процессу переоценки места французских канадцев в Канаде, который начался в 1940-х и 1950-х гг. ${ }^{95}$

Таким образом, сохраняя собственную культурную самобытность и не мешая украинцам делать то же самое, англосаксы полагали, что культурная ассимиляция, которая является долгим и сложным процессом с неизвестным результатом, не является главной. Участие в экономике и политике, будучи главным фактором, является достаточным условием для интеграции или ассимиляции пришельцев-украинцев в пусть еще не совсем определенную канадскую идентичность.

\section{3. Украинское самосознание и отношение к Украине}

Весьма важным фактором было то обстоятельство, что большинство украинцев, которые мигрировали в Северную Америку в рамках первой волны иммиграции, не ощущали себя «украинцами». Слово «украинец» было незнакомо большинству людей, в том числе самим иммигрантам ${ }^{96}$. Подавляющее большинство украинских эмигрантов первой волны стали украинцами, находясь в диаспоре ${ }^{97}$.

Некоторые украинцы в годы войны активно и добровольно сотрудничали с нацистами и убивали евреев. В еврейской среде распространено мнение, что большинство евреев пало от рук украинцев, латышей и эстонцев. По некоторым еврейским оценкам, степень сотрудничества украинцев с нацистами была такова, что в годы войны примерно 90\% украинских евреев было уничтожено ${ }^{98}$.

Украинскую диаспору характеризовали, прежде всего, чувства преследования и жертвенности. Одним из источников чувства пресле- 
дования является их убежденность в том, что они коллективно и несправедливо были изображены отдельными евреями, еврейскими организациями и социалистами как отъявленные расисты, антисемиты и военные преступники ${ }^{99}$. Чувство жертвенности связывают с пресловутыми репрессиями и «голодомором» со стороны советской власти.

В этом смысле украинцы очень часто сравнивают себя с евреями. Сравнение с еврейской диаспорой помогло украинцам, живущим за рубежом, осознать собственную общину. Украинцы указывают на то, что во многом евреи обеспокоены долгосрочным выживанием своих общин точно так же, как и украинцы. Преследование евреев также имеет параллели в рассказах о жизни украинской диаспоры, поскольку многие диаспорные украинцы утверждают, что их этническая группа была жертвой геноцида и что был украинский холокост, который, по крайней мере по ужасу, не уступал холокосту еврейскому. Голод 1932-1933 гг. ими рассматривается как преднамеренная попытка Сталина и советского режима физически уничтожить украинцев как этническую группу. Украинская канадская ассоциация гражданских свобод, которая была образована отчасти для того, чтобы лоббировать у канадского правительства признание и выплату компенсации за интернирование украинских канадцев во время Первой мировой войны, использует вызывающие эмоции термины из лексикона как холодной войны, так и холокоста, чтобы описать случившееся с украинцами ${ }^{100}$.

Важнейшим средством осознания себя и своей самобытности стал язык. В послевоенное время некоторые украинские лидеры предлагали повысить статус украинского языка до уровня, каким пользовался французский. С точки зрения канадского национального вопроса, фактор канадских французов усиливал, а не ослаблял украинский аргумент в пользу двуязычного образования и мультикультурализма ${ }^{101}$. Этому способствовал Конституционный акт Канады, принятый в 1982 г.

Со времени Первой мировой войны многие украинские канадцы и их организации, особенно ветераны войны и интеллигенция второй и третьей волн миграции, жаждали некоммунистическую Украину. Разница между иммигрантами первой и второй волн заключалась в том, что некоторые из последних критически относились к устоявшимся организациям первых, которых они считали слишком «канадскими», слишком озабоченными украинско-канадскими вопросами и недостаточно ревностными в поддержке независимой Украины. Конкурирующие идеологии украинско-канадских левых и правых отражали различные представления о том, каковым должно быть украинское государство. Для людей с коммунистической ориентацией украинская неза- 
висимость не была проблемой, поскольку она определяла Украину, как и СССР, конституционно независимой, политически прогрессивной социалистической республикой в составе Советской Федерации.

Краткое существование Украинской народной республики (УНР) в 1917-1921 гг. способствовало активизации украинской идентичности в Канаде. Это был источник гордости и надежды. Впервые в новейшей истории украинцев УНР показала, что их политическая элита стремилась к объединению и они обладали такими национальными символами, как правительство и армия. Прочные связи между украинскими канадцами и борьбой за «освобожденную/независимую Украину» берут свое начало с УНР. В 1919 г. Лига граждан Канады обратилась к премьер-министру Бордену с просьбой признать украинское правительство, но безрезультатно. Два украинских канадца приняли участие в Парижской мирной конференции в конце Первой мировой войны, а Украинский канадский комитет (УКК) лоббировал на Парижской мирной конференции в конце Второй мировой войны международное признание суверенных прав независимой Украины. В начале 1920-х гг. 10 тыс. украинцев прошли маршем перед польским консульством в Виннипеге в знак протеста против политики польского правительства в Галичине. Украинские канадцы были в авангарде международной поддержки Галицийского правительства в изгнании (Западноукраинской национальной республики), но их надежды рухнули в 1923 г., когда союзные державы признали весь регион частью Польши, а не просто территорией под польской военной оккупацией ${ }^{102}$.

Позиция канадского правительства в отношении Украины никогда не заключалась в поддержке независимости и больше совпадала с коммунистической точкой зрения, чем с позицией националистически настроенных украинских канадцев. В период между мировыми войнами правительство Маккензи Кинга рассматривало Канаду как «огнеупорный дом», который лучше всего держался таким образом, сохраняя молчание по европейским вопросам и избегая вовлеченности в европейские дела. После начала Второй мировой войны правительство запретило Украинскую ассоциацию трудового фермерства (УАТФ) и коммунистическую партию. Оттава призвала другие украинские организации присоединиться к объединенному фронту УКК, цель которого состояла в том, чтобы помочь участию Канады в войне. Больше, чем любая другая этническая группа, украинские канадцы подозревались полицией и другими государственными органами в том, что они негативно воспринимали участие Канады в войне. Результаты референдума по призыву 1942 г. укрепили эти взгляды. В 
то время как британо-населенные районы проголосовали подавляющим большинством голосов «за», украинские, французские и немецкие районы оказали гораздо меньшую поддержку ${ }^{103}$.

Таким образом, в обеих войнах украинским канадцам приходилось сталкиваться с тем, что их изображали как врагов Канады. Когда Советский Союз вступил в войну на стороне союзников, УАТФ и компартия были декриминализированы. Они сразу же осудили УКК как агента Германии. Канадское правительство теперь рассматривало украинско-канадские стремления к независимой Украине как несовместимые с британской политикой и как нежелательный вызов для своего нового и стратегически важного советского союзника, с которым оно установило дипломатические отношения в 1942 г. Канадское правительство активно выступало против обсуждения вопроса о независимости Украины. Для департамента внешних связей эта концепция была «миражом», идеей, которую нужно было вытеснить из сознания украинских канадцев, чтобы «ускорить процесс их ассимиляции». Таким образом, когда УКК внес предложения на этот счет, они были признаны «самонадеянными» и «неприемлемыми». Хотя после войны правительство было готово агитировать за освобождение таких советских союзников, как Польша и Венгрия, оно упорно отказывалось распространить этот принцип на Украину, считая ее экономически и политически нежизнеспособной, даже если СССР откажется от коммунизма. Что касается советского правительства, то оно рассматривало антикоммунистическую украинско-канадскую общину как главное препятствие на пути улучшения советско-канадских отношений, поскольку она была крайне настойчивой и громогласной в оспаривании целостности и самой легитимности $\mathrm{CCCP}^{104}$.

После Второй мировой войны украинские канадцы лоббировали жесткую антисоветскую позицию во внешней политике Канады, предостерегая Оттаву от соблазнения советскими принципами «мирного сосуществования». Лидерами антисоветских нападок были люди из третьей волны иммиграции, из которых были выбраны многие лидеры Канадской лиги за освобождение Украины ${ }^{105}$. Сформированная в конце 1940-х гг, она первоначально действовала вне рамок УКК, но в 1950-е гг. смирилась с тем, что диаспора является явлением постоянным, а не временным. Затем она присоединилась к УКК, как и многие другие послевоенные организации. Будучи обеспокоенным тем, что повестка дня УКК может в большей степени определяться недавними иммигрантами с европейскими, а не канадскими интересами, правительство продолжало вести наблюдение. Однако воздействие по- 
следней волны было приглушено, поскольку ее представителей было меньше и они были более широко расселены, чем предыдущие волны. Большинство из них тяготели к южному Онтарио, куда старые организации - например, Украинский национальный фронт (УНФ) - также после войны переместили свои штаб-квартиры, но где украинское присутствие было менее заметным, чем в прериях.

Еще до того, как в советско-канадские отношения проложили себе путь перестройка и гласность, среди украинских канадцев ослабла жажда освобождения Украины, поскольку все больше и больше их были уроженцами Канады. Их отличало безразличие к судьбе Украины. Тем не менее недоверие к СССР продолжало проявляться в 1980-е гг. в решительных протестах украинских организаций против мандата комиссии по военным преступлениям Дешене и признания канадскими судами документов, предоставленных советским правительством. Подозрения, однако, отошли на второй план по мере того, как мир менялся: украинско-канадские бизнесмены обращались к Советской Украине, где они уже могли иметь дело непосредственно с местными властями. Рост торговли и прямые инвестиции на Украине стали новыми явлениями для украинских канадцев. И наоборот, советские украинцы получили больше доступа к информации об украинских канадцах и их наследии ${ }^{106}$.

Чернобыльская катастрофа предоставила диаспоре одну из первых возможностей играть официально санкционированную роль в украинском обществе ${ }^{107}$. Многие люди из Украины указывали представителям диаспоры, что их помощь не доходит до адресата. Это несколько деморализовало население Украины в целом, так как многие верили, что диаспора поддерживает старую эксплуататорскую элиту, которую они часто называли «мафией», чувствуя, что она мало способствует реальным изменениям, которые могли бы принести общую пользу. Обвинения в коррупции и взяточничестве в украинских правительственных кругах стали более широко освещаться в западной прессе, завершившись в 1998 г. арестом швейцарскими властями бывшего премьер-министра Украины Павла Лазаренко. К середине 1990-х гг. отдельные лица и организации стали гораздо осторожнее относиться к помощи и поддержке Украины ${ }^{108}$.

\section{4. Неоднородность диаспоры}

Украинские канадцы представляли собой весьма пестрое и даже противоборствующее сообщество. Существовали религиозные, идеологические, политические различия. 


\section{1. Религиозное разнообразие}

В отличие от других диаспор, которые хотя бы номинально объединены приверженностью к одной конфессии, члены украинской диаспоры принадлежали различным ветвям украинского православия, украинской католической (грекокатолической, униатской) церкви, римскокатолической церкви и разнообразным протестантским деноминациям.

Исторически украинский католицизм и украинское православие были доминирующими конфессиями в украинской диаспоре ${ }^{109}$. После 1918 г. религиозный спектр еще более расширился. Появились пресвитериане, объединенная церковь, евангельские фундаменталисты, англикане и другие ${ }^{110}$. Теперь римскокатолическая церковь и некоторые протестантские конфессии растут за счет униатов и православной церкви ${ }^{111}$. Сегодня менее половины украинских канадцев заявляет о принадлежности к украинской католической и православной церквам. В период между мировыми войнами религиозные разногласия усиливали политические споры: коммунисты были антицерковными атеистами; большинство гетманцев были католиками и консерваторами; Украинская лига самообеспечения была православной и в основном либеральной. Организованная религия и религиозные различия стали более слабыми силами, а идеологический спектр сузился по мере того, как те, кто находился на крайних позициях (коммунисты, монархисты и националисты), исчезли или переместились в центр ${ }^{112}$.

\section{2. Идеологические различия}

Украинские канадцы никогда не были идеологически однородной группой. Более, чем другие канадские этнические группы, они породили множество ожесточенно антагонистических партий и фракций. Идеологический спектр вмещал либералов и демократов, шовинистов и реакционеров, монархистов и республиканцев, коммунистов, социалистов и социал-демократов. Деятельность некоторых политических групп включала в себя достижение практических целей, таких как улучшение экономического положения и культурного статуса украинских канадцев. В межвоенный период бытовало коммунистическое видение пролетарского интернационализма. Существовала также гетманская мечта о независимой Украине во главе с монархом. При рассмотрении состояния левых и правых организаций всегда необходимо помнить о том, что многие члены были политически неискушенными и присоединились к ним скорее из-за предлагавшихся организациями 
социальных и культурных услуг, чем из-за сильной идеологической предрасположенности ${ }^{113}$.

Социализм, как его коммунистическая, так и социал-демократическая разновидности, был более популярен среди первой волны украинцев, чем среди иммигрантов межвоенных лет и периода холодной войны. Эксплуататорские условия труда в Канаде означали, что к социализму интереса было больше ${ }^{114}$. Но, вместе с тем, идеологические условия Канады не были благоприятны для развития идей социализма.

В составе украинско-канадской общины коммунистов было мало; в рядах коммунистической партии Канады, однако, украинцев было много. Данные, которыми оперирует канадская историография, варьируются, но финны, украинцы и евреи составляли подавляющее большинство членов коммунистической партии, когда она была зарождающейся силой в канадской политике в 1930-е и 1940-е гг. Англосаксы доминировали в руководстве компартии, но остальные три группы составляли, по оценкам ученых, 90\% партии ${ }^{115}$. Украинское влияние сохранялось долгое время: в 1980-х гг. половину финансовых вкладчиков в компартии Манитобы составляли украинцы.

С 1950-х гг. влияние, которое имели социалистические организации в США и Канаде во время Второй мировой войны, уменьшилось, причиной чего стало начало холодной войны. Иногда лица и организации становились объектом государственного наблюдения из-за подозрений в том, что поддержка ими СССР ставит под вопрос их лояльность Канаде. В 1947 г. украинские социалисты в Канаде и США собрали более 300000 долл. на покупку подарков, продуктов питания, одежды и лекарств для послевоенных сирот на Украине. Канадское общество культурных связей с Украиной, придерживавшееся социалистических взглядов, собрало около 5000 книг на английском языке для украинских университетов. Их самый большой успех, однако, заключался в налаживании и поддержании контактов с Советской Украиной в разгар холодной войны. Для социалистов из диаспоры продвижение украинской культуры и языка стало символическим признанием их продолжавшейся солидарности с Советской Украиной. Социалистические организации культивировали отношения с украинскими художниками и интеллектуалами, чтобы демонстрировать международную солидарность и противостоять утверждениям о том, что украинский язык и культура угнетаются. Они принимали у себя артистов, музыкальные ансамбли и танцевальные труппы для демонстрации того, что в СССР процветают украинский язык и культура ${ }^{116}$. 
В Канаде об украинско-канадской политике правого крыла знали меньше по сравнению с тем, что было известно об украинской политике левого крыла. В то время как одни англо-канадцы считали украинцев радикальными коммунистами, другие считали их реакционными националистами, называя «фашистами» и «боевиками». Во вторую волну украинских эмигрантов в конце 1920-х гг. вошли ветераны войны за украинскую национальную независимость. Хотя считается, что в межвоенные годы переселенцы были «в основном» ветеранами украинских вооруженных сил, в 1930 г. в Канаде насчитывалось всего 585 членов Ассоциации ветеранов украинской войны. Тем не менее они стали ядром яростно антикоммунистической Украинской национальной федерации (УНФ), самой сильной украинско-канадской националистической организации, лидерами которой канадское правительство считало лиц, находившихся в военное время в контакте с террористической ОУН. К началу Второй мировой войны УНФ имел 145 филиалов, но по популярности всегда уступал Украинской ассоциации трудового фермерства. В то время как последняя была массовой организацией, которая сознательно имела дело с большим количеством украинцев, УНФ была кадровой организацией, построенной вокруг нескольких лидеров. В отличие от левых, украинские правые были сильно раздроблены и постоянно ссорились. Были конкурирующие церкви, организации мирян и газеты. Менее воинственная в национальном вопросе и более движимая религиозными убеждениями, чем УНФ, Украинская лига опоры на собственные силы, появившись в 1920-е гг., подчеркивала органическую взаимосвязь украинской нации и украинской культуры с украинской православной церковью. Вместо классовой борьбы лига преследовала идею «гармонизации классовых различий». Ее органом была газета «Украинский голос», которая помогала популяризировать термин «украинский» ${ }^{117}$.

Очень консервативной и милитаристской организацией была «Сич», которая также возникла в 1920-е гг. «Сич» была организована при поддержке украинского католического епископа Канады Никиты Будки и представляла собой форму «обновленного» католицизма. В 1930-е гг «Сич» стала Объединенной гетманской организацией и претендовала на наличие 50 отделений. Гетманцы создали Лигу британских украинцев и выступали за монархическую, независимую Украину с формой правления, аналогичной Британской империи. Их программа призывала к «добрососедским <..> политическим и экономическим отношениям между двумя монархическими правительствами - британским и украинским». Вершиной гетманизма в 
Канаде стало посещение в 1938 г. гетманича Даниила Скоропадского, сына гетмана, который краткое время правил Украиной в 1918 г. Его приветствовали ведущие канадские политики. Сторонники рассматривали Скоропадского как «князя» и наследника украинского престола. Украинские коммунисты и сторонники православной церкви, напротив, сравнивали титул гетмана с фюрером и дуче, указывали на немецкую резиденцию Скоропадского и осуждали его как агента Гитлера. Со смертью Скоропадского в 1957 г. с гетманством было покончено.

Идеологические предпочтения украинских канадцев были поляризованными. Крайности в украинско-канадском политическом спектре привели к систематическому наблюдению со стороны полиции, а также эпизодическому особому вниманию со стороны департамента внешних сношений и американских спецслужб. Русская революция и советизация Украины с каждым годом отдаляли историческую родину от украинских канадцев и делали ее для них менее актуальной. По мнению канадских ученых, общественное образование и смена поколений уменьшили глубокие идеологические различия. Украинско-канадская политика стала больше похожа на основную канадскую политику: умеренную, сосредоточенную ближе к центру и движимую ценностями среднего класса ${ }^{118}$.

Однако в Канаде существовали и различные националистические организации. Существовали различия между бандеровским и мельниковским крыльями ОУН, а также другими националистически ориентированными группами ${ }^{119}$. Если социалисты устанавливали связи с Украиной, то националисты, напротив, их не поддерживали, говоря о нарушениях там религиозных, языковых, культурных прав.

\section{3. Политические отличия}

Менялись представления украинцев об их месте в канадской политической системе, при этом никогда не было единой украинско-канадской политической точки зрения. Большая часть истории участия украинских канадцев в политическом процессе разворачивалась в прериях, особенно в Манитобе. Виннипег являлся для украинских канадцев организационной и духовной столицей. К 1919 г. там выходило пять украинских еженедельников. Это единственный крупный канадский город, который начиная с 1911 г. последовательно избирал украинцев на государственные должности, включая мэрию. С 1908 г. и до начала 1960-х более 70 украинцев стали мэрами муниципалитетов Манитобы. Начиная с 1940-х гг. украинцы в законодательном органе этой провинции были представлены более широко, чем среди 
местного населения в целом. Они составляли четверть кабинета новой демократической партии (НДП) в 1981 г. $^{120}$

Канадские либералы и консерваторы признавали и обхаживали потенциальных избирателей-украинцев. Появился даже термин «оптовая торговля галицкими голосами». После 1917 г. украинские социалисты были вдохновлены русской революцией, тогда как среди англо-канадских социалистов оставались популярными фабианизм, методизм и британская лейбористская партия. Социалисты были меньшинством как среди украинцев, так и среди англосаксов. Канадское правительство и политика были для большинства украинцев чем-то, что лучше оставить доминирующим англосаксам, которые их контролировали. Война болезненно подчеркнула шаткий статус, предоставляемый гражданством, полученным в результате натурализации. Для устоявшихся партий украинцы были группой, которой нужно было манипулировать во время выборов. Газета «Канадский фермер» подвела итог того, как многие украинцы воспринимали свою политическую роль накануне выборов в Манитобе в 1922 г.: «И консерваторы, и либералы никогда не пытались просветить украинцев в политических вопросах, а деморализовали их во время предвыборных кампаний, расточая денежные вознаграждения, предлагая крепкие напитки, обещая строить дороги и т. д. за их голоса. Это <..> заставило украинцев считать выборы возможностью заработать немного денег или получить другие награды. Им были выданы документы о натурализации, но им не объяснили, какова реальная ценность и важность этих документов; им было сказано, что документы дают им право голоса, хотя партии подкупили их голоса. Короче, наши поселенцы до сравнительно недавнего времени были прекрасными политическими инструментами в руках англосаксов; какая бы партия ни тратила больше денег на покупку их голосов, эта партия гордилась своими победами и своим господством <...> ни одно правительство не позаботилось информировать украинцев об их политических правах и обязанностях» ${ }^{121}$.

В период между двумя мировыми войнами украинцы голосовали за украинских и других кандидатов, представлявших различные партии. Однако в большинстве случаев они продолжали проводить политику поддержки устоявшихся партий и правительств, особенно в сельских районах. Газета «Канадский фермер» рационализировала логику дифференцированного поведения в 1932 г.: «Канадские украинцы не имеют никакого влияния. Мы бедны и нуждаемся в политической помощи. Существование украинских фермеров и рабочих 
зависит от более сильных. Это заставляет нас поддерживать политически влиятельную партию. Связь с малыми радикальными партиями приносит нам, украинцам, только дискредитацию и разорение». Газета «Украинский голос» выдвинула аналогичный аргумент: «Мы должны избирать кандидатов, выдвинутых правящей партией. <..> Кандидаты от партий, дающие странные и невыполнимые обещания, не принесут нам никакой пользы, только национальное бесчестие» ${ }^{122}$.

Несмотря на эти покорные настроения, большое количество украинцев в Виннипеге голосовали за коммунистов. Голосование за коммунистов - независимо от этнической принадлежности кандидата - увеличилось прямо пропорционально количеству украинцев в каждом избирательном округе. Эта тенденция не прерывалась в 1930-е и 1950-е гг. Исследования голосования в многомандатном избирательном округе Виннипег-Север на провинциальных выборах 1953 г. показали, что, как и в случае с британскими и еврейскими избирателями, процент голосов за украинских кандидатов в округе увеличился по мере увеличения процента украинских избирателей. Все три этнические группы, как правило, предпочитали кандидатов своего этнического происхождения. Но на этом сходство заканчивалось. Если процент голосующих за кандидатов от консервативной, либеральной и социально-кредитной партий увеличивался по мере возрастания числа британских избирателей; процент голосования за кандидатов от Кооперативного содружества федерации увеличивался по мере увеличения количества еврейских голосов, - то поддержка лейбористов-прогрессистов увеличивалась по мере увеличения количества голосов украинских избирателей ${ }^{123}$.

Начиная с 1950-х гг. украинско-канадское поведение при голосовании сильно не отличалось от поведения остального населения в целом. Украинские канадцы голосовали за украинских и неукраинских кандидатов от основных партий. В федеральной политике в прериях, где продолжало жить больше всего украинцев, они голосовали, как правило, как и их соседи: против либералов. Украинцы предпочитали консерваторов и затем НДП. Они также стали более восприимчивыми к провинциальным консервативным партиям, которые исторически были им антипатичны, но отныне стали открытыми для украинских лидеров и украинских общин ${ }^{124}$.

Исследование голосований, проведенных с 1904 до 1980-х гг. в федеральный парламент и парламенты в четырех провинциях, населенных украинцами, показало, что, вопреки широко распространенному мнению, между конкурировавшими украинскими кандидатами и их обе- 
щаниями, которые предположительно помогали им получить место в парламенте, нет никакой существенной связи ${ }^{125}$. Отдельные же украинские кандидаты не были привлекательны для украинских избирателей, поскольку они были хуже, чем их более конкурентоспособные коллеги, и их судьба определялась больше их политической принадлежностью, чем их обращением к этническим чувствам ${ }^{126}$. Политические ориентации украинских канадцев варьируют в зависимости от места и времени. В настоящее время они не сильно отличаются от предпочтений других канадцев, находящихся в аналогичной социально-экономической ситуации ${ }^{127}$.

Рассматриваемые в исследовании Гарасымива доказательства, пускай и косвенно, указывали на отсутствие однородного голосования украинцев, которое могло бы дать украинским кандидатам преимущество на федеральных или провинциальных выборах в Канаде. Неудивительно, что украинскому голосованию уделяют внимание, на словах по крайней мере, только во время выборов ${ }^{128}$.

\section{5. Современность}

С обретением Украиной независимости в 1991 г. некоторые организации и представители диаспоры стали участвовать в ее политической жизни. Это участие принимало форму поддержки конкретных политических партий. Вероятно, первое непосредственное участие в политическом процессе на Украине было осуществлено посредством организации «Друзей Руха». Украинский «Рух» («Движение») образовался в конце 1988 - начале 1989 г. по инициативе ряда украинских писателей и интеллектуалов, многие из которых были диссидентами. «Рух» был украинским эквивалентом народных фронтов, сформировавшихся ранее в некоторых соцстранах и союзных республиках. К осени 1989 г. «Рух» насчитывал почти 280000 членов. Благотворительная организация «Друзья Руха» сформировалась в 1990 г. Она имела отделения в Северной Америке, Европе и Австралии, где собирала деньги от имени «Народного движения Украины» ${ }^{129}$.

Диаспора финансово поддерживала «Рух» только в первые годы его существования. Вскоре после образования отделения в Торонто он скопил 200000 долл. в военный фонд. В декабре 1992 г. «Рух» был зарегистрирован как политическая партия. Среди «Друзей Руха» появились разногласия по поводу того, должны ли они поддерживать новообразованную политическую партию на Украине. «Друзья Руха» по-прежнему сочувствовали целям партии, но в конце концов они прекратили свою финансовую поддержку ${ }^{130}$. 
Существовали и другие способы влияния диаспоры на политический процесс на Украине. Некоторые работали в закулисье, чтобы побудить свои правительства вести политику, благоприятную для интересов Украины. Лоббирование этих интересов влиятельными членами украинско-канадской общины объясняет скорейшее признание премьер-министром Брайаном Малрони независимости Украины после референдума 1 декабря 1991 г. $^{131}$

В сентябре 2000 г. канадский Институт украинских исследований при университете Альберты получил грант в размере 2,7 млн долл. от правительства Канады для оказания содействия в разработке украинского законодательства и проекта соглашения между правительствами Украины и Канады. Стремясь продвигать демократические преобразования на Украине, канадские специалисты в рамках этого проекта работали с украинскими законодателями, государственными чиновниками и экспертами в области политики ${ }^{132}$.

Однако другие сегменты диаспоры продолжали взаимодействовать с политическими партиями на Украине. В 1990-е гг. на Украине было как минимум две политические партии, которые имели связи с организованной украинской диаспорой, в частности бандеровской и мельниковской фракциями ОУН. Конгресс украинских националистов (КУН) был основан в 1992 г. эмигрантами, связанными с бандеровской фракцией. Поначалу партия зарабатывала себе очки на свой престиж своей прямой связи с подпольным движением в годы войны и, по словам Эндрю Уилсона, имела «значительную финансовую поддержку со стороны диаспоры» ${ }^{133}$.

Конгресс возглавляла Ярослава Стецько из бывшего бандеровского антибольшевистского блока и эмигрантов третьей волны, которая навсегда вернулась на Украину после обретения ею независимости. КУН был основан при попытке объединить правые группы под одной крышей. Несмотря на то, что это не удалось, она попыталась вести борьбу за более агрессивную украинизацию украинского общества. Конгресс был «мощной политической силой в Галичине в 1993-94 гг.»» ${ }^{134}$.

Фракция Мельника из ОУН также стала участвовать в украинской политике. Они опирались на свои контакты с диссидентами 1970-х и 1980-х гг., которые в 1988 г. образовали Украинский хельсинкский союз, переименованный в 1990 г. в Украинскую республиканскую партию (УРП) ${ }^{135}$. УРП была более умеренной и влиятельной, чем фракция бандеровцев в КУН. В конце 1990-х гг. УРП имела определенную поддержку в канадской диаспоре, особенно в Украинской национальной федерации среди эмигрантов третьей волны. Джон Коласки, бывший 
коммунист, ставший националистом в 1960-х гг., работал над сбором средств. В 1998 г. группа пожилых членов УНФ, отождествивших себя с фракцией Мельника ОУН, пыталась получить контроль над организацией. Их очевидной целью было распустить организацию диаспоры, ликвидировать ее значительные активы, которые состояли в основном из первоклассной недвижимости в ряде канадских городов, и передать деньги УРП на Украине. Их аргумент состоял в том, что, поскольку Украина достигла независимости, УНФ и другие подобные организации достигли своей цели. Поэтому лучшее, что они могли сделать, - это отправить деньги националистическим партиям на Украине для укрепления ее места в постсоветском мире. Они проиграли битву за УНФ, и в конце концов руководство перешло к молодому, родившемуся в Канаде поколению. Оно было настроено на переориентацию организации, выставляя на первый план нужды канадских украинцев ${ }^{136}$. По исследованию МОМ в 2014-2015 гг., 28\% украинцев, живущих в Канаде, изъявили желание инвестировать в свою страну ${ }^{137}$.

Новейший кризис на Украине был использован представителями диаспоры для вмешательства во внутренние дела Украины и оказания влияния на политику Канады. С началом майданного движения в конце 2013 г., изучив информационные ресурсы, Крашинска пришла к выводу, что украинская диаспора сыграла важную роль в создании и распространении информации об Украине среди западных наблюдателей, включая основные средства массовой информации, политиков и общественность ${ }^{138}$.

По свидетельству Фудзивара, протест украинского народа оказал большое влияние на отношения между правительством Канады и украинско-канадской общиной. Восторженная поддержка Канадой евромайдана стала ответом на политически активную часть многочисленного украинско-канадского населения. Вместе с тем, отмечает он, существовал разрыв между грандиозными жестами и красноречивыми заявлениями лидеров канадского правительства о том, что они будут бороться бок о бок с украинским народом, и действиями, которые они фактически предпринимали. Во-первых, несмотря на растущее давление со стороны украинских канадцев и оппозиционных партий, конкретная политика продвигалась медленно. Во-вторых, правительство полагалось только на совет УКК, когда оно рассматривало свои планы в связи с украинским кризисом. В-третьих, тенденция правительства принимать политические и исторические взгляды УКК без их тщательного изучения мешала канадской политике анализировать пропаганду и расширять свои взгляды ${ }^{139}$. 
Среди канадских интеллектуалов находились и те, кто с большим сомнением относился к действиям Канады. Историк Майкл Блисс, отмечая отсутствие дискуссии по поводу военного участия Канады в украинской ситуации, когда она объявляет о своем решении разместить истребители в Польше, задается вопросом: «не должны ли канадцы в конце концов игнорировать наше говорливое украинское лобби, чтобы задать некоторые трудные вопросы об инвестировании наших ресурсов в то, что большая часть мира видит, как еще один сомнительный крестовый поход Запада?» ${ }^{140}$

Действия Канады объяснялись попыткой завоевать украинские голоса на выборах. Некоторые ученые соглашались, что получение голосов украинских избирателей было целью ряда членов парламента, которые подчеркивали наличие большого украинского населения в своих округах. Тем не менее, другие утверждали, что вклад украинцев в Канаду не ограничивается их голосами, отданными в избирательных округах или участках ${ }^{141}$. Они считали, что интерес Канады был вызван не столько стремлением к завоеванию голосов (поскольку голосование одних только украинцев не могло повлиять на результаты внутренних выборов), сколько сильной исторической связью между Канадой и Украиной ${ }^{142}$. Так об этом сказал Лоуренс Тоет, депутат от Виннипега: «Как известно, исторические связи между нашими странами уходят корнями в поколения украинской эмиграции в Канаду. Вот уже более 120 лет канадцы украинского происхождения вносят свой вклад в социальную, экономическую и политическую ткань Канады <...> Мы считаем, что лучшая надежда Украины на демократию и экономическое процветание заключается в более тесном присоединении к европейским и североамериканским нормам и институтам» ${ }^{143}$.

Вся проводимая Канадой политика - признание решения украинского парламента о лишении Януковича всех полномочий, направление официальной делегации «на встречу с переходным правительством на Украине», финансовая поддержка Украины и продолжение давления на Россию политически и экономически - все это содержалось в письме УКК, направленном премьер-министру в конце февраля 2014 г. ${ }^{144}$ Как отмечал Тарас Кузио, когда правительство принимало решение по украинской проблематике, редко консультировались со специалистами по украинской политике и истории ${ }^{145}$.

Участие УКК в формировании политики Канады по поддержке евромайдана не было удивительным. Это крупнейшая организация, состоящая из ряда провинциальных советов, филиалов и других членских организаций, таких как Украинская лига самообеспечения и Укра- 
ино-канадская федерация профессионалов и бизнеса. Однако она редко представляет все украинские голоса в Канаде. Организованный украинскими националистами в Канаде в 1941 г., УКК выступал в качестве политически наиболее влиятельной лоббистской группы украинцев в Канаде. Будучи обеспокоенным распространением коммунизма, канадское правительство сыграло важную роль в зарождении этой организации, выступив посредником между несколькими соперничавшими фракциями украинских националистов. УКК установил прочные связи с правительством Канады. После обретения Украиной независимости УКК утратил свое значение. Но он быстро переключился в качестве своей главной цели на поощрение прав человека и демократии на Украине, заменив в качестве общей угрозы и врага Советский Союз на Россию. Евромайдан стал неожиданным поводом для того, чтобы УКК укрепил свой статус как надежного представителя украинских канадцев. УКК укрепил свою политическую власть и был неофициально назначен важным участником канадской дипломатии. Председатель УКК Поль Грод был приглашен принять участие в составе канадской делегации, посетившей Украину в начале декабря 2013 г. и в конце февраля 2014 г. ${ }^{146}$

Таким образом, канадский парламент принял украинскую версию политики и истории, предложенную УКК (несмотря на склонность последнего к крайне правым политическим взглядам), что препятствовало сбалансированной трактовке украинского прошлого. Все партии рассматривали рекомендации УКК в качестве руководящих принципов, которым должно следовать правительство ${ }^{147}$. Канадские политики быстро приняли версию, предложенную УКК, о том, что кризис - это борьба Украины против преднамеренного российского экспансионизма, который в прошлом часто лишал украинцев свободы. Леон Бенуа, депутат от консервативной партии украинского происхождения, говорил на парламентских дебатах: «Мои друзья и соседи в округе, которые теперь стали моей семьей посредством брачных уз, обеспокоены тем, что происходящее на Украине может означать ре-советизацию региона, начало движения к экспансии со стороны России к новой власти советского образца» ${ }^{148}$.

Тем не менее, все равно существует недовольство канадской политикой. Председатель УКК Пол Грод, который редко выражал свое разочарование канадским правительством, заявил по этому поводу следующее: «Мы очень удивлены, что Канада, которая считает себя одним из лучших друзей Украины на международной арене, до сих пор не предоставила то, что действительно нужно Украине сегодня» ${ }^{149}$. 
Многие из канадских украинцев преуспели в политике. Ныне самым влиятельным политиком украинского происхождения является Христи Фриланд, министр иностранных дел Канады, которая была назначена на эту должность премьер-министром Джастином Трюдо 10 января 2016 г. ${ }^{150}$

$$
* \quad * \quad *
$$

Украинских мигрантов считали не способными принять англосаксонские ценности. Это породило концепцию мозаичной или надэтнической идентичности канадцев - концепцию мультикультурализма. При этом высокомерие и надменность англосаксов по отношению к канадским украинцам исчезли из речи, но остались в повседневной жизни.

Первые мигранты не называли себя «украинцами» и осознали себя таковыми уже проживая в Канаде. Проукраинская политика Канады объясняется не только влиянием украинской диаспоры. Канада является частью Запада и более широкого антироссийского фронта.

Таким образом, лица, проживающие вне пределов своей исторической родины или ассимилируются, или интегрируются в местное общество, или образуют внутренне взаимосвязанную общину. Первые уже могут считать себя частью канадского общества, но не частью диаспоры. Вторые могут считать себя одновременно частью и общества, и диаспоры. Третьи, еще сохранившие свое этническое самосознание, больше подпадают под категорию общины. Все это обусловлено длительностью проживания в Канаде и степенью сохранения корней.

\section{ПРИМЕЧАНИЯ}

1 "Migration in Ukraine: Facts and Figures. 2016". P. 17. International Organization for Migration. Ukraine. Publications. http://www.iom.org.ua/ sites/default/files/ff_eng_10_10_press.pdf (дата обращения: 18.12.2017).

2 About the UWC // Ukrainian World Congress. URL: http://www. ukrainianworldcongress.org/index.php/id/259 (дата обращения: 18.12.2017).

3 Ukrainian Populations // 24 News. March 24, 2014.

4 Weinfeld M., Troper H. Jews and Ukrainians in Canada: A Comparative Study of Diaspora-Homeland Relations // Political Studies Review. 2: 1-2, Spring 1990. P. 125.

5 Satzewich $V$. The Ukrainian Diaspora. London and New York, 2002. P. 8-9. 
6 Ibid. P. 13.

7 Ibid. P. 30.

8 "Migration in Ukraine: Facts and Figures. 2016". P. 17.

9 Satzewich $V$. The Ukrainian Diaspora... P. 32-37.

10 Osborn B. "Non-Preferred' People": Inter-war Ukrainian Immigration to Canada // Luicik L. and Hryniuk S. (eds.). Canada's Ukrainians: Negotiating an Identity. Toronto, 1991. P. 82.

11 Luciuk L. Y. Without Just Cause. Canada's first national internment operations and the Ukrainian Canadians, 1914-1920. Kingston, 2006. P. 1-2.

12 Ibid. P. 3.

13 Ibid. P. 3-6.

14 Ibid. P. 6-7.

15 Ibid. P. 7-8.

16 Ibid. P. 8.

17 Ibid. P. 9.

18 Ibid. P. 9-10.

19 Ibid. P. 10.

20 Ibid. P. 10-11.

21 Ibid. P. 11-12.

22 Ibid. P. 12.

23 Ibid. P. 12-13.

24 Ibid. P. 13.

25 "Migration in Ukraine: Facts and Figures. 2016". P. 17.

26 Osborn B. "'Non-Preferred' People"... P. 81-82.

27 Satzewich $V$. The Ukrainian Diaspora... P. 56.

28 Marunchak M. H. The Ukrainians in Canada: A History. Winnipeg, 1970. P. 372.

29 Satzewich $V$. The Ukrainian Diaspora... P. 49-50.

30 Osborn B. P. 81-82.

31 Ibid. P. 83.

32 Ibid. P. 84.

33 Ibid. P. 84-85.

34 Ibid. P. 85-86.

35 Ibid.

36 Ibid.

37 Ibid. P. 88.

38 Ibid. P. 91.

39 Ibid. P. 94.

40 Ibid. P. 97.

41 Ibid. P. 96-97. 
42 Ibid. P. 102.

43 Ibid.

44 Ibid.

45 Weinfeld M., Troper H. Jews and Ukrainians... P. 124.

46 Satzewich $V$. The Ukrainian Diaspora... P. 70.

47 Ibid. P. 85.

48 "Migration in Ukraine: Facts and Figures. 2016". P. 17.

49 Satzewich $V$. The Ukrainian Diaspora... P. 89.

50 Marunchak M. H. The Ukrainians in Canada... P. 579.

51 Weinfeld M., Troper H. Jews and Ukrainians... P. 125.

52 Satzewich $V$. The Ukrainian Diaspora... P. 102.

53 Luciuk L. A Troubled Venture: Ukrainian Canadian Refugee Relief Efforts, 1945-51 // Isajiw W. W. et al. (eds). The Refugee Experience: Ukrainian Displaced Persons after World War II. Edmonton, 1992. P. 439.

54 Lubomyr L. Ukrainians in the Making: Their Kingdom Story. Kingston, 1980. P. 96.

55 Ibid. P. 91.

56 Luciuk L. "This Should Never Be Spoken or Quoted Publicly"; Canada's Ukrainians and their Encounter with the DPs // Luicik L. and Hryniuk S. (eds.). Canada's Ukrainians: Negotiating an Identity. Toronto, 1991. P. 116.

57 "Migration in Ukraine: Facts and Figures. 2016". P. 17.

58 Satzewich $V$. The Ukrainian Diaspora... P. 196.

59 Ibid. P. 205.

60 Ibid. P. 12.

61 Ukrainian Populations // 24 News, March 24, 2014.

62 Isajiw W. The Changing Community // Luicik L. and Hryniuk S. (eds.). Canada's Ukrainians... P. 264.

63 Ibid. P. 265-267.

64 Ibid. P. 254-255.

65 Ibid. P. 255-256.

66 Ibid. P. 256-257.

67 Ibid. P. 257.

68 Ibid. P. 258.

69 Ibid.

70 Ibid. P. 260.

71 Ibid. P. 261.

72 Ibid. P. 262.

73 Ibid.

74 Ibid. P. 264.

75 Satzewich $V$. The Ukrainian Diaspora... P. 32. 
76 Ibid. P. 38-39.

77 Wiseman N. Ukrainian-Canadian Politics // Luicik L. and Hryniuk S. (eds.). Canada's Ukrainians... P. 344.

78 Ibid. P. 345.

79 Ibid. P. 346.

80 Ferguson B. British-Canadian Intellectuals, Ukrainian Immigrants, and Canadian National Identity // Luciuk L., Hryniuk S. Canada's Ukrainians... P. 304-305.

81 Ibid. P. 306.

82 Ibid. P. 307.

83 Ibid. P. 308.

84 Ibid. P. 309.

85 Ibid. P. 310.

86 Ibid. P. 311.

87 Ibid. P. 312.

88 Ibid. P. 315.

89 Ibid. P. 316.

90 Ibid. P. 318-319.

91 Ibid. P. 320.

92 Ibid. P. 321.

93 Ibid. P. 322.

94 Ibid. P. 323-324.

95 Ibid. P. 325.

96 Satzewich $V$. The Ukrainian Diaspora... P. 41.

97 Ibid. P. 48.

98 Ibid. P. 167.

99 Ibid. P. 167-168.

100 Ibid. P. 9-10.

101 Wiseman N. Ukrainian-Canadian Politics... P. 351.

102 Ibid. P. 358.

103 Ibid.

104 Ibid. P. 359.

105 Ibid. P. 359-360.

106 Ibid. P. 360.

107 Satzewich V. The Ukrainian Diaspora... P. 208.

108 Ibid. P. 210.

109 Isajiw W. and Makuch A. Ukrainians in Canada // Pawliczko A. L. (ed.). Ukraine and Ukrainians Around the World: A Demographic and Sociological Guide to the Homeland and Its Diaspora. Toronto, 1994. P. 329, 337.

110 Wiseman N. Ukrainian-Canadian Politics... P. 352. 
111 Isajiw W. and Makuch A. Ukrainians in Canada... P. 329, 337.

112 Wiseman N. Ukrainian-Canadian Politics... P. 352.

113 Ibid. P. 352.

114 Ibid. P. 352-353.

115 Ibid. P. 353.

116 Satzewich $V$. The Ukrainian Diaspora... P. 112-113.

117 Wiseman N. Ukrainian-Canadian Politics... P. 355.

118 Ibid. P. 357.

119 Satzewich $V$. The Ukrainian Diaspora... P. 115.

120 Wiseman N. Ukrainian-Canadian Politics... P. 347-348.

121 Ibid. P. 348.

122 Ibid. P. 349.

123 Ibid.

124 Ibid. P. 357.

125 Harasymiw B. Looking for the Ukrainian Vote // Luicik L. and Hryniuk S. (eds.). Canada's Ukrainians... P. 366-367.

126 Ibid. P. 369.

127 Ibid. P. 374.

128 Ibid. P. 375-376.

129 Nahaylo B. The Ukrainian Resurgence. Toronto, 1999. P. 217.

130 Satzewich $V$. The Ukrainian Diaspora... P. 206.

131 Kordan B. Canadian-Ukrainian Relations: Articulating the Canadian Interest // Hajda L. (ed.). Ukraine in the World: Studies in the International Relations and Security Structure of a Newly Independent State. Cambridge, MA, 1998. P. 128.

132 New Pathway. November 11, 2000: 7.

133 Wilson A. Ukrainian Nationalists in the 1990s. Cambridge, 1997. P. 79.

134 Ibid. P. 79.

135 Ibid. P. 69, 79.

136 Satzewich $V$. The Ukrainian Diaspora... P. 207-208.

137 "Migration in Ukraine: Facts and Figures. 2016". P. 18.

138 Krasynska S. Digital Civil Society: Euromaidan, the Ukrainian Diaspora, and Social Media // Marples D., Mills F. (eds.). Ukraine's Euromaidan. Analysis of Civil Revolution. Stuttgart, 2015. P. 186.

139 Fujiwara A. Canada's Response to Euromaidan // Marples D., Mills F. (eds.). Ukraine's Euromaidan... P. 199-200.

140 Bliss M. Why is Canada sending fighter jets to Poland? // The Globe and Mail. April 23, 2014.

141 Fujiwara A. Canada's Response... P. 203-204.

142 Carlson K. Ukrainian-Canadians have a strong voice in Ottawa // The Globe and Mail. February 1, 2014. P. A15. 
143 Canada, House of Commons Debate, January 17, 2014 (Mr. Lawrence Toet, CPC) // http://www.ourcommons.ca/DocumentViewer/en/41-2/ house/sitting-35/hansard (дата обращения: 18.12.2017).

144 Ukrainian Canadian Congress: Positive Steps towards Resolution of Crisis in Ukraine // Community News. February 22, 2014.

145 Kuzio T. Ukrainian Canadian Congress, Shymko, Grod ignore experts on Ukraine // YouTube video. March 27, 2014. Posted by Taras Kuzio.

146 Fujiwara A. Canada's Response... P. 208-210.

147 Ibid. P. 211.

148 Canada, House of Commons Debate, December 10, 2013 (Mr. Leon Benoit, CPC) // http://www.ourcommons.ca/DocumentViewer/en/41-2/house/ sitting-34/hansardb (дата обращения: 18.12.2017).

149 Chase S. Ukraine asks Ottawa: Where's our money? // The Globe and Mai. 24 July 2014. A1.

150 Ее личность представляет большой интерес. Мать министра, Галина Хомяк (1949-2007), является украинкой по происхождению. Из биографии Фриланд можно узнать, что ее родственники считали себя «политическими изгнанниками», видевшими свою миссию в том, чтобы сохранить «идею независимой Украины». «Мои бабушка и дедушка по материнской линии покинули Западную Украину после того, как Гитлер и Сталин подписали пакт о ненападении в 1939 г.» [Цуканова $A$. Главная тайна Христи Фриланд. 02.03.2017 // Фонд стратегической культуры. Политика. История и культура. URL: http://www.fondsk.ru/ news/2017/03/02/glavnaja-tajna-hristi-friland-43618.html (дата обращения: 06.03.2017)]. Свою семью по материнской линии она представила украинскими жертвами русских преследований, покинувшими свои дома в 1939 г. «Фриланд лжет!» — утверждает американский автор Джон Хелмер. Рассекреченные польским правительством в Варшаве архивы свидетельствуют, что дед Фриланд по материнской линии Михаил Хомяк был нацистским коллаборационистом от начала и до конца войны [Helmer J. Victim or aggressor: Chrystia Freeland family record for Nazi war profiteering and murder of the Cracow Jews. 19 January 2017 // Scott. Signs of the Times. URL: https://www.sott.net/article/340146-Victimor-aggressor-Chrystia-Freelands-family-record-for-Nazi-war-profiteeringand-murder-of-the-Cracow-Jews (дата обращения: 06.03.2017)]. Он уехал в Канаду с семьей не в 1939 г., как утверждает министр иностранных дел Канады, а в 1948 г., как это зафиксировано в канадских архивах [Ukrainian Archival Records at the Provincial Archives of Alberta: An Annotated Guide. P. 14 // URL: http://provincialarchives.alberta.ca/docs/ UkrainianGuide-English.pdf (дата обращения: 06.03.2017)]. Сообщения 
о нацистском прошлом семьи Фриланд вызвали волну гнева в Канаде. K ckjde, с марта 2014 г. Фриланд находится в числе официальных лиц Канады, которым запрещен въезд в Российскую Федерацию.

\section{M. Mamedov}

Ukrainian Diaspora of Canada, its history and modernity

Migration of Ukrainians to Canada took place in 4 stages: before the first world war, after it, after the second world war and at the end of the XX century. It was caused, respectively, by economic, political, military-political and socio-economic reasons. The official attitude towards Ukrainians in Canada proceeded from racial beliefs about their inferiority compared to the dominant Anglo-Saxons. Although this policy was later transformed into multiculturalism, in reality it was quietly and tacitly applied in a daily practice.

Keywords: assimilation, diaspora, immigration, integration, Canada, migration, community, Ukrainians, emigration. 


\section{Русские в Уругвае: полевые заметки}

В статье рассказывается о проведенной в апреле 2018 г. экспедиции к русским Уругвая: к потомкам русских колонистов, прибывших под предводительством В. Лубкова в 1913 г., а также к старообрядцам, которые прибыли в Уругвай в 1967 г. Были изучены особенности функционирования русского языка, языковая и этнокультурная ситуация. Особое внимание уделялось тому, как воспринимаются языковые особенности соседей в каждой из групп.

Ключевые слова: русский язык, идентичность, Уругвай, старообрядиы, языковая ситуация, диалект.

DOI: $10.31168 / 2073-5731.2018 .3-4.3 .02$

Выбор Уругвая как страны для изучения функционирования русского языка и поддержания идентичности и культурных традиций русских был сделан неслучайно. Именно в этой республике (полное название Восточная Республика Уругвай) проживают две русские общины, которые тем не менее отличаются по языку, типу культуры, религиозной принадлежности; различным является и время их переселения в Уругвай. Речь идет прежде всего о потомках русских колонистов, последователях секты «Новый Израиль», переселившихся под началом Василия Лубкова в 1913-1914 гг. на берега реки Уругвай ${ }^{1}$ из южных губерний Российской империи (информанты говорят о Воронежской губернии), а также о старообрядцах-беспоповцах часовенного согласия ${ }^{2}$, приехавших в 1967 г. из Бразилии, куда они в свою очередь переселились из Китая 3 . Обе группы русских проживают вблизи друг от друга (в пятнадцати километрах) - в северо-западном департаменте Рио-Негро (Río Negro) в Сан-Хавьере (San Javier). Представители первой волны миграции сконцентрированы в основном в поселении Сан-Хавьер ${ }^{4}$ и на чакрах 5 вокруг поселения. Старообрядцы проживают в колонии Офир (Ofír), расположенной в нескольких километрах от Сан-Хавьера,

Публикация подготовлена в рамках проекта РНФ № 16-18-02080 «Русский язык как основа сохранения идентичности старообрядцев Центральной и Юго-Восточной Европы». 
в той же колонии расположены чакры русских семей - потомков колонистов миграции столетней давности ${ }^{6}$ Кроме того, на въезде в СанХавьер расположена колония немцев-меннонитов Гартенталь, основанная в 1951 г. выходцами из Восточной Пруссии. Представители первой волны русской миграции проживают также в других населенных пунктах департамента Рио-Негро: во Фрай-Бентосе (Fray Bentos), Юнге (Young) ${ }^{7}$, а также в городах Пайсанду (Paysandú), Сальто (Salto) ${ }^{8}$ и в столице страны Монтевидео. Поселение старообрядцев под названием Las pitangas ${ }^{9}$ имеется в департаменте Пайсанду в окрестностях города Гичон (Gichón) (старообрядцы называют свои поселения деревня, тогда как в русском языке у представителей первой волны миграции это слово для обозначения местных реалий уже не используется). Это поселение связано с колонией Офир, где у многих имеются родственники, оно существует приблизительно 25 лет $^{10}$. Уникальность русских колоний Уругвая состоит в том, что здесь концентрируется русская крестьянская миграция, тогда как в соседних странах всё иначе.

Полевое исследование в Уругвае стало третьим по счету, проводившимся автором в странах Южной Америки с целью изучения функционирования диалектов славянских языков ${ }^{11}$. Предыдущие экспедиции показали, что в местах, где действуют русские культурные организации соотечественников, а также где расположены приходы Русской православной церкви, большинство составляют украинцы и белорусы, выходцы из восточных регионов межвоенной Польши (речь идет о провинции Мисьонес в Аргентине и Итапуа в Парагвае). Существуют также общины белоэмигрантов, однако они концентрируются в городах. Что касается старообрядцев, то их поселения на южноамериканском континенте помимо Уругвая расположены в Аргентине (окрестности Чоэле-Чоэль), Боливии (Тоборочи), Бразилии (в штатах Гояс, Парана и Мату-Гросу) ${ }^{12}$. Однако ни в одном из этих районов не сложилось такой необычной социолингвистической и этнокультурной ситуации, как в Сан-Хавьере, когда две группы русских проживают по соседству и контактируют друг с другом ${ }^{13}$. Именно исходя из этого обстоятельства было решено посетить департаменты Рио-Негро и Пайсанду, а также столицу г. Монтевидео. Экспедиция проходила с 5 по 19 апреля 2018 г. ${ }^{14}$ Существуют работы, основанные на полевом материале и характеризующие общину русских в Сан-Хавьере с точки зрения исторического развития и религиозной жизни, однако работ, посвященных русскому языку данной группы ${ }^{15}$, тем более в сопоставлении с языком старообрядцев, нам найти не удалось. Уникальность собранного в экспедиции материала заключается именно в том, что 
были охвачены две группы русских, записаны интервью на двух различных диалектах, а также проведены беседы с уругвайцами.

Следует отметить, что время для знакомства со старообрядцами было выбрано так, чтобы можно было увидеть, как проходят пасхальные дни, поскольку в 2018 г. Пасха приходилась на 8 апреля. В обычные дни в колониях старообрядцев целую неделю все работают, и только воскресенье является днем отдыха ${ }^{16}$, когда не выходят на работу в поле ${ }^{17}$. Для посещения Сан-Хавьера имело значение, чтобы дата визита не совпала с католической Страстной неделей, которая в 2018 г. начиналась 25 марта. В Уругвае эта неделя официально называется «туристической неделей» (Semana de Turismo), когда многие предприятия не работают, а официальные учреждения закрыты или работают по сокращенному графику, все стараются провести это время с семьей, уехать куда-либо. Интересно, что уругвайцы, рассказывая по-испански о старообрядцах и их традициях, используют для обозначения Страстной седмицы по аналогии с общенациональным официальным названием выражение Semana de Turismo 'неделя туризма' вместо религиозного Semana Santa 'Страстная неделя': ellos, los rusos, tienen en estos días la Semana de Turismo (у них, у русских, в эти дни проходит неделя туризма) ${ }^{18}$.

Во время проведения экспедиции в Сан-Хавьере мы не только обсуждали темы, связанные с семейными историями о переселении, с работой в поле, традициями и праздниками, - наше внимание привлекла рецепция старообрядцев русскими первой волны миграции восприятие ими языка, традиций своих иноконфессиональных соседей ${ }^{19}$. Возникновение данной темы обусловлено уникальностью контактирования двух общностей. Что касается русских, приехавших с В. Лубковым, первоначально все они являлись последователями культа «Новый Израиль», считающегося разновидностью религиозного движения секты хлыстов (многие впоследствии отошли от этого течения). В Сан-Хавьере существует Собрание (исп. la sabraña), где проходят встречи членов религиозной общины, сегодня его посещают в основном люди пожилого возраста. Кроме того, в городке есть католическая церковь, священник приезжает по праздникам из ФрайБентоса. У старообрядцев же в каждой из колоний есть моленные. Единственный на всю страну русский православный храм находится в Монтевидео (церковь Воскресения Христова), она принадлежит РПЦЗ (Аг), которая не признает акт о каноническом общении с РПЦ. В целом следует отметить, что традиционная духовная культура в среде мигрантов первой волны сохраняется фрагментарно, очень мало 
свидетельств о праздниках, обычаях, связанных с календарной обрядностью, тогда как несколько лучше сохранились воспоминания о семейной обрядности (свадьба), материальной культуре (строительство дома, традиционная кухня, земледелие). Напротив, у старообрядцев традиции сохраняются более полно, поддерживаются все религиозные предписания (например, в сфере календарной, семейной обрядности, а также соблюдаются социальные, пищевые запреты и т. д.) ${ }^{20}$, поскольку именно религия наряду с языком является важнейшим фактором сохранения их идентичности.

Русские первой и последующих волн миграции во многом различаются. Эти различия проявляются прежде всего в языке. Во-первых, говоры жителей Сан-Хавьера и окрестных поселений относятся к южнорусским говорам ${ }^{21}$, что подтверждает сведения о месте исходной территории проживания (собеседники упоминали, что их предки были выходцами из Воронежской и Курской губерний; в этом мы могли убедиться, ознакомившись с паспортами, которые сохранились до сегодняшнего дня), тогда как диалект старообрядцев-харбинцев - выходцев с Дальнего Востока - является среднерусским говором с чертами северного и южного наречий ${ }^{22}$. Во-вторых, в Сан-Хавьере еще в первой половине XX в. существовала школа, где преподавался русский язык (занятия вел учитель - выходец из белоэмигрантов), позже функционировали курсы русского языка при культурном центре им. Максима Горького ${ }^{23}$, и уже в наше время, в начале XXI в., приезжали учителя из России, проводившие занятия для всех желающих. Сейчас курсов русского языка в Сан-Хавьере не существует, поскольку нет преподавателя. Многие русские из Уругвая в советское время уезжали на учебу в СССР (например, известный врач Владимир Рослик учился в СССР). Таким образом, у жителей Сан-Хавьера была возможность познакомиться с литературной формой русского языка. Старообрядцы сейчас отправляют детей в государственные школы, где занятия проводятся на испанском языке, поэтому говорить о влиянии русского литературного языка на говор русских переселенцев не приходится. До сих пор распространено домашнее обучение детей церковнославянской грамоте (по-славянски). В-третьих, в Сан-Хавьере наблюдается поколенческий разрыв в передаче русского языка: молодежь, дети уже не говорят порусски (понимают в отдельных случаях некоторые слова). Нижняя возрастная граница собеседников, с которыми можно было беседовать по-русски, составляет 55 лет, с остальными можно беседовать только по-испански, основной возраст наших информантов - 70-90 лет. Это обусловлено прежде всего и длительностью проживания русских вне 
метрополии, и распространением смешанных браков, и политическими последствиями военной диктатуры в Уругвае в период с 1973 по 1985 г. $^{24}$ Что касается старообрядцев, у них традиция передачи языка от поколения к поколению не прервана. В старообрядческих деревнях дети говорят на диалектном русском, а испанский выучивают уже в школе и позже - при общении с окружающими ${ }^{25}$. Именно установка на изоляцию и на несмешение с окружающими способствует консервации языка. В-четвертых, языковая ситуация у потомков первой волны миграции из России и старообрядцев отличается разным набором идиомов, которыми владеют информанты. Так, среди мигрантов первой волны были и украинцы, выходцы как из Воронежской и Курской губерний, с Кубани, так и из других губерний Российской империи, где преобладало украинское население. От этих информантов также были записаны нарративы. Таким образом, в среде мигрантов первой волны были распространены как южнорусские говоры (с зафиксированными украинизмами швь́ дко, nозb́́чumь, бáчumь, шукámь, спива́mb), так и говоры украинского языка (в основном юго-восточного наречия, слобожанские и степные говоры). Судя по всему, среди украинцев сформировалась ситуация диглоссии [использование внутри общины русского и украинского языков, за ее пределами (среди молодого поколения — также и внутри общины) испанского языка], а собственный язык все мигранты характеризуют как «смешанный русский и украинский» ${ }^{26}$. Что касается старообрядцев, то для них характерно знание и других языков (помимо испанского) в зависимости от того, из какой страны они переехали в Уругвай. Среди пожилых встречается владение китайским языком, усвоенным во время пребывания в Китае. Кроме того, в языковом репертуаре старообрядцев нередко можно встретить также португальский язык в его бразильской разновидности и американский английский ${ }^{27}$, поскольку колонии старообрядцев в Новом Свете поддерживают тесные контакты друг с другом. Отметим также, что старообрядцы делятся на «синьцзянцев» и «харбинцев», получивших название по той местности, где они жили в Китае. Каждая из этих групп имеет свои, в том числе и языковые, особенности, подмечаемые и самими староверами ${ }^{28}$.

В целом представители первой волны русской миграции признают, что их иноконфессиональные соседи лучше владеют русским языком в отличие от них самих. Это объясняется закрытостью общины, в то время как в Сан-Хавьере (и в окрестных поселениях) русский язык постепенно оказался вытесненным даже из сферы внутрисемейного общения. Сами жители Сан-Хавьера, характеризуя свой русский язык, в шутку часто приводят следующую фразу, свидетельствую- 
щую о процессах языкового смешения: они новья́рили ${ }^{29}$, новья́рили и дэспўэ́ $c^{30} /$ пото́м дэха́рили ${ }^{31}$ [они были женихом и невестой, а потом прекратили (расстались)]. Очевидно, что в этом метаязыковом наблюдении велика доля заимствованных слов из испанского языка. Данное выражение было записано несколько раз в разных вариантах. Однако и в речи старообрядцев фиксируются заимствования из испанского языка ${ }^{32}$, используемые для обозначения современных бытовых реалий, природных явлений, местных блюд или построек: tararira (лат. hoplias malabaricus), surubi (лат. pseudoplatystoma) (названия рыб, которые водятся в реке Уругвай), aire condicionado (кондиционер), celular (сотовый/мобильный телефон), pizza (пицца), nafta (бензин), galpón (сарай, навес, барак). Наблюдается и адаптация лексических заимствований: ср. исп. порт. eucalipto - кали́nта (эвкалипт).

Русские первой волны миграции подмечают расхождения в собственном русском языке и в языке старообрядцев. Например, они готовят вареники с сыром, при этом слово сыр переводят на испанский как ricota (рус. творог). Кроме того, слово cыр в их говоре может обозначать и твердые сыры (исп. queso «сыр»). По наблюдениям собеседников и по нашим собственным данным, старообрядцы используют слова творог и сыр для разных молочных продуктов, а сами вареники называются творожники. В области материальной культуры главное отличие между двумя группами русских прослеживается в использовании термина для обозначения дома: русские Сан-Хавьера используют слово хата, тогда как старообрядцы говорят изба. Кроме того, в колониях старообрядцев есть обязательно баня, куда ходят каждую субботу. Однако русским в Сан-Хавьере баня незнакома, расспросы информантов показали, что такой постройки не было и в прошлом ${ }^{33}$. Чаще всего незнакомо и само слово, собеседники путают его с испанским baño (ванная комната, ванная, туалет); оба слова, впрочем, имеют общий латинский корень ${ }^{34}$. Показательно, что все перечисленные явления отражают особенности материальной и духовной культуры на первичной территории проживания русских переселенцев: южнорусская территория противопоставлена остальным областям России. Однако есть и общие слова, которые мы отметили в речи обеих групп русских: карточка - фотография, верста - вместо слова километр. Необходимо упомянуть еще одну гастрономическую особенность департамента Рио-Негро: небольшие семейные предприятия, где работают потомки первых русских мигрантов, производят квас. Квас объявлен местным достоянием на уровне департамента Рио-Негро ${ }^{35}$. Однако квасом в Уругвае называют напиток, приготовленный из меда ${ }^{36}$, 
а напиток, распространенный у старообрядцев, - бражка — изготавливается главным образом из фруктов.

Таким образом, в экспедиции был собран уникальный лингвистический материал, позволяющий проанализировать и сопоставить функционирование русского языка в двух русских сообществах Уругвая. В завершение приведем некоторые фрагменты бесед с информантами, русскими Сан-Хавьера, о русском языке среди представителей первой миграции и старообрядцами. Отмечается некоторая непохожесть речи старообрядцев на язык русских первой волны миграции, а также более «чистый» язык старообрядцев [2], [3], [5] по сравнению с русским языком в Сан-Хавьере. Подмечено также, что старообрядцы владеют и испанским языком [5]. В тексте [6] приводится свидетельство об этническом соседстве украинцев и старообрядцев в типологически сходной языковой ситуации в окрестностях города Понта-Гросса в бразильском штате Парана. Тексты даны в фонетической записи с использованием графики соответствующих славянских языков.

[1] $K X$ : Тако́й са́ма как [и у нас].

КД: Тако́й-й, как и наш [у них язык] pero ${ }^{37}$ ўжэ мы-ы-ы на-а-а \| ч'уто́к ин... ин... | н’и так пан’им... | так разүава́рувъйьм $\mid$ пъч'иму́ мы ўжэ-э | м’иша́им $\|$ испа́нскъй йъзы́к ис ру́скъмъ-ъ..

$K X: S i^{38} \mid$ йа $\mid$ porque $^{39}$ йа $\mid$ a veces ${ }^{40}$ пры йих н'их нач'áy̆ сп'ива́т' | а он үър'и́т' | a! pero ты ус'ó м'иша́иш! | а йа ужэ́ пр'иўы́к пъ испа́нским | а ано́ м’иша́ицъ! (КД, муж., 75; КХ, муж., 70) ${ }^{41}$.

[2] Э́тъ саўс'э́м | саўс'э́м | ина́ч'эй | ру́скъй и́хн'ий | ч'и́стый | харо́шый ру́скъй! | ну ўъны́ то́жэт' и см'иша́л'и ч'эм | ч'и с'... 3 (в)раз'и́л'скъм што | так и н'и пан'има́иш ъх (БЭ, муж., 70).

[3] А $s i$ ! || ч’ист... ан'и́ чи́ста па ру́ск'и | si si! па ру́ск'и $s i<\ldots>$ а пато́м ан'и́ о́чин' рабо́ч'ийь (СМ, муж., 65).

[4] Зд'эс' э́т'и-и | шо барадач'и́ шо пр'ийэ́хал'и э́т'и | т’э ч'и́ста па ру́ск'и разүава́р'ут' | йа 3 ы́м'и н'и маүу́ разүава́рът' | йа с ы́м'и палав'и́на и палав'и́на <..> аны́ па ру́ск'и | йа пан'има́йу! | pero мно́үъйъ слава́ | дру́үъй рас спрашу́ | он тъ раска́жэт' м'ин’э́ | йа н'и зна́йу как ана́ называ́ицъ | пач'имý на́шы? | мо́жэ быт' стар'ик'и́ үавар'и́л’и и как на́да | а пато́м ужэ́ | ано́ ш п’ьр'ихо́д’ит ско́л'к'и! | кал'исн'и́ца! (КС, муж., 90).

[5] Pero ан'и́ч'ут' ч'ут' | иш'ó ч'и́стай | ру́скъй йазы́к патамý шту | йазы́к у н'их ру́скъй < ..> ан'и́да! | (c) испа́нсам'и үаво́р'йат | так-так | патаму́ штъ пр'иж’а́л'и с'уда́ | у Пайсанду́ < ..> pero йазы́к йаз'и́к йих | ан’и́ ру́скъй йазы́к (MB, муж., 55). 
[6] C. А ў Брази́л'ійі По́нта Гро́са йе одна́ colônia russa ${ }^{42} \mid$ вони́ үово́р'ат' там. Д. По ру́ски пита́йут с'а. С. Ф свойі́х стро́йах хо́д’ат'| ма́йут' свойу́ коло́н'ійу <...> вони́ так хо́д’ат' т'і сорочки́ так йак.

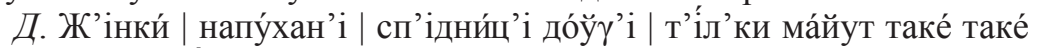
м’істе́чко шо т'іл'ки вони́ там з йіх | н’іхто́ там не мо́же ув’ійти́. $C$. Colônia russa $\mid$ томý ф т'ім м'і́ст'і... (C, жен., 60; Д, жен., 40).

\section{ПРИМЕЧАНИЯ}

1 Реку Уругвай мигранты первой волны называют Раүуа́й.

2 Самоназвание - cтароверы - проникло и в местный испанский язык и используется испаноязычными соседями - starovieri.

3 В настоящей статье русских, переселившихся в Уругвай в начале XX в., мы называем «русские первой волны миграции», «русские СанХавьера».

4 Информанты называют Сан-Хавьер по-испански villa - поселение, среднее между городом и деревней.

5 Chacra (исп.) - ферма, расположенная на некотором отдалении от поселения (общее название для Уругвая, Аргентины, Парагвая).

6 В 1913 г. в Сан-Хавьере праздновали столетний юбилей прибытия первых мигрантов из России.

7 В произношении уругвайцев - Джун или Джон (Young).

8 В этих местах проживали как последователи В. Лубкова, так и баптисты (см.: Герасимчук А., Герасимчук Э. Русские в Сальто // Русские в Уругвае: история и современность. Монтевидео, 2009. С. 79-88. С. 82). Многие являлись выходцами из восточных регионов межвоенной Польши и говорили (и говорят) по-украински. Некоторые украинцы переселились из соседних аргентинских провинций.

9 Pitanga (лат. Eugenia uniflora) - суринамская вишня, произрастает в Южной Америке. Нам встречалось в литературе также наименование данной колонии в единственном числе — la pitanga, возможно из-за ослабленного произношения конечного $s$, что характерно для местной разновидности испанского языка.

10 О. Г. Ровнова упоминает еще одно небольшое поселение старообрядцев Эспинижар на реке Уругвай. См.: Ровнова О. Г. «Полиглоты поневоле»: языковая ситуация в старообрядческих общинах Южной Америки // Staroobrzędowcy za granicą. Toruń, 2010. S. 140.

11 Обследование, проведенное в первой экспедиции, охватывало Аргентину, Парагвай и Уругвай (2015 г.), были обследованы украинцы, 
поляки, хорваты, словенцы; во второй - Аргентину, Парагвай, Чили (2017 г.), когда были изучены украинцы, поляки, хорваты (см., например: Пилипенко Г. П. Экспедиция к славянам в Южную Америку // Славянский альманах. 2018. Вып. 1-2. С. 289-300; Пилипенко Г. П. Маркирование интерференционных явлений в славянской речи Южной Америки // Славяноведение. 2018. № 3. С. 64-80).

12 В области изучения языка и культуры старообрядцев Южной Америки пионерскими являются работы О. Г. Ровновой, которая посетила все колонии старообрядцев и собрала уникальный полевой материал (см., например: Ровнова О. Г. Экспедиция в Боливию // Русский язык в научном освещении. 2014. № 2. С. 300-309; Ровнова О. Г. Экспедиция в Бразилию // Русский язык в научном освещении. 2011. № 1. С. 298-303; Ровнова О. Г. «Полиглоты поневоле»: языковая ситуация в старообрядческих общинах Южной Америки // Staroobrzędowcy za granicą. Toruń, 2010. S. 137-157). О старообрядцах Уругвая писала также В. Бойко де Семка: Бойко де Семка В. Под иным крестом. Староверы в Уругвае // Русские в Уругвае: история и современность. Монтевидео, 2009. С. 109-130.

13 Наверное, в качестве типологически сходной языковой ситуации можно привести ситуацию в старообрядческой колонии в бразильском штате Паране, расположенной рядом с городом Понта-Гросса. В этом крае проживает также много выходцев из западных украинских земель. Мои информанты из предыдущих экспедиций, украинцы из Бразилии, упоминали русских старообрядцев, проживающих в этом регионе (см., например, текст [6]).

14 За помощь в организации экспедиции выражаю благодарность Александре Ратошнюк (Alexandra Ratosñuk), Алисии Боскин (Alicia Boskin), Александру Темлину (Aleksander Temlin) (Монтевидео) и Алехандро Сабелину (Alejandro Sabelin) (Сан-Хавьер).

15 См.: Петров С. Южноамериканский Израиль: предварительные результаты полевых исследований в русской колонии Сан-Хавьер в Уругвае // Религиоведческие исследования. 2010. № 1-2 (3-4). С. 66-84. Об истории Сан-Хавьер пишет Л. Рослик: Рослик Л. Сан-Хавьер // Русские в Уругвае: история и современность. Монтевидео, 2009. С. 53-66. История Сан-Хавьера подробно освещается в книге: Martínez V. Los rusos de San Javier. Perseguidos por el zar. Perseguidos por la dictadura uruguaya. De Vasili Lubkov a Vladimir Roslik. Montevideo, 2013.

16 Большинство наших собеседников в Сан-Хавьере упоминали, что к старообрядцам можно приехать только в воскресенье после утренней воскресной службы, тогда они смогут принять гостей. Считается, что община старообрядцев в Уругвае самая строгая среди всех колоний в Южной Америке и соответственно - самая закрытая. Тем не менее при 
личном знакомстве со старообрядцами встречаешь искренних, отзывчивых и интересных людей.

17 Старообрядцы занимаются сельским хозяйством, выращивают в основном сою, которую называют бобы.

18 Хотя в испанском языке старообрядцев для Страстной недели отмечено выражение Semana Santa.

19 Например, в Уругвае русских старообрядцев часто называют los barbudos (исп. barba - борода, barbudo - бородач).

20 Здесь интересно будет сравнить старообрядцев Уругвая с группой старообрядцев-поморцев, которые были нашими собеседниками во время полевой работы в Латвии (см.: Пилипенко Г. П. Полевое исследование старообрядцев в Латвии // Славянский альманах. 2016. № 3-4. С. 504-509; Плотникова A. А. Об экспедиции к латгальским староверам // Живая старина. 2016. № 4. С. 50-53) в 2016-2017 гг. На юго-востоке Латвии мы записали нарративы о запретах и предписаниях староверов, однако в действительности наблюдать четкое разделение на «своих» и «чужих» (ср., например, «поганую» посуду в Латгалии), а также соблюдение всех запретов уже не приходилось (за редким исключением). Вероятно, сказывается период пребывания в советском государстве, а также современные тенденции урбанизации и глобализации. Большинство записанных нарративов описывают прошлое, а если и касаются настоящего времени, то используют модальность, что так нужно (нужно было бы) делать. Кроме того, в повседневной жизни старообрядцы Уругвая носят традиционную одежду: у мужчин это обязательно рубаха с прямым воротом (в Латгалии — косой ворот) и пояс, у женщин — сарафан, а у замужних женщин на голове шамшура (про одежду старообрядцев Южной Америки см.: Ровнова О. Г. «Маленько переформили сарафан»: современная одежда старообрядцев Южной Америки // Живая старина. 2016. № 3. С. 41-45); тогда как в Латгалии традиционная одежда используется крайне редко (например, ее надевают, идя на службу в моленную).

21 В этом говоре фиксируются следующие особенности: аканье, наличие $\gamma$ фрикативного, мягкого -ть в формах 3 лица ед. и мн. ч. глаголов.

22 См. подробнее: Ровнова О. Г. Говор старообрядцев Южной Америки по письменным материалам // Труды Института русского языка им. В. В. Виноградова. 2014. № 3. С. 375. Среди особенностей мы отметили, что этот говор акающий, вместо щз находим $u$ (например, ешши́, я́шшик), имеются стяженные формы у глаголов (знам, быват), вопросительное местоимение имеет форму чё.

23 Культурный центр им. Максима Горького функционирует также в Монтевидео. 
24 Именно с периодом диктатуры многие информанты связывают потерю языка (el idioma, lo perdimos en la dictadura). В это время выходцев из России преследовали, подозревая в связях с коммунистами. Как рассказывали собеседники, русская фамилия уже могла показаться подозрительной властям (здесь можно провести параллели с последствиями военной диктатуры в Аргентине, где информанты связывали потерю языка с репрессивными действиями правительства).

25 Поражает также и то, что старообрядцы Уругвая сохранили детские игры, например в ло́nту, шаро́вки (аналог игры в городки), прятанки и т.д., тогда как в Латгалии, по нашим данным, была разработана целая программа для возрождения игры лапта́. Показательно и то, что собеседники в Сан-Хавьере и других поселениях, рассказывая о детских играх, не могли вспомнить их русские названия и употребляли испанские: jugar a las escondidas (играть в прятки), jugar a las bolitas (играть в шарики) и т. д.

26 У некоторых информантов в русском языке сохраняются фонетические особенности украинского языка, например оканье, отсутствие смягчения согласных перед гласными переднего ряда.

27 Например, вместо испанского слова heladera (жители СанХавьера произносят эладэ́ра) для обозначения холодильника используется португальское слово geladeira (в произношении - желадэ́ра), поскольку с этой реалией старообрядцы познакомились еще в Бразилии; также фиксируется английское слово mile (в произношении - майл).

28 «Харбинцы» отмечают, что «синьцзянцы» говорят «всё на сь и на uь». Ср. также анализ речи одного из представителей синьцзянцев в работе: Ровнова О. Г. Говор старообрядцев Южной Америки по письменным материалам. С. 377.

29 Исп. noviar - быть женихом и невестой.

30 Исп. después - после, потом.

31 Исп. dejar - оставить, бросить.

32 Точнее - из уругвайской разновидности испанского языка.

33 Однако есть свидетельство, что в самом начале развития русской колонии баня была знакома некоторым переселенцам. См.: Рослик Л. Сан-Хавьер... С. 59.

34 Этимологический словарь славянских языков. М., 1974. Вып. 1. C. $151-152$.

35 Другим символом департамента Рио-Негро и конкретно СанХавьера является подсолнух, семена которого привезли первые мигранты. В Уругвае Сан-Хавьер известен также тем, что местные жители грызут неочищенные семечки подсолнуха. 
36 Ср. выдержку из рекламы кваса, произведенного в департаменте Рио-Негро: «el kwas, conocido como el vino de los rusos o el vodka de los pobres, tiene como traducción exacta "el elexir de los dioses". Es una bebida elaborada por fermentación natural de agua, miel y polen. <...> El kwas llegó a Uruguay en 1913 con el arribo de los primeros inmigrantes rusos, que se ubicaron en la localidad de San Javier, en Río Negro. <...> Esta bebida es un legado de nuestros ancestros y que hoy, queremos compartir con usted» (Квас, известный как вино русских или водка бедняков, точный перевод «эликсир богов». Этот напиток произведен в результате естественного брожения воды, меда и пыльцы <.. > Квас прибыл в Уругвай в 1913 году вместе с первыми русскими эмигрантами, которые поселились в Сан-Хавьере, в Рио-Негро. < .. > Этот напиток является наследием наших предков, и мы хотим поделиться им с вами). Крепость такого кваса $-10-12 \%$.

37 Pеro (здесь и далее) (исп.) - но.

$38 \mathrm{Si}$ (здесь и далее) (исп.) - да.

39 Porque (исп.) - потому что.

40 A veces (исп.) - иногда.

41 В скобках приводятся инициалы информантов, пол и возраст.

42 Colônia russa (порт.) - русская колония.

\section{G. P. Pilipenko}

The Russians in Uruguay: the field research notes

The paper describes the field research carried out among the Russian-speaking communities in Uruguay in April 2018, namely, among the descendants of Russian colonists who arrived under the leadership of V. Lubkov in 1913, as well as among the Old Believers, who arrived in 1967. The peculiarities of the Russian language functioning, language and ethno-cultural situation were studied. The perception of the linguistic characteristics of the neighbors in these groups was also examined.

Keywords: Russian language, identity, Uruguay, Old Believers, language situation, dialect. 
Ю. А. Лабыниев

(Москва)

\section{Судьбы Холмского православия в период революционных потрясений 1910-1920-х гг.: Радочницкий Свято-Антониевский женский монастырь}

В статье рассматривается малоизученная тема революционных событий 1917 г. и судеб церковных организаций православной Холмщины на примере трагического периода существования одного из самых успешных женских монастырей Российской империи начала XX в., Радочницкого Свято-Антониевского, который во время Первой мировой войны был эвакуирован в Петроград, разместившись в собственном подворье. Туда же перевезли и главнейшую христианскую святыню западноукраинских земель чудотворную икону Божией Матери Холмской, датируемую XI в. Несмотря на все усилия игумении монастыря Афанасии (Громека) и группы монахинь, история обители в Петрограде, полная тяжелейших утрат и катастрофических разочарований, формально заканчивается уже на рубеже 1920-1921 гг. А катакомбная жизнь тайной иноческой общины матушки Афанасии длится еще несколько лет и завершается полным разгромом только к началу 1930-х гг. Ключевые слова: Православная Церковь, револючионные события 1917 г., Холмская православная епархия, Радочнииякий Свято-Антониевский монастырь, Холмщина, икона Божией Матери Холмской, беженство.

DOI: $10.31168 / 2073-5731.2018 .3-4.4 .01$

Проблематика влияния революционных событий 1917 г. на судьбы православной церкви, всегда вызывавшая огромный интерес, пока не получила сколь-либо полного обстоятельного отображения в научных исследованиях. Ни у нас в стране, ни за рубежом к столетнему юбилею революций не появилось каких-либо заметных специальных работ, посвященных этому вопросу, хотя он и был затронут в ходе ряда небольших конференций и круглых столов (в основном организованных в России). Известный швейцарский религиоведческий журнал Religion \& Gesellschaft in Ost und West даже опубликовал статью петербургского ученого П. Г. Рогозного, автора вышедшей десять лет назад монографии «Церковная революция 1917 года» ${ }^{1}$, под названием «Die "Kirchenrevolution” von März bis August 1917»², по сути целиком 
основанную на материалах его книги. В ней утверждалось, что тогда «в церковной среде $<\ldots>$ спор шел не о вере, а о власти в церкви» ${ }^{3}$.

Вопросы же восприятия трагических для церкви революционных событий в многомиллионном сообществе мирян, рядовых приходских церковнослужителей и насельников монастырей тем более пока мало разрешимы, не в последнюю очередь вследствие необходимости накопления и последующего анализа колоссального источникового материала. Именно подобный подход, в частности, дал бы в конце концов возможность реализовать формулу, которую предложил известный американский специалист по «народному православию», профессор Г. Фриз: «Понять церковь - значит понять народ...», выявляющую главнейшую идейно-религиозную основу всей тысячелетней жизни восточнославянского сообщества ${ }^{4}$.

В истории духовной культуры украинцев Холмщина, Холмская земля, Terra Chelmensis, Ziemia Chełmska - легендарный край со своей удивительно богатой и трагической историей, когда коренной народ, населявший его в течение тысячелетия, был практически целиком насильственно депортирован отсюда после окончания Второй мировой войны на север и запад Польши, а также в Советский Союз ${ }^{5}$. Расположенная в крайней восточной части современной Польши на ее границе с Украиной, Холмщина еще в межвоенные годы оказалась эпицентром жестоких событий, когда здесь при попустительстве и прямой поддержке польских властей были ликвидированы сотни православных храмов, причем невзирая на громкие протесты, раздававшиеся из разных стран 6 .

Город Холм, основанный могущественным галицко-волынским князем Даниилом Романовичем в первой трети XIII в., где на Княжей горе в кафедральном соборе он и был похоронен, через шесть столетий стал местом рождения академика М. С. Грушевского, сына направленного сюда в 1865 г. царской администрацией видного школьного деятеля С. Ф. Грушевского, много сделавшего для развития образования в здешней восточнославянской среде ${ }^{7}$. Через четыре десятилетия М. С. Грушевский, писавший, что «Холм был вековым историческим центром украинского Забужья» ${ }^{8}$, оказался в числе самых горячих сторонников образования в 1912 г. особой Холмской губернии, настаивая: «...эти земли обязательно должны быть выделены» ${ }^{9}$ в отдельное административное образование.

К сожалению, социально-религиозная и политическая обстановка на Холмщине после ликвидации в 1875 г. униатской церкви и особенно вслед за выходом царского указа 1905 г. о свободе вероис- 
поведания оказалась столь взрывоопасной, что дает современным польским историкам возможность назвать эти земли в тот период «российским Ольстером» ${ }^{10}$. Именно тогда среди части местного населения восточнославянского происхождения начался драматический процесс «денационализации» с переходом в римокатолицизм и очень быстрой и практически полной полонизацией. Правда, такое положение коснулось прежде всего «соседнего южного Подляшья», на самой Холмщине не столь значительная «часть грекокатоликов пополнила ряды “упорствующих", а после <..> 1905 г. перешла в римокатолики, так называемые “калакуты”»11. Еще какое-то время в домашнем обиходе они продолжали объясняться на «малорусском наречии», а затем быстро превратились в определенного рода антагонистов своей коренной идентичности, именуемых тогда в Галиции «латинниками» ${ }^{12}$. Условия, особенности и механизмы такого перехода в римокатолицизм до сих пор детально не изучены, и в немногочисленных работах, в определенной степени тому посвященных, преобладает все же некая политическая заданность ${ }^{13}$. А вместе с тем польско-католическая сторона, и это подтверждается множеством документально зафиксированных фактов, прилагала массу усилий, порой достаточно жестоких, чтобы такой переход стал неизбежным, не гнушаясь элементарным обманом и запугиванием холмских крестьян, вплоть до угроз убийством, объявлением, что сам царь принял католицизм, и др. ${ }^{14} \mathrm{~K}$ прискорбию, костел и ксендзы не только принимали во всем этом непосредственное участие, но и сами были инициаторами подобных действий ${ }^{15}$.

Указанные события были тесно связаны с образованием в 1905 г. отдельной Холмской православной епархии, а позднее и губернии, выделенной из Варшавского генерал-губернаторства (Царства Польского). В период многолетнего обсуждения целесообразности такого выделения разразилась настоящая информационная война, лидерами которой стали - с русской стороны православный епископ Евлогий (Георгиевский), с польской - известный петербургский юрист и одновременно крупный помещик Л. Дымша, автор, резко выступавший против создания Холмской губернии и даже издавший по этому поводу специальный труд ${ }^{16}$, давший исходный материал для многих публикаций о «холмском вопросе» и создании Холмской губернии, в том числе появляющихся до сих пор. Накал страстей достиг такой степени, что на Холмщине начались вооруженные нападения на православных, погром церквей, а в Люблине за ограду Крестовоздвиженского кафедрального собора была брошена бомба ${ }^{17}$. В смертельной опас- 
ности оказался и сам архиепископ Евлогий, на которого готовилось покушение «польскими боевиками». Его планировалось осуществить путем организации взрыва во время богослужения в православном кафедральном соборе в Холме ${ }^{18}$.

Предполагалось, что в этих условиях выделение Холмской губернии из Варшавского генерал-губернаторства значительно укрепит и обезопасит положение ее православного населения, насчитывавшего более трехсот тысяч человек ${ }^{19}$. Казалось, период смятения и неравной национально-религиозной борьбы остался позади, но на самом деле это был лишь кратковременный успех, за которым последовали тяжелейшие испытания ${ }^{20}$. В 1914 г. началась Первая мировая война, а с ней после массированного наступления немецких войск - летом 1915 г. — почти поголовная эвакуация православных вглубь Российской империи, получившая название беженства. В беженство отправлялись целыми селами, при этом вывозилась бо́льшая часть церковной утвари из всех сельских и городских православных храмов и монастырей. Выезжали все православные церковнослужители с семьями, епископат и насельники монастырей. По сей день эти трагические события, к сожалению, очень мало изучены.

В крестный путь беженства отправились и все четыре женских монастыря Холмской православной епархии, основанные на рубеже $\mathrm{XIX-XX} \mathrm{вв.} \mathrm{и} \mathrm{ставшие} \mathrm{абсолютно} \mathrm{феноменальным} \mathrm{явлением} \mathrm{как} \mathrm{в}$ духовной жизни западных окраин Российской империи, так и православия в целом. До сих пор родоначальная обитель этого почти тысячного женского монашеского сообщества, Леснинская, основанная в 1885 г., - один из крупнейших монастырей русского православия. Правда, теперь она существует во Франции. В отличие от трех других женских православных монастырей Холмщины - Вировского, Радочницкого и Турковицкого, для которых период беженства стал последним этапом их существования ${ }^{21}$, — Леснинская община, в основном перемещенная из Петрограда в Бессарабию накануне революционных событий 1917 г., пережив все трудности, сохранилась ${ }^{22}$. Летом 1915 г. основным местом ее эвакуации вместе с Радочницким монастырем была избрана столица империи Петроград, где обе обители имели свои подворья в северной части города. Радочницкий монастырь сразу же стал играть роль духовного центра среди не только женских обителей Холмщины, но и вообще многих беженских православных монастырей. 11 сентября 1915 г. в храм подворья была доставлена «великая Святыня Холмского Края “Холмская чудотворная икона Божией Матери”, имени Которой посвящен и сам храм подво- 
рья» ${ }^{23}$, одна из древнейших дошедших до нас икон, датируемая XI в. После отъезда в начале осени 1916 г. основной группы инокинь Леснинского и Вировского (из Москвы) монастырей в Бессарабию в имперской столице остались насельницы Радочницкой, а в Москве Турковицкой обителей ${ }^{24}$.

Радочницкий Свято-Антониевский женский монастырь возник на месте небольшой мужской православной иноческой общины, располагавшейся с 1881 г. в зданиях упраздненного бернардинского монастыря во имя Антония Падуанского в селе Радочница на востоке современной Польши неподалеку от г. Замостье. Во второй половине XIX в. на территории бывшей католической обители провели ремонтные работы, после которых поселили там группу православных монахов. В 1899 г. здесь была организована женская обитель ${ }^{25}$. Уже через несколько лет слава о новом женском монастыре во имя Антония Печерского, успешно действующем на самых западных территориях исторического существования православия, становится широко распространенной. Во главе обители встала прекрасно образованная игумения Афанасия (Громека), дочь известного публициста и политического деятеля С. С. Громека. Она развернула в монастыре большие строительные работы, результатом которых стало возведение целого комплекса новых зданий, открытие различного рода школ, в том числе учительской семинарии. Была организована крупная иконописная мастерская, ткацкая фабрика, больница и аптека. Монастырь стал местом многотысячных православных паломничеств.

Особое положение Радочницкого монастыря, его значение и возможности позволили возвести в 1911-1913 гг. в Петрограде в Удельной собственное подворье с церковью во имя Рождества Божией Матери, дополнительно расширенное в 1916 г., уже после прибытия сюда эвакуированной обители. Сама же церковь подворья после помещения в ней чудотворной иконы Богоматери Холмской именовалась храмом Божией Матери Холмской. Вплоть до начала 1917 г., невзирая на трудности военного времени, эвакуированный в Петроград Радочницкий монастырь более или менее благополучно продолжал свое существование, располагаясь не только в своем подворье, но и в помещениях других петроградских монастырей. При нем действовали школа и детский приют. Второклассной школой руководила сама игумения Афанасия, внутренние чувства которой в тот период тогда лучше всего передают ее слова: «Теперь Холмский народ в разсеянии, в разных местах центральной России. Придется ему увидеть многое, к чему он не привык дома. Дай, Господи, чтобы сохранилась в нем 
нетронутой его чистая детская вера и преданность родной церкви и чтобы вернулся он в свои родные поля таким, каким вышел от них. Холмский народ - драгоценный народ, очищенный вековыми страданиями, он велик в своем смирении, кротости и терпении, нежный сердцем и отзывчивый на все доброе» ${ }^{26}$.

Школьное дело и многочисленные воспитанницы всех возрастов особенно заботили настоятельницу, ей даже удалось создать целый педагогический коллектив из духовных и светских лиц ${ }^{27}$, добившийся прекрасных успехов даже в условиях беженства. Собственно, монашеская жизнь в обители пока не претерпела каких-либо серьезных изменений вплоть до революционных событий 1917 г. Сильным потрясением для холмских монахинь и их игуменьи стало отречение царя и соответствующие мартовские указы Святейшего правительствующего синода; затем - многочисленные обсуждения многих не слишком касавшихся до той поры монашеской жизни вопросов о партиях, социализме, Учредительном собрании, и, наконец, как гром среди ясного неба - об отделении церкви от государства. Не сбылась «надежда на то, что Русь, сбросив с себя оковавшие ее политические цепи, обратит всю мощь свою на освобождение свое от немецкого ига и весь разум свой - на мирное внутреннее развитие и устроение государства и общего народного блага» ${ }^{28}$. Уже летом 1917 г. явились зловещие признаки будущей жестокой гражданской войны: «Вслед за свободой к нам проник новый злой враг и посеял на Руси плевелы, которые не замедлили дать всходы, заглушающие ростки желанной свободы. Хищения, грабежи, разбои, насилия и обострившаяся партийная политическая борьба стали достоянием нашей новой жизни и поселили в народе озлобление и рознь, повлекшие за собой внутреннюю братоубийственную войну, неоднократное кровопролитие. И в результате - с одной стороны - приостановка блестяще начатого наступления на врага, с другой, вместо свободы - новое взаимное угнетение, вместо братства - охлаждение любви, упадок добрых, мирных, братских общественных отношений. Страна пошла по пути гибели, а в будущем ее ждет та страшная бездна, которая заполнена для всех нас ужасающим отчаянием, если только не прекратится “смятение и попрание и замешательство от Господа Бога" (Исход. 22: 5)» ${ }^{29}$.

Лето 1917 г. — момент начала осмысления своего будущего в новой реальности представителями всех учреждений Холмской православной епархии ${ }^{30}$, в том числе ее монастырей и отдельных приходов. И если для коренных православных холмщан-беженцев светлой спасительной дорогой виделось возвращение на родину в свой родной 
приход, то для монахинь Радочницкого монастыря такой путь был невозможен, так как их возвращение могло состояться только в условиях сохранения государства в его прежних границах, что уже казалось сомнительным. Большие надежды, как и все православные «Российской державы», радочницкие монахини возлагали на Поместный собор, открывшийся 15 августа 1917 г. в Успенском соборе Кремля: «В столь ответственное время представителям стомиллионного населения России, объединившимся на первом Всероссийском съезде духовенства и мирян в Москве, надлежит возвысить свой голос, ясно и твердо сказать в слух всей страны, как они относятся к переживаемым событиям, чего желают в будущем и какие способы считают наилучшими к достижению желаемого» ${ }^{31}$.

Реальный ход событий полностью перечеркнул такие ожидания. Уже Временное правительство нанесло целую серию серьезнейших ударов по церкви. Для Радочницкого монастыря и его игуменьи одним из первых стала передача, согласно специальному постановлению, «церковных начальных $<\ldots>$ церковно-учительских и второклассных школ $<\ldots>$ в ведомство Министерства народного просвещения» ${ }^{32}$. В дальнейшем удары продолжали сыпаться с неослабевающей быстротой и возрастающей силой. Радочницкие монахини в условиях усиливающегося голода и возникающих общецерковных нестроений уже к осени 1917 г. начинают покидать свою обитель. Так одной из первых «из-за отсутствия еды» уходит из монастыря и выезжает в свою «деревню из Петрограда» монахиня Анна Мельникова, пребывавшая в обители около 15 лет $^{33}$.

Уже к зиме 1917 г. следуют попытки вывести детский приют монастыря в Кострому, а позднее и саму обитель из Петрограда, чего сделать не удалось. Игумения Афанасия всеми силами стремилась сохранить Радочницкий монастырь, ее поддерживала в этом значительная группа наиболее стойких монахинь, которых ей удалось сплотить вокруг себя в столь тяжелый момент. Постепенно и это объединение по разным причинам уменьшалось, и петроградский период истории собственно Радочницкого Свято-Антониевского монастыря Холмской епархии закончился в 1920 г., когда сама игумения Афанасия при поддержке митрополита Вениамина (Казанского) пишет прошение «о преобразовании подворья» Радочницкого монастыря «в самостоятельный монастырь с наименованием "Холмский Богородицкий женский монастырь Петроградской митрополии”» ${ }^{34}$. Впрочем, и этот новый «самостоятельный монастырь», находившийся в юрисдикции Петроградской митрополии, официально просуществовал лишь около года 
и был закрыт «обновленцами». Судьба самой игумении Афанасии и ее уже небольшой монашеской общины, перешедшей на нелегальное положение, трагически завершилась к началу 1930-х гг, когда община была окончательно разгромлена, не в последнюю очередь в связи в делом епископа Мануила (Лемешевского) ${ }^{35}$.

Благодаря сохранившейся в архиве митрополита Евлогия (Георгиевского) переписке начала 1920-х гг. с игуменией Афанасией, хранящейся в его фонде ${ }^{36}$, опубликованной Н. Т. Энеевой ${ }^{37}$, нам известно, сколько тяжелейших утрат и катастрофических разочарований пришлось пережить насельницам холмской православной обители, чтобы с величайшей болью и безысходностью заговорить о вступлении церкви в последнюю фазу своего земного бытия. Все последующие годы жизнь монашеской общины матушки Афанасии была так или иначе связана с петроградской деревянной церковью Божией Матери Холмской упраздненного Радочницкого Свято-Антониевского женского монастыря Холмской епархии, церковью, окончательно закрытой в 1939 г. и тогда же снесенной.

В течение нескольких лет в ней находился оригинал чудотворной иконы Божией Матери Холмской XI в., привезенной сюда в начале осени 1915 г., а затем ее освященная копия, также считавшаяся чудотворной. Иконы эти были единственным всеобщим действенным утешением радочницкой игумении, ее монахинь, а еще ранее, вплоть до конца 1917 — начала 1918 г., — и ее послушниц и воспитанниц. Постоянная молитва пред сберегавшейся в стенах храма петроградского подворья иконой Богоматери Холмской, неусыпно днем и ночью читаемый насельницами монастыря акафист перед ней поддерживали и ободряли сестер. Как бы не случайно, по словам Афанасии, икона «прибыла в храм Радочницкого монастырского подворья, на станции Удельной, который смело можно назвать Ее храмом, так как посвящен он имени Пречистой Владычицы Холмской, и в самом устроении его явно была видна помощь свыше. Все в нем дышало Ею, говорило о Ней, и вот, наконец, Сама Она, в Своем Чудотворном Образе, пришла в него. Пришла неожиданно, нечаянно, так далеко, за тысячу верст, в уготованное Самою Себе место. И встречая Преблагословенную, невольно, со слезами радости повторяла малая Обитель слова Евангельские: “и откуду мне сие - да прииде Мати Господа моего ко мне!” На особом возвышении, с правой стороны, около солеи, окруженная тропическими растениями, под сенью ярко-красного бархата, среди благоухающих белых лилий, стоит дивная народная Святыня Холмская. День и ночь неугасимо пред Нею горят три лампады, и вместе с ними молитвенно 
горят и сердца преклоняющихся перед Нею людей. Издалека приезжают и приходят люди, приносят с собою скорби свои, а уносят тихую, благоговейную радость. На всех кротко и благостно смотрит Лик Пречистой, и никто не отходит от Нее “тощ и не услышан”» ${ }^{38}$.

В 1918 г. оригинал чудотворной иконы Божией Матери Холмской, бывшей, по словам митрополита Евлогия (Георгиевского), «историческим знаменем Холмщины», с которым «связана была вся ее горькая судьба на протяжении многих веков», перевезли вместе с братией и имуществом Турковицкого монастыря из Москвы в Киев, во Флоровскую женскую обитель ${ }^{39}$. Несколько позднее, в 1923-1924 гг., уже в период сильнейших гонений на верующих мирян и особенно духовенство, икона хранилась в квартире историка Н. Д. Полонской-Василенко, которая получила ее от своего «приятеля К., холмского патриота», позднее забравшего образ «вновь себе» ${ }^{40}$. Дальнейшая многолетняя запутанная история сохранения и спасения иконы Богоматери Холмской, в которой, например, в один из моментов участвовала двоюродная сестра писателя М. А. Булгакова, коренная холмщанка И. М. Булгакова, вынесшая ее из-под огня во время Второй мировой войны, еще ждет своего достоверного освещения. Долгое время этот образ скрывали православные холмщане, и только осенью 2000 г. он был передан на хранение в Волынский краеведческий музей в Луцке, где и сберегается ныне в Музее волынской иконы.

\section{ПРИМЕЧАНИЯ}

1 Рогозный П. Г. Церковная революция 1917 года: Высшее духовенство Российской Церкви в борьбе за власть в епархиях после Февральской революции. СПб., 2008.

2 Rogosnyj P. Die "Kirchenrevolution" von März bis August 1917 // Religion \& Gesellschaft in Ost und West. № 4/5. S. 27-29.

3 Рогозный П. Г. Церковная революция 1917 года... С. 212.

4 Фриз Г. «Понять церковь - значит понять народ...» // Государство, религия, церковь в России и за рубежом. 2016. № 4. С. 242-250.

5 Від депортації до депортації: суспільно-політичне життя холмсько-підляських українців (1915-1947). Дослідження. Спогади. Документи. Чернівці, 2011. Т. 1.

6 Купріянович Г. 1938: акція руйнування православних церков на Холмщині і Південному Підляшші. Холм, 2008.

7 Наряду с М. С. Грушевским, коренной холмчанкой была Н. П. Кухарчук, супруга Н. С. Хрущева, предлагавшего в 1944 г. по сути 
воссоздать бывшую Холмскую губернию Российской империи в виде особой Холмской области, присоединенной к УССР (копия этого документа хранится в Центральном государственном архиве общественных объединений Украины в Киеве: Ф. 1. Оп. 23. Ед. хр. 711. Л. 6-7).

8 Грушевский М. С. Освобождение России и украинский вопрос. СПб., 1907. С. 283.

9 Там же. C. 278.

10 Szabaciuk $A$. «Rosyjski Ulster»: Kwestia chełmska w polityce imperialnej Rosji w latach 1863-1915. Lublin, 2013.

11 Лабынцев Ю. А., Щавинская Л. Л. Белорусско-украинско-русская православная книжность межвоенной Польши: Исследования и публикации по материалам экспедиции 1996 г. М., 1999. С. 260.

12 В настоящий момент вопрос о «латинниках» можно назвать одним из самых назревших и злободневных в украинской истории, хотя пока его лишь пытаются поставить отдельные исследователи. См., например: Павлишин О. Дилема ідентичності, або історія про те, як «латинники» (не) стали українцями/поляками (Галичина, середина XIX — перша половина XX ст.) // Україна Модерна. 2014. № 21. С. 179-218.

13 Szabaciuk A. Konwersja byłych Unitów na Katolicizm // Ziemia Radzyńska 1864-1918. Radzyń Podlaski, 2016. S. 189-206.

14 Сошлемся, напр., на факты, изложенные известным музыкальным деятелем и этнографом, коренным холмщанином Е. М. Витошинским, сообщенные ему самими участниками этих действий (Витошинський $€$. Селянські оповідання про холмське «возсоединение» // За сто літ. [Київ], 1927. Кн. 1. С. 82).

15 Евлогий (Георгиевский), митрополит. Путь моей жизни. М., 1999. C. $140-144$.

16 Дымша Л. Холмский вопрос. СПб., 1910. Положения и факты, изложенные Л. Дымшей, тогда же были опровергнуты рядом очевидцев во главе с «Нестором славянских филологов» академиком А. И. Соболевским (см., например: Несколько возражений на книгу Л. Дымши «Холмский вопрос». Холм, 1911).

17 Государственный архив в Люблине. Ф. 103. Ед. хр. 93. Л. 23-26. Православный Крестовоздвиженский кафедральный собор в Люблине в 1924-1925 гг. был уничтожен и на его месте устроен фонтан.

18 Остановить этот жуткий террористический акт, когда по «приказанию начальника Стрелецких дружин Мариана Янушайтиса» уже была проведена соответствующая рекогносцировка, удалось лишь из-за боязни, что «убийство архиепископа предоставит православию столь весомый аргумент в виде появления местного святого мученика и станет на- 
чалом боев на религиозной почве» (Paszkiewicz J. A. Gubernia chełmska // Wołanie z Wołynia. 2012. № 1. S. 17).

19 Bieńkowski L. Diecezja prawosławna / Chełmska diecezja // Encyklopedia katolicka. Lublin, 1979. T. 3. Szp. 133.

20 Глубинным летописцем чувств и чаяний простого сельского православного люда Холмщины тех лет можно назвать, например, выходца из его среды народного учителя и журналиста В. П. Островского. В своем стихотворении «Русь» он писал:

«Мы обижены судьбою,

Мы измучены в борьбе...

Русь Великая, родная!

Я взываю вновь к тебе.

Знаешь ли ты, как страдает

Православный наш народ,

Как забытый, разоренный,

Он горюя слезы льет?

Знаешь ли ты, что могилу

Уж готовят для него,

Хоронят его святыни,

Расхищают край его?

Русь Великая, родная!

Слышишь ль жалобу мою?

Русь, подашь ли нам в недоле

Руку крепкую свою?»

(Островский В. П. Вздохи о Холмщине. Холм, 1914. С. 13).

Знаменательно, что почитание личности архиепископа Евлогия, будущего митрополита, достаточно широко распространено среди современных православных холмщан по сей день, а представители поколений $\mathrm{XX}$ столетия и вовсе в значительном своем числе считали его своим заступником, инициатором национального возрождения на Холмщине. До сих пор в некоторых их домах можно видеть портреты митрополита.

Наиболее авторитетные ученые из числа коренных холмщан, такие, как, например, Ю. И. Макар, прямо признают, что тогда «православная церковь, будучи формально не украинской, на самом деле по большей части усилиями местного клира объединяла холмщаков и подляшуков все в большей степени вокруг украинских религиозно-национальных ценностей» (Від депортації до депортації... Т. 1. С. 334).

Следует отметить, что современные исследователи, обращаясь к истории украинского национального движения, начинают специально интересоваться вкладом в него в том числе монархических и черносо- 
тенных организаций, которые содействовали «созданию проукраинского дискурса». См.: Федевич К. К., Федевич К. I. За віру, Царя і Кобзаря: Малоросійські монархісти і український національний рух (1905-1917 роки). Київ, 2017.

21 В 2008 г. на Холмщине, в Турковицах, в составе ЛюблинскоХолмской епархии Польской автокефальной православной церкви начато возобновление женского Покровского монастыря.

22 Каких-либо научных исследований обо всех этих четырех монастырях не существует. Даже о Леснинской обители можно прочитать лишь в небольших популярных брошюрах, последняя из которых сравнительно недавно издана и у нас (Свято-Богородицкий Леснинский монастырь. М., 2015). В отношении же петроградского беженского периода и в ней сведения очень краткие и путаные, а о других монастырях, например Вировском, даже в «Православной энциклопедии» просто неверные (Богодзяж Н. К. Вировский во имя Всемилостивого Спаса женский монастырь // Православная энциклопедия. М., 2004. Т. 8. С. 533).

23 Сведения о Холмской епархии // Холмский народный календарь на 1917 год. М., 1916. С. 70.

24 Там же. С. 69-72.

25 Российский государственный исторический архив. Ф. 821. Оп. 4. Ед. хр. 520, 525.

26 Радочницкий женский монастырь. Пг., [1916]. С. 25.

27 Отчет о состоянии духовных школ Холмской епархии в учебновоспитательном отношении за 1915-1916 учебный год // Холмская церковная жизнь. 1917. № 9-10. Официальная часть. С. 151-152.

28 Холмская церковная жизнь. 1917. № 13-16. Официальная часть. C. 216 .

29 Там же.

30 Щавинская Л. Л. Издательская деятельность Холмской православной епархии в Москве: 1915-1917 гг. // Государство, общество, церковь в истории России XX-XXI веков: материалы XV Международной научной конференции. Иваново, 2016 г. Ч. 1. С. 370-373.

31 Холмская церковная жизнь. 1917. № 11-12. Неофициальная часть. С. 203.

32 Там же. № 13-16. Неофициальная часть. С. 231-233.

33 Лабынцев Ю. А. Петроградский период в истории Радочницкой православной обители и распространение ею паралитургических произведений иеромонаха Христофора (Саковича) // Государство, общество, церковь в истории России XX-XXI веков: материалы XV Международной научной конференции. Иваново, 2016. Ч. 1. С. 223. 
34 Там же. С. 224.

35 Там же. С. 223.

36 ГАРФ. Ф. 5919. Оп. 1. Ед. хр. 25. Всего 5 писем на 11 листах.

37 Письма игумении Афанасии (Громеко) митрополиту Евлогию (Георгиевскому) / Публ. Н. Т. Энеевой // Проблемы истории Русского зарубежья: Материалы и исследования. М., 2005. Вып. 1. С. 362-374.

38 Радочницкий женский монастырь. С. 11-13.

39 Евлогий (Георгиевский), митрополит. Путь моей жизни. С. 89, 291.

40 Мицик Ю. Незнані сторінки // Пам’ятки сакрального мистецтва Волині. Науковий збірник. Вип. 8. Луцьк, 2001. С. 88.

\section{J. A. Labyntsev}

Revolutionary Petrograd in the fate of Cholm Orthodox monastery the keeper of the most important Christian shrine of West Ukrainian border territories

The article focuses on the understudied topic of revolutions in Russia in 1917 and the fate of church organizations. As an example is used the series of tragic events for one of the most successful monasteries of the Russian Empire in the beginning of the 20th century, Radochnitsky Svyato-Antonievsky, that was evacuated to Petrograd in the beginning of WWI. The monastery, that was sent to the rearward during the almost full evacuation of Orthodox Western border regions, received at its metochion in Petrograd the main Christian shrine of West Ukrainian border — the wonder-making icon of Saint Virgin Mary of Cholm, dated by 11th century. Keywords: Orthodox Church, revolutions of 1917, Cholm Orthodox diocese. 


\title{
Проблемы общественной и церковной жизни Холмщины в изданиях Холмской православной епархии в период эвакуации и революционных перемен: 1915-1917 гг.
}

\begin{abstract}
В статье рассматривается литературно-публикаторская деятельность клира и мирян Холмской православной епархии в 1917 г. во время ее пребывания в эвакуации. Официальным центром церковной жизни православных холмщан в этот период была Москва, где размещалась Холмская духовная консистория, Холмский епархиальный училищный совет, Холмская духовная семинария, три из пяти епархиальных монастырей и Холмское Свято-Богородицкое братство, которое сыграло выдающуюся роль в национально-религиозном возрождении Холмщины. Анализ редких холмских православных изданий, осуществлявшихся в Москве в 1917 г. и обладающих ныне огромной ценностью, позволяет детально проследить эволюцию процесса нараставшей украинизации, которая оказывала влияние на взгляды коренных холмщан.

Ключевые слова: Холмщина, Холмская православная епархия, Холмское Свято-Богородиикое братство, беженство, «Холмская иерковная жизнь», «Холмская Русь», украинское национальное движение.
\end{abstract}

DOI: $10.31168 / 2073-5731.2018 .3-4.4 .02$

С древнейшей поры Холмщина была православной. Православие на холмских землях распространилось еще во времена Древней Руси, а в начале XIII в. возникла самостоятельная Холмская православная епархия, просуществовавшая вплоть до XVII столетия, когда, в конце концов, оказалась в руках униатов ${ }^{1}$. Вышедший в 1905 г. указ «Об укреплении начал веротерпимости» серьезнейшим образом сказался на социально-политической обстановке во всей Российской империи, а в данном регионе в буквальном смысле взорвал ситуацию: «...в Холмском крае, как равно и во всех концах России, наступала смута и поднимались волнения» ${ }^{2}$. В июне 1905 г. решением Святейшего синода из Холмско-Варшавской православной епархии была выделена особая Холмская епархия, включавшая территории в составе Люблинской и Седлецкой губерний. Правящим архиереем новообразованной 
епархии стал епископ Евлогий (Георгиевский), будущий митрополит, экзарх Западной Европы Московского патриархата.

Вслед за образованием Холмской епархии в течение ряда лет в Российской империи остро дебатировался ${ }^{3}$ вопрос о создании отдельной Холмской губернии путем выделения ее из состава Варшавского генерал-губернаторства (Царства Польского). В качестве одного из обоснований по этому поводу «местный уроженец и постоянный житель» Холмщины В. Ткач писал в 1911 г.: «...резко заметной разницы между всеми холмскими говорами и украинским народным наречием, или южнорусским языком, нет. Равным образом, нет ни в одном холмском русском народном говоре той фонетической степени сближения или уподобления, <..> по которому можно было бы признать холмские говоры, или хотя бы один из них, более близкими к польскому языку, чем к украинскому» ${ }^{4}$. В дебатах по вопросу образования Холмской губернии принимали активное участие и ученые 5.23 июня 1912 г. было законодательно утверждено создание Холмской губернии, что вызвало необычайный подъем у местного населения: «...этот день стал великим народным праздником Холмской Руси. Последняя стала в непосредственную связь с великим русским народом, готова была забыть свои скорби и печали и зажить новою жизнью» ${ }^{6}$.

К 1913 г. Холмская православная епархия насчитывала более трехсот тысяч прихожан, около трехсот приходов с более чем тремястами священниками, один мужской (Яблочинский) и четыре женских монастыря (Леснинский, Вировский, Радочницкий и Турковицкий). Учреждение особой Холмской губернии виделось современникам важнейшим событием в истории Холмщины ${ }^{7}$. Главными инициаторами этого процесса являлись православные круги Холмщины во главе с епископом Евлогием, в частности, деятельное Холмское Свято-Богородицкое братство.

Трагические события Первой мировой войны, наступление германских войск по всему фронту привели к массовой эвакуации местного православного населения западных окраин Российской империи в ее центральные районы. Сам этот феномен получил название «беженство». В беженство отправлялись все православные церковнослужители ряда епархий во главе с епископатом, а также насельники монастырей. Летом - осенью 1915 г. началась эвакуация на Холмщине, которая для церковнослужителей и мирян Холмской епархии стала настоящим «беженским крестным путем», когда приходилось «видеть голодающий народ, переживать ужасы смерти, которая уносила в могилу, вследствие появления повальных болезней, целые сотни и тысячи нашей паствы» ${ }^{8}$. 
Уже поздней осенью 1915 г. православные жители Холмской губернии, ее церковные организации и причт были расселены во многих внутренних губерниях Российской империи. Все органы епархиального управления и холмские православные монастыри оказались сосредоточены в Москве и Петербурге 9 . Холмская духовная консистория была размещена в Москве в Новоспасском монастыре, Холмский епархиальный училищный совет и Холмская духовная семинария расположились в Заиконоспасском духовном училище на Никольской улице. Три из пяти холмских монастырей тоже нашли приют в Москве: Яблочинский в Богоявленском монастыре, в Алексеевском монастыре - Вировский и Турковицкий - в Марфо-Мариинской обители. Холмское Свято-Богородицкое братство также обосновалось здесь.

Холмская православная епархия сразу же возобновила в Москве свою издательскую деятельность ${ }^{10}$. Первый московский номер журнала Холмской епархии «Холмская церковная жизнь», 13-й по общему годовому счету, вышел уже в конце ноября - начале декабря 1915 г. в типографии А. И. Снегиревой. Редактировался он архимандритом Серафимом (Остроумовым) ${ }^{11}$, ректором Холмской духовной семинарии, ставшим весной 1916 г. епископом Бельским, викарием Холмской епархии. В обращении от лица редакции журнала к читателям, коими являлись как духовные, так и мирские лица, и не только холмщане, говорилось о планах на будущий издательский период начиная с 1916 г. Будучи официальным органом Холмской епархии, «Холмская церковная жизнь» ставила себе ближайшей задачей как можно более широко отображать и освещать жизнь Холмской епархии, которая находилась в рассеянии по всей Российской империи вплоть до Самарканда, Ташкента и Иркутска. Она также должна была содействовать «лучшему направлению церковной и религиозно-национальной жизни епархии, терпящей в настоящее время большие невзгоды». В связи с «натиском воинствующего австро-польского католицизма и политиканствующего униатства» и «нашествием на Холмскую Русь германцев и протестантствующего германизма, влияние которого, возможно, скажется по водворении наших беженцев на своих местах», предполагалось в наступающем году кроме статей «общецерковного положительного содержания» публиковать «миссионерские труды апологетико-полемического характера». «В виде прибавления "Холмская Церковная Жизнь" выдает своим подписчикам издаваемый при журнале "Холмский Народный Листок”, который в популярных статьях и рассказах будет преследовать те же цели содействия лучшему направлению, как церковной, так и национальной жизни епархии, духовенства и народа. 
Журнал временно издается в Москве и вместе с прибавлением выходит два раза в месяц» ${ }^{12}$.

Вместе с епархиальным «религиозно-патриотическим журналом» «Холмский народный листок», рассчитанным прежде всего на местное холмское православное крестьянство, «Холмская церковная жизнь» стала ценнейшим собранием различного рода документальных материалов о судьбе как отдельных прихожан, так и епархии в целом. Весьма интересны и различного рода индивидуальные свидетельства, в том числе стихотворные, печатавшиеся в этих изданиях. «Холмская церковная жизнь» выходила до конца лета 1917 г. ${ }^{13}$

Помимо «Холмской церковной жизни» с приложением, которые «не мало отводят места на своих страницах уяснению вопросов церковных и церковно-исторических в духе исконных православно-русских заветов», начали выходить и другие печатные издания, служившие «церковно-просветительным и национальным запросам епархии», среди которых «Холмская Русь» - народная еженедельная газета, посильно отвечающая на духовные, национальные и экономические запросы и нужды населения Холмщины и Подляшья, которая издавалась Холмским православным Св.-Богородицким братством с 1912 года. С конца ноября 1915 г. издание этой газеты возобновилось в Москве, где временно остановилось и действовало в беженстве Холмское православное Св.-Богородицкое братство. В этот период издавался «Холмский народный календарь» - «можно сказать, домашняя обиходная книга для чтения среди православного русского населения Холмщины и Подляшья и в то же время справочная и памятная местная книга». Календарь, издававшийся Братством с 1885 г., на 1917-й год (32-й год издания) был выпущен уже в Москве. Одним из самых популярных изданий братства был «Богогласник», «сборник “набожных песен”, посвященных Господским, Богородичным и местным праздникам, распеваемых русским населением Холмщины и Подляшья. Отличаясь особой музыкальностью и высоким религиозным чувством, песнопения эти пользуются большой любовию среди населения края. Богогласник - издание Братства; последнее (десятое) издание его было сделано в Москве в 1916 году» ${ }^{14}$.

Большинство членов Холмского Свято-Богородицкого братства к осени 1915 г. обосновалось в Москве, где был нанят дом на Тверской, в котором располагалась его канцелярия, проходили заседания совета братства. Здесь же могли остановиться представители епархиального духовенства, приезжающие в Москву по делам. Братство, обладавшее даже собственной московской типографией, уже в июне приступив- 
шей к работе, развернуло активную деятельность. Было возобновлено издание газеты «Холмская Русь», издан «Богогласник» для бесплатной раздачи беженцам Холмщины, восстановлено издание «Холмского народного календаря» ${ }^{15}$.

Народная еженедельная иллюстрированная газета с ежемесячным приложением «Холмская Русь», издававшаяся до конца 1917 г., оставалась главным печатным органом братства, редакторами которого в этот период были его видные члены, такие как епархиальный наблюдатель церковных школ священник Александр Громадский, будущий митрополит Волынский и Житомирский, автор «Краткого исторического очерка Холмской Руси» ${ }^{16}$; священник Иосиф Захарчук, священник Петр Король, талантливый церковный публицист, много писавший о проблемах пастырства и пастырского авторитета, в том числе в драматический революционный период. Владыка Серафим (Остроумов) осуществлял общее руководство деятельностью братства, в том числе и издательской. Он же был председателем его Совета, который собирался на свои заседания в «Холмском братском доме» на Тверской, 21. Братство издавало также различного рода листки, брошюры и книги, рассчитанные на широкий круг читателей. Газета «Холмская Русь» явилась самой динамичной летописью важнейших событий, происходивших на протяжении всего 1917 г. внутри холмского сообщества во всех его социальных слоях. Благодаря огромному числу публиковавшихся на ее страницах индивидуальных свидетельств перед исследователем проходит целая галерея образов самых разных людей - беженцев из Холмщины: крестьян, священников, учителей, общественных деятелей, чиновников и т. д. И даже самый беглый анализ их мироощущения очерчивает процесс самооткрытия и самопровозглашения украинского самосознания у значительной, если не преобладающей по числу, группы коренных холмщан из самых разных социальных слоев, прежде всего крестьянских.

Один из самых заметных и деятельных коренных холмщан-беженцев М. И. Корнилович писал в своих воспоминаниях: «Так в начале российской революции началось украинское национальное движение среди холмского народа» ${ }^{17}$. Беженцы испытали горькое разочарование от тотальной анархии революционного времени. Российская революция стала для них огромным испытанием, привела к осознанию своей национальной самобытности, отличной от великорусского этноса. Следует заметить, что «до самой революции 1917 года украинское национальное движение в России, которое осуществлялось в интеллигентских организациях, не было связано с широкими на- 
родными массами» ${ }^{18}$. На территории самой же Украины революция «уже с первых дней <..> приобрела и некоторые отличительные и оригинальные черты, которые перевели ее на иные рельсы, нежели те, которыми шла революция вообще в России. Этими чертами были национальное движение, национальный подъем, которые приобрели такой небывалый размах, неожиданный не только для чужих, но и для многих украинцев, что с самого начала революция на Украине пошла отчетливо национальным путем» ${ }^{19}$.

Москва на некоторое время становится центром холмского украинского беженского движения, и уже в апреле 1917 г. на собраниях холмщан констатируется: «В июне и июле 1915 года в связи с общим отступлением русской армии украинское население Холмщины почти в полном составе бросило свои родные места и огромной беженской волной устремилось на восток. За два года своего беженства оно раскидалось небольшими группами по всему необъятному пространству России $<\ldots>$ Старый бюрократический строй, никогда не ставивший своей задачей заботу о благе народа, оказался совершенно бессильным справиться с теми народными нуждами, которые предъявляло к власти беженство <...> Общество было отстранено от возможности помогать народу, так как старая власть ревниво оберегала свое право на имя единственного благодетеля холмского народа, и вот почему положение рассеянного в данный момент крестьянства поистине трагично и приведет народ к неминуемой гибели, если не изменится в корне вся система управления Холмской губернией и если сам народ не возьмет в свои руки заботы о себе и своей дальнейшей судьбе. Политический переворот 2 марта 1917 года дал эту возможность Холмскому народу, и вот почему он немедленно приступил к организационным работам по созданию такого органа, который бы явился выразителем воли всего холмского народа $<\ldots>$ В Москве проживает наибольшее количество интеллигенции Холмского народа. Вот почему Холмская колония в Москве сочла необходимым первой взять на себя заботы о создании общенародной организации для украинского населения Холмщины» ${ }^{20}$.

Вместе с тем вдохновленные образованием Холмской епархии в 1913 г. $^{21}$ холмщане в большинстве продолжали видеть свое будущее в единении с Россией. Однако после бурных революционных событий 1917 г. в каждом новом номере газеты «Холмская Русь» слышна все большая тревога о дальнейшей судьбе своей малой родины, Холмщины, которая может снова войти в состав Польши, все больше обращений к Украине, упование на присоединение к ней: 
До Тебе, рідна Україна,

Я простягаю руки,

Бо Ти - сестра моя едина;

Спаси мене від муки!...

Прийми ж нас, Украіно!22

Наряду с усиливающимися дискуссиями по весьма болезненному для православной Холмщины «польскому вопросу», в газете появлялось все больше индивидуальных и коллективных материалов об Украине, о желании слиться с ней ${ }^{23}$. Холмщане начинают прямо провозглашать: «Холмская земля - украинская земля!» и призывать к присоединению Холмщины к Украине уже летом 1917 г. Все больше материалов публикуются на украинском языке. «Другій раз, брати моі і сестри, пишеця в "Холмскую Русь" на украінський мови, наший рідний мови, про нужди нашого народу, разсіяного по цілий держави Россійскій $<\ldots>$ Велика Россійська революция зробила те, що ми, Холмщане - Украінци, теперь можемо голосно заявити, хто ми і и куди пійдемо $<\ldots>$ ми Украінці $<\ldots>$ ми пійдемо 3 Украінцями» $\rangle^{24}$.

В истории украинизации московских и околомосковских холмщан поворотным моментом стали апрельские дни 1917 г., когда в Москве состоялось второе их весьма расширенное Общее собрание («до 400 человек»). Оно выработало и программный документ для переговоров с российским правительством с просьбой не допускать возвращения холмских земель в состав Польши в каком-либо виде: «Текущие события требуют от украинского населения Холмщины определения своей политической ориентации по примеру всех других народностей $<\ldots>$ Объявленный акт Временного правительства о независимости Польши не оговаривается ни одним словом о том, какая судьба постигнет Холмщину. По вопросу о национальном самоопределении собраниями холмщан приняты следующие резолюции: I. "Оставление Холмщины в пределах Польши собрание считает недопустимым”. II. “Признавая, что только органическое слияние Холмщины с украинским народом может обеспечить ей возможность правильного политического и культурного развития в будущем, - coбрание полагает, что Холмщине необходимо всецело слиться с украинским движением при условии сохранения некоторых особенностей ее жизни" <...> Временное обособление Холмщины от родственных ей земель и включение ее $<\ldots>$ в состав Царства Польского имело для ее религиозной, национальной и культурной жизни весьма вредные последствия $<\ldots>$ оставление крестьянской Холмщины за госу- 
дарственно-политической границей Руси в пределах самостоятельной Польши неминуемо повлечет за собою полную религиозную и общественно-экономическую гибель крестьянских масс Холмщины» ${ }^{25}$. Тогда же, по предложению преподавателя Холмской духовной семинарии М. П. Кобрина ${ }^{26}$, была отправлена специальная телеграмма в Киев с приветствием «Украинскому Конгрессу»: «Второе общее собрание эвакуированных в Москву Холмщан просит Вас радостно приветствовать Украинский Конгресс, собравшийся для объединения всех украинских земель и заявить ему о горячем желании Холмщины присоединиться ко всему украинскому народу. Холмщина всегда входила в состав Малой России, жила одной жизнью с соседними Волынью и Галичиной и до настоящего времени сохранила свою русскую народность, свой вековой уклад жизни и исповедует единую со всей Русью православную веру» ${ }^{27}$.

Записки холмских деятелей свидетельствуют, что многие холмщане летом 1917 г. всецело начинают ориентироваться на Киев, хотя тогда же пять представителей от православной Холмщины принимают участие во Всероссийском церковном соборе, в том числе известный культурный и общественный деятель Е. М. Витошинский, председатель апрельского московского Общего собрания холмщан ${ }^{28}$.

В то же время в Киеве, в первой декаде августа, собирается холмский съезд народных учителей, который положил начало холмским беженским съездам, главнейшим из которых стал Всехолмский съезд, проходивший в Киеве в конце августа 1917 г. На нем от лица нескольких сот тысяч беженцев-холмщан были представлены почти 300 делегатов, около 250 из которых являлись «селянами-хлеборобами» ${ }^{29}$. Во Всехолмском съезде участвовал уроженец Холма «голова Центральной Українськой Рады проф. М. С. Грушевський», который рассказал о своих стараниях в многолетней борьбе за возрождение Холмщины, о «холмском вопросе», долгие годы волновавшем его лично ${ }^{30}$. Примечательно, что в своих выступлениях на съезде холмщане, по воспоминаниям очевидцев, называли себя и «холмскими русинами», хотя в итоговых документах съезда было записано: «народ Холмський визнає себе народом Українським», а «доля його повинна бути спільна 3 долею всего Українського народу» ${ }^{31}$.

Конечно же, тогда, летом — в начале осени 1917 г., говорилось лишь об автономии Украины «в межах федеративної демократичної Російської республіки», и участники киевского Всехолмского съезда, провозглашая славу родной Холмщине, скандировали также: «Слава державі Російській і усьому народові російському!» ${ }^{32}$ Съезд ликвидировал старое 
губернское правление и упразднил должность губернатора, назначил холмского губернского комиссара и исполнительный комитет при нем, а также восемь своих представителей в Центральную Раду, под управлением которой отныне и должна была находиться Холмщина.

Конец 1917 г. стал переломным в истории Холмской православной епархии, тогда же прекращается и всякая ее издательская деятельность. В феврале 1918 г. в условиях фактического отсутствия правящего архиерея в Марфо-Мариинской обители в Москве проходит объединенный епархиальный съезд, проголосовавший за избрание своим первосвященником архиепископа Евлогия (Георгиевского). Вся дальнейшая история Холмской епархии вплоть до последних лет Второй мировой войны пока мало изучена. Достаточно детально она представлена в документах Холмской духовной консистории, архив которой в послевоенные годы попал на хранение в Центральный государственный исторический архив Украины во Львове ${ }^{33}$.

Российская революция стала для всех беженцев огромным испытанием, привела к осознанию своей национальной самобытности, отличности от великорусского этноса, в среде которого все же многие из них остались жить, сроднились с ним, образовали смешанные по национальному составу семьи. Революционная пора была временем гигантских человеческих потерь среди беженцев, моментом этнонациональной консолидации, осознания необходимости возвращения на родину, которое длилось несколько лет, начиная с 1918 г.

\section{ПРИМЕЧАНИЯ}

1 Gil A. Prawosławna eparchia chełmska do 1596 roku. Lublin; Chełm, 1999; Gil A. Chełmska diecezja unicka 1596-1810. Lublin, 2005.

2 Холмская губерния. Холм, 1914. С. 114.

3 См., например: Тыликевич В. Холмская Русь и поляки // Речь. 1906. № 253 (28 декабря); Материалы по вопросу об образовании Холмской губернии. Варшава, 1908.

4 Ткач B. Очерки Холмщины и Подляшья. Холм, 1911. С. 4.

5 См., например: Францев $B$. A. Карты русского и православного населения Холмской Руси со статистическими таблицами к ним. Варшава, 1909; Дымшиа Л. Холмский вопрос. СПб., 1910; Соболевский А. Холмская Русь в этнографическом отношении. Харьков, 1910; Wiercieński H. W sprawie wydzielenia Chełmszczyzny. Warszawa, 1910; Лонгинов А. В. Русский вопрос о Холмщине в историческом освещении. СПб., 1912. 
6 Громадский А., священник. Краткий исторический очерк Холмской Руси // Холмский Народный Календарь на 1917 год. М., 1916. С. 165.

Православные холмщане тогда восклицали:

«Услышал Всевышний молитвы и вздохи,

Услышал он русский народ,

(Что в Холмщине бедной уж много столетий

Под гнетом тяжелым живет)...

Мы духом и сердцем сольемся навеки

В одной общерусской волне

Со всеми родными нам, близкими братьями,

Живущими в русской стране. -

И наши сыны никогда не забудут

О славном спасении дне».

См.: Островский В. П. Услышал Всевышний! (По случаю принятия Государственной Думой законопроекта о выделении Холмщины 26 апреля 1912 г.) // Островский В. П. Вздохи о Холмщине. Холм, 1914. С. 46.

7 Холмский народный календарь на 1917 г. после «Молитвы Пресвятой Богродицы» открывается указанием летоисчисления наступающего года «От сотворения мира 7425-й, [от] Рождества Христова 1917, [от] основания Русского государства (в 862 г.) 1055, <..> [от] образования Холмской губернии (23 июня 1912 г.) 5» (Холмский народный календарь на 1917 г. М., 1916. С. 5).

8 Серафим, епископ. Речь... при открытии Братского съезда духовенства и мирян Холмщины // Холмская церковная жизнь. 1916. № 24. Часть неофициальная. С. 475.

9 См., например: Лабынцев Ю. А. Петроградский период в истории Радочницкой православной обители и распространение ею паралитургических произведений иеромонаха Христофора (Саковича) // Государство, общество, церковь в истории России XX-XXI веков: материалы XV междунар. науч. конф. Иваново, 2016. Ч. 1. С. 220-224.

10 Щавинская Л. Л. Издательская деятельность Холмской православной епархии в Москве: 1915-1917 гг. // Государство, общество, церковь... С. 370-373.

11 В 2001 г. архиепископ Серафим (Остроумов), расстрелянный в 1937 г. в Катыни, причислен к лику святых.

12 Холмская церковная жизнь. 1916. № 1 (1 января). Часть неофициальная. С. 15.

13 Холмская церковная жизнь. 1917. № 13-16 (1 июля - 15 августа).

14 Холмские епархиальные и Братские печатные издания // Холмский Народный Календарь на 1917 год. М., 1916. С. 84-85. 
15 Братства в епархии // Холмский Народный Календарь на 1917 год. М., 1916. С. 81.

16 Громадский А. Краткий исторический очерк Холмской Руси. M., 1917.

17 Корнилович M. Біженська трагедія Холмщини й Підляшшя // Україна. 1927. Кн. 3. С. 126.

18 Власовський I. Нарис історії Української Православної Церкви. Ню Йорк Бавн Брук, 1961. Т. 4. Ч. 1. С. 6.

19 Ефремов С. На вершку національних досяганнів (1917-й рік на Україні) // Нова Рада. 1917. № 220 (31 грудня). С. 3.

20 Записка о нуждах Холмщины, поданная господину Министру внутренних дел от имени общих собраний холмщан в Москве 4 и 9 апреля 1917 г. М., 1917. С. 1-2.

21 Вот один из восторженных откликов на это событие со стороны коренных холмщан:

«Взошла заря. Вставайте братья,

Уж сбылись в жизни наши сны:

Нас приняли в свои объятья

России верные сыны.

Москва и Киев - Русь святая

И величавый Петроград,

Свободу нам ниспосылая

Защитой мощной нас дарят...

Мы спасены, мы живы, живы!

Пред нами новый светлый путь;

В слияньи с Русью наши нивы

Цветами счастья зацветут».

См.: Островский В. П. Взошла заря (Кантата на выделение Холмщины 1 сентября 1913 г.) // Островский В. П. Вздохи о Холмщине. Холм, 1914. С. 52.

22 Павелко Д. Холмщина - до Украіни // Холмская Русь. 1917. № 32 (6 августа). С. 2.

23 Наши очередные задачи // Холмская Русь. 1917. № 25 (25 июня). C. $1-5$.

24 Дмитрюк К. Холмщина до Украины! // Холмская Русь. 1917. № 28 (2 июля). С. 1.

25 Записка о нуждах Холмщины... С. 3-4.

26 Подробнее о нем см.: Лабынцев Ю. А., Щавинская Л. Л. Белорусско-украинско-русская православная книжность межвоенной Польши: Исследования и публикации. М., 1999. С. 251-254. 
27 Второе Общее собрание уроженцев и деятелей Холмщины в Москве // Холмская Русь. 1917. № 16-18 (16-23-30 апреля). С. 2-3.

28 Корнилович М. Біженська трагедія Холмщини й Підляшшя... C. 128.

29 Там же. С. 129.

30 Там же. С. 130.

31 Там же. С. 131.

32 Там же.

33 Центральный государственный исторический архив Украины во Львове. Ф. 693.

\section{L. Shchavinskaia}

Cholm Orthodox diocese in 1917: Publisher chronicles of social and private church life at the time of groundbreaking changes

The article concentrates on the literary and publishing activities of the clergy and lay people of Cholm Orthodox diocese in 1917 during its evacuation in the Russian rearward. The official center of the church life of the Orthodox dwellers of Cholm becomes Moscow. The analysis of Cholm Orthodox publications in Moscow in 1917 shows in details the evolution of increasing Ukrainization in the views of Cholm people.

Keywords: Cholm Land, Cholm Orthodox diocese, Cholm Brotherhood of Saint Virgin Mary, refugees, "Cholm Church Life", "Cholm Rus", Ukrainian national movement. 
A. А. Плотникова

(Москва)

\section{«Водные хорваты» и специфика их традиции: обзор этнолингвистической экспедиции}

Исследованные хорватские села самого юга административного деления Братиславы представляют собой одно целое в силу одинаковой исторической ситуации: эта небольшая территория на пересечении австрийской, венгерской и словацкой территорий была присоединена к Чехословакии лишь после Второй мировой войны, что в XX в. позволило хорошо сохранить хорватскую традицию в окружении неродственного венгерского языка. В статье показаны особенности народного календаря, семейной обрядности и народной мифологии, общие для всех градищанских хорватов (Австрии, Венгрии и Словакии), особенности, аналогичные тем, которые отмечаются в самой Хорватии, а также заимствования из соседствующих языков и традиций австровенгерского пространства и из народной культуры собственно Словакии, внутри государственных границ которой находятся исследованные хорватские анклавы.

Ключевые слова: градищанские хорваты в Словакии, народный календарь, народная мифология, семейная обрядность, архаические ареальl, мультилингвизм.

DOI: $10.31168 / 2073-5731.2018 .3-4.5 .01$

В мае 2018 г. было предпринято обследование трех поселений градищанских хорватов на территории Словакии: Яровцы (словац. Jarovce, хорв. Jandrof), Русовцы (словац. Rusovce) ${ }^{1}$ и Чуново (словац. $\check{C}$ unovo, хорв. С̆unova). Выбор этих сел был обусловлен их близостью к селам градищанских хорватов северной части Австрии (где проводились полевые исследования автора 2007, 2013-2015 гг.) и западной части Венгрии (экспедиция 2017 г.) $)^{2}$. Особенность региона к югу от Братиславы, находящегося на перекрестке австрийской, венгерской и словацкой территорий, состоит в том, что эти земли были присоединены к Чехословакии лишь после Второй мировой войны (1947 г.), в отличие от поселений градищанских хорватов к северо-западу (Де-

Авторская работа выполнена при поддержке гранта РНФ № 17-18-01373 «Славянские архаические зоны в пространстве Европы: этнолингвистические исследования». 
винска Нова Весь, Дубравка, Ламач) $)^{3}$ и востоку (Хорватский Гроб) от центра столицы, которые вошли в Словакию почти век назад, после Первой мировой войны (1921 г.). В результате достаточно позднего вхождения в состав Словакии территории, на которой расположены Яровцы, Чуново и Русовцы, в двух первых до сих пор сохраняется этнокультурная традиция градищанских хорватов, сопоставимая с той, которая была отмечена в других анклавах, а именно на территории Австрии и Венгрии.

Этнолингвистическая экспедиция 2018 г., участниками которой были А. А. Плотникова и Д. Ю. Ващенко, проходила в селах Яровцы и Чуново. Обнаружилось, что село Русовцы, где остановились исследователи, в настоящее время является словацким (градищанских хорватов здесь не было с XIX века), несмотря на то, что в сознании жителей Словакии оно до сих пор считается «хорватским» ${ }^{4}$. Среди жителей Русовцев обнаружилось достаточно много носителей хорватских фамилий, говорящих по-словацки и не ощущающих себя хорватами; при этом некоторые говорили о прабабушках и прадедушках, которые еще идентифицировали себя как хорватов. Местное кладбище изобилует надписями на памятниках с хорватскими, венгерскими, немецкими и словацкими фамилиями. Один день экспедиции был также полностью посвящен посещению и интервью в селе Хорватский Гроб, где было опрошено четыре информанта, как выяснилось, достаточно слабо владеющих градищанскохорватским ${ }^{5}$.

В селах Яровцы и Чуново были проведены интервью с 15 информантами, от которых были записаны сведения об исчезнувших и сохраняющихся обрядах, обычаях и обслуживающая их лексика традиционной духовной культуры из области народного календаря, сельскохозяйственной обрядности, семейных обычаев (рождение, свадьба, смерть) и народной мифологии. Были записаны и легенды о происхождении названий сел, рассказы о взаимных шутливых прозвищах соседей, что связано с тесными взаимоотношениями жителей обоих хорватских поселений, порой даже родственными. Примечательно, в частности, что «яровчане» и «чуновчане» ходили в одну и ту же, единственную в округе, школу, расположенную в Русовцах, т. е. в месте, находящемся между селами Яровцы (в трех километрах) и Чуново (в пяти километрах) на одной дороге. Необходимо также добавить, что оба градищанскохорватских села в настоящее время формально находятся в черте города Братислава, что существенно облегчает связи между всеми тремя селами: между ними обеспечено непрерывное транспортное сообщение, четко работает администрация (obecný úrad 
«местное правление»), развита сеть магазинов и туристического обслуживания в связи с непосредственной близостью Дуная и электростанцией в Габчиково, Чуновскими озерами, парком и замком в Русовцах, расположенными в пойме Дуная на его многочисленных рукавах. Было тем более удивительно обнаружить, что, несмотря на наличие практически городской структуры, в Чунове и Яровцах сохраняется язык и традиция градищанских хорватов.

Впервые в этих селах (первый раз мы услышали об этом в Чунове) было зафиксировано необычное самоназвание градищанских хорватов Wasserkroaten «водные хорваты», объясняемое тем, что «все» градищанские хорваты переселялись ближе к Дунаю, поэтому по-немецки их так и называли. На самом деле в полном смысле слова такое самоназвание применимо лишь к «чуновчанам», поскольку именно Чуново расположено ближе всего к Дунаю, который дугой огибает его с северо-востока (ср. название села Dunavčun, отмеченное в адресе на одном из частных писем, показанных нам во время экспедиции). Хорватское название села С̆ ипоvа самими жителями справедливо трактуется как производное от *čblnъ 'челн, средство переправы через воду'6, поскольку во время многочисленных наводнений лодки были главным средством передвижения по затопляющему местность Дунаю. Географический ландшафт послужил источником шуток в адрес друг друга в соседствующих селах. Именно близостью к Дунаю обусловлено именование чуновчан со стороны яровчан «комарами», говорили также, что когда-то к куполу костела в Чунове «был привязан большой комар» ${ }^{7}$, что и послужило дополнительным поводом ироничного именования жителей села «чуновскими комарами». В свою очередь чуновчане жителям Яровцев адресовали прозвище «яровские гнилушки», поскольку в окрестностях села не было леса, а «только одни трухлявые деревья». На «мифологической карте» территории опасным местом считался остров между «Большим» и «Малым» Дунаем, куда ведьмы якобы переносили ночью человека из Чунова, вытащив ему одно ребро; бедняга вынужден был оставаться на острове, пока его утром не находили рыбаки. В Чунове при сильном урагане было принято говорить, что «в Яндрофе кто-то повесился». В самом же Яндрофе (Яровцах) считалось, что черные градоносные тучи идут «из Бабьего угла» (zis Babinog kuta) — c северо-запада, где находятся уже градищанские села Австрии.

Отметим наиболее интересные факты собранного полевого материала: далее они представлены в соответствии с разделами этнолингвистического вопросника, при этом особое внимание уделено архаи- 
ческим чертам народной духовной культуры, связывающим этот ареал с первичной территорией проживания населения - Хорватией - и хорватской традицией. Кроме того, отмечаются схождения записанных данных с особенностями народной культуры «австрийских» и «венгерских» хорватов, указываются заимствования из венгерского и немецкого языков. Следует отметить, что в настоящее время сами носители хорватской традиции - жители сел Яровцы и Чуново - при рассказе о сохранившихся обычаях сопровождают свои слова указанием на то, какие именно обычаи в их народном календаре являются словацкими заимствованиями (реже - венгерскими или немецкими). Иная ситуация в селе Хорватский Гроб, где почти все бытующие там обряды и обычаи считаются жителями градищанскохорватскими, свойственными именно этому селу, несмотря на очевидный местный словацкий субстрат - возможно, культурный диалект, бытовавший здесь до прихода хорватов и освоенный ими в полной мере (например, комические похороны контрабаса на Масленицу, выпекание «оплаток» на Рождество и др. ${ }^{8}$.

Народный календарь. В обоих хорватских селах народный календарь и связанные с ним ритуалы сохраняют важные архаические черты прошлого, несмотря на влияние родственной славянской католической традиции Словакии. Как и в других хорватских селах бывшей Австро-Венгрии, предрождественские и предновогодние праздники включают обряды, связанные со стремлением способствовать благополучию следующего года. На праздник св. Варвары (4.XII) ставятся черешневые и яблоневые ветки в воду, при этом расцветшие на Рождество ветки означают успех домочадцев и их хозяйства в будущем году. На св. Люцию (13.XII) сеют в тарелку пшеницу, чтобы зеленые ростки поднялись на несколько сантиметров на Рождество это должно обеспечить плодородие будущего года, в середину ставят свечу, которая горит все праздничные дни (ср. аналогичный обычай в Хорватии, картографируемый в «Этнологическом атласе Югославии» как «сады Адониса» ${ }^{9}$ ). В этот же день в Чунове молодежью совершаются обходы «с крылом» - с метлой или гусиным крылом, которой, по поверьям, Люция подметает оставшуюся пыль по углам ${ }^{10}$, а также устраивает еще больший беспорядок в доме, если дом представляется ей плохо прибранным. В обоих селах известно поверье об изготовлении «люцииного стульчика», который следует делать начиная с этого дня в течение всего периода до Рождества (иногда говорят, что он должен быть без единого гвоздя; Яровцы). Во время мессы на Рождество следует встать на этот стульчик, и тогда увидишь будущее (Яровцы) 
или же распознаешь местную ведьму, которая сразу выбежит из церкви (Чуново), либо требуется поднять стульчик вверх и посмотреть через него, чтобы увидеть, как «танцуют ведьмы», а заодно узнать своего будущего жениха, если это делает девушка (Чуново).

На Рождество совершали обходы «пастухи» (pastiri) — музыканты со звездой (Яровцы) или реальные пастухи, щелкающие бичами и произносящие благопожелания, собирая деньги, подарки в качестве платы за сезонный выпас скота (Чуново), на Трех королей (6.I) до сих пор обходят дворы подростки, наряженные в белые одежды и с высокими колпаками на головах (Яровцы). В обоих селах сохраняется обход юношей с кнутами, сплетенными из вербовых веток, в день Невинных Младенцев (Mladenci, 28.XII). Парни, стегая девушек кнутами (korbači), произносят, обыгрывая градищанскохорватское прилагательное frižak 'быстрый, подвижный, свежий': «Frižuncun, frižuncun, friška budi kot ribica u vodi, rano se staj, jabuku daj» ${ }^{11}$ [Фрижунцун, фрижунцун ${ }^{12}$, будь подвижной, как рыбка в воде, рано вставай, яблоко давай]. В Чунове этот обычай сохраняется и сегодня ${ }^{13}$. Жители Яровцев, четко различая «свои» и «чужие» обычаи, говорят, что у словаков ритуальное битье с пожеланиями здоровья проходит на второй день Пасхи (как и взаимное поливание водой), что, впрочем, уже постепенно внедряется и в традиции рассматриваемых сел ${ }^{14}$.

Известны и многочисленные обходы на св. Николая с положительными и отрицательными персонажами, о чем жители Яровцев говорят, что раньше в селе таких обходов не было. К устрашающим процессиям относятся также известные в обоих селах масленичные процессии norci (nuоrci) (букв. 'безумные') в страшных масках из коровьей кожи, вывернутых шерстью наружу тулупах, с палками и скотьими колокольчиками в руках. Помимо устрашающей функции их цель - собрать от жителей села продукты для своего праздника, с этой целью часть группы веселит окружающих, пока другие ловят кур у невнимательных соседей, собирают другое съестное. Если о зимних процессиях пастухов (pastiri) на Рождество (Чуново) или на Трех королей (Яровцы) говорят: pastiri gredu («пастухи идут»), — то при виде бесчинствующих участников обходов принято говорить: Mikule (или norci) bižu («“Микулы” (или “безумные”) бегут»), что побуждает к ответным действиям окружающих: в первом случае следовало подготовиться к встрече высказывающих благопожелания и собирающих дары подростков, во втором - прятаться, закрывать на замок сарай с домашней птицей и т. п., чтобы «безумные» не нанесли вред здоровью или хозяйству. На Масленицу известны и ритуальные бесчинства: за- 
таскивание телеги на крышу, рассыпание соломы во дворе и под. Среди ритуальных бесчинств обращает на себя внимание и «наказание» девушки, отвергшей жениха, который поставил ей 1 мая дерево в знак любви (maja, majuško drivo 'майское дерево') ${ }^{15}$ : в этом случае высокий ствол срубают так, чтобы было видно, что «май» все-таки стоял здесь раньше, а к воротам двора прикрепляют соломенное чучело мужчины с перекошенным уродливым лицом (Чуново).

Для весенней обрядности ранее были характерны обходы и освящение полей на праздник св. Марка (25.IV), возвращаясь, участники плели веночек из освященных в этот день колосьев, который вешали на ручку окна, чтобы защитить дом от несчастья и грома во время непогоды (Чуново ${ }^{16}$. Также в обоих селах сохраняется вера в защитную силу свечи, возжигаемой на Сретение, 2.II (словац. Hromnice) ${ }^{17}$, с целью обезопасить дом от бури и грома.

Важно отметить, что раньше в Чунове перед всеми четырьмя алтарями, устраиваемыми семьями из зеленых веток под открытым небом перед воротами дома на католический праздник Tijelova (праздник Божьего Тела, четверг после Троицы), служба велась по-хорватски ${ }^{18}$, в последние же годы с учетом специфики региона перед каждым из зеленых алтарей молитвы произносятся на одном из четырех языков: перед первым - по-словацки, перед вторым - по-хорватски, перед третьим - по-венгерски, перед четвертым - по-немецки.

В Чунове были также записаны многочисленные предписания и запреты, выполнявшиеся с целью благотворно повлиять на плодородие полей, приплод домашней птицы, здоровье человека: в последнюю ночь перед Великим постом следовало как можно дольше танцевать под громкую музыку в корчме, чтобы велись гуси ${ }^{19}$, macice (повсеместное для Бургенланда название освященных вербовых веток на Вербное воскресенье) $)^{20}$ относили курам, чтобы они хорошо неслись; их также сжигали при приближении грома, градоносного облака; на Масленицу нельзя было шить, чтобы не зашить курам «зад»; если же будешь шить на Пасху, то «зашьешь себе разум». Жители Чунова помнят и запрет убивать лягушку, иначе пойдет сильный дождь, ср. также поверье о том, что «в радуге скачут лягушки» ${ }^{21}$. В обоих селах сохраняется запрет приходить в дом на Новый год женщине (а не мужчине) первой — это ведет к несчастью в будущем году.

Семейная обрядность. Для семейной обрядности характерна терминологическая лексика и народные поверья, сходные как с южнославянскими и западнославянскими (например, družba 'свидетель мужского пола'; družica 'свидетель женского пола'; в обоих селах) $)^{22}$, так и гра- 
дищанскохорватскими из Австрии и Венгрии. Так, например, известны: pir 'свадьба' (то же у градищанских хорватов на севере Австрии) в селе Чуново, но veselje в Яровцах (ср. то же наименование свадьбы у хорватов-«долинцев» в Австрии). Сами жители часто сопоставляют название, принятое в своем селе, с соседним («Мы говорим veselje, а в Чунове свадьбу называют pir») $)^{23}$, а также и с повсеместным словацким (svadba). Соответственно, в Чунове всех участников свадьбы называли pirovnjaki, среди которых выделялись piruovni otac 'отец жениха' и piruovna mati (majka) 'мать жениха'. В Чунове для обозначения главного обрядового лица на свадьбе (созывающего на свадьбу, собирающего подарки, ведущего свадьбу) известно редкое сегодня и до сих пор ни разу нами не встреченное у градищанских хорватов наименование stolnik (stounik) наряду с stat'ilo, тогда как в Яровцах используется лишь лексема stat'ilo 'главное обрядовое лицо на свадьбе', известная как обозначение дружки-парня у «полянцев» — градищанских хорватов на севере Австрии. Отметим, однако, что функции предводителя свадьбы переходят к дружке и у градищанцев Венгрии: там функции главного обрядового лица выполняет также stat'ilo ${ }^{24}$. В Чунове до сих пор используются названия дружек puotprnja (potpornja) 'дружка-девушка' и puotpornjak (potprdac) 'дружка-парень', трактуемые самими информантами как обозначения «поддерживающих, подпирающих» невесту и жениха на свадьбе и имеющие параллели у градищанцев-«полянцев» Австрии ${ }^{25}$. Для наименования невесты и жениха в обоих селах используются традиционные для градищанских хорватов zaručnja и zaručnjak. Воспоминания о свадебном обрядовом хлебе vrtanj встретились в селе Яровцы, более близком к хорватам на севере Австрии, где эта обрядовая реалия - типичный атрибут градищанской свадьбы, тогда как в Чунове $v r t a n j$ - это плетеный хлеб, который раньше пекли на Рождество (о нем помнят лишь старожилы села).

Для описания похоронной обрядности используется традиционная градищанскохорватская лексика (аналогичная употребляемой до сих пор в ряде регионов Хорватии) ${ }^{26}$ : cimiter/cimitor 'кладбище', puogreb 'похороны', karminja 'поминки после похорон', dvoriti 'молиться при покойном, пока он оставался первые две ночи в доме', Se svete 'Задушки, день Всех Святых, 1.XI', Mrtvi god 'ежегодное поминовение усопших, 2.XI' и т. д. На поминках после похорон до сих пор сохраняется обычай оставлять лишнюю тарелку для умершего (Чуново). Добавим также, что в Чунове еще в конце XX в. умерших хоронили в традиционной народной одежде, в частности мужчин - в черном плотном кафтане ${ }^{27}$. 
Народная мифология представлена в исследуемых селах не только традиционной для южных славян верой в сглаз, в существование местных ведьм и их силу обращаться в разных животных (прежде всего - в кошку), но и такими архаическими сюжетами, как обитание в Дунае «зеленого» водяного (называемого vaserčan (voserčank), т. е. немецким заимствованием, производным от Wasser 'вода'; Чуново), стремящегося утопить детей в Дунае; появление «огненных людей» (ognjeni človiki, ognjivi muži), способных остановить телегу или танцующих с огнем на сапогах на месте бывшей старой корчмы (Яровцы, Чуново). Следует особо отметить, что мифологические рассказы сохраняются здесь до сих пор (несмотря на то что в настоящее время хорватские анклавы этого региона входят в черту города Братиславы). Неудивительно, что еще в 1966 г. ученые-фольклористы из Загреба фиксировали достаточно полные тексты о летающем змее, белых вилах, ведьме (и тогда, и сегодня называемой венгерским заимствованием bosorka, которое используется наряду с южнославянской лексемой $v i s ̌ k a$, отмеченной уже в ходе нынешней экспедиции $)^{28}$, «огненных людях» и т. д.

Так, в распоряжение автора данной статьи поступили копии текстов от И. Мааса о виле (так говорили красивым девушкам), $1074 / 74^{29}$; о «босорке», седлавшей по ночам метлу и оборачивающейся кошкой, чтобы пугать людей (1074/75); о «босорках», собирающихся вместе ночью с метлами при зарождении молодого месяца (1074/89), о «босорках», которые, собравшись вместе, заменили одной из них ребро на деревянное, и о распознавании их влюбленным юношей, намазавшимся волшебной мазью, но исказившим слова заклинания, в результате чего он оказался на верхушке дерева, откуда наблюдал этот шабаш ведьм (1074/93); о ведьмах, переносящих человека ночью через Дунай, после чего тот обнаружил, что держит в руках одно свое ребро (1074/91); о крылатом змее, называемом также и венгерским заимствованием šarkanj, прилетающем в дом через печную трубу и приносящем деньги (1074/76, 1074/88, 1074/94); о татарах, после боя с которыми люди якобы распространились по всему свету (1074/77); о турках, уничтоживших население мест, куда затем переселились хорваты (1074/78); о персонаже «мора» (называемом также и bosorka), которая постоянно давит (gnjavi) деда по ночам, и о распознавании этой ведьмы-моры (1074/82); об «огненных людях» (ognjeni človiki), светящихся в ночи (1074/86); о водяном человеке, называемом wosačantil (vosačantil) (тоже германизм, от Wasser 'вода', см. выше), будоражащем воду и утаскивающем детей 
на дно (1074/87). Все эти материалы записаны в Чунове. Материал из Яровцев несколько дополняет чуновский, при этом опять-таки ощущается близость к селу австрийских хорватов-градищанцев «хатов», у которых, например, до недавнего времени сохранялись четкие представления о «белых вилах» (соб. зап. от жителя Нового Села в Австрии, 2013 г.).

Копии текстов из Яровцев включают: легенду о «белой виле», помогающей королевичу Марко (1074/107); былички о «белой виле» (bjela vila), которая своей красотой манит ночью человека вне дома, и тот теряет дорогу (1074/132), летающем огненном змее, приносящем через трубу хозяевам деньги (1074/109; 1074/121), «босорке», перенесшей человека ночью в Будапешт и оставившей его на «Ланченом мосту» ${ }^{30}(1074 / 110)$, о ведьмах, называемых и bosorke, и viške, останавливавших телеги жителей, даже если они только лишь проезжали мимо (1074/118), о ведьмах, вредивших в новолуние, на «молодой месяц» (1074/128), о душащей людей «море» (1074/130), об «огненных людях», скачущих верхом на лошадях (1074/116) или «висящих» на телеге и утяжеляющих ее (1074/126), об их происхождении от умерших неправедной смертью, повесившихся (1074/119), местное объяснение, почему женщины не имеют права идти в процессии утром на Пасху (1074/115), а также исторические легенды и рассказы, например текст, повествующий о причине прихода хорватов на эти земли, стремившихся уберечь своих детей от служения в турецких войсках (1074/100). Выделяется рассказ, объясняющий наличие по утрам спутанной гривы и заплетенных косичек у лошадей: по ночам, запутывая гриву и заплетая на ней косички, скакали на конях «босорки», «те самые моры», для защиты от которых следовало повесить в конюшне при входе подкову или образок (1074/131). По поверьям из западной части Южной Славии, косички коням заплетают скачущие на них по ночам вилы (соб. зап., Босния, 2011 г., записано по воспоминаниям детства проф. Сенахида Халиловича).

Материал, собранный в экспедиции 2018 г., в целом отражает ту же мифологическую картину, причем ряд мотивов (о водяном, огненных людях, ведьмах) также представлен быличками и мифологическими рассказами, до сих пор не фиксировавшимися. Вместе с тем невозможно не заметить процесс угасания мифологической традиции в настоящее время: так, нередко информанты смешивают термины viška 'ведьма' и vila 'сверхъестественное существо женского пола, помогающее или вредящее людям', имея в виду один персонаж - ведьму; отсутствует представление о «море», давящей по ночам людей, 
жители практически не помнят быличек о летающем змее, хотя понимают значение лексемы zmaj 'змей летающий'.

Тем не менее жители преимущественно села Чуново до сих пор помнят рассказы старших о том, как «вила» летает в лесу по воздуху или как «ночные вилы» танцуют на теплом мелководье Дуная рядом с лесом; как мужчина в облике огня (ognjeni človik) садится на телегу и не дает ей тронуться с места. В Яровцах был записан рассказ о том, как отец мальчика объяснял наличие на своей спине сильных ожогов и волдырей: «Меня обнял огненный человек». Сильный ветер у хорватов Чунова ассоциируется с танцем или полетом ведьм (реже «вил»): viške (bosorke) tancaju (letu) 'ведьмы танцуют (летят)'. Иногда о прошедшей грозе с громом можно услышать выражение vrazi ženili 'черти женились' (ср. общеславянские архаические представления о непогоде, представляемой как свадьба чертей $\left.{ }^{31}\right)$.

Таким образом, отмечаются архаические черты народной культуры, общие для всего хорватского Бургенланда (например, из сферы народной мифологии - представление вихря или сильного ветра как полет ведьм, танец ведьм; былички об «огненных» демонах, останавливающих повозки; о вредоносных или миролюбивых существах — вилах), устанавливаются параллели с терминологической лексикой непосредственно придалматинского региона Йосипдола и Огулина (свадебная и похоронно-поминальная лексика) ${ }^{32}$ как возможного основного центра исхода градищанских хорватов с первичной территории проживания. Многочисленны и общие для южных славян особенности народной культуры, в настоящее время находящиеся под сильным влиянием словацкой традиции (например, на вопрос, кто такая vila, можно услышать ответ, что так словаки говорили о красивой девушке, - вторичное свидетельство о наличии персонажа «вила» у самих словаков, а также о словацко-южнославянских фольклорных и лингвистических связях) и постепенно исчезающие (представления о летающем к людям змее, о давящей по ночам «море» и др.).

Особо подчеркнем, что исследованные хорватские села юга Братиславы представляют собой одно целое в силу одинаковой исторической ситуации - времени вхождения в границы нового государства. Их традиция не претерпела ожидаемых сильных изменений, как можно было предполагать изначально (вследствие возможного контакта родственных славянских языков и народных традиций), из-за позднего присоединения к территории Словакии. Определенным барьером для такого контакта служит венгерский язык, которым время от времени пользуются жители территории и который позволяет им 
формировать мироощущение «другого», особого, славянского народа, владеющего многими европейскими языками. При этом Чуново, как более удаленное от центра и расположенное уже на самой границе с Венгрией, отличается большей сохранностью традиции.

\section{ПРИМЕЧАНИЯ}

1 От хорватов также можно слышать венгерское название этого поселения Orosvar (Rosvar), реже - немецкое Karlsburg.

2 См.: Плотникова A. А. Славянские островные ареалы: архаика и инновации. М., 2016. С. 114-168; Плотникова А. А. Этнолингвистическое обследование градищанских хорватов Венгрии // Славянский альманах. 2017. Вып. 3-4. С. 408-421.

3 Эти три поселения были обследованы В. Важным после Первой мировой войны и описаны в обширной монографии, включающей описание особенностей диалекта, а также словарик диалектных слов, см.: Vážný V. Čakavské nářéčí v slovenském Podunají. Bratislava, 1923. В монографии отмечаются и отдельные схождения языка этих сел с говором села Хорватский Гроб.

4 В этом участники экспедиции смогли убедиться лично, когда услышали из уст пожилой венгерки, вышедшей замуж в Хорватский Гроб из местечка Подунайске Бискупице (с другой стороны Дуная от территории Русовцев, Чунова и Яровцев), уверенное утверждение о том, что в Русовцах проживают хорваты и что именно там с ними можно поговорить по-хорватски. Ср. также карту хорватских сел Г. Невекловского (Neweklowsky $G$. Die Kroatischen Dialekte des Burgenlandes und der angrenzanden Gebiete. Wien, 1978. S. 347), включающую Русовцы. На карте можно видеть и соседние села Kitsee и Pama на территории Австрии, которые часто упоминают в своих рассказах жители Яровцев.

5 Примечательно, что язык, на котором говорили информанты, ими самими характеризовался как «хорватанка», т. е. смесь градищанскохорватского (кайкавского, по мнению самих жителей) и словацкого. Одна из собеседниц - Анна Галович (1964 г. р.) - сразу призналась, что выучила литературный хорватский язык, чтобы чувствовать себя уверенно в общении с носителями хорватского языка на любой территории.

6 Ср., например, в: Фасмер М. Этимологический словарь русского языка. М., 1973. Т. 4. С. 327.

7 Подробности о привязанном комаре или о том, что его напоминало окружающим, отсутствуют. Возможно, такое «воспоминание» - лишь вымысел, хотя подобную фразу о привязанном когда-то 
к костелу комаре можно сегодня услышать и в Чунове, и в Яровцах. То же фиксировали и ученые из Загреба (Институт народного искусства, собиратель - М. Бошкович-Стулли), проводившие экспедицию в 1966 г. и передавшие копии своих записей местным жителям: «Про чуновцев говорят, что у них комар к куполу привязан. Но его никто никогда не видел». И. Маас, один из авторов двух томов краеведческой книги о селе Чуново (Maász J., Mallinerits $J$. Čunovo. Naše selo i naša obec. Bratislava, 2012. T. 1; Maász J., Miletić Š. Čunovo. Bratislava, 2017. T. 2), любезно предоставил нам часть копий из этого «Архива народных рассказов», хранящихся в Чунове и касающихся некоторых интересующих нас подробностей, в частности из народной демонологии («Вила», «Босорка» и др.). Речь идет о листках с текстами, которые транскрибированы собирателями и затем напечатаны на машинке. К сожалению, эти тексты не совсем точно передают особенности местного диалекта (о чем прежде всего сожалеет сам И. Маас), поскольку целью фольклористов было собрать сами былички, легенды и другие типы народной прозы хорватов в словацком анклаве. Примечательно, что материал, собиравшийся загребскими учеными более 50 лет назад, записан в тех же двух селах данного региона - Яровцах и Чунове.

8 Ср. описание словацких обрядовых действий и обрядовых реалий в книге: Валенцова M. M. Народный календарь чехов и словаков. Этнолингвистический аспект. М., 2016.

9 Etnološki atlas Jugoslavije. Karte s mapama. Zagreb, 1989. Sv. 1.

10 Именно этот обход имеет прямые соответствия у словаков, см.: Валенцова М.М. Народный календарь... С. 131.

11 Ср. также вариации благопожелания в: Maász J., Mallinerits J. Čunovo... T. 1. S. 47; Janković R. Ljeto... S. 251.

12 Германизм, производный от нем. frisch und gesund «свежий и здоровый», cp. Jankovič R. Ljeto... S. 251.

13 По словам молодых матерей из Чунова, в настоящее время мальчики 12-14 лет, совершая этот ритуальный обход, зарабатывают до 70 евро каждый, поэтому ждут этого дня каждый год с нетерпением: запасаются вербовыми ветками, плетут кнуты.

14 В Яровцах с целью сохранения хорватской традиции выпущены книга Р. Янковича на хорватском языке с выборочным переводом текста на словацкий (Jankovič $R$. Ljeto va jačka Hrvatskoga Jandrofa $=$ Rok v piesňach Jaroviec. [Bratislava], 2017) и CD-диск с часовым фильмом (Nemeth $D$. Naše selo. 2014) о хорватском календарном годе в селе.

15 В Яровцах для его именования используют германизм - Majpem.

16 Maász J., Mallinerits J. Čunovo... T. 1. S. 69. 
17 Ср. также сведения из небольшого раздела об обычаях хорватов в Яровцах в источнике на словацком языке: Hradsky J., Mallinerits J. Jarovce. Villa Ban. Bratislava, 2008. S. 203.

18 См.: Maász J., Mallinerits J. Čunovo... T. 1. S. 70.

19 Ср. то же предписание «громко топать» во время масленичных танцев в Хорватском Жидане (Венгрия) с мотивировкой: «чтобы вытоптать сорняки в поле».

20 Любопытно, что в селе Хорватский Гроб вербовые ветки на Вербное воскресенье имеют наименование cicke, в Бургенланде нами не встреченное.

21 Нельзя не упомянуть и архаический запрет улыбаться при виде лягушки, иначе она «пересчитает тебе зубы», что приведет к их выпадению (Яровцы, Чуново), ср. аналогичное боснийское поверье, подробнее об опасном действии счета и измерения см. в: Толстая С. М. Счет // Славянские древности: этнолингвистический словарь / Под общ. ред. Н. И. Толстого. М., 2012. Т. 5. С. 218.

22 Гура А. В. Брак и свадьба в славянской народной культуре: семантика и символика. М., 2012. С. 786.

$23 \mathrm{Cp}$. подобные лингвистические высказывания градищанских хорватов о своей лексике свадьбы в книге: Плотникова $A$. $A$. Славянские островные ареалы... С. 133.

24 Села Хорватский Жидан, Присика, подробнее см.: Плотникова А. А. Этнолингвистическое обследование... С. 410.

25 См.: Плотникова А. А. Славянские островные ареалы... С. 132.

26 Там же. С. 155-156.

27 Эти и другие этнографические предметы выставлены в краеведческом музее - старом доме И. Мааса, по которому он сам с большим удовольствием проводит экскурсии. Ср. подобную ситуацию в с. Присика (Венгрия), где из своего старого дома И. Думович сделал местный музей и библиотеку (подробнее в: Плотникова А. А. Этнолингвистическое обследование... С. 419).

28 Можно услышать мнение о том, что viška - это старое название ведьмы, тогда как bosorka - новое (Чуново). Вместе с тем отметим, что заимствование глубоко укоренилось у «водных хорватов», поскольку здесь многочисленны дериваты: bosorkovati 'колдовать', zabosorkariti 'заколдовать; нанести порчу’ и под. Наряду с: viškariti ‘колдовать’ (ona zna viškarit - «она умеет наводить и снимать порчу») (Чуново). В Яровцах же термин stara viška уже часто используется только как ругательство.

29 Здесь и далее даются номера учетной карточки текста из «Архива народных рассказов», см. примечание 7. 
30 Lančeni most букв. 'Цепной мост'; речь идет о Цепном мосте Сеченьи в Будапеште (венг. Széchenyi lánchíd), построенном в 1849 г.

31 Ср., например: Левкиевская E. E. Вихрь // Славянские древности: этнолингвистический словарь / Под общ. ред. Н. И. Толстого. М., 1995. T. 1. C. $379-380$.

32 Отметим также, что многие термины из сферы похоронной обрядности отмечаются также у словенцев Прекмурья и Порабья, как показали полевые исследования Г. П. Пилипенко, М. В. Ясинской, А. В. Гуры, проведенные в 2018 г., см.: Пилипенко Г. П., Ясинская М. В. Язык и культура словенцев в Прекмурье и Порабье // Славяноведение. 2018. № 6 (в печати).

\author{
A. A. Plotnikova \\ "Water Croats" and the specifics of their tradition: \\ A review of an ethnolinguistic expedition
}

Croatian villages of the southmost district of Bratislava are studied. Due to similar historical circumstances, these villages shape a single unit. This small territory on the cross-border of Austria, Hungary, and Slovakia was accessed to Czechoslovakia only after WWII, that preserved in good state the Croatian tradition in the $20^{\text {th }}$ century in the genetically non-related Hungarian milieu. The article covers features of their folk calender, family rites, and folk mythology, common for all Burgenland's Croats (in Austria, Hungary, and Slovakia), parallel to those that can be found in Croatia proper. It also covers borrowings from neighboring languages and traditions of Austrian-Hungarian space and from Slovakia, within the borders of which the Croatian enclaves under scrutiny are located.

Keywords: Burgenland's Croats in Slovakia, folk calendar, folk mythology, archaic areas, multilingualism. 


\title{
Символика деревьев в традиционной культуре славян: липа
}

\begin{abstract}
Статья посвящена символике и ритуальным функциям липы в традиционной культуре славянских народов. С одной стороны, липа выполняет ряд культовых функций и считается священным деревом, а с другой - символизирует слабость и недолговечность. Ключевые слова: символика, дерево, липа, функиии, культ, фольклор.
\end{abstract}

DOI: $10.31168 / 2073-5731.2018 .3-4.5 .02$

Липа - род деревьев и крупных кустарников (Tilia), произрастающих на территории всех стран Славии. О липе имеются главки в сводных трудах по славянской этноботанике П. Соботки, К. Мошиньского, В. Чайкановича и др.; из специальных работ укажем на известную статью Б. Шулека, посвященную почитанию липы в Южной Славии, заметку о лексемах с корнем лип- в русских диалектах, а также на статью М. Малохи о символике липы и калины ${ }^{1}$.

Предлагаемая ниже «портретная зарисовка» одного из символов славянского фольклорного «дендрария» не является его исчерпывающим описанием, а предполагает изучение доминирующих особенностей липы, комбинация которых и создает неповторимый образ именно данного, конкретного дерева. При исследовании славянских дендрообразов мы исходим из того, что символический «портрет» дерева является, с одной стороны, культурной проекцией его реальных ботанических свойств, а с другой - результатом взаимодействия разных дендросимволов в рамках всего этнокультурного дискурса.

Наряду с дубом липа чаще других деревьев выполняла культовые функции и считалась святым деревом, особенно у южных славян. Большие старые липы сажали вблизи церквей, монастырей и мечетей, или же, наоборот, там, где росли старые липы, ставили церкви или кресты. Б. Шулек обратил внимание на то, что, когда вблизи какой-нибудь церкви не росли старые липы, эта церковь оказывалась новой. О старой чудотворной липе (которая некогда росла в Славонии, близ Черника), называвшейся Kažotićeva lipa, упоминается в Житии епископа Августина (начало XIV в.). Под такими старыми деревьями устраивали суды, проводили праздники и собрания жителей; там 
останавливался крестный ход во время религиозных процессий, двигавшихся по полям, там читали Евангелие и организовывали трапезы; под старыми липами люди собирались перед богослужениями и т. д. ${ }^{2}$

Традиции общественных собраний, проводившихся под липами, сохранялись в Южной Славии до самого последнего времени. У болгар в окрестностях Ловеча (с. Голец) под вековой липой, которая росла на поле, на Вознесение еще не так давно совершали жертвоприношения ${ }^{3}$. В западной Македонии (Железник) липа и водный источник под ней, находившиеся около местного монастыря св. Афанасия, были местом совершения лечебных ритуалов ${ }^{4}$. У словенцев Лютомера старая ветвистая липа в центре села служила местом традиционного сбора парней, отмечавших свой праздник в день св. Флориана (4.V): здесь разводили костры, отсюда же начинался обход села, во время которого парни разносили по домам «новый» огонь, зажженный с помощью священного дерева, и домочадцы таким образом обновляли огонь у себя в очагах ${ }^{5}$ Вообще традиция извлекать «живой» огонь с помощью древесины липы была широко известна южным славянам, а сам этот огонь использовался в профилактических и лечебных целях ${ }^{6}$.

Согласно известию XVII в., оставленному неким духовным лицом, посетившим окрестности Пожеги в Славонии в 1629-1630 гг, к почитаемой в этих местах святой липе и мусульмане и христиане приходили на первой неделе девятого месяца года; они приносили дары и свечи и священник служил молебен. Эту липу считали чудотворной, к ней обращались с просьбами, целовали дерево и кланялись ему как святыне, веря, что она поможет тем, кто приносил ей жертвы и давал обеты ${ }^{7}$. К. Мошиньский увидел в дате, к которой был приурочен обычай (первая неделя девятого месяца), указание на канун празднования Рождества Богородицы (отмечаемого 8/21 сентября), что, по его мнению, объясняет тот факт, что в фольклорной традиции липа оказалась связана именно с культом Богородицы. В доказательство такой связи он указал на то, что, например, в Лукувском повете (ныне Мазовецкое воеводство) местные жители именно потому считали липу святым деревом, поскольку в ней якобы живет Богородица. В подтверждение этому обычно рассказывали предание о бедной падчерице, которой мачеха позволяла носить лишь свиной кожух; падчерица молилась о помощи под липой; в ответ на ее молитвы из дерева вышла Богородица и, сжалившись, отдала падчерице свою одежду ${ }^{8}$.

Культовые функции липы нашли применение и в семейных обрядах. В Герцеговине венчание в прошлом заключалось в троекратном обходе места, где совершалось богомолье, во время которого над го- 
ловой молодоженов держали липовую ветвь 9 . В Боснии и некоторых других местах липы сажали на кладбищах ${ }^{10}$.

Почитание липы и ее участие в культовых практиках известны также в других регионах Славии. В Польше каплички (вырезанные из дерева часовенки с фигурками святых) часто располагали в тени липовых деревьев или вешали на них ${ }^{11}$. На липе могли «являться» чудотворные иконы ${ }^{12}$, ср. рус. диал. липопоклонник «человек, входящий в особую [какую?] религиозную секту. Липопоклонники совершали возлияние богу пивом. Нижегор.» ${ }^{13}$.

Как и многие другие деревья, липа играла важную роль в народной медицине (что имеет и вполне объективные основания: напомним хотя бы о потогонных свойствах липового цвета). Примечательно, однако, что в ряде целебных ритуалов липа выступала скорее как субъект, к которому обращались за помощью, нежели как объект, на который символически переносили болезни. В Боснии (Баня-Лука) человек, страдавший от туберкулеза, должен был в течение 40 дней ходить по утрам под липу, и считалось, что за это время он выздоровеет $^{14}$. На западе Витебщины (Шарковщинский р-н) местные жители рассказывали о так называемой Святой липе - дереве, к которому в день св. Юрия (23 апреля / 6 мая) совершали крестный ход от местной церкви и у которого оставляли «жертвы» (деньги, овечью шерсть и др.); к этому же дереву ходили в случае болезни ${ }^{15}$. В Полесье вокруг липы обносили больных детей и просили избавить их от бессонницы, а женщины, желая излечиться от бесплодия, сами обходили вокруг старой липы (подобно тому как это же делали вокруг дуба) ${ }^{16}$.

В качестве культового дерева липа фигурирует и в восточнославянских заговорах. В частности, в белорусских заговорах от укуса змеи липа расположена в мифологическом центре и на ней живет старшая змея, своего рода царица змей, к которой обращаются с призывом «унять» змей, чтобы спасти человека от укуса. Примечательно, что в единичных случаях липа (подобно дубу) получает в этом контексте имя собственное, выделяющее ее из ряда других деревьев: «У поли за полем стоиць липа Матруна, у той липи Матруни болное <так!> гняздо, у том гняздзе зьмея Шкуропея, зьмея Палагея, зьмея Кацярина - дзяцей породзила, на сьвет пусьцила... Унимай-ка ты своих дзяцей...» ${ }^{17}$.

Липа часто упоминается в народной версии христианской истори и и является «действующим лицом» легенд и преданий. Вопервых, она выступает защитницей Святого семейства и спасает его во время бегства в Египет, укрывая своими ветвями; именно поэтому якобы «piorun nigdy w lipę nie uderzy» [молния никогда не ударит в 
нее] (поляки обл. Мазовше) ${ }^{18}$. Лемки считали, что дома на Русальной неделе украшали липой именно потому, что липа спрятала Богородицу ${ }^{19}$. Во-вторых, липа принимает косвенное участие в крестных муках Христа. Словенские легенды рассказывают, что крест Распятия был сделан из липы, что, впрочем, не помешало этому дереву сохранить позитивное к себе отношение, поскольку Богородица нашла под ней пристанище во время своего бегства ${ }^{20}$. И наконец, в легендах третьей группы (у поляков, словаков, белорусов) именно липа чаще других деревьев и кустарников связывалась с местами чудесного явления Богородицы и святых. В преданиях и легендах Богородица появляется, живет или отдыхает на липе, когда сходит с небес на землю ${ }^{21}$, и именно она наказывает человека, причинившего вред этому дереву ${ }^{22}$.

В сюжетах легенд и преданий липа сополагается с другими природными объектами, имеющими высокий статус. Прежде всего это относится к пчеле, которая воспринимается у славян как божья тварь ${ }^{23}$, хотя соотнесенность липы с пчелой имеет вполне рациональное объяснение, поскольку во многих регионах липа является едва ли не основным медоносом. Белорусы Гродненщины считали, что, осаживая рой, надо сначала протереть улей липовыми веточками, а затем свить из них венок и положить на дно улья, чтобы и пчелы вились ${ }^{24}$. У кашубов засвидетельствован обычай сажать липы около придорожных крестов с распятием, чтобы пчелы собирались и своим жужжанием славили Бога ${ }^{25}$. Примечательна чешская легенда, которая связывает липу, пчелу и сюжет о бегстве в Египет. Согласно легенде, во время этого путешествия Святое семейство сопровождали рои пчел, чтобы защитить их от солдат Ирода. Пчелы, безусловно, погибли бы, так как в пустыне, по которой они бежали, не было никакой цветущей зелени. Однако Христос позаботился об их пропитании, и в пустыне неожиданно выросла липа и появился колодец. Люди освежились водой, а пчелы подкрепились липовым нектаром. На обратном пути пчелы встретили солдат Ирода и сильно покусали их ${ }^{26}$.

В фольклоре и верованиях липа предстает преимущественно как «свя тое», «доброе» и в целом дружелюбное по отношению к человеку дерево, с ярко выраженными охранительными и патронажными функциями. И прежде всего эта черта ее образа отразилась в обыкновении сажать липы вблизи жилища, поэтому, в частности, сербы, живущие в Хорватии, называли липу чуваркућа, т. е. «хранитель дома» ${ }^{27}$; боснийцы полагали, что хорошо спать под липой ${ }^{28}$; словенцы в общине Водице (Средняя Словения) сажали липу около дома при рождении в семье первенца ${ }^{29}$ и т. д. 
Почти повсеместно считалось, что в липу не бьет молния, и тем не менее в Словении липы, растущие около церквей, служили своего рода громоотводами. Объясняли это тем, что некогда липа якобы попросила Бога, чтобы он направлял молнии в нее, а не в церкви, которые строили рядом с ней; поэтому липу называли охранительницей церквей и находящихся в ней людей. Эта способность липы, а также ее иные полезные свойства (целебная сила, медоносность, мягкость древесины и т. д.) рассматривались словенцами как результат ее благословения свыше. Известны легенды, в которых в ответ на готовность липы служить громоотводом для церкви Бог награждает липу всеми названными качествами, а также морозостойкостью, способностью быстро восстанавливаться после попадания в нее молнии и мн. др. ${ }^{30}$

Согласно историческим преданиям, несправедливо осужденный или оклеветанный человек, желая доказать, что был невиновен, сажал где-нибудь в землю липу вверх корнями и вниз ветвями; в доказательство его невиновности липа пускала ветви и листья прямо из своих корней. Подобные липы якобы имелись в Чехии, Моравии и Германии еще в конце XIX в. ${ }^{31}$

Липа занимала заметное место в календарных обрядах поздней весны и начала лета. Венками из липовых веток, освященных в праздник Божьего Тела, отмечаемый в 9-й четверг после Пасхи, окуривали коров для охраны от ведьм; парни втыкали веточки в свои головные уборы; ветками липы «маили» (украшали) дома, хозяйственные постройки, поля, посевы и даже могильные памятники и кресты в канун летнего Иванова дня, Троицы, праздника Божьего Тела, их же втыкали в окна и двери домов и т. д. Эти обычаи были известны практически повсеместно, и потому они едва ли могут быть сведены к какому-то одному толкованию. Во всяком случае в отношении использования липы в этих обрядах таких толкований, пусть даже поверхностных, имеется несколько.

Традицию украшения домов липой связывали с представлением о ней как «святом» дереве. Мораване, например, в форме липового листа усматривали язычок пламени, в виде которого Дух Святой снизошел на апостолов ${ }^{32}$. А словенцы Каринтии украшали дома липовыми ветками для того якобы, чтобы на них в Духов день сошел Святой Дух, поскольку верили, что Святой Дух спускается именно на липовые ветки, реже - на березовые ${ }^{33}$.

Практике «озеленения» культурного пространства в эти праздники, в том числе липой, приписывали магический смысл. В Полесье, например, застилание полов липовыми ветками объяснялась тем, что 
таким образом люди оберегались от русалок: «Цэ на Зэлэну недиэлю. Кажуть, ў чэтвэр чы ў пьятницу русалки. Липу застромлювали, лэпэху брасали на пол, шоб русалки нэ хадили» ${ }^{34}$.

Еще одно толкование этого обычая связывает его с поминальным культом и функцией дерева как медиатора. В окрестностях Ловеча (Болгария) на Троицу, когда души провожали на тот свет, женщины приносили в церковь липовые ветви, устилали ими пол и становились на колени; после освящения ветвей их относили на могилы родных и помещали «над устата», т. е. над головами умерших, чтобы тем самым очистить их души ${ }^{35}$. Аналогичные обряды совершались и в других местах Болгарии, обычно с использованием зелени грецкого ореха.

В контексте сказанного о липе как дереве культовом и одновременно сопричастном священной истории, естественным выглядит з а прет причинять вред почитаемым липам, прежде всего рубить их. У жителей Боснии запрет как раз тем и объясняли, что «липа је свето дрво и је грјехота посјећи је» [липа святое дерево и его грех рубить $]^{36}$. М. Филипович в публикации, посвященной северовосточной Боснии, привел аналогичные сведения о почитании липы у местных сербов: «Старики-сербы, - писал он, - говорили, что липа святое дерево, и липовые стволы берегли больше любого другого дерева. Они не использовали липу как строительный материал, не допускали, чтобы кто-то липу портил и касался дерева. Потому что, если бы кто-нибудь срубил липу, у него бы умер ребенок, отсохла рука и т. д. Липы сажали у церквей, на могилах и в тех местах, где служили молебны, т. е. в общественных местах. Она обязательно должна была там быть. Перед домом липу не сажали, чтобы не срубать, а срубали, только если находили в лесу; приносили из леса молодые липы и сажали их ради липового цвета - для лекарственного чая, для пчел и т. д. Один дед рассказывал, что он плел веревки из липового лыка, правда, лыко он воровал, и подобно тому, как высыхали липы, лишенные лыка, так и он высыхал (tako se i on sušio) и болел в течение долгого времени на старости лет» ${ }^{37}$.

Поляки называли старые липы «святыми»: срубивший такое дерево должен был ожидать скорой смерти в своей семье. При этом ссылались, в частности, на историю о человеке, поплатившемся жизнью жены за то, что в 1897 г. срубил липу, стоявшую не один век ${ }^{38}$. В Силезских Бескидах бытовали рассказы о липах, «кровоточивших» от удара топора ${ }^{39}$. Среди свидетельств из Тенишевского архива в интересующем нас аспекте выделяется предание о липе, называвшейся «Исколена» (Троицк Пензенской губ.), которая якобы выросла из колена девушки, убитой прохожим, 
который хотел надругаться над ней; липа, простоявшая на вершине горы долгое время и пользовавшаяся почитанием местных жителей, вызывала недовольство местного священника, который попытался срубить ее, но был ослеплен брызнувшей из дерева кровью ${ }^{40}$.

Высокий статус липы и ее связь с комплексом положительных значений определили ее использование в качестве апотропея. В поверьях и быличках восточных и западных славян липа фигурирует в качестве средства, оберегающего от ведьм, водяных и некоторых других демонов. В таком качестве использовались обычно ветки и даже специальные предметы из липы: у восточных славян (особенно у русских) это были «голые», обструганные ветки липы («лутошки»), а у западных - веревки и другие предметы, сплетенные из липового лыка. Заметим в скобках, что мотив «голой», т. е. ободранной, обструганной, ветки липы широко представлен в языке, но уже в метафорических значениях, ср. рус. гол как липа, ободрать как липку, т. е. обобрать кого-л. ${ }^{41}$

В Белоруссии, когда жених с невестой шли к венцу и были более всего уязвимы для сглаза и порчи, самым действенным средством их защиты считался поясок из липового лыка, которым они опоясывались по голому телу ${ }^{42}$. В пермских быличках о вещице/векшице или колдунье оберегом от нее и одновременно средством вернуть ей изначальный облик (после того как она «обернулась» в кого-то) считался удар наотмашь липовой палкой или «лутошкой»: «Есть колдуньи. Овечек стригут, коров доят. Свинья по дороге шла. Ее липовой палкой били, колдунья оказалась. Липовую не любят - боятся» ${ }^{43}$. В Нижегородском Поволжье ударами липовых «лутошин» и липовой палки прогоняли чужого домового, который мучил скотину и домашнюю птицу4 ${ }^{44}$

«Лутошками» оберегались от визитов покойников, являющихся живым. В Пермском крае голые липовые ветки, внесенные в избу, положенные на постель или воткнутые вокруг дома, предохраняли человека от тоски по умершим мужу или жене, а также и от визитов «ходячего» покойника ${ }^{45}$; от той же напасти избу «объезжали», сидя верхом на липовой палке ${ }^{46}$; на Тамбовщине, чтобы уберечь женщину от огненного змея, в окна и двери домов втыкали крестики, сделанные из голых «лутошек» ${ }^{47}$. Русские обставляли липовыми крестиками постель человека, мучимого наваждениями; во время выпаса скота липовую ветку втыкали посредине пастбища, чтобы коровы не разбредались и их не трогали звери в лесу ${ }^{48}$.

По наблюдениям К. Мошиньского, надежным средством для обезвреживания вампиров, водяных и других демонов, были липовое лыко, 
узда из липового лыка и липовый кий ${ }^{49}$. Рассказы о подобных случаях занимают заметное место в западнославянском мифологическом дискурсе. В Ивониче (ныне Подкарпатское воеводство, Польша) записана быличка о том, как однажды мельник прибег к помощи дьявола при строительстве церкви, однако когда позже он попытался избавиться от дьявола, последний разрушил мельницу; на помощь мельнику пришла местная бабка, которой удалось с помощью куска липы загнать дьявола в пустую корчму и привязать там ${ }^{50}$. Чехи полагали, что перевяслом из липового лыка можно поймать и связать «водника» (водяного) ${ }^{51}$.

Липа наряду с березой (что неслучайно, учитывая позитивный ореол того и другого дерева, представление о них как о «добрых» деревьях) является главным персонажем этиологических легенд о происхождении медведя из человека. В легендах на сюжет ATU 555 «Рыбак и его жена» (то же: СУС 555 «Коток золотой лобок (золотая рыбка, чудесное дерево)») липа выступает в качестве чудесного дерева, в роли судьи или Бога, исполняет желания старика и старухи, но в итоге наказывает их за жадность ${ }^{52}$. В севернорусской сказке «От чего пошли медведи» мужик, который пытался срубить в лесу липу, был остановлен ее голосом; липа просила не рубить ее, а взамен обещала выполнить любое его желание; по указу своей вздорной и тщеславной жены он вытребовал у нее богатство, но когда попросил сделать так, чтобы их еще и все боялись, липа превратила его с женой в медведей ${ }^{53}$. В сербской фольклорной традиции известны легенды о том, почему раньше деревья ходили и разговаривали, а теперь не делают этого. Сюжет в них развивается следующим образом: ленивая баба, придя в лес за дровами, просит дерево пойти за ней домой; дерево вытаскивает корни из земли и отправляется следом за ней, но по пути она начинает требовать, чтобы дерево везло ее на себе; дерево осуждает неблагодарную бабу, и с тех пор не дерево носит человека, а человек носит дрова у себя на спине ${ }^{54}$.

А. В. Гура, отметив, что этиологическая сказка-легенда является частью более широкого корпуса текстов о происхождении медведя от человека (в том числе не имеющих никакого отношения к деревьям), обратил внимание на то, что связь медведя и липы вычитывается и из других фольклорных сюжетов: сказки «Медведь на липовой ноге» (СУС 160А), а также польских шуточных песен о священнике-медведе на липовом мосту, к которому дикие животные приходят на исповедь 55 .

Древесину липы отличает особая мягкость, легкость в обработке, поэтому в быту из нее изготавливали предметы домашней утвари, церковного обихода, а также использовали в строительстве (из 
нее делали алтари, скульптурные изображения святых, ульи, столы, посуду и мн. др.); из липового лыка плели обувь, а также сита и решета. Простота обработки липовой древесины отразилась в фольклоре, в частности русском, где упоминается большое количество предметов из липы: это липовая плаха (в былинах «Михайло Данилович», «Алеша Попович и сестра Петровичей»), липовые жребии, которые герои кидают в воду, чтобы выбрать свою судьбу (былины «Наезд литовцев», «Садко» и др.), липовая петля (былины «Соломан и Василий Окульевич», «Неудавшаяся женитьба Алеши Поповича»), липовая балка, липовый мост и т. д.

Мягкость и податливость древесины липы была переосмыслена в разных жанрах славянского фольклора, причем, в отличие от бытовой практики, где это свойство липы оценивалось позитивно и оказалось широко востребовано, в фольклоре эпитет липов вы й получал значение 'недолговечный, слабый, бедный'. Это значение заметно, например, в русской лирике, где «липовый дом» - дом бедняка-горюна: «Иван молодой, не качай головой, / Не качай головой, мне не быть за тобой <.. > / У Ивана горюна ни скота, ни живота; / Одна липова изба, решощаты ворота» ${ }^{56}$, см. в пословице, иронизирующей над бедностью: «Богат стал: вместо лаковых сапог обул липовые» ${ }^{57}$. Образ «заиндевелой липы» (в подблюдных песнях) стал символом безбрачия: «Стоит липа на крутой горы, ды макушки с корня ўся за-

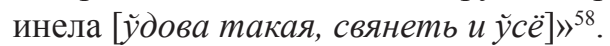

Но более всего такие значения характерны для боснийских и хорватских колядок. В северо-восточной Боснии колядники, которых хозяева не одарили как следует, произносили пожелание-проклятие: «Ova vrata lipova, do godine nikoga» [Эти двери липовые, через год — никого] — желая тем самым, чтобы за грядущий год волки, которые смогли бы проникнуть в дом через слабые «липовые» двери, сожрали домочадцев ${ }^{59}$. В боснийском и хорватском фольклоре широко известен также образ липового дома (липова кућа), связываемый с мотивами запустения и смерти, см. варианты проклятий участников обходных обрядов, которым хозяева отказали в угощении, с использованием этого образа: «Ова кућа липова, у њој нема никога, не било га никада» ${ }^{60}$; «Ова кућа липова, у њој њема никога, мртвим коцем затворена» - ответ обходников-«чароиц» хозяевам, которые ничем их не одарили или одарили плохо ${ }^{61}$. Б. Сикимич усмотрела в таких мотивах отражение представлений о липе как бесплодном дереве ${ }^{62}$.

Тот факт, что в фольклоре эпитет липовый получал значение 'недолговечный, слабый, бедный', может быть одновременно поставлен в связь со вторым словарным значением сущ. липа — 'о чем-то поддель- 
ном, фальшивом' (с пометой «простореч.») и прил. липовый 'поддельный, фальшивый', с той же пометой ${ }^{63}$. В обоих случаях упоминается, что эти слова относятся преимущественно к документам. Словарь Ушакова расширяет узус этих слов, приводя значения 'ненастоящий, мнимый, плохой', с пометой «простореч. вульг., из воровского арго» ${ }^{64}$. И действительно, в лексике арго (воровской, шулерской, торговой) обнаруживается немало выражений с прилагательным «липовый»: липовый глаз 'поддельный паспорт' ${ }^{65}$; липовая сара 'фальшивые деньги', липовые очки 'поддельный паспорт',66, липовик 'тот, кто занимается сбытом фальшивых кредитных билетов ${ }^{97}$ и т. д., ср. укр. липу справляти 'обманывать, подделывать (как правило, документы') ${ }^{68}$; пол. lipny ‘фальшивый’. Диалекты практически ничего не добавляют к этим значениям выражений с прилагательным липовый, тем не менее укажем на рус. рязан. липовый гриб 'гриб, похожий на белый; горький, ядовитый гриб' 69 .

Как отмечают авторы современного словаря русского арго, на рубеже XIX-XX вв., во время интенсивного заимствования германизмов, вместо русских лексем липовый, липковый стали активно употребляться соответствующие заимствования из немецкого типа линковый; они же обращают внимание, что в современном арго активно используются лексемы с корнем лип- типа липовать 'лгать', 'бояться' и т. д. ${ }^{70}$

Можно предположить, что формирование значений 'фальшивый', 'поддельный', ‘ненастоящий’ у восточнославянских лексем с корнем лип- могло учитывать в том числе фольклорные контексты, где, как мы показываем, липа иногда ведет себя как «ненастоящее», мягкое и податливое дерево.

Некоторое время назад в рамках проекта, посвященного расшифровке надписей-граффити из Новгородского Софийского с об ора, исследователями была заново прочитана надпись № 199, фактически представляющая собой заклинательный текст. Вот вариант ее последнего прочтения:

Голоде-железньчь, камАн[е]и пьрьси, медАнаА голова, лип(о)ва челюсть, зоуб[е] ахидьне.

Вороже, бесе, сотона, тать, м[ы]тарь, Июдо безаконьна^! 
Оу, л<ю> $>$ т]е Дан(и)ле, б[р]атие!

Аминъ.

Перевод: 'Голод-Железнец, каменная грудь, медная голова, липовая челюсть, зубы ехиднины. Враг, бес, сатана! Грабитель, мытарь! Иуда беззаконный! О, горе Даниле, братья! Аминь'. Публикаторы этого прочтения констатируют двучастную композицию текста, в первой части которого, по их мнению, «предстает гротескный образ Голода, персонифицированного в виде истукана» ${ }^{71}$.

Нам уже приходилось писать о подобных образах, которые мы называем образами гетерогенного тела (тела, разные части которого как бы сделаны из разных веществ и материалов): в данном случае у персонажа «каменная грудь, медная голова, липовая челюсть, зубы ехиднины». Подобные «агрегатные» персонажи и образы встречаются в фольклоре разных традиций, причем очень часто именно в магических текстах. Появление таких образов в заговорах связано с принципиальной установкой текста на переделку действительности в соответствии с целями субъекта (магической практики). Моделирование таких «гетерогенных» и агрегатных объектов - это способ придать адресату заговора искомые качества (слабость или силу), «собрав», сложив, сконструировав персонаж с требуемым набором характеристик и свойств ${ }^{72}$.

Наши наблюдения, касающиеся подобных фольклорных образов в магическом фольклоре, подтверждаются и при рассмотрении надписи из Софии Новгородской. Известно, что «голоду» (как массовому бедствию и вообще злой силе) в языке часто приписывается такое действие, как «пожирать», ср., например: «Вне дома меч, а в доме мор и голод. Кто в поле, тот умрет от меча; а кто в городе, того пожрут голод и моровая язва» (Иез. 7: 15). Именно связь голода с мотивами пожирания и образами рта и пасти объясняет, на наш взгляд, тот факт, что в надписи из Софии Новгородской персонажу, называемому «Голод-железнец», приписывается «липовая челюсть», заведомо слабая, мягкая и потому наименее опасная для всех, кого она может коснуться.

В восточнославянском фольклоре аналогичные образы («липовых» частей тела) крайне редки и встречаются только в заговорах от укуса змеи. Цель таких заговоров - избавить человека от вреда и боли при укусе. О змее в заговорах говорится, что у нее «липовый зуб»: это должно сделать ее укус безболезненным для человека, а сам зуб легко горючим. См. фрагмент заговора от укуса: «Под межой гад, у гада липовый зуб; липовый зуб, не берись за белое тело, а берись за огонь» ${ }^{73}$, ср. в другом заговоре: «Катится, валится гнилая колода $<$ т. е. змея>; на той колоде сидят 
красных две девицы. “Вот, - говорят, — как тому гаду ярость унять?” Пусть будет <ярость, т. е. яд, воспаление, боль от укуса > мягкая, как липовый лист $\rangle^{74}$. Мотив мягкости/безвредности в связи с липой встречается также в заговорах и рукописных молитвах, призванных защитить имярека от ушиба или удара упавшим деревом: «...и сколь лехко падет липовый лист на землю, и столь бы лехко пало на меня, раба Божия имярек, вяз и всякое древо от человеческого помаху» ${ }^{75}$.

Мы, разумеется, осознаем, насколько рискованно проводить параллель между граффити XII в. и заговорами, в том числе записанными в начале века XX-го. Некоторым оправданием такой попытке может служить тот факт, что все эти тексты происходят с сопредельных территорий северо-запада - граффити из Новгорода, заговор от укуса змеи - из Псковской губ., заговор от ушиба деревом — из Олонецкой губ., при том что других «липовых» мотивов в фольклоре мы нигде больше пока не встретили.

$$
\text { * * * }
$$

Представленный здесь образ липы складывается как бы из двух составляющих: с одной стороны, липа - священное и доброжелательное по отношению к человеку дерево, с другой - слабое и мягкое, а потому также относительно безопасное для человека. В рамках славянского этнодендрария липа коррелирует с дубом как его первым деревом (особенно в качестве культового и сакрального дерева), а также с другими его «положительными» образами, такими как лещина и береза (преимущественно в легендарных сюжетах).

\section{ПРИМЕЧАНИЯ}

1 Sobotka $P$. Rostlinstvo a jeho význam v národních písních, pověstech, bájích, obřadech a pověrách slovanských. Praha, 1879. S. 86-100; Moszyński K. Kultura ludowa Słowian. Warszawa, 1967. T. 2: Kultura duchowa. Cz. 1. S. 532-534; Чајкановић B. Речник српских народних веровања о биљкама. Београд, 1985. C. 164-168; Šuljek B. Zašto Slaveni poštuju lipu // Rad Jugoslavenskoj akademiji znanosti i umjetnosti. Zagreb, 1878. T. 43. S. 149-188; Этерлей E. Н. «С цветущих лип знакомый аромат...» // Русская речь. 1978. № 5. С. 108-113; Малоха М. Образ липы и калины в традиционной культуре и языке славян // Мова і культура / Язык и культура. Пятая международная конференция. Київ, 1997. Т. 4. С. 102-109.

2 Šuljek B. Zašto Slaveni poštuju lipu. S. 159-167; Franković M. Kult drveta u životu i običajima stanovništva sjeveroistočne Bosne // Zbornik ra- 
dova XXXIV kongresa Saveza udruženja folklorista Jugoslavije. Tuzla, 1987. S. 254; Vinšćak T. Vjerovanja o drveću u Hrvata u kontekstu slavističkih istraživanja. Jastrebarsko, 2002. S. 68-70.

3 Ловешки край. Материална и духовна култура. София, 1999. С. 314.

4 Крстева А. Народната медицина во Железник // Македонски фолклор. 1987. Год. ХХ. № 39-40. С. 120.

5 Kuret N. Praznično leto Slovencev. Starosvetne šege in navade od pomladi do zime. Celje, 1965. D. 1: Pomlad. S. 307.

6 Тројановић C. Ватра у обичајима и животу српског народа. Београд, 1930. С. 75, 79-81.

7 Moszyński K. Kultura ludowa Słowian. S. 533.

8 Ulanowska S. Boże Narodzenie u Górali, zwanych «Zagórzanami» // Wisła. 1888. T. 2. S. 292; вариант сказочных сюжетов о мачехе и падчерице, в частности, с аллюзиями к сюжету ATU/CУC 510B.

9 Чајкановић В. Речник... С. 167.

10 Franković M. Kult drveta... S. 254.

11 Grajnert J. Drzewa podaniowe // Tygodnik illustrowany. 1863. T. 8. № 220; Niebrzegowska S. Przestrach od przestrachu: Rośliny v ludowych przekazach ustnych. Lublin, 2000. S. 114.

12 Красностав Волынской обл. (Полесский архив Института славяноведения РАН).

13 Словарь русских народных говоров / Гл. ред. Ф. П. Филин. Л., 1981. T. 17. C. 57.

14 Лилек E. Вјерске старине из Босне и Херцеговине // Гласник Земаљског музеја Босне и Херцеговине у Сарајеву. Сарајево. 1894. Св. 6. C. 372 .

15 Полацкі этнаграфічны зборнік. Вып. 2: Народная проза беларусаў Падзвіння. Ч. 1 / уклад. У. А. Лобача. Наваполацк, 2011. № 598, 599.

16 Андреевка Черниговской обл. (Полесский архив...).

17 Романов Е.Р. Белорусский сборник. Витебск, 1891. Вып. 5. С. 185, № 106, Могилевский у.

18 Archiwum katedry etnologii i antropologii kulturowej Uniwersytetu Warszawskiego, $\mathrm{O} / 31$.

19 Reinfuss R. Śladami Łemków. Warszawa, 1990. S. 84.

20 Чајкановић B. Речник... С. 165, 166.

21 Moszyński K. Kultura ludowa Słowian. S. 529; Niebrzegowska S. Przestrach od przestrachu... S. 86.

22 Karwicka T. Zakazy związane z drzewami i motywujące je wierzenia // Etnografia Polska. Wrocław; Warszawa; Kraków; Gdańsk, 1973. T. 17. Z. 1. S. 132-133. 
23 Гура А. В. Символика животных в славянской народной традиции. М., 1997. С. 448.

24 Federowski M. Lud Białoruski na Rusi Litewskiej. Materały do etnografii słowiańskiej. Kraków, 1897. T. 1. № 2101.

25 Perszon J. Na Jastra Wielki Post i okres wielkanocny w wejherowskiem. Luzino, 1992. S. 58.

26 Koštál J. Rostlinstvo v podání prostonárodním. Velké Meziříčí, 1902. S. 289.

27 Vinšćak T. Vjerovanja o drveću... S. 71.

28 Филиповић M. Живот и обичаји народни у Височкој Нахији // Српски етнографски зборник. Београд, 1949. Књ. 61. С. 200.

29 Vinšćak T. Vjerovanja o drveću... S. 71.

30 Rasla je jelka do neba. Zgodbe iz našega ljudskega herbarija / Ur. Z. Šmitek, M. Kropej, R. Dapit. Radovljica, 2012. S. 42-43.

31 Sobotka P. Rostlinstvo a jeho význam... S. 97.

32 Húsek J. Hranice mezi zemí Moravsko-slezskou a Slovenskem: Studie etnografická. Praha, 1932. S. 266.

33 Kuret N. Praznično leto Slovencev. Starosvetne šege in navade od pomladi do zime. Celje, 1967. D. 2. S. 26, 27.

34 Олбин Черниговской обл. (Полесский архив...).

35 Ловешки край... С. 315.

36 Лилек E. Вјерске старине из Босне и Херцеговине. С. 372.

37 Filipović M. Prilozi etnološkom poznavanju severoistočne Bosne. Sarajevo, 1969. S. 110.

38 Biegeleisen H. U kolebki. Przed ołtarzem. Nad mogiłą. Lwów, 1929. S. 454.

39 Morcinek G. Uroda Beskidu Śląskiego // Wierchy. 1931. Rocz. 9. S. 22.

40 Максимов С.В. Нечистая, неведомая и крестная сила. СПб., 1903. C. 284-285.

41 Wysoczański Wt. Językowy obraz świata w porównanich zleksykalizowanych. Na materiale wybranych języków. Wrocław, 2006. S. 118.

42 Беларускі фальклор. Мінск, 2014. Вып. 1. С. 285.

43 Куединские былички. Мифологические рассказы русских Куединского района Пермской области в конце XIX - XX в. / Сост. А. В. Черных. Пермь, 2004. С. 62, 69.

44 Мифологические рассказы и поверья Нижегородского Поволжья / Сост. К. Е. Корепова, Н. Б. Храмова, Ю. М. Шеваренкова. СПб., 2007. № 115, 218, 220, 221, 224.

45 Куединские былички... С. 91, 95.

46 Подюков И. А., Белявин А. М., Крыласова Н. Б., Хоробрых С. В., Антипов Д. А. Усольские древности. Традиционная культура русских конца XIX - XX в. Усолье, 2004. С. 159. 
47 Бузин В. С. Рождение, вступление в брак и смерть в традиционной южнорусской обрядности (Липецкая, Тамбовская, Пензенская области). Материалы и исследования. СПб., 2015. С. 619.

48 Российский этнографический музей. Архив. Ф. 1. Оп. 7 (Тенишевский архив). Д. 1446. Л. 16.

49 Moszyński K. Kultura ludowa Słowian. S. 529-530.

50 Gustawicz B. Podania, przesądy, gadki i nazwy ludowe w dziedzinie przyrody. Cz. 2 // Zbiór wiadomości do antropologii krajowej. Kraków, 1882. T. 6. S. 299-300.

51 Koštál J. Rostlinstvo v podání prostonárodním. S. 290.

52 O сюжете см.: Сравнительный указатель сюжетов. Восточнославянская сказка / Сост. Л. Г. Бараг и др. Л., 1979. С. 157-158; У истоков мира. Русские этиологические сказки и легенды / Сост. и коммент. О. В. Беловой, Г. И. Кабаковой. М., 2014, № 138-145 и коммент. к опубликованным текстам.

53 Криничная Н. А. Крестьянин и природная среда в свете мифологии. Былички, бывальщины и поверья Русского Севера. М., 2011. № 2, Пудожский у.

54 Самариија С. Д. Приче о постанку и особинама биља и растиња (Антологија) // Гора Љиљанова Нови Сад, 2016. (Биљни свет у традиционалној култури Срба; 3). С. 211-212, № 38-39.

55 Гура А. В. Символика животных... С. 160.

56 Соболевский А. И. Великорусские народные песни. СПб., 1898. Т. 4. № 559 .

57 К пиру едется, а к слову молвится. Народная паремика Пермского края / Науч. ред. И. А. Подюков. СПб., 2014. С. 52.

58 Смоленский музыкально-этнографический сборник. Т. 1: Календарные обряды и песни / Отв. ред. О. А. Пашина. С. 657.

59 Filipović M. Prilozi... S. 79.

60 Гласник Земаљског музеја Босне и Херцеговине у Сарајеву. Сарајево, 1899. Св. 3. С. 714.

61 Босанска вила. Сарајево, 1887. Год 2, св. 1. С. 7.

62 См.: Сикимић Б. Ђаво и јалова жена // Славянские этюды. Сборник к юбилею С. М. Толстой. М., 1999. С. 424.

63 Словарь современного русского литературного языка. М.; Л., 1957. Т. 6. С. 242, 244.

64 Электронное издание «Толковый словарь русского языка Ушакова». М., 1999. S. v. Липовый.

65 Смирнов Н. Слова и выражения воровского языка, выбранные из романа В. С. Крестовского «Петербургские трущобы» // Известия Отделения русского языка и словесности. СПб., 1899. 4, кн. 3. С. 1074. 
66 Попов В. М. Словарь воровского и арестантского языка. Киев, 1912. S. v. Липовый.

67 Словарь русских народных говоров. Т. 17. С. 56.

68 Словник української мови. Київ, 1973. Т. 4. С. 487-488.

69 Словарь русских народных говоров. Т. 17. С. 57.

70 Грачев М. А., Мокиенко В. М. Русский жаргон. Историко-этимологический словарь. М., 2009. С. 173-174.

71 Гиппиус А. А., Михеев С. М. О подготовке Свода надписей-граффити Новгородского Софийского собора // Письменность, литература, фольклор славянских народов. История славистики. XV Международный съезд славистов. М., 2013. С. 167-168.

72 Агапкина T. А. Восточнославянские лечебные заговоры в сравнительном освещении: Сюжетика и образ мира. М., 2010. С. 208-221; об этом тексте см. также: Топорков А. Л. Русские заговоры против вражеского меча // О вере и суевериях: сборник статей в честь Е. Б. Смилянской / Сост. В. Е. Борисов; отв. ред. Д. И. Антонов. М., 2014. С. 15-26.

73 Фридрих И. Д. Фольклор русских крестьян Яунлатгальского уезда. Кн. 1: Песни детские, хороводные, беседные, обрядовые, заговоры и духовные стихи. Рига, 1936. № 630.

74 Фольклор старообрядцев Литвы. Т. 2: Народная мифология. Поверья. Бытовая магия / Издание подготовил Ю. Новиков. Вильнюс, 2009. № 846.

75 Заговоры и молитвы из коллекции Корниловых / Подготовка текстов и комментарии А. В. Пигина // Отреченное чтение в России XVIIXVIII веков. М., 2002. С. 245-246, Олонецкая губ.

\section{T. A. Agapkina}

Symbolic functions of trees in Slavic traditional culture: Linden

The article is dedicated to the symbolic and ritual functions of trees in Slavic traditional culture. On the one hand, linden has several cult functions and is considered a sacred tree. On the other hand, it symbolizes weakness and short lifespan, and thus is connected to some negative meanings and motifs.

Keywords: symbolic functions, tree, linden, functions, cult, folklore. 


\title{
Об одном архаическом способе мотивировки значения в снотолкования х
}

\begin{abstract}
В статье описываются способы интерпретации сновидений, основанные на языковых созвучиях (рифме, анафоре, анаграмме и т. п.) как особом виде вербальной магии. Жанр снотолкований определяется архаической функцией гадания и прорицания, реализуемой в практике толкования снов, и языковой архаикой, заложенной в магических свойствах звуковых повторов, образующих бинарную снотолковательную формулу. Мотивировки символических значений, основанные на звуковом сближении слов, дают представление о способах создания мифопоэтического образа мира и раскрывают особенности архаического языкового мышления.

Ключевые слова: жанр снотолкований, архаика, рифма, анафора, анаграмма, гадания, вербальная магия, символика.
\end{abstract}

DOI: $10.31168 / 2073-5731.2018 .3-4.5 .03$

Среди различных приемов толкования сновидений особо выделяются интерпретации, основанные на созвучиях слов, одно из которых обозначает реалию (предмет, событие и т. п.), выполняющую в соннике роль сновидения, а другое расшифровывает его смысл, имеющий функцию прогноза. Поскольку символическое значение таких снотолкований имеет языковую природу, они характерны, прежде всего, для устной народной, а не книжной традиции, которая содержит в языковом отношении генетически разнородный, переводной материал.

Фонетические созвучия могут быть разного рода. Нередко в снотолкованиях используется рифма, созвучие в окончании слов, подчас при отсутствии какой-либо видимой логической связи между тем, что обозначается этими рифмованными словами. Так, снотолкование на основе рифмы «вода - беда» образует ареал, включающий Волынь, Ровенщину, реже центральное белорусское Полесье (мозырское, лунинецкое), а также некоторые районы Белоруссии (Гродненщина,

Работа выполнена в рамках проекта РНФ № 17-18-01373 «Славянские архаические зоны в пространстве Европы: этнолингвистические исследования». 
Могилевщина, Витебщина) $)^{1}$. Иногда рифма присутствует неявно, в скрытом виде: «Купаться - беда, плавать - беда»². Рифма «вода беда» бывает задействована и в других малых фольклорных жанрах. Например, в загадке про глаза: «По краям волоса, / В середине чудеса: / Как случится беда — / Потечет вода» ${ }^{3}$. В пословице: «Лейся беда, что с гуся вода» ${ }^{4}$. В присловьях о жителях Каменец-Подольска, Луцка, Мозыря: «Мазырь, как пузырь: кругом вода, а в средине беда» 5 .

Немало примеров снотолкований на основе анафоры (повтора начальных звуков), например, характерные в основном для великорусской традиции снотолкования «река (речка) - речи» ${ }^{6}$ и производные от них скрыто-фонетические варианты с заменой речей на разговоры или пересуды, а реки - на воду, лодку на реке: «Река - быть разговорам» ${ }^{7}$; «Вода - к речам» ${ }^{8}$; «Плыть по воде - к злым речам» ${ }^{9}$; «Переходить воду — речи говоруть про тябе» ${ }^{10}$; «Лодка, вода — разговоры» ${ }^{11}$; «Плавать в лодке - люди тябе судють» ${ }^{12}$.

Примеры анафорического соотнесения слов речь и река и соответствующих понятий можно найти и в некоторых других малых фольклорных жанрах. Например, в псковской загадке: «Ходит без ног, / Рукава — без рук, / Уста - без речи. - Река» ${ }^{13}$. Сближение речи с рекой, несмотря на отсутствие этимологического родства обозначающих их слов в славянских языках, представляет собой, по мнению Н. Б. Мечковской, «древнейший архетипический образ, отраженный в некоторых мифологических традициях и языках. <...> Возможно, это поэтическая этимология, но именно в народном, мифопоэтическом сознании речь человека издавна сближалась со звучащим течением воды» ${ }^{14}$. Ср. языковые выражения льется речь, плавная речь, поток слов и т. п., а также в сказке А. С. Пушкина: «А как речь-то говорит, / Словно реченька журчит».

Ареал распространения другого основанного на анафоре снотолкования «лошадь - ложь» (иногда только лошадь священника или еврея, без упряжи, черная, скачущая $)^{15}$, включая скрытую анафору в виде синонимических замен: наговоры, брехня ${ }^{16}$, напраслина ${ }^{17}$ и клевета $^{18}$, охватывает великорусскую территорию, распространяясь также на северную и центральную Белоруссию. Не исключено, что звуковое сближение лошади и лжи поддерживается книжной традицией - словами из 32-го псалма: «Ложь конь во спасение, во множестве же силы своея не спасется» (Пс. 32: 17) ${ }^{19}$.

Анафористические повторы встречаются в польских толкованиях снов о грибах и хлебе: «grzyby — grzychy» [грибы — грехи $]^{20}$ и «chleb chlepać» (пол. chlipać 'всхлипывать, плакать со всхлипыванием') ${ }^{21}$. В русской традиции аналогичных снотолкований не отмечено. 
Характерное для южных славян толкование, связывающее виноград во сне с чем-то ужасным, продиктовано анафорическим созвучием соответствующих слов грозд, грозде (грожђе) и грозни: «Если снится виноград (грозди), ужасные (грозни) слова услышишь: поссоришься с кем-либо» (у болгар Велико-Тырнова) ${ }^{22}$; «Черный виноград (чърну гроздьи) грозит чем-то ужасным (нещу грозну за измене́ш)» (у болгар Баната) ${ }^{23}$; «Виноград (грожђе) - столкнешься с чем-то ужасным (нешто грозно)» (у сербов Шумадии) ${ }^{24}$. Сравните также скрытую анафору grožđe - grožnja 'ужас, угроза' у хорватов Далмации: «Виноград снится - большое несчастье (velika nesrića)»; «Ешь виноград во сне - что-то с тобой случится» ${ }^{25}$.

Разными видами созвучий мотивированы толкования сна о рыбе, при этом каждый имеет свою географическую локализацию. Так, рыба как предвестье плача на основе анафоры рыба - рыдать или рынать (ярослав. 'плакать') встречается у русских на Севере ${ }^{26}$. Иное толкование этого сна, обусловленное парономазией риба (рыба) - прибыль (прыбыль), сулящее «прибыль» (в разных значениях этого слова, в том числе и как прибытие гостей), характерно для волынского, ровенского и гомельского Полесья ${ }^{27}$. Наконец, рыба во сне как предвестье забот, беспокойств, толкуемых на основе анафонии, почти анаграммы (перестановки некоторых или всех звуков) риба - брига, отмечена у сербов, хорватов и боснийцев ${ }^{28}$.

Для Полесья, соседних с Волынью районов Польши и некоторых, главным образом южных, районов России характерны разного рода парономастические (аллитерационные, рифмованные и др.) толкования коровы во сне: «коров $a-$ хвороба» (иногда в скрытом виде: болезнь, «слабість») ${ }^{29}$, пол. «krowa - churoba» ${ }^{30}$ или «корова - корогвa», т. е. хоругвь, объясняемая как предвестье болезни или смерти ${ }^{31}$, а также аллитерационное (с повтором согласных) толкование «корова - на кровь» ${ }^{32}$. Рифмованное снотолкование «корову [видеть] - к рёву» встречается у русских ${ }^{33}$ (ср. рус. рёва-корова 'плакса' и детскую дразнилку «Рёва-корова, дай молока, сколько стоит - три пятака»). Особенно любопытны толкования этого сна на основе анаграммы или анафонии (перестановки звуков). Так, в Вологодской обл. зафиксировано анафоническое снотолкование «корова - оброк»: «Корова — обрёк: обрекла себя вроде, задумала сделать что-то (например, обещала справить годовщину смерти отца) и не сделала» ${ }^{34}$. А на Украине, в основном в Подолии и на Волыни, а также в прилегающих районах Польши распространено толкование этого сна, представляющее собой анаграмму, почти палиндром (перестановку звуков в обратном порядке): корова (корови) - ворог (вороги), krowy - wrogi ${ }^{35}$. 
Подобные фонетические созвучия в толкованиях снов представляют собой вид вербальной магии, что неслучайно, поскольку по своей сути жанр снотолкований относится к онейромантике, к гаданиям и прорицаниям, предсказаниям будущего. Наиболее архаическим приемом такого рода является анаграмма, которой приписывалось магическое значение. $Ф$. де Соссюр считал ее общей особенностью древних индоевропейских поэтических текстов. Она встречается в Библии, в ведийских гимнах, древнегреческом эпосе, в хеттской, армянской, славянской и других традициях. Анаграмма выполняла магическую роль табуистической замены сакральных имен, произносить которые было запрещено ${ }^{36}$. Использование анаграммы известно и в древнейших сонниках. Так, Артемидор Далдианский в своем знаменитом сочинении II в., говоря об искусстве толкования снов и ссылаясь на величайшего снотолкователя IV в. до н. э. Аристандра Телмесского и некоторых других древних толкователей, придававших большое значение анаграммам, писал: «Особенно приходится прилагать старание и уменье к искаженным снам, в которых как бы нет никакой связи, - особенно когда являются писания, лишенные смысла, или имена, ничего не значащие: здесь бывает нужно переставлять, менять, прибавлять буквы или слоги, а то даже придумывать равные по числовому значению слова, чтобы только прояснить смысл». Об анаграммах, «будь то перестановка слогов, отбрасывание или добавление букв», он писал своему сыну: «Советую тебе пользоваться анаграммами всякий раз, когда, истолковывая сновидения, ты захочешь показаться более искусным толкователем по сравнению с другими. Однако в своих собственных толкованиях этим способом не пользуйся, иначе ошибешься» ${ }^{37}$.

Анафорические созвучия в снотолкованиях названий свадьбы и ссоры (поддерживающие семантическое сближение слов ${ }^{+} \operatorname{svar}\left(\right.$ ' $\left.^{\prime}\right) b a$ и сварка или вызывающие народно-этимологическое осмысление слова ${ }^{+} \operatorname{svad}\left(\right.$ ') ba как производного от ${ }^{*}$ sъvaditi) прямо (в случае ${ }^{+}$svar-) либо опосредованно (в случае ${ }^{+}$svad-) вовлекаются в семантическое поле свар-, в котором сходятся связанные между собой значения брака и огня (что косвенно может свидетельствовать в пользу древности названия свадьбы ${ }^{+}$svarba в славянских языках ${ }^{38}$ ). В прямом виде анафорическое толкование сна «Сварьба - к сваре» отмечено лишь в Ярославской губ. ${ }^{39}$ В других случаях - у русских, белорусов Полесья, украинцев и македонцев - толкования носят скрыто-фонетический характер: только вторая часть снотолкования (предвестье ссоры) сохраняет лексические дериваты от свар-: «Свадьба - сварка» (в Брестской и Волынской обл.) ${ }^{40}$, «будэш 3 кимсь сварытысь» (в Ровенской обл. $)^{41}$; или даже и вторая часть выражена синонимичными названия- 
ми ссоры: «лайка» (в Екатеринославской губ. $)^{42}$, «скандал» (в Краснодарском крае и в Брестской обл. ${ }^{43}$, «ке се скараш» (у македонцев Прилепа) $)^{44}$. Ср. также белорусское толкование сновидения о вихре, устойчиво воспринимаемом в народных представлениях как свадьба черта: «Вихрь видеть - черти да тябе́ у сваты придуть (говорят иронически девушкам)», а также: «сварка, битва́ (драка)» (в Минской губ.) $)^{45}$. Аналогичные по смыслу анафорические снотолкования с дериватами от (c)вад- во второй части отмечены у белорусов и у некоторых южных славян: Свадьба - «жонка з мужиком (т. е. мужем) пова́дютца (поссорятся)» (у белорусов Минской губ.) ${ }^{46}$; «Свадьба (сва́бда) приснится будет драка (сва́dа)» (у болгар Баната) ${ }^{47}$; «Свадьба (свадба) — означает ссору (свађу)» (у сербов южной Шумадии $)^{48}$. Шире распространены снотолкования об огне или пожаре, который предвещает ссору: сварку (в Витебской и Могилевской губ., в Гомельской и Ровенской обл. $)^{49}$, драку (в мозырском Полесье) $)^{50}$, «калатню» (в Гродненской губ. $)^{51}$, скандал (в ровенском Полесье) $)^{52}$, спор (в Екатеринославской губ. $)^{53}$, страдание, болезнь или ссору (в Боснийской Краине) $)^{54}$, вражду (у австрийских словенцев южной Каринтии $)^{55}$. При этом наблюдается и взаимообратимость такого снотолкования: «Ругаться, ссориться с кем-нибудь - пожар будет» (в Ровенской обл.) ${ }^{56}$. Картину дополняют белорусские, болгарские, боснийские и лужицкие снотолкования об огне или пожаре как предвестье свадьбы: «Пожар сьніцься - веселе будзя», а гасить огонь — «веселе разкі́даецса» ${ }^{57}$; «Горит дом - будет свадьба, бракосочетание» ${ }^{58}$; «Пожар с пламенем - скорое приглашение на свадьбу» ${ }^{59}$; «Яркий огонь - означает свадьбу» ${ }^{60}$. Характерно, что приведенные снотолкования, основанные на анафорическом сближении слов и дополняющие архаические лексико-семантические связи слов в поле свар-, подтверждают архаику и в своей географической проекции, поскольку представлены в некоторых архаических славянских зонах: в Полесье и ряде маргинальных, периферийных традиций - у болгар Баната, у австрийских словенцев, у лужичан. Таким образом, мифопоэтическая архаика снотолкований накладывает определенный отпечаток на их географическую дистрибуцию и способна маркировать на карте ареалы, имеющие важное значение в плане сравнительной этногенетической интерпретации особенностей их традиционной культуры в целом.

Звуковые повторы характерны прежде всего для малых фольклорных жанров. Причину этого М. Л. Гаспаров видел в том, что в малых формах «уловить стихотворную форму по ритму невозможно: текст короток, ритмическое ожидание едва успевает возникнуть, как 
он уже обрывается. Поэтому, чтобы показать, что перед нами текст повышенной важности, а не случайный, приходилось пользоваться другим средством: густо насыщать эти немногие слова однородными звуками» ${ }^{61}$. К снотолкованиям в этом отношении наиболее близки загадки. Они же и наиболее изучены. В них так же, как и в снотолкованиях, распространено анаграмматическое кодирование (напр.: ярослав. «Черный конь / Прыгат в огонь. - Кочерга»; ставропол. «Под палатями - / Растаки матери. - Тараканы» ${ }^{62}$ ) и имеются загадки не со смысловой, а с чисто фонетической отгадкой, когда она сводится к подбору рифмующегося слова с тем, что в вопросе (ставропол. «Что в избе гадко? - К $\left.а \partial \kappa a{ }^{63}\right)^{64}$. Звуковые повторы используются в пословицах (напр.: «В дороге и ворога назовешь батюшкой») ${ }^{65}$, в приметах («К Варварину дню дорогу заварит», т. е. закует), в шутках и дразнилках («Обросим - ерша оземь бросил» $)^{66}$. Аллитерации, повторы, рифму, анаграммы, глоссолалии и прочие элементы магической и тайной речи обнаруживает звуковая организация заговоров ${ }^{67}$. Звуковая игра широко представлена в заклинаниях, например в болгарских, использующих имя Стоян для остановки кровотечения ${ }^{68}$; в сербских - использующих имя Вида или Видан для лишения зрения, способности видеть дневной свет (видело): «Видо, видело да не видиш!» ${ }^{69}$. Кроме того, показателем архаичности заклинательных формул может служить их синкретизм, когда они представляют собой перформатив и самостоятельный вербальный ритуал.

Действие языковых созвучий не ограничивается малыми жанрами фольклора и рамками фольклора в целом. Наряду с реальными предметными, акциональными и прочими признаками объекта (внешним обликом, цветом, акустическими проявлениями, утилитарной функцией и т. д.) фонетические сближения соответствующих словесных обозначений могут участвовать в процессе символизации, мотивируя символическое значение, которым наделяется этот объект. Так, апотропейная символика бороны в ее ритуальном применении обусловлена не только наличием у нее защитных переплетений и ячеек, но и сближением омонимов "borna - как 'борона' и как 'оборона, защита, преграда' (возможно, сближением вторичным, поскольку разошедшиеся значения скорее всего восходят к семантически единому слову); символика воровства у воробья определяется не только тем, что он вредит посевам, но и анафорическим сближением слов воробей и вор; хтоническая, связанная со смертью символика ворона у болгар — аллитерационным созвучием слов гарван 'ворон', грача 'каркать' и гроб 'могила'; символика кражи, присущая вороне у поляков, - созвучием слов krakać 
'каркать' и kraść 'красть', wrona 'ворона' и роrwanie 'похищение'; а группа пушных животных выделяется своими психическими характеристиками на основе звуковых ассоциаций: ласка - ласковая (ласкает и ласкочет 'щекочет' скотину, пол. tasica, taska 'ласка' tasi się 'ластится', становится laskawa 'податливая, ласковая, ручная'), бобр - добр, бел. вудра 'выдра' - мудра, выдра - быдра 'проворная'70.

Место и значение жанра снотолкований определяется магической, архаической в своих истоках функцией гадания и прорицания, реализуемой в практике толкования снов, а также глубокой языковой архаикой, заложенной в магических свойствах анаграммы и других видов звуковых повторов, которые активно используются в построении бинарной снотолковательной формулы. Мотивировки символического значения сновидений, основанные на звуковом сближении слов, позволяют понять традиционные способы и механизмы осмысления семантического родства слов, дают представление о средствах создания мифопоэтического образа мира и раскрывают особенности архаического языкового мышления.

\section{ПРИМЕЧАНИЯ}

1 Полесский архив отдела этнолингвистики и фольклора Института славяноведения РАН, Волынская обл., Ковельский р-н, Уховецк, Ратновский р-н, Пески Речицкие, Ровенская обл., Рокитновский p-н, Каменное, Дубровицкий р-н, Лесовое, Озерск, зап. автора; Брестская обл., Лунинецкий р-н, Велута, зап. Н. А. Микоян; Гродненская губ., Волковыский у., Мстибово, Шандры, Federowski M. Lud białoruski na Rusi litewskiej. Materyały do etnografii słowiańskiej zgromadzone w latach 1877-1891. Kraków, 1897. T. 1. S. 212; Минская губ., Мозырский у., Дорошевичи, Moszyński K. Polesie Wschodnie. Warszawa, 1928. S. 153; Могилевская, Витебская губ., Романов Е. Опыт белорусского народного снотолкователя // Этнографическое обозрение. 1889. № 3. С. 56.

2 Полесский архив, Ровенская обл., Рокитновский р-н, Глинное, зап. И. А. Мямикеевой.

3 Татарская АССР, Чистопольский р-н, слоб. Черемуховая, Загадки из фольклорного архива МГУ // Русский эротический фольклор. Песни. Обряды и обрядовый фольклор. Народный театр. Заговоры. Загадки. Частушки. М., 1995. С. 377.

4 Даль В. Пословицы русского народа. М., 1957. С. 72.

5 Снегирев И. М. Русские народные пословицы и притчи. М., 1999. C. 404 . 
6 Вологодская обл., Вытегорский р-н, Морозово, зап. автора; Ярославская губ., Пошехонский у., Дерунов С. Материалы для народного снотолкователя. ІІІ. Ярославской губернии // Этнографическое обозрение. 1898. № 1. С. 149; Русские крестьяне. Жизнь. Быт. Нравы. Материалы «Этнографического бюро» князя В. Н. Тенишева. СПб., 2006. Т. 2: Ярославская губерния. Ч. 1: Пошехонский уезд. С. 224; Рязань, Мансуров A. A. Описание рукописей этнологического архива Общества исследователей Рязанского края. Рязань, 1933. Вып. 5. С. 29.

7 Краснодарский кр., ст. Северская, зап. В. А. Потаповой.

8 Вологодская обл. и р-н, Дулепово, зап. автора.

9 Воронежская губ., Бобровский у., Ясырок, Патриикий Н. Умственные и нравственные способности и образование жителей Бобровского уезда Воронежской губернии // Архив Русского географического общества. Разряд IX. Оп. 1. № 73. Л. 11об.

10 Витебская, Могилевская губ., Романов Е. Опыт... С. 56.

11 Брестская обл., Малоритский р-н, Мыслячи, зап. автора.

12 Минская губ., Минский, Борисовский, Бобруйский у., Ляцкий $E$. Материалы для народного снотолкователя. II. Минской губернии // Этнографическое обозрение. 1898. № 1. С. 144.

13 Садовников Д. Загадки русского народа. СПб., 1901. С. 153.

14 Мечковская Н. Б. Язык и религия. Лекции по филологии и истории религий. М., 1998. С. 55-56.

15 Карелия, Кемский р-н, Поньгома, зап. О. В. Беловой; Вологодская обл., Вытегорский р-н, Морозово, Белозерский р-н, Маекса, зап. автора; Калужская обл., Таруса, зап. Е. А. Васиной; Рязанская губ., Мещерский край, Мансуров А. А. Описание рукописей... Рязань, 1928. Вып. 1. С. 44; Курская обл., Железногорский р-н, Золотой, Михайловка, Разветье, Карманово, Остапово, зап. С. Сусликовой, Н. Касьяновой и др.; Краснодарский кр., Северская, зап. В. А. Потаповой; Витебская губ., Полоцкий у., Махирово, Никифоровский Н. Я. Материалы для народного снотолкователя. І. Витебской губернии // Этнографическое обозрение. 1898. № 1. С. 136-137; Витебская, Могилевская губ., Романов Е. Опыт... С. 68; Минская губ., Минский, Борисовский, Бобруйский у., Лящкий $E$. Материалы... С. 148.

16 Курская обл., Остапово, зап. Н. Касьяновой.

17 Вологодская обл., Белозерский р-н, Маекса, зап. автора; Воронежская губ., Бобровский у., Ясырок, Патриикий $Н$. Умственные и нравственные способности... Л. 11об.

18 Рязанская губ., Касимовский у., Павловка, Мансуров А. A. Описание рукописей... Вып. 1. С. 11. 
19 Ср. также наделение рыжего (огненного) коня символикой лжи в поэме М. И. Цветаевой «Переулочки»: «Красен тот конь, / Как на иконе. / Я же и конь, / Я ж и погоня. / Скачка-то / В гру — ди! / Жарок огонь! / Жги! / В обе вожжи! / Гей, мои рыжи! / Лжей-то в груди / Семь, да семижды / Семь, да еще - / Семь. / Жги, ямщичок, / В темь!» (Цветаева М. Сочинения. В 2 т. М., 1980. T. 1. С. 360).

20 Седлецкое воев., Соколовский пов., Репки, Niebrzegowska S. Polski sennik ludowy. Lublin, 1996. S. 60.

21 Хелмское воев. и пов., гм. Дорогуск, Сьверже, Ibid.

22 Гъбюв П. К. Тълкувания на природни явления, разни народни вярвания и прокобявания. От В.-Търново // Сборник за народни умотворения, наука и книжнина. София, 1900. Кн. 16 и 17. II. Материали. C. 225.

23 Телбизов К., Векова-Телбизова М. Традиционен бит и култура на банатските българи // Сборник за народни умотворения и народопис. София, 1963. Кн. 51. С. 191.

24 Левач и Темнич, $C m$. M. M. Снови (по народном веровању и тумачењу) из Левча и Темнића // Караџић. Алексинац, 1903. Год. 4. С. 121.

25 Р-н Сплита, Полица, Ivanišević F. Poljica. Narodni život i običaji // Zbotnik za narodni život i običaje Južnih Slavena. Knj. 10. Zagreb, 1905. S. 287.

26 Вологодская обл., Белозерский р-н, Маекса, Вологодский р-н, Дулепово, зап. автора; Ярославская губ., Пошехонский у., Дерунов $C$. Материалы... С. 151.

27 Полесский архив, Волынская обл., Ковельский р-н, Уховецк, зап. автора; Ровенская обл., Дубровицкий р-н, Залишаны, зап. А. Б. Страхова; Гомельская обл., Ветковский р-н, Большие Немки, зап. Э. А. Акулина.

28 Сербия, Шумадия, Левач и Темнич, Сm. М. М. Снови... С. 120; Хорватия, Ступник близ Загреба, Korenić S. Život, jezik i običaji Stupničana kraj Zagreba // Zbornik za narodni život i običaje Južnih Slavena. Zagreb, 1896. Sv. 1. S. 146; Боснийская Краина, p-н Бихача, Magična vjerovanja i običaje iz Cazinske krajine. http://www.skripta.info/wp-content/uploads/2016/04/ Narodna-Vjerovanja-u-Bosni-i-Hercegovinil.pdf (Praznovjerice, izreke, sanovnik. [S. 25]).

29 Полесский архив, Брестская обл., Малоритский р-н, Олтуш, зап. автора; Житомирская обл., Попельнянский р-н, Харлеевка, зап. Т. В. Зубович, Корнин, зап. О. В. Килимник; Овручский р-н, Тхорин, зап. О. В. Беловой, Дзержинский р-н, Карвиновка, зап. В. В. Хомяк, С. И. Головень; Красноармейский p-н, Ивановичи, зап. В. А. Голомах; Володарско-Волынский р-н, Писаревка, зап. Р. И. Боряченко; Хорошевский р-н, Небеж, зап. С. В. Гордийчук; Буда-Кошелевский р-н, Кривск, зап. С. Гончаровой, 
Рея, зап. Н. С. Комунарец; Радомышльский р-н, Вихля, зап. А. М. Лотоцкого; Ружинский р-н, Вербовка, зап. Е. А. Гуменюк; Черняховский р-н, Высокое, зап. Т. Г. Куреша; Львовская обл., Мостисский р-н, Гостинцово; Гомельская обл., Добрушский р-н, Дубровка, зап. автора; Киевская обл., Сквирский р-н, Малые Ерчики, зап. С. И. Белинской; Сумская обл., Краснопольский р-н, Мирополье; Брянская обл., Почепский р-н, Семцы, зап. М. И. Серебряной, С. Шевцовой; Климовский р-н, Челхов, зап. О. В. Санниковой; Трубчевский р-н, Радутино, зап. автора; Стародубский р-н, Картушино; Курская обл., Железногорский р-н, Карманово, зап. Н. Касьяновой и др., Михайловка, Ратманово, Золотой, зап. С. Сусликовой и др.; Калужская обл., Куйбышевский р-н, Селилово, Архив кафедры фольклора МГУ, зап. Е. А. Галинской, М. В. Поляковой.

30 Замойское воев., Грубешовский пов., Мирче, Томашовский пов., Крынице, Bartmiński J., Baczkowska G. Materiały do sennika ludowego // Etnolingwistyka. Lublin, 1988. T. 1. S. 157.

31 Ровенская обл., Дубровицкий р-н, Озерск, Житомирская обл., Овручский р-н, Журба, зап. автора, Тхорин, зап. О. В. Беловой.

32 Гомельская обл., Ельский р-н, Кочище, зап. О. А. Толстихиной.

33 Вологодская обл. и р-н, Дулепово, Белозерский р-н, Маекса, зап. автора; Ярославская губ., Балов А. Сон и сновидения в народных верованиях. Из этнографических наблюдений, собранных в Ярославской губернии // Живая старина. 1891. Вып. 4. С. 210; Курская обл., Железногорский р-н, Разветье, зап. С. Сусликовой и др., Остапово, зап. Н. Касьяновой и др.

34 Вытегорский р-н, Морозово, зап. автора.

35 Хмельницкая обл., Полонное, зап. В. А. Задирайко; Винницкая обл., Ильинецкий р-н, Улановка, зап. Н. Л. Данилюк; Житомирская обл., Новоград-Волынский р-н, Курчица, зап. автора, Андрушевский р-н, Старая Котельня, Червоное, зап. М. П. Меняйло, В. П. Костюк; Волынская обл., Ковельский р-н, Радошин, зап. Н. В. Осиюк; Замойское воев., Томашовский пов., Крынице, Полянувка, Bartmiński J., Baczkowska G. Materiały do sennika... S. 157.

36 О подобных анаграммах у славян см., напр.: Мартынов В. В. Славянские анаграммы // Этимология. 1977-1999. М., 2000. С. 102-106; Крегждис Р. Восточнославянские боги Киевской Руси: Стрибог // Studia mythologica Slavica. 2010. Št. 13. S. 211-232.

37 Артемидор. Сонник / Сост., общ. ред. Р. В. Грищенкова. СПб., 1999. C. 349-350.

38 Оно восходит к архаич. "svariti 'сковывать что-л. горячим', к которому в Древней Руси возводилось название языческого божества 
Сварога и которое отражено в позднейших диалектных названиях огня, глагольных обозначениях устройства, слаживания свадьбы, связывания дружескими узами и т. п. См.: Гура А. В. Брак и свадьба в славянской народной культуре: семантика и символика. М., 2012. С. 430-432.

39 Пошехонский у., Русские крестьяне... С. 224.

40 Брестская обл., Малоритский р-н, Олтуш, Волынская обл., Ратновский р-н, Речица, зап. автора.

41 Дубровицкий р-н, Озерск, зап. автора.

42 Манжура И. И. Малорусские сказки, предания и поверья, записанные в Екатеринославской губ. // Сборник Харьковского Историкофилологического общества. Т. 6. Труды Педагогического отдела Историкофилологического общества. Харьков, 1894. Вып. 2. С. 192.

43 Краснодарский кр., Северская, зап. В. А. Потаповой; Брестская обл., Малоритский р-н, Мокраны, зап. автора.

44 Цепенков М. К. Съновидения и тълкуванията им // Сборник за народни умотворения, наука и книжнина. София, 1892. Кн. 7. С. 130.

45 Минский, Борисовский, Бобруйский у., Ляикий Е. Материалы... C. 139.

46 Там же. С. 142.

47 Телбизов К., Векова-Телбизова М. Традиционен бит... С. 191.

48 Левач, Ст. М. М. Снови... С. 121.

49 Витебская, Могилевская губ., Романов Е. Опыт... С. 57; Гомельская обл., Мозырский р-н, Жаховичи, зап. С. М. Толстой, Хойникский р-н, Дубровица, Золотуха, зап. А. Б. Страхова; Ровенская обл., Дубровицкий p-н, Лесовое, зап. автора, Сварицевичи, зап. И. А. Мямикеевой.

50 Дорошевичи, Moszyński K. Polesie Wschodnie... S. 152.

51 Сокольский у., Federowski M. Lud białoruski... S. 214.

52 Рокитновский р-н, Глинное, зап. И. А. Мямикеевой.

53 Новомосковский у., Манжура И. И. Малорусские сказки... С. 192.

54 Р-н Бихача, Magična vjerovanja i običaje iz Cazinske krajine...

55 Долина Розенталь, Möderndorfer V. Verovanja, uvere in običaji Slovencev. Celje, 1946. Knj. 5: Borba za pridobivanje vsakdanjega kruha. S. 24.

56 Рокитновский р-н, Глинное, зап. И. А. Мямикеевой.

57 Гродненская губ., Волковыский у., Federowski M. Lud białoruski... S. 213, 214.

58 Центр. Болгария, p-н Казанлыка, Шипка, p-н Тетевена, Лесидрен, Маринов Д. Народна вяра и религиозни народни обичаи. София, 1914 (Сборник за народни умотворения и народопис. Кн. 28). С. 115.

59 Лужица, Veckenstedt E. Wendische Sagen, Märchen und abergläubische Gebräuche. Graz, 1880. S. 467; Клингер В. Животное в античном 
и современном суеверии. Киев, 1909-1911 (Университетские известия. Киев, 1909. № 10, 11; 1910. № 1, 5, 11; 1911. № 3). С. 345.

60 Ниж. Лужица, Müller E. Das Wendetum in der Niederlausitz. Kottbus, 1894. S. 144.

61 Гаспаров М. Л. Очерк истории европейского стиха. М., 2003. С. 31.

62 Садовников Д. Загадки... С. 29, 178.

63 Там же. С. 39.

64 Левин Ю. И. Семантическая структура русской загадки // Труды по знаковым системам. Тарту, 1973. [Вып.] 6. (Ученые записки Тартуского гос. университета. Вып. 308). С. 183.

65 Снегирев И. М. Русские народные пословицы... С. 71.

66 Топоров B. Н. К использованию анаграмматических структур (анализы) // Топоров В. Н. Исследования по этимологии и семантике. Т. 1: Теория и некоторые частные ее приложения. М., 2004. С. 755.

67 Толстая С. М. Заговоры // Славянские древности. Этнолингвистический словарь. М., 1999. Т. 2. С. 244.

68 Топоров В. Н. К использованию... С. 755.

69 Ђаповић Л. Смрт и оностраност у клетвама. Београд, 2009. С. 17.

70 Гура А. В. Борона // Славянские древности... М., 1995. Т. 1. С. 235-236; Гура А. В. Символика животных в славянской народной традиции. М., 1997. С. 200, 244-245, 250-252, 533, 536-537, 587, 590-594.

\section{A. V. Gura}

On an archaic way of motivation of meaning in interpretation of dreams

The article describes ways of interpretation of dreams based on language assonance (rhyme, anaphora, anagram etc.) as a specific type of verbal magic. The genre of interpretation of dreams is defined through the archaic function of divination and prophecy applied in the process of interpretation, as well as through language archaism of magic qualities of sound repetitions that shape a binary interpretive formula. Motivation of symbolic meanings based on sound proximity of words give an idea about ways of creating a mythopoetic image of the world and peculiarities of archaic language thinking.

Keywords: interpretation of dreams, archaics, rhyme, anaphora, anagram, divination, verbal magic, symbols. 


\title{
Исконная лексика с семантикой 'залив' в диалектах Европейского севера России
}

\begin{abstract}
Статья посвящена лексемам, имеющим значение 'залив', в диалектах Европейского севера России. Весь выявленный комплекс лексем анализируется с точки зрения происхождения слов и специфики семантического наполнения лексем. Интерпретируются ономасиологические модели.

Ключевые слова: лексема, семантика, значение, русский язык, семантика 'залив', географическая терминология, диалектная лексика.
\end{abstract}

DOI: $10.31168 / 2073-5731.2018 .3-4.5 .04$

Европейский север России - регион, в котором имеется разветвленная речная система и большое количество озер. Берега Белого моря служат границей территории на крайнем севере. Реки, озера и моря Европейского севера России имеют неровную береговую линию и изобилуют заводями и заливами. Зали́вом называется 'часть водного пространства, вдавшаяся в сушу' [ТСРЯ, 254]. Лексема является отглагольным образованием, ср. зали́ть 'покрыть сплошь водой' [ТСРЯ, 254]. В диалектах семантика слова и производных шире: зали́в 'старый рукав реки' (Влг.: Ник.) [КСГРС], 'заливной берег, заливной луг’ (Арх.: Пин., Плес.; Костр.: Нейск.) [КСГРС], (Яр.: Брейт., Тут.) [ЯОС 4, 80], 'овраг' (Влг.: Шексн.) [СВГ 2, 128], 'топкое место на болоте' (Влг.: Кир.) [КСГРС], зали́ва 'водоворот’ (Арх.: Вель.) [КСГРС], за́ливень 'сырое место' (Арх.: Пин.) [КСГРС], зали́вина ‘глубокое место в реке' (Яр.: Пош.) [ЯОС 4, 81], 'яма в пойме реки, наполненная водой' (Влг.: Баб.) [КСГРС], 'заливной берег, заливной луг' (Влг:: Ваш.) [КСГРС], 'топкое место на болоте' (Влг.: Баб.) [КСГРС], зали́винка 'небольшой залив' (Арх.: Карг.) [КСГРС], зали́вистый бе́рег 'берег реки, широко заливаемый по весне водою' (Влг.: Кадн.) [Дилакторский, 154], зали́вка 'длинная лужа, яма с водой' (Влг.: Сок.) [КСГРС], зали́вное 'заливной покос' (Арх.: Кон.) [КСГРС], зали́вье 'заливной берег, заливной луг' (Яр.: Гавр.) [ЯОС 4, 81]. В Онежском районе Архангельской области записано взлив 'небольшой речной залив’ (Арх.: Он.) [КСГРС]: течение рек Онежского района является 
очень сильным и быстрым, поэтому значение приставки здесь может быть интерпретировано как 'быстрое возникновение, наступление действия, состояния’ [ТСРЯ, 87].

Праславянское чередование li- / loi- (ср. глагол *liti) отражено в зало́й 'небольшой речной залив’ (Арх.: Вель., Нянд., Пин., Уст., Шенк.; Влг.: Бел., В.-Важ., Влгд., Вож., Сок., У.-Куб., Устюж., Хар.; Костр.: Кологр., Чухл.; Яр.: Некр.) [КСГРС], (Влг.: Вель., Влгд., Кадн., Ник., Тот., Устьс., Ярен.) [Дилакторский, 155], (Влг.: Кад.) [СРГК 2, 151], (Влг:: Сок.) [СВГ 2, 129]. Лексема имеет широкую «водную» семантику: 'поемное, затопляемое в половодье пространство в речной долине' (Моск.) [Даль 1, 597], (Арх.: Он., Холм., Шенк.) [Подвысоцкий, 20], (Арх.: Пин.) [КСГРС], 'яма в пойме реки, залитая водой' (Арх.: Вель., Пин., Шенк.), 'водоворот в реке' (Арх: Уст; Влг: Бабуш.), 'речной омут’ (Арх.: Вель., Шенк.; Влг.: В.-Важ.), 'протока между берегом и озером, речной рукав' (Арх.: Пин., Шенк.; Влг.: Сок.), 'поток талой воды, весенний ручей' (Арх.: Вель.), 'намытая отмель, коса' (Арх.: Пин.) [КСГРС], 'низменное место, затопляемое водой' (Арх.: Вель., Пин.; Влг:: Сок.) [КСГРС], (Яр.) [Мельниченко, 72], (Яр.: Люб., Некр.) [ЯОС 4, 82]. Формой женского рода к зало́й является зало́ 'залитая водой низина, залив, заводь' (Влг.: Бел.) [КСГРС], (Яр.) [Мельниченко, 72], (Яр.: Дан.) [ЯОС 4, 82].

Дериваты лексемы зало́й реализуют как основное значение производящего слова, так и весь спектр вторичных, при этом развивая собственную частную географическую семантику: зало́йка 'небольшой речной залив' (Яр.: Люб.), 'низменное место, затопляемое водой' (Влг.: Сок.), ‘старица' (Влг: Тот.), зало́йчик 'яма в пойме реки, залитая водой' (Влг.: Сямж.), 'низменное место, затопляемое водой’ (Арх.: Вель., Нянд., Уст.; Влг:: Сок., Устюж.) [КСГРС], зало́ина 'небольшой речной залив' (Влг.: Кир., У.-Куб.; Костр.: Мант., Нейск.) [КСГРС], (Костр.: Костр.; Яр.: Тут.) [ЯОС 4, 82], 'водоворот в реке' (Влг.: Кир.) [СРГК 2, 151], 'протока между берегом и озером, речной рукав’ (Влг:: Вож.), ‘прибрежная полоса земли на повороте реки’ (Костр.: Чухл.) [КСГРС], 'низменное место, затопляемое водой’ (Яр.) [Мельниченко, 72], (Яр.: Больш., Люб., Толб.) [ЯОС 4, 82], 'низкое, малоплодородное место на поле’ (Яр.: Больш., Дан., Некр., Тут.) [ЯОС 4, 82], ‘яма на лугу' (Костр.: Мант.) [КСГРС].

Результатом эпентезы 8 взало́ина является зало́вина' залив, бухта' (Яр.) [Мельниченко, 72], (Яр.: Брейт.; Ив.) [ЯОС 4, 82], имеющая акцентологический вариант залови́на 'то же' (Влг.: Вож.) [КСГРС]. Вторичные значения лексемы зало́вина в целом повторяют или до- 
полняют семантику производящего слова: 'участок реки с более широким руслом и тихим течением’ (Влг.: Гряз., Кир., У.-Куб.) [КСГРС], 'низкое место, затопляемое водой' (Яр.: Брейт.; Костр.: Сол.) [ЯОС 4, 82], 'открытое, не заросшее кустами место' (Влг.: У.-Куб.) [КСГРС]; ср. также уменьш. зало́винка 'низкое место, затопляемое водой' (Влг.: Влгд.) [КСГРС].

Другим приставочным образованием от корня лой- является поло́й 'узкий залив реки, никуда не впадающий рукав' (Влг.) [Даль 3, 263], (Костр.: Костр.) [КСГРС], имеющее уменьш. поло́йчик 'то же' (Влг:: Влгд.) [КСГРС].

Значение 'небольшой залив на реке, озере с замедленным течением' манифестируют лексемы за́водь (Арх.: Вель., В.-Т., Вин., Пин., Уст., Холм.; Влг.: Ник., Хар.) [КСГРС], ср. также за́водь 'залив в реке, озере, ручье, болоте' (Арх.) [Подвысоцкий, 47], (Яр.) [Мельниченко, 68], (Влг.: Череп.) [Герасимов, 39], (Помор.) [Гемп, 287]. Производные имеют ту же семантику: за́водье 'залив в реке, озере, ручье, болоте' (Яр.: Брейт.) [ЯОС 4, 61], заво́дье 'тоже' (Арх.) [Даль 1, 561], (Яр.) [Мельниченко, 68], (Яр.) [ЯОС 4, 61], заводи́на 'тоже' (Костр.: Галич., Чухл.; Яр.: Пош.) [КСГРС], (Яр.: Бор., Пош., Рост.; Ив.) [ЯОС 4, 60].

Лексема за́водь имеет широкую «водную» семантику: 'глубокое место в море, закрытое островом или мысом, или же искусственно огражденное, - в море для уменьшения волнения, в реке для ослабления быстроты течения' (Арх.) [Подвысоцкий, 47], 'глубокое место в реке, омут’ (Арх.: Вель., В.-Т., Карг., Пин., Уст.; Влг.: Бел., Ник.) [КСГРС], 'голое место среди зарослей в озере или реке' (Яр.) [ЯОС 4, 60], 'место у речного порога, где вода, ударяясь о камень, принимает обратное течение' (Арх.: Кем.) [Опыт, 60], (Арх.: Он.) [Подвысоцкий, 47], 'водоворот в реке' (Арх.: Вель., В.-Т., Вин., Пин., Уст., Холм.; Влг.: Ник., Хар.) [КСГРС], 'место, где река берет свое начало’ (Яр.) [ЯОС 4, 61], 'старое русло реки' (Костр.: Мант., Чухл.) [КСГРС], 'небольшое озеро на месте старого русла реки' (Влг.: М.-Реч., Ник., Тарн.) [СВГ 2, 103], (Яр.) [ЯОС 4, 60], 'место, покрытое водой после половодья' (Костр.: Меж., Чухл.) [КСГРС], (Яр.) [Даль 1, 561; Мельниченко, 68], (Яр.: Дан., Некр., Перв., Тут.) [ЯОС 4, 60], 'полоса воды, появившаяся около берега перед началом таяния всего льда’ (Яр.: Рост.) [ЯОС 4, 60], 'мелкий заросший пруд’ (Яр.: Рост.) [ЯОС 4, 60], 'изгородь, перегораживающая реку’ (Влг.: Кадн.) [Дилакторский, 142], 'изгородь у взморья для невыпуска скота' (Арх.: Он.) [Подвысоцкий, 47], 'сырое место рядом с болотом, на котором растет лес' (Яр.: Дан.) [ЯОС 4, 60], 'место, защищенное от ветра' (Олон.: Пт.) [Куликовский, 25]. 
Дериваты немногочисленны: заводи́на 'излучина реки' (Костр.: Галич.), 'рукав реки’ (Костр.: Галич.) [КСГРС], 'голое место среди зарослей в озере или реке' (Яр.) [ЯОС 4, 60], 'сырое затопленное место на берегу реки' (Яр.: Пош.) [КСГРС], 'низкое болотистое место' (Яр.: Бор.) [ЯОС 4, 60], за́водье 'место, покрытое водой после половодья' (Яр.: Дан.) [ЯОС 4, 61], заво́дье 'место на реке с наибольшей шириной и наименьшим течением' (Яр.: Люб.) [ЯОС 4, 61], 'глубокое место в реке, омут' (Арх.: В.-Т.) [КСГРС], 'место, покрытое водой после половодья’ (Яр.) [Мельниченко, 68], ‘топкое трясучее место’ (Костр.: Пыщуг.) [КСГРС].

Специфической севернорусской лексемой является губа́ 'на севере России: название морских заливов' [ТСРЯ, 175], 'морской, озерный или речной залив’ (Арх.: Он., Холм.; Влг.: Кир.) [КСГРС], (Кол.) [Меркурьев, 37], (Помор.) [Мосеев, 54; Гемп, 286]. Лексема интерпретируется как дериват с первоначальным значением 'складка, загиб' от праслав. *gub- 'гнуть' [Фасмер 1, 469]. Наиболее частотны производные от губа́ с приставкой за-, обозначающие как сам залив, так и прилегающее к нему пространство: за́губа 'участок берега возле озерной губы' (Карел.: Медв.) [СРГК 2, 111], загу́ба 'залив реки, озера, губа' (Карел.: Кондоп.; Ленингр.: Подп.) [СРГК 2, 111], загуба́винка 'то же'(Карел.: Кондоп.) [СРГК 2, 111], загу́бина 'то же' (Карел.: Кондоп., Медв.) [СРГК 2, 111], загу́бинка 'то же'(Карел.: Медв.) [СРГК 2, 111], загу́бка 'то же' (Карел.: Медв., Пуд.) [СРГК 2, 111], (Влг.: Выт.) [КСГРС], загу́бочка 'то же' (Карел.: Кондоп.) [СРГК 2, 111], за́zубье 'залив реки, озера, губа' (Карел.: Медв.) [СРГК 2, 111], (Кол.) [Меркурьев, 48], 'речной залив, дельта в морской губе' (Помор.) [Гемп, 287], 'участок берега возле озерной губы' (Карел.: Кондоп., Медв.) [СРГК 2, 111]. Используется в деривации также приставка при-: при́суб 'морская губа, залив' (Мурм.: Тер.) [СРГК 5, 154], пригу́бок 'то же' (Мурм.: Тер.) [СРГК 5, 154], пригу́бочка 'небольшой залив' (Карел.: Медв.; Мурм.: Канд.) [СРГК 5, 154]. Особый диалектный термин, не имеющий семантических аналогов в русском литературном языке, - пригу́б 'место на реке, где сходятся две губы' (Арх.: Мез.) [КСГРС]. Значимым оказывается также обозначение конца губы, залива — коне́и губье (Олон.: Заон.) [Куликовский, 40], конеи гу́бье (Карел.: Медв.) [СРГК 2, 413].

От корня лук- (< праслав. *lqkъ, производному с вокализмом -oот *lękti 'гнуть, сгибать' [ТСРЯ, 418]) образованы лука́, лучо́к 'залив, губа' (Твер.) [Доп.-Опыт, 104], залу́чина 'залив, заводь на реке' (Влг.: Кад.), прилу́к ‘заводь' (Влг.: Кир.) [КСГРС]. 
Праслав. корень *pon-, имеющий семантику соединения и связанный чередованием гласных с *pinati (русск. пина́mь), отражен в за́nонь 'заводь, залив' (Арх.: Плес.; Влг.: Кир.) [КСГРС]. Синонимичный праслав. корень *ton- представлен в зато́н 'речной или озерный залив' (Арх.: Вин.; Киров.: Халт.) [КСГРС], (Костр.: Костр., Красн., Мант., Нейск., Парф.) [ККОС, 127-128], затя́z 'залив, глубоко врезавшийся в материковый берег’ (Арх.: Шенк.) [Опыт, 68; Подвысоцкий, 54], (Арх.) [Даль 1, 655], (Помор.) [Гемп, 288], затяга́лка 'залив' (Арх.: Пин.) [КСГРС]. Праслав. *plets- (< *plet- 'плести') [ТСРЯ, 652 ] отражено в плёс 'залив озера' (Костр.: Галич.) [ККОС, 250], приплёсок 'залив'(Влг.: Тот.) [Дилакторский, 406]. Результатом обратного словообразования от последнего является при́nлеск 'залив' (Влг.: У.-Куб.) [КСГРС].

К праслав. *xab- (< праслав. *skob- 'скрести, скоблить' [ТСРЯ, 710]) восходят хаб 'длинный узкий залив’ (Костр.: Кологр., Мант.; Яр.: Некр.) [КСГРС], хаби́на 'речной залив' (Арх.: Шенк.) [Подвысоцкий, 182], (Арх.: Вель.) [КСГРС], заха́бина 'заводь, непроточное место в излучине реки’ (Карел.: Медв.; Ленингр.: Лод., Подп.) [СРГК 2, 230], ср. хаб 'течение, ударяющее в берег' (Костр.: Мант., Пыщуг.) [КСГРС], хаби́на 'вырванная водой часть берега' (Арх.: Вель.) [КСГРС].

Праслав. корень *kos-/*kes-, представленный в косá 'идущая от берега низкая и узкая полоса земли’ [ТСРЯ, 370] (cp. чесámb 'употребляется для обозначения быстрого, энергичного действия', < *česati [ТСРЯ, 1089]), отражен в зако́ска 'заводь' (Костр.: Кологр.) [КСГРС], за́косок 'небольшой открытый залив в реке' (Влг:: Сольв.) [Дилакторский, 153], (Арх.: Котл., Лен.) [КСГРС], зако́сок 'залив' (Костр.: Кологр., Меж., Пыщуг.) [КСГРС].

Наименование заколу́пок 'небольшой залив' (Арх.: Нянд.) [КСГРС] соотносится с глаголом колупа́ть 'ковырять, отдирать' < праслав. kolupati, являющемуся сложением префикса *ko- и глагола *lupati, соотносимого с *lupiti (русск. лупи́ть 'сильно бить, хлестать') [ТСРЯ, 351, 419].

Лексема чеку́ша ‘небольшой узкий заход от залива в берег’ (Арх.: Прим.) [КСГРС] связана с праслав. *čekati 'тыкать' [ТСРЯ, 1085]. Ей близка по внутренней форме лексема заколю́га 'небольшой залив' (Арх.: Плес.) [КСГРС], имеющая производное заколюжсина (Помор.) [Гемп, 288] с тем же значением: слово имеет праслав. корень *kol-, представленный в русск. коло́ть 'раздроблять, рассекать, делить на куски' [ТСРЯ, 350].

Поздними отглагольными наименованиями по динамическому признаку реалии являются вы́ пад ‘залив реки’ (Киров.: Халт.) 
[КСГРС] (вторичное к вы́nad 'устье реки' (Влг.: В.-Важ.; Киров.: Халт.; Костр.: Нейск.) [КСГРС], (Арх.: Шенк.) [АОС 8, 47], (Карел.: Лоух.) [СРГК 1, 275]), за́nadв 'залив' (Арх.: Карг., Кон.), запа́дина 'то же' (Влг.: Бел.) [КСГРС], про́йма 'залив речной, заводь' (Арх.) [Даль 3, 500], заперту́ха 'залив между берегом и речной косой' (Арх.: Леш.) [КСГРС], запла́в 'небольшой речной залив' (Влг.: Сок.) [СВГ 2, 139], отро́сток 'залив' (Яр.: Некр.) [КСГРС], урь́лина 'небольшой залив на реке' (Арх.: Шенк.) [КСГРС], по́тыць ‘мелкая морская губа' (Помор.) [Мосеев, 100] (корень тыци- отражает цоканье и восходит к *tyk-, который представлен в *tykati (русск. ты́ккать) [ТСРЯ, 1009]). Лексема ножо́мина 'небольшой залив на реке' (Влг.: Вож.) [КСГРС] - результат гиперкорректного оканья: < *нажо́мина, — производному от глагола нажа́mь 'давя, притиснуть, надавить' [ТСРЯ, 480].

Единственной лексемой, во внутренней форме которой отражается связь с деятельностью человека, является засто́и 'пристанища для судов в заливах Онежского озера' (Олон.) [Куликовский, 24].

Залив, заводь нередко номинируются по одному из значимых для называющего признаков локуса: глади́нка 'тихое место, заводь' (Карел.: Медв.) [СРГК 1, 333], го́лымя 'залив на озере' (Арх.: Плес.) [КСГРС], тихово́д 'небольшой залив у реки' (Влг.: Тот.), тихово́дь 'спокойное место на реке, заводь' (Костр.: Пыщуг.), тихово́дье 'то же' (Арх.: Лен.), múхое плёсо 'то же' (Арх.: В.-Т., Карг.) [КСГРС], за́тишь ‘залив’ (Влг.: Кир.), зати́шье 'то же' (Арх.: Вил.) [КСГРС], кругля́ха 'залив круглой формы с узким проливом в реку' (Арх.: Он.) [КСГРС], заому́ток, заоми́mье 'залив с непроточной водой на реке или старица' (Арх.: Он.) [СРГК 2, 166], острога́ны 'мелкие заливцы по песчаному берегу озера' (Твер.) [Даль 2, 622], балабо́льник 'заводь, заросшая балаболками (кувшинками)' (Арх.: Прим.) [КСГРС].

Наименование калу́жина 'залив реки, озера' (Влг.: У.-Куб.) [КСГРС] вторично от калу́жина 'яма с водой, лужа' (Киров.: Халт.; Костр.: Антр., Галич., Кологр., Костр., Макар., Меж., Пыщуг., Чухл.) [КСГРС], (Яр.) [Мельниченко, 84], (Яр.: Брейт., Дан., Люб., Мышк., Пош., Преч., Рыб.; Костр.: Антр., Галич.) [ЯОС 5, 16], которое является приставочным образованием с архаическим префиксом к $a$ - от лу́жа 'небольшое углубление на почве, наполненное дождевой или подпочвенной водой’ [ТСРЯ, 418].

Севернорусское куm 'залив на озере' (Арх.: Карг., Леш., Мез.) [КСГРС], 'узкий конец залива' (Арх.: Прим.) [КСГРС], (Арх.: Кем., Кол., Он.) [Подвысоцкий, 79], (Мурм.: Тер.) [СРГК 3, 74], (Помор.) [Гемп, 292] и производное прилагательное кутово́й 'небольшой по 
длине, похожий на залив (о реке)' (Арх.: Прим.) [КСГРС] образованы от кym 'угол помещения' (< праслав. *kotъ) [ТСРЯ, 393]. Близкая по модели метафора представлена в зау́лок 'залив' (Костр.: Кологр., Пыщуг.) [КСГРС], ср. зау́лок 'переулок, проулок между домами в деревне' (Влг.) [Дилакторский, 165], (Арх.: Он.) [Подвысоцкий, 54], (Арх.: Он.; Влг.: Баб., Бел., Ваш., Влгд., Кир., Устюж., Череп., Шексн.; Карел.: Кем.; Ленингр.: Кириш., Лод., Тихв.; Мурм.: Канд.; Новг:: Новг., Пест., Чуд.) [СРГК 2, 226], (Влг.: Баб., Влгд., Вож., Гряз., Кир., К.-Г., М.-Реч., Ник., Сок., Сямж., Тот., У.-Куб., Шексн.) [СВГ 2, 158], (Яр.: Брейт., Гавр., Люб., Нек., Некр., Перв., Пересл., Преч., Рыб., Ряз., Тут., Яросл.; Костр.: Буйск.) [ЯОС 4, 109], (Яр.: Люб., Пош.) [КСГРС].

Лексемы рука́в 'залив в реке или озере' (Арх.: Карг., Кон.), рукави́на 'то же' (Арх.: Он.), рука́вка 'узкая заводь' (Арх.: Прим.) [КСГРС] - метафоры от рука́в 'часть одежды, покрывающая руку' [ТСРЯ, 843]. Анатомическая метафора представлена в коленова́тый 'имеющий много заливов (о реке или озере)' (Псков.; Твер.) [Доп.Опыт, 86].

В целом исконные наименования залива преимущественно отглагольны, их внутренняя форма отражает внешние признаки объекта, особенности возникновения географического локуса.

\section{СОКРАЩЕНИЯ}

\section{1. Словари и источники}

АОС - Архангельский областной словарь / Под ред. О. Г. Гещовой. М., 1980-. Вып. 1-.

Гемп - Гемп К. П. Сказ о Беломорье. Словарь поморских речений. М.; Архангельск, 2004.

Даль - Даль В. И. Толковый словарь живого великорусского языка. М., 1955. Т. 1-4.

Дилакторский - Дилакторский П. А. Словарь областного вологодского наречия в его бытовом и этнографическом применении. Вологда, 1902.

Доп.-Опыт - Дополнение к «Опыту областного великорусского словаря». СПб., 1858.

ККОС - Живое костромское слово. Краткий костромской областной словарь / сост. Н. С. Ганцовская, Г. И. Маширова. Кострома, 2006.

КСГРС - Картотека «Словаря говоров Русского Севера» (хранится на кафедре русского языка и общего языкознания УрФУ). 
Куликовский - Куликовский Г. Словарь областного олонецкого наречия в его бытовом и этнографическом применении. СПб., 1898.

Мельниченко - Мельниченко Г. Г. Краткий ярославский областной словарь. Ярославль, 1961.

Меркурьев - Меркурьев И. С. Живая речь кольских поморов. Мурманск, 1979.

Мосеев - Мосеев И. И. Поморьска говоря. Краткий словарь поморского языка. Архангельск, 2005.

Опыт - Опыт областного великорусского словаря, изданный Вторым отделением Академии наук. СПб., 1852.

Подвысоцкий - Подвысоикий А. Словарь областного архангельского наречия в его бытовом и этнографическом применении. СПб., 1885.

СВГ - Словарь вологодских говоров. Вологда, 1983-2007. Вып. $1-11$.

СРГК - Словарь русских говоров Карелии и сопредельных областей. Вып. 1-6 / Гл. ред. А. С. Герд. СПб., 1994-2005.

ТСРЯ - Толковый словарь русского языка с включением сведений о происхождении слов. М., 2008.

Фасмер - Фасмер М. Этимологический словарь русского языка: в 4 т. М., 1964-1973.

ЯОС - Ярославский областной словарь. Ярославль, 1981-1991. Вып. 1-10.

2. Языки и диалекты

праслав. — праславянский язык

русск. - русский язык

3. Географические названия

Антр. - Антроповский район Костромской области

Арх. - Архангельская область (губерния)

Баб. - Бабаевский район Вологодской области

Бабуш. - Бабушкинский район Вологодской области

Бел. - Белозерский район Вологодской области

Больш. - Большесельский район Ярославской области

Бор. - Борисоглебский район Ярославской области

Брейт. - Брейтовский район Ярославской области

Буйск. - Буйский район Костромской области

Ваш. - Вашкинский район Вологодской области

В.-Важ. - Верховажский район Вологодской области

Вель. - Вельский район Архангельской области 
??? - Вельский уезд Вологодской губернии

Вил. - Вилегодский район Архангельской области

Вин. - Виноградовский район Архангельской области

Влг. - Вологодская область (губерния)

Влгд. - Вологодский район Вологодской области

Вож. - Вожегодский район Вологодской области

В.-Т. - Верхне-Тоемский район Архангельской области

Выт. - Вытегорский район Вологодской области

Галич. - Галичский район Костромской области

Гавр. - Гаврилов-Ямский район Ярославской области

Гряз. - Грязовецкий район Вологодской области

Дан. - Даниловский район Ярославской области

Заон. - Заонежский уезд Олонецкой губернии

Ив. - Ивановская область

Кад. - Кадуйский район Вологодской области

Кадн. - Кадниковский район Вологодской области

Канд. — Кандалакшский район Мурманской области

Карг. - Каргопольский район Архангельской области

Карел. - республика Карелия

К.-Г. — Кичменгско-Городецкий район Вологодской области

Кем. - Кемский уезд Архангельской губернии

??? - Кемский район Карелии

Кир. - Кирилловский район Вологодской области

Кириш. - Киришский район Ленинградской области

Киров. - Кировская область

Кол. - Кольский уезд Архангельской губернии

??? - Кольский полуостров

Кологр. - Кологривский район Костромской области

Кон. - Коношский район Архангельской области

Кондоп. - Кондопожский район Карелии

Костр. - Костромская область

??? - Костромской район Костромской области

Красн. - Красносельский район Костромской области

Лен. - Ленский район Архангельской области

Ленингр. - Ленинградская область

Леш. - Лешуконский район Архангельской области

Лод. - Лодейнопольский район Ленинградской области

Лоух. - Лоухский район Карелии

Люб. - Любимский район Ярославской области

Мант. - Мантуровский район Костромской области 
Медв. - Медвежьегорский район Карелии

Меж. - Межевской район Костромской области

Мез. - Мезенский район Архангельской области

Моск. - Московская область

М.-Реч. - Междуреченский район Вологодской области

Мурм. - Мурманская область

Нейск. - Нейский район Костромской области

Нек. - Некоузский район Ярославской области

Некр. - Некрасовский район Ярославской области

Ник. - Никольский район Вологодской области

Новг. - Новгородская область

Нянд. - Няндомский район Архангельской области

Олон. - Олонецкая губерния

Он. - Онежский район Архангельской области

Парф. - Парфеньевский район Костромской области

Перв. - Первомайский район Ярославской области

Пересл. - Переславский район Ярославской области

Пест. - Пестовский район Новгородской области

Пин. - Пинежский район Архангельской области

Плес. - Плесецкий район Архангельской области

Подп. - Подпорожский район Ленинградской области

Помор. - Поморье (побережье Белого моря)

Пош. - Пошехонский район Ярославской области

Преч. - Пречистенский район Ярославской области

Прим. - Приморский район Архангельской области

Псков. - Псковская область

Пт. - Петрозаводский уезд Олонецкой губернии

Пуд. - Пудожский район Карелии

Пыщуг. - Пыщугский район Костромской области

Рост. - Ростовский район Ярославской области

Рыб. - Рыбинский район Ярославской области

Ряз. - Рязанский район Ярославской области

Сок. - Сокольский район Вологодской области

Сол. - Солигаличский район Костромской области

Сольв. - Сольвычегодский уезд Вологодской губернии

Сямж. - Сямженский район Вологодской области

Тарн. - Тарногский район Вологодской области

Твер. - Тверская область (губерния)

Тер. - Терский район Мурманской области

Тихв. - Тихвинский район Ленинградской области 
Тот. - Тотемский район Вологодской области

Тут. - Тутаевский район Ярославской области

У.-Куб. - Усть-Кубинский район Вологодской области

Уст. - Устьянский район Архангельской области

Устьс. - Устьсысольский уезд Вологодской губернии

Устюж. - Устюженский район Вологодской губернии

Халт. - Халтуринский район Кировской области

Хар. - Харовский район Вологодской области

Холм. - Холмогорский район Архангельской области

Череп. - Череповецкий район Вологодской области

Чуд. - Чудовский район Новгородской области

Чухл. - Чухломской район Костромской области

Шексн. - Шекснинский район Вологодской губернии

Шенк. - Шенкурский район Архангельской области

Яр. - Ярославская область

Ярен. - Яренский уезд Вологодской губернии

Яросл. — Ярославский район Ярославской области

\section{O. A. Teush}

The native vocabulary with the semantics of 'bay' in the dialects of the European North of Russia

The article is devoted to vocabulary with the semantics of 'bay' in the dialects of the European North of Russia. All of the identified set of tokens is analyzed from the point of view of the origin of words and their semantic relations; the onomasiological models are interpreted.

Keywords: lexeme, semantics, meaning, Russian language, the semantics of 'bay', geographical terminology, dialect vocabulary. 


\title{
Место визуального кода в поэзии русского авангарда и его эволюция в 1910-1920-е годы
}

\begin{abstract}
В статье рассматривается феномен книги русского футуризма 1910-х гг. (печатные поэтические сборники и «самописные» издания), установка на разрушение канона книжного издания и разработка новых изобразительных приемов, которые формируют модель книги авангарда. Второй ключевой этап в создании такой модели являет собой конструктивистская книга 1920-х гг. Особый акцент в статье делается на изучении визуального оформления сборников маленьких поэтических групп начала 1920-х гг. («экспрессионисты», фуисты, ничевоки, биокосмисты), выступающих преемниками новаторских находок «будетлян».

Ключевые слова: поэзия русского авангарда, русский футуризм, книга русского авангарда, конструктивизм, поэтические группь 1920-х г2., «экспрессионистыл», фуисты, ничевоки, биокосмисты.
\end{abstract}

DOI: $10.31168 / 2073-5731.2018 .3-4.6 .01$

Русский авангард в своем стремлении средствами искусства выразить новое мировосприятие, запечатлеть его целостность и всеохватность, отразить новые отношения человека с миром был нацелен на поиски универсальной художественной техники. Установка авангарда на синтез искусств выражалась в поиске «общих для всех видов искусств принципов, позволяющих выявить близость элементов различных художественных языков на основе схожести ощущений при их восприятии» ${ }^{.}$Если символизм был преимущественно ориентирован на музыку, то для авангарда и футуризма определяющей оказалась панживописная концепция. Традиционно русский кубофутуризм рассматривается именно как живописно-поэтический, непосредственно связанный с художественной практикой левых течений в искусстве. Так, в рамках словесного искусства «будетлян» проходит активная реализация принципов, характерных для изобразительного искусства, сами деятели авангарда являются одновременно художниками, поэтами и теоретиками искусства.

Уникальным объектом становится книга, объединяющая в себе работу литератора, художника и типографа, нацеленная благодаря 


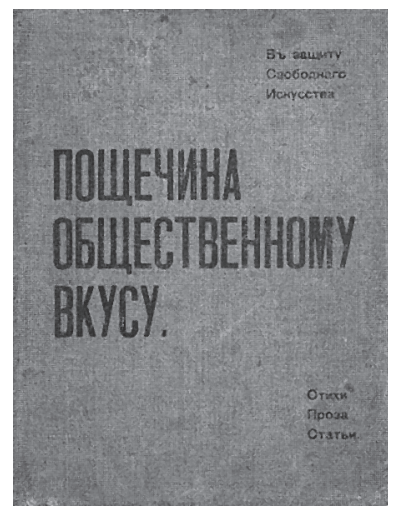

Ил. 1

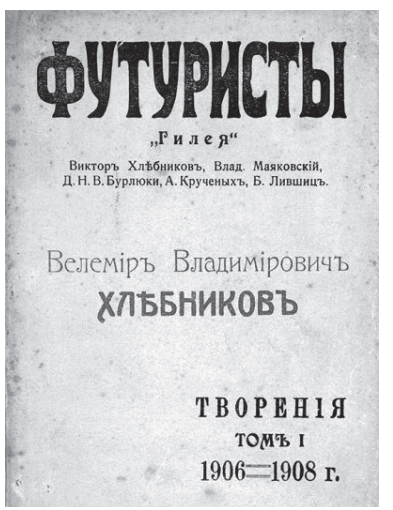

Ил. 3

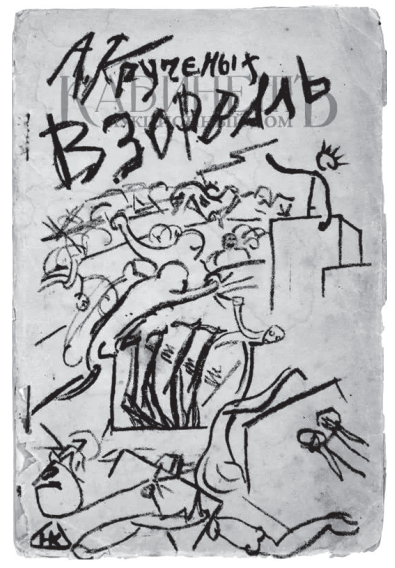

Ил. 5

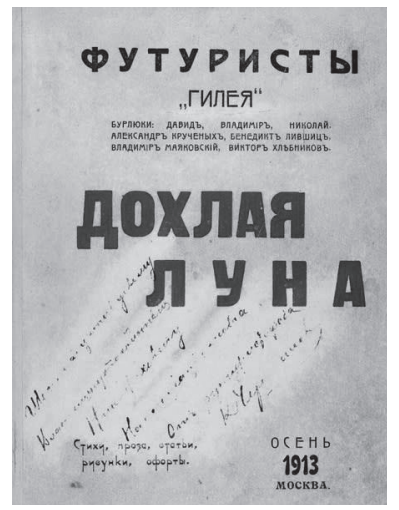

Ил. 2

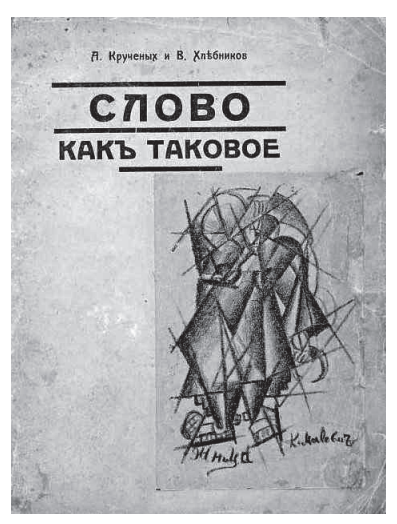

Ил. 4

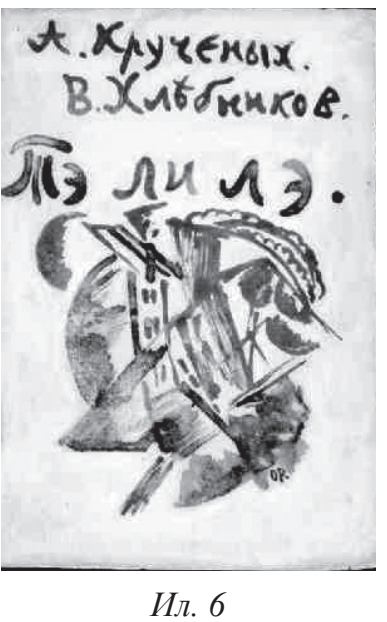


своему печатному характеру на массовую аудиторию, она становится своего рода моделью искусства авангарда ${ }^{2}$. Оге А. Ханзен-Лёве в своем исследовании интермедиальности в русской культуре отмечает, что «здесь речь идет о фундаментальной, а не об орнаментальной рефлексии и презентации медиума. >..> Медиум или знаковые структуры вербального и изобразительного элемента уже не выступают в орнаментальной гармонии или в гармонии настроения так, как это происходит в югендштиле. Связь между текстом и текстурой является принципиальной, конструктивной, структурной. Сама буква точно так же, как звучание слова и материальный язык бумаги и типографской краски, становится носителем самостоятельного значения» ${ }^{3}$. Книга в русском футуризме 1910-х гг., таким образом, смогла объединить все опыты по созданию нового языка, которые проводились художниками в изобразительном искусстве и поэтами в словесном творчестве, демонстрируя эволюцию от примитивизма к беспредметности в живописи и от словотворчества к зауми.

Из известных примеров в европейском искусстве авангарда достаточно упомянуть опыты Т. Маринетти («Zang Tumb Tuuum», 1914) и Г. Аполлинера («Калиграммы. Стихотворения мира и войны (1913-1916)», 1918), альбомы немецких экспрессионистов, книги М. Жакоба и П. Пикассо («Св. Маторель», 1911, «Осада Иерусалима», 1914), Б. Сандрара и С. Делоне («Проза о транссибирском экспрессе и маленькой Жанне Французской», 1913). Владимир Поляков, сравнивая классические образцы футуризма в книге с работами русских мастеров, справедливо отмечает: «Всё, что традиционно относится к футуристическим экспериментам в книге, — разрушение логической связанности текста, многообразие ритмики строк, использование на пространстве одной страницы разных типов шрифта и т. д. - можно обнаружить и в русской книге. Но эти эксперименты отнюдь не являются ее главной особенностью. Истинное новаторство русских мастеров заключалось как раз в полном отказе от безликости типографского шрифта, в возврате к эмоциональной непосредственности, свойственной рукописной книге. Художник перестает быть только автором иллюстраций. Благодаря возможностям литографии он становится автором всей книги от ее первой до последней страницы - от исполнения рисунков до написания текста» ${ }^{4}$. Среди работ русских мастеров следует, таким образом, выделить два типа книг: печатные сборники русских футуристов и так называемые «самописные» издания. Последние представляют собой уникальную находку русских авангардистов, полностью отказавшихся от типографского набора и обратившихся к 
технике литографии, которая давала возможность передать авторский почерк - важный элемент в восприятии поэтического текста, находящийся в композиционном и стилистическом единстве с рисунками. Оба элемента, как правило, выполнялись единовременно одной рукой, формируя цельное пространство страницы. Так, по наблюдению Ханзен-Лёве, «футуристическая книга, с одной стороны, в духе неопримитивизма отступает в догутенберговский мир уникальных предметов и hand-made, т. е. в ауретический мир средневековых писцов, с другой стороны - в сферу тривиальной, массовой типографской продукции, проспектов, плакатов, лозунгов и рекламных щитов» ${ }^{5}$. Среди значительного числа сборников можно упомянуть следующие: «Студия импрессионистов» (СПб., 1910), «Садок судей», «Садок судей ІІ» (СПб., 1910; 1913), «Пощечина общественному вкусу» (М., 1912), «Затычка» (М., 1913), «Трое» (СПб., 1913), «Требник троих» (М., 1913), «Дохлая луна» (М., 1913), «Слово как таковое» (М., 1913), А. Крученых «Чорт и речетворцы» (СПб., 1913), Зина В., А. Крученых «Поросята» (СПб., 1913), «Победа над солнцем» (СПб., 1913), «Молоко кобылиц» (М., 1914), В. Хлебников «Творения» (М., 1914), В. Маяковский «Владимир Маяковский» (М., 1914), «Ослиный хвост и мишень» (М., 1913), В. Каменский «Танго с коровами: железобетонные поэмы» (М., 1914) и др. «Самописная» книга представлена изданиями: А. Крученых «Старинная любовь» (М., 1912), «Помада» (М., 1913), «Полуживой» (М., 1913), «Пустынники» (М., 1913), «Взорваль» (СПб., 1913), «Утиное гнездышко... дурных слов» (СПб., 1913); А. Крученых, В. Хлебников «Игра в аду», «Игра в аду. 2-е дополненное издание» (М., 1912; 1914), «Мирсконца» (М., 1912), «Тэ ли лэ» (СПб., 1914); В. Хлебников «Изборник» (СПб., 1914); А. Крученых, Р. Алягров «Заумная гнига» (М., 1915-1916), А. Крученых, О. Розанова «Вселенская война» (Пг., 1916) и др. ${ }^{6}$ Художниками изданий выступили К. Малевич, О. Розанова, М. Ларионов, Н. Гончарова, Н. Кульбин, П. Филонов и др.

Русская футуристическая книга 1910-х гг. представляет, таким образом, начальный ключевой этап в радикальном преобразовании феномена книги: всего за несколько лет с 1909 по 1916 г. были сформированы все основные подходы и приемы в оформлении, которые в дальнейшем будут применяться во всех левых изданиях ${ }^{7}$. К ним можно отнести: разрушение классического канона издания, грубую, агрессивную экспрессию, ориентацию на примитив, акцент на шероховатости фактуры, присущей как литографическому штриху, так и используемому материалу (тонированной оберточной бумаге, обоям, мешковине и т. д.), провокационную скудность полиграфических 
средств, обращение к технике коллажа, установку на нераздельное восприятие текста и визуального оформления. Всё это неизменно указывает на изначальную нацеленность на нечто табуированное и маргинальное, приобретающее идеологический и стилистический статус для «левых» течений в искусстве. Именно визуальная составляющая поэтических сборников со временем начинает приобретать всё более самодовлеющий характер, уводящий изобразительные элементы в область абстракции. Связующим звеном между «самописной» книгой 1910-х гг. и конструктивистской книгой 1920-х гг, которая представляет следующий ключевой этап и своего рода второй полюс в развитии книги русского авангарда, выступили тифлисские «заумники» из группы « $41^{\circ} »$, отошедшие от использования корявого рукописного почерка литографированных футуристических сборников и обратившиеся к наборному шрифту с разными литерами, по-новому организовывая плоскость листа: «Создавался жесткий ритм, плакатная монументальность. Слова впечатывались в текст и в сознание читателей, словно заголовок афиши или рекламы» ${ }^{8}$. Опыт тифлисцев не прошел без следа для конструктивистов-лефовцев: согласно замечанию Юрия Молока, плакатные принципы проявили себя в замене изобразительного орнамента геометрическим, рисованного шрифта - афишным, иллюстрации - фотомонтажом, а также в обнажении типографской краски, применении газетной верстки и т. д. ${ }^{9}$ Конструктивистская книга отходит от уникального, единичного, рукописного характера футуристической книги 1910-х гг. и стремится к унификации, к устранению индивидуального в пользу коллективного, единого принципа для всех. Конструктивистский визуальный ряд опирается на объективную данность фотографии, тем самым встраиваясь в принцип «жизнестроения», книга в данном случае уже направлена на окружающую действительность, на реально существующие объекты и «соотносится с ней не как идеал, но как данность» ${ }^{10}$ (ил. 7).

В промежутке между этими двумя ключевыми этапами оказались маленькие поэтические группы начала 1920-х гг, их творчество исследователи, как правило, относят к поэзии «второго ряда», оформление их сборников позволяет увидеть, насколько поэтический авангард сумел ассимилировать и продолжал разрабатывать изобразительные приемы, сформированные кубофутуристами в начале 1910-х гг. Показательно творчество ряда групп: московских «экспрессионистов» (1919-1922) в составе поэтов Ипполита Соколова, Бориса Земенкова, Сергея Спасского, Гурия Сидорова-Окского, Бориса Лапина, Евгения Габриловича и др.; фуистов (1921-1923) — Бориса Перелешина, Николая Тихомирова, 


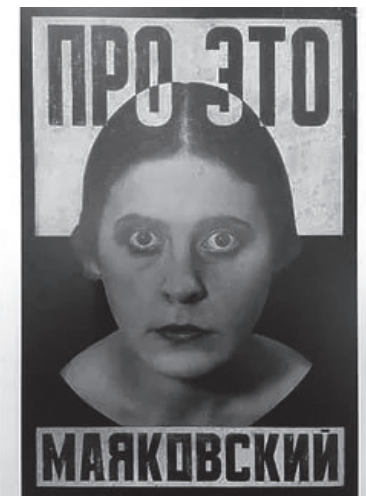

Ил. 7

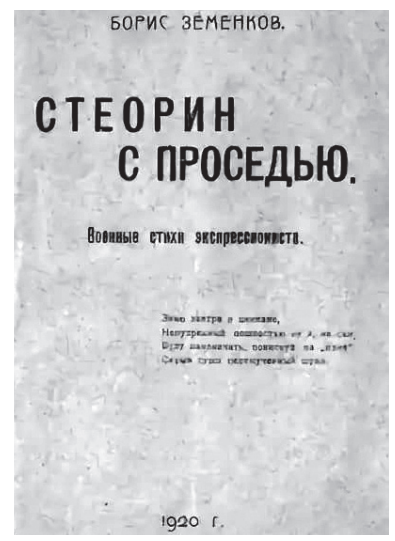

Ил. 9

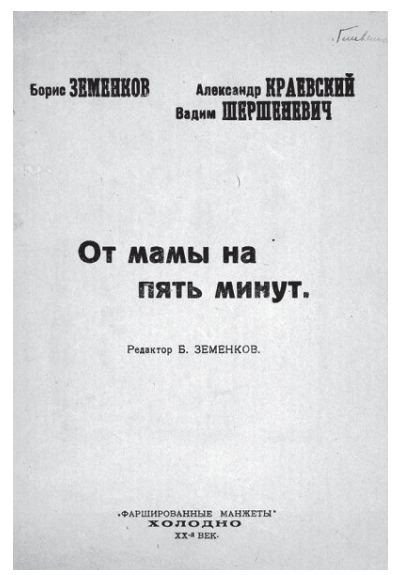

Ил. 11

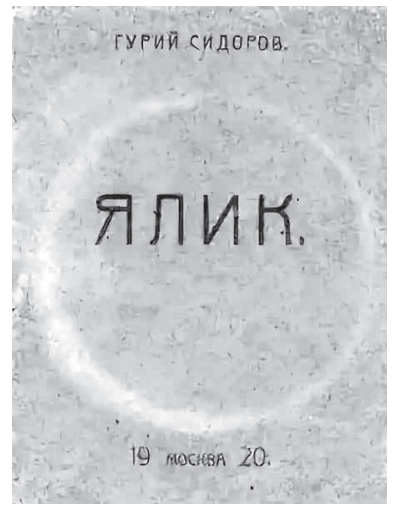

Ил. 8

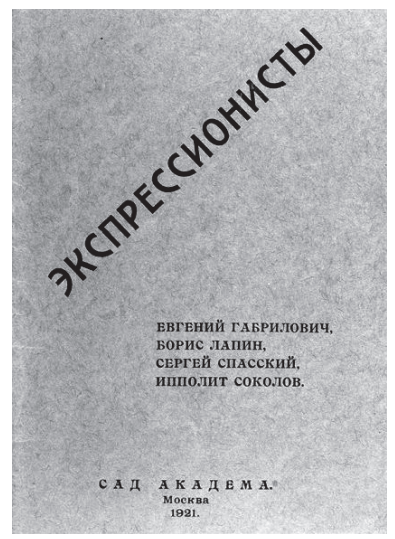

Ил. 10

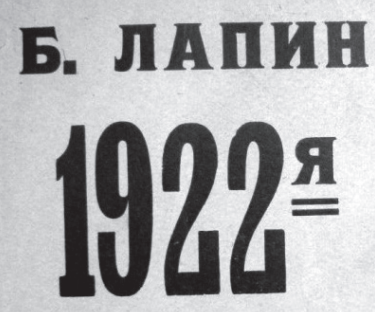

КНИГА

CTИХOB

Ил. 12 
Бориса Несмелова, Николая Лепка и Александра Ракитникова; ничевоков (1920-1923), среди которых были Рюрик Рок, Сусанна Мар, Олег Эрберг, Борис Земенков, Лазарь Сухаребский, Аэций Ранов, Сергей Садиков и др.; а также движение биокосмистов (1920-1923) во главе с Александром Святогором (Агиенко), Павлом Иваницким и Александром Ярославским. «Экспрессионисты» и примыкающие к ним фуисты представляют собой экспрессионистскую составляющую русского левого искусства ${ }^{11}$; ничевоки в своем творчестве выступают продолжателями «экспрессионистов», в частности демонстрируя следующий этап эволюции течения в направлении своего рода русского аналога европейского дадаизма. Биокосмисты в этом ряду оказываются обособленными, ориентируясь на явление русского космизма и исключительную востребованность его идей в культуре авангарда, артикулируя оптимистический, созидательный аспект последней.

В первые годы после революции, до того как начал набирать обороты конструктивизм, знаменующий собой после завершения деструктивной и индивидуалистической фазы раннего авангарда вступление искусства в созидательную стадию, молодое поколение поэтов вслед за новаторами 1910-х гг. невольно продолжало традиции футуристических сборников, хотя и громко отмежевывалось от них в своих манифестах. Оставив в стороне поэтику «экспрессионистов» и прилегающих к ним групп, которые в своей поэтической практике во многом оказывались зависимыми от имажинизма и вопреки словотворческим экспериментам не отваживались обращаться к зауми, молодые поэты, судя по внешнему оформлению их изданий, испытывали воздействие печатных сборников кубофутуристов (в частности модели, выработанной Давидом Бурлюком), а также - в несколько меньшей степени - зависели от авторитета «самописных» книг. Самой важной парадигматической фигурой для маленьких групп начала 1920-х гг. являлся Велимир Хлебников - ни один молодой поэт не избежал его поэтического влияния, визуальная составляющая его поэтики, оформление изданий сказались на художественной практике последующего поколения экспериментаторов.

Внешний облик обложек маленьких групп свидетельствует о том, что эффективность и аскетизм они заимствовали именно у Д. Бурлюка, первым обратившегося к афишному принципу оформления. Провокационность здесь присутствовала во всем, упреки в плохом вкусе воспринимались как самые лестные комплименты. Набор названия заглавными литерами наподобие газетных заголовков, заимствование приемов оформления из плакатов и рекламы с названием 
(часто эпатирующим), расположенным посередине крупными буквами на пустом листе, а также по диагонали или по вертикали, что тут же обращало на себя внимание; использование чистой типографской краски — черной и красной; фактура дешевой бумаги, оберточной, грубой тонированной, обоев; игра с различными шрифтами, их размерами, утолщением, курсивом, разрядкой — всё это представлялось абсолютным новшеством в начале 1910-х гг, а десять лет спустя вошло в обязательный арсенал оформления авангардной книги. Особая популярность данной модели была также обусловлена нехваткой средств и большим дефицитом бумаги в послевоенное время. В качестве программных моделей служили обложки таких изданий, как «Пощечина общественному вкусу» (М., 1912), «Дохлая луна» (М., 1913), В. Хлебников «Творения» (М., 1914) (ил. 1, 2, 3). Очевидно влияние последних на изобразительное решение поэтических сборников 1920-х гг:: И. Соколов «Полное собрание сочинений: Издание не посмертное. Т. 1: Не стихи» (М., 1919), Г. Сидоров «Ялик» (М., 1920), Б. Земенков «Стеарин с проседью» (М., 1920), «Экспрессионисты» (М., 1921), Б. Земенков, А. Краевский, В. Шершеневич «От мамы на пять минут» (М., 1920), Б. Лапин «1922-я книга стихов» (М., 1923); Б. Перелешин, А. Ракитников, И. Соколов «А» (М., 1921), Н. Лепок, Б. Перелешин «Мозговой ражжиж» (М., 1921); «Ничевоки. Собачий ящик, или Труды творческого бюро ничевоков в течение 1920-1921 гг. Вып. І» (М., 1921), «Биокосмисты. Десять штук» (Пг., 1923), И. Яковлев «Брызги бестиализма» (Боровичи, 1923) (ил. 8-17).

«Самописные» футуристические книги, а также иллюстративные обложки изданий Крученых, в которых название составляло непосредственную часть рисунка, также стали своего рода парадигмой для изобразительных обложек 1920-х гг. (ил. 4, 5, 6). Так, художником обложки сборника поэта-«экспрессиониста» Гурия Сидорова «Ходули» (М., 1920) выступил другой член группы Борис Земенков: изображение напечатано литографированным способом, название и имя автора в виде стилизованных пляшущих букв гармонирует с полуабстрактным рисунком, вполне отвечая концепции единства текста и визуальной составляющей «самописных» книжек (ил. 18). «Московский Парнас. Сборник второй» (М., 1922) - коллективное издание одноименной группы, примкнувшей во главе с Б. Лапиным и Е. Габриловичем к «экспрессионистам», тоже имеет иллюстративную обложку, на сей раз работы Серафимы Сирвинт (ил. 19). Стилизованные, словно вырезанные при помощи техники коллажа литографированные буквы и цифры, их угловатая графика, построенная на черно-белых контрастах, еще раз отсылают к индивидуальному, экс- 


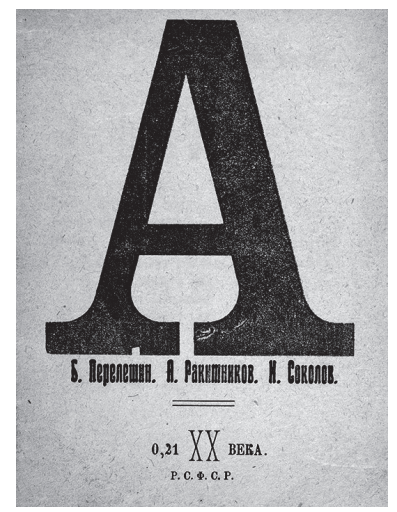

Ил. 13

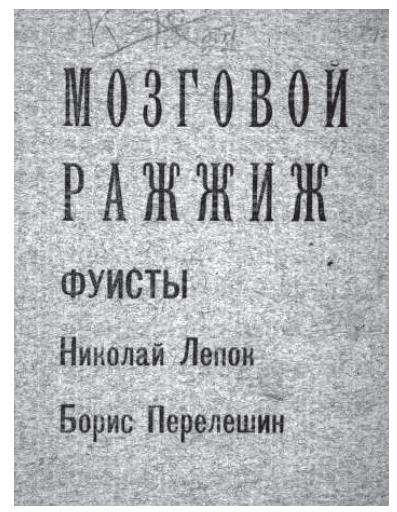

Ил. 14

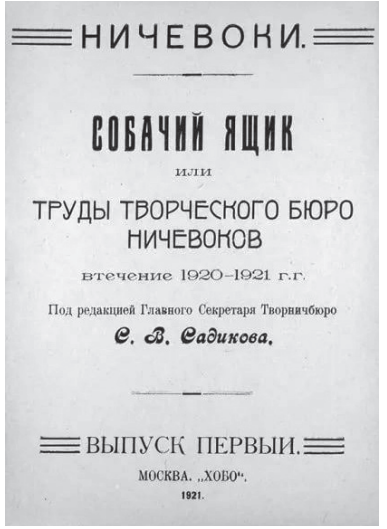

Ил. 15

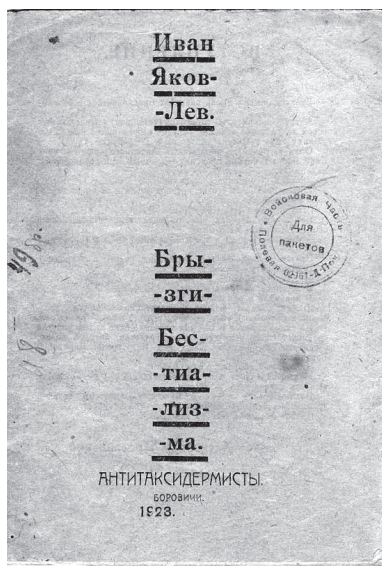

Ил. 17

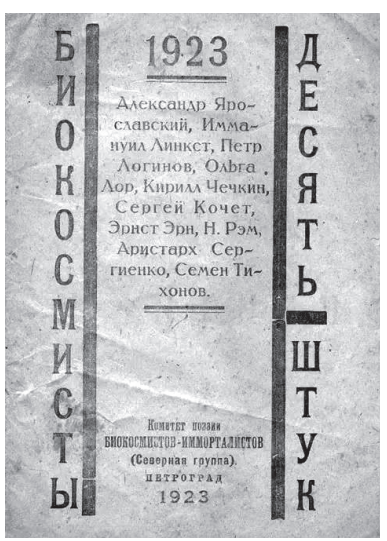

Ил. 16

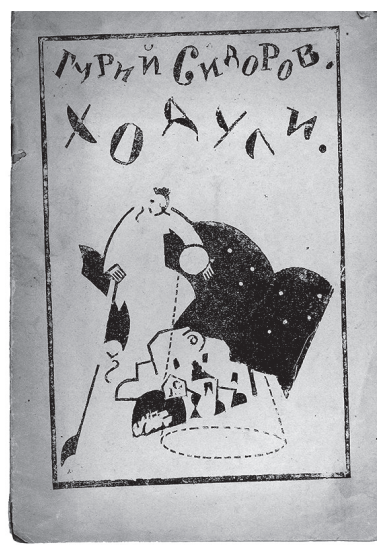

Ил. 18 


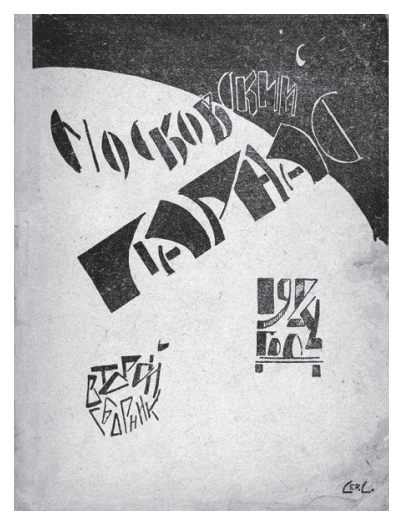

Ил. 19

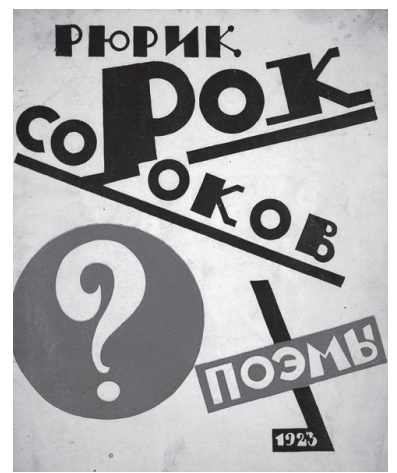

Ил. 21

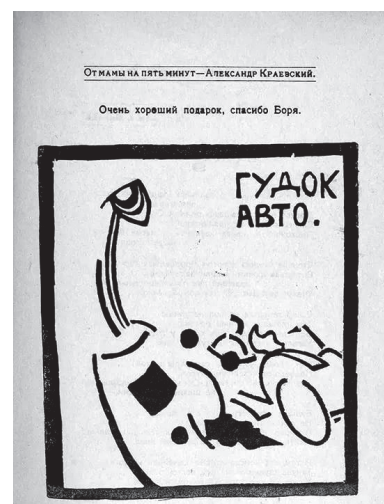

Борие. Земенхов: ГУДОК ИвТО.

Ил. 23

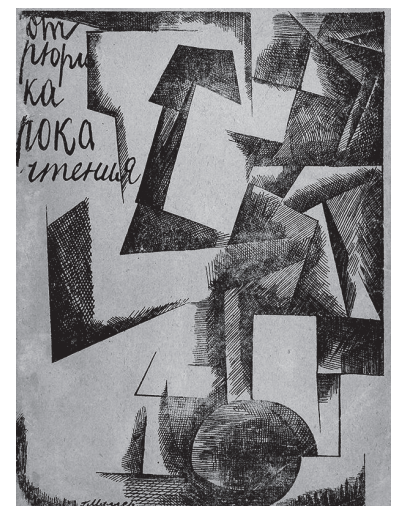

Ил. 20

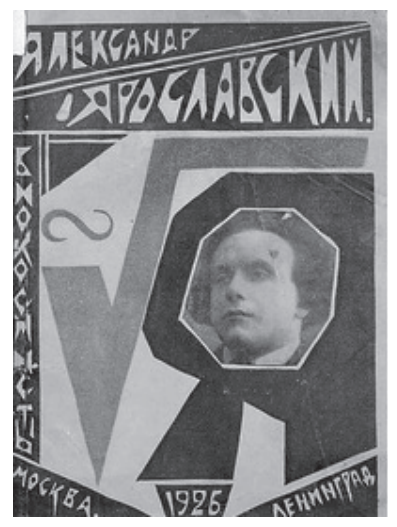

Ил. 22

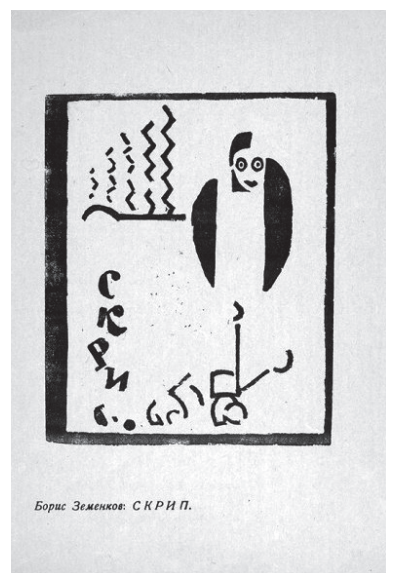

Ил. 24 
прессивному характеру обложек О. Розановой и Н. Гончаровой. Обложки изданий ничевоков также обращают на себя внимание необычностью своего визуального решения. Кубистически-абстрактное изображение работы Г. Миллера на обложке сборника «От Рюрика Рока чтения: Ничевока Поэма» (М., 1921) с вписанным в него корявым почерком названием, полностью состоящим из строчных букв без знаков переноса, вносит эмоционально-личностный элемент в напряженный тон геометрических форм рисунка (ил. 20). Другой сборник Рюрика Рока «Сорок сороков. Диалектические поэмы Ничевоком содеянные» (М., 1923) отсылает уже к другим приемам 1910-х гг., а именно к технике коллажа, здесь увеличенные в размере черные и красные буквы будто вырезаны ножницами и приклеены на белый лист бумаги (ил. 21). Интересным синтезом двух фаз в развитии искусства книги русского авангарда - кубофутуризма и конструктивизма - является книга А. Ярославского «Корень из Я», вышедшая в Москве в 1926 г. всё еще под маркой биокосмистов (ил. 22). Здесь приемы коллажа и вырезного, литографированного характера букв в названии с применением также математического знака сочетаются с конструктивистским приемом фотографической вставки.

В завершение несколько слов об иллюстрациях художника, поэта и теоретика искусства Бориса Земенкова (1902-1963)12, который становится продолжателем традиций синтеза искусств, заложенных ранним авангардом. Земенков являлся членом группы «экспрессионистов», позже, в 1922-1923 гг., примкнул к ничевокам. Художник выступал иллюстратором нескольких сборников, в частности издания, ставшего плодом сотрудничества с имажинистами А. Краевским и В. Шершеневичем, — «От мамы на пять минут» (М., 1921). Здесь помещены два его литографированных рисунка, несущие отчетливо синестезийный характер, - «Гудок авто» и «Скрип» (ил. 23, 24): художник при помощи изобразительных средств намекает на ощущения при восприятии звуковых эффектов. Подобного рода опыт был продолжен художником в уникальном тандеме с поэтом-конструктивистом А. Чичериным при работе над его книгой «Звонок к дворнику» $\left(\right.$ М., 1927) ${ }^{13}$, представляющей «графическую поэму» без слов: шесть рисунков для нее были выполнены Земенковым в экспрессионистской манере «по заданию и коррективам автора» (ил. 25). Радикальные эксперименты Чичерина были нацелены на отказ от слов и текста как такового и создание картинных и предметных композиций; таким образом, упор делался именно на визуальной составляющей поэтического творчества, что делает опыты Чичерина уникальным явлением в мировой литературе. 


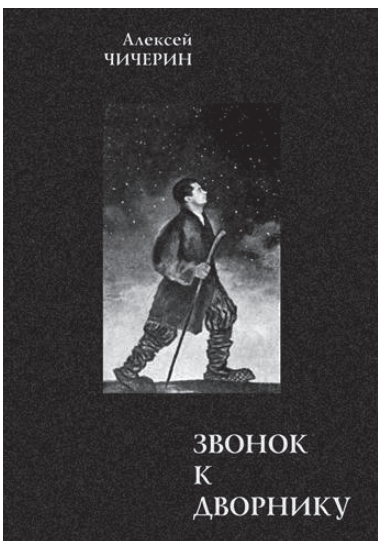

Ил. 19

Примат изобразительности и фундаментально новой эстетики, таким образом, еще больше утверждается в своих правах в 1920-е гг., визуальный ряд обложек сборников маленьких поэтических групп авангарда начала десятилетия служит тому подтверждением, следуя модели футуристической книги 1910-х гг. и предвосхищая поворот к конструктивистской книге.

\section{ПРИМЕЧАНИЯ}

1 Зайцева М. Л. Синестезия в русском авангарде М., 2014. С. 99.

2 Среди авторитетных изданий, посвященных книге русского авангарда, следует упомянуть: Gray C. The Great experiment. 1863-1922. London; New York, 1962; Compton S. The world backwards: Russian Futurist books. 19121916. London, 1978; Compton S. Russian Avangard Books. 1917-1934. London, 1992; Kowtun E. F. Die Wiedergeburt der kunstlerischen Druckgraphik: aus der Geschichte der russischen Kunst zu Beginn des zwanzigsten Jahrhunderts. Dresden, 1984; Janecek $G$. The look of Russian literature: avant-garde visual experiments. 1900-1930. Princeton, 1984; Харджиев Н., Тренин В. Поэтическая культура Маяковского. М., 1970; Харджиев Н. Статьи об авангарде: в 2 т. М., 1977; Кофтун Е. Ф. Русская футуристическая книга. М., 1989; Поляков В. Книги русского кубофутуризма. М., 1998; Бобринская E. Ранний русский авангард. М., 1999; Молок Ю. Начала московской книги. 20-е годы // Искусство книги 1967. М., 1971. Вып. 7; Герчук Ю. Русская экспериментальная поэтическая книга 1910-х годов // Искусство книги 1972-1980. М., 1987. Вып. 10; Кричевский В. Обложка: графическое лицо эпохи революционного натиска, 1917 1937. М., 2002; Кричевский В. Николай Ильин. М., 2000; Rowell M., Wye D. The Russian avant-garde book. 1910-1934. New York, 2002; Хачатуров С. В. Искусство книги в России 1910-1930-х годов. Мастера левых течений: материалы к каталогу. М., 2004; Для голоса! Книга русского авангарда, 1910-1934. Книга художника, 1970-2005: каталог выставки. СПб., 2005.

3 Ханзен-Лёве О. А. Интермедиальность в русской культуре: от символизма к авангарду. М., 2016. С. 55-56.

4 Поляков В. Книги русского кубофутуризма. С. 11.

5 Ханзен-Лёве О. А. Интермедиальность в русской культуре... С. 55. 
6 См.: Каталог литографированных и гравированных изданий // Ковтун Е. Ф. Русская футуристическая книга. М., 2014. С. 208-222.

7 Поляков В. Книги русского кубофутуризма. С. 228.

8 Хачатуров С. В. Искусство книги в России 1910-1930-х годов. Мастера левых течений: материалы к каталогу. М., 2004. С. 9.

9 Молок Ю. А. Начала московской книги... С. 46-47.

10 Поляков В. Книги русского кубофутуризма. С. 230.

11 Терехина В. Н. Экспрессионизм в русской литературе первой трети XX века. М., 2009. С. 201-266.

12 Борис Сергеевич Земенков окончил ВХУТЕМАС, он также художник и член редсовета журнала «Крысодав» (1923), в издании которого принимали участие В. Маяковский, К. Зданевич, И. Терентьев и др. Земенков является автором иллюстраций к роману А. Белого «Московский чудак» (М., 1926). В дальнейшем он работает как художник и искусствовед, в 1925-1929 гг. входит в группу художников «Бытие», автор изданий по истории Москвы (Гоголь в Москве. М., 1954; Памятные места Москвы. М., 1959; Очерки московской жизни. М., 1962; М. С. Щепкин в Москве. М., 1966) и серии пейзажей, запечатлевших Москву 1930-1950-х годов.

13 Чичерин А. Н. Звонок к дворнику: поэма / Ил. Б. Земенкова. Факсимильное издание. Б. м., 2017. Поэма Чичерина, по всей видимости, была создана еще в начале 1924 г., рисунок к главе 4 был опубликован в первом сборнике конструктивистов «Мена всех: конструктивисты-поэты» (М., 1924).

\section{A. N. Krasovec}

The place of visual code in the poetry of Russian avant-garde and its evolution in 1910s-1920s

The article focuses on books of Russian futurism of the 1910s (printed poetic collections and "self-written" publicatons), its orientation to destruction of the canonic way to publish and creating new art techniques that shape the model of an Avant-garde book. The second key stage in its development is the Constructivist book of the 1920s. A special accent is placed on the study of visual design of collections belonging to small poetic groups of the beginning of the 1920s ("expressionists", fuists, nichevoki, biocosmists) that were successors of innovative findings of the "avenirists". Keywords: Russian avant-garde poetry, Russian futurism, book of Russian avant-garde, constructivism, small poetic groups of the 1920 s, "expressionists", fuists, nichevoki, biocosmists. 


\section{Чешская литературная критика периода нормализации}

В статье рассматривается влияние официальной критики Чехословакии на литературный процесс периода нормализации. Также характеризуются типичные для 1970-1980-х гг. явления в литературно-критической публицистике и выступлениях ряда критиков (Й. Гаек, Г. Грзалова, В. Достал, Й. Рыбак, П. Беличек и др.).

Ключевые слова: чешская литература, сочиалистический реализм, нормализачия, литературная критика.

DOI: $10.31168 / 2073-5731.2018 .3-4.6 .02$

1968 год для Чехословакии был особенно значимым по двум причинам: с одной стороны, он знаменовал собой вершину проводимых в стране в течение 1960-х гг. демократических преобразований, с другой - стал временем крушения надежд и веры в проводимые реформы. В апреле 1968 г. была подписана «Программа действий», осудившая несовершенство сложившейся в предыдущее двадцатилетие системы, нарушение прав и свобод человека. В мае была проведена очередная амнистия, подарившая свободу многим политическим заключенным. С «Программой действий» была тесно связана и экономическая реформа вице-премьера ЧССР О. Шика, подразумевавшая поиски «третьего пути» развития экономики и бо́льшую коммерциализацию рынка. Реакцией на эти демократические шаги стал ввод на территорию ЧССР в ночь с 20 на 21 августа 1968 г. войск стран Варшавского договора. Чехословацкое общество пережило настоящий шок. Первый секретарь КПЧ А. Дубчек, председатель правительства Й. Смрковский и другие лидеры Чехословакии были вывезены в Москву, где 27 августа они подписали так называемый «Московский протокол»*. Именно в нем впервые был использован термин «нормализация». «Нормализовать» необходимо было состояние партии и государственного аппарата, для чего нужно было отстранить дискредитировавших

* Полное название - «Программа выхода из кризисной ситуации». Документ, состоявший из 15 пунктов, формулировал стоявшие перед страной «проблемы» и пути их решения, а также легитимировал пребывание войск Варшавского договора на территории ЧССР. 
себя в течение реформ 1960-х гг. членов КПЧ, восстановить дореформенную экономическую систему, чтобы решить насущные вопросы в кратчайшие сроки. В современной чешской историографии термином «нормализация» обозначается весь период с 1969 г. (избрание на пост первого секретаря КПЧ Г. Гусака) по 1989 г. («бархатная» революция* $)^{1}$. Он включает в себя процессы политической, экономической и культурной жизни Чехословакии, направленные на восстановление предшествующих реформам «Пражской весны» условий регламентации жизни государства на основе марксистско-ленинской идеологии, возвращение прежнего статуса КПЧ и сближение в решении этих задач с Советским Союзом.

Особое внимание нормализационное правительство уделяло вопросам культуры и литературы. 30 августа 1968 г. было создано Управление по делам печати и информации, что фактически означало восстановление цензуры. Все официально публикуемые тексты начала нормализации служили своего рода инструментом для формирования у населения «верной» картины действительности, пропаганды одностороннего восприятия событий. Особенно сильное влияние политическая ситуация оказала на литературоведческую периодику, которая начинает навязывать писателям различные идеологические клише, что не могло не наложить отпечаток и на весь литературный процесс. В литературе периода нормализации вновь усиливаются различия между произведениями официально разрешенными, диссидентскими и изданными в эмиграции. Целью нашей статьи является описание художественных и идеологических требований официальной критики по отношению к произведениям, допускавшимся к печати в 1970-1980-х гг.

Чешскую литературную критику рассматриваемого периода, находившуюся на службе режима, можно разделить на два взаимосвязанных направления: политическое и теоретическое. Содержанием первого, непосредственно связанного с внутренней политикой, были развернутые на страницах крупных изданий («Руде право», «Творба», «Турбина», «Кветы» и т. д.) идеологические кампании против оппозиционно настроенных деятелей культуры и искусства 1960-х и представителей андеграунда и самиздата 1970-х гг. В начале 1970-х в официальных изданиях подверглись резкой критике как отдельные яркие

* «Бархатной» или иначе «нежной» революцией называют мирные гражданские манифестации и последовавшие за ними политические реформы в период с 17 ноября до 29 декабря 1989 г., приведшие к падению коммунистического режима в стране. 
авторы 1960-х гг, так и весь литературный процесс тех лет как «отклонившийся» от идей социализма ${ }^{2}$. Из продажи были изъяты уже опубликованные произведения («Бутоны» (Poupata) Б. Грабала, сборник текстов 1938-1952 гг., был уничтожен на складах в 1970 г.), ставился вопрос о запрете издания переводов произведений западных авторов (например, романа Э. Хемингуэя «По ком звонит колокол», участие в редактировании которого принимал эмигрировавший Й. Шкворецкий $\left.{ }^{3}\right)$. Особенно ярко в деле переоценки предшествующего десятилетия проявили себя такие критики и публицисты, как Л. Штолл, В. Достал, В. Рзоунек и другие. Особую роль сыграла публикация в 1970 г. книги Й. Гаека «Миф и реальность января 1968 г.» ${ }^{4}$. Она стала первой официальной интерпретацией событий 1960-х гг. Одним из переломных моментов в истории послевоенной Чехословакии критик считает II съезд Союза чехословацких писателей 22-29 апреля 1956 г.5, на котором звучали отрытые призывы к отмене цензуры, освобождению искусства от идеологии и т. д. Именно оппозиционно настроенная интеллигенция привела, по мнению Гаека, страну сначала к подписанию «Программы действий», а позже - к кризису 1968 г. В главе «Программа действий КПЧ — миф и реальность» ${ }^{6}$ автор подробно разбирает текст программы и его негативное влияние на обстановку в стране. Критике литературного процесса 1960-х гг. и его современного состояния были посвящены несколько статей Гаека, вошедшие впоследствии в сборник «Конфронтация» (1972) 7 .

Примечательны идеологические кампании против писателей Л. Вацулика и М. Кундеры, некогда членов КПЧ, постепенно пришедших к критике режима. Например, в статье «Эжен де Растиньяк нашего времени» (1972), опубликованной в «Творбе», а затем вошедшей в сборник «Конфронтация», Гаек утверждает, что читательский успех романа «Шутка» (1967) Кундеры обусловлен исключительно «лихорадочным сумасшествием» 1960-х гг. ${ }^{8}$ Роман «Шутка» повествует о том, как студента Людвика из-за глупой шутки (он отправляет подруге легкомысленную открытку с подписью «Да здравствует Троцкий!») сначала исключают из института, а потом и из партии, как деформируется под влиянием эпохи его жизнь, превращая героя в озлобленного циника, жаждущего отомстить подставившему его однокласснику Земанеку. Инструментом мести Людвик избирает жену Земанека Гелену. Совращение Гелены, по мнению Людвика, должно причинить Земанеку такую же боль, которую причинили когда-то ему. Однако план Людвика превращается в очередную шутку судьбы - измена Гелены оказывается на руку Земанеку, нашедшему новую возлюблен- 
ную и ищущему повод для развода. Роман завершается целым калейдоскопом нелепых, трагичных и гротескных случайностей: провалившейся попыткой суицида оскорбленной Гелены, смертью одного из действующих лиц, друга Людвика - Ярослава, и контрастирующей со всеми остальными сценами игрой Людвика на национальных инструментах. Подобная литература, по мнению Гаека, несомненно, может удовлетворить вкусу определенной категории читателей: «... если читателю удастся не замечать того факта, что в постельных состязаниях Людвика и Гелены на самом деле изображен акт преодоления социальной несправедливости и способ решения идеологических споров (а это надо хорошо постараться), то ему удастся воспринимать “Шутку” как вполне хорошую порнографию, к сожалению, слегка испорченную чередой напряженных философствований и банальными сантиментами» ${ }^{9}$. Идейным ключом к роману, по мнению критика, становится авторская позиция, согласно которой главного героя нельзя считать виновным в собственных злоключениях и в некоем помешательстве на плане мести - он лишь деформирован эпохой: «И это как раз то, что необходимо было произнести, чтобы открыть дорогу к 1968 г., чтобы группка честолюбивых интеллектуалов получила моральное обоснование собственной роли гробовщиков социализма» ${ }^{10}$. Автор, как считает Гаек, своим романом лишь угождал вкусам «маломещанского солипсизма» 1960-х гг., чем хотел добиться успеха произведения (в том числе и коммерческого) ${ }^{11}$.

Статья Гаека помимо очевидной идеологической подоплеки содержит показательное рассуждение о взаимосвязи содержательного и формального планов произведения. Утверждая, что нельзя не разделять в произведении «идейную» и «эстетическую» стороны, он в то же время подчеркивает: «Поверхностность автора, весь его нарциссический, эксгибиционистский субъективизм непосредственно отражаются на художественной ценности и сюжетной организации романа, на появлении сюжетных дыр, низком эстетическом воздействии и неубедительности описания отдельных персонажей» ${ }^{12}$. Эти выводы демонстрируют отличительную особенность литературной критики нормализационного периода: ее отдаление от теории. Литературнокритическая публицистика все меньше опирается на теоретическую базу, все чаще прибегает к оценке произведения через набор идеологических клише.

Подобная участь постигла и роман Л. Вацулика «Секира» (1966) еще одно яркое психологическое произведение 1960-х гг. Примечательно, что негативная характеристика, данная роману критикой, стала лишь 
следствием всей идеологической кампании начала 1970-х гг., направленной против писателя за текст «Две тысячи слов» ${ }^{*}$ Уже в начале 1970 г. в «Творбе» за авторством Й. Соботецкого выходит статья «Миф божьего человека» ${ }^{13}$, в которой автор пытается продемонстрировать извращенность и лицемерие «божьего человека», которым хочет казаться Вацулик. Соботецкий считает, что разложение писателя началось еще до вступления в партию (приводя в пример приветственную речь Вацулика, в которой тот утверждал, что «принимает лишь основы коммунизма», однако не отрицал, что в дальнейшем некоторые его аспекты «будет трактовать лучше или иначе» ${ }^{14}$ ) и вылилось в роман «Секира», ставший «демонстрацией внутреннего идеологического беспорядка, депрессии и глубокого недоверия автора по отношению к социализму» ${ }^{15}$. Рассказчик (с достаточно выраженными автобиографическими чертами) после смерти отца возвращается в родную деревню. Вспоминая детство, отца, мать и брата, он анализирует собственное «я»; в форме риторических вопросов и саркастических замечаний переоценивает свое отношение к таким явлениям, как коллективизация, индивидуальность, положение личности в истории: «К сожалению, есть непреодолимое противоречие - хорошее дело должно быть мудрым, мудрости, однако, нам удается достичь в том возрасте, когда мы уже не столь несгибаемы и когда в нас уже проникает слабость: давайте же оставим все коллективу, он сообразительнее!» ${ }^{16} \mathrm{He}$ касаясь мировоззренческого и этического аспектов, Соботецкий трактует роман с идеологических позиций, видя в нем «произведение, относящееся к официально пропагандируемому интеллектуальному критиканству, извращающему ценности и подготавливающему разрушение социалистической теории и практики» ${ }^{17}$.

В конце 1970-х гг. критика обрушились на активистов андеграунда и самиздата, в первую очередь на подписавших Хартию-77. Негативно были встречены произведения П. Когоута, как и Вацулик, прошедшего путь от активного члена КПЧ до ее критика, а позже эмигранта. Критические статьи против этого автора андеграунда и самиздата выходили вплоть до 1979 г. и утихли после короткой заметки в «Руде право» об эмиграции Когоута в Австрию — «Петушок докукарекался» ${ }^{* *}$ (1979). Подобным образом действовала пропаган-

* Один из самых известных, наряду с «Программой действий», текстов пражской весны, осуждающий перегибы в политике КПЧ, разложение партии, бюрократизм и т. д.; призывающий к внутрипартийным реформам (но не отказу от коммунистических идей). Вышел сразу в нескольких печатных изданиях 27 июня 1968 г. (через день после официальной отмены цензуры).

** Когоут (Kohout) — по-чешски «петух». 
дистская публицистика и против В. Гавела. Статьи, осуждающие его деятельность и характеризующие Гавела как контрреволюционера и агента Запада, выходили до 1989 г. (например, «Руде право», 1989, № $\left.46^{18}\right)$. Об опубликованных в самиздате и заграницей произведениях официальная периодика умалчивала. «Замалчивание» критикой проявлений художественного инакомыслия становилось одним из способов борьбы с ними. В конце 1970-х гг. статьи ряда официальных критиков против активистов оппозиционных движений были объединены в сборник «Во имя социализма и счастливой жизни - против вредителей и самозванцев» $(1977)^{19}$.

Второе направление официальной критики фокусировалось в большей степени на обновлении сформировавшегося еще в 1950е гг. канона социалистического реализма. В программной декларации восстановленного Союза чешских писателей 18 ноября 1971 г. социалистический реализм был снова объявлен ведущим литературным методом, однако на практике он представлял собой своего рода бесплотную конструкцию: «В реальности понятие "социалистический реализм” представляло из себя лишь фигуру речи, к которой обращались на официальных встречах и праздничных выступлениях ${ }^{20}$, сами авторы все чаще употребляли термин «социалистическая литература» ${ }^{21}$. Назрела необходимость восстановить и обновить декларируемый как единственно правильный художественный метод. В этом смысле программным стало выступление Я. Козака на учредительном съезде чешских писателей 31 мая 1972 г. Козак, новый председатель Союза чешских писателей, разделил всех авторов на «здоровые силы» и «ревизионистское, либеральное» меньшинство во главе с Я. Сейфертом**. По мнению Козака, такие авторы, как И. Клима, М. Кундера, А. Лустиг, М. Голуб и другие, под видом реформирования партии и социалистической литературы намеревались внедрить в художественную практику «снисхождение и смирение перед всеми буржуазными и мелкобуржуазными идеологическими тенденциями и настроениями, перед антикоммунизмом, его пропагандой и распространением $\rangle^{22}$. Авторы обновленного Союза чешских писателей наперекор им должны были создавать произведения, доступные для рабочего класса, способствовать его всестороннему развитию. Интересно, что Козак не

* В конце 1971 г. министерство внутренних дел постановило создать новый Союз чешских писателей, учредительное собрание которого проходило под названием «Литература на службе социализма - на службе человека» с 31 мая по 1 июня 1972 г.

** Я. Сейферт был председателем Союза чешских писателей в 1969-1970 гг. 
призывает автоматически восстановить эстетические и тематические особенности социалистического реализма 1950-х гг: «В искусстве нет повторений. Социалистический реализм для нас - способ, которым литература реагирует на постоянно развивающееся социалистическое общество и которым его сама обогащает» ${ }^{23}$. Он, однако, не предлагает никаких определенных ориентиров, будь то конкретные имена, произведения или приемы, сюжеты и мотивы.

Вслед за Козаком попытки укрепить теоретическую базу социалистического реализма предпринимались рядом критиков, среди них В. Достал, Й. Рыбак, В. Рзоунек, П. Беличек, Г. Грзалова и др.

Наиболее простой способ достижения намеченной цели выбрали Рыбак и Беличек, которые настаивали на необходимости возвращения к эстетическим и идеологическим идеалам литературы 1950-х гг. Так, Рыбак в статье «Наш писатель и общественность» (1974) объявляет образцами для современных писателей произведения признанных классиков социалистического реализма послевоенного десятилетия И. Ольбрахта, С. К. Неймана, В. Ванчуру, В. Незвала ${ }^{24}$. Основными положительными чертами качественного литературного произведения критик называет его «правдивость и народность, способность противостоять врагу, нравственную чистоту; безупречность художественного произведения, воспринимаемого в едином ключе с незапятнанностью личности его творца» ${ }^{25}$. Анализ произведения с учетом политической позиции автора, принятый в пропагандистской публицистике, распространился и на художественную критику. Рыбак также уделяет внимание роли эксперимента в творчестве современных авторов: «Если творец тверд в своих убеждениях, он не должен бояться экспериментов и попыток применить их на практике. Откуда бы они ни брались» ${ }^{26}$. При этом к понятию «эксперимент» Рыбак подходит исключительно с формальной точки зрения: прибегая к экспериментальным элементам в поэтике, автор не должен заимствовать и передавать «содержательные компоненты, представления и взгляды иного мира, дух бунтарства, основанный на других идеях, идеях с противоположного берега» ${ }^{27}$. Именно такое чужеродное влияние, по мнению критика, господствовало в литературе 1960-х гг. и привело к кризису 1968 г.

Вслед за Рыбаком Беличек в аналитических трудах, посвященных современной поэзии (например, «Перспективы молодой литературы», 1973), также опирается на идеалы, сформированные в послевоенной литературе, критикуя литературу 1960-х гг. за ее индивидуализм и безыдейность: «Молодой автор может выбрать из двух вариантов: литературы или ее имитации. Потому что литература может быть лишь 
одна: простая, правдивая и идейная. Идейность - не только политическая декларация. Идейность - стремление к жизненным ценностям. Только тогда, когда литература имеет идейное наполнение, она становится жизнью, реальным действием» ${ }^{28}$.

Критические статьи Грзаловой в некотором отношении примыкали к работам Беличека и Рыбака. В своем труде «Совместное формирование действительности» (1976) она говорит о том, что современное творчество «возвращается к классическим основам социалистической литературы межвоенной и послевоенной, обновляются контакты с классической советской литературой и творчеством современных советских авторов» ${ }^{29}$. Однако Грзалова воспринимает социалистический реализм нового времени не как механически воссозданные концепты 1950-х гг, а как синтез предшествующих достижений соцреалистического метода и современных экспериментов ${ }^{30}$. К приведенному выше списку «образцов новой литературы» Рыбака Грзалова прибавляет имена Й. Кратохвила, К. Библа, Е. Ф. Буриана.

Особый интерес работа Грзаловой представляет потому, что в ней автор выводит основные аспекты, на которых должно быть основано «идейно выдержанное» произведение:

- партийность (классовый подход);

- историзм;

- связь прошлого и будущего («изображение жизни как целого $<\ldots>$ как в его современном состоянии, так и в отношении к прошлому и будущему» $\left.{ }^{31}\right)$;

- назидательность;

- коллективизм («Социализм ликвидирует разрыв между частной и общественной жизнью» $\left.{ }^{32}\right)$.

Этой схеме, по мнению Грзаловой, удовлетворяют произведения Я. Козака («Святой Михаил», 1972), Я. Коларжовой («Мой мальчик и я», 1974), Я. Рыбака («Время босых ног», 1973; «Европа танцевала вальс», 1974). В них она в первую очередь отмечает стремление к преодолению мещанства, обращенность к нуждам простого рабочего человека, доступность и народность ${ }^{33}$.

Однако не все критики призывали брать за основу канон соцреализма 1950-х гг. Так, например, вышеупомянутый Гаек в статье «Предпосылки для дальнейшего пути» (1972) рассуждает о том, что современной социалистической литературе следовало бы освободиться от строгого давления и найти свой собственный путь в развивающемся социалистическом обществе, что в определенном смысле является признанием необходимости новых эстетических идеалов: «Чтобы ис- 
кусство смогло стать освобождающей силой, активным творцом позитивных духовных, этических и чувственных идеалов, оно должно сначала само стать свободным» ${ }^{34}$. Под «освобождением» Гаек понимает, во-первых, определенную толерантность со стороны критики («художники должны быть уверены в том, что их не будут подозревать в злых умыслах, если у них не получится какая-либо книга, статья или пьеса» ${ }^{35}$ ), а во-вторых - открытость официального литературного поля и критики к диалогу с оппозиционными деятелями искусства: «Только такие дискуссии могут стать действенным способом коллективного решения проблем, объективного подхода к их преодолению, эффективного идеологического влияния партии на дальнейшее развитие страны» ${ }^{36}$. Эта статья явно выделяется на фоне односторонних по отношению к художественному инакомыслию текстов данного автора.

Интересную позицию в вопросе характеристики соцреалистического метода 1970-х гг. занял Достал. Критик считал, что только метод соцреализма позволяет автору «достичь точки наивысшего внутреннего расцвета и угодить демократическим чаяниям общества» ${ }^{37}$, а потому, в отличие от Гаека, настаивал на том, что соцреалистический метод и его содержание все это время сохраняли актуальность и не нуждаются в изменениях и дополнениях. Критик, однако, обращал внимание, что на протяжении почти всего существования понятие «соцреализм» трактовалось негативно, так как было прочно связано с именем Сталина. Именно этим Достал объяснял отказ большей части передовых авторов от соцреалистического метода в 1960-е гг.: «Социалистический реализм был сдан в утиль вместе с остальными “останками сталинизма” < .. >. С того момента в обществе от него начали воротить носы, а со временем он вообще стал закрепляться за произведениями как негативная характе-

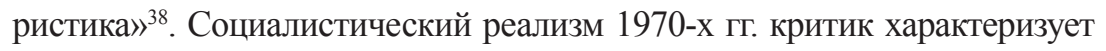
как «правильный», освободившийся от предрассудков, создаваемый для народа и его блага. Период же 1950-х гг. Достал оценивает негативно, как состояние эйфории, в котором литературный процесс еще не умел «отделять зерна от плевел» ${ }^{39}$. Современный социалистический реализм 1970-х гг., по его мнению, «сумел вобрать в себя все позитивное, что в ограниченном ассортименте предлагали современные течения, но не путем заимствования внешних элементов и в погоне за модой, а благодаря поиску собственных ответов на вопросы, поставленные эпохой» ${ }^{40}$.

О необходимости обновления эстетических идеалов пишет в своей масштабной статье «Нужды поколения» ${ }^{41}$ (1974) Пельц. Критик анализировал поэтическое творчество, однако выдвинутые им эстетические и идеологические принципы применимы в равной мере ко 
всем родам литературы. Основными качествами новой соцреалистической эстетики критик считает:

- борьбу с индивидуализмом;

- опору на общечеловеческие моральные ценности;

- изображение элементарных житейских истин (использование в произведении таких сюжетов, как воспоминания о прошлом, родственниках, друзьях; отсылки к детству демонстрируют не столько эгоистичную заинтересованность персонажа в собственной личности, сколько попытки понять чаяния народа, найти в себе причины для дальнейшей борьбы ${ }^{42}$ ).

Подводя итог, можно отметить, что для обоих направлений функционирования нормализационной критики характерны две основные тенденции:

- осуждение развития искусства и литературы 1960-х гг;

- характеристика нормализационного процесса как рационального выхода из сложившейся кризисной ситуации; легитимация происходивших под влиянием политики явлений художественной жизни, ужесточение цензуры.

Под влиянием «рекомендаций» со стороны официальной критики ведущими в рассматриваемый период становятся произведения, изображающие «процессы социального развития в недавнем прошлом» ${ }^{43}$, среди которых были и те, что «правильно» освещали конфликты предшествующих десятилетий (прежде всего, ситуацию 1960-х гг.). Произведения такого плана критик А. Фиалова называет «ретроспективными» ${ }^{44}$. В начале 1970-х гг. была предпринята попытка обновить жанр производственного романа (чеш. budovatelský román), излишний схематизм которого должен был быть преодолен с помощью усиления психологизма, изображения более правдоподобных сюжетов и социального контекста ${ }^{45}$. Однако критикам, игравшим в период нормализации роль теоретиков литературы, не удалось оформить устойчивой и практически применимой методологической базы социалистического реализма. Неспособность объективно охарактеризовать допустимость и недопустимость тех или иных приемов или мотивов в произведении приводила, даже в рамках наиболее цензурируемых жанров, к трансформации, а в некоторых случаях деформации канона социалистического реализма. И если в начале 1970-х гг. критика основывала свои «рекомендации» на осуждении кризисной ситуации конца 1960-х гг, то уже к концу первого десятилетия нормализации подобные тенденции утратили актуальность и были заменены замалчиванием выступлений литературной оппозиции. В начале 1980-х гг. 
наблюдается резкое сокращение идеологически ангажированных критических статей и критических обзоров. Происходит постепенное смягчение цензуры, обусловленное как внутриполитической ситуацией в стране, так и исчерпанностью эпохи застоя в Советском Союзе.

\section{ПРИМЕЧАНИЯ:}

1 CM.: Činátl $K$. Věčné časy: československé totalitní roky. Praha, 2009; Emmert F. Průvod cečeskými dějinami 20. století. Brno, 2012; Rychlik J., Penčev V. Od minulosti k dnešku: dějiny českých zemí. Praha, 2013; Pažout J. Každodenní život v Československu 1945/48-1989. Praha, 2015; Emmert F. Průvod cečeskými dějinami 20. století. Brno, 2012; Бобраков-Тимошкин А. У нас была нормальная эпоха. 1970-е гг. в Чехословацкой Социалистической Республике // Неприкосновенный запас. 2007. № 2 (52). URL: http://magazines. russ.ru/nz/2007/2/ti11.html. Дата обращения: 22.04.2018.

2 Z dějin českého myšlení o literatuře: antologie k Dějinám české literatury 1945-1990. Praha, 2005. Sv. 4, 1970-1989. S. 119.

3 Janoušek P., Čornej P. Dějiny české literatury 1945-1989. Praha, 2008. S. 656.

4 Hájek J. Mýtus a realita ledna 1968. Praha, 1970.

5 Ibid. S. 10.

6 Ibid. S. 74.

7 Hájek. J. Konfrontace. Praha, 1972.

8 Z dějin českého myšlení o literatuře... S. 299.

9 Ibid. S. 304.

10 Ibid. S. 306.

11 Ibid. S. 307.

12 Ibid. S. 311

13 Ibid. S. 57.

14 Ibidem.

15 Ibidem.

16 Vaculik L. Sekyra. Praha, 1966. S. 16.

$17 \mathrm{Z}$ dějin českého myšlení o literatuře... S. 57.

18 Ibid. S. 76.

19 Ve jménu socialismu a št’astného života — proti rozvratníkům a Samozvancům. Praha, 1977.

20 Janoušek P., Čornej P. Dějiny české literatury 1945-1989. S. 173.

21 Ibidem.

$22 \mathrm{Z}$ dějin českého myšlení o literatuře... S. 27. 
23 Ibid. S. 37.

24 Ibid. S. 23.

25 Ibidem.

26 Ibidem.

27 Ibidem.

28 Ibid. S. 88.

29 Hrzalová H. Spoluvytvářet skutečnost: k vývoji české socialistické kritiky a prózy v letech 1945-1975. Praha, 1976. S. 151.

30 Ibid. S. 153.

31 Ibid. S. 155.

32 Ibid. S. 157.

33 Ibid. S. 151.

$34 \mathrm{Z}$ dějin českého myšlení o literatuře... S. 16.

35 Ibid. S. 19.

36 Ibid. S. 17.

37 Ibid. S. 48.

38 Ibid. S. 42.

39 Ibid. S. 41.

40 Ibid. S. 49.

41 Ibid. S. 510.

42 Ibid. S. 102. Подобная интерпретация была характерна для большинства статей Я. Пельца. Апофеозом стала вышедшая в 1977 г. книга «Новое содержание», в которой окончательно формируется мысль объединения понимания «коллективного» через «индивидуальное» (как воспоминания, так и ощущения, мысли и эмоции).

43 Fialová A. Poučeni z krizového vývoje: poválečná česká společnost v reflexi normalizační prózy. Praha, 2014. S. 63.

44 Ibid. S. 63-64.

45 Janoušek P., Čornej P. Dějiny české literatury 1945-1989. S. 473.

\section{S. A. Kozhina}

The Czech literature criticism during Normalization

The article dwells upon the influence of the official critics of Czechoslovakia on the literary process during Normalization. The phenomena in literary critics publications, typical for 1970-1980s, and actions of some critics (J. Hájek, H. Hrzalová, V. Dostál, J. Rybák, P. Belíček and others) are analyzed.

Keywords: Czech literature, socialist realism, Normalization, literature criticism. 


\title{
Словацко-венгерское пограничье как мультикультурное сообщество и объект художественной рефлексии (романы Л. Баллека и Л. Грендела)
}

\begin{abstract}
В литературе Словакии традиционно присутствует тема сосуществования и взаимодействия культур словацкого и венгерского этноса, прежде всего в исторически сложившейся пограничной области. В статье рассматриваются посвященные этой теме романы, предлагающие взгляд на словацко-венгерское сообщество с двух разных сторон.

Ключевые слова: мультикультурный регион, литература Словакии, роман, психологизм, гротеск.
\end{abstract}

DOI: $10.31168 / 2073-5731.2018 .3-4.6 .03$

Южное пограничье - особый регион Словакии, где на протяжении всей его истории складывалось сообщество разных этносов; словацкое население издавна соседствовало здесь с самым многочисленным национальным меньшинством - венграми. Политические факторы играли при этом, как правило, разрушительную роль и вели к национальным трениям, о чем свидетельствуют, в частности, события 1938 г. и первых послевоенных лет, когда спорная территория переходила от одного государства к другому, а большие группы населения подвергались депортациям и притеснениям. Важным моментом в жизни пограничья представляется мирное и во многом продуктивное сосуществование культур и национальных традиций словаков и венгров. Проблематика этого региона нашла отражение и в литературе Словакии, в частности в творчестве Л. Баллека, а также Л. Грендела, автора, пишущего на венгерском языке.

Среди произведений выдающегося словацкого прозаика Ладислава Баллека (1941-2014) особое место занимают романы о жизни небольшого городка на юге страны, которому он дал название Паланк.

Исследование выполнено в рамках программы фундаментальных исследований президиума РАН «Культурно-сложные общества: понимание и управление», проект «Язык и культура в полиэтничных и поликонфессиональных сообществах Юго-Восточной Европы: междисциплинарное исследование». 
Его прототипом, как указывал и сам писатель, стал старинный город Шаги, бывший некогда центром исторической области Гонт, расположенной на плодородных равнинных землях словацко-венгерского пограничья. Пышная природа, луга и акациевые рощи окрестностей Паланка, особое сочетание в нем черт многих национальных культур - всё это нашло отражение в прозе Баллека, прежде всего в его романах «Помощник» (1977) и «Акации» (1981).

Первый из них, «Помощник» (с подзаголовком «Книга о Паланке»), написан в традициях реалистического романа с социально-психологической направленностью. Фабула развивается в нем линейно и последовательно, с небольшими сюжетными пояснительными экскурсами в прошлое. Время действия ограничено двумя историческими событиями - окончанием Второй мировой войны в 1945 г. и приходом к власти в Чехословакии правительства коммунистов в 1948 г.

Главный герой романа - Штефан Риечан, мясник родом с бедного словацкого севера, потерявший всё имущество во время Словацкого национального восстания 1944 г. В поисках лучшей жизни он вместе с семьей переезжает на богатый и плодородный юг, в область, только что отсоединенную от Венгрии и вернувшуюся в состав Чехословакии. Через восприятие Риечана автор показывает картину богатства и, одновременно, упадка этого края: «Юг был ярко-зеленый и белый, весь в зеленой траве и цветах, однако показался ему голым, пустым и потерянным. Достаточно было взглянуть на неубранное кукурузное поле, хозяин которого пропал где-то в вихре войны, то ли погиб, то ли уехал за границу» ${ }^{1}$. Многих из прежних владельцев земель и домов, венгров, новые власти выселили, а на их место приехали новые жители - словаки из северных провинций. Однако часть венгерского и смешанного населения осталась, сохранив традиции и дух некогда процветавшего, буржуазного Паланка. Баллек рисует красочный портрет здешнего горожанина: «Типичный житель Паланка, чрезвычайно разнородного в национальном отношении города, где жили представители всех народов старой монархии, <..> обычно обладал следующими качествами: это был человек неторопливый, даже медлительный, с виду ленивый, но при этом амбициозный, серьезный, солидный, он разбирался в людях, имел свою жизненную позицию $<\ldots>$ и талант к разного рода коммерции ${ }^{2}$. Наиболее ярко и развернуто этот типаж воплотился в одном из центральных персонажей романа - помощнике Риечана Валенте Ланчариче, доставшемся ему от прежнего владельца мясной лавки. Сюжет построен во многом на контрасте двух характеров - честного труженика и заботливого семьянина Риечана и 
беспринципного, алчного дельца Ланчарича. Взаимоотношения этих противоположностей заканчиваются для обоих крахом всех их планов и надежд. Семья Риечана, во многом по вине помощника, распадается, а сам он уезжает из города своей мечты Паланка назад, в родные места; «Он никому не доверял, жил одиноко, но никогда не жаловался. Прошлого он почти никогда не касался, старался о нем забыть» ${ }^{3}$. А его подмастерье Ланчарич, не сумев приспособиться к новой социалистической действительности, а главное - к новым законам, попадает в тюрьму. При относительной простоте фабулы драматизм повествования усиливается его психологическим планом, большим количеством несобственно-прямых монологов, передающих чувства и размышления героев. Автор детально прослеживает трансформацию психологического состояния Риечана - от радостных ожиданий и надежд, опасений и непонимания близких до болезненных переживаний и отчаяния. Непривычная среда южного города с его атмосферой роскоши и моральной раскрепощенности остается для него чуждой.

Анализируя роман «Помощник», Я. Штевчек отмечал: «В фигурах Риечана и Ланчарича представлено столкновение двух разных сред - балканской, проникнутой духом коммерции, гедонизма, наслаждений, и словацкой с ее неразвитой склонностью к предпринимательству и жизненным аскетизмом. Таким образом, социологическая и психологическая составляющие персонажей рисуют общую картину среды и места действия» ${ }^{4}$.

«Акации» (с подзаголовком «Вторая книга о Паланке») - это роман, построенный совсем иным, мозаичным способом. Две его части состоят из девяти относительно самостоятельных глав, связанных между собой пространством (южнословацкий город и его окрестности) и временем (речь идет преимущественно о послевоенных годах). Свойственная роману многофабульность еще более усиливается добавлением в основное повествование о центральных героях параллельных историй и эпизодов с участием второстепенных персонажей.

В самом начале, в главе «Паланк - квартал кошек», автор описывает город в первый послевоенный год, приводя историко-социологические данные: «После вступления в Паланк войск Малиновского сюда вернулись прежние времена. Паланк, город на словацко-венгерской демаркационной линии, перешел из-под власти короны снова под знак льва ${ }^{5}$ Вернулась довоенная администрация, жандармерия, зазвучал новый государственный язык» ${ }^{6}$. От политических реалий Баллек переходит к социальным и национальным: «Сюда приезжали новые чиновники с семьями, перебирались торговцы, ремесленники, 
учителя, врачи $<\ldots>$ из разных уголков республики, преимущественно - из горных областей Словакии» ${ }^{7}$. И далее он рисует картину полиэтничного сообщества, которое представлял собой Паланк: «Из предвоенных жителей квартала в городе не осталось почти никого. До того момента, как Хорти забрал себе Паланк ${ }^{8}$, здесь жило пестрое многонациональное общество, в основном хорошо обеспеченные люди. Вслед за словаками, чехами, людьми со всех уголков Балкан и депортированными евреями отсюда уехало и большинство венгров. $<\ldots>$ Некоторых выселили из их домов новые учреждения, чтобы разместить там своих служащих и репатриантов из Венгрии, Румынии и Югославии» ${ }^{9}$.

Еще более детализируя картину Паланка, Баллек перечисляет фамилии новых жителей, обозначая таким образом героев, с которыми читателю предстоит встретиться в романе: «Приехали, например, Гнилицы, Юрковичи, Гаврилы, Блашчаки, появилась не только красавица Гамплова со своим мужем-строителем [герои главы “Агава”. Л. Ш.], но и загадочная портниха Тишлерова, которая взбаламутила весь город, утверждая, что в ее доме живет падший ангел [глава “Ангел и дом кошек”. - Л. Ш.] $\rangle^{10}$. Роль персонажей в романе меняется: в одних главах это центральные, а в других — эпизодические фигуры; встречаются в «Акациях» и упоминания о мяснике Риечане и его ловком подмастерье Ланчариче, героях романа «Помощник».

О функции большого числа персонажей в романе «Акации» пишет в своей монографии о творчестве Л. Баллека И. Гохел, делая вывод о том, что «автор поставил перед собой цель показать посредством индивидуальных судеб, изображаемых на фоне исторических и политических обстоятельств, как можно более полную картину социальной структуры города и пестроту его жизни» ${ }^{11}$. Сам писатель не раз подчеркивал культурную специфику словацко-венгерского пограничья, традиционное сосуществование и взаимодействие на этой территории разных этносов. В эссе «Провинция?» он вспоминает о городе своей юности - Шагах, ставшем литературным Паланком: «Шаги всегда были культурным городом. Здесь не враждовали, а естественным образом состязались - на общее благо города - все культуры, причем не только две доминирующие - словацкая и венгерская. $<\ldots>$ И все они ярко проявляли себя, поскольку хорошо здесь себя чувствовали. Мы узнавали их в людях, домах, церквях, кухнях, музыке» ${ }^{12}$.

Три романа Лайоша Грендела (р. 1948), составившие позднее «Нью-Гонтскую трилогию» ${ }^{13}$ («У нас дома, в Нью-Гонте», 2001; «Массовое захоронение близ Нью-Гонта», 1999; «Король Матей в 
Нью-Гонте», 2004) написаны на рубеже XX-XXI вв., когда в словацкой литературе было сильно увлечение постмодернизмом. Некоторые приемы этого течения (тяготение к гротеску, фабуляция, авторская самоирония) широко использовал в своих произведениях и Грендел, однако романам трилогии присущи и реализм, и психологическая глубина образов. Они объединены общим местом действия - своего рода общим «коллективным героем» - это южнословацкий городок с вымышленным названием (местным ироническим самоназванием) Нью-Гонт ${ }^{14}$ и его окрестности. Общей является и тема местного патриотизма, принимающего у Грендела юмористические, часто даже гротескные черты. В каждой из книг присутствует повествователь от первого или от третьего лица, в роли которого выступают, чередуясь, то автор, то центральный герой. Экскурсы в прошлое ведут читателя в XX век, к периоду Второй мировой войны, послевоенным годам строительства социализма, временам краха Пражской весны в 1968 г. и «нежной революции» 1989 г. Основное же время повествования - актуальная для времени написания современность, представленная в условиях замкнутого социума провинциального городка как вневременное состояние неизменности и застоя.

Завязка первого романа трилогии и тривиальна, и комична: молодому литератору, редактору столичного издательства, поручают написать книжку о неизвестном ему Нью-Гонте. Директор издательства, принявший заказ от старосты безвестного городка, объясняет потребность в такой публикации тем, что о нем никто никогда не писал, и многие даже не подозревают о его существовании: «Нью-Гонт обходит стороной не только большая политика, но и пресса, будто его и нет на свете, будто там никогда не случалось ничего достойного внимания - ни наводнений, ни землетрясений, ни эпидемий» ${ }^{15}$. Основная цель «отцов города» - придумать «идею Нью-Гонта», которая была утеряна и без которой он так и будет прозябать в забвении. Прославлению городка в республиканском и, возможно, мировом масштабе призвана служить будущая книжка о его истории и достопримечательностях, а также памятник какому-нибудь знаменитому земляку на центральной площади.

Размышляя о подходящем для увековечивания герое, местный старожил и своего рода патрон и душа Нью-Гонта дядя Коломан вспоминает самое бурное для жителей время конца Второй мировой войны; городок тогда оставили немцы, посчитав, что он «со стратегической точки зрения - сущий ноль», а затем «как неотвратимое стихийное бедствие» ${ }^{16}$ пришли со страхом ожидаемые горожанами рус- 
ские. Сформировав местную «директорию» из равного числа венгров и словаков «для соблюдения принципа паритетного представительства» ${ }^{17}$, карикатурно изображаемые русские принялись реквизировать у населения часы и выявлять подозрительных личностей, расстреляв при этом единственного понимавшего русский язык горожанина главу «директории», венгра Дюсо Негеза. Пришедшие на смену этим солдатам другие, «монголы, замаскированные под русских» ${ }^{18}$, тоже занялись грабежами и насилием.

В числе появившихся на свет после этого нашествия тринадцати младенцев был и один из центральных героев романа Иван, мощный, с крутым нравом человек, глаза которого - один обычный, другой раскосый - говорили о его происхождении и «буйном естестве». Сквозную сюжетную линию составляет история бурной любви преуспевающего адвоката Ивана и молодой сельской вдовы Барборы, которых то сводила их роковая страсть, то разъединяли несхожие традиции и представления о жизни.

Решение магистрата о постановке памятника затрудняло то обстоятельство, что знаменитых, прославившихся в истории земляков в Нью-Гонте не оказалось. Спор достиг предела, когда венгерские депутаты предложили «кандидатуру» Лайоша Кошута, а словацкие - Людовита Штура: «Кошут - отец всех венгров, а значит - и венгров Нью-Гонта. - Но не наш! - возмутились депутаты словацкой национальности» ${ }^{19}$. Идея возвести два памятника по разные стороны центральной площади тоже показалась им сомнительной: «Они стояли бы друг против друга и создавали бы впечатление, что и здешние венгры и словаки тоже - друг против друга» ${ }^{20}$. О пребывании в НьюГонте короля Матея Корвина свидетельств не нашлось, и в итоге было решено увековечить память первого послевоенного старосты НьюГонта - Дюсо Негеза.

Мотив межнациональных трений вновь возникает в рассказе скульптора, уроженца городка Штево Барана, которому заказали изготовление монумента. Он вспоминает о послевоенной истории, когда на возвращенных территориях власти ускоренно внедряли словацкий язык и «упорядочивали использование венгерского языка» ${ }^{21}$. Реализация этой политики в Нью-Гонте показана в комических сценках в бакалейной лавке и корчме, где проводила ревизию «комиссия по проверке языковой ситуации в городе» ${ }^{22}$.

Гротеск преобладает в эпизодах романа, относящихся к событиям августа 1968 г, когда в Чехословакию были введены войска стран Варшавского договора: «К большому удивлению жителей в Нью-Гонт 
вошли танковые подразделения венгерской армии. <.. > Над главными общественными зданиями города вновь реяли государственные флаги Венгрии» ${ }^{23}$. А венгерский офицер в ответ на вопросы пытавшегося дискутировать с ним дяди Коломана твердил: «Мы проявили решительность и подавили контрреволюцию раньше, чем она тут началась» ${ }^{24}$.

Повторяющийся мотив захвата города армией принимает абсурдные формы во всё более грандиозных планах дальнейшего прославления и обогащения Нью-Гонта, рождаемых фантазией старосты: для привлечения туристов и зарубежных инвесторов он хочет восстановить руины заброшенного замка и устраивать там исторические баталии, а для возможных государственных бюджетных вливаний предложить министерству обороны провести в городе военные учения «с небольшой бомбардировкой» ${ }^{25}$.

Скульптор Штево Баран, рассказывая о местной специфике повествователю-редактору, написавшему в итоге заказанную книжку, говорит об особом состоянии времени в Нью-Гонте: «Истории здесь никогда не кончаются; прежде чем закончиться, они начинаются снова, колесо истории может повернуться вспять. <.. > У нас дома, в НьюГонте, жизнь уже давно остановилась. Здесь всё вечно и неизменно» ${ }^{26}$.

Городок представлен в романе как символ провинциальной замкнутости и застоя, где пространство ограничено «своей» территорией, а время течет по «своим» местным законам, почти не соприкасаясь с «чужим» большим миром.

Вторая часть трилогии, «Массовое захоронение близ Нью-Гонта», была написана раньше первой, однако при издании всех трех романов как целого ее поместили на вторую позицию, вероятно, согласуясь с логикой развития авторской идеи. Кроме того, в этом романе сюжет также построен на истории более или менее вынужденного включения столичного интеллигента в жизнь маленького замкнутого словацко-венгерского сообщества; здесь это - деревня Т., расположенная неподалеку от местного районного центра, Нью-Гонта.

Повествование в первом лице ведется от имени университетского преподавателя истории из Братиславы, получившего в наследство участок земли и дом в деревне Т. При копке нового колодца там были обнаружены захороненные останки множества людей, и под предлогом расследования этого дела героя вызывают местные активисты староста, начальник полиции, нотариус и «патрон» деревни, пенсионер-фармацевт из Кошиц доктор Деметер. Однако они преследуют другие цели; после устроенного приезжему доценту пышного приема 
и предложения стать почетным гражданином деревни они настойчиво убеждают его написать статью, своего рода хронику трагических событий военных лет, свидетелем которых, по его рассказу, стал в молодости Деметер. «Несколько сотен людей, женщины и дети. <..> Их вели в том направлении вооруженные солдаты СС. <..> Мы так никогда и не узнали, что с ними стало» ${ }^{27}$. Его повествование об увиденной им колонне идущих на расстрел мирных жителей, полное оговорок и недосказанности, вызывает у историка сомнения, и он старается как можно более деликатно отклонить предложение радушных хозяев.

Из рассказа местного жителя, посетившего его в Братиславе, он узнает о переменах, произошедших в деревне Т. после окончания войны, когда он вернулся туда «из русского плена»: «Однажды ночью погрузили на машины половину деревни. Потом в опустевшие дома и дворы постепенно стали заселяться новые жители» ${ }^{28}$. Старик просил его держать всё в тайне, намекая на участие в этой акции неких «фальшивых партизан», среди которых были и родственники представителей нынешней деревенской верхушки.

Повествователь предпочел занять позицию рефлексирующего стороннего наблюдателя, не столько занятого решением вставших перед ним проблем, сколько погруженного в самоанализ: «У меня решительно не было таких достоинств, как смелость, ловкость, изобретательность, напротив, лень и нерешительность пустили в меня свои корни и тянули в болото бездействия» ${ }^{29}$.

Далее следует история долгих уговоров, призывов к местному патриотизму и даже шантажа в адрес героя-повествователя со стороны деревенских активистов. Староста раскрыл перед ним грандиозные планы строительства в деревне памятника жертвам фашизма, на открытие которого «приехали бы представители прессы, политики, писатели и предприниматели - без предпринимателей нет инвестиций» ${ }^{30}$. Подобно идеям старосты Нью-Гонта из первого романа трилогии, прожекты старосты Т. приобретают всё более глобальные размеры: «Может, к нам приедет и посол Германии, чтобы возложить к памятнику венок и принести свои извинения, - немцы уже перед всеми извинились, а перед нами - нет» ${ }^{31}$.

В финале романа герой-повествователь, потеряв волю к сопротивлению, подчиняется влиянию активистов деревни Т. и переселяется туда на правах «своего», местного писателя, сознавая при этом, что находится в тупике и безвременье: «Жизнь моя на этом завершилась» $^{32}$. Город Нью-Гонт для этого малого социума — граница дома и 
остального мира: «Поезда либо отправляются в Нью-Гонт, либо прибывают из Нью-Гонта. < . .> За Нью-Гонтом начинается широкий мир, а всё, что ближе, - это наш родной край» ${ }^{33}$.

Заключительная часть трилогии - «Король Матей в НьюГонте» - гротескный роман о нравах и типажах «лихих девяностых» в словацком провинциальном городке и о карикатурной попытке совершить там путч по примеру советского ГКЧП, предпринятой группой бывших коммунистических функционеров. Повествование ведется, в отличие от предыдущих частей, от третьего лица. Центральный герой - молодой неудачник, несостоявшийся поэт Мишо Шилер, которого безденежье и неустроенность вынудили заняться сутенерством, а потом, к концу романа, стать членом влиятельной словацкорусско-украинской мафиозной группировки.

Экскурсы в прошлое, в годы правления компартии, раскрывают трагикомические стороны семейной истории, связанной с нелепыми по сути, но политически правильными для того времени действиями властей по отношению к отцу Мишо, школьному учителю с венгерской фамилией Реваи. «В Словакии учитель не может носить фамилию Реваи. <..> Реваи был землевладельцем, который эксплуатировал словацкий люд и приказал повесить народного героя Юра Яношика» ${ }^{34}$, - указывал секретарь горкома, требуя от учителя срочно сменить фамилию. Однако и девичья фамилия матери тоже оказалась венгерской: «Это устаревшая фамилия. Сегодня каждого Тота уже зовут Словак. И Олаг устаревшая. И Рац. Этот, первый, сегодня - Влах, а второй - Серб» ${ }^{35}$. В фамилиях, производных от названий цветов, секретарь увидел излишнюю символику и предложил варианты, «связанные с социалистическим настоящим», от которых решительно отказался учитель, выбрав себе нейтральную фамилию Шилер. В другой раз отец Мишо Шилера пострадал от властей, неудачно сыграв роль Ленина в любительском спектакле венгерской труппы.

Московский путч 1991 г. пробудил в отставных чиновниках, спешно создавших собственный «комитет», надежду на возврат к старому порядку. При этом бывший секретарь горкома, Матей Краль, настолько уверовал в свое высшее предназначение, что слился в своем больном сознании с фигурой «прогрессивного» венгерского короля Матея Корвина, а после сообщения о крахе ГКЧП совсем потерял связь с реальностью.

Финал романа пессимистичен; родной город кажется герою «пустырем, огромным пустым местом», где «жизнь остановилась, стала одним долгим мгновением, в котором ничего не происходит, 
разве что люди вокруг рождаются и умирают», где царит «постоянная временность» ${ }^{36}$.

Представленные здесь произведения двух писателей Словакии, обращенные к схожей тематике словацко-венгерского пограничья, различаются по целому ряду характеристик, прежде всего - по авторскому взгляду на изображаемый объект: Паланк Баллека исполнен ностальгии по прошлому и населен персонажами, достойными авторской симпатии, тогда как Нью-Гонт Грендела построен на пародии и становится для героев трилогии одновременно и местом притяжения, и тупиком замкнутого, вневременного пространства.

\section{ПРИМЕЧАНИЯ}

1 Ballek L. Pomocník. Kniha o Palanku. Bratislava, 1977. S. 9.

2 Ibid. S. 65.

3 Ibid. S. 391.

4 Števček J. Dejiny slovenského románu. Bratislava, 1989. S. 551.

5 Корона св. Стефана (Иштвана) - символ Венгрии, лев - символ Чехии (Чехословакии).

6 Ballek L. Agáty. Druhá kniha o Palanku. Bratislava, 1981. S. 7.

7 Ibid. S. 8.

8 В результате Венского арбитража 1938 г. Венгрии были переданы области южной и юго-восточной Словакии. М. Хорти - правитель Венгерского королевства до 1944 г.

9 Ballek L. Agáty... S. 9.

10 Ibid. S. 199.

11 Hochel I. Príbeh ako princíp. Bratislava, 2005. S. 100.

12 Ballek L. Južná pošta. Pomocník. Bratislava, 2007. S. 545.

13 Романы Грендела, наряду с их оригинальными венгерскими изданиями, выходили и на словацком языке в переводе К. Влаховского.

14 Гонт - историческое название одной из областей на юге Словакии.

15 Grendel L. Newhontská trilógia. Bratislava, 2016. S. 11.

16 Ibid. S. 15.

17 Ibid. S. 23.

18 Ibid. S. 35.

19 Ibid. S. 30.

20 Ibid. S. 31.

21 Ibid. S. 56.

22 Ibid. S. 57. 
23 Ibid. S. 80.

24 Ibid. S. 101.

25 Ibid. S. 181.

26 Ibid. S. 175.

27 Ibid. S. 262.

28 Ibid. S. 209.

29 Ibid. S. 202.

30 Ibid. S. 266.

31 Ibid. S. 268.

32 Ibid. S. 328.

33 Ibid. S. 333.

34 Ibid. S. 356.

35 Ibid. S. 358.

36 Ibid. S. 475.

\section{F. Shirokova}

Slovak-Hungarian border area as a multicultural community and an object of artistic reflection (novels by L. Ballek and L. Grendel)

In the literature of Slovakia there is a traditional theme of coexistence and interaction of cultures of Slovak and Hungarian ethnic groups, first of all in the historically established border area.The article deals with the novels devoted to this topic, offering a view of the Slovak-Hungarian community from two different sides.

Keywords: multicultural region, literature of Slovakia, novel, psychologism, grotesque. 


\title{
Память о польско-еврейском прошлом: проблема пространства и вектора (молодая польская проза 2000-2010-х гг.)
}

\begin{abstract}
В статье рассматривается пространственное преломление проблемы польско-еврейского прошлого Польши в прозе третьего поколения после холокоста - текстах молодых авторов, связанных своим происхождением как с еврейской (П. Пазиньский), так и с польской (С. Хутник, И. Остахович) частью этого прошлого. Ключевые слова: современная польская проза, польско-еврейское прошлое, холокост, постпамять, топос, вектор памяти, историческая травма.
\end{abstract}

DOI: $10.31168 / 2073-5731.2018 .3-4.6 .04$

Применительно к проблеме польско-еврейского прошлого в восприятии писателей, родившихся в 1970-1980-е гг., можно говорить, разумеется, прежде всего о специфической форме памяти, опирающейся не на реальные воспоминания, а на воображение, эмпатию, чувство долга. Это память тех, кто не пережил травматические события лично, но подвергается воздействию памяти о них, т. е. потомков свидетелей и участников или «жертв» травматического культурного наследия. Исследователи акцентируют в определениях ее вторичность, призрачность, парадоксальность, называя постпамятью ${ }^{1}$,

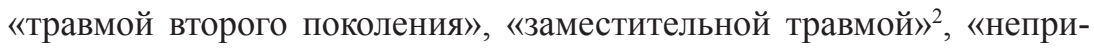
сутствующей памятью» ${ }^{3}$, «памятью памяти свидетелей», создающей «замещающее (альтернативное), опосредованное прошлое» ${ }^{4}$, «продырявленной», «простреленной памятью» ${ }^{5}$, памятью «свидетелей свидетелей» ${ }^{6}$, симулякром, «постмодернистским явлением» ${ }^{7}$.

Постпамять, отделенная от непосредственной памяти свидетелей и участников поколенческой дистанцией, обусловлена и опосредована рядом психологических и этических проблем и потребностей:

Исследование выполнено в рамках программы фундаментальных исследований президиума РАН «Культурно-сложные общества: понимание и управление», проект Института славяноведения РАН «Язык и культура в полиэтничных и поликонфессиональных сообществах Юго-Восточной Европы: междисциплинарное исследование». 
«Постпамять - это сильная и очень специфическая форма памяти именно потому, что ее отношение к предмету или источнику опосредовано не воспоминанием, а воображением и творчеством. <..> Истории предыдущего поколения, порожденные травматическим опытом, который не поддается ни пониманию, ни переработке, “подминают" под себя их собственные запоздавшие истории» ${ }^{8}$. Поскольку поколенческая память в целом способствует обновлению восприятия социального и культурного наследия ${ }^{9}$, «позволяет обществу взглянуть на себя по-новому» ${ }^{10}$, постпамять с точки зрения коллективной памяти выполняет очевидные связующие функции: это механизм выявления и постепенного заполнения неизбежно образующихся «белых пятен». Проблема носителей постпамяти неразрывно связана с поиском формы в ситуации отсутствия единого источника воспоминаний, она «касается не того, как запечатлеть всё запечатленное памятью, а того, что делать с памятью, которая помнит не непосредственные события, а повествования о них ${ }^{11}$, что неизбежно приводит к использованию «противоречивых данных, на которых лежит печать травмы», и попыткам придать им «структуру упорядоченного знания» ${ }^{12}$.

Внукам Выживших во время холокоста, в отличие от предыдущего поколения, уже не пришлось открывать собственное происхождение, преодолевать родительское молчание и свою немоту (по разным причинам, в первую очередь вследствие сильного послевоенного антисемитизма, многие Выжившие продолжали жить по «арийским» документам). Они не наследуют травму холокоста столь непосредственно, как их родители, которым пришлось столкнуться не только с опытом смерти, но и с вторичной травмой - невозможностью символически «обменять» трагический военный опыт на признание в обществе, необходимостью по-прежнему жить в укрытии, ощущая собственную инаковость, переживая массовую травму как индивидуальную, будучи обреченным на внутреннюю цензуру и т. д. Вместе с тем это поколение, вынужденное подвергнуть переоценке собственную идентичность и саму проблему еврейства в современной Польше ${ }^{13}$.

Повествователь «Пансионата» (2010) Петра Пазиньского, который критики назвали «первым литературным голосом поколения внуков холокоста» ${ }^{14}$, приезжает спустя годы в полупустой еврейский пансионат под Варшавой, где ребенком бывал с бабушкой. Встречается с призраками - персонажами из прошлого, погружается в детство и - через подслушанные тогда взрослые разговоры - в еврейскую историю, рассматривает открытки, фотографии, собранные старика- 
ми, ощущая собственную неразрывную связь с ними («последний из цепочки поколений, уцепившийся за самый кончик» $\left.{ }^{15}\right)$ - и уезжает.

Автор вводит топос пансионата - пространства не столько замкнутого, сколько, во-первых, «выделенного», «огороженного», вовторых - временного («- Вы надолго? - На несколько дней. - На несколько дней. Проездом, значит» $\left.{ }^{16}\right)$. Это было место относительно замкнутое и временное также для того поколения, к которому приходит «в гости» повествователь («Наша маленькая, забытая станция с облезлой табличкой. В конце весны мы высаживались на ней, нагруженные чемоданами и узлами. < . .> Запасались на несколько месяцев, до первых холодов. <..> Тогда мы сразу собирались домой, потому что приближалась зима» $\left.{ }^{17}\right)$. В послевоенные годы сюда ездили уцелевшие и не эмигрировавшие польские евреи, чтобы в меланхолической атмосфере пансионата ненадолго ощутить иллюзию существования собственного мира, отсылающего к довоенному, воскресить чувство принадлежности: «И всё же что-то влекло их сюда. В этот неприглядный дом отдыха с вечно отваливающейся штукатуркой? Они чувствовали себя дома. Во всяком случае здесь, за оградой. Это не такая уж простая и пустяковая штука — чувствовать себя дома. Не каждому дано. Так говорил пан Хаим. Мы никогда не бываем дома, всегда в пути, словно на этом барельефе сзади памятника героям гетто, где раввин с Торой ведет свой народ»; «Если уж человек еврей, так ему хочется побыть среди своих»; «Доктор Кан, пани Ханка, пани Пеля и пани Зюта, все держались как-то вместе, заодно. Горсточка друзей»; «Пан Хаим любил тут сидеть. В креслице, подложив под голову надувную подушку. Взгляд устремлен на кроны сосен. Пан Хаим смотрел вперед и жадно вдыхал смолистый воздух. - Почти как на Святой земле. А знаете, почему евреи так любят “привислинскую ветку”? Она напоминает им дом! - Дом. Где-то там, далеко. Несколько дней на пароходе. Поселения первопроходцев в Сионе» ${ }^{18}$. Это вырванное из повседневности пространство отсылает, таким образом, одновременно к санаторию (буквально - это место когда-то было санаторием $^{19}$, а также метафорически - его обитателей вслед за И. Ивасюв можно назвать «больными, страдающими от меланхолии в результате катаклизма холокоста» ${ }^{20}$ ) и убежищу.

Пансионат, каким его видит взрослый повествователь, подобен, с одной стороны, опустевшему дому, с другой стороны - склеny, царству мертвых: «Здесь уже почти никого не осталось»; «- Тихо тут, правда? - заговорил директор. - Всё вымерло»; «- А, эти! - махнул он рукой с вилкой. — Но они тут всегда, это всё равно, как если 
бы их вообще не было»; «Что у нас за пансионат! Не то больница, не то мертвецкая!» ${ }^{21}$ Неслучайно предметы сравниваются с мумиями, а обитатели подобны «восковым куклам» и теням, сливающимся с призраками прошлого, те, в свою очередь, - в том числе через цитируемые ими на иврите фрагменты Ветхого Завета - с библейскими персонажами: «Я пытался отыскать это лицо в закоулках памяти, извлечь оттуда, словно с особенно неудачного негатива, чтобы заново подретушировать, дополнить деталями, которые предстали теперь передо мной в лице сидящего»; «Тщетно. Ни один хранившийся в памяти портрет незнакомцу не соответствовал. И тем не менее я был уверен, что пан Якуб не совсем мне незнаком. Честно говоря, он вообще не годился на роль незнакомца. Он явно был тем, кто существовал, кто не мог не существовать. Если не теперь, то в те времена»; «Доктор ли Кан был передо мною или всё же пан Якуб из столовой? Клювоносые старички слились теперь в одного персонажа»; «- Ма тову огалеха... - пропел он. Шатры Иакова. Почему мы должны жить в шатрах? Так долго скитаться по пустыне, чтобы оказаться там, где мы теперь? - Нашли свою кровать? - Он внимательно глядел на меня. Человек по имени Якуб. Каждое имя что-то означает, говорят, в нем записана вся жизнь человека. Патриарх Иаков. Пятница. Потому что в лоне матери ухватился за пяту брата-близнеца. Где теперь брат твой, лохматый Исав? Дом его будет соломой, а наш будет огнем. Пророкам тоже свойственно ошибаться: порой огонь задыхается, если набросать слишком много соломы, и остается от него лишь столб черного дыма. - Вы знаете эту библейскую историю? - спросил старик, когда мы сели за стол друг напротив друга. - И вышел Иаков из Беэр-Шевы... Это парашат ваеце, осенний отрывок, который читали в синагоге, когда с деревьев опадут все листья. Он задумался. За окном зашумели ветви сосен. Это продолжалось довольно долго. С шоссе доносился гул редких машин» ${ }^{22}$.

Призраки прошлого, воскрешающие и собственные воспоминания повествователя, и его воспоминания об обрывках воспоминаний взрослых, сохраненные ими обветшавшие предметы, фотографии, газетные вырезки превращают это пространство в своеобразный заповедник прошлого - послевоенного, военного, довоенного, библейского: «Вещи, более живучие, чем люди. Теперь уже всеми покинутые. Кто их похоронит, чтобы не валялись на какой-нибудь помойке?»; «...картонная коробка из-под обуви с надписью: "Хелмек, лодочки дамские коричневые”. Крест-накрест перевязанная розовой ленточкой, уже немного истлевшей»; «Пани Теча развязала бантик и под- 
няла крышку. Внутри, уложенные тесно, вплотную друг к другу, покоились бумажные свертки. Похожие на миниатюрные мумии, словно их хозяева так и не покинули дом неволи: каждый пакетик завернут в газету, потом еще для верности перехвачен резинкой»; «пожелтевшие картонки»; «В другом пакетике оказались письма, военных лет, из Варшавы»; «Довоенных снимков, картонных карточек, некоторые с зубчатыми краями, сохранилось довольно много, пожалуй несколько десятков. Во всяком случае больше, чем людей. Те, кто тогда выжил, тоже уже умерли. От них остались фототени»; «Это напоминало египетский папирус, остатки букв на папиросной бумаге. Письма, возможно уже послевоенные, на идише» ${ }^{23}$.

Нашу эпоху П. Нора называет временем ухода памяти ${ }^{24}$. Повествователь Пазиньского физически ощущает ее исчезновение: «Но всё равно остались лишь разрозненные, рассыпанные слова. Трудно разобрать, словно написано не чернилами, а луковым соком»; «Я сидел, наверное, целый час <..>, пытаясь расшифровать содержимое свертков. В комнате постепенно темнело, а мне не хотелось вставать и зажигать люстру. Буквы в письмах, и так едва различимые, таяли в темноте. С каждой секундой их становилось всё меньше, там, где еще мгновение назад я мог разглядеть контуры и даже пытался снова сложить их в слова, уловить образуемый ими сообща смысл хоть на каком-нибудь языке, теперь простиралась исключительно пустота потрепанного по краям пергамента. Так что я снимал очередные резинки, разворачивал папиросную бумагу и срывал слои газет, которые крошились в руках, словно под бременем напечатанных на них в свое время слов. Каждый листок почтовой бумаги сперва вздрагивал в моих пальцах, отчего казалось, будто в нем еще тлеет крохотная частичка забытой жизни. Я вертел его, поднимал повыше, к остаткам дневного света, пробивавшегося сквозь ажур занавесок. Напрягал зрение и, прищурив глаза, пытался разобрать клонившиеся набок фразы, но листок замыкался в себе, всё стремительнее угасал и чернел, так что я уже ничего не видел» ${ }^{25}$. Своим присутствием повествователь соединяет воедино память об услышанном и пережитом, открывает, словно спрятанные одна в другой китайские шкатулки, собственные и чужие воспоминания. Чужое повествование накладывается на свое и дополняется своим, в котором воображение заполняет «белые пятна» («Об этом писали в книгах, многие видели это своими глазами, но картинка из стольких неизвестных не складывается. Погибла ли она прямо на улице или ее потащили в подворотню, где сподручнее убивать? От немецкой пули или украинской нагайки? А может, ее расстреляли лишь 
на следующий день, во время акции в тюрьме “Бригидки”? Никто уже этого не выяснит, и никто не узнает правды о ее последних минутах. Фотографа тогда рядом с тетей Груней не случилось. Поэтому я вижу ее так, как умею разглядеть, словно в немом кино <.. > Дальше картинка размывается, словно пленка засвечена» $\left.{ }^{26}\right)$, в результате сам текст становится «местом памяти», «предназначенным для трансмиссии забытого прошлого» ${ }^{27}$.

Призраки прошлого («И стоит - перед пансионатом, между крыльцом и железнодорожной станцией, — толпа теток и дядей, стоят дюжины панов Леонов, панов Абрамов и двойников доктора Кана, отряды бабушкиных подруг, дедушкиных и дяди Мотиных кузенов и все сестры пани Цукерман. Стоят и глядят на меня») обладают, как им и пристало, магической силой: «Я хотел убежать, но почувствовал, что меня держит какая-то сила < ..> словно ноги мои спутаны веревкой, словно я принадлежал к поколению пана Абрама и пани Мали, словно между мной и дядей Шимоном не было никакой разницы в возрасте, ни малейшей щелочки, которая могла бы наши судьбы разделить. Они держали меня в стальных объятиях» ${ }^{28}$. Важен, однако, своеобразный вектор, движение повествователя по направлению к духам прошлого: «— Я иду к вам! — крикнул я»; «— Я? К себе, — пробормотал я. — К себе? — Она явно возмутилась. - Это дом отдыха. <..> Знаю и хотел бы войти внутрь. - Почему вы хотите войти? < . . — Я здешний <..> Я тут когда-то жил»; «Хорошо, что ты приехал»; «я наконец смогу войти в дом» ${ }^{29}$. Этот вектор передает ностальгию по эпохе, когда еще существовал хотя бы такой временный, словно бы выгороженный в пространстве послевоенной Польши дом, теперь же этим домом могут служить лишь память и текст.

Во второй книге Пазиньского «Птичьи улицы» (2013) появляется также топос подземелья, фундамента Варшавы — города, где существует уникальный район, выстроенный на руинах гетто и из руин, но при этом представляющий собой воплощенное забвение («Порой делали вид, что его история не имеет никакого значения и что в Варшаве не слышны уже его шаги. В цене были новые дома, прекрасные сады и сверкающий асфальт, под которым тянулись прежние артерии»; «сетка современных улиц была накинута как попало, словно до нее ничего не было, она не прилегала к почве, зависала в пустоте, неловко скрывая небытие»; «каждая мысль о том, чем были те улицы <..>, впитывалась в брусчатку, исчезала между камнями, в расщелинах, ведущих куда-то вглубь, откуда еще никто не вернулся живым»; «Пустота, заселенная заново» ${ }^{30}$ ), где пласт сегодняшнего 
повседневного и чудовищного прошлого соприкасаются буквально: «...новые городские кварталы построили на человеческих костях, лежащих близко от поверхности земли, прямо под ногами прохожих. Этот образ <..> сжился с городом как следует, становясь естественным элементом повседневности. Мы были на него обречены, как люди, которым пришлось жить на руинах умершей цивилизации»; «слышен был тот шум — и те жалобы, всё еще доносящиеся из-под земли, из-под остатков тротуаров» ${ }^{31}$ ), причем здесь возникает тот же вектор - вглубь, к предкам. Это некая параллельная современной польской реальность, доступная посвященным («рассказы о том, что кое-где в боковых, редко посещаемых пространствах, несколько нелегальных и сомнительных, существует еще Варшава, как бы параллельная той, по которой обычно водят профанов, Варшава неопределенного статуса, трудноуловимая, мерцающая на грани бытия и пустоты»; «Говорили, что город полон лакун и сдвигов и через них можно пробраться вглубь, где по-прежнему курсируют трамваи, весело бренча звонками, и где люди изучают Книгу. Это можно сделать днем, необязательно под покровом ночи, нужно только найти нужный ход в подвалы или старый телефонный колодец, иногда отодвинуть свободный кирпич или кусок бровки. Через такую щель можно проскользнуть внутрь» ${ }^{32}$.

В циркуляцию посттравматической памяти включены и те, кто не связан с исторической травмой непосредственно, «генетически» ${ }^{33}$. По утверждению Д. Лакапры, травма «заразна» - она распространяется не только через непосредственное общение со свидетелями, но и посредством научных исследований, художественной рефлексии, СМИ, включается в процесс самоидентификации как проекция ${ }^{34}$. Это опыт младшего поколения польских писателей нееврейского происхождения, которые остро ощущают на себе бремя исторической травмы - десятилетиями вытеснявшегося чувства вины, - неразрывно связанной также с потребностью в пересмотре последствий травмы, ставшей фундаментом национального этоса ${ }^{35}$, - трагической и героической польской мартирологии, являющейся культурным капиталом, основой национальной идентичности и играющей в сегодняшней Польше весьма тенденциозную идеологическую роль. Собственные страдания занимают в коллективной памяти слишком много места, не оставляя его для страданий, перенесенных другими и особенно причиненных другим. Кроме того, опыт стыда «с трудом включается в багаж памяти, поскольку не создает позитивного образа себя или социума» ${ }^{36}$ : 
любое национальное государство «тщательно конструирует общее историческое наследие и делает всё возможное, чтобы дискредитировать или подавить память о событиях, нарушающих декларируемую общность национальной традиции» ${ }^{37}$. Поэтому такого рода опыт долго не находит символического выражения, не становится частью коллективной или культурной памяти, а «в случае отсутствия адекватных форм памяти психический шрам травмы может неосознанно переноситься на следующие поколения» ${ }^{38}$. Общественная дискуссия, связанная с ролью поляков как свидетелей холокоста - включающая в себя элементы публицистического, документального, собственно художественного дискурса, - будучи «отложена» в свое время, идет с середины 1980-х гг. и не только далеко не закончена, но переживает очередное обострение. Проблема холокоста оказывается неотделима от причудливого сплетения «мании собственной невиновности» ${ }^{39}$ с подсознательным чувством вины, страхом запятнать романтическую роль жертвы приятием роли со-виновного, мегаломанией и эгоцентризмом мартирологии, а в конечном счете - с необходимостью переосмыслить дискурс польского патриотизма, польской идентичности. Перед литературой же встает задача выражения нового для польского большого нарратива опыта - страха и стыда. И здесь - в обновлении коллективной памяти, особенно когда речь идет о проработке постыдных воспоминаний ${ }^{40},-$ также важнейшую роль играет смена поколений. По словам И. Токарской-Бакир, вспоминать будут «польские дети и внуки - вместо молчащих отцов и дедов» ${ }^{41}$. В самом деле, чувство стыда и страха, потребность прервать «культуру молчания» ${ }^{42}$, сознательно проработать прошлое ощущается, как показывают тексты, в мировосприятии младшей генерации.

«Пазиньский на самом деле призывает задуматься также и нас третье поколение неевреев. Что мы сделали и что мы делаем с памятью наших дедов?» ${ }^{43}$ - восклицает К. Казимеровская. Показательно, что эта проза также использует топос подземелья и мотив призраков, однако в иной перспективе.

В прозе авторов младших поколений 2000-2010-х гг. звучит ощущение как личной травмы «запятнанности» Польши сотворенным на ее территории и на глазах у поляков Злом. Неслучайно само название романа Игоря Остаховича «Ночь живых евреев» (2012) отсылает к фильму Дж. Ромеро «Ночь живых мертвецов» (1968), снятому в стиле gorno, который предполагает не появление зла извне, но нахождение его источника внутри изображаемого мира. Для них 
«мучительна прогулка по Варшаве» ${ }^{44}$, чувство личного стыда вызывает осознание стирания еврейского слоя варшавского «палимпсеста», освоения территории как чистого листа. Остахович начинает свой роман со слов: «Я родился и живу в городе золотоискателей. В свое время они съехались сюда со всей сожженной равнины. Искатели золотых коронок и серебряных ложечек. Их привлек дым руин и зловоние сожженных тел богатых горожан. <..> Мы не предаемся воспоминаниям о своих несчастьях, так что не приходится о них помнить, когда мы кладем сахар в чай нашим детям. Варшава некрасивый город, но здесь любят жизнь в ее самой чистой форме» ${ }^{45}$ : память об уничтоженных жителях заново заселенного района предана забвению. Сильвия Хутник в «Карманном атласе женщин» (2009) касается проблемы единого - единственного - официального мартирологически-патриотического дискурса: героиня всю жизнь опасается, что ее лишат патриотически-польского военного прошлого и раскроют его «еврейскую изнанку» (участие сначала в восстании варшавского гетто, и лишь затем в варшавском восстании - «куда бы я отдала повязку со звездой Давида? Я хранила их вместе. Прильнувшие друг к другу, словно пара любовников. Проникнутые одним запахом. Снятые с одного плеча, одного места»): «В этом городе есть место только для одного героического подвига - у него имеется свой музей, своя мартирология, свое место в памяти» ${ }^{46}$. (С этими мыслями героини словно бы перекликаются слова представительницы второго поколения Выживших Б. Кефф: «Но евреи якобы не сражались, и якобы их история не пересекалась - никак - с историей поляков. Она существовала отдельно. Она действительно в значительной степени существовала отдельно. И когда откроется Музей истории польских евреев [это произошло в 2013 г., а уже в 2017 г. начальник Организации польского туризма сделал попытку исключить музей, а также мемориал в Освенциме из программы, рекомендуемой иностранным гостям Польши. - И. А.], можно будет сказать: ведь у вас есть СВОЙ музей! И засвидетельствовать эту отдельность на веки вечные» ${ }^{47}$.) Варшава описывается как город, стоящий в буквальном смысле на трупах, на крови, на костях. Чувство стыда сублимируется в мотивы страха и возмездия - умершие напоминают о себе.

Происходит буквализация восприятия еврейского прошлого как непосредственно соприкасающегося с мирной жизнью подполья. Проза исследует топос уже конкретного, «одомашненного», включенного в повседневную польскую жизнь подземелья - подвала - как 
пространства, связанного с инфернальной областью, пространства смерти, спуск в которое ассоциируется с погребением заживо, а выход откуда призраков - с посмертным блужданием неупокоенной души (в романе Остаховича жертвы холокоста выходят из подвалов и заполоняют Варшаву, в рассказе Хутник «Мурано-о-о» в подвал спускаются и на какое-то время оказываются там заперты польские дети). Одновременно подвал оказывается метафорой глубин памяти и замалчиваемой травмы (из дыры в подвале доносится «шум, как из раковины, если ее приложить к уху» ${ }^{48}$ : в раковине, как известно, шумит не море, а наша собственная кровь — так и здесь шумят не мертвые, а память живых).

Эта проза активно эксплуатирует мотив духов, призраков. Район Муранов, по сути, воплощает топос «проклятого дома», населенного привидениями: «Муранно-о-о, повесть о несуществующем городе в центре города, о духах эта повесть, о шептухах» ${ }^{49}$. Одновременно он осмысляется и как своего рода огромный «подвал», вытесняемое в подсознание прошлое Варшавы и, шире, Польши. Неслучайно спустившиеся в подвал польские дети чувствуют, «как их постепенно засасывает эта подвальная история, скользкая повесть, блуждающая вдоль стен и шепчущая все громче: “Мурано-о-о” $>$ "

Возвращение души-призрака всегда аномально и свидетельствует о нарушении «отношений» между миром живых и миром мертвых. История о призраке - это, как правило, история о некой не разрешенной в положенное время проблеме. В данном случае это вытеснение памяти о жертвах холокоста, не совершённая работа траура (отсюда противопоставление еврейских жертв холокоста польским жертвам, многократно оплаканным ${ }^{51}$, — чужие страдания вытесняются из памяти, уступая место отечественной мартирологии).

Рассказ Хутник «Мурано-о-о» (сб. «В стране чудес», 2014) помесь сказки в духе братьев Гримм и детской «страшилки» с ее абсурдом, развернутый эпизод черного юмора, совмещающий в себе элементы комического и ужасного. В рассказе причудливо сочетаются «гриммовская» простота и жестокость логики («Когда бабушку стали по ночам пугать привидения, у нее возник план: приготовить из детей мацу, покрошить в подвале, и пускай эти крошки превратятся в золотые камешки. Евреи бросятся их подбирать и потравятся») и доведенные до абсурда узнаваемые национальные стереотипы (евреи в гетто «были ленивыми. Им попросту неохота было убегать. Поляки то и дело высовывались из-за ограды и кричали им: “Эй!” А те: “Да ладно”. Тогда поляки снова: “Эй! Мы вам ковер-самолет дадим, сядете 
на него да и улетите из этого гетто". Из-за стены в ответ, что, мол, ковры грязные. Тогда польская армия - давай пылесосы сбрасывать. <..> Энергосберегающие пылесосы в гетто кидали, чтобы эти неженки задницы себе не испачкали. А они - ноль реакции, передумали, мол. Капризничают: “Не-ет. Неохота. Нам и тут хорошо”» ${ }^{52}$ ). Брат с сестрой, подстрекаемые бабушкой-людоедкой, спускаются в подвал, где якобы лежат зарытые еврейские сокровища (т. е. эксплуатируется еще один стереотип). Связь с земной жизнью прерывается, из груд щебня появляется пресловутый еврейский призрак - маленький мальчик. Вместо сокровищ брат с сестрой находят потерянную мальчиком машинку - как символ его утраченного, непрожитого детства ${ }^{53}$. Таким образом, стыд маскируется гротеском, страх черным юмором, однако всё возвращается на круги своя - проблема присутствующего в коллективном подсознании чувства вины не решена: «Все варшавские призраки закопались еще глубже - сидят, ждут-пождут ${ }^{54}$.

Воплощает страх перед вытесненным, неоплаканным еврейским прошлым и неожиданное появление призраков - жертв холокоста на пороге квартиры современного поляка в горькой комедии Остаховича «Ночь живых евреев». Роман по сути представляет собой фантасмагорическое воплощение слов Я. Блоньского (эссе «Бедные поляки смотрят на гетто»), в которые не верит поначалу главный герой: «Лето, улица Анелевича, трепещущие листочками липы, их медовый запах $<\ldots>$ людей мало, потому что жара, но каждый бы у виска покрутил, услышав, что зло не засыпать щебнем и землей, что страдание нужно почтить и рассчитаться за него, а кровь, если ее вовремя не смыть и позволить спокойно впитаться в землю, смешавшись с глиной, выберется когда-нибудь наружу ордой големов $<\ldots>$, а поломанные кости и оскверненные тела облачатся в те остатки тряпья, которые у них не успели украсть, превратятся <..> в двуногих призраков, не знающих ничего, кроме боли, и понесут эту боль другим, бегая, скрючившись, от двери к двери наших спокойных квартир» ${ }^{55}$.

Роман основан на игре с поп-культурой, отсылает к эстетике комикса, компьютерных игр, различных киножанров, представляет собой гротескное смешение кодов, жанров, цитат. Это карнавальное освоение болезненной для коллективного сознания темы. В романе всё реально и наглядно - и зло (дьявол), и вытесненное из коллективной памяти, неоплаканное прошлое (еврейские трупы-призраки, обитающие в подвале польского дома), и страх перед этим прошлым (борьба варшавян с трупами, отсылающая к реалиям Большой акции 
1943 года). Глубинный смысл миссии превращающегося из эвримена в супермена героя - спасение еврейских трупов в Ночь живых евреев («Если в эту ночь труп будет убит, он исчезнет из мира в прошлом, будущем и настоящем» ${ }^{56}$ ) - это сохранение памяти, солидарность с теми, кого некому оплакать, сопротивление вытеснению постыдных фрагментов отечественного прошлого.

Именно такой, гротескный, отсылающий к масскультуре сюжет, позволяющий жертвам холокоста буквально и зримо постучаться в польскую дверь, заставляет молодого героя-повествователя пройти своего рода «ускоренный курс» эмпатии и сострадания. Это словно бы иллюстрация к словам Лакапры о том, что реакция на травматические события даже у свидетеля второй степени связана с эмпатическим беспокойством, которое оказывается «необходимым, аффективным измерением» исследования прошлого и «играет важную роль в попытках понять травматические события и жертв травмы» ${ }^{57}$. Д. Уолкер ${ }^{58}$ также говорит о том, что травмированная память является действенным инструментом исследования прошлого. Вне зависимости от того, в какой степени она позволяет получить достоверное изображение прошлого, механизм ее производен от самой раны, а потому повествование раскрывает правду травмы несмотря на возможные ошибки в воспроизведении фактов. Эту мысль почти буквально иллюстрируют сцены, связанные с «пребыванием» героя в Освенциме и беседой с Дьяволом. Ад Освенцима и холокоста невообразим и невыразим, попытаться осознать его можно, лишь придумав ад в соответствии с возможностями собственного воображения.

«Запутанная польская память о евреях <..> по-прежнему нуждается в потрясении, - утверждает польская исследовательница Б. Пшимушала. - Нуждается порой даже и в триллере, чтобы увидеть собственную чудовищность» ${ }^{59}$. Созвучны ее мысли размышлениям актера А. Жмиевского: «Есть в Варшаве < .. > памятник, на улице Ставки, на месте бывшей Умшлагплац. Белый куб с написанными на двух языках - польском и иврите - именами; вокруг черная каменная полоса. Как-то я слышал радиопередачу < ..> Журналистка опрашивала учащихся экономического института, здание которого стоит вплотную к памятнику, знают ли они, где была Умшлагплац и где находится памятник жертвам холокоста. Студенты, дважды в день проходящие мимо, не знали, где находится памятник, не знали, что такое Умшлагплац. Не знали, что в здании, где они учатся, находилась еврейская больница. $<\ldots>$ Я подумал, что нам $<\ldots>$ нужны 
другие памятники - не белые кубики, а истории с фигурами, как в комиксе. $<\ldots>$ Эстетический императив мы не воспринимаем, а вот цветные комиксы - пожалуйста» ${ }^{60}$.

В текстах Остаховича и Хутник можно также увидеть параллель с иронично-парадоксальной провокационной психотерапией Фрэнка Фарелли, стремящейся к формированию - при помощи юмора, гротеска, доведения до абсурда - у пациента «комического сознания» ${ }^{61}$. Комическое тесно связано с защитно-приспособительными возможностями человека и социума, может становиться «механизмом безопасности, придающим человеку равновесие, перспективу и оптимальную психологическую дистанцию» ${ }^{62}$. Ирония и сарказм, являясь эмоциональной трансформацией, жестким высмеиванием события, поиском в нем абсурдного, служат вербальной разрядке эмоций (неслучайно черный юмор В. И. Жельвис называет «прививкой от подлинной агрессивности» ${ }^{63}$ ). Предметом осмеяния соединяющего смех и жестокость черного юмора становятся сферы, в той или иной степени табуированные. Кроме того, по словам Н. А. Масленковой, терапевтический эффект черного юмора порождается тем, что «маркируя границу между смертью (или угрозой смерти, жестокостью, страшным и пр.) и жизнью, подобный смех отделяет пространство смеющегося от изображаемого» ${ }^{64}$. Если говорить о психологическом измерении художественного и художественном измерении психологического в этих текстах, представляется, что визуализация ужаса памяти и беспамятства, национальных стереотипов необходима для его диссоциации и дальнейшего осмысления. Перспектива же гротеска, абсурда, комического и пр., деконструкция клише массовой культуры призваны действовать в качестве своего рода обезболивающего, «кавычек». Черный юмор в случае Хутник и карнавальное обыгрывание кодов масскультуры у Остаховича способствуют, таким образом, помимо эмоциональной разрядки в ситуации вытесненного чувства вины и порожденного вытеснением страха, психологической интеграции - содействуют «трансформации ранее отчужденных аспектов “я” в полноправные аспекты целостной личности, “избегая при этом откровенной идентификации с ними"» ${ }^{65}$.

Постпамять о польско-еврейском прошлом, таким образом, касается не только истории, но прежде всего неразрывно связана с настоящим и будущим. Это своего рода стратегия идентичности, как в смысле индивидуально-психологическом, так и в перспективе формирования коллективной памяти. Постпамять оказывается своего рода 
поколенческой стратегией преемственности ${ }^{66}$, будь то меланхолическая археология памяти или гротескная охота за привидениями.

\section{ПРИМЕЧАНИЯ}

1 Hirsch M. Family Frames: Photography, Narrative and Postmemory. London, 1997.

2 Hirsch J. Postmodernizm, drugie pokolenie i międzykulturowe kino posttraumatyczne // Antologia studiów nad traumą. Kraków, 2015. S. 256.

3 Fine E. S. The absent memory: the act of writing in Post-Holocaust French literature // Writing and the Holocaust. New York, 1998. Р. 41-57. Цит. по: Hirsch J. Postmodernizm, drugie pokolenie i międzykulturowe kino posttraumatyczne. S. 256.

4 Young J. E. At Memory's Edge. After - Images of the Holocaust in Contemporary Art and Architecture. New Haven; London, 2000. Р. 2. Цит. по: Ziębińska-Witek A. Wizualizacje pamięci — upamiętnianie Zagłady w muzeach // Kwartalnik Historii Żydów. 2006. № 3. S. 367.

5 Raczymow H. Pamięć podziurawiona // Tygiel Kultury. 2013. № 7-12. S. 12.

6 Pinchevski A. Archive, Media, Trauma // On Media Memory: Collective Memory in a New Media Age. Houndmills, 2011. S. 258. Цит. по: Łysak T. Trauma — od genealogii pојкcia do studiów nad traumą // Antologia studiów nad traumą. S. 8.

7 Fresco N. Remembering the unknown // International Review of Psycho-Analysis. 1984. № 11. Р. 421. Цит. по: Hirsch J. Postmodernizm, drugie pokolenie i międzykulturowe kino posttraumatyczne. S. 256.

8 Hirsch $M$. Żałoba i postpamięć // Teoria wiedzy o przeszłości na tle współczesnej humanistyki. Antologia. Poznań, 2010. S. 254.

9 Мангейм К. Проблема поколений // Новое литературное обозрение. 1998. № 30. С. 22.

10 Айерман Р. Культурная травма и коллективная память // Новое литературное обозрение. 2016. № 5. (URL: http://www.nlobooks.ru/ node/7960).

11 Bojarska K. Historia Zagłady i literatura (nie)piękna. «Tworki» Marka Bieńczyka w kontekście kultury posttraumatycznej // Pamiętnik Literacki. 2008. Z. 2. S. 95.

12 Gilmore L. Przypadki graniczne: trauma, autoreprezentacja i prawne formy tożsamości. S. 370.

13 Reszke K. Powrót Żyda. Narracje tożsamościowe trzeciego pokolenia Żydów w Polsce po Holokauście. Kraków; Budapest, 2013. 
14 Sobolewska J. Taniec z cieniami. Powiastka filozoficzna o żydowskim losie // Polityka. 2009. № 1. S. 40.

15 Paziński P. Pensjonat. Warszawa, 2010. S. 134.

16 Ibid. S. 31.

17 Ibid. S. 100.

18 Ibid. S. 20, 31, 37, 51.

19 Ibid. S. 7, 84-86.

20 Iwasiów I. Literatura sanatoryjna // Tygodnik Powszechny. 2010. № 11. (URL: https://www.tygodnikpowszechny.pl/literatura-sanatoryjna-145166; дата обращения: 28.08.2018).

21 Paziński P. Pensjonat. S. 16, 26, 29, 32.

22 Ibid. S. 10, 30, 12, 57, 65.

23 Ibid. S. 19, 21, 22, 23, 43, 24.

24 Нора П. Франция-память // Нора П., Озуф М., Пюимеж Ж. де. М.; СПб., 1999. С. 17.

25 Paziński P. Pensjonat. S. 23-24.

26 Ibid. S. 49.

27 Rybicka E. Miejsce, pamięć, literatura (w perspektywie geopoetyki) // Teksty Drugie. 2008. № 1-2. S. 29.

28 Paziński P. S. 97, 134.

29 Ibid. S. 134, 11, 25, 12.

30 Paziński P. Ptasie ulice. Warszawa, 2013. S. 119-124.

31 Ibid. S. 128, 123.

32 Ibid. S. 138-139.

33 Szczepan A. Polski dyskurs posttraumatyczny. Literatura polska ostatnich lat wobec Holokaustu i tożsamości żydowskiej // Kultura po przejściach, osoby z przeszłością. Polski dyskurs postzależnościowy — konteksty i perspektywy badawcze. Kraków, 2011. S. 243.

34 La Capra D. Historia w okresie przejściowym. Doświadczenie, tożsamość, teoria krytyczna. Kraków, 2009. S. 108.

35 Ibid. S. 78; LaCapra D. Trauma, nieobecność, utrata // Antologia studiów nad traumą. Kraków, 2015. S. 103.

36 Assmann A. Między historią a pamięcią. Antologia. Warszawa, 2013. S. 51.

37 Bauman Z. Wieloznaczność nowoczesna, nowoczesność wieloznaczna. Warszawa, 1995. S. 94.

38 Assmann A. Między historią a pamięcią. S. 52.

39 Tokarska-Bakir J. Obsesja niewinności // Tokarska-Bakir J. Rzeczy mgliste. Sejny, 2004. S. 14.

40 Ассман А. Длинная тень прошлого. Мемориальная культура и историческая политика. М., 2014. С. 16. 
41 Tokarska-Bakir J. Obsesja niewinności. S. 14.

42 Tokarska-Bakir J. Historia jako fetysz // Tokarska-Bakir J. Rzeczy mgliste. S. 98.

43 Kazimierowska K. Gdy nie ma już kogo zapytać, czyli Żydzi tacy jak my // Kultura Liberalna. 2009. № 29 (URL: http://kulturaliberalna. pl/2009/08/03/kazimierowska-gdy-nie-ma-juz-kogo-zapytac-czyli-zydzi-tacy-jak-my/; дата обращения: 28.08.2018).

44 Chutnik S. Kieszonkowy atlas kobiet. Kraków, 2009. S. 134.

45 Ostachowicz I. Noc żywych Żydów. Warszawa, 2012. S. 76.

46 Chutnik S. Kiesz konkowy atlas kobiet. S. 99.

47 Keff B. Trup, horror, ojczyzna. Przedmowa // Janicka E. Festung Warschau. Warszawa, 2011. S. 13.

48 Ostachowicz I. Noc żywych Żydów. S. 54.

49 Chutnik S. W krainie czarów. Kraków, 2014. S. 121.

50 Ibid. S. 135.

51 Ibid. S. 136; Ostachowicz I. Noc żywych Żydów. S. 87.

52 Chutnik S. W krainie czarów. S. 125-126, 123.

53 Ibid. S. 138.

54 Ibid. S. 140.

55 Ostachowicz I. Noc żywych Żydów. S. 14.

56 Ibid. S. 228-229.

57 La Capra D. Trauma, nieobecność, utrata. S. 100.

58 Walker $J$. The traumatic paradox: autobiographical documentary and the psychology of memory. Contested Pasts: The Politics of Memory / Ed. by K. Hodgkin, S. Radstone. Routledge, 2003. Цит. по: Legg S. Memory and nostalgia // Cultural Geographies. 2004. № 11. S. 104.

59 Przymuszała B. Smugi Zagłady. Emocjonalne i konwencjonalne aspekty tekstów ofiar i ich dzieci. Poznań, 2016. S. 182.

60 Janicka E. Festung Warschau. S. 90.

61 Фарелли Ф. Провокационная терапия. Екатеринбург, 1996. (URL: http://royallib.com/book/farrelli_frenk/provokatsionnaya_terapiya.html; дата обращения: 28.08.2018).

62 Там же.

63 Жельвис В. И. «Черный юмор: анатомия человеческой деструктивности» (URL: www.yspu.yau.ru; дата обращения: 28.08.2018).

64 Масленкова Н. А. (Не)культурный формат «черного юмора» // Studia Culturae. Вып. 12. С. 147.

65 Jakab I. Humor and psychoanalysis // L'Humor. Histoire, culture et psychologie. Paris, 1998. Р. 17-18. Цит. по: Копытин А. И. Юмор в искусстве и арт-терапии: феноменология, диагностика, защитно-адаптивные 
возможности // Медицинская психология в России. 2012. № 4 (15) (URL: http:/medpsy.ru/mprj/archiv_global/2012_4_15/nomer/nomer02.php).

66 Ibid. S. 114.

\section{E. Adel'gejm}

The memory of Polish and Jewish past: The problem of space and vector (young Polish prose of the 2000-2010s)

The article sheds lide on the spatial aspect of the problem of Polish and Jewish past of Poland in the prose of the third generation after the Holocaust. It studies texts written by young authors who are connected by their origin both to Jewish (P. Paźiński) and Polish (S. Chutnik, I. Ostachowicz) parts of this past.

Keywords: Polish and Jewish past, Holocaust, post-memory, space, vector. 


\section{Фрагмент статейного списка посольства А. С. Матвеева к Богдану Хмельницкому и другие документы русско-украинских отношений XVII в. в составе книги № 120 архива Малороссийского приказа}

Публикуется фрагмент статейного списка Артамона Матвеева и дьяка Ивана Фомина к Богдану Хмельницкому в июне 1657 г. До недавнего времени этот источник - единственное свидетельство о последней русской миссии к запорожскому гетману до его кончины - не привлекал внимание историков. В предисловии к публикации характеризуются и другие неизвестные исследователям документы, посвященные русско-украинским отношениям XVII в.

Ключевые слова: А. С. Матвеев, Ф. В. Бутурлин, Богдан Хмельницкий, статейный список, русско-украинские отношения, архив Малороссийского приказа.

DOI: $10.31168 / 2073-5731.2018 .3-4.7 .01$

В фонде № 229 (Малороссийский приказ) Российского государственного архива древних актов среди книг второй описи находится книга № 120. Согласно давно составленным и недавно опубликованным описям, данное дело содержит материалы 1710-1720-х гг., относящиеся главным образом к гетманству И. И. Скоропадского ${ }^{1}$. Однако знакомство с книгой показывает, что опись не отражает значительной части документов, представляющих собой ряд весьма ценных источников для изучения истории русско-украинских отношений. В частности, именно в 120-й книге содержится переписка, касающаяся казацких старшин-эмигрантов (сторонников Мазепы, бежавших вместе с ним во владения Османской империи) в 1712-1713 гг., которую подробно рассмотрел в своем труде «Мазепинцы» Н. И. Костомаров ${ }^{2}$. Однако в описи никаких упоминаний об этих бумагах нет.

Есть в указанном деле и ряд других совершенно неизвестных исследователям документов, причем часть из них касается периода XVII в. Последние - это главным образом фрагменты дел, имеющие разную степень ценности для исследователя, в частности отрывочные документы, связанные с контактами гетмана Самойловича и московского правительства в 1679 г. ${ }^{3}$, переписка приказа с киевскими 
воеводами за 1678 г. (отпуск грамоты с запретом впускать в Россию выезжих на царскую службу немцев и поляков; отписка с информацией об отпуске из киевского гарнизона заболевшего жильца; отпуски грамот с распоряжением прислать сыскное дело касательно убытков, нанесенных служилыми людьми владениям Киево-Печерского монастыря, а также с требованием прислать информацию по поводу данного ранее указа о расследовании многочисленных конфликтов русских ратных людей и киевских мещан) ${ }^{4}$ и 1694 г. (отпуск об отправлении в город стругов с продовольствием; отписка о доставке леса для укрепления Киева и пограничного местечка Остер)

Весьма любопытен самый ранний документ книги № 120 - оригинал письма на имя царя Алексея Михайловича королевского старосты из Гадяча Мартына Длуцкого (Длузкого) ${ }^{6}$ от 5 марта 1647 г. Он вступался за подданных князя Иеремии Вишневецкого, нескольких торговцев во главе с Климом Демиденко, которые ездили в Воронеж. Купцы, везшие с собой среди прочего табак и вино, жаловались, что в десяти верстах от Белгорода их встретили посланные воеводой князем Н. И. Одоевским ${ }^{7}$ ратные люди, которые передали приказ, чтобы торговцы «вино и табак под Билагород к мосту припровадили». Однако когда они сделали это, воевода распорядился все бочки с вином «порубати и табак пожечи». «Коли, великий господарь, царь, не потребно было горелки и табаки, то было иноземцов не заварочати и через ратных, господарь, оголосити, щобы иноземцы ни з якого города до твоего царского величества, так же и воинов твоего царского величества не возили жадного товару», — жаловался Длуцкий. Он просил, чтобы правительство заставило Одоевского, который «не ведомо для якое прычыны убогих людей, з степы ку Воронижу идучих, збил и до шкоды не малое приправил», компенсировать убытки подданных Вишневецкого ${ }^{8}$.

Помимо вышеупомянутых документов, в книге содержатся два фрагмента статейных списков царских послов к Богдану Хмельницкому 1657 г. Посольства эти отправились к гетману одно за другим. Первой была миссия окольничего Федора Васильевича Бутурлина и дьяка Василия Михайлова. Ее материалы опубликованы ${ }^{9}$, и сама она хорошо исследована в научной литературе ${ }^{10}$. Издание было осуществлено еще в позапрошлом веке в рамках серии «Акты Южной и Западной России» по двум спискам, сохранившимся до наших дней, - оригиналу в столбцах ${ }^{11}$ и более поздней его копии, переписанной в тетради со скрепами дьяка Приказа тайных дел Федора Казанцева 1677 г. ${ }^{12}$ Оба экземпляра уже в XIX столетии были в плохом состоянии, в них недоставало мно- 
гих листов, в связи с чем в публикации остался ряд лакун. Пропавший фрагмент, который не вошел в публикацию, также переписан в тетради со скрепами Ф. Казанцева ${ }^{13}$, следовательно, относился к экземпляру из фонда № $124^{14}$. Текст его должен был располагаться на месте пропуска, обозначенного в публикации «Актов Южной и Западной России» сразу после описания встречи Бутурлина с отцом генерального писаря Ивана Выговского, Остафием Выговским ${ }^{15}$. В нем говорится о прибытии послов в Киев 25 мая 1657 г. и о последовавших затем встречах царских дипломатов сначала с Лазарем Барановичем (в тот же день), недавно посвященным в черниговские епископы, затем с киево-печерским архимандритом Иннокентием Гизелем (на следующий день). С последним послы по наказу обсуждали проблему имений Киево-Печерского монастыря в Белоруссии, о чем уже упоминалась в литературе на основе отписки Бутурлина ${ }^{16}$. Однако факт свидания последнего с Лазарем Барановичем остался неизвестным исследователям.

Послы посетили обедню в храме св. Софии, после которой епископ, «которой ныне ведает Киевскую митрополию до обрания митрополита», пригласил их на трапезу. В «розговорных речех» царские послы сказали, что «в дороге» узнали, что киевское духовенство, после смерти митрополита Сильвестра Косова, якобы посылало к царю Алексею и патриарху Никону «бити челом $<\ldots>$, кому великий государь $<\ldots>$ на Киевской митрополии изволит быть и великий государь, святейший Никон патриарх благословит». Послы желали подтверждения этого известия, однако черниговский епископ опроверг его, сообщив лишь, что приезжавший в Киев «для своего веселья» (свадьбы) генеральный писарь Войска Запорожского Иван Выговский передал приказание гетмана Хмельницкого «о обранье киевского митрополита в Киеве съезд учинить» 15 августа. Лазарь Баранович заявил, что «духовные наши о том порадят на соборе, от кого благословение получити, понеже от початку Киевские митрополиты имели благословение от патриархов Констянтинополских». Последняя ремарка вызвала недовольство Бутурлина и Михайлова, упиравших на то, что после того, как Малая Россия «учинилас под высокою рукою великого государя $<\ldots>$ и под властью $<\ldots>$ святейшаго Никона патриарха, и вам, православным, единоверным, достойно быти под паствою святейшаго Никона патриарха идеж убо царское благочестие тут и верх священства». Владыка Лазарь обещал вынести данное предложение на собор, который уже сможет обратиться к царю и патриарху. «А без совету всех того учинит ему немочно», - подытожил он, одновременно уверяя русских представителей, что «они де царского величества богомолцы о том радуются и 
особную утеху имеют, что ныне Бог благоловил им быти под высокою рукою благочестиваго великаго государя $<\ldots>$ також де $<\ldots>$ и под паствою $<\ldots>$ святейшаго Никона патриарха московского и всеа Великия и Малыя и Белыя Росии» и всегда молятся о здравии представителей царского семейства и патриарха ${ }^{17}$. Уже упоминавшийся Г. Карпов, не имевший в своем распоряжении данного известия, полагал, что царское правительство «как бы нарочно не обращало внимания на тогдашние церковные дела в Малороссии», не дав послам соответствующих указаний об избрании киевского митрополита ${ }^{18}$. Это оказало влияние на построения В. Эйнгорна, автора фундаментального труда о контактах малороссийского духовенства с московским правительством ${ }^{19}$. Однако, как видно из неизвестного фрагмента статейного списка, это было не так. На самом деле правительство в Москве предприняло через послов зондаж настроений киевских церковных верхов с намерением инициировать обращение в Москву о переходе новоизбранного киевского митрополита под власть московского патриарха.

Несомненно, наиболее интересным и ценным для исследователя является другой документ - фрагмент статейного списка стольника Артамона Матвеева и дьяка Ивана Фомина, возглавивших последнее русское посольство, которое застало Богдана Хмельницкого в живых в июне 1657 г. Долгое время историки знали лишь о самом факте этой миссии, реконструируя ее содержание на основе вторичных и весьма неточных пересказов. Лишь недавно она была обстоятельно исследована с привлечением указанного фрагмента статейного списка ${ }^{20}$. Поэтому, не входя в детали, отметим, что посольство это было снаряжено в конце весны 1657 г., когда русско-украинские отношения находились на пике кризиса. Хмельницкий выступал против заключенного Россией и Речью Посполитой Виленского перемирия 1656 г., вопреки царским распоряжениям и политике Москвы заключил союз со Швецией и выслал свои войска для участия в совместном походе на польские земли с трансильванским князем Дьердем II Ракоци - еще одним союзником шведского короля Карла Х Густава. Царские послы, прибывавшие в Чигирин с начала 1657 г., пытались убедить гетмана изменить свою политику, шедшую вразрез с интересами России, но безуспешно. Лишь по прибытии Матвеева старый гетман, получивший, с одной стороны, известия о провале похода Ракоци, а с другой - о возросшей угрозе со стороны Крымского ханства и Османской империи, признал ошибочность своей политики, согласившись разорвать союзные отношения со Швецией.

Важность этого момента, несколько иначе представляющего политику Хмельницкого в отношении России незадолго до смерти, 
как представляется, делает необходимым и публикацию самого документа.

Статейные списки А. С. Матвеева и Ф. В. Бутурлина (в случае последнего - и столбец, и тетради) хранились в архиве Тайного приказа. После смерти царя Алексея Михайловича, в ходе многолетнего разбора приказных бумаг, они были отосланы в другие ведомства. «Список с статейного списка» (тетради) Бутурлина отправили в Посольский приказ в 1677 г. (дата передачи совпадает с датой скреп, поставленных Ф. Казанцевым), столбец со скрепами дьяка Даниила Полянского - в 1683 г. в Малороссийский. Туда же и в том же году отослали и статейный список А. С. Матвеева ${ }^{21}$. Относительно последнего не указано, какой тип рукописи был передан, но думается, что тетради, фрагмент которых со скрепами подьячего Приказа тайных дел Порфирия Оловяникова и содержится в книге № $120^{22}$.

Публикация новооткрытого фрагмента статейного списка А. С. Матвеева и И. Фомина осуществлена согласно «Правилам издания исторических документов» (М., 1990).

\section{Не позднее июля 1657 г. Фрагмент статейного списка поездки стрелецкого головы А. С. Матвеева на Украину}

(Л. 147) Да писар же Иван Выговской говорил, гетман де Богдан Хмелницкой велел вам говорит, чтоб вам, Артемону и Ивану, нынешняго дня у него гетмана быт на отпуске, а как время будет, и в те поры под вас пришлет лошади.

Да того ж числа к Ортемону и к Ивану приходили на двор подписки Гарасим Каплонской со товарыщи три человека, а приносили лист, а говорили, каков де лист гетман Богдан Хмелницкой пошлет с вами, Артемоном и Иваном, к великому государю нашему, к его царскому величеству, и тот де лист велел вам писар Иван Выговской прочест, чтоб вам про то было ведомо. А после того в розговорных речех говорили, после де виленской комисии к гетману Богдану Хмелницкому приехали ево посланцы, а сказали, что царского величества (л. 147об.) великие и полномочные послы в шатер не пущали и ничего им ведат не дали. И у гетмана де и у полковников и у всего Войска Запорожского было сумненье болшое, и гетман де Богдан Хмелницкой с полковниками о том радил не по одиножды, как де учинитца великий государь наш, его царское величество, на Коруне Полской и на Великом княжстве Литовском королем и нас де казаков ляхом выдаст, и нам де от них будет гонение и обиды такие ж, как и преж сего от них было. А на тех де радах гетман 
говорил, не поискат ли де нам иного государя? И полковники де все учали говорит гетману, того де себе и не помышляй, что то дело учинит, не токмо нам, и тебе казаки за такое дело не умолчат, а быт нам по прежнему своему челобитью и по присяге под высокою рукою великого государя (л. 148) нашего, его царского величества, до своей смерти. И после де того гетман о том деле рады отставил.

Да того ж числа к Ортемону и к Ивану на двор приходил писаря Ивана Выговского отец Остап Выговской, а в розговорных речах про раду гетмана Богдана Хмелницкого с полковники говорил те ж речи, что говорили подписки Гарасим Каплонской с товарыщи.

Да того ж числа гетман Богдан Хмелницкой к Ортемону и к Ивану на двор прислал ясаула Миска, а за ним привели лошеди.

И Артемон и Иван к гетману поехали, а за ними ясаул Миско, а с ним 8 человек казаков шли пеши. (л. 148 об.) И как приехали к гетману на двор и с лошедей ссели у крылца и пошли в сени, а на крылце де встретил Артемона и Ивана писар Иван Выговской с казаки, а в сенях по обе стороны стояли казаки ж. А как пришли в светлицу и гетман Богдан Хмелницкой стоит у постели на одну рубашку в чюге ${ }^{23}$ и с Ортемоном и с Ываном витался. И после того Артемон и Иван сели за столом, а гетман сел на постели. И учал гетман говорит речь, что б великий государь наш, его царское величество, милость показал, велел ему вину отдать, что он бес повеления великого государя нашего, его царского величества, полковника Антона с Войском Запорожским, сложас с венграм Ракоцею и с мултяны и с волохи и с свейским королем, посылал воеват ляхов, а впред де он, гетман, бес повеления (л. 149) великого государя нашего, его царского величества, войско в войну никуда не пошлет и никому помочи не учинит.

Да гетман же Богдан Хмелницкой Артемону и Ивану говорил, чтоб вы, Артемон и Иван, великому государю нашему, его царскому величеству, известили, чтоб великий государь наш, его царское величество, надо мною, гетманом, и надо всем Войском Запорожским милость показал, велел дат помочь своими ратными людми, как турские люди и крымской хан со всею ордою, совокупяс с ляхи, наступят войною царского величества на черкаские городы.

И Артемон и Иван гетману говорили, писано (л. 149об.) к тебе, гетману, в великого государя нашего, его царского величества, в грамоте с посланцом твоим, Федором Коробкою, будет тебе подлинная ведомость учинитца, что турские люди учнут Дунай перевозитца и похотят Днестр перейти и наступят царского величества на черкаские городы, и ты б, гетман, против указу великого государя нашего, его царского величества, отписал к турскому салтану, а к великому государю нашему, к 
его царскому величеству, отписал же наскоро, чтоб великому государю нашему, его царскому величеству, про то было ведомо.

И гетман Богдан Хмелницкой говорил, что де мы против грамоты царского величества к турскому салтану писали и послали к нему посланца своего Лаврина Капусту, а чает де он от турского салтана к нему, (л. 150) гетману, будет вскоре. А что к нему, гетману, турской салтан отпишет, и он де, гетман, про то великому государю нашему, его царскому величеству, ведомо учинит.

И Артемон и Иван гетману говорили, что мы у тебя слышим, и о том великому государю нашему, его царскому величеству, известим.

Да Артемон же и Иван гетману Богдану Хмелницкому говорили прежние речи, что б он по указу великого государя нашего, его царского величества, с Войском Запорожским шол войною на свейского короля или в свое место ково послал.

И гетман Богдан Хмелницкой говорил, что ему ныне с Войском Запорожским на свейского короля войною (150 об.) итти не мочно и в свое место послати нелзя, потому что турские люди и крымской хан со всею ордою и с ляхи идут войною царского величества на черкаские городы, а как та война успокоитца, и он, гетман, со всем Войском Запорожским на свейского короля и на всех царского величества неприятелей войною итит готов.

А говоря те речи, гетман Богдан Хмелницкой взяв у писаря Ивана Выговского лист, встав, отдал Артемону, а молыл, великому государю нашему, царю и великому князю Алексею Михайловичю, всеа Великия и Малыя и Белыя Росии самодержцу, я, гетман, с началными людми и со всем Войском Запорожским челом бью, и поклонился ниско, а говорил со слезами, чтоб де великий государь наш, его царское величество, (л. 151) пожаловал нас милостию своею как начал, а мы должны ему, великому государю, служит и на неприятели ево царского величества готовы.

И Артемон и Иван, взяв лист, пошли из светлицы, а писар Иван Выговской провожал их до лошадей.

А как Артемон и Иван от гетмана поехали, и ясаул Миско с казаки шли за ними пеши и провожали до двора. И после того к Ортемону и к Ивану приехал на двор писар Иван Выговской, а за ним привели две лошеди. А говорил писар, прислал де гетман Богдан Хмелницкой к вам, Артемону и Ивану, по лошеди да в дорогу на корм Артемону ортами ${ }^{24}$ на семнатцат рублев, а Ивану ортами ж на восм рублев. (л. 151об.)

И Артемон и Иван на гетманской любви били челом и тех людей, с которыми лошади и таляр(ы) присланы, дарили. 
И того ж дни Артемон и Иван ис Чигирина поехали, а писарь Иван Выговской, а с ним с 30 человек казаков, провожали от Чигирина с три версты. И с писарем с Ываном Выговским розъехалис.

Да Артемон же и Иван, будучи в Чигирине, проведывали вестей.

После цесаря римского обран на цесарство брат ево Леополд ${ }^{25}$, а зато обиране наступил на цесарскую землю францужской корол ${ }^{26}$ для того, что францужского короля не обрали.

(л. 152) Турскому салтану виницейской княз силен ${ }^{27}$, в нынешнем во 165-м году многие гале(р)ные и каторги побил и розных государств полоняников з 20000 от турских людей из неволи свободил и у себя держит их по воле, а дает им месячной корм, и против турка те полоняники бьютца. А которые полоняники не похотели у него служить, и корму имат, и те пошли в свои земли.

Да писар же Иван Выговской Артемону и Ивану сказывал, что у венгерского Ракоци и у мутьян и у волохов и у Антона полковника ${ }^{28} \mathrm{c}$ свейским королем рознь и меж собою розошлис в недружбе за корысть. Российский государственный архив древних актов. Ф. 229. On. 2. Д. 120.

\section{ПРИМЕЧАНИЯ}

1 Малороссийский приказ. Описи фонда № 229 Российского государственного архива древних актов / Отв. ред. Т. Г. Таирова-Яковлева. М., 2012. C. 306-308.

2 Костомаров Н. И. Мазепинцы // Он же. Исторические монографии и исследования. СПб., 1885. Т. 16. С. 659-670.

3 Отпуск царской грамоты гетману от 13 июня 1679 г. // Российский государственный архив древних актов (далее - РГАДА). Ф. 229. Оп. 2. Д. 120. Л. 141-142; Память из Разряда в Малороссийский приказ. 12 июня 1679 г. (без окончания)// Там же. Л. 142-142об., 144-144об.; Фрагмент наказа посланному к гетману И. Самойловичу стольнику В. С. Нарбекову [4 июня 1679 г.] // Там же. Л. 143-143об.; 145-146об. Перед нами, несомненно, фрагменты несохранившейся книги, в которую были переписаны оригинальные документы, содержащиеся в столбце малороссийских дел за 1679 г., который сохранился. См.: Там же. Ф. 124. Оп. 1. 1679 г. Д. 17. Л. $27-$ 61 (наказ В. С. Нарбекову), 62-63 (отпуск грамоты гетману), 64-68 (память из Разряда, причем оригинал датирован 10 июня).

4 Там же. Ф. 229. Оп. 2. Д. 120. Л. 582-589об. На л. 589а заголовок: «185 году си листы книги по Малоросийскому приказу». 
5 Там же. Л. 560-567об. Фрагменту предшествует страница с заголовком «Из дел Приказу Малыя Росии» (Там же. Л. 559a), а сам он представляет собой копии отпуска и отписки, переписанных в книгу.

6 В 1643 г. М. Длузский получил от коронного гетмана С. Конецпольского право на аренду города Гадяч, местечек Лютенки и Рашавы с окрестными селами сроком на три года (на 1644-1647 гг.). Текст контракта на аренду см.: Воссоединение Украины с Россией. Документы и материалы: В 3 т. М., 1954. Т. 1. 1620-1647. С. 359-362.

7 Воевода «большого полка» со ставкой в Белгороде, руководивший в 1646 г. работами по сооружению Белгородской черты. См.: Загоровский В. П. Белгородская черта. Воронежб 1969.С. 120-123.

8 РГАДА. Ф. 229. Оп. 2. Д. 120. Л. 30-31. Характерно, что автор обращается к царю как к «Божиею милостию великому господарю, царю и великому князю <...> всея Руси самодержцу». Вообще, хотя в письме использован полный царский титул, скрупулезные приказные бюрократы все равно отметили, что «в том листу в государеве титле не написано удорскому» (Там же).

9 Акты, относящиеся к истории Южной и Западной России, собранные и изданные Археографической комиссией (далее - АЮЗР). СПб., 1861. Т. 3. 1638-1657. С. 554-589.

10 О посольстве Бутурлина см.: Грушевський М. С. Історія України-Руси. Київ, 1997. Т. 9. Кн. 2. С. 1250-1252, 1378, 1411-1427; Флоря Б. Н. Русское государство и его западные соседи (1655-1661 гг.). М., 2010. C. 231-232, 252-255.

11 РГАДА. Ф. 229. Оп. 1. Д. 22.

12 Там же. Ф. 124. Оп. 1. 1657 г. Д. 7. Л. 1-107. Федор Казанцев служил в Приказе тайных дел с 1656 г., с 1673 г. - дьяк того же приказа (Веселовский С. Б. Дьяки и подьячие XV-XVII в. М., 1975. С. 223).

13 РГАДА. Ф. 229. Оп. 2. Д. 120. Л. 590-598. Скрепа по полям листов: «Федор Казанцев, дьяк».

14 Ср.: АЮЗР. Т. 3. С. 588-589. Фрагмент статейного списка из книги № 120 должен был располагаться между листами 8-9об. современной пагинации дела № 7 за 1657 г. первой описи 124-го фонда.

15 АЮЗР. Т. 3. С. 557.

16 Карпов Г. Дионисий Балабан, митрополит Киевский. Из истории отношений Киевской церковной иерархии к московскому правительству 1654-1661 гг. // Православное обозрение. 1874. № 1. С. 118. Исследователь использовал не статейный список, а отписки Ф.В. Бутурлина, также сохранившиеся. См.: РГАДА. Ф. 229. Оп. 1. Д. 22.

17 РГАДА. Ф. 229. Оп. 2. Д. 120. Л. 590-592об.

18 Карпов Г. Дионисий Балабан. С. 118. 
19 В. Эйнгорн оспаривал тезис Г. Карпова о невнимании московского правительства к будущим митрополичьим выборам, но полагал, что все указания по этому вопросу были направлены киевскому воеводе А. В. Бутурлину. См.: Эйнгорн В. О сношениях малороссийского духовенства с московским правительством в царствование Алексея Михайловича. СПб., 1890. С. 100-101.

20 Кочегаров $K$. A. Посольство Артамона Матвеева к гетману Богдану Хмельницкому в 1657 г. // Российская история. 2018. № 3. С. 114-120.

21 Русская историческая библиотека, издаваемая Императорской археографической комиссией. СПб., 1907. Т. 21. Дела Тайного приказа. Кн. 1. Стб. 7, 18, 345, 352, 621, 645, 648, 653.

22 Скрепа «[Пор]филей Оловеников» на полях л. 148, 149, 150, 151, 152. П. Ф. Оловяников служил в Тайном приказе подьячим с 1660 по 1674 г. (Веселовский С. Б. Дьяки и подьячие. С. 386).

23 Чуга - разновидность плаща, верхней накидки.

24 Орт - польская либо немецкая серебряная монета.

25 В рукописи ошибочно «Деополд». Речь идет об императоре Священной Римской империи Леопольде I, который после смерти (в апреле 1657 г.) отца Фердинанда III был избран императором и коронован в июле 1658 г.

26 Людовик XIV (правил в 1643-1715 гг.).

27 Речь идет о турецко-венецианской («Кандийской») войне 16451669 гг.

28 В тексте ошибочно «полковником».

\section{K. A. Кочегаров}

A fragment of diplomatic mail (stateyny spisok) of A. S. Matveev embassy to Bohdan Khmelnytsky and other documents on Russian-Ukrainian relations in the $17^{\text {th }}$ century in Book 120 of the archive of the Little Russia Office

This is a publication of a diplomatic letter (stateyny spisok) of Artamon Matveev and dyak Ivan Fomin to Bohdan Khmelnytsky in June 1657. Until lately this only sourse on the last Russian mission to the hetman of Zaporizhia before his death did not draw much attention of the historians. In the foreword to the publication the author dwells upon other documents unknown to previous researchers that are dedicated to Russian-Ukrainian relations in the 17th century. Keywords: A. S. Matveev, F. V. Buturlin, Bohdan Khmelnytsky, stateyny spisok, Russian-Ukrainian relations, archive of the Little Russia Office. 
А. И. Колин (Кичинев),

А. С. Стыкалин (Москва)

\title{
«Историку-архивисту и археологу чужды мечты о лаврах, срываемых разными крикунами на митингах...» Письмо Ивана Халиппы архиепископу Арсению (Стадницкому), 1910 год
}

\begin{abstract}
Бессарабский историк-краевед Иван Халиппа, который за свою причастность к молдавскому национальному движению, связанному с Румынией, подвергся гонениям губернских властей, нашел заступника в лице своего земляка, влиятельного архиепископа Русской православной церкви Арсения (Стадницкого). Ключевые слова: Российская империя, Бессарабия, Русская православная иерковь, митрополит Арсений (Стадниикий), молдавское национальное движение.
\end{abstract}

DOI: $10.31168 / 2073-5731.2018 .3-4.7 .02$

Среди многочисленных корреспондентов выдающегося российского церковного деятеля митрополита Арсения (Стадницкого) был его земляк и ученик по кишиневской семинарии Иван (молд.: Иоан) Николаевич Халиппа (1871-1941), в родной Молдове известный как замечательный историк, архивист, бессарабский краевед, а на Украине прежде всего как педагог и организатор системы образования. С 1910 г. Халиппа служил инспектором народных училищ Бердянского уезда, а позже, в 1920-е гг., был заведующим Бердянских педагогических курсов, из которых со временем вырос местный пединститут ${ }^{1}$. Вниманию читателей предлагается документ из хранящегося в Государственном архиве Российской Федерации (ГАРФ) обширного личного фонда митрополита Арсения (в миру Авксентий Георгиевич Стадницкий, 1862-1936)2. Он продолжает серию документальных публикаций, раскрывающих через переписку владыки Арсения широкие связи этого крупного иерарха молдавского происхождения и историка церкви с земляками-бессарабцами

Публикуемое ниже письмо Стадницкому проливает свет на некоторые конкретные факты биографии Ивана Халиппы, предопределившие его отъезд в 1910 г. из Кишинева в приморский Бердянск. Кишиневский школьный инспектор И. Халиппа не только просит высокопоставленного церковного функционера (в это время пока еще не митрополита Новгородского и Старорусского, а архиепископа Псковского и 
Порховского, члена госсовета Российской империи, представляющего в нем монашествующее духовенство) похлопотать о предоставлении ему новой должности в школьной системе Российской империи, но и излагает свою версию событий, в конце концов вынудивших его фактически навсегда покинуть родную Бессарабию.

Уроженец с. Куболта Сорокского уезда Бессарабской губернии, Иван Халиппа закончил в 1891 г. Кишиневскую духовную семинарию, где в числе его педагогов был и молодой А. Стадницкий, будущий митрополит Арсений, преподававший в семинарии с 1885 г. Высшее образование Халиппа получил в Киевской духовной академии с получением степени кандидата богословия в 1895 г. Вернувшись в родные края, он начал государственную службу в ноябре 1896 г. в качестве помощника инспектора духовной семинарии. Дальнейшая его деятельность была связана с Бессарабской губернской ученой архивной комиссией, «правителем дел» (фактически ученым секретарем) которой он был с 1898 г. В 1904 г. он становится секретарем Бессарабского историко-археологического общества. Халиппа координировал работу над трехтомной публикацией «Трудов Бессарабской губернской ученой комиссии», в которых наряду с архивными первоисточниками увидели свет статьи по истории, археологии, этнографии и статистике. В этом издании он опубликовал ряд собственных ценных работ по истории Бессарабии ${ }^{4}$. Наиболее значительная из них, «Город Кишинев времен жизни в нем А. С. Пушкина», подготовленная и опубликованная к столетию великого русского поэта в 1899 г., была переиздана в Кишиневе уже в XXI в.

Надо сказать, что в 1910 г. Иван Халиппа уезжал из Бессарабии, найдя другое место службы, не впервые. В августе 1905 г. он (к этому времени уже видный историк-краевед) покидает Кишинев, получив место школьного инспектора в Новомосковском уезде Екатеринославской губернии. На этом месте он проработал два года, после чего вернулся в родной край на равнозначную должность - инспектора народных училищ Кишиневского уезда Бессарабской губернии. Свой перевод обратно в Бессарабию И. Халиппа в письме Стадницкому объясняет содействием, или, как он пишет, «участливым вмешательством», тогдашнего бессарабского губернатора Алексея Николаевича Харузина.

Выпускник физико-математического факультета Московского университета (1889 г.) Алексей Харузин (1864-1932) был не только чиновником, но и серьезным ученым - этнографом и антропологом, участником многих полевых научных экспедиций и автором большого количества научных публикаций5. Харузин был бессарабским губернатором с ноября 1904 г. по октябрь 1908, т. е. его пребывание в этой 
должности совпало с революцией 1905-1907 гг. и активизацией национального движения бессарабских молдаван. Историкам известно о его попытках противопоставить движению, ориентированному на тесные связи с Румынией (рупором которого была газета «Басарабия»), более умеренный и лоялистский проект - газету «Молдованул» ${ }^{6}$. Как узнаем, однако, из переписки, И. Халиппа познакомился с будущим бессарабским губернатором еще в 1902 г., за два года до приезда Харузина в Бессарабию7 ${ }^{7}$ Можно предполагать, что в их знакомстве сыграла свою роль общность научных интересов, в частности интерес к проблемам миграции населения из балканских владений Османской империи в пределы Российской империи в конце XVIII - начале XIX в. ${ }^{8}$

Из письма выясняется, что в 1905 г., уже будучи бессарабским губернатором, Харузин предлагал Халиппе должность секретаря Бессарабского губернского статистического комитета, но назначение не состоялось, ибо Халиппа предпочел этому месту должность инспектора народных училищ сначала в Екатеринославской, а затем, по возвращении в Кишинев, в Бессарабской губернии.

В 1908 г. И. Харузин получает новое назначение - директора департамента духовных дел иностранных исповеданий и отбывает в Петербург. Его преемником на посту бессарабского губернатора становится граф Иван Викторович Канкрин. Первоначально, казалось бы, ничто не предвещало плохих отношений Халиппы с новым губернатором. Граф одобрительно высказывался о его планах реорганизации школьной жизни в Кишиневе и уезде, характеризовал его перед губернским и уездным предводителями дворянства как «отличного инспектора», в 1909 и 1910 гг. Халиппа приглашался на пасхальные губернаторские приемы, и более того, в начале 1910 г. был награжден с согласия губернатора орденом Св. Анны 3-й степени. Довольно скоро, однако, их отношения совершенно неожиданно для Халиппы меняются в худшую сторону. Граф начинает проявлять некоторое недоверие к инспектору народных училищ, подозрения в его политической неблагонадежности. Собственно говоря, для этого были определенные основания, ведь Иван Халиппа был старшим братом Пантелеймона Халиппы (1883-1979), активиста прорумынского национального движения бессарабских молдаван, а впоследствии одного из его харизматических лидеров и, более того, человека, ставшего со временем видным румынским политиком, многократно входившим в состав правительств межвоенной Румынии, пока профранцузские влияния в нем не сменились прогреманскими и прогитлеровскими. 
Граф Канкрин, видимо, с первых месяцев своего пребывания на губернаторском посту был наслышан о политической активности молодого Пантелеймона Халиппы и стал подозревать Ивана в сочувствии политическим убеждениям младшего брата. Очевидно, для таких подозрений были некоторые причины, ведь, как известно из литературы ${ }^{9}$, И. Халиппа в общем симпатизировал зарождавшемуся национальному движению бессарабских молдаван, выступавшему в это время с умеренными требованиями активизации школьного обучения на родном языке, поддерживал с ним связи, и об этом не могли не знать в окружении губернатора. Показательно, что уже в ходе одной из первых встреч со школьным инспектором граф Канкрин полушутя предупредил его, что объявит ему войну, если тот вдруг вздумает встать во главе местного национального движения. И. Халиппа в сложившейся ситуации счел за лучшее отмежеваться от сторонников «утопических национально-сепаратистских движений», любящих покричать на митингах. И позже, в интересах сохранения своего места школьного инспектора, он продолжал всячески подчеркивать свою лояльность власти. Инцидент после этого можно было считать исчерпанным, но только до тех пор, пока внимание губернатора не было привлечено к ряду программных статей Пантелеймона Халиппы о национальной школе в Бессарабии и о деятельности Бессарабского молдавского общества. Встретив после этого И. Халиппу на одном из деловых свиданий, граф Канкрин поставил вопрос, что называется, ребром: «Сочувствуете ли вы идее молдавской школы в Бессарабии?» В этих условиях у И. Халиппы не было иного выбора, кроме как прямо отмежеваться от своего младшего брата. За газетными статьями не надо было далеко ходить, И. Халиппа держал их в боковом кармане своего кителя. Вытащив их, он обратил внимание губернатора на то, что они принадлежат не его перу, а перу его младшего брата, человека вполне самостоятельного и придерживающегося иных, а именно левых, убеждений. Это, однако, не помогло, поскольку в конце мая И. Халиппа в конфиденциальном порядке получил письмо за подписью самого министра народного просвещения А. Н. Шварца с предложением не позже 1-го августа подать попечителю Одесского учебного округа прошение об отставке от службы по министерству народного просвещения, «приискав себе место в другом ведомстве». Это вызвало удивление не только И. Халиппы, но и директора народных училищ Бессарабской губернии, а также и попечителя Одесского учебного округа, к которому Халиппа уже на следующий день приехал в Одессу на прием. Можно было предполагать, что основанием для распоряжения министра были некоторые донесения местных бессараб- 
ских властей в Петербург. И. Халиппа добивается аудиенции у губернатора, который, по его словам, был уже в курсе намерения министра перевести его в другой учебный округ, оставив при этом служащим своего министерства. По мнению графа, Халиппе вновь повредила активность его брата, который организовал поездку в Яссы группы бессарабской молодежи, главным образом учащихся реального училища, и выступал при этом в качестве экскурсовода, внушавшего молодым людям румынофильские идеи. И. Халиппа вновь счел целесообразным дистанцироваться от своего брата, с которым он, по его словам, не поддерживает тесных отношений после того, как тот, получив стипендию ясского благотворительного общества, устроился вольнослушателем в Ясский университет вопреки воле родителей и увещеванию старшего брата. В беседе с губернатором И. Халиппа в принципе дал согласие перейти на службу по тому же ведомству в другой учебный округ, если, «по каким-либо соображениям», его дальнейшее пребывание в Бессарабии «представляется нежелательным или опасным». Договорились о том, что во время своей рабочей поездки в Петербург, намеченной на начало июня, губернатор переговорит с министром, попросив его заменить отставку переводом в другой учебный округ. Но в Петербурге граф так и не посетил министра, хотя и просил знакомого чиновника навести справку по делу Халиппы. В конце концов И. Халиппа решил с согласия попечителя Одесского учебного округа сам «войти в министерство с обстоятельной докладной запиской, изложив в ней историю всей своей 14-летней государственной службы и 12-летней научной деятельности». Наконец 31 июля было получено принципиальное согласие министерства на оставление его на службе по линии министерства народного просвещения с переводом из Одесского в другой учебный округ. В письме владыке Арсению И. Халиппа просил иерарха, члена госсовета империи, использовать свои связи в целях получения им хорошей должности по линии министерства народного просвещения в одном из близлежащих к Бессарабии учебных округов. Причем, по возможности, такой должности, которая оставляла бы время для научной работы. Правда, впоследствии науку Халиппе фактически пришлось оставить, всецело сосредоточившись на педагогическом поприще.

О том, какую роль сыграли в дальнейшей судьбе И. Халиппы ходатайства архиепископа, мы можем только предполагать. Из источников выясняется, что с 23 октября 1910 г. он приступил к выполнению обязанностей инспектора народных училищ в Бердянском уезде тогдашней Таврической губернии ${ }^{10}$. С городом Бердянском на берегу Азовского моря была связана вся его последующая жизнь ${ }^{11}$. Однако его дальней- 
шие научные планы, связанные с изучением истории Бессарабии, были реализованы лишь в очень незначительной степени. Причем увольнение И. Халиппы и его последующий отъезд из Бессарабии не могли не быть замеченными общественным мнением края. Либеральная газета «Бессарабская жизнь» выразила сожаление по поводу того, что лишился своей должности «один из лучших знатоков местной старины» ${ }^{12}$.

Случай с Иваном Халиппой показывает, насколько серьезные опасения вызывала в 1910 г. не только у бессарабских губернских властей, но и в Петербурге хотя бы самая отдаленная причастность чиновника школьной системы к одному из национальных движений этнических меньшинств Российской империи, в данном случае к национальному движению бессарабских молдаван, тогда еще весьма умеренному по своей политической программе ${ }^{13}$. Хотя И. Халиппа в целом симпатизировал этому движению и поддерживал личные связи с некоторыми его активистами, его никак нельзя было назвать в числе идеологов или активистов движения. Сферой его первоочередных интересов оставалась не актуальная политика, а изучение истории Бессарабии. Как выясняется из документов, имя И. Халиппы действительно фигурировало в некоторых донесениях Департамента полиции, и в частности в донесении от 31 декабря 1909 г,, как имя человека, имеющего непосредственные контакты с движением бессарабских молдаван ${ }^{14}$. Вместе с тем подозрения внушала, видимо, не столько его активность в этом движении (она была весьма слабой), сколько сам факт его близкого родства с одной из ключевых, а впоследствии даже харизматических фигур. С другой стороны, И. Халиппа едва ли видел себя в будущем как активного политика и дорожил своим местом чиновника в системе народного просвещения, дававшим ему возможность заниматься и научными исследованиями в области краеведения. Сделанный им выбор был вполне продуманным и логичным, ведь в 1910 г. Российская империя еще отнюдь не трещала по швам, никакие автономистские проекты не могли быть востребованы властями, а любого рода увлечения панрумынистскими идеями могли казаться не более чем уделом мечтателей. Отсюда делается понятной готовность И. Халиппы отмежеваться в глазах губернских властей и министерства просвещения от своего брата и его политической деятельности.

Последующие судьбы братьев Халиппа сложились по-разному. Иван был арестован летом 1940 г. после включения в состав СССР Бессарабии - очевидно, во избежание его возвращения в родные края и восстановления нежелательных для советской власти контактов с земляками из числа старой интеллигенции. Скончался он при неизвестных 
обстоятельствах в заключении летом 1941 г., через три дня после нападения Румынии вместе с гитлеровской Германией на СССР. Пантелеймон также прошел, уже после Второй мировой войны, через арест находился в лагере сначала в СССР, а в 1953-1957 гг. в Румынии. Позже он был не только амнистирован, но в эпоху Чаушеску фактически реабилитирован, получая персональную пенсию за заслуги в отстаивании румынских национальных ценностей. Правда, так и не был восстановлен в ранге члена-корреспондента Румынской академии, из которой был исключен в 1948 г., - это вызвало бы ненужную румынским властям шумиху в Советской Молдавии, где его упоминание находилось под запретом, и вызвало бы новый скандал в и без того непростых советскорумынских отношениях. Вплоть до последних дней жизни (П. Халиппа умер 96-летним старцем в своем бухарестском доме весной 1979 г.) он последовательно сохранял свою верность юношеским идеалам: Бессарабия, по его мнению, по праву должна считаться румынской землей. В условиях обострения советско-румынских отношений вследствие глубоких расхождений Москвы и Бухареста в оценках чехословацких событий 1968 г. он писал письма руководству румынской компартии, в которых призывал проявлять больше твердости в отстаивании государственных интересов перед лицом диктата «советской империи». В новых условиях это уже вполне отвечало установкам национал-коммунистического руководства Румынии ${ }^{15}$. В сегодняшней Молдове именем Пантелеймона Халиппы названы площадь и улица в Кишиневе, улицы еще в шести городах республики, а его старший брат Иван, высоко ценимый и сегодня как историк-краевед, включен в общенациональный мартиролог жертв коммунистического режима.

ПРИЛОЖЕНИЕ

Ваше Высокопреосвященство, Высокопреосвященный Владыко,

Милостивый Архипастырь, Отец и Благодетель!

Тяжелые обстоятельства, обрушившиеся нежданно-негаданно на меня, мирного кабинетного труженика, вынуждают меня обеспокоить Ваше Высокопреосвященство покорнейшей просьбой о защите. Дело в следующем.

В 1908-м году, вскоре после перевода моего из Новомосковска в Кишинев ${ }^{16}$ - перевода, состоявшегося благодаря участливому вме- 
шательству бывшего бессарабского губернатора Алексея Николаевича Харузина (ныне директора департамента духовных дел иностранных исповеданий), - произошла смена губернаторов: на место г. Харузина, лично знавшего меня с 1902-го года и даже предлагавшего мне в 1905-м году занять должность секретаря Бессарабского губернского статистического комитета, был назначен граф Ив. Виктор. Канкрин. В одно из первых свиданий по делам Инспекции народных училищ Кишиневского уезда граф полушутя предупредил меня, что если я вздумаю стать во главе местного национального движения, то он мне объявит войну. Я, не давая чувствовать графу, насколько меня оскорбляют $<\ldots>^{17}$ конечно - из недоверия ко мне, мною совершенно незаслуженного, постарался разъяснить, насколько мог, что историку-архивисту и археологу чужды мечты о лаврах, срываемых разными крикунами на митингах, и что никогда я не примыкал и не намерен примыкать к утопическим национально-сепаратистским движениям - тем более что по мужской линии я «россиянин», как явствует из «формуляров» моего отца, деда и прадеда (последний священник Стефан Халиппа - переселился из Малороссии в Бессарабию в момент присоединения последней к России). Я считал инцидент исчерпанным; но достаточно было моему брату Пантелеймону X. напечатать в местной газете две статейки: «О национальной школе в Бессарабии» и «О деятельности Бессарабского молдавского общества» ${ }^{18}$, как граф - также на одном из деловых свиданий - поставил мне вопрос: «Сочувствуете ли вы идее молдавской школы в Бессарабии?» Поняв намек графа на упомянутые статьи, я тут же вынул из бокового кармана мундира №№ газеты и указал графу на то, что статьи напечатаны за полною подписью моего брата, 28-летнего, вполне самостоятельного субъекта, разошедшегося со мною в убеждениях и сотрудничающего в левых органах печати. Казалось, моя $<\ldots>^{19}$ корректность покорила первоначальное предубеждение графа против меня. По крайней мере, граф всегда одобрял мои предположения касательно упорядочения школьной жизни в уезде и городе Кишиневе, аттестовал меня пред губернским и уездным предводителями дворянства как «отличного инспектора», в 1909-м и нынешнем 1910-м году я был приглашаем графом на пасхальные разговоры, а к 1-му января сего года я был награжден орденом Св. Анны 3-й степени - конечно, не без согласия графа как начальника губернии. И вдруг, накануне Вознесения Христова, я получаю конфиденциальное предложение г. министра народного просвещения ${ }^{20}$ не позже 1-го августа подать попечителю Одесского учебного округа прошение об 
отставке от службы по министерству народного просвещения, «приискав себе место в другом ведомстве»! Это было в сумерки. В душе еще звучали слова церковной песни «не оставь нас, сирот, Господи!». Благодарю Бога! Он поддержал меня в тот ужасный момент! Я воспылал жгучим желанием побороть клевету, чего бы мне это ни стоило! Повидавшись в тот же день с директором народных училищ Бессарабской губернии, а через день и с г. попечителем Одесского учебного округа, я убедился, что они не менее меня озадачены неожиданным распоряжением обо мне г. министра, и понял, что основанием для такого распоряжения послужили какие-то донесения местных, бессарабских властей! В первый же приемный после этого день являюсь к графу и рассказываю о постигшем меня ударе. Еще я не поставил вопроса о том, неизвестны ли графу причины моей опалы, как граф заявил: «Я знаю о намерении вашего министра перевести вас в другой учебный округ, а об отставке первый раз слышу». Тут я ставлю вопрос: «Но для чего понадобился этот перевод? Что побудило министерство прийти к такому решению?» На это граф отозвался: «Полагаю, что вам повредило неуместное выступление вашего брата в роли руководителя по г. Яссам Кишиневских реалистов-экскурсантов». Слыша впервые об этом факте, я мог только сказать графу, что я тут уже решительно ни при чем и что брат записался в вольнослушатели Ясского университета ${ }^{21}$ вопреки воле родителей и моим увещаниям; к тому же от меня он не получает ни малейшей помощи и доволен доставшейся ему стипендией какого-то благотворительного общества в Яссах; со мною брат вовсе не переписывается... В конце концов я заявил графу, что если, по каким-либо соображениям, дальнейшее пребывание мое в Бессарабии представляется нежелательным или опасным, то я ничего не имею против перевода меня в другую губернию. На это граф ответил, что, выезжая в Петербург (31 мая), он берется переговорить с г. министром народного просвещения в видах отмены моей отставки и замены ее переводом в один из центральных учебных округов. При этом граф находил невозможным для себя хлопотать о переводе меня в Киевский и Харьковский округа, а предлагал согласиться на перевод в Московский или Казанский округ, а то - пожалуй - на Кавказ. На это я только заметил, что у меня второй год жена страдает легкими и потому на север я не могу проситься. Граф обещал сделать «все возможное» и отбыл в Петербург, где пробыл 2 недели. По приезде - являюсь к нему, горя нетерпением узнать о результате ходатайства, но узнаю, что, за болезнью г. министра, граф с ним не виделся, но просил знакомого 
чиновника навести справку по моему делу и сообщить ему - графу — в Кишинев. «Если получу — сообщу вам», - закончил граф. Крайне обескураженный таким результатом «ходатайства» графа, я решил войти в министерство с обстоятельной докладной запиской, изложив в ней историю всей своей 14-летней государственной службы и 12-летней научной деятельности. На подачу таковой записки г. попечитель Одесского учебного округа проявил свое полное согласие, и она мной была через него подана 21-го июня. В результате 31 июля мне объявлено г-ном попечителем округа, что министерство не встречает препятствий к дальнейшей моей службе по министерству, но при условии перехода в другой учебный округ. Ввиду этого мною подано 31-го же июля прошение г. попечителю Одесского учебного округа ${ }^{22}$ возбудить пред Министерством ходатайство о переводе меня в Киевский или Харьковский учебный округ, так как легочная болезнь жены моей препятствует мне проситься на север.

Из изложенного, полагаю, легко понять, какую пытку я несу вот уже третий месяц, ежечасно терзаясь мыслию, что не сегодня-завтра семья моя, состоящая из 4 душ, окажется без крова и куска хлеба, а я, живший $<\ldots>^{23}$ верою в принципе, что «за Богом молитва и за царем служба не пропадают», стану фигурировать в роли «прожектёра, искателя мест» - я, всегда высоко державший знамя «человека долга», самоотверженного службиста! Я бы не вынес этого позора! С 31 июля эта жесточайшая пытка кончилась, или, вернее, она заменена более слабой: я не уверен, что министерство само меня пристроит в Киевский или Харьковский округа! Быть может, мне опять будет предложено самому хлопотать пред гг. окружными попечителями о месте, а это сведется к тому, что я не избегну перерыва в службе и таки попаду в разряд искателей мест! И ценою таких нравственных пыток я должен искупить чью-то ошибку, чье-то недоразумение! Как это невыразимо обидно - особенно в виду того, что 1-го текущего августа исполнилось пять лет моего инспекторства и я вправе был надеяться на улучшение своего служебного положения в смысле повышения или перехода на должность, предоставляющую больше досуга, чем инспекторство по народным училищам. А этот досуг мне крайне необходим: ибо у меня накопилось много материалов для 4-го тома «Трудов Бессарабской губернской ученой архивной комиссии» и для «Известий Бессарабского церковного историко-археологического общества», и я никак не удосужусь взяться за окончательную отделку намеченных к изданию научных работ, а к занятиям диссертацией (о бессарабских монастырских имениях) я с 1908 г. совершенно не возвращался! 
Излив постигшее меня горе, я обращаюсь теперь к высокому заступничеству Вашего Высокопреосвященства и, помня всегда участливое внимание Вашего Высокопреосвященства к трудам моим по изучению исторических судеб общей нам родины - Бессарабии, покорнейше прошу не отказать замолвить слово в мою пользу и в ограждение от бедствий семьи моей пред г. министром народного просвещения или г. товарищем министра д. с. с. [действительным статским советником] Георгиевским. Если же почему-либо признано будет за лучшее Вашим Высокопреосвященством обратиться с ходатайством непосредственно к одному из лично знакомых Вам окружных попечителей, то я убедительнейше просил бы ходатайствовать о предоставлении мне должности более обеспечивающей, чем ныне занимаемая мною. Я рад был бы получить место директора учительской семинарии или другого среднего учебного заведения, а в виду перехода к должности директора готов занять должность инспектора гимназии или реального училища и надеюсь оправдать доверие ко мне, ибо я десять лет служил помощником инспектора Кишиневской духовной семинарии, пансион которой достигал до 170-ти воспитанников, и деятельность моя была взыскана монаршею милостью. Я был награжден орденом Св. Станислава 3-й степени. О том, что моя деятельность по начальному народному образованию награждена на 1-е января 1910 года орденом Св. Анны 3-й степени, я уже упомянул выше. Прибавлю, что виною намеченного перевода моего из Бессарабии является исключительно мое местное происхождение, да еще не по-русски звучащая фамилия, хотя в российском Академическом Словаре слово «халипа» (галичанско-малорусское) и рязанское «халепа» занимают свое место, а кроме того, мое исконно русское происхождение доказано мною документально (ІІІ-й том «Трудов Бесс. губ. учебн. архивной комиссии, стр. 218 прим.).

Вашего Высокопреосвященства преданный воспитанник и почитатель Ив. Халиппа

Государственный архив Российский Федеращии (ГАРФ). Ф. 550. On. 1. Д. 470. Л. 5-8 с оборотами. Рукопись ${ }^{24}$.

\section{ПРИМЕЧАНИЯ}

1 См.: Лыман И., Константинова В. Бессарабский историк Иван Халиппа - лектор и заведующий Бердянских педагогических курсов // Revista de istoriei a Moldovei. Chişinău, 2015. № 4. P. 100-119. 
2 ГАРФ. Ф. 550. Оп. 1.

3 Среди публикаций см.: Колин А., Стыкалин А. Бессарабия начала $\mathrm{XX}$ в. глазами русских священнослужителей и церковных миссионеров (по материалам переписки митрополита Арсения) // Славянский альманах. 2016. № 1-2. С. 55-68; Колин А. Румыния 1905 г. глазами будущего бессарабского митрополита // Славянский мир в третьем тысячелетии. М., 2016. С. 335-344. О том, насколько велико было влияние Арсения в Русской православной церкви, свидетельствует хотя бы тот факт, что на церковном соборе 1917 г. он был вторым по количеству полученных голосов на выборах патриарха Московского и всея России.

4 О вкладе И. Халиппы в изучение истории Бессарабии см.: Poştarencu D. Ioan Halippa, cercetător pasionat al istoriei Basarabiei // Tyragedia, Serie Nouă. Vol. IX (XXIV). № 2. Chişinău, 2015. P. 143-154.

5 О его жизни, деятельности и вкладе в науку, а также о преследованиях, которым он подвергался в советское время, см.: Керимова М. М., Наумова О. Б. А. Н. Харузин - этнограф и антрополог // Репрессированные этнографы. Вып. 1 / Сост. Д. Д. Тумаркин. М., 1999; Керимова M. М. Жизнь, отданная науке. Семья этнографов Харузиных. М., 2011; Керимова М. М. Алексей Николаевич Харузин // Вопросы истории. 2012. № 7. C. $30-43$.

6 См.: Negru G. Culisele publicării ziarului "Moldovanul". Corespondenţa secretă a guvernatorului Basarabiei cu înalţi demnitari ai Imperiului Rus (1906-1908) // Anuarul Institutului de Istoriei. Chişinău, 2012. № 2.

7 В 1902-1904 гг. А. Харузин был управляющим делами виленского генерал-губернатора.

8 В это время Харузин много занимался этнографией южных славян и совершил в 1899-1901 гг. две поездки в южнославянские земли Габсбургской монархии в целях проведения полевых исследований.

9 Poştarencu D. Ioan Halippa, cercetător pasionat al istoriei Basarabiei.

10 Лымман И., Константинова В. Бессарабский историк Иван Халиппа... С. 101.

11 Там же.

12 Г-у Ж. К увольнению И. Н. Халиппы // Бессарабская жизнь. № 150. 03.07.1910. С. 3.

13 См.: Гром О. А. Молдавское национальное движение в Бессарабии в конце XIX - начале XX в. Канд. дисс. Ставрополь, 2018.

14 См.: Negru Gheorghe. Documente referitoare la problema şi mişcarea naţională în Basarabia (a doua jumătate a secolului al XIX-lea — începutul secolului al XX-lea) // Revista de istoriei a Moldovei, 1994. № 2. P. 29-46.

15 См. в этой связи: Стыкалин А. С. Полемика советского посла и 
румынского функционера (март 1980 года) об освещении прошлого двусторонних отношений // Славяноведение. 2017. № 1. С. 12-30.

16 Как следует из личного дела И. Халиппы, заполненного 8 декабря 1923 г. в период работы в г. Бердянске и хранящегося в Государственном архиве Запорожской области Украины, с 1 августа 1905 г. он служил инспектором народных училищ Новомосковского уезда Екатеринославской губернии, а с 15 августа 1907 г., возвратившись в Кишинев, служил инспектором народных училищ Кишиневского уезда. См.: Лыман И., Константинова В. Бессарабский историк Иван Халиппа... С. 101.

17 Из-за порванной страницы не читается ряд слов, речь идет о том, насколько оскорбили И. Халиппу подозрения Канкрина.

18 Вопрос о том, о публикациях в какой газете идет речь, нуждается в дальнейшем изучении.

19 Следующее слово неразборчиво из-за порванной страницы.

20 Эту должность занимал А. Н. Шварц.

21 Пантелеймон Халиппа учился в Ясском университете в 19081912 гг.

22 Письма с ходатайствами И. Халиппы попечителю Одесского учебного округа и в министерство народного просвещения нам не известны.

23 Следующее слово неразборчиво из-за порванной страницы.

24 На письме имеются рукописные пометы А. Стадницкого и черновой набросок ответного письма с признанием заслуг И. Халиппы в изучении истории своего края и обещанием оказать посильную помощь в его дальнейшем трудоустройстве. Ответное письмо не сохранилось.

\section{A. I. Kolin, A. S. Stykalin}

"To a historian, archivist and archeologist, alien are the dreams of laurels of screamers at rallies..." A letter of Ivan Halippa to archbishop Arsenius (Stadnitsky), 1910

The Bessarabian local historian Ivan Halippa, who was persecuted by the provincial authorities for his involvement in the Moldavian national movement, connected with Romania, found a patron in his compatriot native from Bessarabia, the influential archbishop of the Russian Orthodox Church Arsenius (Stadnitsky).

Keywords: Russian Empire, Bessarabia, Russian Orthodox Church, Metropolitan Arsenius (Stadnitsky), the Moldavian National Movement. 


\section{Балаклава под оккупацией}

Публикуемые воспоминания написаны незадолго до смерти Л. А. Серафимовым. Они показывают жизнь предвоенной и военной Балаклавы, удивительного города, во многом сохранявшего еще отпечаток многолетнего присутствия российских греков. Ключевые слова: Балаклава, оккупация, балаклавские греки.

DOI: $10.31168 / 2073-5731.2018 .3-4.7 .03$

Читателю предлагаются записки уроженца Балаклавы Леонида Антоновича Серафимова (1929-2018)1, подростком пережившего оккупацию своего родного города в годы Великой Отечественной войны. Позже после окончания средней школы в Ялте он поступил в Московский институт тонкой химической технологии им. М. В. Ломоносова. В этом институте он проработал всю жизнь, защитив докторскую диссертацию, став профессором и заслуженным деятелем науки и техники. Записки написаны рукой Л. А. Серафимова. Они потребовали лишь минимальной редакторской обработки. Название - авторское.

\section{Фрагменты воспоминаний. Предвоенные и военные годы}

\section{Предвоенные годы}

В детстве моя мама Серафимова (Губарева) Милетина Стефановна настойчиво заставляла меня учить стихи. У моего деда Стефана Федоровича Губарева ${ }^{2}$ была небольшая библиотека, включавшая собрания сочинений Пушкина, Лермонтова, Некрасова. Учил я и современные для того времени стихи.

На 1 мая 1938 г. я, по-видимому, по предложению директора школы, должен был выступить на митинге в честь праздника. Я стоял вместе с руководителями Балаклавы на трибуне на площади города (перед сквером). На митинге были выстроены краснофлотцы сторожевых катеров, базировавшихся в Балаклаве, весь состав ЭПРОНа루, преподаватели и ученики балаклавской школы и др. Площадь была заполнена народом. После митинга дали слово мне, и я читал стих-приветствие, написанный моей тетей Ираидой Стефановной Губаревой: 
Товарищи, сегодня праздник Мая -

День солидарности трудящихся всех стран,

Кругом цветы и музыка играет,

Где духовой оркестр, где струнный, где баян.

Шумят на площади красивые знамена

И в воздухе проносится салют!

А за границею расправы, кровь и слезы,

Там митинг провести спокойно не дают.

Там голод и нужда, кровавый гнет, безволье,

Там безработица рабочих фабрик ждет,

Компартия там загнана в подполье

И жандармерия шаг каждый стережет...

Раздалась команда: «Пионеру, отличнику учебы Серафимову Леониду — ура»! Мои родители стояли у трибуны, и гордый отец, Антон Петрович Серафимов, в то время рабочий Балаклавского рудника, говорил всем: «Это мой сын выступает».

После окончания митинга началась демонстрация - с площади по улице мимо базара до здания кинотеатра, не доходя до церкви с выходом на набережную (ныне улица Назукина). Отец сказал: «Леня, дарю тебе 100 рублей (я в это время с мамой и тетей Ирой собирал деньги на письменный стол, который мы вскоре купили).

После этого я выступал с различными стихами по местному радио (Балаклава была радиофицирована). Участвовал в концертах, которые проводились в балаклавском Доме культуры, стоящем на развилке дорог в Севастополь и Байдары при выезде из Балаклавы. Выезжал в Симферополь на областной фестиваль от города Балаклава. В общем, был «показательным» мальчиком. Как сын рабочего я получил путевку в пионерский лагерь «Артек», единственный из всех балаклавских ребят. В школе я редактировал стенную газету и пел по просьбе ребят артековские песни.

Отец купил радиоприемник. Первый радиоприемник, выпущенный в СССР. Это была большая коробка с полукруглым верхом зеленого цвета. В это время шла война Абиссинии и Италии. В скором времени Италия напала на Грецию. Отец слушал передачи на греческом языке и радовался победам греков. После вмешательства немецких войск, оккупации Франции в Греции началась партизанская война. Я перешел в пятый класс, в школу, расположенную в старом большом здании около кинотеатра, покинув начальную школу, находившуюся рядом с основным зданием ЭПРОНа на пригорке. В школе преподава- 
ли немецкий язык. У меня появились новые приятели. Один из них Володя Луппиян и двоюродный брат Петр Юрьевич Серафимов (сын дяди Юрия Петровича). Брат был отменный хулиган, и его сверстники боялись. Его друг и он не раз исключались из школы. Потом к директору ходила мать, просила его восстановить, и его восстанавливали.

Один из эпизодов. Петя запустил чернильницей в учителя, а попал в портрет Сталина, что в то время могло принять политический оборот. Но его замяли, а Петра исключили из школы. Мать, рыдая, пошла снова на прием к директору. Петра восстановили, и он явился в класс, где его ждал друг Сухомлинов. Они затеяли беготню друг за другом. Петр, убегая, в прыжке ногой ударил в дверь, ведущую в коридор. По ту сторону двери находился преподаватель музыки по прозвищу Бомба-головастик. От удара двери преподаватель упал без чувств, а Петра исключили из школы, где он не провел и часа. После этого случая его отдали в ремесленное училище, где он учился на токаря.

Достигнув совершеннолетия, Петр в начале Великой Отечественной войны был отправлен на Кавказ в школу младших лейтенантов, которую окончил и вскоре погиб на фронте. Известно, что Красная Армия в первые дни войны несла огромные потери младшего командного состава. К слову, со мной в школе никто не задирался, боясь моего брата (он был старше меня).

\section{Начало войны}

Севастополь отбомбили в первый день войны. Ночью был налет нескольких самолетов, днем - выступление Молотова о нападении Германии на СССР. Со слов очевидцев, немцы сбрасывали наряду с бомбами торпеды или морские мины на парашютах. Наш флот не пострадал от этого налета. Первыми жертвами стали цыгане. В Севастополе был квартал, заселенный цыганами. Одна торпеда (или мина) застряла парашютом на большой акации. Цыгане постарались достать парашют, который был, как говорили, из шелка, пытались его снять с дерева. В результате торпеда (мина) коснулась земли, и половину цыганского квартала снесло. Лично я с другом видел, как за немецким бомбардировщиком гнался наш «Як». Оба ушли в открытое море, и дальнейший итог этого боя мне неизвестен.

В Балаклаве была объявлена мобилизация. Мой отец как грек, а скорее как инвалид, был мобилизован в рабочий батальон, который пока оставался в резерве. Рудоуправление приняло решение выдать работникам по мешку картошки с отдачей после урожая двух мешков. Я слышал, как мать его попрекала за это, говорила: «Где ты будешь 
ее сажать?» Отец отвечал, что наша армия отступает, немцы у Перекопа. Береговая батарея Балаклавы стреляет в сторону степного Крыма. Многие готовятся к эвакуации. «Сажать картошку мы не будем, а будем ее есть».

Рано утром рабочий батальон, в котором состоял отец, был отправлен в сторону Ялты и Алушты рыть окопы. Какой-то шальной немецкий самолет, вылетев из-за горы, сбросил две небольшие бомбы, которые упали ниже контрофорса, на котором стоял наш дом (в нем уцелели даже стекла). Мы с мамой покинули дом, поднявшись по балке Кефало-Вриси в одинокий дом Совхоза, где хранилось сено. В это время из-за горы (мы там за бастионом Николая II копали до этого всей семьей окопы) начали лететь снаряды и мины.

Немцы оккупировали уже Алушту и Ялту, и остатки рабочего батальона, изрядно пьяные, вернулись в Балаклаву. Рассказывали, что из разбитых бочек Массандры вино текло ручьями прямо по земле - пей не хочу. Милиция из Балаклавы вместе с военными уехали. Какой-то недоумок из военкомата отдал паспорта всех мобилизованных в рабочий батальон Абибке, рабочему-истопнику при военкомате, велев раздать паспорта, если рабочие вернутся в Балаклаву. Абибка знал хорошо отца, и когда тот появился в Балаклаве, отдал ему паспорт. «А где остальные паспорта?» - спросил отец. «Я их сжег, — отвечал Абибка, — придут немцы и, увидев у меня паспорта, решат, что я работник милиции, и расстреляют меня». «Что ты наделал, — закричал отец, — ты оставил людей без документов!» «У меня не было выхода», - отвечал Абибка.

Мы перебрались в подвал школы старших классов. Пробыв там некоторое время, заняли квартиру в доме ЭПРОНа. После того, как упал большой снаряд (стреляла, по-видимому, «Дора» - мощная сверхтяжелая железнодорожная пушка), отец, который работал электромонтером на Балаклавском руднике, перевел нас в пещеру, прорубленную в горе рабочими рудника, длиной метров сто.

Немцы вышли на бастионы, построенные по указу Николая II, вечером. Наша армия отступила к Севастополю. Город Балаклава остался на одну ночь без власти. Начался грабеж магазинов и других объектов. На путях, подходящих к руднику, горела цистерна с нефтью, рядом была цистерна с этиловым спиртом. Отыскав ее, люди ведрами черпали спирт и уходили по домам. Рассказывали, что немцы ночью в город не входили. Утром наша армия вернулась и начала закрепляться, роя окопы под горой. Оказывается, пришел приказ Сталина оборонять Севастополь (и Балаклаву). Отец снова вступил в артель рыбаков. 
Ночью они, обвязав ключицы для весел тряпьем, чтоб не скрипели, переправляли по морю за линию фронта людей из партизанского движения. В остальном ловили рыбу (тоже ночью). Днем немцы обстреливали разрывными пулями набережную. В Севастополь из Одессы прибыли остатки конницы Буденного. Они оставили лошадей в Балаклаве, а сами, спешившись, заняли оборонительные окопы под горой. Лошадей съели жители Балаклавы. Шкуры использовали татары.

Артели рыбаков, в том числе и отца, перевели сначала в крупную бухту Севастополя, а потом часть рыбаков, в том числе отец и его брат Юрий Петрович, обосновались в небольшой бухте между мысом Фиолент (ближе к нему) и 35 батареей, где ловили рыбу и сдавали ее для приготовления пищи для фронта. Мы с мамой и тетей обосновались сначала в копях Инкермана, где в штольнях хранилось на выдержку шампанское завода шампанских вин г. Севастополя. Шампанское отправлялось машинами на фронт. Рыбаков иногда мобилизовывали рыть окопы.

Рассказ Юрия Петровича: «Привели нас на нейтральную полосу перед рассветом и дали задание рыть окопы. Мы копали до рассвета. Все было хорошо. Когда рассвело, немцы стали обстреливать нас из минометов. Мы побежали в сторону наших окопов. Я чувствую, что очень медленно двигаюсь. Когда добрался до окопов и остановился, то увидел, что мне на ноги намотался пук колючей проволоки. Вот что делает страх».

Из штольни Инкермана мы перебрались жить в квартиру наших знакомых, которые эвакуировались. В Севастополе был подземный кинотеатр, который я посещал. В нем я впервые увидел фильм «Разгром немецких варваров под Москвой». Перед демонстрацией выступали различные агитаторы. Кинотеатр посещали старушки, иногда раненые. Вот один эпизод. Выступая, агитатор говорил: «Немец что, когда он спускается на парашюте, его можно убить лопатой, так как он не может стрелять из автомата». Одна старуха возразила: «А вот фильм показывали: он - немец, спускаясь на парашюте, стрелял из автомата. Что тогда делать?» «Тогда надо тикать», - ответил агитатор.

Обстрелы и налеты на город усиливались и днем, и ночью. Тетя Ираида Стефановна работала в агиткоме в каком-то отделе горисполкома Севастополя. Втроем мы перебрались жить в убежище около севастопольского базара, где стоял знаменитый бетонный дом Анненкова. Он построил дом в несколько этажей наверху и несколько внизу, под землей. Дом пользовался дурной славой, там обосновалась банда. Убежище было организовано на канализационном канале, туннель в который был пробит давно. К запахам быстро привыкаешь. 
Через месяц отец и Юрий Петрович пришли в это убежище и ночью повели нас на стоянку у мыса Фиолент. Севастополь горел. Идти по улицам было страшно - все дома вокруг горели, на улицах в середине был жар, как на сковородке. Уходя из горящего Севастополя, Юрий Петрович попросил зайти к своей бывшей жене Татьяне, чтобы захватить ее с собой. На их улице была огромная воронка, в которую мог спрятаться двухэтажный дом. Дома вокруг сгорели. Татьяны не было, и мы пошли дальше к выходу из города. Ночь была очень темной. Наконец, мы пришли, сначала заблудившись и выйдя на дот, который вел огонь по немцам. Это была, по-видимому, третья или четвертая линия обороны Севастополя.

Берег, когда мы пришли, имел такой вид: вверху степь, дальше обрыв, который оканчивался небольшой террасой - метров двадцать, дальше - снова скалистый обрыв к морю, где была узкая полоска гальки. К террасе и морю вели среди скал тропинки, по-видимому, созданные природой. Говорили, что богатый грек разводил на террасе, которая была очень длинной (километра два-три), виноградные кусты. Я обратил внимание на первый обрыв - он состоял из скалистой породы с прослойкой, выходящей на террасу белого слипшегося песка с большими песчинками, - и, найдя от чего-то железную деталь, стал копать пещеру. Когда я выкопал пещеру метра в два глубину и полтора в высоту, рыбаки где-то наверху (там стояла какая-то военная часть) достали лопаты, углубили мою пещеру и, начав копать рядом, сделали ее двухходовой, то есть туннелем. Это всех спасло во время налета немецких пикирующих бомбардировщиков, которые потопили тральщик и катер у берега, где швартовались лодки рыбаков. Дело в том, что вдоль берега который день пролетал разведчик - самолет-рама.

Мы наблюдали с берега, как ночью приходили линкор «Севастополь» и другие корабли. Запомнился крейсер (или эсминец) «Ташкент». Он умело отбивался от налетавших врагов. Потом я узнал, что его потопили у причала в Новороссийске, пришвартованного к берегу. Ранним утром линкор «Севастополь» уходил на Кавказ, обязательно дав несколько залпов по немецким позициям из главного калибра. Снаряды главного калибра, когда летят, то не свистят, как обычные снаряды, а издают шум, близкий к инфразвуку, действующий угнетающе на человека. Снаряды летели к немецким позициям через нас. На обрыве, где были мы, сыпались от звука небольшие камни.

В одну ночь мы увидели, что к нам стали на якоря тральщик, небольшой корабль и катер - обычный, не торпедный. Утром был налет, катер сразу потопили, тральщик горел. Рыбаки на лодках бро- 
сились на помощь. Отец тащил наверх на спине обгоревшего командира (или комиссара) тральщика. За его спасение он был представлен к награде, которую так и не получил, так как после этой бомбежки события развивались с огромной быстротой.

Через несколько дней в окрестности высадили наш десант. Две огромные баржи привезли пополнение. Это были молодые люди из республик Северного Кавказа. Целая дивизия. Оружие им пока не выдали. Следовательно, решили мы, Севастополь еще не сдают. Но на другой день госпиталь, который расположился на террасе (там тоже после нас выкопали пещеры), был эвакуирован, и Ираида Стефановна вскоре встретила наверху солдат, которые были в нашем доме (доме Губарева). Там располагалась наша разведка. Ребята рассказали, что прорвана линия фронта в долине Кефало-Вриси. Командование, которое ушло на башню (был страшный обстрел), погибло, ибо снаряд попал в башню До. Снаряд также попал в угол нашего дома, но дом уцелел (у него были стены в 1,5 м).

Во время обороны Севастополя в воздухе господствовала немецкая авиация. Когда мы были у мыса Фиолент, брат Владимира Богуса ${ }^{4}$ обычно говорил: «Что, голубчик, кусты проверяешь, целы кусты, на месте». Наша авиация поднималась в малом количестве поздно вечером. Несмотря на это, за ними гонялись «мессершмиты». «Яки» и «По-2» не могли им противостоять, хотя мужественно отбивались, будучи более маневренными (скорость у них была меньше).

По окрестностям Балаклавы, где шли бои во время обороны Севастополя, бродил некто Громов (имени я не помню). Он искал сына (это по рассказам). Громов был осужден, то ли за экономические, то ли за политические дела. Он жил с сыном моего возраста. Когда его арестовали, сын стал, очевидно, кем-то вроде сына полка. Отец, говорили, его нашел в дзоте у пулемета мертвым. Все вокруг были убиты. Дзот был около Херсонеса (последний рубеж обороны).

Немцы заняли Балаклаву, наши с боями отступили. Последним оплотом оборонявшихся был мыс Фиолент. Но попытки их эвакуации морем оказались неудачными. Шквальный огонь немцев не давал пристать к берегу советским судам. В результате немцы захватили в плен остатки советских войск и спасавшихся вместе с ними жителей Балаклавы, рывших до этого на мысе окопы.

Под вечер наверху появился немец, который на ломаном русском языке приказал всем подняться наверх. Захватив кое-что, мы поднялись, там уже находились солдаты, которых привезли на баржах. Нас окружили. Положение ребят из северокавказских республик было 
ужасно. Многие не знали русского языка. Их избивали палками, так как они не понимали, что от них хотят немцы.

Мы вместе с пленными переночевали и утром, построившись по десять человек в ряд, двинулись по шоссе, ведущему к Бахчисараю. По мере продвижения нашей колонны пленных к нам присоединялись другие колонны слева и справа. Через несколько километров пути колонна образовалась от горизонта до горизонта. В колонне говорили: «Нас предали, Октябрьский улетел, Севастополь сдали, попала в плен вся армия, все защитники Севастополя, флот не сумел подойти к берегу, велись заградительный огонь артиллерии и бомбежки самолетов. Флот отбивался и ушел на Кавказ».

Вот несколько запомнившихся мне эпизодов.

1. Километров через десять я почувствовал себя очень плохо, идти не мог. Отставших немцы пристреливали. Отец нес меня на спине примерно километр, пока я не пришел в себя и пошел сам.

2. «Посмотри, у меня очень чешутся руки», - сказал один пленный, шедший рядом с нами, другому. Руки у того пленного были ранены и забинтованы. На ходу размотали бинт, все раны были в червях. Червей смахнули охапкой бинтов. Один пленный сказал: «Ну, повезло тебе, черви съели весь гной, так как раны загноились. Теперь начнется заживление». Была разорвана нательная рубаха, и руки снова забинтовали.

3. Около селения Чергунь был обнесенный забором сад. На деревьях были видны плоды. Часть пленных ринулась туда, раздалась серия взрывов, сад был заминирован. Немцы-конвоиры стали расстреливать солдат без ног, без рук, то есть всех тяжелораненых. Один вывернулся, держась на ногах. У него сорвало левую часть груди, не затронув сердце и легкие. Немцы погнались за ним, но он затерялся в толпе, и они отстали. Его перевязали чьей-то разорванной рубахой. Говорили, что он прошел километр, затем упал на дороге и был пристрелен.

Немцы всю дорогу шныряли по колонне, выявляя комиссаров, командиров, людей, похожих на евреев, и т. д. Командиров и комиссаров выдавали не выгоревшие кубики и другие знаки, хотя сами знаки отличия были оторваны. Здесь сказалось, любили солдаты своего командира или нет. В одном случае окружающие пленные наперебой говорили, что «это не командир и не комиссар, его гимнастерка истлела и порвалась, он взял гимнастерку у убитого». Немцы отставали от этого человека. В другом случае вокруг пленного с оторванными знаками отличия образовывалась пустота, и его, стреляя в упор, убивали конвоиры-немцы. 
4. Навстречу ехали повозки, на которых сидели румыны (мы научились различать с помощью наших солдат: румынская форма была светло-зеленой с желтизной, а немецкая — темно-зеленой). Слышалась ругань на румынском языке, свист и удары кнутом. Это со встречных повозок били кнутами по пленным.

5. Однако не все румыны были злобливы. Последние два километра до Бахчисарая, а это было уже под вечер (шли мы весь день), румын усадил меня (выглядел я бледным и уставшим) на попутную повозку, где он был возничий. Мама и тетя шли, опираясь на повозку. Отец шел сам.

Вечером прибыли мы в Бахчисарай. Нас загнали на пустырь, огороженный колючей проволокой, то есть в Бахчисарайский лагерь, сооруженный немцами и добровольцами-татарами, которые охраняли этот лагерь. Уставшие и голодные, мы повалились на землю спать. Пленных солдат погнали дальше. Здесь остались только штатские мужчины, женщины и дети.

Утром мужчин отделили от женщин и детей и погнали в Симферополь, как выяснилось потом - в тюрьму. Женщин и подростков потом отпустили, вернее - они разошлись сами, поскольку крымским татарам надоело их охранять. Мы устроились под одним из навесов, где было сено, на котором можно было спать. Под навесом были уже люди из окраин Севастополя. Как выяснилось, нас кормить никто не собирался, выдали в комендатуре аусвайсы (вроде паспортов) и пайку - 100 г хлеба, красивого на вид, но выпеченного из проса с малым количеством муки. Хлеб стоял в горле, есть его можно было только запивая водой.

Один румын пришел и попросил сшить ему брюки. Мать хорошо сшила. Она сказала, если он достанет иголку и нитки, она сошьет ему брюки. Брюки вручную были сшиты. Румын остался очень доволен и дал мне черствую булку белого хлеба. Булку пытались отобрать мальчишки. До драки дело не дошло, я ее принес домой, объяснив нападающим, что это плата за работу. В другой раз тетя Ира выменяла, сняв с себя, бюстгальтер на хлеб.

Нам сообщили, что можно раз в три дня самим по справке из комендатуры получать обезжиренный творог на заводе, где сбивали масло для оккупантов. Имея творог, мы кое-как перебивались. Однажды я пришел с чашкой за творогом, но отпускавшая женщина выдала всем нам ведро творога, сказав, чтобы мы делили сами. Делила творог толстая баба - себе, свату, родственникам. Делила так, что мне творога не хватило. Здесь я впервые столкнулся с подлостью. Я по- 
шел в комендатуру, но там справки больше не дали. Тогда в слезах я снова пошел на завод, где выдавали творог. Сердобольная женщина, это была другая смена, выдала мне творог, когда я ей все рассказал. Причем выдала больше, чем было в справке. Толстая баба исчезла, она не жила под навесом.

Мы решили уйти из Бахчисарая в Балаклаву (30 км). Мать где-то выпросила мешочек зерна и сделала на нем петли. Получился рюкзак. Я его надел и двинулся в Балаклаву. За мной на расстоянии примерно километра шли мать и тетя Ира (мы не знали, выпустят ли нас из Бахчисарая в сторону Севастополя и Балаклавы). Шли под утро и весь день и пришли в Инкерман. Мать знала адрес татарина Виктора Бейтулаева, который раньше жил с друзьями в доме Губарева. Виктор работал на рыбзаводе. Он нас принял, накормил, мы вымыли ноги и переночевали у него дома.

\section{Балаклава под оккупацией}

На другой день мы дошли до Балаклавы и сначала поселились в доме моего другого деда Серафимова Петра Ивановича 5 . Там мы узнали, что расстреляли Владимира Богуса — коммуниста, братья которого были с нами у мыса Фиолент (сам Владимир не работал рыбаком) Председателем управы был Богданчиков, в прошлом скромный и незаметный работник Госбанка в Балаклаве. Он клял советскую власть, но отпускал обезжиренное молоко беременным женщинам и женщинам с детьми.

Во время оккупации в самой Балаклаве стояло два немецких подразделения и еще одно подразделение румын в Кадыковке. Если немцы отбирали только ценные вещи, то румыны - все подряд, включая и помойные ведра. Один раз румыны украли у немецкого коменданта любовницу - немку из штаба, знавшую русский язык. Утром Балаклаву разбудили выстрелы - это немцы пошли на Кадыковку отбивать уведенную женщину. Форма у румын была очень плохого качества, пошитая из какого-то гнилого сукна. В городе было довольно голодно, но у немцев снабжение было лучше, причем офицеры питались тем же, что и солдаты. У румын была строгая социальная иерархия: офицеры ели отдельно, к солдатам относились как к прислуге, иногда в отношении подчиненных доходило и до рукоприкладства.

Подростки оказывали мелкие услуги, вроде чистки сапог. Я фактически кормил семью. Чистил обувь немцам, получал за это десяток, а то и меньше, сигарет, которые выменивал на базаре на хлеб. Ходили мы, мальчишки, с котелками, куда немцы сливали из своих котелков 
то, что не доедали. Мать добавляла украденную мной картошку, которую я воровал из кучи, привезенной по морю и сваленной на набережной. Получался суп, который мы ели. Вскоре вернулся Юрий Петрович, а за ним пришел из Симферопольской тюрьмы больной отец. Их на поруки взял брат Иван Петрович (у немцев была такая практика). Отец стал поправляться.

Возясь на свалках, я заболел какой-то кожной болезнью. Под кожей образовывались на обеих руках до локтя гнойные нарывы. Они были глубоко, при попытке их выдавливать шла кровь. Немцы организовали школу, 5-й класс. Мы учили английский язык, другие предметы кое-как, но тех, кто учился, не отправляли в Германию. У меня появились друзья - Фатя, Поша и другие. У одного мальчика сестра работала медсестрой у врача-немца в комендатуре, которая размещалась в доме ЭПРОНа. Он поговорил с сестрой, и она попросила врача (рыжего мужчину лет сорока) принять меня. Я пришел на прием. Он взял большую банку какой-то красной мази и намазал мне все руки, где были прыщи. Сестра сказала, что я должен ходить целый день с этой мазью, а поздно вечером смыть мазь. Она дала мне также кусочек мыла, сделанного из глины Кил, которая была в Крыму. Болезнь прошла.

Во время оккупации немцы вели себя по-разному. Были не только репрессии. В частности, иногда для подростков организовывался просмотр кинофильмов в клубе ЭПРОНа, а после сеанса в фойе можно было чего-то съесть.

Проблему снабжения немцы пытались решить, в том числе заставляя балаклавских рыбаков, объединенных в артель, сдавать пойманную ими рыбу. Отец стал ловить рыбу, вступив в артель. Рыба поставлялась на рыбзавод для немцев. Однако рыбаки оставляли улов у входа в балаклавскую бухту в сетках с притопленными ниже уровня воды буйками, а в Балаклаву уже приплывали с пустыми руками. Немцы недоумевали, почему у рыбаков рыбы нет, а на городском рынке ее полно. После ужесточения контроля за рыбаками они стали сдавать немцам в качестве улова катранов - малосъедобную черноморскую акулу, приговаривая при этом: «Große Fisch». А по ночам продолжали выбирать нормальную рыбу из оставшихся в море сеток и обменивать ее у крымских татар на муку. Балаклавцы также продавали рыбу на оккупационные марки и советские рубли, которые также были в ходу. Кстати, из-за жесткого противодействия крымских татар партизан около Балаклавы почти не было. Столкновения с партизанами происходили в районе Симферополя и еще дальше. 
Базар продолжал кишеть хорошей рыбой. Немцы стали назначать конвоира с ружьем на выезжающие в открытое море лодки рыбаков. Конвоир поначалу был строгим, но его вовлекли со скуки играть в карты, и он вдребезги проигрался. Проиграл все марки и нижнюю одежду. С ним поговорили, вернув все проигранное. Суть договоренностей: ему выделяют рыбу, продают ее на рынке и отдают вырученные деньги, но он смотрит сквозь пальцы, если рыбаки берут и себе рыбу, чтобы прожить. Договор состоялся. Вечером рыбаки при въезде в бухту (она на ночь была заслонена металлической сеткой от подводных лодок) опускали мешки с рыбой в воду, оставляя привязанный на веревке поплавок на поверхности. Поздно вечером мешки с рыбой поднимали на борт лодки, и рыба делилась, причем один пай рыбы выделяли немцу.

Затея немцев сорвалась, но однажды вечером часть рыбаков попалась, вытаскивая один мешок. Немцы доложили в комендатуру. Собрали общее собрание, на которое пришел заместитель коменданта, толстый немец с добродушным лицом. Он ничего не понимал порусски. Переводчика на этом собрании не было, его вызвали в Симферополь на какой-то допрос. Председатель артели говорил собравшимся рыбакам: «Хотите - тащите мешками, хотите - тащите матрасами. Это рыба нашего моря, она наша, а не немцев. Но не попадайтесь, мать вашу, попавшиеся исключаются из артели. За кражу немцы будут вешать!» И, сопровождая слова непередаваемым рыбацким матом, показал жестом повешение. «Гут», - сказал немец, и собрание разошлось. С тех пор воровство сократилось, но продолжалось. Приходили из сел татары, рыба менялась на муку каждым рыбаком отдельно.

В это время совсем неожиданно арестовали председателя управы Богданчикова ${ }^{7}$. Старшую его дочь Галину, женщину с некрасивым лицом красного цвета, но прекрасной, как говорили старшие, фигурой, нажившую двух своих детей, из управы уволили. Младший сын Богданчикова Николай — защитник Севастополя - был ранен (ему вырвало мышцу предплечья) и взят в плен. Богданчиков взял его на поруки. Одной рукой Николай колол дрова в комендатуре. Когда арестовали отца, тоже был уволен. Жена Богданчикова, женщина 55-60 лет, осталась с двумя детьми Галины - Валерием и какой-то младшей (3-5 лет). С матерью жил и Николай, с которым я подружился. Богданчиков исчез в застенках гестапо, передачи не принимали. Было несколько арестов среди балаклавцев. Фамилий я не помню.

Мои отец и мать в очередной раз разошлись, и мы с мамой переехали в дом, где жили Богданчиковы. Этот дом стоял на горе у выезда 
из Балаклавы за зданием Дома культуры на дороге в Байдары. Мать научила Богданчикову шить. Она стала брать заказы. Этим кормились. Крыша над нашей комнатой текла, я чинил ее, беря листы железа с развалившихся домов. Знакомый кровельщик научил меня поднимать стоящий и делать лежащий фальц при кровле крыши, и я ее починил. Эти знания потом пригодились.

Во время оккупации стало известно, что немцев под Сталинградом разгромили. В Балаклаве были вывешены траурные флаги на комендатуре. Все пошло вспять. При штурме Керченского пролива к нам стало заносить течением утопленников. Течение в Черном море идет от Керчи вдоль побережья до Евпатории и там поворачивает на Болгарию и Румынию. К нам занесло рано утром, когда сняли сеть от подлодок, моряка в бушлате и тельняшке и командира в военной тужурке. Немцы окружили два тела (их прибило около Балаклавской бани) и никого не подпускали. Когда расстегнули тужурку, на кителе командира был орден Ленина. Немцы подрались из-за этого ордена. Трупы куда-то увезли, где похоронили, не знаю. Этим занимались немцы. Стоявшая в Балаклаве дивизия была отправлена на фронт, говорили, в Сталинград. Вернулся назад один переводчик. Дивизия была, по-видимому, разгромлена и взята в плен.

Во время оккупации (наши войска уже были в Крыму) вечером в Балаклаву вошли две самоходные баржи и большой теплоход. Наутро девять наших самолетов из-за горы совершили налет: теплоход осел и наклонился, одна самоходная баржа с продовольствием была потоплена. Немцы искали сбежавшего кочегара с теплохода (шварцмана, как они говорили). Вечером караван с накренившимся теплоходом на буксире уплыл. Рассказывали: один старик вылез на крышу сарая и кричал: «Наши прилетели, наши прилетели!» Его убило осколком бомбы (или немцы пристрелили).

Вскоре, в апреле - мае 1944 г., война докатилась до Балаклавы. Во время отступления немцев из Балаклавы многое ими бросалось. Так, был брошен чемодан с оригинальными ручками для дверей, очевидно, их собирал немец - коллекционер дверных ручек. Бросались награбленные швейные машинки и разное барахло. Бросались мотоциклы, велосипеды и техника (военная).

В годы оккупации в бывшей даче графа Николая Апраксина немцы организовали публичный дом. Причем женщин завезли своих. Это заведение называлось «солдат-хайм». Покидая Балаклаву, немцы его взорвали.

Вспоминается. Двое местных жителей играют на солнышке вда- 
ли от домов в карты. «Ты мне что расплачиваешься немецкими марками, не видишь, немцы тикают, и их марки просто бумажки». Второй: «Ты мне брось, а то я пожалуюсь коменданту, и он тебя посадит. Немецкая марка пока действует». Это была оккупационная марка, и она никогда ничего не стоила.

Еще в самом начале, когда не занимали Балаклаву наши войска, но подошли к ней, небо было заполнено нашими «Илами»штурмовиками, бомбившими немецкие позиции на сопке Безымянной (на карьере). К нам пришла разведка советской армии. Мы увидели впервые погоны на наших солдатах. Один из них достал текст гимна Советского Союза (сложенный листок), и Иван Петрович (он перед этим приехал к нам из Симферополя) сыграл гимн на скрипке. Разведка спустилась с гор выяснить, имеет ли бухта выход в открытое море. Это была разведка Приморской армии, у каждого было пороховое пятно у правого глаза. Мы объяснили, на ту сторону перейти от башен нельзя, бухта имеет выход в море (пролив на карте у них стерся на изгибе). Командир попросил тазик воды и вымыл ноги. Одна была забинтована (легкое ранение).

Он написал донесение командованию. С донесением отправился солдат, но не вернулся, не возвратился и второй. Командир сказал: «Ну, Вася, тебе идти, их, наверное, снайпер подстерег». Вася взял донесение и ушел. Через два часа он вернулся и сказал, донесение вручил, наши убитые лежат рядом, успеть бы их к ночи похоронить. Разведка ушла, когда стало темнеть. Из балаклавцев мы первые (в доме Губарева) увидели наши войска. Наш дом и гору, под которой он стоял, немцы обстреливали все утро и день до вечера, очевидно, заметив наших солдат-разведчиков. Солдаты падали вокруг дома Губарева, мы прятались за домом.

Освобождали Балаклаву и Севастополь в том же порядке, что и оставляли. Последнее сопротивление в Балаклаве немцы, среди которых было много власовцев, оказывали на сопке Безымянная (на карьеpe). Наши войска уже были в Балаклаве, а рубеж проходил по карьеру через Кадыковку (она была нашей), и далее шла немецкая оборона по Сапун-горе и т. д. Это всё описано и известно. В таком положении всё находилось три месяца. Наша армия шла двумя путями - по приморским городам (Приморская армия Петрова) и через Сиваш (4-й Украинский фронт Толбухина). Соединились они под Севастополем, который немцы подготовили к обороне.

Штурмовала карьер дивизия, состоявшая из штрафников. Первая попытка штурма кончилась неудачей. Штурмовавших накрыла наша 
же артиллерия. Вторая попытка (пополненный состав дивизии, потери были большие) окончилась также неудачно. Двигаться надо было в гору по камням карьера. Сражение я наблюдал из дома, где мы жили с Богданчиковыми. Оттуда все хорошо было видно. В Севастополь со стороны Балаклавской дороги (это то, что я видел) прорвались наши танки, ворвались в разрушенный город, но без пехоты (она берет города) вернулись назад и стали за одинокими домиками в Золотой балке на ночь. Всю ночь их обстреливала артиллерия: дома были разрушены, часть танков сожжена. Штрафным батальонам удалось закрепиться на горе и выбить немцев штыковой атакой только с третьей попытки. Потери штрафбатовцев были огромны - до $2 / 3$ личного состава. Тех, кто уцелел, наградили.

Во время взятия Севастополя нашими войсками в воздухе уже господствовала наша авиация. Самолеты, прозванные «летающие танки», устраивали карусель: первый заход - бомбометание, второй того же самолета - обстрел из пушек и пулеметов. Небо было всё в самолетах, их немцы сбивали, но они всё равно бомбили и бомбили немецкие позиции. Падали сбитые самолеты в открытое море. Один упал в бухту. Я слышал, его потом достали, и летчиков с почестями похоронили. Один самолет летчик посадил на склон горы у участка Куприна (выше деревьев грецкого ореха) и прибежал к нам в дом Губарева. Первый вопрос: «Где немцы?» Его успокоили: немцев здесь нет, Балаклава наша. Наши «катюши», стоявшие в районе Байдар, тогда вели непрерывный огонь. Рассказывал один солдат, что немецкий дот выломало разрывами и он катался по земле. Наши обнаружили в нем трех сумасшедших немцев.

\section{После освобождения}

После того, как наши войска вошли и закрепились в Балаклаве, начали работать «тройки» СМЕРШа. Отца и Юрия Петровича арестовали, и больше мы их не видели. Мы с мамой и Ираидой Стефановной перебрались в дом ЭПРОНа (здание на площади Балаклавы). Туда же привели директора кинотеатра (кинотеатр был в этом же здании), который крутил немецкие фильмы, иногда с титрами по-русски, иногда титров не было. Фильмы были с немецкими артистами, одного я запомнил - Тео Линген. Туда же привели женщин, которые встречались с немцами. Все женщины Балаклавы, моя мама, тетя Ира и другие, прошли собеседование.

Рассказ Ираиды Стефановны о собеседовании Наташи, балаклавской проститутки, с молодым лейтенантом (она была в соседней ком- 
нате и ждала своей очереди). Дело в том, что Галина Богданчикова была не первой «леди» по этой части. Первое место занимала Наташа. До нее королевой, у которой перебывали многие, была Горбатая Стратариха, которая известна тем, что пожилой грек, рыбак Панае, забыл у нее сапоги и пришел домой в носках. О Наталье шла слава, что любила мужчин в летах, говоря: «Что молодой, тыр-пыр и сгорел, а старый помалу-помалу — дух захватывает». «Что же ты с любыми немцами спала, теперь с тобой ни один советский солдат не захочет иметь дело», - распекал ее лейтенант. «Врешь ты всё! — отвечала Наталья. - Уже многие переспали со мной». Всех подобных выслали куда-то на север.

Исчезновение в оккупацию Богданчикова, начальника управы, обосновали внутринемецкими разборками и отправили инвалида Николая Богданчикова как сына врага народа в рабочий батальон подвозить снаряды. Старуха осталась одна с двумя малышами. Николая где-то при переходе к границе Венгрии убило ${ }^{8}$.

Жена Богданчикова нашла мужа Василия Яковлевича по скрюченному мизинцу в противотанковом рву, окружающем Севастополь. Этот ров копали все севастопольцы и балаклавцы. Наша семья тоже принимала в этом участие. Через несколько месяцев после возвращения из эвакуации многих людей из Балаклавы выяснилось, что Богданчиков возглавлял очень глубокое подполье, однако списки этого подполья каким-то образом (по-видимому, среди руководства был предатель) попали к немцам (первое подполье расстреляли раньше). Говорили, жене Богданчикова за мужа и сына назначили пенсию, и она вырастила двух внуков.

Жизнь налаживалась. Нас кормили обедами из затирухи с какимто жиром. Снова начала работать школа. Меня назначили старшим (председателем совета дружины пионеров). Я подружился с Воликом Добробротиным, Рындиным и многими другими ребятами.

Я нашел румынскую гранату. Эти румынские гранаты были плохого качества. Они взрывались в руках, не долетев до врага, либо вообще не взрывались. Приятель Фатя, когда я ее принес в школу, сказал, что он такие находил, знает их. Решили пойти в туалет, который стоял на пригорке за школой. Это было деревянное сооружение, слева для мальчиков, справа для девочек. Упавшая неподалеку бомба снесла крышу туалета. Нас пять ребят пошли в мужской туалет (во время большой перемены). Фатя один зашел внутрь и долго не выходил оттуда. Мы уже решили войти, как раздался мощный взрыв, и скоро вышел Фатя, с ног до головы облитый стекающей 
с него жижей с фекалиями. Обернувшись, мы увидели, что все четыре этажа школы облиты этой жижей. Мы побежали вниз к бухте, где отмывали одежду Фати, и он мылся сам (это было на площади). Мыло было местного производства из глины Кил. Принес (кто-то) из дома немецкое мыло, но оно было не лучше. Перемена заканчивалась, мы прибежали в школу, где были выстроены все, а директор-немец ходил между рядами с вопросом, кто опоганил школу?! Дойдя до Фати, он выругал его и сказал, чтобы в школу он больше не приходил. Домой мать его не пустила (сильно пахло), а нас из брандспойта и пожарного насоса, качавших воду из бочек, заставили мыть школу. Воду для бочек брали из бухты и носили ведрами в гору. Школу отмыли. Одежду Фати мать сожгла. Из школы его не исключили. Он потом взорвал гору снарядов, мин и погиб при взрыве. Я недосчитался во время и сразу после войны более половины своих однолеток, они погибли по разным причинам, кого убил снайпер, кто подорвался на мине и т. д.

Балаклава стала портом подводных лодок. На базе подлодок на корабле «Львов» (теплоход) жил медведь, который в обед становился в очередь за первым и потом - за вторым. Если не подавали компота, он рычал и негодовал, ему наливали кружку. Медведь без привязи гулял с матросами по городу и однажды стал в очередь за пивом, чем вызвал переполох в очереди. В райкоме комсомола я узнал, что мой отец в Сталиногорске работает в шахтерском поселке. Мне не возбранялось ему написать, что я и сделал.

Татар к этому времени всех выслали из Крыма. К нам в дом Губарева еще раньше переселился Юрий Спиридонович Серафимов с женой. Спиридон Иванович, его отец, умер к этому времени. Юрий Спиридонович был художник и организовал при кооперативе Балаклавы художественную мастерскую. Я стал учеником в этой мастерской. Мы вырезали из железа рамку, писали на ней имена тех, кого временно похоронили. Я рисовал гирлянду из листьев вокруг надписи. Именная железная с виньеткой надпись прибивалась к деревянной пирамиде, которая устанавливалась на могиле солдата, наверху вырезали из жести и красили красной краской пятиконечную звезду. В общей сложности мы сделали около 2000 таких надписей. Кто-то в Севастополе тоже занялся этим делом.

Греков выслали с татарами, а Юрия Спиридоновича с женой оставили доделать надписи. Когда окончилась работа (через 4-5 месяцев), Юрий Спиридонович с женой и коровой, наняв телегу с лошадью, уехал из Балаклавы по приказу НКВД и осел где-то в Мелитополе. 
Я остался один в мастерской, и мне поручили подкрасить кабинет председателя горисполкома. Денег мне не платили, кончилась олифа. Я бросил работу и ушел к приятелю в Севастополь.

После войны и высылки коренных крымских народов на их место прислали жителей Воронежской области. Непривычные к местным условиям воронежские коровы ломали на крымских горах ноги. Начался голод.

$$
\text { * * * }
$$

В 1945 г. Ираиду Стефановну перевели в Ялту. Ее назначили начальником отдела страхования при Дерикойском (потом Ущельновском) горисполкоме. Я, сдав экстерном за шестой класс, стал учиться в седьмом, но всё равно отстал на год от сверстников. Мать стала работать зав. пошивочной мастерской в Балаклаве (она же закройщик), потом устроилась на работу в театр имени Луначарского и переехала жить в Севастополь. Я жил с тетей Ирой в Ялте. После окончания средней школы в Ущельном был переведен в школу № 15 (мужскую), которую закончил в 1954 г.

До окончания средней школы я около года жил с отцом в Сталиногорске. Нам выделили комнату в бараке, и я учился в сталиногорской школе. В Сталиногорске были татары, греки, приволжские немцы, русские, украинцы. Я изучал английский, поэтому уроки, где немец преподавал немецкий, не посещал. Через примерно год я уехал из Сталиногорска и приехал опять к тете в Ялту, где и окончил школу.

В Ялте прекрасная библиотека, которую, учась в школе, я регулярно посещал. Приехав в Москву подготовленным, я прошел по конкурсу в МИТХТ им М. В. Ломоносова по специальности СК (синтетический каучук). Потом, став секретарем парторганизации (я окончил институт, будучи сталинским стипендиатором), я узнал, что на меня две студентки из моей группы написали донос НКВД, что у меня отец - враг народа, и я не могу учиться на секретной специальности (нас засекречивали на два «с» - совершенно секретно). Ответ из Сталиногорска был один: «Никаких компрометирующих действий за Серафимовым Антоном Петровичем не числится. Он гражданин Советского Союза и пользуется всеми правами гражданина». Отдыхал в отпуске отец в Крыму, отмечая командировку в Москве, он участвовал в выборах и т. д. Правда, ему разрешалось жить только в Сталиногорске. 


\section{ПРИМЕЧАНИЯ}

1 Подробнее о семье балаклавских греков Серафимовых см.: Никифоров К. В. Семья Серафимов-Серафимовых в архивных документах и воспоминаниях // Греки Балаклавы и Севастополя. М., 2013. C. $228-240$.

2 С. Ф. Губарев в 1910 г. построил в Балаклаве в балке КефалоВриси прямо под развалинами генуэзской крепости двухэтажный дом. Он умер от тифа в 1918 г. в Харькове. Перед войной в этом доме жили две его дочери, зять и внук - Леня Серафимов. Дом Губарева (с недавней пристройкой) сохранился до наших дней (Историческая ул., д. 2).

3 ЭПРОН (Экспедиция подводных работ особого назначения) государственная организация в СССР, занимавшаяся подъемом судов и подводных лодок. Существовала в 1923-1942 гг.

4 Богусы - известная балаклавская семья.

5 П. И. Серафимов умер в 1928 г., сразу после венчания своего сына Антона. Жил он в небольшом родовом доме на 2-й линии, недалеко от балки Кефало-Вриси (ныне - ул. Кирова, д. 34). Дом сохранился.

6 Еще один Богус, Георгий, рыбак рыбколхоза и партизан, был расстрелян немцами в Балаклаве 4 ноября 1943 г.

7 Богданчиков Василий Яковлевич, 1885 г. р., г. Курск. Расстрелян фашистами 23 октября 1942 г.

8 Богданчиков Николай Васильевич, 1922 г. р., г. Курск. Рядовой. Умер от ран 23 ноября 1944 г. Похоронен в Венгрии, волость Хотван.

\section{K. V. Nikiforov}

Balaklava under occupation

This is a publication of memoires written by L. A. Serafimov shortly before his death. They show the life of Balaklava before and during the war. At that time this wonderful town still kept traces of the long presence of Russian Greeks.

Key words: Balaklava, occupation, Greeks of Balaklava. 
К. В. Шевченко

(Минск)

\title{
«Жемчужина у моря» под микроскопом этнологов и историков: этнология Одессы в исторической и современной перспективах
}

\begin{abstract}
В коллективной монографии «Этнология Одессы в исторической и современной перспективах», изданной в 2017 году, представлен всесторонний анализ социокультурного феномена Одессы. Коллектив авторов прослеживает различные аспекты формирования и функционирования уникального социокультурного механизма, который способствовал формированию особого «одесского мифа».

Ключевые слова: Одесса, этнология, «одесский миф», этнокультурная ситуация, межнацฺиональные отношения.
\end{abstract}

DOI: $10.31168 / 2073-5731.2018 .3-4.8 .01$

Коллективная монография «Этнология Одессы в исторической и современной перспективах», изданная в одесском издательстве «Ирбис» в 2017 г., стала заметным явлением в международной научной жизни и серьезным вкладом в междисциплинарное изучение социокультурного феномена Одессы. Несмотря на почти тридцать лет, прошедших после распада СССР, и растущее размежевание между постсоветскими государствами, Одесса продолжает оставаться городом-брендом и городом-легендой для среднего и старшего поколения постсоветских граждан. Данная монография, опираясь на последние достижения гуманитарных наук, раскрывает многие социокультурные механизмы, способствовавшие формированию особого «одесского мифа». Авторами монографии являются известный чешский антрополог, доктор философии, заведующий кафедрой антропологии Западночешского университета (г. Пльзень, Чехия) П. Лозовюк, одесский этнолог, доктор исторических наук, профессор Одесского национального университета им. И. И. Мечникова А. Пригарин, а также другие одесские историки и этнологи.

На богатом и разнообразном эмпирическом материале авторы монографии анализируют различные аспекты социокультурной эволюции Одессы как полиэтничного и мультикультурного мегаполиса, стремительное развитие которого в XIX — начале XX в. было в значительной степени связано как с уникальным географическим положе- 
нием Одессы, ставшей южными воротами Российской империи, так и с рядом других факторов социально-экономического, демографического и культурного развития России в XIX - начале XX в. Как отмечает П. Лозовюк, доминирование мигрантов из различных областей России, а также с Балкан и Центральной Европы среди основателей Одессы в конце XVIII в. (город был основан в 1794 г.) предопределило исключительно пестрый состав и мультикультурный, многоязыковой, поликонфессиональный и полиэтнический облик населения Одессы, что надолго стало визитной карточкой города (с. 358).

Анализируя место Одессы в перспективах различных культур и ретроспекциях исследователей, П. Лозовюк и А. Пригарин отмечают характерную для Одессы «переплавку» этнических различий и образование «метаэтнических общностей» как конструктов высшего порядка; при этом, по мнению авторов, одессита можно обоснованно считать «примером множественной идентичности, подчиненной прагматике жизнедеятельности» (с. 14). И если в настоящее время «подобные процессы модернизации и глобализации никого не удивят», то важным отличием Одессы является то обстоятельство, что в данные «тренды» она оказалась втянута принципиально раньше (с. 15). Особенностью урбанистической среды Одессы как мегаполиса является то, что она «выступает синтетической конструкцией взаимодействия примордиальных традиций в конструктивных моделях инноваций», а характерный для одесского региона «масштаб фронтира позволяет одесскому обывателю жить сразу в нескольких измерениях этничности, не рефлексируя об их противоречиях» (с. 15).

В своей статье, посвященной протоэтнографическому восприятию одесского пространства, П. Лозовюк приводит целый ряд ярких примеров, иллюстрирующих зачатки этнологически мотивированного интереса к урбанистической среде на примере Одессы. Автор, в частности, отмечает важность и колоссальную научную ценность одесских наблюдений немецкого исследователя Коля в конце 1830х гг., нашедших отражение в его пространных «Очерках о путешествиях по Южной России». Данная работа Коля, для которого всегда было характерно внимание к городу как к особой этносоциальной среде, имела «формирующее влияние на ряд последователей Коля и его подражателей (например, Юзефа Игнацы Крашевского)» (с. 55). Ценные с этнологической точки зрения отзывы об Одессе оставили и чешские путешественники, в частности С. Геллер и известные чешские литераторы Й. С. Махар и С. Чех. Так, для Й. С. Махара самой яркой чертой Одессы было «вавилонское смешение» народов и 
языков, «под которым Махар понимал <.. > присутствие множества этноконфессиональных групп в ограниченном пространстве большого города» (с. 78).

Большой интерес представляет исследование П. Лозовюка, раскрывающее особенности чешского восприятия Одессы на рубеже XIX и XX вв. Одесса, привлекавшая многих чехов своей этнокультурной экзотикой, космополитизмом и приморским расположением, стала местом творческой самореализации известного чешского музыканта и дирижера Й. Прибика, который, приехав в Одессу еще в 1893 г., стал здесь первым дирижером городского оркестра и профессором Одесской филармонии. Прибик остался «в Одессе на позиции шеф-дирижера и педагога до конца своей жизни, вплоть до 1937 г.», получив впоследствии почетное звание народного артиста УССР (с. 92-93). Примечательно, что «чешский одессит» Й. Прибик прославился в Одессе как неутомимый пропагандист русских композиторов и инициатор замены итальянского репертуара одесской оперы на русский репертуар, став своего рода «будителем» русского патриотизма в области оперного искусства. Нельзя не вспомнить в этой связи, что известный чешский политик К. Крамарж после своих поездок в Россию в конце XIX в. с явным неудовольствием отмечал чрезмерный космополитизм русской интеллигенции, призывая русских стать «сознательными националистами». Примечательно и то, что инициаторами переименования Санкт-Петербурга в Петроград после начала Первой мировой войны были представители именно петербургской чешской общины. Чехи на рубеже столетий, таким образом, нередко выполняли в России вакантную здесь миссию «будителей», прививая русским искусство любви к родине и в существенной мере способствуя «пробуждению» русских национальных чувств. Именно эту роль в области оперного искусства сыграл в Одессе на рубеже XIX и ХХ вв. и Й. Прибик.

Известный одесский этнолог и историк А. Пригарин в своих статьях прослеживает зарождение и раннюю историю знаменитой одесской Молдаванки, анализирует этнологические аспекты торговли современной Одессы, а также исследует весьма сложный культурогенез городской системы питания, уделяя особое внимание балканским субстратам в одесской кухне и демонстрируя при этом отменное знание этой специфической части культуры повседневности. Культурогенез специфической одесской кухни довольно убедительно отражает успешный процесс взаимопроникновения и взаимовлияния различных кулинарных традиций среди полиэтничного населения Одессы. 
Возможно, особенности одесской кухни в известной степени объясняют витальность и развитое чувство юмора одесситов, ибо, как известно, человек является отражением того, что он ест и пьет.

Предметом исследования Е. Князевой стали непростые межнациональные отношения и культурно-языковая ситуация в Одессе за годы независимости Украины. Е. Князева подчеркивает, что, несмотря на рост численности тех, кто считает себя украинцем, за последние двадцать лет только украинским языком предпочитают пользоваться не более 3-4\% взрослых одесситов; при этом только русским языком - 80-85\% населения Одессы (с. 182). Автор отмечает, что среди одесситов, считающих себя украинцами, с 1991 г. доля предпочитающих пользоваться русским, а не украинским языком за последние десятилетия выросла почти на 30\%, объясняя данный феномен тем, что «попытка осуществить украинизацию русскоязычных одесситов административными методами $<\ldots>$ не удалась» (c. 182).

Коллективная монография «Этнология Одессы в исторической и современной перспективах», выполненная на высоком академическом уровне с учетом самых последних достижений истории, этнологии, социологии и других гуманитарных наук, вносит колоссальный вклад в постижение одесского социокультурного феномена и его истоков. Данная монография обречена стать настольной книгой не только для историков и этнологов, занимающихся Одессой и одесским регионом, но и вообще для всех тех, кто интересуется историей и оригинальной культурой любимой всеми «жемчужины у моря».

Остается пожелать, чтобы успешное междисциплинарное комплексное изучение Одессы было продолжено и чтобы наряду с Одессой объектами исследования стали и другие знаковые города постсоветского пространства с богатой имперской родословной, интересным историческим наследием и ярким социокультурным имиджем. Представляется, что первым в этом ряду может стать современная столица юга России - город Ростов-на-Дону, имеющий весьма схожую с Одессой историческую судьбу и социокультурные характеристики. Общеизвестно, что популярный в южнорусском этнокультурном пространстве образ «Одессы-мамы» органично соседствует с не менее популярным образом «Ростова-папы»... 


\section{K. V. Shevchenko}

"The Pearl at the Sea" under the microscope of ethnologists and historians.

Ethnology of Odessa in historical and contemporary perspective

The collective monograph "Ethnology of Odessa in historical and contemporary perspectives" published in 2017, presents a wide-scale analysis of the social and cultural phenomenon of Odessa. The authors of the collective monograph trace various aspects of the formation and functioning of the unique socio-cultural mechanism, which contributed to the formation of the special "myth of Odessa"

Keywords: Odessa, ethnology, "myth of Odessa", ethnocultural situation, interethnic relations. 
М. Ю. Дронов, С. М. Слоистов

(Москва)

\section{Международная научно-практическая конференция «Церковь в исторических судьбах народов Центральной и Восточной Европы»}

3 марта 2018 г. в белорусской столице состоялась научно-практическая конференция, приуроченная к 220 -летию со дня рождения митрополита Литовского и Виленского Иосифа (Семашко; 1798-1868) лидера воссоединения грекокатоликов с православием в 1839 г.

В год двойной памяти митрополита Иосифа (220 лет со дня рождения и 150 лет со дня кончины) церковная и научная общественность в Белоруссии и Литве постаралась актуализировать в широкой повестке научных и общественно значимых тем вопросы, связанные с проблематикой служения иерарха. Белорусский экзархат РПЦ, Виленско-Литовская епархия РПЦ организовали целый ряд культурных, просветительских и научных мероприятий.

Отрадно, что наряду с классическими для такого рода памятных событий просветительскими и образовательными чтениями были также запланированы и сугубо научные конференции (круглые столы). Руководство экзархата стремилось создать условия для вдумчивого изучения проблем, связанных с воссоединением униатов в 1839 г., способствовать диалогу между исследователями этой непростой темы церковной истории. Об изначальном стремлении придать неминуемо развернувшейся накануне 180 -летия воссоединения грекокатоликов дискуссии более глубокий характер, направить ее в русло скрупулезного анализа фактов, постараться избежать резких оценочных суждений и упрощенных интерпретаций свидетельствует привлечение в Организационный комитет по подготовке и проведению в 2017-2019 гг. в пределах Белорусского экзархата общецерковного празднования представителей светской науки - профессорско-преподавательского состава государственных вузов Белоруссии, в частности из Минска, Гродно, Бреста, Могилева.

Наряду с Институтом теологии имени святых Мефодия и Кирилла Белорусского государственного университета особые позиции в разработке проблем истории церковно-государственных отношений в Белоруссии занимает Центр евразийских исследований филиала Российского государственного социального университета (далее - РГСУ) 
в г. Минске (заведующий Центром - проф., д. и. н. К. В. Шевченко). Как показывает уровень и содержание проводимых Центром в последние годы научных конференций, рассмотрение конкретных сюжетов истории Белоруссии в более широком региональном и тематическом контексте позволило по-новому взглянуть на, казалось бы, давно изученные вопросы. Не стала исключением и данная встреча белорусских историков церкви и их коллег из соседних славянских стран.

Тематические рамки мероприятия были очерчены весьма широко: докладчики говорили о проблемах разных христианских церквей как в Восточной, так и в Центральной Европе преимущественно в XIX и XX столетиях. В научном плане вместе с Центром евразийских исследований филиала РГСУ в г. Минске в организации конференции принял участие международный журнал социальных и гуманитарных наук «Аспект». В решении практических вопросов ее проведения также участвовало Православное братство в честь Святого Архистратига Михаила при приходе Покрова Пресвятой Богородицы в г. Минске.

Первый научный доклад на конференции по праву принадлежал наиболее авторитетному ее участнику — проф. Института теологии Белорусского государственного университета (далее - БГУ) д. и. н. А. Ю. Бендину. Ученый осветил тему взаимодействия митрополита Иосифа и графа М. Н. Муравьева (1796-1866), гродненского, минского и виленского генерал-губернатора в 1863-1865 гг., дав взвешенную оценку этому, по словам историка, «опыту церковно-государственного сотрудничества». Протоиерей Александр Романчук, заведующий кафедрой церковной истории Минской духовной семинарии (далее - МДС), поделился своими размышлениями о значении деятельности митрополита Иосифа для современной Белорусской православной церкви. Коллега о. Александра Романчука по МДС магистр исторических наук иерей Алексей Хотеев осветил тему «Канонические основания для воссоединения униатов в 1839 году». Белорусско-российский политолог $\kappa . u . н$. A. Д. Гронский (Национальный исследовательский институт мировой экономики и международных отношений им. Е. М. Примакова РАН) выступил с сообщением «Петиция против канонизации митрополита Литовского и Виленского Иосифа (Семашко) как образец белорусского антиправославного интернет-дискурса».

Палитра сюжетов конференции содержала также тематический блок, не связанный напрямую с церковной историей Белоруссии, что позволило собравшимся более широко, отталкиваясь от типологической схожести и сравнительного анализа особенностей, посмотреть на поставленные проблемы. Так, содержательный обзор «Уния и на- 
циестроительство в Трансильвании, Валахии и Молдавии» сделал д. и. н. К. В. Шевченко. Доцент Белорусского государственного университета информатики и радиотехники (г. Минск) к. и. н. A. A. Киселев посвятил свой доклад польскому ученому и публицисту Ф. Конечному, в частности его оценкам церковной унии. Историк-русинист к. и. н. О. Г. Казак (Минский городской педагогический колледж) поведал о деятельности мадьяронов среди грекокатолического духовенства Подкарпатской Руси в 1939-1944 гг. К. и. н. М. Ю. Дронов (ИСл РАН) представил личность Прешовского грекокатолического епископа Павла Петра Гойдича (1888-1960) в качестве национального лидера русинов Пряшевщины (северо-восточных районов Словакии). С. М. Слоистов (ИСл РАН) посвятил свое выступление словакизации религиозной жизни кальвинистов в Чехословацкой республике.

Таким образом, программа конференции позволила рассмотреть проблематику влияния религии и религиозных институтов на развитие народов Центральной и Восточной Европы. Идея поставить в центр проблемного поля заседания вопросы, связанные с изучением служения митрополита Иосифа (Семашко), дала свои положительные результаты. Компартивно представленная в докладе А. Ю. Бендина деятельность религиозного лидера митрополита Иосифа и государственного политика М. Н. Муравьева открыла возможность для выявления взаимного влияния процессов конфессионального, этнонационального, культурного и социально-экономического развития. Выйти за пределы региона, при этом продолжая рассмотрение истории униатов и их роли в реализации национальных проектов, позволил доклад К. В. Шевченко. Обращение ряда других докладчиков к более частным сюжетам церковно-государственных отношений на примере других регионов с ярко выраженным культурным пограничьем (Подкарпатской Руси, Пряшевщины, Южной Словакии) послужило уместным дополнением, позволяющим сравнить происходившие там процессы со схожими явлениями на границе соприкосновения католичества и православия, польского и восточнославянского начала в Белоруссии.

Подводя итог в целом, можно сказать, что конференция принесла интересные результаты в непростом деле изучения вопросов, связанных с воссоединением униатов в 1839 г. Развернувшаяся на заседании дискуссия позволила более широко посмотреть на деятельность митрополита Иосифа (Семашко). В то же время представленные доклады и высказанные в процессе их обсуждения мнения дают основание говорить о необходимости дальнейшего изучения столь важных для истории церкви и церковно-государственных отношений сюжетов. 
Ю. В. Лобачева

(Москва)

\section{Круглый стол «Тенденции современных национальных историографий стран Центральной, Юго-Восточной и Восточной Европы»}

DOI: $10.31168 / 2073-5731.2018 .3-4.9 .02$

15 мая 2018 г. в отделе истории славянских народов периода мировых войн Института славяноведения РАН состоялся Круглый стол «Тенденции современных национальных историографий стран Центральной, Юго-Восточной и Восточной Европы». Он был проведен в рамках Программы фундаментальных исследований Президиума РАН 0178-20180008 «Австро-Венгрия: механизмы (само)организации культурно-сложных сообществ в композитарной монархии». Первоначально идея этого мероприятия принадлежала безвременно ушедшему коллеге, выдающемуся историку, преданному своему делу, - Андрею Леонидовичу Шемякину (1960-2018). Именно светлой памяти этого ученого и человека и был посвящен Круглый стол.

В ходе Круглого стола, проведение которого взял на себя С. 3. Случ, прозвучало 11 докладов сотрудников отдела, сопровождавшихся вопросами, комментариями и дискуссией. Открывал первое заседание доклад А. А. Силкина «А. Л. Шемякин и мифы современной сербской историографии», посвященный вкладу А. Л. Шемякина в преодоление некоторых стереотипов, присутствующих в современной сербской историографии. Докладчик отметил, что один из наиболее устойчивых стереотипов связан с интерпретацией истории Сербии конца XIX - начала XX в., в рамках которой эта страна предстает в качестве «современного европейского государства» с «аутентичной парламентской демократией». Не оставалось без внимания А. Л. Шемякина и присущее некоторым сербским авторам обыкновение безосновательно возлагать на Россию ответственность за те или иные трагические эпизоды сербской истории указанного периода (например, Майский переворот 1903 г., в результате которого с престола была свергнута династия Обреновичей).

Н. С. Гусев в докладе «“По ком жужжит шредер”: современные российские (псевдо)научные исследования по Новой истории Балкан» на примере некоторых современных статей по истории Балкан продемонстрировал последствия гонки за наукометрическими показателями деградацию региональных научных сборников из списка ВАК, череду «мусорных» статей из изданий, входящих в РИНЦ или имеющих DOI. 
Выделил он и типичные недостатки подобных публикаций — заявки на раскрытие обширных тем в рамках нескольких страниц, незнание историографической базы, нерелевантная или отсутствующая источниковая база. Докладчик отметил, что действенным способом борьбы с появлением подобной продукции являются попытки научной общественности легальными методами противодействовать тому, чтобы такие (псевдо) исследователи успешно защищали диссертации.

В докладе Ю. В. Лобачевой «Женщины в истории независимой Сербии (1878-1918) в освещении современной сербской историографии» был сделан обзор основных направлений исследований, рассматривающих «бытие и быт» сербских женщин. Среди них - историография по истории «женского вопроса» (феминизма), биографические исследования, изучение статуса женщин в связи с проблемами модернизации Сербии в XIX-XX вв., женская тематика в рамках гендерных исследований и в контексте истории повседневности, частной жизни и семьи, изучение восприятия сербской женщины «другими» с точки зрения имагологии.

А. В. Ганин в докладе «Современная украинская историография военно-политических событий 1917-1922 гг. на Украине (2008-2018 гг.)» заметил, что оценка событий 1917-1922 гг. украинскими историками базируется в основном на концепции украинской диаспоры, которая рассматривает этот период как Украинскую национально-освободительную революцию и освободительную войну. Итогом событий 1917-1922 гг. считается экспансия коммунистической революции из России на Украину как независимое государство (это противоречит отечественной концепции Гражданской войны в России). В некоторых работах встречаются искажения исторического материала и надуманные выводы. Однако отмечено докладчиком и издание на Украине серьезных конкретно-исторических трудов по военно-политической проблематике 1917-1922 гг.

Завершали первое заседание два выступления по чешской тематике. В докладе Н. Н. Станкова «Чехословацко-германские отношения после Первой мировой войны в современной чешской историографии» говорилось о том, что с начала 1990-х гг. в Чешской Республике происходит стремительное возрождение исторической науки. Подчеркивалось, что устранение цензуры, открытие архивных хранилищ, появление возможностей для развития широких международных научных контактов создали благоприятные условия для исследования внешней политики ЧСР в межвоенный период, в том числе и чехословацко-германских отношений, значительный вклад в изучение которых внесли В. Оливова, Р. Бржах, Й. Деймек, 3. Карник, Э. Кубу, Д. Моравцова. 
Доклад Е. П. Серапионовой «Современные тенденции чешской исторической науки» был посвящен анализу тематики научных мероприятий, состоявшихся в Чешской Республике в 2017-2018 гг. и запланированных на 2018 г. Рассматривались, в частности, основные проблемы политической, экономической, социальной истории и истории литературы и искусства XIX-XXI вв., обсуждаемые на научных семинарах, конференциях и круглых столах в преддверии 100-летнего юбилея со дня образования Чехословацкого государства. Особое внимание было уделено подготовке исторических кадров, связям чешских историков с коллегами из-за рубежа, а также привлечению к организации научных мероприятий политиков, работников музеев и архивов.

Второе заседание открыл доклад С. З. Случа «О некоторых тенденциях в отечественной и зарубежной историографии внешней политики СССР и международных отношений в Европе в 1930-е годы». В нем шла речь об освещении историками Германии, Польши и России проблем, относящихся к предыстории Второй мировой войны, - особенно тех из них, которые стали не только предметом научных исследований, но и объектом политических манипуляций («исторической политики»). Среди них особо выделялись Мюнхенское соглашение от 30 сентября 1938 г. и советско-германский договор о ненападении от 23 августа 1939 г., актуальность исследования которых во многом связана с долговременным характером территориально-государственных последствий пакта Молотова-Риббентропа, а также стремлением немалого числа российских историков исказить значение этого соглашения.

Продолжили Круглый стол два доклада по югославянской тематике. В докладе А. С. Аникеева «Истоки югославской политики неприсоединения в современной сербской историографии» была рассмотрена трактовка внешней политики Югославии после возникновения советско-югославского конфликта 1948 г. в официальной историографии СФРЮ 1960-1980 гг. в сравнении с ее нынешней интерпретацией сербскими учеными. Отмечено стремление югославской историографии представить становление внешнеполитического курса послевоенной Югославии как непрерывный процесс, естественно сформировавшийся еще в 1941-1945 гг. По мнению же современных сербских авторов, правящая югославская элита после разрыва отношений с СССР с учетом внутренних и внешних обстоятельств выбирает прагматическую политику, позволившую Югославии во второй половине 1950-х гг. в равной степени дистанцироваться от двух блоков.

Л. Я. Гибианский в докладе «Цепкость старых и соблазн новых мифов: тенденции постюгославской историографии в освещении причин, 
характера и механизма конфликта Сталин - Тито (при сопоставлении с некоторыми тенденциями в российской и западной историографии)» обратил внимание на то, что в историографии фактически всех государств, возникших после распада СФРЮ, отправным пунктом при освещении истории конфликта Сталин - Тито явилось влияние трактовки, господствовавшей в официальной пропаганде и историографии бывшей Югославии. Эта трактовка во многом состояла из мифов, возникших в период конфликта как противовес советским официальным мифам. В докладе было прослежено развитие югославской мифологии, ее воздействие на западную и постюгославскую историографию, а также было проанализировано явление возникновения новых мифов.

В докладе В. В. Волобуева «Современная польская историография о ПНР и реалии польской политики» рассматривались научные дискуссии относительно природы социалистического строя в Польше, поднимались вопросы политического применения исторических вопросов. Особо было подчеркнуто то, что на волне победы партии Я. Качиньского «Право и Справедливость» происходит активное насаждение определенного взгляда на историю социалистической Польши. Активную роль в этом играют ангажированные историки, с чьей подачи взгляды их оппонентов увязываются с политической позицией, неугодной новой власти.

В завершившем второе заседание докладе А. С. Стыкалина «Некоторые тенденции развития современной венгерской историографии в контексте исторической политики Виктора Орбана» освещались историческая политика доминирующей в сегодняшней Венгрии правой партии ФИДЕС во главе с В. Орбаном, ее влияние на трактовку ключевых событий венгерской истории, отношение к конкретным научным проектам, монументальной пропаганде и музейной деятельности. Отмечено, в частности, что к числу политиков, составляющих национальную гордость, причисляется премьер-министр хортистской Венгрии граф И. Бетлен, а видные леволиберальные политики М. Каройи и О. Яси трактуются как представители чуждого национальным ценностям либерального космополитизма, проложившего дорогу большевизму и беспримерному национальному унижению в виде Трианонского мирного договора 1920 г.

Подводя итог, заметим, что рассмотрение на Круглом столе широкого круга проблем из истории стран Центральной, Юго-Восточной и Восточной Европы в историографическом ключе обогатило представление участников о состоянии и некоторых особенностях современной постюгославской, украинской, чешской, польской, венгерской, германской и российской историографии. Кроме этого, оно способствовало обретению более полного понимания того значения, которое придается российским исследованиям зарубежными научными сообществами. 


\section{Сведения об авторах}

Агапкина Татьяна Алексеевна - доктор филологических наук, ведущий научный сотрудник отдела этнолингвистики и фольклора Института славяноведения РАН, главный редактор издательства «Индрик». agapi-t@yandex.ru

Адельгейм Ирина Евгеньевна - доктор филологических наук, ведущий научный сотрудник отдела современных литератур Центральной и ЮгоВосточной Европы Института славяноведения PAH. adelgejm@yandex.ru

Аржакова Лариса Михайловна - доктор исторических наук, доцент СанктПетербургского государственного университета. 1.arzhakova@spbu.ru

Борисёнок Елена Юрьевна — доктор исторических наук, заведующая отделом восточного славянства Института славяноведения PAH. vostslav@yandex.ru

Борисёнок Юрий Аркадьевич — кандидат исторических наук, доцент кафедры истории южных и западных славян исторического факультета МГУ им. М. В. Ломоносова. rodina2001@mail.ru

Вишняков Ярослав Валерьянович - доктор исторических наук, профессор кафедры Всемирной и отечественной истории МГИМО МИД России. vishnyakov@yandex.ru

Галимзянова Евгения Александровна - соискатель Московского государственного университета им. М. В. Ломоносова. egenie1990@yandex.ru

Ганин Андрей Владиславович - доктор исторических наук, ведущий научный сотрудник отдела истории славянских народов периода мировых войн Института славяноведения РАН. andrey_ganin@mail.ru

Гура Александр Викторович — доктор филологических наук, ведущий научный сотрудник отдела этнолингвистики и фольклора Института славяноведения РАH. avgura@mail.ru

Гусев Никита Сергеевич — кандидат исторических наук, научный сотрудник отдела истории славянских народов периода мировых войн Института славяноведения РАН. gusevns@gmail.com 
Дронов Александр Михайлович - младший научный сотрудник отдела истории славянских народов Центральной Европы в Новое время. dronov938@rambler.ru

Дронов Михаил Юрьевич - кандидат исторических наук, научный сотрудник отдела восточного славянства Института славяноведения РАН. mikhaildronov@rambler.ru

Кожина Светлана Анатольевна - младший научный сотрудник Отдела современных литератур Центральной и Юго-Восточной Европы Института славяноведения РАН. lana-0391@mail.ru

Колин Анжела Ивановна - кандидат исторических наук, старший научный сотрудник Институт истории АН Молдовы (г. Кишинев).

Короткова Дарья Юрьевна - кандидат исторических наук, научный сотрудник отдела восточного славянства Института славяноведения РАН. dasza1981@yandex.ru

Кочегаров Кирилл Александрович — кандидат исторических наук, старший научный сотрудник отдела истории славянских народов Центральной Европы в Новое время. kirill-kochegarow@yandex.ru

Красовец Александра Николаевна - кандидат филологических наук, научный сотрудник отдела истории культуры славянских народов Института славяноведения РАН. aleksandrakrasovec@yahoo.com

Лабынцев Юрий Андреевич - доктор филологических наук, ведущий научный сотрудник отдела восточного славянства Института славяноведения РАН. slavia@hotbox.ru

Лобачева Юлия Владимировна - кандидат исторических наук, старший научный сотрудник отдела истории славянских народов периода мировых войн Института славяноведения РАН. lobachevaj@gmail.com

Мамедов Ильгар Махалович - кандидат исторических наук, старший научный сотрудник отдела современной истории стран Центральной и Юго-Восточной Европы Института славяноведения РАН. ilgarmm@ yandex.ru 
Неменский Олег Борисович - научный сотрудник отдела истории средних веков Института славяноведения РАН. nemenski@yandex.ru

Никифоров Константин Владимирович - доктор исторических наук, директор Института славяноведения РАН. inslav@inslav.ru

Новосельцева Людмила Константиновна - младший научный сотрудник отдела истории славянских народов Центральной Европы в Новое время. mnovoseltseva91@gmail.com

Пилипенко Глеб Петрович - кандидат филологических наук, научный сотрудник отдела славянского языкознания Института славяноведения PAH. glebpilipenko@mail.ru

Плотникова Анна Аркадьевна - доктор филологических наук, главный научный сотрудник отдела этнолингвистики и фольклора Института славяноведения PAH. annaplotn@mail.ru

Робинсон Михаил Андреевич - доктор исторических наук, руководитель Центра междисциплинарных исследований славянской книжности Института славяноведения PAH. m.a.robinson@mail.ru

Слоистов Сергей Михайлович - младший научный сотрудник отдела истории Восточной Европы после Второй мировой войны Института славяноведения РАН. centrum821@rambler.ru

Станков Николай Николаевич - доктор исторических наук, ведущий научный сотрудник отдела истории славянских народов периода мировых войн Института славяноведения РАН. stankov11@yandex.ru

Стыкалин Александр Сергеевич - кандидат исторических наук, ведущий научный сотрудник отдела истории славянских народов периода мировых войн Института славяноведения PAH. zhurslav@mail.ru

Теуш Ольга Анатольевна - кандидат филологических наук, доцент Уральского федерального университета им. Первого Президента России Б. Н. Ельцина (г. Екатеринбург). olga.teush@yandex.ru 
Фалькович Светлана Михайловна - доктор исторических наук, научный сотрудник отдела истории славянских народов Центральной Европы в Новое время. inslav@inslav.ru

Флоря Борис Николаевич - доктор исторических наук, членкорреспондент РАН, зав. отделом истории средних веков Института славяноведения РАН. sredveka_inslav@land.ru

Фролова Марина Михайловна - кандидат исторических наук, старший научный сотрудник отдела истории славянских народов Юго-Восточной Европы в Новое время Института славяноведения РАН. marinafrolova59@, mail.ru

Чуркина Искра Васильевна - доктор исторических наук. kirilina.Ljuba@ rambler.ru

Шевченко Кирилл Владимирович - доктор исторических наук, профессор Минского филиала Российского государственного социального университета. shevchenkok@hotmail.com

Широкова Людмила Федоровна - кандидат филологических наук, старший научный сотрудник отдела современных литератур Центральной и Юго-Восточной Европы Института славяноведения РАН. shirocco@mail.ru

Щавинская Лариса Леонидовна - кандидат филологических наук, старший научный сотрудник отдела восточного славянства Института славяноведения РАН. slavia@hotbox.ru 


\section{About the authors}

Agapkina Tatyana Alekseevna - Doctor of Letters, leading research fellow, Department of Ethnolinguistics and Folklore, Institute of Slavic Studies, Russian Academy of Sciences, editor-in-chief of the publishing house "Indrik". agapi-t@yandex.ru

Adelgejm Irina Yevgenyevna - Doctor of Letters, leading research fellow, Department of Modern Literatures of Central and South-Eastern Europe, Institute of Slavic Studies, Russian Academy of Sciences. adelgejm@yandex.ru

Arzhakova Larisa Mihaylovna - Doctor of History, associate professor in Saint Petersburg State University. 1.arzhakova@spbu.ru

Borisenok Elena Yuryevna - Doctor of History, head of the Department of Eastern Slavic Studies, Institute of Slavic Studies. vostslav@yandex.ru

Borisenok Yuriy Arkadyevich - Candidate of History, associate professor, Chair of history of South and West Slavs, Department of History, Lomonosov Moscow State University. rodina2001@mail.ru

Churkina Iskra Vasilyevna - Doctor of History. kirilina. Ljuba@rambler.ru

Dronov Aleksandr Mikhaylovich - junior research fellow, Department of Modern History of Slavic Peoples in Central Europe. dronov938@rambler.ru

Dronov Mihail Yuryevich - Candidate of History, research fellow, Department of Eastern Slavic Studies, Institute of Slavic Studies, Russian Academy of Sciences.mikhaildronov@rambler.ru

Fal'kovich Svetlana Mihaylovna - Doctor of History, leading research fellow, Department of Modern History of Slavic Peoples in Central Europe. inslav@inslav.ru

Florya Boris Nikolayevich - Doctor of History, corresponding member of the Russian Academy of Sciences, head of the Department of Medieval History, Institute of Slavic Studies, Russian Academy of Sciences. sredveka_inslav@, land.ru 
Frolova Marina Mikhaylovna - Candidate of History, senior research fellow Department of South East Europe' Slavs Early Modern History, Institute of Slavic Studies. marinafrolova59@mail.ru

Galimzyanova Yevgeniya Aleksandrovna - aspirant, Lomonosov Moscow State University. egenie1990@yandex.ru

Ganin Andrey Vladislavovich - Doctor of History, leading research fellow, Department of Slavic History of the World Wars Period, Institute of Slavic Studies, Russian Academy of Sciences. andrey_ganin@mail.ru

Gura Aleksandr Viktorovich - Doctor of Letters, leading research fellow, Department of Ethnolinguistics and Folklore, Institute of Slavic Studies, Russian Academy of Sciences. avgura@mail.ru

Gusev Nikita Sergeevich - Candidate of History, Department of the World Wars Period in the Institute of Slavic Studies, Russian Academy of Sciences.gusevns@gmail.com

Kochegarov Kirill Aleksandrovich - Candidate of History, senior research fellow, Department of Modern History of Slavic Peoples in Central Europe. kirill-kochegarow@yandex.ru

Kolin Angela Ivanovna - Ph.D. in History, senior research fellow, Institute of History, Academy of Sciences of Moldova (Chisinau).

Korotkova Darya Yuryevna - Candidate of History, research fellow, Department of Eastern Slavic Studies, Institute of Slavic Studies, Russian Academy of Sciences.dasza1981@yandex.ru

Kozhina Svetlana Anatol'evna - junior research fellow, Department of Modern Literatures of Central and South-Eastern Europe, Institute of Slavic Studies, Russian Academy of Sciences. lana-0391@mail.ru

Krasovec Aleksandra Nikolayevna - Candidate of Letters, research fellow, Department of Cultural History of Slavic Peoples, Institute of Slavic Studies. aleksandrakrasovec@yahoo.com

Labyntsev Juri Andreevich - Doctor of Letters, leading research fellow, Department of Eastern Slavs, Institute of Slavic Studies, Russian Academy of Sciences.slavia@hotbox.ru 
Lobacheva Yulia Vladimirovna - Candidate of History, senior research fellow, Department of Slavic History of the World Wars Period, Institute of Slavic Studies.lobachevaj@gmail.com

Mamedov Il'gar Mahalovich - Candidate of History, senior research fellow, Department of Contemporary History of Central and South-Eastern Europe. Institute of Slavic Studies. ilgarmm@yandex.ru

Nemensky Oleg Borisovich — research fellow, Department of Medieval History, the Institute of Slavic Studies, Russian Academy of Sciences. nemenski@yandex.ru

Nikiforov Konstantin Vladimirovich - Doctor of History, director, Institute of Slavic Studies, Russian Academy of Sciences. inslav@inslav.ru

Novosel'tseva Lyyudmila Konstantinovna - junior research fellow, Department of Modern History of Slavic Peoples in Central Europe. mnovoseltseva91@gmail.com

Pilipenko Gleb Petrovich - Candidate of Letters, Department of Slavic Linguistics, Institute of Slavic Studies, Russian Academy of Sciences. glebpilipenko@mail.ru

Plotnikova Anna Arkadyevna - Doctor of Letters, chief research fellow, Department of Ethnolinguistics and Folklore, Institute of Slavic Studies, Russian Academy of Sciences. annaplotn@mail.ru

Robinson Mihail Andreevich - Doctor of History, head of Centre of Interdisciplinary Research of Slavic Literatures, Institute of Slavic Studies. m.a.robinson@mail.ru

Shchavinskaya Larisa Leonidovna - Candidate of Letters, senior research fellow, Department of Eastern Slavs, Institute of Slavic Studies, Russian Academy of Sciences.slavia@hotbox.ru

Sloistov Sergey Mihaylovich - junior research fellow, Department of History of Eastern Europe after WWII, Institute of Slavic Studies, Russian Academy of Sciences. centrum821@rambler.ru

Stankov Nikolay Nikolayevich - Doctor of History, leading research fellow, Department of Slavic History of the World Wars Period, Institute of Slavic Studies, Russian Academy of Sciences. stankov11@yandex.ru 
Stykalin Aleksandr Sergeyevich - Candidate of History, leading research fellow, Department of Slavic History of the World Wars Period, Institute of Slavic Studies, Russian Academy of Sciences. zhurslav@mail.ru

Shevchenko Kirill Vladimirovich - Doctor of History, professor, Minsk branch of the Russian State Social University. shevchenkok@hotmail.com

Shirokova Lyudmila Fedorovna - Candidate of Letters, senior research fellow, Department of Modern Literatures of Central and South-Eastern Europe, Institute of Slavic Studies, Russian Academy of Sciences. shirocco@mail.ru

Teush Ol'ga Anatolyevna - Candidate of Letters, associate professor, Ural Federal University, Named after the First President of Russia B. N. Yeltsin (Yekaterinburg). olga.teush@yandex.ru

Vishnyakov Yaroslav Valeryevich - Doctor of History, Professor of the Chair for World and Russian History, Moscow State Institute of International Relations at the Ministry of Foreign Affairs of Russia. vishnyakov@yandex.ru 



\section{Славянский альманах}

\section{$3 \cdot 42018$}

\section{Издательство «Индрик»}

Начиная с 2019 года в нашем журнале вводятся новые правила представления рукописи, доступные по электронному адресу: http://inslav.ru/page/pravila-napravleniya-i-opublikovaniya-nauchnyhstatey-v-zhurnale-slavyanskiy-almanah

По вопросу приобретения книг издательства «Индрик» обращайтесь по тел.:

(495) 938-01-00

market@indrik.ru

www.indrik.ru

INDRIK Publishers has the exceptional right to sell this book outside Russia and CIS countries.

This book as well as other INDRIK publications

may be ordered by

www.indrik.ru

Формат $60 \times 9011 / 16$. Печать офсетная.

32 п. л. Тираж 400 экз.

Отпечатано в ОАО «Первая Образцовая типография»

Филиал «Чеховский печатный Двор»

142300, Московская область, г. Чехов, ул. Полиграфистов, д. 1

www.chpd.ru, sales@chpk.ru, 8(495)988-63-87 